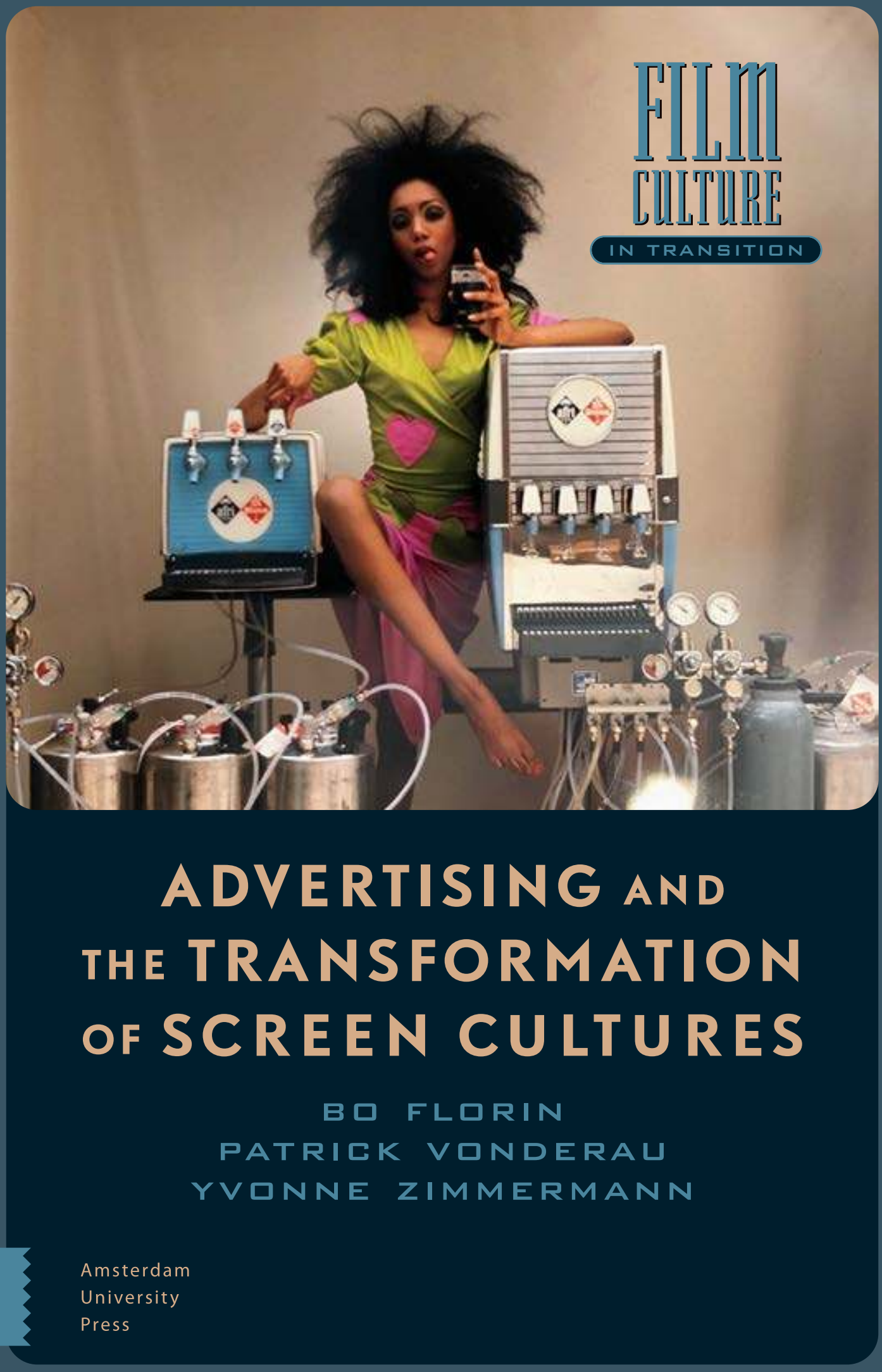


Advertising and the Transformation of Screen Cultures 



\title{
Advertising and the Transformation of Screen Cultures
}

\author{
Bo Florin, \\ Patrick Vonderau and \\ Yvonne Zimmermann
}


The publication of this book is made possible by a grant from the Swedish Foundation for Humanities and Social Sciences (Riksbankens Jubileumsfond, P13-1261:1)

Cover illustration: @ bpk-Bildagentur / Charles Wilp

Cover design: Kok Korpershoek

Lay-out: Crius Group, Hulshout

$\begin{array}{ll}\text { ISBN } & 978 \text { 94 62989153 } \\ \text { e-ISBN } & 9789048541560 \\ \text { DOI } & 10.5117 / 9789462989153 \\ \text { NUR } & 670\end{array}$

\section{(i) (1) $\Theta \Theta$}

Creative Commons License CC BY NC ND

(http://creativecommons.org/licenses/by-nc-nd/3.o)

@ B. Florin, P. Vonderau, Y. Zimmermann / Amsterdam University Press B.V., Amsterdam 2021

Some rights reserved. Without limiting the rights under copyright reserved above, any part of this book may be reproduced, stored in or introduced into a retrieval system, or transmitted, in any form or by any means (electronic, mechanical, photocopying, recording or otherwise).

Every effort has been made to obtain permission to use all copyrighted illustrations reproduced in this book. Nonetheless, whosoever believes to have rights to this material is advised to contact the publisher. 


\section{Table of Contents}

Introduction

Bo Florin, Patrick Vonderau and Yvonne Zimmermann

1. Early Cinema, Process Films, and Screen Advertising

Yvonne Zimmermann

\section{Part I Approaches and Methods}

2. Advertising and Modernity: A Critical Reassessment

Patrick Vonderau

3. Advertising and Avant-Gardes: A History of Concepts, 1930-1940

Yvonne Zimmermann

4. Advertising as Institution: Charles Wilp and German

Television, 1950-1970

Patrick Vonderau

5. Advertising and the Apparatus: Cinema, Television, and Out-of-Home Screens

Yvonne Zimmermann

6. Advertising as Commercial Speech: Truth and Trademarks in Testimonial Advertising

Patrick Vonderau

7. Advertising's Self-Reference: From Early Cinema to the Super Bowl

Yvonne Zimmermann

\section{Part II Cases and Materials}

8. Moving Objects: The Case of Volvo 
9. Cinematic Intertexts: H\&M Goes YouTube

Bo Florin

10. Beyond Promotion: The UN Global Goal Campaign

291

Bo Florin

Select Bibliography

315

Index

333 


\title{
Introduction
}

\author{
Bo Florin, Patrick Vonderau and Yvonne Zimmermann
}

The real business of the historian of advertising is more difficult: to trace the development from processes of specific attention and information to an institutionalized system of commercial information and persuasion; to relate this to changes in society and in the economy: and to trace changes in method in the context of changing organizations and intentions. Raymond Williams ${ }^{1}$

As an aesthetic, industrial, and social practice, advertising has played a pivotal role in shaping the history of virtually every modern communications medium. In its ubiquity and everyday ephemerality, avant-gardist designs and persuasive rhetorics, advertising over the course of the last century has become the epitome of modernity as much as of pop culture; it is inextricably linked to capitalism, material cultures, lifestyles, and media histories. Accordingly, a rich body of scholarship has evolved within the humanities that aims to capture and explain this role advertising appears to have in culture and society. A major cluster of studies has described advertising as an institution that is both distinct and unique in its capability to shape human consciousness. ${ }^{2}$ In line with the institutional view on advertising and its underlying sociopolitical concerns, other scholars have attempted a more theoretical description of advertising as a social practice of language,

1 Raymond Williams, 'Advertising: The Magic System', in Problems in Materialism and Culture (London: Verso, 1980), 170.

2 See, for instance, Daniel Boorstin, The Image: A Guide to Pseudo Events in America (New York: Harper \& Row, 1961); Paul Baran and Paul Sweezy, Monopoly Capital (New York: Monthly Review Press, 1966); Judith Williamson, Decoding Advertisements: Ideology and Meaning in Advertising (London: Marion Boyars, 1978); Stewart and Elizabeth Ewen, Channels of Desire: Mass Images and the Shaping of American Consciousness (New York/St. Louis: McGraw-Hill, 1982); or Kevin Hetherington, Capitalism's Eye (New York/London: Routledge, 2007).

Florin, B., P. Vonderau, Y. Zimmermann, Advertising and the Transformation of Screen Cultures. Amsterdam: Amsterdam University Press, 2021 DOI 10.5117/9789462989153_INTRO 
signification, and ideology. ${ }^{3}$ Still others have provided important cultural histories of consumerism and advertising. ${ }^{4}$ Within film and media studies, however, advertising has not developed into a distinctive disciplinary field. ${ }^{5}$ Somewhat surprisingly, what seems to mark advertising as an object of scholarly inquiry when it comes to film and cinema first and foremost is this object's apparently elusive or shape-shifting character.

The relation of advertising to moving pictures has often been claimed to be parasitic in nature. By the 1980 s, it had become a cliché of mass communication research to describe ads as 'parasitic upon their surroundings

3 For instance, Erving Goffman, Gender Advertisements (London: Macmillan, 1979); Gillian Dyer, Advertising as Communication (London: Methuen, 1982); Guy Cook, The Discourse of Advertising (London/New York: Routledge, 1992); Greg Myers, Words in Ads (London: Edward Arnold, 1994); Scott Lash and John Urry, Economies of Signs and Spaces (Thousand Oaks: Sage, 1994); Charles Forceville, Pictorial Metaphor in Advertising (London: Routledge, 1996); or Lars Hermerén, English for Sale: A Study of the Language of Advertising (Lund: Lund University Press, 1999).

4 See, among others, Merle Curti, "The Changing Concept of "Human Nature" in the Literature of American Advertising', The Business History Review 41, no. 4 (Winter 1967): 335-357; Jackson Lears, 'Some Versions of Fantasy: Toward A Cultural History of Advertising 1880-1930', Prospects 9 (1984):567-593; Fables of Abundance: A Cultural History of Advertising in America (New York: Basic Books, 1994); Stephen Fox, The Mirror Makers: A History of American Advertising and Its Creators (New York: Vintage, 1984); Michael Schudson, Advertising, the Uneasy Persuasion: Its Dubious Impact on American Society (New York: Basic Books, 1984); Roland Marchand, Advertising the American Dream: Making Way for Modernity, 1920-1940 (Berkeley: University of California Press, 1985); Stuart Culver, 'What Manikins Want: The Wonderful Wizard of Oz and The Art of Decorating Dry Goods Windows', Representations 21 (Winter 1988): 97-116; William Leach, 'Strategists of Display and the Production of Desire', in Consuming Visions:

Accumulation and Display of Goods in America 1880-1920, ed. Simon J. Bronner (New York/London: W.W. Norton \& Company, 1989), 99-132; Susan Strasser, Satisfaction Guaranteed: The Making of the American Mass Market (New York: Pantheon, 1989); James W. Cook, The Arts of Deception: Playing with Fraud in the Age of Barnum (Cambridge,

MA: Harvard University Press, 2001); Charles McGovern, Sold American: Consumption and Citizenship, 189o-1945 (Chapel Hill: The University of North Carolina, 2006); Marina Moskowitz and Marlis Schweitzer, eds., Testimonial Advertising in the American Marketplace (New York: Palgrave, 2009); or Stefan Schwarzkopf, 'Discovering the Consumer: Market Research, Product Innovation, and the Creation of Brand Loyalty in Britain and the United States in the Interwar Years', Journal of Macromarketing 29, no. 1 (2009), 8-2o.

5 Notable exceptions include, among others, Malcolm Cook and Kristin Moana Thompson, eds., Animation and Advertising (New York: Palgrave, 2020); Ralf Forster, Ufa und Nordmark: Zwei Firmengeschichten und der deutsche Werbefilm 1919-1945 (Trier: Wissenschaftlicher Verlag Trier, 2005); Jeremy W. Groskopf, Profit Margins: The American Silent Cinema and the Marginalization of Advertising (Georgia State University: unpublished manuscript, 2013); and Cynthia B. Meyers, A Word from Our Sponsor: Admen, Advertising, and the Golden Age of Radio (New York: Fordham University Press, 2014). 
and other genres'. ${ }^{6}$ The trope of a host-parasite relationship can already be found in industry discourse decades earlier, and in ways that evoke correspondences to contemporary 'media infection' theories. ${ }^{7}$ Recently, media historians have again taken up the term, stressing that films commissioned for advertising, public relations, and other purposes do not constitute a genre but are a 'strategically weak and parasitic form' that adapt to any organizational purpose they aim to fulfil. ${ }^{8}$ While thought provoking, this position has been criticized for downplaying the strength or persistence of sponsored arrangements, and for failing to account for the mutuality in the relationship. ${ }^{9}$ In opening this book and its explorations of advertising's role in the transformation of screen cultures over the past hundred years, it is thus reasonable to think through this and other conceptual frameworks that research has frequently been locked into. What do we mean by 'advertising'? Is advertising everywhere, and is it the same everywhere? Is it related to modernity? Is advertising an institution? A genre? An archival object? A cultural practice of language, signification, and ideology?

\section{Some Basic Distinctions}

A way to begin our exploration is to counter the suggestive, but misleading, metaphor of the parasite with a simple distinction. Advertising and advertisements are two different things. In a traditional industry view, the first is a type of marketing communication distinct from other types, such as packaging or sales promotion. For the purposes of our book, 'advertising' can more broadly be defined as an institutionalized process that goes along with a

6 See, for instance, Arthur Asa Berger, Television as an Instrument of Terror: Essays on Media, Popular Culture, and Everyday Life (New Brunswick and London: Transaction Publishers, 1980), 143; Guy Cook, The Discourse of Advertising (London and New York: Routledge, 2001), 133-134 [quote taken from this source].

7 Groskopf, Profit Margins, 54. Trade journals such as Exhibitors Herald, Moving Picture World, Sponsor, Variety, and others frequently brought up the term in either defensive or accusing ways, at least since the 1920s. More recently, Pinboard-founder and blogger Maciej Cegłowski noted, 'Advertising is like a flu, it always changes in order to avoid resistances', (http://idlewords.com, last accessed 5 April 2021).

8 Vinzenz Hediger and Patrick Vonderau, 'Record, Rhetoric, Rationalization: Industrial Organization and Film', in Films that Work: Industrial Film and the Productivity of Media, ed. Vinzenz Hediger and Patrick Vonderau (Amsterdam: Amsterdam University Press, 2oog), 46.

9 Bert Hogenkamp, 'A Strategically Weak and Parasitic Form? Reflections on the History of Corporate and other Useful Media in the Netherlands', talk delivered at the Faculty for the Humanities, Vrije Universitet Amsterdam, 6 November 2015. 
set of partly codified practices and a host of cultural forms designed to inform or persuade larger groups of people. That is, to advertise means to engage in a process that is organized according to specific rules, norms, and standards stabilized over time. This includes trademark law, for instance, given that demand for goods implies that such goods can be properly distinguished. It also includes more local or temporal frameworks and forms of boundary work; over much of the past century, advertising was organized in a way that loosely regulated who could call themselves advertisers and charge for their services as such, as richly documented in historical trade papers, for instance. Processes change, of course, and their institutional character may be more or less explicit, but they certainly are neither arbitrary nor do they change at will. Practices of advertising were manifold, but codified in the sense as to adhere to rules of thumb within the advertising industry, and to more general social, ethical, and legal standards; just think of the ways historical divisions of labour between various related practices worked to differentiate advertising and public relations, for instance. The very fact that industry actors still easily settle on the above definition of advertising as a type of marketing communication demonstrates the degree to which such divisions of labour have become axiomatic over the years. ${ }^{10}$

Distinct from advertising as a process, yet intimately related to its logics is a multitude of cultural forms that surround, accompany, guide, or irritate us almost everywhere we go. Traditionally defined, such 'advertisements' are paid communications intended to inform and/or persuade people. As such, ads are inextricably linked to media in the sense of technical means of mass communication: print, radio, television, cinema, and the internet. Media format, programme, store, and disseminate advertisements but have traditionally neither paid for nor produced them. This is the task of advertisers and agencies, respectively; agencies specialize in producing advertising campaigns, while retailers, manufacturers, governments, and various other actors may act as advertisers in commissioning them. A lot of the confusion regarding advertising, including referrals to its allegedly parasitic character, seems related to this tripartite relation between advertisers, media, and agencies, with only the latter principally engaged in advertising as profession and exclusive source of revenue. Historically, mass media have developed different styles of address and may target promotional messages to all, to some, to the few, or to no one in particular. The mass delivery of ads also has great diversity in time and space, scale and speed. Finally, and most

10 Winston Fletcher, Advertising: A Very Short Introduction (Oxford: Oxford University Press, 2010). 
importantly, media differ markedly in their capacity to carry classified and display ads.

Simply put, there are ads that people look for (classifieds), and ads that look for people (display). ${ }^{11}$ Classified advertisements, those found in newspapers or on the internet, rely on people perusing them for information for which they are actively searching. Display ads, on the other hand, must catch the attention of people initially not interested in their messages. Cinema and television, as well as radio or posters, are almost exclusively designated to carry display advertisements. Our book primarily deals with film, but display ads and related media technologies have historically encompassed posters and print alongside a broad variety of moving pictures, such as flip-books, mechanical trade cards, lantern slides, slide projections, cartoons with cinematic narratives, outdoor animated billboards or light bulb installations, television broadcasts, streamed video, and more.

\section{Screen Ads as Analytical Category}

While our own specific focus in this book is on filmed advertisements, a case could be made to employ a more general term such as screen ads to denote a recurring set of moving image formats used for display advertising. The notion of screen ads opens an analytical space for examining interrelations between television spot commercials, lantern slides, digital video, ads screened in public spaces or as part of theatrical entertainment programming, and other display advertisements that use both movement and images. One may rightfully object that history demands a distinguishment between all these media and formats, given that a glass slide with minimal animation as seen in the us in the late 1910s might have little or nothing in common with a Chinese YouTube advertorial made in 2020 or a German television spot from the 1970s. We do not debate the need for such careful differentiation; hopefully, our book contributes to this differentiation. Our point rather is to propose thinking of screen ads as both a conceptual space and a dominant form when writing histories of display advertising, as we aim to do in this book.

Opening up the notion of screen advertisement as a conceptual space means to include moving images that are usually seen as marginal to or outside of advertising in the sense of an institutionally sanctioned, and partly legally codified, process. Screen ads include a diversity of forms spread out 
across a spectrum of more or less direct, theatrical, or institutional modes of filmed advertising. For instance, trademarks may appear in direct or indirect ways on-screen, that is, through forms that link a product to a film with or without overtly calling attention to product qualities or price. Brand placements in film are not what would traditionally be considered advertising, however. This distinction between a paid, unambiguous announcement in a communications medium, and other, partly freely given, forms of promotion is of course related to the division of labour in the industry, with direct and indirect advertising developing as separate professional fields. Yet there is also significant overlap over time that requires closer scrutiny. Speaking of screen ads in an analytical sense, rather than relying on the traditional industry understanding of display ads, allows for the tracing of these and other historical connections. The term may also help in discovering, or emphasizing, interlinkages between cinema and television, for instance. Taking film as a starting point, we suggest to approach 'cinema' as an open system, one whose institutional borders were both clearly defined and then soon quickly contested. As an instantiation of 'useful cinema', ${ }^{12}$ screen ads stimulate us to ask questions about clients and addressees, about recurrent rhetorical forms and their re-versioning over time, about non-theatrical screenings and manifold relations to print, radio, television, and digital media.

While our book does not aim to cover the broad entirety of this spectrum, a guiding principle for our work was to abandon the conventional delineation of the field by medium, country, or period. Instead, our research moved laterally, shedding light on advertising's specific objects, screens, practices, and intermediaries. The intent here was to follow the 'object lessons ${ }^{13}$ of specific products advertised in moving image media, or the careers of such objects across campaigns as much as the work of ad agencies or the specific functions of moving images in a given context. We found it more enlightening and useful to move inductively across the spectrum of direct/ indirect, institutional/non-institutional, and theatrical/non-theatrical forms of film than to stick to already known national 'pioneers' and proponents. In addition to such a lateral view, we also understood our work as explorative in the sense of probing various approaches, rather than developing a consistent

12 Charles R. Acland and Haidee Wasson, eds., Useful Cinema (Durham, NC and London: Duke University Press, 2013).

13 See Bill Brown, 'Thing Theory', in The Object Reader, ed. Fiona Candlin and Raiford Guins (London and New York: Routledge, 2009), 86-92; and Bruno Latour, Reassembling the Social: An Introduction to Actor-Network-Theory (New York: Oxford University Press, 2005). 
or prescriptive model for future research. Here, to think of screen ads rather than advertising film allowed us to discover and trace genealogies and connections across media, countries, and periods that may otherwise be hard to observe.

At the same time, however, screen ads are also associated with a dominant form of film-making for good reason. In many ways, the spot commercial is the epitome of display advertising. Here, it is worthwhile to return to the metaphor of the parasite, because it obscures what has made the spot a dominant form. To think of filmed advertisements as parasites means to emphasize their allegedly weak, mutable, and ephemeral character. From an archival perspective, commercials and other moving image ads are indeed often considered as part of the category of ephemeral films, alongside industrial, educational, and other instances of non-fictional film-making. Ads have instrumental, rather than cultural, value; they are short lived, confined to a specific pragmatic purpose for a limited time; their aesthetic is characterized by a non-mutual, dependent relationship to other cultural forms; and since they are not intended to be retained or preserved, they tend to disappear after initial distribution. And yet, the metaphor of the parasite misses the fact that screen ads, as epitomized by the spot commercial, may take on a stable, enduring form. In fact, what we know today as the commercial advertising 'spot' developed in the early 1910s out of the theatrical exhibition practice of glass slide adverts, or 'slide-vertising'. By the late 1910s, short theatrical advertising 'trailers', or spots, had fully developed into their actual form in the us and Europe. ${ }^{14}$ The spot commercial thus is neither weak nor ephemeral, but surprisingly robust in both its key parameters (e.g., length, structure, trademark mention) and perlocutionary functions (i.e., to induce a particular response in viewers). As an analytical term, 'screen ads' contributes to shedding light on such stability.

\section{About This Book}

While there is no historical reason to emphasize stasis over change, given the multitude of forms that display advertising nevertheless has taken on over time, there certainly is also no reason to use metaphors that do the opposite. In speaking of advertising as parasitic upon media, scholars risk mistaking a cultural category for an analytical one. This book avoids projecting the common disdain for advertising as industrial practice expressed in the 
parasite metaphor onto analytical categories. While using various terms when speaking of the relation between advertising and moving images, and while doing so from differing perspectives, the following chapters have common ground in taking up the challenge articulated by Raymond Williams in the epigraph above:

to trace the development from processes of specific attention and information to an institutionalized system of commercial information and persuasion; to relate this to changes in society and in the economy: and to trace changes in method in the context of changing organizations and intentions.

Taking up this challenge means to think through traditional self-definitions of actors within advertising. It also means to critically engage with existing frameworks, concepts, methods, and materials. The book resulting from these efforts neither presents a comprehensive historical survey nor a definite theory of screen advertising. Rather, it documents the probing, exploratory character of the research on which it is based, with chapters following the individual trajectory its three co-authors pursued over the course of three years, during which they participated in the project Advertising and the Transformation of Screen Cultures (2014-2017), generously funded by Riksbankens Jubileumsfond, the Swedish Foundation for the Humanities and Social Sciences.

These various research trajectories have been dedicated to broader conceptual frameworks in advertising research and related methodological issues (Patrick Vonderau), to mid-level research on the history of concepts and the way such concepts allow for the integration of the study of screen advertising into cinema studies (Yvonne Zimmermann), and to fine-grained, exemplary studies of materials that document the histories of exemplary campaigns and their contexts (Bo Florin).

In her opening essay, 'Early Cinema, Process Films, and Screen Advertising', Yvonne Zimmermann looks back at early cinema and the entanglements between entertainment, education, and advertising. The focus is on a process film about milk production in Switzerland, which serves as a paradigmatic example for the fluidity of the category of genre and for the typical colour aesthetics of process films that speak of how deeply visual culture and consumption culture were imbricated in ideas of colonialism. The essay takes up notions and frameworks that resonate throughout the book, among them the robustness of screen advertising also addressed in the introduction, and its sited-ness; in other words, its historical specificities 
and localized appearance. All in all, this opening essay invites readers to reflect on continuities and changes in advertising and the transformation of screen cultures.

'Approaches and Methods', the first section, then sums up the more conceptually oriented work of Vonderau and Zimmermann. Vonderau's part of this section addresses the way advertising research, perhaps inevitably, tends to get locked into a historical frame (modernity), a social frame (institution), and a legal frame (trademark law and policy) to develop its argument. His first chapter, 'Advertising and Modernity: A Critical Reassessment', aims to deconstruct the category of modernity by confronting a prevailing abstracted view on screen advertising with the contingencies of its archival history. Taking as a case study the 196os 'cola wars' and the marketing of cola soft drinks, the chapter shows how this competition between Pepsi and Coke related to stylistic innovations such as montage sequences, and what relevant mid-level finds can be made regarding one specific Pepsi campaign of that era without indulging in overly general arguments about modernism or modernity. In 'Advertising as Institution: Charles Wilp and German Television, 1950-1970', a similarly self-reflexive view is proposed vis-à-vis the Charles Wilp Collection at the Deutsche Kinemathek, the museum for film in Berlin, a collection dedicated to the work of one of Germany's best-known (and most notorious) advertisers of the 1960s and 1970s. After critically reviewing the notion of institution as it is used in advertising research, the main part of the text provides a historical account of Wilp's work and proposes a definition of screen advertising and an analytical heuristics for describing moving image advertisements. Vonderau's last chapter, 'Advertising as Commercial Speech: Truth and Trademarks in Testimonial Advertising', explores moving images' promotional relation to trademarks by focussing on American case law and a controversy that surrounded a brief moment in the feature film The Hangover II (2011), and presents a typology of moving image testimonials.

Interspersed are three chapters by Yvonne Zimmermann that relate some of cinema studies' key concepts - 'the documentary', 'self-reference', and the dispositif - to screen advertising with the aim to test these notions and frameworks on forms and practices of moving images that have been situated rather at the periphery of the discipline. Zimmermann's first chapter, entitled 'Advertising and Avant-Gardes: A History of Concepts, 1930-1940', looks at advertising as a form of persuasive communication that includes forms otherwise associated with both documentary and avant-garde cinema of the 1930s and early 1940s. Focussing on the (mainly written) work of John Grierson, Paul Rotha, and Hans Richter, the chapter shows how 
debates among intellectuals, pedagogues, and artists on both sides of the Atlantic revolved around concepts of propaganda and education to promote democracy. At a politically critical moment, they shared a belief in moving images as powerful tools for shaping the human mind. In Zimmermann's second chapter, 'Advertising and the Apparatus: Cinema, Television, and Out-of-Home Screens', the notion of the dispositif serves as a conceptual framework to both theorize and analyse the programming of moving image advertising on three types of screens: cinema, network-era television, and digital out-of-home displays. The chapter shows how screen ads stitch together different forms of intermittent movements - of bodies, images, and objects - and thus help to create flows. Zimmermann's final chapter, 'Advertising's Self-Reference: From Early Cinema to the Super Bowl', takes up the notion of self-reference and redefines it as a particular mode of address. When looked at from the perspective of screen advertising and screen ads, self-reference exhibits the assumed media knowledge of the viewers as much as it displays the medium itself. It thus works as acknowledgement and celebration of the audience's media expertise.

The second section in the book, written by Bo Florin, is dedicated to 'Cases and Materials'. In 'Moving Objects: The Case of Volvo', Florin investigates the concept of mobility on several levels - the movement of cars, the movement of people, and the movement of the camera - and how this concept is launched within the ads along with 'Scandinavian' values. The commercials also point to the basic definition of cinema qua moving images, aiming in turn to move the audience. In 'Cinematic Intertexts: $H \& M$ Goes YouTube', Florin studies the designer collaborations of $H \& M$, with a focus on these campaigns at the point of breakthrough for social media. The campaigns as such combine high culture and popular culture, and spans from exclusive consumerism to equal opportunities for all, with the Lanvin collaboration as an early example of 'friendvertising' - and using You Tube as an archive. The third and final chapter in the section, entitled 'Beyond Promotion: The UN Global Goals Campaign', deals with the latter as a particularly interesting example, given the way this campaign did not advertise a product, but rather a policy. Does this change the way of relating to history? Advertising sustainability requires both economic development, environmental protection, and social responsibility. The chapter shows that the launch of this campaign, not least by using Aardman Animations, relies heavily on both film history and the history of commercials. 
The authors would like to acknowledge the generous support from the Swedish Foundation for Humanities and Social Sciences (Riksbankens Jubileumsfond, $\mathrm{P}_{13-1261: 1)}$, which allowed us to conduct the research project on which this book - and many of our other publications over the past few years - have been based. We would also like to thank Charles R. Acland, Cynthia B. Meyers, and Haidee Wasson for invaluable input and advice in the early stages of this project. Our work has been tremendously enriched by the many exchanges and conversations we have had and continue to have with colleagues who joined us in the Screen Advertising Research Network, including Roszita Alexandrova, Lucie Česálková, Sema Colpan, Malcolm Cook, Michael Cowan, Jeremy Groskopf, John Hoffmann, Martin L. Johnson, Frank Kessler, Sabine Lenk, Cynthia B. Meyers, Karin Moser, Lydia Nsiah, Matthew Ogonoski, Joachim Schätz, and Gregory A. Waller. Thanks to Dan Streible for allowing us to host our 2018 event, The Love that Speaks Its Name: Advertising Film Workshop, in conjunction with the Orphan Film Symposium in New York City that year, and to all additional attendees, including Dominique Brégent-Heald, Joseph Clark, Susmita Das, Jason Cody Douglass, Tanya Goldman, Jelena Rakin, Natalie Snoyman, and Alexander Stark. We would like to thank Julia Noordegraaf for initiating, in 2009, the dialogue between archivists and scholars that prompted our own collaboration. A subsequent conference, Exploring Advertising, was held in cooperation with the Swedish Film Institute in Stockholm in May 2012, and we would like to extend our thanks to the participants of this lively event, including Mats Björkin, William Boddy, Mats Jönsson, Martin Koerber, Charles McGovern, Anke Mebold, Sean Nixon, Jacob Östberg, Floris Paalman, Amy Sargent, and Jon Wengström. Thanks are also due to Jörgen Andersson and Jan Nord (Esprit), Andreas Hellström (SWE Advertising Agency), and Stefanie Pahmeyer (BBDO), and especially to research archivist Annette Groschke at the Deutsche Kinemathek. We have been fortunate in having editorial assistance and owe much gratitude in this respect to Heather MacDougall and Tabitha Volohonsky. This book also benefitted from assistance supplied by Amsterdam University Press's expert editorial and production team, most notably Maryse Elliott and Danielle Carter. 


\section{Bibliography}

Acland, Charles R., and Haidee Wasson, eds. Useful Cinema. Durham, NC and London: Duke University Press, 2013.

Baran, Paul, and Paul Sweezy. Monopoly Capital. New York: Monthly Review Press, 1966.

Berger, Arthur Asa. Television as an Instrument of Terror: Essays on Media, Popular Culture, and Everyday Life. New Brunswick and London: Transaction Publishers, 1980.

Boorstin, Daniel. The Image: A Guide to Pseudo Events in America. New York: Harper \& Row, 1961.

Brown, Bill. 'Thing Theory.' In The Object Reader, edited by Fiona Candlin and Raiford Guins, 86-92. London and New York: Routledge, 2009.

Cook, Guy. The Discourse of Advertising. London and New York: Routledge, 2001.

Cook, James W. The Arts of Deception: Playing with Fraud in the Age of Barnum. Cambridge, MA: Harvard University Press, 2001.

Cook, Malcolm, and Kristin Moana Thompson, eds. Animation and Advertising. New York: Palgrave, 2020.

Culver, Stuart. 'What Manikins Want: The Wonderful Wizard of Oz and The Art of Decorating Dry Goods Windows.' Representations 21 (Winter 1988): 97-116.

Curti, Merle. 'The Changing Concept of "Human Nature" in the Literature of American Advertising.' The Business History Review 41, no. 4 (Winter 1967): 335-357.

Dyer, Gillian. Advertising as Communication. London: Methuen, 1982.

Ewen, Stuart, and Elizabeth Ewen. Channels of Desire: Mass Images and the Shaping of American Consciousness. New York and St. Louis: McGraw-Hill, 1982.

Fletcher, Winston. Advertising: A Very Short Introduction. Oxford: Oxford University Press, 2010.

Forceville, Charles. Pictorial Metaphor in Advertising. London: Routledge, 1996.

Forster, Ralf. Ufa und Nordmark: Zwei Firmengeschichten und der deutsche Werbefilm 1919-1945. Trier: Wissenschaftlicher Verlag Trier, 2005.

Fox, Stephen. The Mirror Makers: A History of American Advertising and Its Creators. New York: Vintage Books, 1985.

Goffman, Erving. Gender Advertisements. London: Macmillan, 1979.

Groskopf, Jeremy. Profit Margins: The American Silent Cinema and the Marginalization of Advertising. Dissertation, Georgia State University, 2013.

Hediger, Vinzenz, and Patrick Vonderau. 'Record, Rhetoric, Rationalization: Industrial Organization and Film.' In Films that Work: Industrial Film and the Productivity of Media, edited by Vinzenz Hediger and Patrick Vonderau, 35-49. Amsterdam: Amsterdam University Press, 2009. 
Hermerén, Lars. English for Sale: A Study of the Language of Advertising. Lund: Lund University Press, 1999.

Hetherington, Kevin. Capitalism's Eye. New York and London: Routledge, 2007. Hogenkamp, Bert. 'A Strategically Weak and Parasitic Form? Reflections on the History of Corporate and other Useful Media in the Netherlands.' Talk delivered at the Faculty for the Humanities, Vrije Universiteit Amsterdam, 6 November 2015.

Lash, Scott, and John Urry. Economies of Signs and Space. London: Sage, 1994.

Latour, Bruno. Reassembling the Social: An Introduction to Actor-Network-Theory. New York: Oxford University Press, 2005.

Leach, William. 'Strategists of Display and the Production of Desire.' In Consuming Visions: Accumulation and Display of Goods in America, 1880-1920, edited by Simon J. Bronner. New York: W. W. Norton, 1989.

Lears, Jackson. 'Some Versions of Fantasy: Toward A Cultural History of Advertising 1880-1930.' Prospects 9 (1984): 567-593.

Lears, T.J. Jackson. Fables of Abundance: A Cultural History of Advertising in America. New York: Basic Books, 1994.

Marchand, Roland. Advertising the American Dream: Making Way for Modernity 1920-1940. Berkeley, Los Angeles, and London: University of California Press, 1986.

McGovern, Charles. Sold American: Consumption and Citizenship, 189o-1945. Chapel Hill: The University of North Carolina, 2006.

Meyers, Cynthia B. A Word from Our Sponsor: Admen, Advertising, and the Golden Age of Radio. New York: Fordham University Press 2014.

Moskowitz, Marina, and Marlis Schweitzer, eds. Testimonial Advertising in the American Marketplace. New York: Palgrave, 2009.

Myers, Greg. Words in Ads. London: Edward Arnold, 1994.

Schudson, Michael. Advertising, the Uneasy Persuasion: Its Dubious Impact on American Society. New York: Basic Books, 1984.

Schwarzkopf, Stefan. 'Discovering the Consumer: Market Research, Product Innovation, and the Creation of Brand Loyalty in Britain and the United States in the Interwar Years.' Journal of Macromarketing 29, no. 1 (2009): 8-20.

Strasser, Susan. Satisfaction Guaranteed: The Making of the American Mass Market. New York: Pantheon, 1989.

Williams, Raymond. 'Advertising: The Magic System.' In Problems in Materialism and Culture. London: Verso, 1980.

Williamson, Judith. Decoding Advertisements: Ideology and Meaning in Advertising. London: Marion Boyars, 1978. 



\title{
1. Early Cinema, Process Films, and Screen Advertising
}

\author{
Yvonne Zimmermann
}

\begin{abstract}
This chapter explores what early process films can tell us about advertising and the transformation of screen cultures. Starting with a detailed historical study of an exemplary process film, the chapter addresses a number of conceptual issues that resonate with takes on screen advertising suggested in the present book. A particular focus lies on screen advertising's entanglement with entertainment culture, education, visual culture, and commodity culture. Questions of genre and aesthetics, in particular the colour aesthetics of process films in early cinema as well as their colonialist ideology, are also addressed. The chapter argues that screen advertising, despite its often-acknowledged ephemeral nature, is an utterly robust or persistent phenomenon - persistent in regard to the objects, screens, and practices of screen advertising.
\end{abstract}

Keywords: early cinema, process film, advertising, colour, colonial visual culture

It is 1909, a sunny spring day in Bernese Oberland; cherry trees are in blossom and cows leave the barn, driven by cowherds dressed in traditional local costumes. ${ }^{1}$ Cowbells in bronze try to outshine the cherry blossom tree and the marvellous mountain scenery. Two calves strain at the leash in youthful zeal under the eyes of a prudent Bernese mountain dog. A horizontal pan across the alpine pasture reveals the substantial size of the herd, the stately

1 I dedicate this chapter to my father, who was a committed Swiss cheesemaker, an ardent admirer of free jazz, and a cinephile. I suspect he would not have loved the films I write about - but perhaps I am wrong.

Florin, B., P. Vonderau, Y. Zimmermann, Advertising and the Transformation of Screen Cultures. Amsterdam: Amsterdam University Press, 2021 DOI 10.5117/9789462989153_CHO1 
farmhouse, and the well-maintained agricultural buildings. Then it is time for the cows to be milked and for the cowherds to carry the precious white liquid in traditional wooden containers on their backs down to the valley.

This 'dispatch to the factory' (title card; my translation) marks a switch in location and in work procedure; it is a shift from the alp to the factory and from a pre-industrial, artisanal extraction of raw material to the industrial processing of it into condensed milk. And it is, surely not by chance, the moment for the company name to make an entrance: BAMG (Berner Alpenmilchgesellschaft / Bernese Alps Milk Company). 'Stalden' is easily legible on the horse-drawn carriages fully loaded with milk cans that drive past the camera in a diagonal angle towards the factory located in the vanishing point.

The film Milcherzeugung in der Schweiz / Préparation et exportation du lait par la Sté Laitière des Alpes Bernoises (Milk Production in Switzerland) is a typical example of what scholars retrospectively have termed 'process film[s]' in early cinema. ${ }^{2}$ Produced by Pathé Frères, the film depicts, step by step, the transformation of raw milk into a consumable good, that is, into canned condensed milk. Following the pastoral overture in the Swiss mountains, the industrial production process is presented in a factual mode with title cards explaining the pasteurization and condensation of the milk in great detail: "The milk is heated to 100 degrees Celsius, mixed with six per cent sugar, and reduced in volume by half through evaporation of its liquid content.' It goes on: 'The milk is filled in tin cans or bottles, which are put into a water bath for the purpose of sterilization.' The images offer glimpses into all production departments that are involved in the process, from the laboratory and production department to the packing and shipping department. The packing and shipping shots allow for the inclusion of cans, shipping cases, and wall posters that are labelled with the company name and/or the brand name, the 'Bear Brand', and its logo, a brown bear sitting on its back, holding a white baby bottle. In this way, the film brands factual information, thus following a promotional strategy that could be termed branded education and that in today's TV advertising practice is called an infomercial. At the same time, Milcherzeugung in der Schweiz can also be considered an early form of branded entertainment, for the visual pleasure it provides, especially in the opening scenes that are lavishly stencil coloured (an aspect I will come back to later on). Following Jay Newell, Charles T. Salmon, and Susan Chang, who define product placement, also known as tie-in or tie-up, as 'the insertion of branded products or services into mass

2 A 35 mm print of Milcherzeugung in der Schweiz is preserved at the Bundesarchiv-Filmarchiv Berlin. Unfortunately, to this date, the film is not available online or on DVD. 

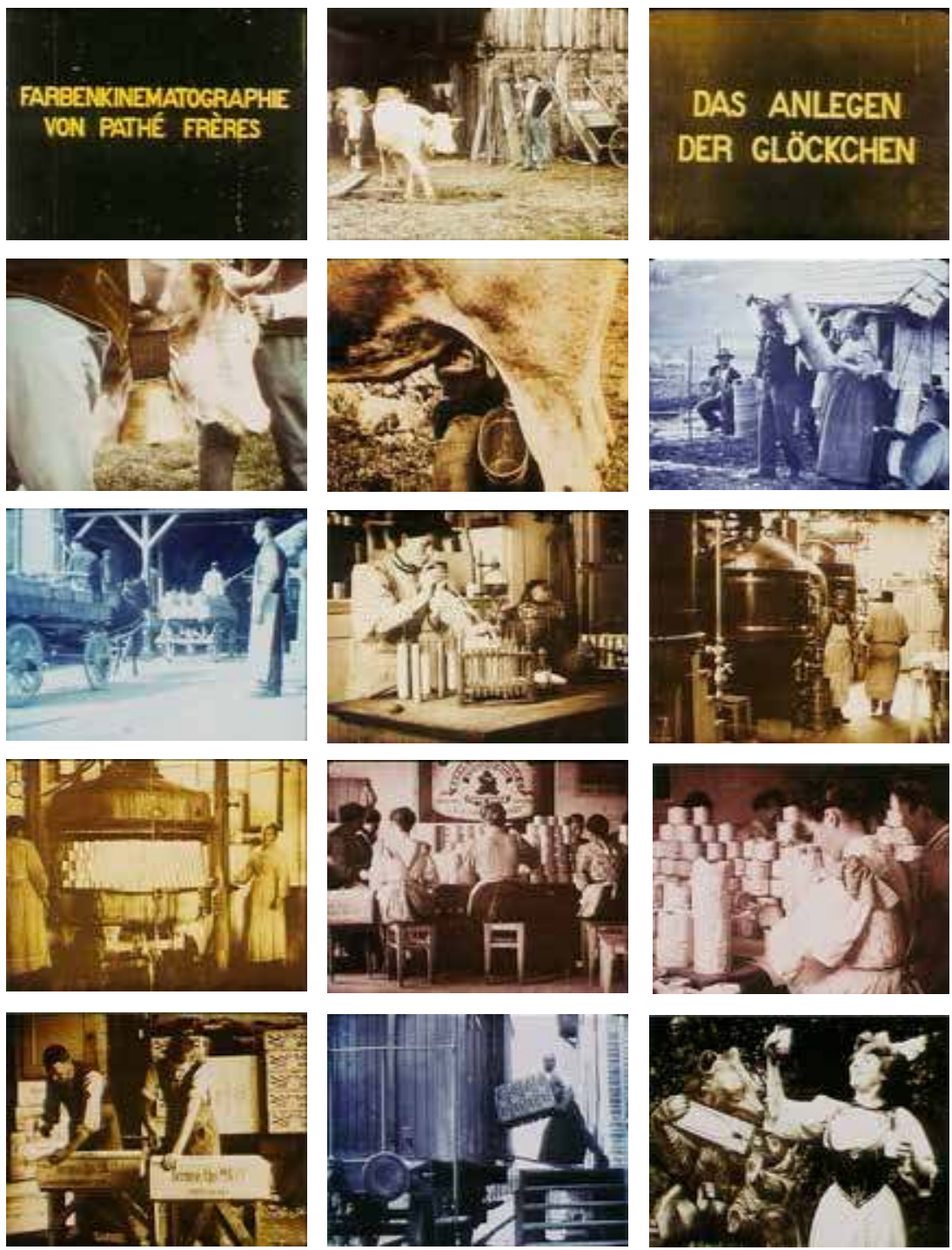

Figures 1.1-1.15: Screenshots from Milcherzeugung in der Schweiz (Pathé Frères, 1910). 
media content with the intent of influencing consumer attitude or behaviour', the presence of the 'Bear Brand' also qualifies as product placement. ${ }^{3}$

The last scene of the film is dedicated to 'The tasting' (title card) and yet again provides a shift in audience address. It switches from an instructional mode of address and an overall gesture of showing and displaying to address the audience directly and in an appellative way as is typical for 'outright' advertising: next to a cardboard mother bear giving her baby a bottle stands a young woman in costume who raises the glass of condensed milk she is tasting to the audience and, with sweeping gestures and a big smile, gives animated testimony to the tastiness of the product. In this way, the film ends on a humorous note. Milcherzeugung in der Schweiz uses astonishment and awe to attract viewers' attention for the instructional and promotional parts, then rewards spectators for staying with the film by giving them a good laugh at the end.

In this opening essay, I explore what early process films can tell us about advertising and the transformation of screen cultures and in what ways they can be instructive in thinking about how to conceptualize screen advertising from the point of view of cinema and media studies. I do this on the basis of a detailed historical consideration of a single object - an exemplary process film - in context, with the aim to address a number of conceptual issues that resonate with perspectives on screen advertising suggested in the essays in the present book. Thereby, facets like the place of moving image advertising in media programmes and in institutions surface, the latter leading here to considerations of screen advertising's entanglement with entertainment culture, education, visual culture, and commodity culture. Questions of genre and aesthetics, in particular the colour aesthetics of process films in early cinema as well as their colonialist ideology, are also addressed. The overall argument that runs through this essay, though, is that screen advertising, despite its often-acknowledged ephemeral nature, is an utterly robust phenomenon - robust or persistent in regard to the objects, screens, and practices of screen advertising. It is this persistence of screen advertising that this chapter wishes to draw attention

3 Jay Newell, Charles T. Salmon, and Susan Chang, 'The Hidden History of Product Placement', Journal of Broadcasting \& Electronic Media (December 2006): 575-594, here 577. See also Jane Gaines, 'From Elephants to Lux Soap: The Programming and "Flow" of Early Motion Picture Exploitation', The Velvet Light Trap 25 (Spring 1990): 29-43; Patrick Vonderau, 'Kim Novak and Morgan Stairways: Thinking about the Theory and History of the Tie-in', in Films That Sell: Moving Pictures and Advertising, ed. Bo Florin, Nico de Klerk, and Patrick Vonderau (London and New York: Palgrave, 2016), 209-220. 
to. It is a remarkable robustness or persistence that, curiously, goes hand in hand with an equally remarkable ephemerality of screen advertising.

\section{Object Lessons: Process Films and/as Travelogues}

Process films display a trajectory from raw material to consumable good. This trajectory enacts, as Tom Gunning has argued, a basic narrative of industrial capitalism. ${ }^{4}$ This narrative was largely prefigured by other media that preceded film, such as lantern slide shows, photography, and printing, which helps explain why the process film as a category or genre, if you will, counts among the earliest and most persistent types of industrial film. At the same time, it was a common and popular genre in early cinema. As Frank Kessler and Eef Masson have emphasized, many of the generic markers of early process films originated outside the context of industrial organization and often predated the systematic use of film by the industry. ${ }^{5}$ In fact, these films were part and parcel of the repertoire of popular entertainment culture. Pathé, for example, included process films under the name of scènes (d'art et) d'industrie in its company distribution catalogues in the early $1900,{ }^{6}$ and the German trade press started to advertise them as Industriebild (industrial view) in 1907.7 In the United Kingdom, the genre was usually called 'industrial moving pictures'. ${ }^{8}$ In the United States, Ernest E. Dench, a journalist and self-proclaimed expert in motion pictures, used the term 'industrialog' in 1916 to describe a type of film that portrays 'the process by which certain goods are manufactured', ascertaining that the industrialog was the most common type of advertising film in the us. ${ }^{9}$ The genre is highly formulaic

4 Tom Gunning, 'Before Documentary: Early Nonfiction Films and the "View" Aesthetic', in Uncharted Territory: Essays on Early Nonfiction Film, ed. Daan Hertogs and Nico de Klerk (Amsterdam: Stichting Nederlands Filmmuseum, 1997), 9-24, here 17.

5 Frank Kessler and Eef Masson, 'Layers of Cheese: Generic Overlap in Early Non-Fiction Films on Production Processes', in Films That Work: Industrial Film and the Productivity of Media, ed. Vinzenz Hediger and Patrick Vonderau (Amsterdam: Amsterdam University Press, 2009), 75-84, here 75 .

6 Ibid., 77.

7 Martin Loiperdinger, 'Early Industrial Moving Pictures in Germany', in Films That Work, ed. Hediger and Vonderau, $65^{-73}$, here 65 .

8 Ibid.

9 Ernest A. Dench, Advertising by Motion Pictures (Cincinnati: Standard Publishing Company, 1916), 47. For a larger discussion of Dench's book and early advertising in the us, see Yvonne Zimmermann 'Advertising and Film: A Topological Approach', in Films That Sell, ed. Florin, de Klerk, and Vonderau, 21-39. 
with conventionalized components, among them a workers-leaving-thefactory scene that, in many process films, precedes or replaces the scene of joyful consumption. Production, packaging, and dispatch are the core features of process films, whereas the extraction of raw material, workers leaving the factory, and consumption can be found in varying combinations.

Scholars such as Martin Loiperdinger, Jennifer Lynn Peterson, and others have pointed to the similarities of process films and travelogues. ${ }^{10}$ Tom Gunning has summarized the two types of films under the category of 'view films', for they both organize a number of single views within a larger, multi-shot logic of exposition. But while films that tour and display locations present space and place as a series of views, films about activities and processes, according to Gunning, obey a temporal rather than a spatial logic of organization and follow 'a more determinate sequential logic of transformation.' ${ }^{11}$ Gunning's observation is certainly correct, but, as Milcherzeugung in der Schweiz illustrates, process films do follow a specific spatial logic as well, and perhaps even more so than travelogues, in that they display a travel from an often distant, certainly traditional, agricultural, and typically 'exotic' place to modern and industrialized sites of production and to Western urban bourgeois spaces of consumption. The trajectory depicts the value chain of a product, which goes in one direction only. A returning traffic to the spaces of raw material extraction is not provided. The step-by-step transformation of raw materials into consumable goods is not only presented as a process but also as a civilizational progress from raw to refined. From an ideological point of view, process films are not innocent, but like travelogues, are deeply imbricated in ideas of colonialism, imperialism, and consumption - consumption of landscapes, people, products, and images.

If we consider a film like Milcherzeugung in der Schweiz not in isolation, but as part of a larger programme, more correspondences between process films and travelogues surface, for they had a similar place in the short film programmes in early cinema, which were characterized by a variety format. Charles Musser describes the place of non-fictional films in the programme as follows:

These films, if they were shown in 1912 when one-reel or occasionally two-reel fiction films dominated, must often have served as pauses between fictional

10 See Martin Loiperdinger, 'Early Industrial Moving Pictures in Germany', in Films That Work, ed. Hediger and Vonderau, 65-73; Jennifer Lynn Peterson, Education in the School of Dreams: Travelogues and Early Nonfiction Film (Durham, NC and London: Duke University Press, 2013). 11 Gunning, 'Before Documentary', 15. 
narratives, allowing audiences to recover from one story and prepare for another. They kind of ease the transition from one fictional narrative to another. Perhaps a succession of story films may have been considered too abrupt. Of course, the nonfiction films also undoubtedly served a simple industrial function of allowing the spectator to sort of regroup. ${ }^{12}$

The humorous last scene in Milcherzeugung in der Schweiz, for example, may have perfectly eased the transition to a burlesque film. In this sense, non-fictional films such as travelogues and process films were interstitials or 'in-betweens' that helped manage transitions between fictional films. As further research presented in this book illustrates, being 'in between' is a typical place for moving image advertising within programme structures across different media institutions (cinema, network television, out-of-home screens), and stitching together different forms of intermittent movements into a flow is its typical function (see 'Advertising and the Apparatus'). Also, from a broader institutional perspective, screen advertising is characterized by being 'in between' different institutions (see Vonderau's chapter 'Advertising as Institution'). Searching for a framework to explain advertising's relation to moving pictures and 'cinema proper', Patrick Vonderau has proposed an understanding of screen advertising as 'para-sited cinema'. The 'para-' refers to screen advertising's being 'over and above, in and out of cinema'. This is to stress that screen advertising does not exclusively belong to this or that social space, but moves in between, 'borrowing from the different logics or cultural series that constitute cinema as an open system.' ${ }^{13}$

This borrowing or appropriation of different logics or cultural series is 'the favoured procedure of all advertising discourse', as Jane Gaines has put it, ${ }^{14}$ and that certainly holds true for process films. Gaines argues that forms of product placement in motion pictures evolved out of a tradition of circus and freewheeling stunts. ${ }^{15}$ Process films however, insofar as they share characteristics with early product placement practices, did not originate primarily in the entertainment business and the circus, but instead are rooted in the encyclopaedia tradition of the eighteenth- and nineteenth-century pedagogy of visual education. Like travelogues, process films provided what Peterson has called 'instructive entertainment' - namely, a form of attraction that

\footnotetext{
12 Comment by Charles Musser in Nonfiction from the Teens, ed. Daan Hertogs and Nico de Klerk (Amsterdam: Stichting Nederlands Filmmuseum, 1994), 29.

13 Patrick Vonderau, 'Introduction: On Advertising's Relation to Moving Images', in Films That Sell, ed. Florin, de Klerk, and Vonderau, 13.

14 Gaines, 'From Elephants to Lux Soap', 31.

15 Ibid., 40.
} 
'packaged didactic intentions as an aesthetic commodity'. ${ }^{6}$ This somewhat uneasy relation between dazzlement and knowledge, according to Gunning, marks the experience of modern visuality, including the contemporary cinema of attractions. ${ }^{17}$ Taking the 1904 St. Louis World Fair as his example, Gunning describes the new visual culture as

a new faith in the power of visual knowledge; a conception of the world itself as a consumable picture, imaged through the collapse of space and time; and an aggressive visual address aimed at dazzling the viewer with a new control over the gaze. ${ }^{18}$

More than travelogues, process films make these features of modern visual culture visible in that they offer explicit images of consumable goods for visual consumption. They are not only presenting the world as a consumable image, they are overtly about consumption, thus rehearsing the protocols of real-life consumption. In that sense, process films are almost reflexive. If travelogues deliver instructive entertainment, process films provide branded instructive entertainment; if travelogues are object lessons, process films are branded object lessons.

\section{Screen Culture, Consumer Culture, and (Un-)Branded Content}

If Milcherzeugung in der Schweiz can tell us anything about screen advertising and the transformation of screen cultures, it is first of all that moving image advertising cannot be reduced to what for decades has been the epitome of advertising, the TV commercial. In her research on advertising after the network era in the United States, Amanda D. Lotz accounts for the emerging post-network norm, which includes, in addition to the 30 -second ad, multiple advertising strategies such as product placement, integration, branded entertainment, and sponsorship. ${ }^{19}$ To assume that these forms are totally new is obviously wrong, but to consider them as reappearing is equally incorrect, for they have never been absent. They may have been elsewhere, beyond the institutions of classical cinema and television, and

\footnotetext{
16 Peterson, Education in the School of Dreams, 2.

17 Tom Gunning, 'The World as Object Lesson: Cinema Audiences, Visual Culture and the St. Louis World Fair, 1904', Film History 6 (1994): 422-444, here 427.

18 Gunning, 'The World as Object Lesson', 441.

19 Amanda D. Lotz, The Television Will Be Revolutionized (New York: New York University Press, 2007), 153 .
} 
for a long time also beyond scholarly attention. With the digital turn, the emergence of networked and social media, the proliferation of digital screens, and the proclamation of the 'post-cinema' and 'post-television' era, screen advertising has multiplied as well as diversified and now comes in new shapes, formats, and scales. However, in their basic structure, some of these forms and strategies have been utterly robust - product placement being a case in point. As process films illustrate, there have been efforts to efface boundaries between content and advertising and attempts to turn advertising into content and content into advertising since the beginning of moving images. Seen in this light, screen advertising does not appear as a weak and ephemeral object and practice, as is often claimed, but on the contrary as an extremely robust one.

If I underline the robustness or persistence of screen advertising, as other contributions in this book do (see the 'Introduction', for instance), it is not to argue for a discontinuity of historical change between, let's say, 1909 and today's digital multimedia and convergence culture. Instead, while acknowledging the persistence of screen advertising in transformative media cultures, the authors of this book advocate for a downsized, localized analysis of screen advertising that takes into account historical peculiarities, which has also been termed the 'sited-ness' of moving images, that is, to quote Gregory A. Waller, 'the varied and historically specific ways that motion pictures have been put to a host of different uses across a wide range of locations well beyond the commercial movie theatre.. ${ }^{20}$ This is to say that the 'robustness' of screen advertising had historically specific, localized appearances, and needs be studied as such.

With its strategy to provide instruction together with entertainment, and to brand both, Milcherzeugung in der Schweiz is an example of how entertainment, instruction, and advertising were found together in early cinema. Thus, the film stands as much for a new mass media culture as it does for a new commercial culture. However, cinema and moving images were never outside of commercial culture, but have rather been part and parcel of it from the very beginnings. Or, as Musser has put it, 'Audiences may have routinely paid good money to be entertained, informed or even instructed; but many of these films were implicitly - and sometimes explicitly - serving an advertising or promotional agenda'. ${ }^{21}$ Examining the

20 Gregory A. Waller, 'International Harvester, Business Screen and the History of Advertising Film', in Films That Sell, ed. Florin, de Klerk, and Vonderau, 40-53, here 40.

21 Charles Musser, 'Early Advertising and Promotional Films, 1893-1900', in Films That Sell, ed. Florin, de Klerk, and Vonderau, 83-90, here 83. 
subjects produced at Edison's Black Maria film studio and/or distributed by the Edison Manufacturing Company in the late nineteenth century from the angle of advertising, Musser concludes that most films become a form of advertising or publicity for someone, something, or somewhere. The forms that he describes include advertising films explicitly made for open-air advertising, but which were occasionally screened in theatrical and other settings (such as Admiral Cigarette [1897] or Dewar's Scotch Whisky [1898], both can presently be seen on YouTube); product placements and sponsoring; various examples of criss-crossing mutual endorsements of variety performers, Edison, and the kinetoscope; and direct forms of selfpromotion - the latter strategy introduced by the Lumière brothers whose films endorsed themselves, their family, their customers, their factory, and, most importantly, their new device, the Cinématographe Lumière. In the era of an emergent consumer society, Edison's early films embody a dialectical tension, according to Musser, in that they both act as a new commodity form and promote other kinds of services and commodities: 'In a multiplicity of ways, the motion-picture industry was intensively engaged in the commodification of culture from its earliest years.' ${ }^{22}$

This entanglement of entertainment culture and advertising was, however, by no means a specific feature of the us film industry, but was also part and parcel of European visual culture. It is noteworthy that the concessionaires for the Cinématographe Lumière in England, Germany, and Switzerland were a variety performer (Félicien Trewey); a sales manager of Stollwerck Bros \& $\mathrm{Co}$, Germany's leading chocolate manufacturer before World War I (Ludwig Stollwerck); and the Swiss importer of Sunlight Soap, manufactured by British Lever Brothers (François-Henri Lavanchy-Clarke). Trewey, Stollwerck, and Lavanchy-Clarke were all involved in the entertainment industry, and all drew on the commercial and promotional potential of the Cinematographe in the service of their pre-existing businesses. It was most probably Stollwerck's interest in automated candy vending machines that brought him to mechanical entertainment. Similar motives led Lavanchy-Clarke to co-found, together with Stollwerck, Georges Demenÿ's Société générale du Phonoscope (1892-1895). ${ }^{23}$ In March 1895, Stollwerck opened the first

22 Ibid., 89.

23 Roland Cosandey, 'Lavanchy-Clarke, François-Henry', in Encyclopedia of Early Cinema, ed. Richard Abel (London and New York: Routledge, 2005), 373. For a detailed account, see Martin Loiperdinger and Roland Cosandey, eds., 'L'Introduction du Cinématographe en Allemagne: De la case Demeny à la case Lumière: Stollwerck, Lavanchy-Clarke et al., 1892-1896', Archives, no. $5^{1}$ (November 1992): 16. On Trewey, see John Barnes and Stephen Herbert, 'Félicien Trewey', in Who's Who of Victorian Cinema, http://www.victorian-cinema.net/trewey (last accessed 5 April 2021). 
Kinetoscope parlour in Germany, and in March 1896, he bought the German rights to the Cinématographe Lumière. The first film screening began in Cologne one month later. ${ }^{24}$ As Loiperdinger's research into Stollwerck's business with living pictures has shown, Stollwerck's motivation to invest in the Cinématographe Lumière was to provide an additional popular attraction to his new branch, the permanent exhibition of entertainment machines such as Edison's phonograph and kinetoscope and machines for stereoscope images. The aim was to entice both business partners interested in buying machines as well as a broad audience fascinated by the pleasure the machines offered. In this way, Stollwerck used the Cinématographe Lumière as a side business that enriched the patron's machine exhibitions and promoted the 'modern' image of the company - and as such, if indirectly, also enhanced Stollwerck's main business, the selling of chocolate. ${ }^{25}$

In a somewhat similar vein, Lavanchy-Clarke obtained the rights to exploit the Cinématographe Lumière in Switzerland with the aim to promote Sunlight products. As Roland Cosandey and Jean-Marie Pastor have shown, the Swiss subjects recorded in the Catalogue Lumière (and filmed for the most part by cameraman Constant Girel), mainly derive from this concession. The first film screenings took place on the occasion of the Swiss national exposition in Geneva on 6 May 1896 in the Palais des Fées, which was part of the amusement park adjunct to the exhibition. ${ }^{26}$ Remarkably, from a total of 199 films shot with the Cinémathographe Lumière and deposited in France in 1979 by Lavanchy-Clarke's grandson Jack W. Lavanchy, about forty are not listed in the Catalogue Lumière. ${ }^{27}$ The reason for their absence is that they are either home movies or directly linked to promotional activities. Interestingly enough, there are some explicit promotional views that do figure in the Catalogue, among them Laveuses (Laundresses, also known as Washing Day in Switzerland) discussed in my chapter 'Advertising's Self-Reference'. There are other examples such as Défilé du 8e Bataillon (Deployment of the $8^{\text {th }}$ Battalion; my translation), Vue Lumière no. 316 , shot in Lausanne at Place St François in 1896. This film, which is less than a minute long, depicts the deployment of a battalion marching from the left background of the frame to the right, the left foreground lined with

24 Martin Loiperdinger, 'Stollwerck, Ludwig', in Encyclopedia of Early Cinema, ed. Abel, 612-613, here 612 .

25 Martin Loiperdinger, Film \& Schokolade. Stollwercks Geschäfte mit lebenden Bildern (Frankfurt and Basel: Stroemfeld, 1999).

26 Roland Cosandey and Jean-Marie Pastor, 'Lavanchy-Clarke: Sunlight \& Lumière, ou les debuts du cinématographe en Suisse', Equinox, no. 7 (June 1992), 9-27, here 13.

27 Ibid., 24. 


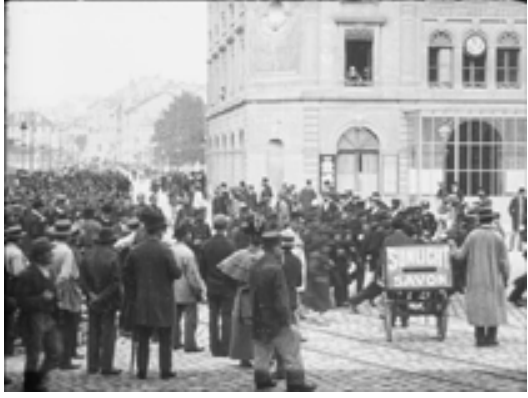

Figure 1.16: Screenshot from Défilé du $8 e$ Bataillon, vue Lumière, 1896.

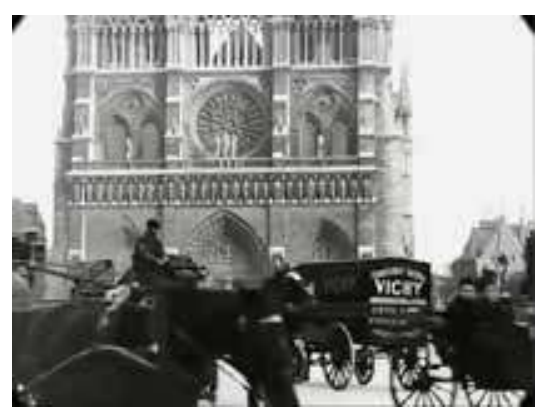

Figure 1.17: Screenshot from Parvis de NotreDame, vue Lumière, 1986.

spectators. A third of the way through the film, a man enters the scene from the right, pulling a handcart that displays a panel reading 'Sunlight Savon' (Sunlight soap). With the cart, Lavanchy-Clarke himself makes a short entrance, thus 'signing' the view, as was typical for him. Two-thirds into the film, the cart is in place, eye-catching and impossible to ignore the space in front of the sign is not crowded, so the spectator has a clear view of it. It is hard to imagine a blunter product placement. According to Newell, Salmon, and Chang, product placement in mass media began with the beginnings of motion-picture projection in the mid 189os. In their historical account on product placement, Lavanchy-Clarke figures as the first to use this strategy. ${ }^{28}$ Whether he was the first is less important than recognizing that he was definitely not the only one. It suffices to refer to Parvis de Notre-Dame shot on 25 October 1896 (Vue Lumière no. 691), ${ }^{29}$ in which a horse-drawn carriage with prominent advertising for Vichy on the back crosses the image in a diagonal from the right foreground to the centre middle ground, right in front of the cathedral.

Clearly, moving images and advertising do not have separate histories, for hardly any films at that time can be understood outside advertising financing practices. In particular, advertising was much more prominent in early cinema than written sources suggest. Musser's comment on Edison's advertising practices is also pertinent in Lavanchy-Clarke's case: 'What is striking is the way in which such signing went unacknowledged in catalogue

28 Newell, Salmon, and Chang, 'The Hidden History of Product Placement', 575-594.

29 https://catalogue-lumiere.com/parvis-de-notre-dame/ (last accessed 5 April 2021). The film is accessible on YouTube: https://www.youtube.com/watch?v=2eXu7IMM-yQ (last accessed 5 April 2021). 
descriptions' $3^{0}$ This practice of effacing traces of advertising in written documents has contributed to the fact that product placement's past is a 'hidden history', as Newell, Salmon, and Chang have put it. ${ }^{31}$ In this sense, screen advertising is at the same time persistent and ephemeral. Or, to put it differently, the ephemeral nature of screen advertising has obscured its robustness. From a methodological perspective, this instance hints at the necessity of combining, wherever possible, discourse analysis on cinema and advertising in specialist publications and the general press (a method that has taken off, especially in the United States, with the extensive digitization of relevant magazines) with textual analysis. This is to argue that the emergence of new, and for certain purposes extremely useful, digital research methods does not make established analytical methods such as close readings, individual and serial analysis, and heuristics superfluous, but that it provides an extension of the historiographical toolbox, which works best if tools are used together in a meaningful manner.

\section{Cross-Branding Film, Consumer Culture, and National Economies}

Lavanchy-Clarke's moving images advertised both Sunlight's laundry soap and Lumière's technological novelty, the Cinematographe. Milcherzeugung in der Schweiz advertises the Bear Brand and the corporation that produces it, the Bernese Alps Milk Company (BAMG), to international audiences, for company and brand names are in English throughout the film. We do not know whether BAMG actively commissioned the film from Pathé or whether Pathé initiated the production and BAMG paid for it (in whole or in part), for there are no archive materials that illuminate the case.$^{32}$ It is also not known whether BAMG used the film for its own promotional activities

30 Musser, 'Early Advertising and Promotional Films, 1893-1900', 88.

31 Newell, Salmon, and Chang, 'The Hidden History of Product Placement', 575-594.

32 Email correspondence with Tanja Aenis, archivist at Nestlé Historical Archives, Vevey, 21 September 2018. Nestlé took over BAMG in 1971, which was then part of the Ursina-Franck group. No company archive exists. The Dorfmuseum alter Bären (Village Museum Old Bear - an old tavern) in Konolfingen has preserved a large number of company documents, but they are tacit about Milcherzeugung in der Schweiz. As a side note, BAMG achieved its breakthrough in 1895, three years after it was founded, when it succeeded in producing an exportable unsweetened condensed milk, the Bärenmarke. On the company history, see Christoph Zürcher, 'Berneralpen Milchgesellschaft', in Historisches Lexikon der Schweiz / Dictionnaire historique de la Suisse / Dizionario storico della Svizzera, 16 Sepember 2010, http://www.hls-dhs-dss.ch/textes/d/D42024. php (last accessed 5 April 2021). 
(although comparable cases would suggest this). As the title indicates, Milcherzeugung in der Schweiz not only advertises a specific company and brand but also a country. As Kessler has outlined, it was a production strategy at Pathé to make films, whether fiction or non-fiction, that are distinguishable by national characteristics, through the use of folkloristic national stereotypes. Hence the highlighting of stereotyped markers of Switzerland such as the traditional costumes of the farmers, the alpine landscape, and cows. This was also probably the motivation to make a film about a milk product and include both 'milk' and 'Switzerland' in the title. Milcherzeugung in der Schweiz uses the same strategies of imagery to brand the film 'Swiss' as Herstellung von holländischem Käse / Comment se fait le fromage de Hollande (The Production of Dutch Cheese, 1909) uses in the opening scenes to brand the film as 'Dutch'. It is in the openings that process films resemble place films the most, because they adopt the visual rhetoric of travelogues as well as their pragmatics to not only substitute for real travel but also encourage real travel. In that sense, early process films helped shape stereotypical ideas about the world and promoted not only companies and brands but also nations as travel and tourist destinations.

At the same time, Milcherzeugung in der Schweiz is a Pathé brand product, which brings us back to cinema and popular entertainment. The film's opening title card announces 'Farbenkinematographie von Pathé Frères' (Colour cinematography by Pathé Frères; my translation), typed in a saturated yellow on a black background that sets the standard for all of the title cards to come. It announces Pathécolor, a stencil-colouring procedure that Pathé patented in 1905 and that was often combined with tinting and toning, as is the case here (for tinting, at least). There were rivalling colour procedures at the time, such as Kinemacolor and Chronochrome (also known as Gaumontcolor), but these techniques required a special projector or were to be seen only in Paris. Not so for Pathécolor, which was widely shown for over 20 years. ${ }^{33}$

Retracing advertising strategies of movie production companies before 1915, Richard Abel has noticed that distinctive trademarks such as George Méliès's 'star', Kleine Optical's doubly circled K, and Pathé's French cockerel 'tinted red on its film prints' appeared as early as 1902, followed shortly by Vitagraph's and Biograph's trademarks. ${ }^{34}$ According to Abel, Pathé was the

33 Mariann Lewinsky, 'Grand Tour of the World in Colour: A Guide to the DVD Set', in I Colori Ritrovati: Kinemacolor e altre magie / Kinemacolor and Other Magic, ed. Mariann Lewinsky and Luke McKernan, DVD booklet (Bologna: Edizioni Cineteca di Bologna, 2017), 28-31, here 29.

34 Richard Abel, 'From Pathé to Paramount: Visual Design in Movie Advertising to 1915', in The Image in Early Cinema: Form and Material, ed. Scott Curtis, Philippe Gauthier, Tom Gunning, and Joshua Yumibe (Bloomington: Indiana University Press, 2018), 78-93, here 80. For a more 

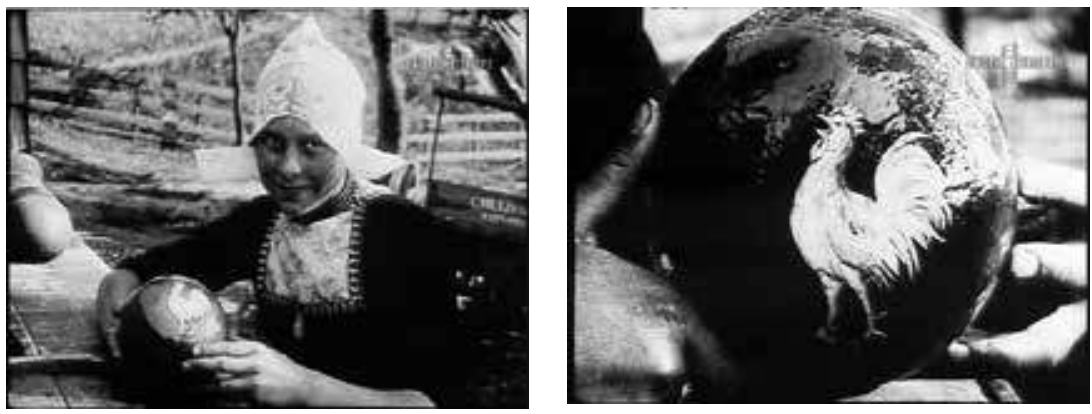

Figures 1.18-1.19: Screenshots from Herstellung von holländischem Käse (Pathé Frères, 1909).

first company to place ads in American daily press, in 1908. The ads were designed to look like film title cards and intended to persuade the public that good moving picture theatres would use only 'pictures with the well-known little red rooster' trademark. ${ }^{35}$

Pathé also found creative ways to promote its red rooster trademark in black-and-white films, as Herstellung von holländischem Käse illustrates. While this process film does not advertise particular cheeses or cheese brands, instead portraying the making of cheese as an artisanal production process, it does prominently stage the industrial scale of cheese production, sales, and international export. ${ }^{36}$ The last title card 'Cheese for export (Painted red)' announces shots that depict two women in costumes who colour wheels of cheese for international export and one woman in a close-up who takes great care to paint something onto some cheese. This something turns out to be, as we discover when she turns the cheese and, with a smile, looks directly into the camera - Pathé's (supposedly red) rooster. The final shot is a full-screen image of a wheel of cheese with a cockerel on it. Abel describes the Pathé red rooster as a kind of 'supersalesman' for the company's films as they travelled the globe, and he holds that Pathé was probably the first film producer 'to use the trademark much like the American companies selling packaged soaps or cereals: it forged a direct link to consumers' ${ }^{37}$ This illustrates how Pathé films were advertised as brand products.

detailed account, see Richard Abel, The Red Rooster Scare: Making Cinema American, 190o-1910 (Berkeley, Los Angeles, and London: University of California Press, 1999).

35 Pathé ad in Chicago Sunday Tribune (5 April 1908): 3.2, quoted in Abel, 'From Pathé to Paramount', 82.

$3^{6}$ On the generic status of the film, see the discussion in Kessler and Masson, 'Layers of Cheese', $75^{-84 .}$

37 Abel, The Red Rooster Scare, 18-19. 
Pathé adhered to this promotional strategy when cinema converted to sound and Pathé-Natan, France's largest production company at the time, advertised the fidelity of Pathé sound films just as much as it advertised Renault and the French automobile industry in a 1934 Pathé journal such as L'Automobile de France, which was dedicated 'To the Glory of the French Industry' (my translation), as one of the opening title cards indicates. With sound being very much a central thematic focus of the film, Pathé presents itself as part of this national industry whose grandeur the film praises..$^{3}$ In fact, as Stéphanie Salmon has retraced, Pathé had already adopted the national emblem of France, the cockerel, as the trademark for the company by 1898 , when Pathé invested in the phonograph and the rooster was used to advertise the sound device with the words 'Je chante haut et clair' (I sing with a high and clear voice; my translation)..${ }^{39}$ With the conversion to sound, Pathé could prove its ability to deliver on this early advertising claim also in cinema. From this perspective, Milcherzeugung in der Schweiz is an early example of Pathé's long-term strategy to cross-brand and cross-merchandise entertainment products with consumer goods, while at the same time putting films in the service of national stereotypes, identities, and economies.

\section{Advertising and Paid Placement versus Non-Paid Placement}

Some scholars have suggested distinguishing advertising from other promotional forms by drawing a distinction between paid placement (the defining feature of advertising) and non-paid placement. While it is evident that paid placement is a marker for advertising intentions, there are myriad examples of non-paid placements that are equally made for advertising purposes - viral ads are among the latest examples. BAMG may or may not have paid for the production of Milcherzeugung in der Schweiz; it certainly did not pay for its placement in commercial cinemas. The film figured in the Pathé catalogue, which indicates that it was for sale and rent to cinema

$3^{8}$ The film circulates on the internet and can be found here, for example: http://louisrenault. com/2015/12/23/automobilefrance2808/ (last accessed 5 April 2021). On the film (if not on Pathé's cross-branding in particular), see Alain P. Michel, Travail à la chaîne: Renault $1898-1947$ (Boulogne-Billancourt: Editions ETAI, 2008), 108-115; Alain P. Michel, 'On the Cover: An Image mise en abyme', Technology \& Culture (October 2008): 967-973. On Pathé and the conversion to sound in France, see Charles O'Brien, Cinema's Conversion to Sound: Technology and Film Style in France and the U.S. (Bloomington: Indiana University Press, 2005).

39 See the advertisement in Stéphanie Salmon, Pathé: A la conquête du cinéma 1896-1929 (Paris: Edition Tallandier, 2014), illustration no. 9, n.p. 
owners worldwide. This means that the latter would pay for the placement of a film such as Milcherzeugung in der Schweiz - a film that cross-promotes two companies, two brands, and two countries - and endorses an underlying ideology of capitalism, colonialism, and consumption. To exclude such films from studies on moving image advertising would make it difficult if not impossible to acknowledge the variety and complexity of advertising objects, screens, and practices over time.

In the United States in the mid 1910s, however, advertising films, including process films, were a supplement to the regular programme, which meant that companies and other advertisers paid for the placement of their films. ${ }^{40}$ Whether the placement of moving image advertising was paid for depended not so much on the advertising rhetoric intrinsic to the moving images, the filmic text, but on the placement, that is on the specific places in which they were screened. This again illustrates the 'sited-ness' of screen advertising and the necessity to adopt a localized analytical perspective that takes into account the specific exhibition contexts and particular uses of moving images. In the case of process films, as with other films also considered of educational value, whether fictional or non-fictional, the very same films would circulate in a variety of institutional contexts and were framed in manifold ways, as the growing body of research of useful cinema has shown. Some exhibitions were paid placements; others were not. Whether films served mainly promotional, entertainment, or educational purposes depended as much (if not more) on the off-screen framing of the exhibition than on the on-screen presence of markers. Corporations would often donate process films to distributors of classroom films, which rented such films to schools. Thus, they made educational institutions seeking instruction pay for advertising. ${ }^{41}$ Hence, advertising has been the price for access to information and entertainment not only since the rise of online media cultures, but since the earliest days of moving images.

At the same time, advertising films turned into educational films on their trajectory to the classroom, which is to say that the generic identity of such films was not fixed, but flexible, and would change with changing institutional exhibition contexts. ${ }^{42}$ This is another facet of the persistent,

40 See Dench, Advertising by Motion Pictures, 47. See also Jeremy Groskopf, 'Profit Margins: Silent Era Precursors of Online Advertising Tactics', Film History 24, 1 (2012): 82-96.

41 See, for example, Yvonne Zimmermann, ed., Schaufenster Schweiz: Dokumentarische Gebrauchsfilme 1896-1964 (Zurich: Limmat, 2011).

42 This could be read as a response to Waller's question about how much generic identity depends on when and where a film is exhibited. See Waller, 'International Harvester', 5o. On the question of genre and screen advertising, see Yvonne Zimmermann, 'Advertising and 
yet at the same time ephemeral nature of screen advertising; other aspects of this quality are the performative character of off-screen framings in specific exhibitions through live commentary, discussions, and give-aways, for example. The filmic text, then, was and is but a potential (or, metaphorically speaking, a projection): a potential for entertainment, education, and advertising. When screened, all potentials are actualized. But which ones are accented depend on the specific exhibition event.

\section{Colour, High-End Advertising, and Colonial Imagery}

The last section of this essay leaves exhibition and turns to Milcherzeugung in der Schweiz as a film in itself and to its colour aesthetics. In the first decade of the 190os, Pathé was the leading film production company internationally. This dominance was largely due to the success of Pathé's colouring processes and practices. ${ }^{43}$ Pathé was particularly known for its stencilling, which, according to Joshua Yumibe, reached a technical high point in terms of precision for the cutting of the stencils and for the dye-application process by the end of the decade. ${ }^{44}$ While in the 'cinema of attractions' years leading up to 1907 , colour was mainly seen in the trick and fairy genres, Pathé expanded production of colour films to historical dramas, films d'art (literary adaptations), and non-fiction - among them most prominently travelogues and process films. Yumibe has observed that, with these changes, Pathé 'crafted its colouring styles to be subdued, genteel, and less saturated, a stylistic emphasis that resonated better with the emerging norms of unobtrusive narration, for light, pastel hues could be deployed in ways less distracting to the eye'. ${ }^{45}$ This stylistic development is certainly the case for fictional genres, if not for travelogues and process films in general, because the latter continued to bear typical features of the cinema of attractions such as the exhibitionist gesture of display, the importance of the act of looking, direct

Film: A Topological Approach', in Films That Sell, ed. Florin, de Klerk, and Vonderau, 21-39. A useful genre taxonomy according to distribution and exhibition contexts is suggested by Ralf Forster, Ufa und Nordmark: Zwei Firmengeschichten und der deutsche Werbefilm 1919-1945 (Trier: Wissenschaftlicher Verlag Trier, 2005), 27-44.

43 See Abel, The Red Rooster Scare.

44 Joshua Yumibe, 'The Color Image', in The Image in Early Cinema, ed. Curtis, Gauthier, Gunning, and Yumibe, 142-150, here 144. See also Joshua Yumibe, Moving Color: Early Film, Mass Culture, Modernism (New Brunswick: Rutgers University Press, 2012).

45 Yumibe, 'The Color Image', 144. 
audience address, and frequent looks into the camera. ${ }^{46}$ Colour was part of this stylistic repertoire, for early cinema's applied colours added a special attraction to films shot in black and white. Films would be sold in black and white or in colour, with colour being a selling point and commercial factor. Colour films were expensive, but they stood out in the programmes and functioned as a means of drawing attention - a function that is key to advertising and also a main feature of the cinema of attractions. Or, as Daan Hertogs has put it, 'stencilled nonfiction films are the ideal tool for demonstrating that a spectator cannot afford to miss anything going on on the screen'. ${ }^{47}$ Underlining the role of colour for the conception of advertising in the emerging mass consumer culture, Gunning holds that colour was not only a means to draw attention to advertisements themselves, but also a way of 'endowing consumer goods with an indefinable surplus to their use value'. ${ }^{48}$ With its sophisticated colour scheme combining stencilling and tinting, Milcherzeugung in der Schweiz was a prestige product for both Pathé and BAMG, with colour testifying to the quality of the moving picture and of what it depicts: BAMG's condensed milk.

On a reflexive conceptual and methodological note, taking a film with appealing aesthetic features and high production values as an example is an approach typical not only in film historiography but also in studies on screen advertising. With its focus on remarkable advertising campaigns, funny self-referential commercials, stylish advertisements made by people with a name in the film industry and/or the art scene, and on discourses that intersect with prominent figures from acknowledged academic fields such as the documentary and the avant-garde, the present book is no exception. The observations that John Ellis has made in his work on interstitials and how they define television programmes may serve as a valid justification for this approach: holding that product differentiation (as the main function of interstitials) needs both explanation and aestheticization of products, commercials and interstitials in general produce a sense of beauty (with the help of greater production values) that makes them stand out from the

46 The features of the cinema of attractions are described in Tom Gunning, 'The Cinema of Attractions: Early Film, Its Spectator and the Avant Garde', in Early Cinema: Space Frame Narrative, ed. Thomas Elsaesser (London: British Film Institute, 1990 [1986]), 56-62.

47 Daan Hertogs, 'Attention Essential: Coloured Nonfiction Films from the 1910s', in Uncharted Territory, ed. Hertogs and de Klerk, 97-103, here 101.

48 Tom Gunning, 'Colorful Metaphors: The Attraction of Color in Early Silent Cinema', Fotogenia: Storie e teorie del cinema, Il colore nel cinema 1 (1995): 249-255,

https://archivi.dar.unibo.it/files/muspe/wwcat/period/fotogen/numo1/numerold.html (last accessed 5 April 2021). The essay is also published in Living Pictures 2.2 (2003): 4-13. 
rest of the TV programme. In the elegance and perfection of their images, interstitials, according to Ellis, 'present a vision of television as it could be [...] if only it were even more costly that it already is. ${ }^{49}$ To stand out, cinema and TV commercials generally have had more production resources per minute than feature fiction films or Tv broadcasts. So did Milcherzeugung in der Schweiz, in comparison to longer narrative black-and-white films in the programmes.

The academic predilection for the exceptional in advertising, for innovative advertising campaigns, advanced aesthetics, and the signature of acknowledged authors is paired with little interest in the overwhelming number of upfront, dull, boring, and often annoying commercials that we come across anywhere and any time. This tendency to neglect the large quantity of neither outstanding nor particularly poor, but mediocre advertisements stands in opposition to our ordinary experiences, which are characterized by average advertising objects and practices that all seem to look more or less the same. The robust mediocrity - another facet of the robustness of advertising - and the sameness of moving image advertising and advertisements could be a productive epistemic field to complement studies on the exceptional and outstanding, and provide new insights especially into phases of continuity and stability in the history of advertising media and screen cultures at large. Other related and as yet largely neglected areas are local advertising as well as semi-professional and amateur advertising objects, screens, and practices, which are often hard to mine due to their small production and dissemination scale. They may have left little trace individually, but taken as a whole, these advertisements and advertising practices have been extremely widespread, and therefore make a pertinent object for further studies.

On a final note, I would like to return to high-end and large-scale advertising, and to Milcherzeugung in der Schweiz. Discovering the richness of early colour films at a workshop at what was then the Netherlands Film Museum in Amsterdam in 1995, early cinema scholars were baffled by the 'disorderly order' of colouring practices, because they could not find colour codes that applied to all films..$^{0}$ They noticed that some production companies such

49 John Ellis, 'Interstitials: How the "Bits in Between" Define the Programmes', in Ephemeral Media: Transitory Screen Culture from Television to YouTube, ed. Paul Graine (London: Palgrave Macmillan, 2011), 59-69, here 99.

$5^{0}$ See Daan Hertogs and Nico de Klerk, eds., Disorderly Order: Colours in Silent Film (Amsterdam: Stichting Nederlands Filmmuseum, 1996). 
as Film d'Arte Italiana and Pathé stencilled more or less systematically for some genres, but also found that, in addition to the codes, there was a fair amount of free variation. ${ }^{51}$ Process films produced by Pathé were among those genres that were highly standardized also in regard to colouring, based on my observations of examples researched in film and corporate archives or made available on DVD, and Milcherzeugung in der Schweiz is a case in point. In early cinema, both hand-colouring and stencilling were at times used to heighten the realism of the moving images, but more often than not, they were applied for aesthetic and artistic purposes, thus eschewing naturalism in favour of sensationalism and adding a painterly and metaphorical quality to the images. ${ }^{2}$ In the pastoral opening of Milcherzeugung in der Schweiz, the stencilling draws attention to certain bucolic and visually attractive aspects such as the traditional costumes, the cowbell shimmering in bronze, and the trees blooming in pastel purple and white. In other words, all the features that refer to an idea of a pristine mountain place and a traditional way of working and living are highlighted through colouring. With the milking of the cow, the film switches from stencilling to tinting (a procedure in which black-and-white film strips were soaked in dye) and presents the scene in saturated sepia. Another noticeable change in colour occurs in the next view, which marks the dispatch of the milk to the factory and which is tinted in blue, the coded blue-for-night or dawn colour, which serves as a temporal marker in this case. From here onwards, the film is tinted. The testing of the milk as well as scenes of the indoor production processes are in sepia, whereas the two scenes (not following each other) that depict women wrapping cans are in pastel purple. The making of shipping cases - men's work - is presented in sepia again. Obviously, different working spaces are coloured differently according to gender. Finally, the loading of the goods on a freight train is tinted in blue again, signalling both an outdoor activity in contrast to the indoor manufacturing processes and a time shift.

Overall, the film takes great care to change colours frequently in order to provide visual diversity. At the same time, the colour changes work as attention-grabbers. Colours are a visual effect to attract viewer attention, and at the same time function as temporal and spatial markers in that they orient the viewer to time of day and to locations, including gendered work spheres. They have both a crucial aesthetic and a narrative function. In the final scene, the film changes from tinting to stencilling again. This colour change emphasizes the switch in rhetoric and audience address 
from indirect to direct, appellative address, and the change of sphere from production to consumption.

My contention is that in using stencilling for the extraction of raw material and the consumption of the final product - that is, for views that depict either the traditional and the 'exotic' or the pleasures of consumption - and in using tinting for the presentation of industrial production processes, Milcherzeugung in der Schweiz is an exemplary case for process films in Pathécolor around 1910. To support this thesis, I would like to turn to another process film produced by Pathé in 1909, Le Thé: culture, récolte et préparation industrielle (Tea: Cultivation, Harvesting, and Industrial Processing)..$^{53}$ Le Thé uses strikingly similar colour codes - namely, stencilling for the cultivation and harvesting of tea leaves in the opening scenes of the film, tinting for the industrial processing of raw material, and stencilling for the consumption of tea. Stencilling is both a marker for the exotic - the cultivation of tea in foreign territories (here, most probably in the former Ceylon, now Sri Lanka) - and for the exquisite - the preparation and consumption of tea in a bourgeois Victorian home. What Le Thé makes clearer than Milcherzeugung in der Schweiz is the fact that process films in the period of early cinema were aesthetically and ideologically proponents of a visual culture that was deeply entangled with ideas of colonialism and 'the exotic other', and colouring played a part in this. Stencilled non-fictional films are not 'uninterpreted fact', as Hertogs has underlined. Instead,

the filmmakers in the studios coloured the images and in doing so made choices. During the process of colouring, the filmmakers "interpret" the world that they see on the film (which they do not necessarily need to be familiar with in reality) [...] in an arbitrary manner. ${ }^{54}$

Like travelogues, process films address Western audiences, and they depict the world from a Western-centric perspective. Those who look at - and consume - the films are 'us'. Those who are looked at are 'them', 'the other' - 'other' in terms of habits, customs, race, and 'level of development', staged for the camera as 'exotic' visual attraction. Stencilling highlights the act of looking and depicts the 'imperial gaze' as a legitimate form of 'just looking', which, ideologically, is of course never innocent. At the same time, stencilling

53 The film is included in the DVD I Colori ritrovati: Kinemacolor e altre magie / Kinemacolor and Other Magic, ed. Mariann Lewinsky and Luke McKernan (Bologna: Cineteca di Bologna, 2017).

54 Hertogs, 'Attention Essential', 103. 

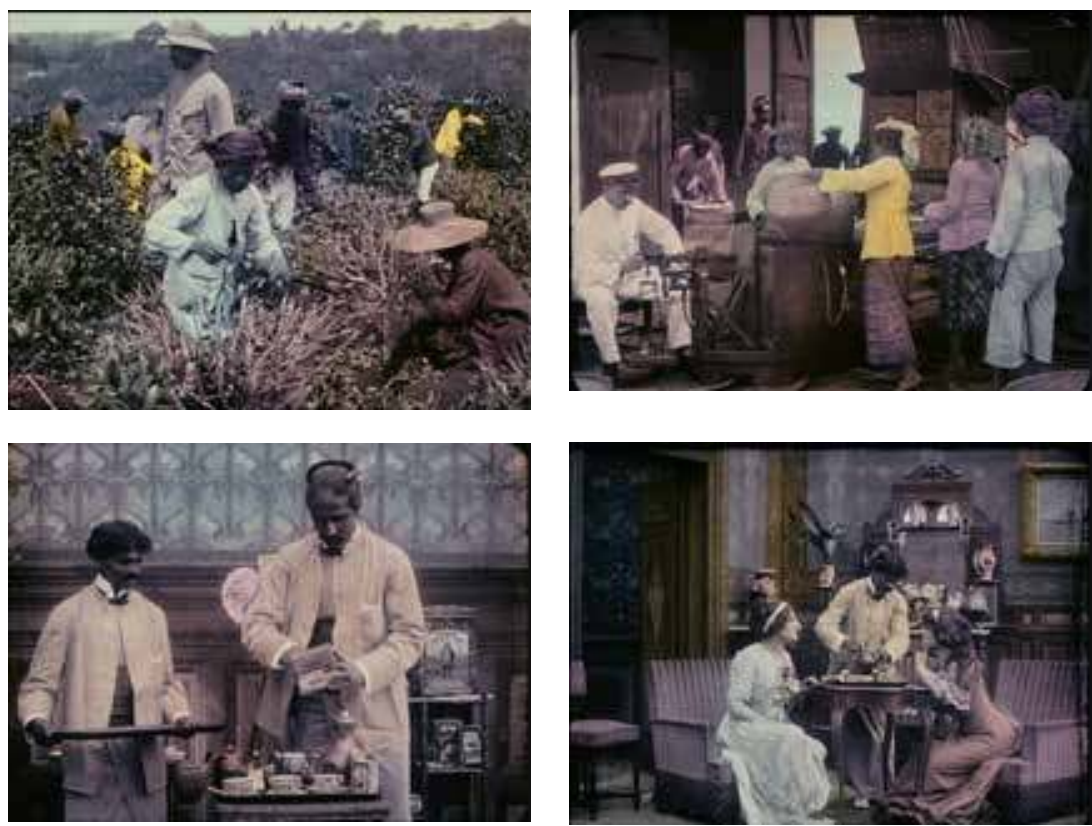

Figures 1.20-1.23: Screenshots from Le Thé: culture, récolte et préparation industrielle (Pathé Frères, 1909).

produces notions of racial difference and white supremacy alongside gender and class sensibilities. This not only accounts for process films that display raw material extraction in colonies overseas, but also for Milcherzeugung in der Schweiz, which, with the help of colour, depicts the Bernese Oberland as an 'internal colony'. The concept of internal colonialism emerged in the late 1950 s with the intention to generate attention to structural, political, and economic inequalities between regions within a state. According to Stephen Howe, internal colonialism refers to geographically close, yet culturally distinct locations (distinct in terms of language, physical appearance, technological development, etc.) and is used to describe the separation between centre and periphery, between metropole and colony. ${ }^{55}$ With the same narrative, aesthetic, rhetoric, and ideological use of colouring, Le Thé and Milcherzeugung in der Schweiz produce cultural differences. They depict

55 Stephen Howe, Empire: A Very Short Introduction (New York: Oxford University Press, 2002). On the current place of the concept of internal colonialism in postcolonial theory and social theory, see Paulo Henrique Martins, 'Internal Colonialism, Postcolonial Criticism and Social Theory', Revue du MAUSS permanente (11 August 2018), http://www.journaldumauss. net/./?Internal-Colonialism-Postcolonial-Criticism-and-Social-Theory (last accessed 5 April 2021). 
both the former Ceylon and the Bernese Oberland as traditional, primitive, and exotic 'other', distinct from an industrialized, modern, urban, and consumerist way of living. Process films not only adopted and propagated this perspective, they also helped legitimize and naturalize it. In this sense, Milcherzeugung in der Schweiz draws attention to advertising screen cultures' entanglement with colonial and imperial perceptions of the world.

\section{An Outlook Instead of a Conclusion}

Process films are particularly fascinating because they do not hide their imperial ideology, but rather exhibit it explicitly. The sheer visibility of white supremacy, racism, and segregation opens these films for postcolonial critique. Process films addressed cinema audiences worldwide and provided a common base of shared experiences of screen advertising in cinemas. This common base of collective experiences has been surprisingly stable throughout the history of screen advertising, if we think of television's decades-long ability to aggregate dispersed (national) publics, coupled with its predominance as advertising medium. With an emerging industry for big data capture, increasingly personalized advertising, and audience fragmentation, these shared public reference points disaggregate progressively in contemporary digital media cultures. Along with this trend, advertisements as objects of study also disaggregate, since researchers can no longer count on a common arena of advertising objects, audiences (designed as clear-cut target groups), and experiences..$^{6}$ While I have stressed the robustness of objects, screens, and practices of moving image advertising and highlighted continuities rather than changes, big data mining, personalization in advertising, and algorithms that customize advertisements according to gender, race, and domicile ${ }^{57}$ appear to be instantiations of a transition phase that represent significant methodological challenges. Such new forms of advertising produce new forms of racism and segregation that are far less visible, and thus less recognizable, examinable, and criticizable than ever before. Notwithstanding whether we want to see this as a genuinely

$5^{6}$ On personalized advertising and big data with regard to democracy, see Nick Couldry and Joseph Turow, 'Advertising, Big Data, and the Clearance of the Public Realm: Marketers' New Approaches to the Content Subsidy', International Journal of Communication 8 (2014): 1710-1726. 57 See Joseph Turow, The Daily You: How the Advertising Industry Is Defining Your Identity and Your Worth (New Haven: Yale University Press, 2012). See also, if less specific to advertising, Safiya Umoja Noble, Alogrithms of Oppression: How Search Engines Reinforce Racism (New York: New York University Press, 2018). 
new development in screen advertising or, as I would argue, as a new level of robustness - and ephemerality - it is a development that calls for our critical attention.

\section{Bibliography}

Abel, Richard. 'From Pathé to Paramount: Visual Design in Movie Advertising to 1915.' In The Image in Early Cinema: Form and Material, edited by Scott Curtis, Philippe Gauthier, Tom Gunning, and Joshua Yumibe, 78-93. Bloomington: Indiana University Press, 2018.

Abel, Richard. The Red Rooster Scare: Making Cinema American, 1900-1910. Berkeley, Los Angeles, and London: University of California Press, 1999.

Barnes, John, and Stephen Herbert. 'Félicien Trewey.' In Who's Who of Victorian Cinema, http://www.victorian-cinema.net/trewey. Last accessed 5 April 2021. Cosandey, Roland. 'Lavanchy-Clarke, François-Henry.' In Encyclopedia of Early Cinema, edited by Richard Abel, 373. London and New York: Routledge, 2005.

Cosandey, Roland, and Jean-Marie Pastor. 'Lavanchy-Clarke: Sunlight \& Lumière, ou les debuts du cinématographe en Suisse.' Equinox, no. 7 (June 1992): 9-27.

Couldry, Nick, and Joseph Turow. 'Advertising, Big Data, and the Clearance of the Public Realm: Marketers' New Approaches to the Content Subsidy.' International Journal of Communication 8 (2014): 1710-1726.

Dench, Ernest A. Advertising by Motion Pictures. Cincinnati: Standard Publishing Company, 1916.

Ellis, John. 'Interstitials: How the "Bits in Between" Define the Programmes.' In Ephemeral Media: Transitory Screen Culture from Television to YouTube, edited by Paul Graine, 59-69. London: Palgrave Macmillan, 2011.

Forster, Ralf. Ufa und Nordmark: Zwei Firmengeschichten und der deutsche Werbefilm 1919-1945. Trier: Wissenschaftlicher Verlag Trier, 2005.

Gaines, Jane. 'From Elephants to Lux Soap: The Programming and "Flow" of Early Motion Picture Exploitation.' The Velvet Light Trap 25 (Spring 1990): 29-43.

Groskopf, Jeremy. 'Profit Margins: Silent Era Precursors of Online Advertising Tactics.' Film History 24, no. 1 (2012): 82-96.

Gunning, Tom. 'Before Documentary: Early Nonfiction Films and the "View" Aesthetic.' In Uncharted Territory: Essays on Early Nonfiction Film, edited by Daan Hertogs and Nico de Klerk, 9-24. Amsterdam: Stichting Nederlands Filmmuseum, 1997.

Gunning, Tom. 'Colorful Metaphors: The Attraction of Color in Early Silent Cinema.' In Fotogenia: Storie e teorie del cinema, Il colore nel cinema 1 (1995): 249-255, https://archivi.dar.unibo.it/files/muspe/wwcat/period/fotogen/numo1/numero1d.html. Last accessed 5 April 2021. 
Gunning, Tom. 'The Cinema of Attractions: Early Film, Its Spectator and the AvantGarde.' In Early Cinema: Space Frame Narrative, edited by Thomas Elsaesser, 56-62. London: British Film Institute, 1990 [1986].

Gunning, Tom. 'The World as Object Lesson: Cinema Audiences, Visual Culture and the St. Louis World Fair, 1904.' Film History 6 (1994): 422-444.

Hertogs, Daan. 'Attention Essential: Coloured Nonfiction Films from the 1910s.' In Uncharted Territory: Essays on Early Nonfiction Film, edited by Daan Hertogs and Nico de Klerk, 97-103. Amsterdam: Stichting Nederlands Filmmuseum, 1997.

Hertogs, Daan, and Nico de Klerk, eds. Disorderly Order: Colours in Silent Film. Amsterdam: Stichting Nederlands Filmmuseum, 1996.

Hertogs, Daan, and Nico de Klerk, eds. Nonfiction from the Teens. Amsterdam: Stichting Nederlands Filmmuseum, 1994.

Howe, Stephen. Empire: A Very Short Introduction. New York: Oxford University Press, 2002.

Kessler, Frank, and Eef Masson. 'Layers of Cheese: Generic Overlap in Early NonFiction Films on Production Processes.' In Films That Work: Industrial Film and the Productivity of Media, edited by Vinzenz Hediger and Patrick Vonderau, 75-84. Amsterdam: Amsterdam University Press, 2009.

Lewinsky, Mariann. 'Grand Tour of the World in Colour: A Guide to the DVD Set.' In I Colori Ritrovati: Kinemacolor e altre magie / Kinemacolor and Other Magic, edited by Mariann Lewinsky and Luke McKernan, DVD booklet, 28-31. Bologna: Edizioni Cineteca di Bologna, 2017.

Loiperdinger, Martin. 'Early Industrial Moving Pictures in Germany.' In Films That Work: Industrial Film and the Productivity of Media, edited by Vinzenz Hediger and Patrick Vonderau, 65-73. Amsterdam: Amsterdam University Press, 2009. Loiperdinger, Martin. Film \& Schokolade: Stollwercks Geschäfte mit lebenden Bildern. Basel: Stroemfeld, 1999 .

Loiperdinger, Martin. 'Stollwerck, Ludwig.' In Encyclopedia of Early Cinema, edited by Richard Abel, 612-613. London and New York: Routledge, 2005.

Loiperdinger, Martin, and Roland Cosandey, eds. 'L'Introduction du Cinématographe en Allemagne: De la case Demeny à la case Lumière: Stollwerck, Lavanchy-Clarke et al., 1892-96.' Archives, no. 51 (November 1992): 16.

Lotz, Amanda D. The Television Will Be Revolutionized. New York: New York University Press, 2007.

Martins, Paulo Henrique. 'Internal Colonialism, Postcolonial Criticism and Social Theory.' Revue du MAUSS permanente (11 August 2018), http://www.journaldumauss.net/./?Internal-Colonialism-Postcolonial-Criticism-and-Social-Theory. Last accessed 5 April 2021. 
Michel, Alain P. 'On the Cover: An Image mise en abyme.' Technology \& Culture (October 2008): 967-973.

Michel, Alain P. Travail à la chaîne: Renault 1898-1947. Boulogne-Billancourt: Editions ETAI, 2008.

Musser, Charles. 'Early Advertising and Promotional Films, 1893-190o.' In Films That Sell: Moving Pictures and Advertising, edited by Bo Florin, Nico de Klerk, and Patrick Vonderau, 83-9o. London and New York: Palgrave, 2016.

Newell, Jay, Charles T. Salmon, and Susan Chang. 'The Hidden History of Product Placement.'Journal of Broadcasting \& Electronic Media (December 2006): 575-594.

Noble, Safiya Umoja. Alogrithms of Oppression: How Search Engines Reinforce Racism. New York: New York University Press, 2018.

O'Brien, Charles. Cinema's Conversion to Sound: Technology and Film Style in France and the U.S. Bloomington: Indiana University Press, 2005.

Peterson, Jennifer Lynn. Education in the School of Dreams: Travelogues and Early Nonfiction Film. Durham, NC and London: Duke University Press, 2013.

Salmon, Stéphanie. Pathé: A la conquête du cinéma 1896-1929. Paris: Edition Tallandier, 2014.

Turow, Joseph. The Daily You: How the Advertising Industry Is Defining Your Identity and Your Worth. New Haven: Yale University Press, 2012.

Vonderau, Patrick. 'Introduction: On Advertising's Relation to Moving Images.' In Films That Sell: Moving Pictures and Advertising, edited by Bo Florin, Nico de Klerk, and Patrick Vonderau, 1-18. London and New York: Palgrave, 2016.

Vonderau, Patrick. 'Kim Novak and Morgan Stairways: Thinking about the Theory and History of the Tie-in.' In Films That Sell: Moving Pictures and Advertising, edited by Bo Florin, Nico de Klerk, and Patrick Vonderau, 209-220. London and New York: Palgrave, 2016.

Waller, Gregory A. 'International Harvester, Business Screen and the History of Advertising Film.' In Films That Sell: Moving Pictures and Advertising, edited by Bo Florin, Nico de Klerk, and Patrick Vonderau, 40-53. London and New York: Palgrave, 2016.

Yumibe, Joshua. Moving Color: Early Film, Mass Culture, Modernism. New Brunswick: Rutgers University Press, 2012.

Yumibe, Joshua. 'The Color Image.' In The Image in Early Cinema: Form and Material, edited by Scott Curtis, Philippe Gauthier, Tom Gunning, and Joshua Yumibe, 142-150. Bloomington: Indiana University Press, 2018.

Zimmermann, Yvonne. 'Advertising and Film: A Topological Approach.' In Films That Sell: Moving Pictures and Advertising, edited by Bo Florin, Nico de Klerk, and Patrick Vonderau, 21-39. London and New York: Palgrave, 2016. 
Zimmermann, Yvonne, ed. Schaufenster Schweiz: Dokumentarische Gebrauchsfilme 1896-1964. Zurich: Limmat, 2011.

Zürcher, Christoph. 'Berneralpen Milchgesellschaft.' In Historisches Lexikon der Schweiz / Dictionnaire historique de la Suisse / Dizionario storico della Svizzera, 16, September 2010, http://www.hls-dhs-dss.ch/textes/d/D42024.php. Last accessed 5 April 2021. 


\section{Part I}

Approaches and Methods 



\title{
2. Advertising and Modernity: A Critical Reassessment
}

\author{
Patrick Vonderau
}

\begin{abstract}
This chapter aims to deconstruct the category of modernity by confronting a prevailing abstracted view on screen advertising with the contingencies of its archival history. Taking as a case study the 196os 'cola wars' and the marketing of cola soft drinks, the chapter shows how this competition between Pepsi and Coke related to stylistic innovations such as montage sequences, and what relevant mid-level finds can be made regarding one specific Pepsi campaign of that era without indulging in overly general arguments about modernism or modernity.
\end{abstract}

Keywords: modernity, cola wars, spot commercial, creative revolution, Ed Vorkapich, montage

The most general and widespread category for thinking about advertising in the 20 th century seems to be the category of modernity. ${ }^{1}$ Advertising, historians tell us, has 'dreamed', 'made way for', and 'sold' modernity. ${ }^{2}$ It

1 My point here is to identify a categorial descriptivism (Brian Carr) in the way that 'modern' and 'modernity' are often spoken of when it comes to advertising: in academic discourse, modernity, the modern, or even modernism are used interchangeably not to describe a historical reality, but to draw out ontological categories and categories of meaning. My argument here largely follows Peter Osborne, Anywhere or Not at All: Philosophy of Contemporary Art (London: Verso, 2013) and Don Slater, 'Marketing as Monstrosity: The Impossible Place between Culture and Economy', in Inside Marketing. Practices, Ideologies, Devices, ed. Detlev Zwick and Julien Cayla (Oxford: Oxford University Press, 2010), 23-41.

2 See, for instance, Roland Marchand, Advertising the American Dream: Making Way for Modernity 1920-1940 (Berkeley and London: University of California Press, 1985); Pamela E. Swett, Jonathan Wiesen, and Jonathan R. Zaitlin, Selling Modernity: Advertising in Twentieth-Century Germany (Durham, NC: Duke University Press, 2007); or the advertising-related chapters in

Florin, B., P. Vonderau, Y. Zimmermann, Advertising and the Transformation of Screen Cultures. Amsterdam: Amsterdam University Press, 2021 DOI 10.5117/9789462989153_CHO2 
is seen as the very epitome or 'sign of sweeping change in modern society', forming part of interlocked processes of 'advertising-modernising' that often clashed with the sensibilities of 'avantgardists-modernists' of the past. ${ }^{3}$ In this view, advertising appears to be inextricably linked to art, urban life, and new technologies, promoting a visual culture that is said to have recast the nature of memory, experience, and desire. Consequently, it is also seen as having deeply affected the human sensorium, assaulted and reconfigured the subject, and contributed to the creation of cinematic or televisual spectatorship. ${ }^{4}$ Advertising has arguably 'metastasized [...] into a twentieth-century mechanism that radically reshaped the experience of idle flanerie into distraction with an applied purpose' ${ }^{5}$ Moving picture advertising, we are taught, has become integral to the genealogy of the dispositif, informing widespread public perceptions of corporate power, subliminal communication, and the 'terror' exerted by various 'influencing machines'. ${ }^{6}$ And even those that have come to critically distance themselves from the category of modernity, such as Jacques Rancière, still maintain that advertising historically introduced 'new styles' that proposed 'a new way of living amongst words, images, and commodities'.

Advertising, then, is also treated as a kind of category - one that is useful to frame and explain both the dynamics of the new and the unwanted effects, contradictions, and struggles at the core of what is understood to be 'modern'. While the adjective 'modern' has come to designate a 'new

Laura Markus, Dreams of Modernity: Psychoanalysis, Literature, Cinema (New York: Cambridge University Press, 2014).

3 Leo Charney and Vanessa R. Schwartz, eds., Cinema and the Invention of Modern Life (Berkeley: University of California Press, 1995), 125; Thomas Elsaesser, Weimar Cinema and After: Germany's Historical Imaginary (New York: Routledge, 2000), 394.

4 Anne Friedberg, Window Shopping: Cinema and the Postmodern (Berkeley: University of California Press, 1993), 37.

5 Janet Ward, Weimar Surfaces: Urban Visual Culture in 1920s Germany (Berkeley: University of California Press, 2001), 101.

6 Theodor W. Adorno, The Culture Industry: Selected Essays on Mass Culture (London and New York: Routledge, 1991), 47; Max Horkheimer and Theodor W. Adorno, Dialectics of Enlightenment: Philosophical Fragments, ed. Gunzelin Schmid Noerr, trans. Edmund Jephcott (Stanford: Stanford University Press, 2002), passim; Jeffrey Sconce, 'On the Origins of the Origins of the Influencing Machine', in Media Archaeology: Approaches, Applications, and Implications, ed. Erkki Huhtamo and Jussi Parikka (Berkeley and Los Angeles: University of California Press, 2011), 70-94; Charles R. Acland, Swift Viewing: The Popular Life of Subliminal Influence (Durham, NC: Duke University Press, 2011).

7 Jacques Rancière, The Politics of Aesthetics. Translated with an Introduction by Gabriel Rockhill (London: Continuum, 2004), 25. 
regime, an acceleration, a rupture, a revolution in time', as Bruno Latour pointed out, ${ }^{8}$ 'advertising' as a noun seems to signify all those combined forces provoking that rupture, that very break in the passage of time we have come to understand as intrinsically modern. Indeed, it appears difficult to describe the modern without also referring to advertising. How could we ever have been 'seduced by modernity's if promotion had not tempted us? Put even more poignantly, how to speak of reification, 'banal expropriation', the 'deterioration' of high culture, the 'absorption' of art or surplus value, 'self-destructive consumerism', and the 'junk spaces' of contemporary urban life without immediately evoking modernist commercials, screaming billboards, or consumer discipline? ${ }^{10}$ What would Marxists have done without J. Walter Thompson and the 'commodity as spectacle', ${ }_{11}$ and Jean-Luc Godard without Coca-Cola? How could it ever have been possible to make philosophical claims about the malleability of time, and the representation or experience of the present, and how would a critique of modernity and its afterlives have been forcefully articulated if advertising had not existed? ${ }^{12}$

As a category, then, advertising has markedly contributed to an idea of the modern that involves, as philosopher Peter Osborne argues, a temporal logic of negation splitting the present from within. The modern sense of the present as an irreversible break with the past rests on this logic that picks out from within the present those things that are new and makes them constitutive of its historical meaning. 'In the modern', Osborne notes,

the new within the present does not merely demand more attention than what is not new; increasingly, it negates the latter's claim on the definition of the present itself. 'Modern' is both a term of temporal ontology and a critical term. [...] The present becomes divided internally into the new and the old. ${ }^{13}$

8 Bruno Latour, We Have Never Been Modern, trans. Catherine Porter (Cambridge, MA: Harvard University Press, 1993), 10.

9 Markus 2014, ibid.

10 Adorno, The Culture Industry, 47, 68, 85; Gilles Deleuze and Felix Guattari, Anti-Oedipus (London: Continuum, 2004), 235; Fredric Jameson, 'Future City', New Left Review 21 (June 2003); Mike Featherstone, Consumer Culture and Postmodernism (London: Sage, 1991), 24; cf. Sean Cubitt, The Cinema Effect (Cambridge, MA and London: MIT Press, 2004), 287.

11 Cubitt, The Cinema Effect, $5^{2}$.

12 See, for instance, Stuart Ewen, Captains of Consciousness: Advertising and the Social Roots of Consumer Culture (New York: McGraw-Hill, 1976); Vance Packard, The Hidden Persuaders (London: Longmans and Green, 1957).

13 Osborne, Anywhere or Not at All, 73 . 
Not only is advertising often considered a 'new' phenomenon. The top cliché of categorical thinking about advertising states that advertising precisely operates, as capitalist economies do more generally, by parsing the present as new. In this view, advertising not only lures buyers by appealing to newness, it essentially functions as part of an endless devaluation spiral that both constantly destructs the old and creates new value. Versions of this view have circulated widely and in what follows I am not at all aiming to refute its ambitious and general claims. My proposition will be rather modestly founded on the fact that, despite its proven usefulness in defining the idea of the modern, and in generating various meta- and counter-narratives of modernity, 'advertising' remains a cliché of categorical thinking. Hence, what screen advertising research obviously needs to begin with is not another critique of advertising's twisted relation to the modern, but a critique of the category of advertising.

We could argue that it is the very idea of the modern - the 'modern' in the sense of a critical term - that picks out from within the present those things that are new and makes them constitutive for 'advertising'. Outside of any categorical reasoning, advertising indeed may appear as something altogether different. Historically, it is of course hardly confined to promoting the new, for instance, or to shaping consumer desire; there is immense variation when it comes to the ways advertisements over time have related, for instance, to price competition, product differentiation, trademark reputation, consumer benefit - or novelty. Emotional persuasion, often considered a key trait of contemporary 'modern' advertising, appears contingent upon systems of production that may be situated in a longer view reaching back to the eighteenth century. ${ }^{14}$ Advertising's complex relationships to a given historical time are thus neither captured nor explained by relying on any category. Rather, that relationship would need to be explored by studying in more detail the ways advertising - and in our case, moving picture advertising - has indeed, or has not, contributed to a 'break' in the passage of time.

\section{Rope Swing, the Modern, and Advertising History}

The broader aim of this chapter is to deconstruct the category or conceptual framework that screen advertising research tends to be locked into. 
The way the chapter proceeds is neither theoretical nor philosophical; rather, the chapter confronts the prevailing abstracted view on screen advertising with the contingencies of its archival history. To do this, I have chosen as my starting point cola soft drinks, a product often deemed quintessentially empty to the degree that its producers are described as 'want makers', who allegedly succeed in persuading people to buy something they don't need or like. ${ }^{15}$ More specifically, the focus is on the so-called 'cola wars' of the 196os, a period when Coca-Cola and Pepsi engaged in identifying, and then constantly recreating, the differential boundaries between their brands. This inter-cola competition spurred stylistic innovations such as montage sequences, which, according to Lynn Spigel, were a key marker of modernism in 196os American television advertising. In her book TV By Design: Modern Art and the Rise of Network Television (2008), Spigel contrasts these montages with the 'static, talky feel of 1950s demonstrational ads', claiming that this formal device worked together with 'moving camera, mood lighting, location sets, and/or color photography' in creating something new, the 'art-cinema commercial'. ${ }^{16}$ Did art and modernism, epitomized by the cinematic device of montage, help television advertisers to sell the present as new? Is Spigel's comment itself indicative of a modern sense of history that selects from history those things that were new, in order to make them constitutive for advertising?

To answer these questions, I will focus on one particular television 'spot commercial' produced and screened in the United States in 1968-1969 for Pepsi, and now circulating on YouTube and elsewhere, entitled Rope Swing (USA 1968, 6o seconds). Part of a sports-themed campaign, Pepsi's spot develops a simple scenario of two young couples having fun in nature on a late summer afternoon, repeatedly jumping off a diving platform, swinging on a long rope and arching before hitting the water of a lake. For reasons not entirely clear, the Rope Swing spot has been singled out by historians as symptomatic of 'advertising' in its alleged entanglement with 'modernity', if only in a negative sense. Noted advertising historian T. Jackson Lears, for instance, speaks of a 'formalist modernism' that allegedly had come to mark the decade. If advertising's 'purpose' was 'persuading people to buy goods',

15 See, for instance, Mark Pendergrast, For God, Country, and Coca-Cola (New York: Penguin, 2000) and his entry 'Cola-Wars', in The Oxford Companion to American Food and Drink, ed. Andrew F. Smith (Oxford and New York: Oxford University Press, 2007), 139-140.

16 Lynn Spigel, TV By Design: Modern Art and the Rise of Network Television (Chicago: Chicago University Press, 2008), 216-217. 
then, like political propaganda', it 'needed "human interest" and "real life"' to fulfil this goal. ${ }^{17}$ Pointing specifically to Pepsi's Rope Swing commercial, Lears suggests its director, Ed Vorkapich, borrowed backlighting styles from Leni Riefenstahl, crediting Triumph des Willens (1934-1935) as having shown backlit divers jumping off a platform into water (although the correct reference here should have been to Riefenstahl's Olympia, 1936-1938). Rope Swing, he conceded, was a film in which

the imagery of Currier \& Ives met the propaganda techniques of the Third Reich. If one defined one's modernism solely as formal innovation, then modernist experiments could be used to promote just about any sentiment at all. In the world of advertising, as in that of mass politics, the courtship of avantgarde and kitsch could finally be consummated in marriage. ${ }^{18}$

While Lears saw Rope Swing as a mixture of mass printing and propaganda technologies, cultural historian Michael Thomas Carroll even interpreted that same film as 'fascist', claiming that such allegedly Riefenstahl-inspired 'aesthetic borrowings cannot be made without carrying traces of their original ideological content. [...] Both fascism and consumerism are strategies for managing mass populations in the context of popular modernity'. ${ }^{9}$

Although crystallizing around one specific commercial, such arguments are not uncommon when it comes to the alleged functions of moving image advertising in 'modernity' at large. A widespread tendency is to use the notion of modernity - and by extension, modernism - as a template block periodization, based on the belief that advertisers and avant-gardists shared the same 'culture', and by treating 'advertising' as a noun or series of cultural artefacts. For instance, in his book Walter Ruttmann and the Cinema of Multiplicity: Avant-Garde, Advertising, Modernity (2014), Michael Cowan aims

to examine how the commissioning occasion of the films at hand and the broader context of German and European questions of modernity are intertwined: i.e. how did Ruttmann's commissioned works enfold questions of modernity into their more immediate contexts and projects. ${ }^{20}$

17 T. Jackson Lears, Fables of Abundance: A Cultural History of Advertising in America (New York: Basic Books, 1994), 301-343.

18 Ibid., 342-343.

19 Michael Thomas Carroll, Popular Modernity in America: Experience, Technology, Mythohistory (New York: State University of New York Press, 200o), 127.

20 Michael Cowan, Walter Ruttmann and the Cinema of Multiplicity: Avant-Garde, Advertising, Modernity (Amsterdam: Amsterdam University Press, 2014), 11. 
Distancing himself from the type of 'Mephisto question' often brought up in advertising research - namely, how an avant-garde artist of the political left such as Ruttmann could collaborate both with capitalist industries and a totalitarian regime ${ }^{21}$ - Cowan avoids treating Ruttmann's oeuvre as an auteur's compromise to his time. While following research on industrial and sponsored film in suggesting a relational view that would neatly link the practical or use value of those films to their aesthetic, he nevertheless suggests that the analysis of such commissioned work should not be confined to the immediate purpose of its commission. ${ }^{22}$ Emphasizing a notion of design over form or style, Cowan analyses Ruttmann's works as emerging at the intersection of avant-garde aesthetics and the science of advertising, tracing analogies to science in design practices within a broader context of interwar avant-garde visual culture understood as a sphere uniting often contradictory identities, projects, and aesthetic programmes.

It is worthwhile to examine the notion of modernity at the heart of such an account. Cowan here draws from Mary Ann Doane's attempt to describe the emergence of cinematic time in the context of an epistemological framework arguably shared by cinema, science, and industry since the late nineteenth century. ${ }^{23}$ As Doane states, 'the manifest project of modernity - and of the cinema in the wake of Marey and Muybridge - is to make time visible, representable, to store and, hence, to defeat time as relentless passage'. ${ }^{24}$ Doane relates this project of representing and managing time to an 'epistemology of contingency' in emerging disciplines such as statistics, and in capitalist modernity at large. ${ }^{25}$ Following Doane's line of thought, Cowan's key framework for explaining Ruttmann's works are the shared conditions for the possibility of knowledge imposed by the capitalist system of his time. Accordingly, advertising appears to be a technique of regulation; it is, as is film more generally, an 'instrument for regulating multiplicity'. ${ }^{26}$ This approach allows, for instance, the linking of the famous 'cross-sectional' montage or 'Querschnittmontage' in Ruttmann's Berlin - Die Sinfonie der Großstadt (1927) to scientific illustrations,

21 Ibid., 14.

22 See Vinzenz Hediger and Patrick Vonderau, eds., Films that Work: Industrial Film and the Productivity of Media (Amsterdam: Amsterdam University Press, 2009).

23 Mary Ann Doane, The Emergence of Cinematic Time: Modernity, Contingency, the Archive (Cambridge, MA and London: Harvard University Press, 2002).

24 Ibid., 190.

25 Doane narrows down Foucault's argument to a simple binary.

26 Cowan, Walter Ruttmann and the Cinema of Multiplicity, 18. 
and to a then widespread form of sociological analysis based on statistic epistemology. If the overall function of (sponsored) film was to regulate multiplicity, such statistical montage developed as a form of 'contingency management', Cowan argues. ${ }^{27}$

Accounts like these are productive in deviating from a static and self-evident notion of 'media' as objects already given, highlighting the many cultural linkages between forms of mediation at a given point in time instead of isolating a given commercial from the situation it was commissioned for. Again, montage sequences are specifically singled out to make an argument about modernity. Given that modernity's 'project' was to make time not only visible but also mutable, it is suggestive to claim that montage, with its capacity to manipulate temporal order or speed, became a key cinematic device for 'contingency management', perhaps even in a 1960 s television advertising context. And yet, I would argue that historians of screen advertising might learn more by turning the premise of this and similar arguments on its head. What might we gain by suspending the conventional relationship between modernity, the avant-garde, cinema, and authorship? Insofar as it remains indebted to a categorical notion of advertising, Cowan's history may be seen as itself deeply invested in a nostalgic project of modernity - to the degree that it displaces all that which always already contradicted this project's own promises: interminable series of industrial and political failures to capture, and manage, contingency; strident differences in the knowledges produced by science, cinema, or industry; the situatedness of moving images within an abundance of other, aesthetically unremarkable promotional forms and practices; the non-theatrical life of film; and the ultimate insignificance of film for advertising in a wider context of institutions, technologies, and cultural intermediaries that included broadcasting or ad agencies.

\section{Dissecting a Spot Commercial}

While most screen advertising research seems to suggest that it is insufficient to merely study one spot commercial, this chapter follows the opposite approach and does precisely that. Let's have a closer look at Rope Swing, the spot's production history, the context of the Pepsi campaign, and of course the montage sequence. My main point here is not so much 
to prove conventional screen advertising histories wrong, but to follow through on their intuition to look more closely at the 'dynamics of the new' associated with advertising, without delving into categorical assumptions about societal change or the alleged determinist powers of filmed screen advertisements.

\section{The Agency}

In The Conquest of Cool: Business Culture, Counterculture, and the Rise of Hip Consumerism (1997), Thomas Frank has written in great detail about the 'cola wars' of the 196os that made the market practice of product differentiation well-known to the lay public. While Coke had massive success as early as 1904, based on a mass retail marketing paradigm at the time, Pepsi's late rise during the 1960 s was 'made possible by an ad campaign that made skilful use of the subversive, anarchic power of the carnivalesque and of the imagery of youth rebellion', Frank observes. In massive print ad and television commercial campaigns, Pepsi positioned 'Pepsi-ness' against 'Coke-ness': 'Pepsi is hip, Coke is square; Pepsi is youthful, Coke is fogey; Pepsi smashes rules and inhibitions, Coke is hopelessly entangled in the stultifying post-war order; Pepsi is for individualists, Coke is for conformists'. ${ }^{28}$ While Coca-Cola offered a uniform product, distributed worldwide in one uniform package, and closely identified with all things American, Pepsi offered a new American model consumer, identified with youthfulness and vitality in a countercultural sense. Starting in 1960, after having shifted its advertising account from Kenyon \& Eckhardt to the ad agency of Batten, Barton, Durstine \& Osborn (BBDo), Pepsi's ad campaigns turned against the adult, workplace-oriented, suburban imagery of Coke, featuring instead a fictionally liberated generation (the 'Pepsi Generation', as the slogan went) engaging in fast-moving pleasures of leisure and consumption: riding motorbikes, sand sailing, playing rugby at the beach, and the like.

When BBDO took over the Pepsi account from Kenyon \& Eckhardt in 196o, the agency faced the problem of a soft drink whose taste was indistinguishable from Coca-Cola in blindfold tests. Retrospectively assessing its strategy for the client around 1970, BBDO reminded Pepsi executives that colas did not 'have sharp demographic profiles or even sharp psychographic profiles', 
and that Coke had managed to establish itself as the standard during the $195 \mathrm{os}^{29} \mathrm{~A}$ previous campaign, entitled 'The Sociables', that had aimed to position Pepsi as a 'modern' refreshment for the young urban elites of its time had disastrously failed to lift the brand's image from merely being Coke's cheaper alternative. Pepsi's strategy was to combine basic product promises of soft drinks such as 'superior taste, thirst appeal, lift, coldness, sparkle, refreshment', with a demography that targeted older pre-teens, teenagers, and young adults while cautiously avoiding the exclusion of other segments of the population..$^{30}$ The scope of this youth market was outlined as 'a 13- to 19-year-old segment that possesses a 440-bottle per capita, spends some $\$ 30$ billion annually, and accounts for 12 per cent of the population and 18 per cent of the soft drink consumer public'. ${ }^{11}$ Between 1960 and 1969, BвDO devised five different campaigns building on the youth trend observed by its strategists:

1961 Now Its Pepsi for Those Who Think Young 1963 Think Young

1964 Come Alive: You're in the Pepsi Generation 1966 Taste that Beats the Others Cold - Pepsi Pours It On 1969 You've Got a Lot to Live, Pepsi's Got a Lot to Give

During that same period, Coca-Cola settled on three campaigns with no comparable demographic or strategic intent. While direct causal relations between marketing and sales are hard to prove, the BBDO strategy for Pepsi was considered hugely successful, managing to turn Pepsi 'from a poor second in the soft drink industry to the neck and neck leader with Coke'. ${ }^{2}$ Between 1960 and 1970 , net sales increased from about $\$ 158$ million to $\$ 1,123$ million. ${ }^{33}$

29 BвDo, 'Pepsi-Cola: The ввDo Point of View.' вBDo Archives, New Jersey (uncatalogued, c. 1970). Thanks to Cynthia B. Meyers for providing me with this document.

30 Ibid.

31 Anon., 'Sweet Worth of Youth', Pepsi Cola Magazine 27, no. 2 (February 1966): 2. The National Museum of American History. Archives Center. The 'Pepsi Generation' Oral History and Documentation Project. Series 1: Research Files. Subseries b: Materials produced by Pepsi-Cola. Pepsi-Cola World, 1963-1966. Collection 111, box no. 5 .

32 Scott Ellsworth, 'Project Handbook. Coming Alive: A Historical Context for the Pepsi Generation', 1984. The National Museum of American History. Archives Center. The 'Pepsi Generation' Oral History and Documentation Project. Series 1: Research Files. Subseries a: Materials gathered by Archives Center, 1969-1985. Collection 111, Box no. 1.

33 Ibid. 
In branding its soft drink, Pepsi had long engaged with Hollywood. In the 1950s, this partnership had been marked by Pepsi's chairman Albert Steele, who married film star Joan Crawford in 1955. Subsequently, Crawford became Pepsi's number one spokesperson and was featured in many of its ads. In 1964, Pepsi commissioned arranger Sid Ramin, who had won an Academy Award for West Side Story, to compose the theme song for the Come Alive! campaign, which launched the Pepsi Generation strategy that would be maintained for the rest of the decade. While employing Joanie Sommers to perform the song - 'a voice so young, so special, so right, that it's actually the sound of the Pepsi Generation', according to Pepsi's Marketing Services VP at that time, Alan Pottasch - the score itself was still more traditionally conceptualized as a swinging big band song. ${ }^{34}$ Pepsi then teamed up with more youth market-oriented celebrities such as Ryan O'Neal, and consciously built on 'new media concepts' such as a 1965 television 'full-color spectacular' of 'violent refreshment' featuring James Bond star Sean Connery, shared via NBC's network, and finally, in 1966, 'disk jockey radio'. ${ }^{35}$ Music - and especially jingles, that is, brief, catchy tunes with lyrics that included the name of the advertised product - were indeed considered to be of key importance. Marketers had used radio jingles regularly since the 1940s, and in the 1960s, standalone songs became a key driver in consumer interest, with Pepsi investing heavily in attracting top musicians for its ads. For instance, while Coca-Cola had teamed up with Aretha Franklin, Petula Clark, or Ray Charles for its Things Go Better with Coca-Cola campaign (1963-1967), Pepsi involved The Turtles and The Four Tops for their Taste that Beats the Others Cold campaign, and Johnny Cash, B.B. King, and Roberta Flack for the You've Got a Lot to Live campaign.

BBDo's approach differed from Kenyon \& Eckhardt's not only in terms of demography and media but the agency also commanded a much higher budget. Overall, its five campaigns in the 1960 s were both versatile and

34 Anon., 'Advertising: The Why and the What', Pepsi-Cola World, October 1964. The National Museum of American History. Archives Center. The 'Pepsi Generation' Oral History and Documentation Project. Series 1: Research Files. Subseries b: Materials produced by Pepsi-Cola. Pepsi-Cola World, 1963-1966. Collection 111, box no. 5.

35 Anon., 'The Bondwagon', Pepsi-Cola World 26, no. 10 (November 1965); Anon., 'Sweet Worth of Youth', Pepsi Cola Magazine 27, no. 2 (February 1966). The National Museum of American History. Archives Center. The 'Pepsi Generation' Oral History and Documentation Project. Series 1: Research Files. Subseries b: Materials produced by Pepsi-Cola. Pepsi-Cola World, 1963-1966. Collection 111, box no. 5. See also Timothy D. Taylor, The Sounds of Capitalism:Advertising, Music, and the Conquest of Culture (Chicago: Chicago University Press, 2012), 154-155, for a background documentation of this case. 
innovative. Versatile in their ability to adapt to societal change and widespread feelings, such as those caused by the Vietnam War, reflected in the muted You've Got a Lot to Live campaign of 1969. Innovative in their high impact on TV advertising, and more specifically, in bringing 'motion picture quality cinematographic techniques, "cinéma verité" approaches, professional film-makers, and rock music' to television. ${ }^{36}$ In this context, it is somewhat ironic that Rope Swing tends to be singled out by advertising historians, given that both Pepsi and ввDO regarded the campaign it belonged to as an aberration, a 'change in direction', which they later felt 'was a mistake'. ${ }^{77}$ What happened?

\section{The Campaign}

To understand the decision for Rope Swing and the Taste that Beats the Others Cold - Pepsi Pours It On (1966-1969) campaign, it is necessary to get a sense of how the process of adopting an ad campaign worked in general. Usually, the company (Pepsi) would inform the agency (вBDo) and its creatives of the message or image that their marketing people wanted to convey, alongside some ideas and suggestions of how this message could be executed. The agency would then propose five to six possible solutions, of which three would be put onto storyboards with rough demo music. A subsequent process of reviewing and decision-making would involve the company's president and key executives..$^{8}$ Campaign proposals were then discussed with Pepsi's bottlers, a powerful group in the soft drink franchise business. Six to eight of Pepsi's bottlers were elected to the Marketing Committee of Bottler's Association (MARCOM), a sounding board for Pepsi's campaign ideas that met before the campaign was presented at a convention, a major event that took place every third or fourth year, often involving a stage show with Broadway talent, and culminating in the presentation of the new campaign.

The idea for the Taste that Beats the Others Cold campaign was based on tests Pepsi had conducted, and which seemed to indicate that 'Pepsi served

36 Ellsworth, 'Project Handbook', 1984.

37 BвDо, 'Pepsi-Cola: The BвDo Point of View'. BвDo Archives, New Jersey (uncatalogued, c. 1970).

$3^{8}$ Scott Ellsworth, 'Oral History Interview with Alan M. Pottasch', Purchase, New York, 1984. The National Museum of American History. Archives Center. The 'Pepsi Generation' Oral History and Documentation Project. Series 2: Interviewee Files. Abstracts of Interviews. Collection 111, box no. 13 . 
very cold was considered better tasting than Coke and other colas' ${ }^{39}$ Pepsi's then CEO James B. Somerall as well as Sidney Maran, its marketing head and company vice president, aimed for a more product-centred approach than the one employed by the Pepsi Generation campaigns of the past. As Pottasch, who was against this idea, later recollected,

They conducted taste tests on Pepsi and Coke and found that Pepsi - when chilled to a certain temperature - beat Coca-Cola. Presidents usually like to leave their 'thumbprint' on the company in the area of advertising and 'Taste' was Somerall's 'thumbprint'. Maran thought that this 'hard-sell' campaign would benefit the product enormously. ${ }^{40}$

BBDO, however, found 'this product claim represented a trivial advantage to the consumer', later calling it 'an example of artificial product differentiation'. ${ }^{41}$ The result was a campaign that was not primarily youthoriented, but rather aimed to remind consumers of Pepsi's basic soft drink promises while highlighting its alleged superiority in taste when drunk really cold. The campaign was presented to Pepsi's bottlers at the 1966 convention and launched that fall.

\section{The Spot}

Rope Swing was conceived in 1968, nearly two years into this campaign, as part of an attempt to adjust spot production to earlier audience responses. Previous spots had featured several sports scenes, and the adjusted television strategy wanted to move away from 'multi-situation commercials' to instead include only one situation. The reason for this was the marketers' aim 'to facilitate an "easier involvement" on the part of the viewer' and to present 'the expenditure of energy and its reward, Pepsi-Cola, in its strongest, barest and most exciting terms'. ${ }^{2}$ To do so, one type of athletic action - in this case, to swing from a rope into a lake - was meant to be combined with

39 ввDо, 'Pepsi-Cola: The ввDo Point of View'. ввDо Archives, New Jersey (uncatalogued, c. 1970).

40 Ibid.

41 Ibid.

42 Anon., 'New Flight', Pepsi-Cola World 29, no. 10 (November 1968). The National Museum of American History. Archives Center. The 'Pepsi Generation' Oral History and Documentation Project. Series 1: Research Files. Subseries b: Materials produced by Pepsi-Cola. Pepsi-Cola World, 1963-1966. Collection 111, box no. 5. 
some formal 'device that would catch [the viewer's] attention, the way slow motion does. While working up the story boards, the agency hit upon the idea of the "stroboscopic" visual device and the "water guitar" sound to accompany it'. ${ }^{43}$ While in Rope Swing, stroboscopic effects were not used, the so-called Hollywood montage in the film was also a formal device 'accomplished via a film-editing technique in the laboratory': montages are a form of compositing, a visual effect pioneered by Slavko Vorkapich, the father of Ed, who shot this commercial. ${ }^{44}$

The spot formed part of a colour 'package' for network television, consisting of a series of 6o-second commercials with fast-action scenes and visual effects, and accompanied by five 20-second spots and eight shorter-duration 'lifts' based on the 6o-second spots. ${ }^{45}$ Rope Swing's production lay in the hands of BвDO's young agency producer, and later famous Hollywood director-producer, Jerry Bruckheimer, working together with the recently founded, New York-based production house BFB. At BFB, production was executed through a division of labour between producer Herb Freed, art director Kong Wu, director Ed Vorkapich, and editor Jack Cottingham. As the cinematographer, BFв had hired Bert Stern, one of the so-called creative revolution's top advertising and celebrity photographers, known since 1953 for his backlit Smirnoff magazine ads, for directing the documentary Jazz on a Summer's Day (USA 1959), and for his 1962 portraits of the late Marylin Monroe. The jingle for the revamped television package was composed by freelance composer-arranger Anne Philips with her band, Queen Anne's Lace (Jerry Kelly, Jerry Duane, Trade Martin, Gene Maharry, and Gene Steck). Shooting took place at Malibu Lake in California and involved 'some of the world's best divers and gymnasts, including Ron Rondell, Hollywood's famed stunt man, and Dave Smith, who has accomplished such feats as swimming the shark-filled Straits of Gibraltar'. ${ }^{6}$ Vorkapich later claimed that he did not follow BBDo's storyboard, and that the agency only 'put jingles together and sold the client on the idea', implying that he and Stern, whom he had first met during the Korean War in a camera combat unit, decided the spot's final design. ${ }^{47}$ Shooting in the late afternoon and using high-speed footage,

43 Ibid.

44 I have detailed the genealogy of Vorkapich's montages in 'Hollywood Montage: Theorie, Geschichte und Ästhetik des "Vorkapich-Effekts", Montage AV 25, no. 2 (2016): 201-224.

45 Anon., 'Pepsi Action Spots Build a New Thirst for a Young America', BBDo Newsletter, October 1968.

46 Ibid.

47 Scott Ellsworth, 'Oral History Interview with Ed Vorkapich', 23 November 1984, New York City. The National Museum of American History. Archives Center. The 'Pepsi Generation' 
an Imar combat and an Aeroflex camera, trampolines, and backlighting, Rope Swing managed to turn 'what is ordinarily a child's sport into a graceful art', Pepsi found. ${ }^{48}$ Rope Swing and the new 'Pepsi package' first aired in mid October of 1968 and ran until replaced by the subsequent campaign, You've Got a Lot to Live, in 1969.

As of today, all that remains of this production effort is a low-resolution, black-and-white version of the former colour television spot on YouTube, where it forms part of an aggregate reel entitled 'Pepsi Commercials 1960s'. ${ }^{49}$ By analysing these remains, what can be learned about the spot's montage and, following up on earlier arguments, about advertising's allegedly persistent relation to modernity? To come to terms with Rope Swing's production of temporality, a storyboard-like rendering of its shot breakdown, often used in contemporary trade journals such as Madison Avenue, may help describe its editing pattern..$^{0}$

Rope Swing roughly consists of six sequences. The first one establishes the action, followed by the second sequence repeating and detailing this action, and by the product claim and benefit. The fourth sequence links the previously seen action to drinking Pepsi, followed by a fifth, elaborate montage sequence that renders this action, including the drinking of Pepsi, in a more graphical way, using multiple shots and intercut lines of action. The sixth sequence repeats the diving action from a girl's viewpoint and matches the man and the woman drinking Pepsi, interrupted by a graphical and acoustic rendering of Pepsi's key slogan. The spot ends with the man, already seen earlier in this sequence, falling out of the frame and into the water. In sum, what characterizes Rope Swing's editing is not just its frantic pace, but rather a calculated mix of (elliptic) continuity editing and discontinuity editing - the latter including a mismatch of spatial and temporal relations, violations of axis of action, graphic matches, jump cuts, and non-diegetic inserts. Most remarkable, however, is indeed the use of the extended, twelve-second montage, or what in Hollywood parlance had long been known as the 'transition shot' or 'Vorkapich effect'. ${ }^{11}$ Codified in

Oral History and Documentation Project. Series 2: Interviewee Files. Abstracts of Interviews. Collection 111, box no. 13 .

48 Anon., 'Pepsi Action Spots Build a New Thirst for a Young America', BBDo Newsletter, October 1968 .

49 By the time this book is printed, the spot might of course have disappeared. musickeys8, 'Pepsi Commercials 196os', www.youtube.com/watch?v=oVf9g5yC_pg (last accessed 5 April 2021). The title of this video is incorrect, as it also includes spots from the 1950s and 1970s. Rope Swing can be found at 6:38-7:38 in this video. Other versions of course exist elsewhere.

$5^{0}$ In what follows, I use the YouTube version of the spot, because it is most widely accessible.

$5^{1}$ These and similar coinages, such as 'Vorkapich shot', circulated widely in American Cinematographer, Motion Picture Herald, and other trade periodicals. 

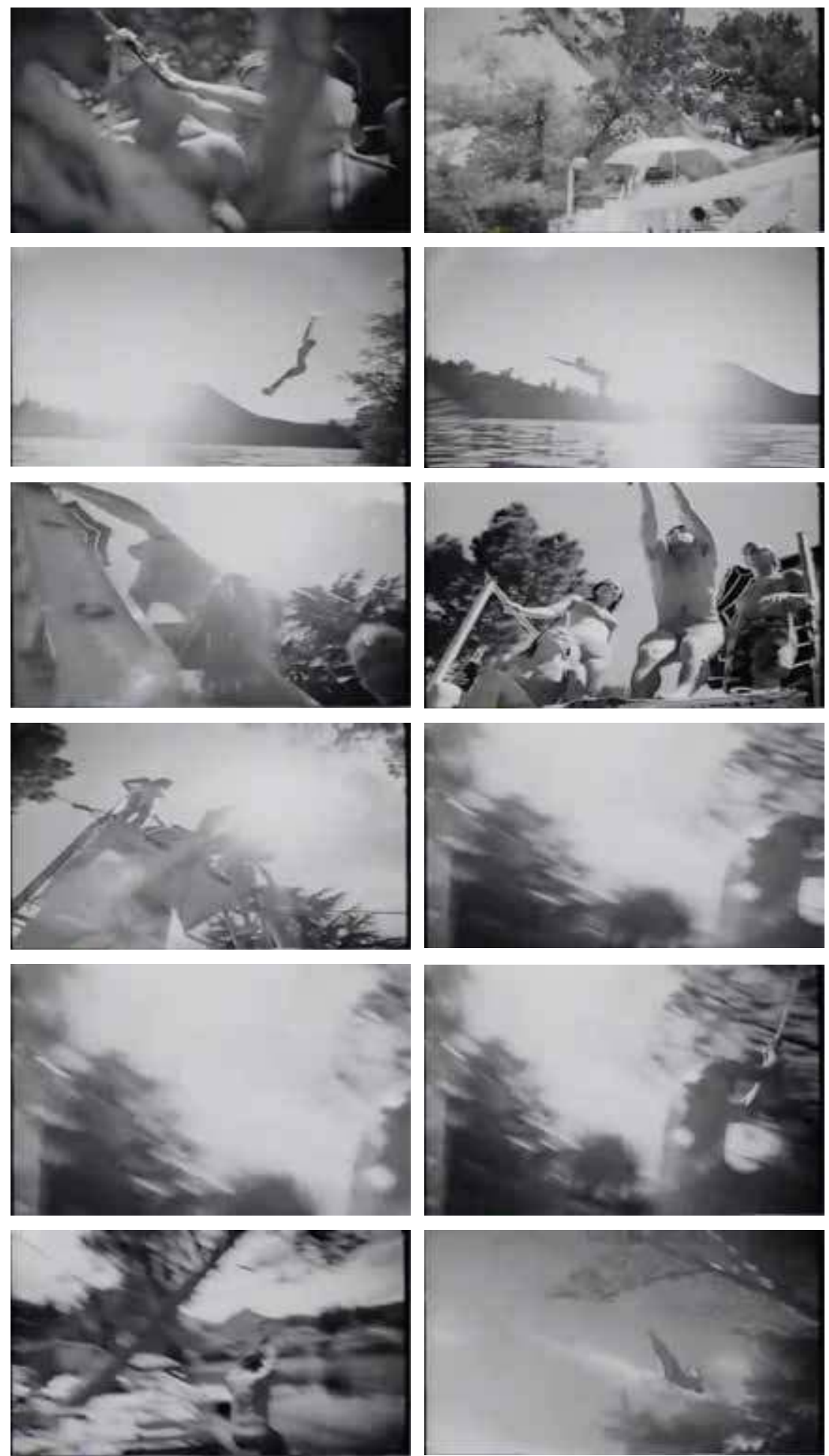

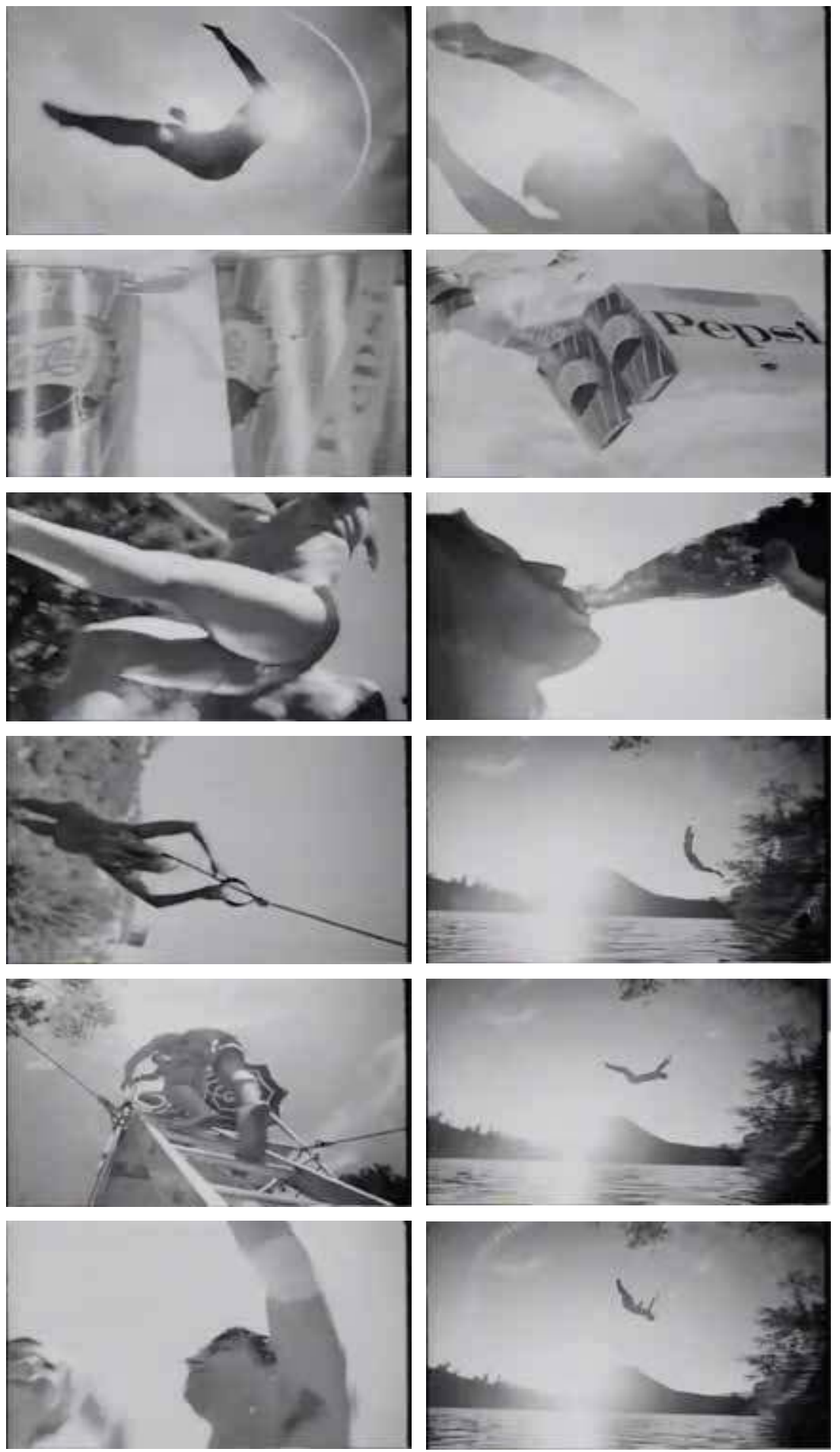

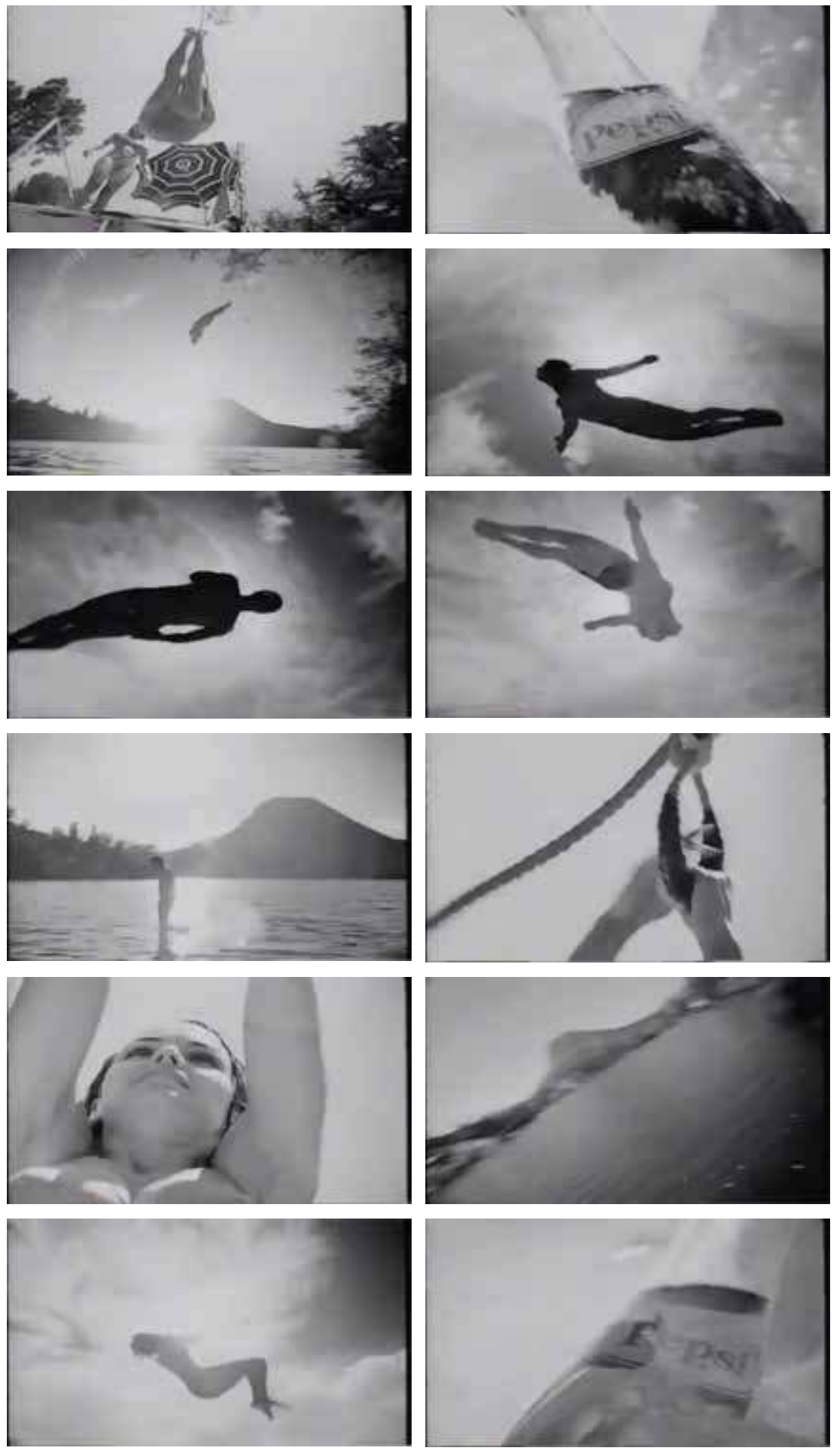

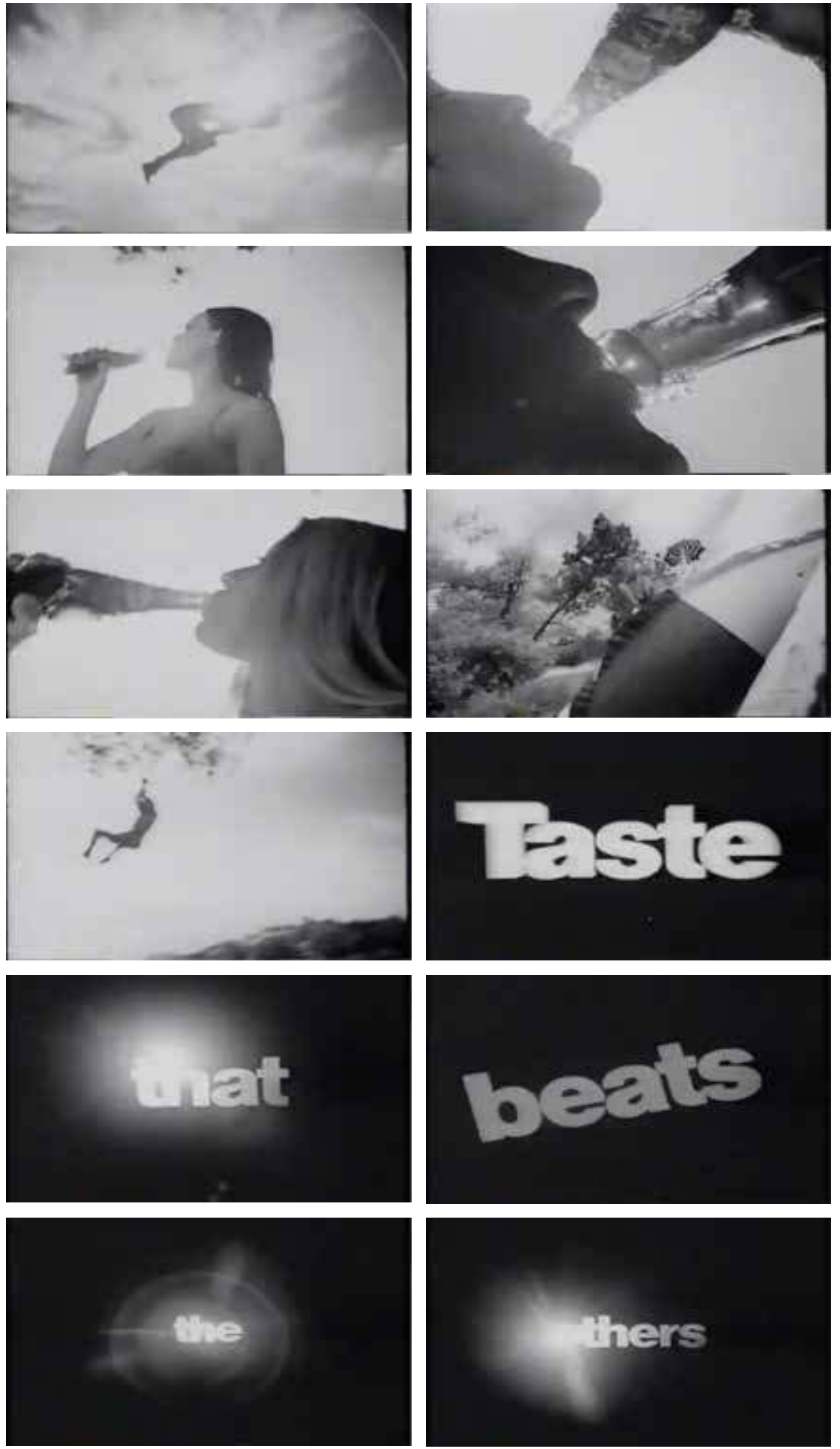

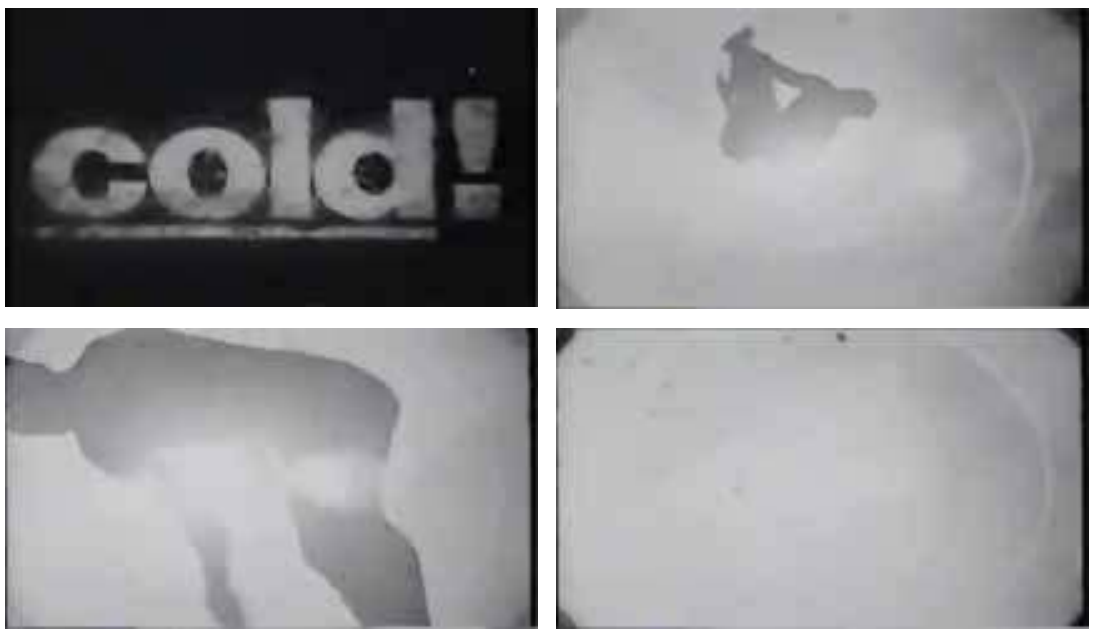

Figures 2.1-2.52: Rope Swing shot breakdown (YouTube).

the late 1920 s by director Ed Vorkapich's father, the Serbian émigré Slavko Vorkapich, as a suprarealistic form of montage, this effect has been widely used in commercials before and after 1967 .

As Spigel correctly notes in her book, rapid montage and graphic collage belonged to a 'cinematic' repertoire of stylistic codes that had become standard by 1967. In adopting this design, BBDO's and BFB's producers opted for Ed Vorkapich, Slavko Vorkapich's son, as a director known for his work at Filmex, a 'top company' for TV commercial production, according to trade papers, where he was employed as part of a newly founded 'experimental film division', together with his father, 'a well-known Hollywood movie director [who] has developed many montage principles which apply to today's TV commercials.$^{2}$ Rather than vaguely borrowing from Nazi propaganda, Rope Swing thus explicitly integrated Hollywood montage as a key principle for designing time and objects in motion.

\section{Conclusion}

Vorkapich offers more than a just biographical thread through the anonymous assemblage of advertising styles. Instead of being an auteurist

52 Anon., 'Slavko and Edward Vorkapich Join New York Staff of Filmex', Business Screen Magazine, vol. 28 (January-December 1967). Anon., 'Filmex adds unit', Broadcasting 72, No. 32 (15 May 1967) and 'Balancing art and business in film making' (5June 1967), in the same journal. 
exception, Ed became an award-winning role model for aspiring advertising directors in the 1970s before turning to video and MTV in the 1980s. In statements and interviews, Ed's persona was crafted through references to his father's montage principles as guiding current practices of television advertising. 'Both men' were said to have 'agreed that the hand-held style which has become so closely associated with [Ed] Vorkapich's work for Pepsi, 7-Up, Noxzema, Revlon and other top advertisers was incredibly similar to the material he [Slavko]'d shot years ago'.53 In taking up the standardized stylistic codes of his time, the younger Vorkapich thus supported agencies, trade organizations, and production houses in actualizing an aesthetic programme dating back to the $1920 \mathrm{~s}$. He would, for instance, describe a 'director's job' as 'to transfer an idea rhythmically to film', insisting on each shot having 'its own "note", as it 'is the organization of these notes that creates the visual music'. ${ }^{4}$ Such statements and Ed Vorkapich's kinaesthetic montages in Rope Swing or Pepsi's earlier Girl Watcher (USA 1967, 6o seconds) evoked the theories Slavko had articulated between 1926 and 1973 with surprisingly little variation in trade articles and lectures. These theories were in themselves deeply rooted in 1920 avant-garde discourses revolving around notions of visual music, as they defined 'cinematics' as an art of pure motion, 'spatial like painting and temporal-dynamic like music', and 'comparable to a symphony' in its 'organization of the moving volumes and their rhythmical arrangement from shot to shot'.55

Rope Swing presents its branded bottles and cans in movement, "life flowing through them', in Raymond Williams's words, as they chill, turn, are lifted up, emptied out. Following the idea that, in order to find 'a new kind of visual beauty in the ordinary world', motion pictures of all sorts would have to 'liberate bits of dynamic visual energy, extracted from a simple event in reality', Slavko Vorkapich had codified a Hollywood best practice of montage, rather than 'inventing' it..$^{6}$ Montage, initially developing as a form of 'time effects' based on optical compositing in Hollywood's special effects departments, was described by Vorkapich as the

53 Anon., ‘Close Up: Ed Vorkapich', Millimeter 5, no. 8 (September 1977): 70.

54 Ed Vorkapich, 'Directors Should Get A First Cut', Backstage 25, no. 8 (24 February 1984): 36.

55 Slavko Vorkapich, 'Cinematics: Some Principles Underlying Effective Cinematography', Cinematographic Annual 1 (1930): 29-33.

56 Slavko Vorkapich, 'Towards True Cinema', American Cinematographer 54, no. 7 (July 1973): 884-886, 930-933. For a summary of Vorkapich's theoretical positions, see Arthur LeRoy Swerdloff, A Comparative Analysis of the Filmic Theories of Slavko Vorkapich (dissertation, June 1950, University of Southern California, unprinted manuscript). 
putting together two or more images, one next to another, one after another, one on top of another - so-called superimposed shots - to depict an event, to suggest lapse of time, to convey an idea, to arouse an emotion, to express a state of mind or create a mood or atmosphere. ${ }^{57}$

In a similar vein, Rope Swing's montage employed 'graphic picture symbolism', what in 1970 art, design, and advertising circles became known as 'graphic dynamism', to create meaning through movement..$^{8}$ While film scholars continue to label Vorkapich as an aesthetic 'modernist' influenced by Eisenstein, he indeed had a background in advertising and kept contradicting Eisenstein and other avant-gardists of cinema by stating that the art of cinematics was not at all bound to the cinema. ${ }^{59}$ Objecting both to cinema's narrative content and the 'empty formalism' of contemporary television, Vorkapich envisioned moving images as an art of attraction, similar to the techniques 'advertisers use to attract buyers: barber-poles gyrate, windmills revolve and electric signs do a dervish dance every night'. ${ }^{60}$ Such art, he concluded, some decades before Williams, would only be possible in the cultural form of short 'passages' ${ }^{61}$ Vorkapich indeed sometimes used the diving sequence in Riefenstahl's Olympia in lectures to illustrate his idea of kinaesthetic montage. ${ }^{62}$

As this chapter has shown, there is no simple or direct relation between advertising and modernity. Using Rope Swing as a case in point, the chapter has demonstrated that historians need to relate a given spot and its campaign to the broader marketing trends of its time, to specific agency practices, aesthetic concepts, and even to biographies. Given contemporary network television's 6o-second slots for advertising, montage allowed an advertiser

57 Swerdloff, A Comparative Analysis, 71; Slavko Vorkapich, 'Montage and the Creative Camera', National Board of Review Magazine 14 (5) (May 1939): 8-12.

$5^{8}$ Slavko Vorkapich, 'Montage: A Look Into the Future with Slavko Vorkapich', Cinema Progress 2 (5) (December-January 1937): 18-22, 34; see also, Julie A. Turnock, Plastic Reality: Special Effects, Technology, and the Emergence of 1970 s Blockbuster Aesthetics (New York: Columbia University Press, 2015), 49. Thanks to Julie Turnock for her comments and suggestions.

59 Swerdloff, A Comparative Analysis, 1950, passim. Cf., for instance, David E. James, The Most Typical Avant-Garde: History and Geography of Minor Cinemas in Los Angeles (Berkeley: University of California Press, 2005). See also the excellent article by Barbara L. Kevles, 'Slavko Vorkapich on Film as a Visual Language and as a Form of Art', Film Culture (Fall 1965): 1-46.

6 o Slavko Vorkapich, 'Cinematics. Some Principles Underlying Effective Cinematography', Cinematographic Annual 1 (1930): 30.

61 Swerdloff, A Comparative Analysis, 19 and passim.

62 Turnock, Plastic Reality, 64. 
to 'cram dozens of ideas and suggestions into a brief footage' ${ }^{63}$ and to evoke the effects tradition of the big screen for an audience that had become used to the small screen. In employing montage, Filmex, BFB, and other production companies established a standard that put more emphasis on visuals ${ }^{64}$ filling the breaks in television's programme flow with an art of the intermittent. This aesthetic standard was neither entirely new to television, nor a simple adoption of earlier film practice. Rather, it employed a trope of designing time that had circulated, and continued circulating, from early electronic moving image displays via Hollywood to MTV. ${ }^{65}$

\section{Bibliography}

Acland, Charles R. Swift Viewing: The Popular Life of Subliminal Influence. Durham, NC: Duke University Press, 2011.

Adorno, Theodor W. The Culture Industry: Selected Essays on Mass Culture. London and New York: Routledge, 1991.

Anonymous. 'Balancing art and business in film making.' Broadcasting 72 , no. 32 (5 June 1967).

Anonymous. 'Close Up: Ed Vorkapich.' Millimeter 5, no. 8 (September 1977): 70. Anonymous. 'Filmex adds unit', Broadcasting 72, no. 32 (15 May 1967).

Anonymous. 'Pepsi Action Spots Build a New Thirst for a Young America.' BBDO Newsletter (October 1968).

Anonymous. 'Slavko and Edward Vorkapich Join New York Staff of Filmex.' Business Screen Magazine, vol. 28 (January-December 1967).

Anonymous. 'The Hollywood Scene.' Motion Picture Herald 131, no. 7 (14 May 1938). Anonymous. '12-time-and-dollar savers to check before shooting.' Sponsor (8 June 1964): 48-49.

Boddy, William. 'A Genealogy of Electronic Moving Image Displays.' Rebecca. Revista brasileira de estudos de cinema e audiovisual 2, no. 3 (January-July 2013): 15-32. Carroll, Michael Thomas. Popular Modernity in America: Experience, Technology, Mythohistory. New York: State University of New York Press, 2000.

63 Anon., 'The Hollywood Scene', Motion Picture Herald 131, no. 7 (14 May 1938).

64 Anon., '12-time-and-dollar savers to check before shooting', Sponsor (8 June 1964): 48-49. This article describes Filmex's efforts to streamline and standardize the visual design of the commercials produced. Thanks to Cynthia Meyers for pointing me to this article.

65 See William Boddy, 'A Genealogy of Electronic Moving Image Displays', Rebecca. Revista brasileira de estudos de cinema e audiovisual 2, no. 3 (January-June 2013): 15-32; and Turnock, Plastic Reality. 
Charney, Leo, and Vanessa R. Schwartz, eds. Cinema and the Invention of Modern Life. Berkeley: University of California Press, 1995.

Cowan, Michael. Walter Ruttmann and the Cinema of Multiplicity: Avant-Garde, Advertising, Modernity. Amsterdam: Amsterdam University Press, 2014.

Cubitt, Sean. The Cinema Effect. Cambridge, MA and London: MIT Press, 2004.

Doane, Mary Ann. The Emergence of Cinematic Time: Modernity, Contingency, the Archive. Cambridge, MA and London: Harvard University Press, 2002.

Elsaesser, Thomas. Weimar Cinema and After: Germany's Historical Imaginary. New York: Routledge, 2000.

Ewen, Stuart. Captains of Consciousness: Advertising and the Social Roots of Consumer Culture. New York: McGraw-Hill, 1976.

Featherstone, Mike. Consumer Culture and Postmodernism. London: Sage, 1991.

Frank, Thomas. The Conquest of Cool: Business Culture, Counter Culture, and the Rise of Hip Consumerism. Chicago: University of Chicago Press, 1997.

Friedberg, Anne. Window Shopping: Cinema and the Postmodern. Berkeley: University of California Press, 1993.

Hediger, Vinzenz, and Patrick Vonderau, eds. Films that Work: Industrial Film and the Productivity of Media. Amsterdam: Amsterdam University Press, 2009.

Horkheimer, Max, and Theodor W. Adorno. Dialectics of Enlightenment:Philosophical Fragments, edited by Gunzelin Schmid Noerr, translated by Edmund Jephcott. Stanford: Stanford University Press, 2002.

James, David E. The Most Typical Avant-Garde: History and Geography of Minor Cinemas in Los Angeles. Berkeley: University of California Press, 2005.

Jameson, Fredric. 'Future City.' New Left Review 21 (June 2003).

Kevles, Barbara L. 'Slavko Vorkapich on Film as a Visual Language and as a Form of Art.' Film Culture (Fall 1965).

Latour, Bruno. We Have Never Been Modern, translated by Catherine Porter. Cambridge, MA: Harvard University Press, 1993.

Lears, T.J. Jackson. Fables of Abundance: A Cultural History of Advertising in America. New York: Basic Books, 1994.

Marchand, Roland. Advertising the American Dream: Making Way for Modernity 1920-1940. Berkeley, Los Angeles, and London: University of California Press, 1986.

Markus, Laura. Dreams of Modernity: Psychoanalysis, Literature, Cinema. New York: Cambridge University Press, 2014.

McFall, Liz. Advertising: A Cultural Economy. London: Sage, 2004.

Osborne, Peter. Anywhere or Not at All: Philosophy of Contemporary Art. London: Verso, 2013.

Packard, Vance. The Hidden Persuaders. London: Longmans and Green, 1957.

Pendergrast, Mark. For God, Country, and Coca-Cola. New York: Penguin, 2000. 
Pendergrast, Mark. 'Cola-Wars.' In The Oxford Companion to American Food And Drink, edited by Andrew F. Smith, 139-140. Oxford and New York: Oxford University Press, 2007.

Rancière, Jacques. The Politics of Aesthetics. Translated with an Introduction by Gabriel Rockhill. London: Continuum, 2004.

Sconce, Jeffrey. 'On the Origins of the Origins of the Influencing Machine.' In Media Archaeology: Approaches, Applications, and Implications, edited by Erkki Huhtamo and Jussi Parikka, 70-94. Berkeley and Los Angeles: University of California Press, 2011.

Slater, Don. 'Marketing as Monstrosity: The Impossible Place between Culture and Economy.' In Inside Marketing: Practices, Ideologies, Devices, edited by Detlev Zwick and Julien Cayla, 23-41. Oxford: Oxford University Press, 2010.

Spigel, Lynn. TV By Design: Modern Art and the Rise of Network Television. Chicago: Chicago University Press, 2008.

Swerdloff, Arthur LeRoy. A Comparative Analysis of the Filmic Theories of Slavko Vorkapich. Dissertation, June 1950, University of Southern California. Unprinted manuscript.

Swett, Pamela E., Jonathan Wiesen, and Jonathan R. Zaitlin. Selling Modernity: Advertising in Twentieth-Century Germany. Durham, NC: Duke University Press, 2007 .

Taylor, Timothy D. The Sounds of Capitalism:Advertising, Music, and the Conquest of Culture. Chicago: Chicago University Press, 2012.

Turnock, Julie A. Plastic Reality: Special Effects, Technology, and the Emergence of $1970 s$ Blockbuster Aesthetics. New York: Columbia University Press, 2015.

Vonderau, Patrick. 'Hollywood Montage: Theorie, Geschichte und Ästhetik des "Vorkapich-Effekts".' Montage AV 25, no. 2 (2016): 201-224.

Vorkapich, Ed. 'Directors Should Get A First Cut.' Backstage 25, no. 8 (24 February 1984$): 36$.

Vorkapich, Slavko. 'Cinematics: Some Principles Underlying Effective Cinematography.' Cinematographic Annual 1 (1930): 29-33.

Vorkapich, Slavko. 'Montage: A Look Into the Future with Slavko Vorkapich.' Cinema Progress, vol. 2, no. 5 (December-January 1937): 18-22.

Vorkapich, Slavko. 'Montage and the Creative Camera.' National Board of Review Magazine, vol. 14, no. 5 (May 1939): 8-12.

Vorkapich, Slavko. 'Towards True Cinema.' American Cinematographer 54, no. 7 (July 1973): 884-886, 930-933.

Ward, Janet. Weimar Surfaces: Urban Visual Culture in 1920s Germany. Berkeley: University of California Press, 2001. 



\title{
3. Advertising and Avant-Gardes: A History of Concepts, 1930-1940
}

\author{
Yvonne Zimmermann
}

\begin{abstract}
The chapter takes advertising as an umbrella term for persuasive communication. Looking at screen advertising as a specific type of communication - one that is made to persuade - the documentary, educational films, and avant-garde works of the 1930 s and early 1940 s come into view together under the label of advertising. Focussing on the work of John Grierson, Paul Rotha, and Hans Richter, the chapter shows how debates among intellectuals, pedagogues, and artists on both sides of the Atlantic revolved around concepts of propaganda and education to promote democracy. The chapter contributes to the field of useful cinema studies by mapping the transnational network of people, ideas, and materials involved in using moving images as tools for shaping the human mind.
\end{abstract}

Keywords: avant-garde, documentary, educational film, propaganda, democracy, useful cinema

I look on cinema as a pulpit, and use it as a propagandist. ${ }^{1}$ John Grierson

I look upon cinema as a powerful, if not the most powerful, instrument for social influence today. ${ }^{2}$

Paul Rotha

1 John Grierson, 'Propaganda: A Problem for Educational Theory and for Cinema', Sight and Sound 2, no. 8 (Winter 1933-1934): 119 .

2 Paul Rotha, Documentary Film: The Use of the Film Medium to Interpret Creatively and in Social Term the Life of People as It Exists in Reality, in collaboration with Sinclair Road and Richard Griffith (London: Faber \& Faber, 1968 [1935]), 25.

Florin, B., P. Vonderau, Y. Zimmermann, Advertising and the Transformation of Screen Cultures. Amsterdam: Amsterdam University Press, 2021 DOI 10.5117/9789462989153_CHO3 
Much less has been written [...] about why and from where the cinema really derived its particular spirit and particular artistic, organizational, technological, political and economic, i.e., social form, and hence about its 'usefulness' to society. ${ }^{3}$

Hans Richter

In his book The Democratic Surround, Fred Turner traces the origins of multimedia and the countercultural psychedelic 196os back to World War II, arguing that these phenomena are rooted in a liberal effort to produce a 'democratic personality' as a democratic alternative to the 'authoritarian personality' endorsed by totalitarian regimes. ${ }^{4}$ Facing the growing menace of fascism, the production of a new 'New Man' - the democratic American citizen, defined as a highly individuated, rational, and emphatic mindset that embraced racial and religious diversity - called for intellectuals and artists to develop new, 'democratic' modes of communication. Multi-image, multi-sound-source media environments, or what Turner calls 'surrounds', were considered the democratic answer to single-source mass media. Refugee artists from the Bauhaus, such as architect Walter Gropius and multimedia artists László Moholy-Nagy and Herbert Bayer, put themselves, following Turner's main argument, in the service of this democratic social vision. Together with American intellectuals, they created 'democratic' environmental multimedia techniques and the networks of ideas and people that would survive well into the $1960 \mathrm{os}$. In doing so, they joined forces to defeat totalitarianism and thus became 'propagandists' for democracy.

If Turner retraces the genealogy of multimedia back to the early 1940 s to reclaim a new understanding of the origins of contemporary multimedia, the aim of this chapter is somewhat related. It intends to provide what could be called a prequel to Turner's analysis of European avant-garde artists committing themselves to the creation of new media forms with the purpose of educating for democracy. ${ }^{5}$ The focus of this contribution is on the 1930 s and early 1940 and on projects that were developed in Europe both by avant-garde artists and within the documentary film movement, with the ambition to reform cinema as an educational tool to produce

3 Hans Richter, The Struggle for the Film. Towards a Socially Responsible Cinema, ed. Jürgen Römhild, trans. Ben Brewster (New York: St. Martin's Press, 1986), 23.

4 Fred Turner, The Democratic Surround: Multimedia \& American Liberalism from World War II to the Psychedelic Sixties (Chicago and London: The University of Chicago Press, 2013).

5 Turner's The Democratic Surround is already a prequel to his book From Counterculture to Cyberculture: Stewart Brand, the Whole Earth Network, and the Rise of Digital Utopianism (Chicago and London: The University of Chicago Press, 2005). 
democratic citizens that would resist totalitarian forces. These projects contributed to the building of transatlantic networks of educational film culture in the service of democracy.

\section{Advertising as a Category for Film in the Service of Persuasion}

To unravel the complex transnational relations and exchanges of ideas, films, and people that revolved around the creation of an art of film for selling democracy, this study brings the British documentary film movement into dialogue with the European film avant-garde and the American progressive educational movement under the umbrella term of advertising. Advertising, for that matter, is understood here neither as an institution nor as a genre. Instead, the term refers to objects, networks of ideas, and practices related to film in the service of persuasion. In this sense, advertising stands for a specific form of communication: one that addresses its addressees with specific goals to change their thoughts and actions; one that is sponsored by interest groups, be they governmental, corporate, non-profit, or other. The notion of advertising in this chapter serves as an approach to link historical theories of the documentary, propaganda, and education together and to look at them as methods of persuasion to reframe contemporary debates among intellectuals, pedagogues, and artists on both sides of the Atlantic that revolved around the concepts of propaganda and education to promote democracy.

As historical terms, advertising and propaganda witnessed a new prominence as a means of mobilizing public opinion during World War I. The term propaganda carried pejorative connotations in the interwar years, particularly in the United States, because of its overuse and its association with lies. Beginning in 1933, the Nazi government instituted a strict regulation of terminology, drawing a distinction between Werbung, for economic advertising, and Propaganda, for the propagating of political ideas. Elsewhere, advertising, public relations, propaganda, and education were still used interchangeably and terms would often be conflated, but there were also intense discussions about how to define and interpret these terms. Most prominently, debates flourished in the advertising industry, which had professionalized in the 1920 s and produced a cohort of 'experts' such as Walter Lippmann and Edward L. Bernays, to name but two, whose theories in no minor way also served to advertise advertising.

However, considerations about how to conceptualize and use media (including film) for social intervention were equally significant in European 
interwar film culture, informed not only by advertising theories but also by art movements such as Russian constructivism. Disputes about propaganda and education in the service of democracy were also lively among avant-garde and documentary film-makers, as this chapter will show. To use advertising in this setting as a broad category for film in the service of persuasion brings to light the underlying ideas - some shared, others divergent - that informed these debates and helps to place these discourses, which are often considered separately, in conversation with each other. Such an approach has several implications: first, it means, as mentioned above, that I do not refer to advertising as a particular institutional field, 'the advertising industry', as most studies on the relationship between the avant-garde and advertising in the 1920 do. ${ }^{6}$ Second, it implies that advertising is not narrowed down to a particular body of advertising film in the narrow sense of the term, in other words, the typical cinema and television commercials. Instead, I consider advertising as a pragmatic category that includes all kinds of films that share a particular form of communication: one that is made to persuade. ${ }^{7}$ Thus, it is persuasion, in concert with sponsorship, that serves as a criterion to involve cinematic forms such as the documentary and avant-garde cinema as objects of investigation in a study of screen advertising. Understood in this sense, advertising appears to be a form of communication that seeks to influence the minds, hearts, and deeds of its addressees. It intends to induce cooperation and it is a tool for social management. From a historical perspective, there has been an ongoing debate among practitioners and scientists alike whether to consider advertising or propaganda as the main category or as a subcategory. In using advertising as the umbrella term for the 'art of mass persuasion', I do not follow communication historians Garth S. Jowett and Victoria O'Donnell, for example, who hold that 'advertising is the most ubiquitous form of propaganda in our society, ${ }^{8}$ but rather

6 See, among others, Michael Cowan, Walter Ruttmann and the Multiplied Image: Avant-Garde and Sponsored Film Culture Between Weimar Modernity and National Socialism (Amsterdam: Amsterdam University Press, 2014); Michael Cowan, 'Advertising, Rhythm, and the Filmic Avant-Garde in Weimar: Guido Seeber and Julius Pinschewer's Kipho Film', October 131 (Winter 2010): 23-50; Sabine Hake, 'Das Kino, die Werbung und die Avantgarde', in Die Spur durch den Spiegel. Der Film in der Kultur der Moderne, ed. Malte Hagener, Johann Schmidt, and Michael Wedel (Berlin: Bertz, 2004), 193-206.

7 On the distinction between advertising as a genre and a pragmatic category, see Yvonne Zimmermann, 'Advertising and Film: A Topological Approach', in Films That Sell: Moving Pictures and Advertising, ed. Bo Florin, Nico de Klerk, and Patrick Vonderau (London and New York: Palgrave, 2016), 23-24.

8 Garth S. Jowett and Victoria O'Donnell, Propaganda and Persuasion, $2^{\text {nd }}$ ed. (Newbury Park, London, and New Dehli: Sage, 1992), 117. 
side with the likes of Johann Plenge, a German sociologist and pioneer in propaganda studies who, in 1922, regarded propaganda as a particular form of promotional communication, in other words, advertising. ${ }^{9}$

From this perspective, screen advertising is not limited to the selling of goods and services, but is deeply involved in the shaping of ideas and attitudes. It is part of the history of what has been called 'useful cinema' - in German called 'Gebrauchsfilm' (utility film). This research field has in recent years been very productive for the study of so far largely overlooked 'ephemeral' and 'orphan' films, such as science and industrial films, educational and classroom films, newsreels and home movies..$^{10}$ The epistemic gain from such a take on advertising is that it brings together bodies of films, institutions, and media cultures that have traditionally been viewed as distinct categories and discussed separately in film studies - such as avant-garde, documentary, and educational cinema. In her article on the emergence of educational film in the 1920 s and its relation to documentary film proper, Laurel E. Ahnert has recently shown how such distinctions between different categories of non-fictional film were made by contemporary actors, most prominently by John Grierson, and how these distinctions primed later film theorists and historians to adopt those categories for analysis - even though, as Ahnert convincingly demonstrates, the educational films of the 1920 s were not dramatically different from documentary films of later decades. ${ }^{11}$

Reconsidering non-fictional film from the perspective of screen advertising, as this chapter intends, questions the boundaries between the categories of avant-garde, documentary, and educational film in new ways. Studies on the British documentary film movement typically address the documentary film as a particular form of educational cinema, while discussion of the movement's relations to the avant-garde is often limited to the influence of Soviet cinema and its montage style. Examinations of the relationship between the documentary and the avant-garde on the other hand tend to focus on formal elements and emphasize, as Bill Nichols does in his contribution to the topic, the radical potentialities of the 1920 avant-garde

9 Johann Plenge, Deutsche Propaganda. Die Lehre von der Propaganda als praktische Gesellschaftslehre (Bremen: Angelsachsen-Verlag, 1922).

10 See for example Vinzenz Hediger and Patrick Vonderau, eds., Films That Work: Industrial Film and the Productivity of Media (Amsterdam: Amsterdam University Press, 2009); Charles R. Acland and Haidee Wasson, eds., Useful Cinema (Durham, NC: Duke University Press, 2011); Devin Orgeron, Marsha Orgeron, and Dan Streible, eds., Learning with the Lights off. Educational Cinema in the United States (New York and Oxford: Oxford University Press, 2012).

11 Laurel E. Ahnert, 'The Factual Treatment of Actuality: The Emergence of Educational Film in the 1920 s and its Relation to Documentary Film Proper', InterDisciplines 1 (2013): 77-101. 
while at the same time criticizing Grierson's commitment to government and corporate sponsorship for harnessing these radical aesthetic - and social - potentials. ${ }^{12}$

My attempt here is to bring the documentary, the avant-garde, and educational film together within the framework of advertising to retrace discourses, ideas, and visions that ran across various institutional, cultural, and geographic milieus. The goal is to reconsider the triad as intersecting and overlapping fields that shared the central idea of film as a tool for teaching democracy. This is to help overcome not only 'a false division between the avant-garde and documentary' that, according to Nichols, obscures their necessary proximity, ${ }^{13}$ but also an equally false division between the avant-garde, educational cinema, and advertising. Behind this is the idea that a transatlantic histoire croisée or entangled history ${ }^{14}$ of the European avant-garde and the documentary film movement from the perspective of advertising can bring to light an underlining pedagogical impulse that connects the avant-garde with the documentary film movement and educational cinema. At a politically critical moment in time, and following the strong media effects theory, they shared the belief that moving images were powerful tools for influencing the masses. And both the documentary film movement and educational cinema worked on the same project: the development and deployment of this tool - film - for training about democracy.

In the following, I draw on the writings by John Grierson and Paul Rotha, on the one hand, and on a body of writings and sponsored films by German avant-garde artist Hans Richter, on the other hand, to provide insights into the theories and methods that were developed by these film-makers to produce democratic citizenship with the help of moving images. Thereby, different models of screen advertising emerge that were grounded in divergent notions of propaganda and education due to diverging political ideologies.

Grierson and Rotha are probably the most prominent representatives and most influential promoters of the British documentary film movement.

\footnotetext{
12 Bill Nichols, 'Documentary Film and the Modernist Avant-Garde', Critical Inquiry 27, no. 4 (Summer 2001): $5^{83}$. Nichols detects three pre-existing elements - photographic realism, narrative structure, and modernist fragmentation - that in combination are involved in the appearance of documentary, along with a new emphasis on the rhetoric of social persuasion (p. $5^{82}$ ).

13 Ibid., 581.

14 On the concept of 'entangled history', see Michael Werner and Bénédicte Zimmermann, 'Vergleich, Transfer, Verflechtung: Der Ansatz der Histoire croisée und die Herausforderung des Transnationalen', Geschichte und Gesellschaft 28 (2002): 607-636; De la comparaison à l'histoire croisée (Paris: Seuil, 2004); 'Beyond Comparison: Histoire Croisée and the Challenge of Reflexivity', History and Theory 45, 1 (2006): 30-50.
} 
Rotha's book The Film Till Now: A Survey of World Cinema, first published in 1930, and his study The Documentary Film, which followed in 1935, are both pioneering books on film history. Grierson's definition of documentary (as 'the creative treatment of actuality') and his construction of the documentary tradition have had a lasting effect on the historiography of non-fiction film. Grierson's conceptualization of the documentary as a state-sponsored instrument for public management that is 'primarily concerned with attitudes of mind"15 characterizes the documentary unmistakably as a form of useful cinema - and of screen advertising.

To include Richter's work from the late 1930s and early 1940s in this study is less obvious. Richter is best remembered for the abstract films he made together with the Swedish painter Viking Eggeling in the early 1920 s (alongside Walter Ruttmann, the third 'pioneer' of German abstract or 'absolute' cinema). Still well-known, if less studied than his abstract works, are Richter's Dadaist and surrealist shorts from the late 1920s, among them Vormittagsspuk / Ghosts Before Breakfast (1928); Rennsymphonie / Race Symphony (1928); and Alles dreht sich, alles bewegt sich / Everything Turns, Everything Revolves (1929). Other aspects of Richter's work, such as his corporate-sponsored films from the 1930 s and his involvement with documentary theory in the service of democracy during his exile in Switzerland (1937-1941) have largely been neglected. Likewise, little scholarship exists on Richter's contribution to documentary pedagogy after he immigrated to the United States in 1941. Excavating Richter's theoretical and practical work in democratic film pedagogy (while in exile on both sides of the Atlantic) reveals Richter's deep imbrication in the documentary tradition and calls for a reassessment of his contribution to documentary film culture and screen advertising. More importantly, from the point of view of advertising, it provides a new avenue of research to reconsider the relationship between the avant-garde, the documentary, and educational film within the economic framework of corporate and government sponsorship. Indeed, sponsorship as the basic principle of funding non-fiction film is a shared feature that integrates the allegedly distinctive cultural fields into a useful cinema and screen advertising culture that saw films neither as money-making commodities nor as autonomous works of art, but as tools for social management. Finally, Richter's work in the 1930s and early 1940s opens up a transatlantic perspective on the concepts and dramaturgies of film as a tool for teaching democracy under the shackles of war.

15 John Grierson, 'The Documentary Idea: 1942', in Grierson on Documentary, ed. Forsyth Hardy (London and Boston: Faber \& Faber, 1979 [1946]), 117. 


\section{Paul Rotha, Hans Richter, and the Notion of Propaganda}

In his book The Struggle for the Film: Towards a Socially Responsible Cinema, a manuscript written between 1934 and 1939 (finally published in full in 1976 and translated into English in 1986, although parts of it were in circulation in contemporary articles), Hans Richter dedicates a short page to propaganda in which he explicitly refers to Paul Rotha and his notion of propaganda: 'the English documentarist Paul Rotha arrives at the view that propaganda can also be a means for a progressive cinema - namely, so long as the ends it serves remain social ones, ${ }^{16}$ Richter rejects Rotha's understanding of propaganda expressed in the book Documentary Film, first published in 1935, arguing that Rotha 'forgets that propaganda does not allow independent thought, it persuades by presenting pre-prepared, apparently illuminating thought models in advance of their conclusions, refusing to recognise the audience's freedom of decision. ${ }^{17}$ Richter concludes his short criticism on Rotha:

To make propaganda for truth, thought and judgement is one dramatic principle; propaganda for the concealment of the truth and for an uncritical reception is something else. - It is misleading to give the two the same name, for they strive for two different goals and must necessarily use different methods if they want to reach those goals. ${ }^{18}$

The dispute illustrates a larger concern about the nature of propaganda and its relationship to public relations, information, instruction, and education that was equally prevalent among academicians in the United States, who developed a theory and pedagogy for analysing contemporary propaganda. Debates on propaganda emerged in different fields, from progressive critique and communication research to practitioner expertise, after World War I. 'Propaganda anxieties' haunted liberal thoughts and politics in the United States from World War I to the Cold War, as Brett Gary illustrates in his study The Nervous Liberals. ${ }^{19}$ Edward L. Bernays, American pioneer of public relations and advocate of the contested term 'propaganda', famously stated

\footnotetext{
16 Richter, The Struggle for the Film, 143.

17 Ibid.

18 Ibid.

19 Brett Gary, The Nervous Liberals: Propaganda Anxieties from World War I to the Cold War (New York: Columbia University Press, 1999). See also Charles R. Acland's study Swift Viewing: The Popular Life of Subliminal Influence (Durham, NC: Duke University Press, 2012) on the popular concern about subliminal messages and 'hidden persuaders' since the $1950 \mathrm{~s}$.
} 
that the only difference between propaganda and education is the point of view: "The advocacy of what we believe is education. The advocacy of what we don't believe is propaganda,. ${ }^{20}$ Bernays's view conflicts with the progressives' favoured definition of propaganda as a covert and institutionally promoted threat to intelligent public opinion and participatory democracy - a threat that fuelled the mission of progressives to expose propaganda, as J. Michael Sproule explains in his book Propaganda and Democracy. ${ }^{21}$

In Britain, the documentary film movement deliberately wrote itself into a 'propagandist tradition', holding that a cinema 'pursuing the ends of propaganda and persuasion' had largely been responsible for the documentary method. ${ }^{22}$ For Rotha, while serving the needs of propaganda (a term that for him was interchangeable with public relations), the documentary fulfils an instructional purpose at the same time. Indeed, propaganda and education are so closely related and interconnected that Rotha does not even try to draw a distinction between them, admitting instead that 'it would be extremely difficult to define where instruction begins and propaganda ends'. ${ }^{23}$ Importantly, Rotha sees in propaganda a valid instrument for democracy, and in documentary its most effective method.

If Rotha refrains from clearly distinguishing propaganda and education, he does draw a line between totalitarian and democratic propaganda, arguing that totalitarian propaganda is based on a single idea, and, as a consequence, is the more powerful:

It asks for an unquestioning obedience by the individual in the interest of the State. It thereby relieves the individual of all the obligations of citizenship save that of acquiescence. The State and its leaders do all the social thinking which, in democracy, is demanded of the individual. ${ }^{24}$

To prevent the success of competing governmental systems and to preserve democracy, imparting citizenship knowledge is therefore perceived as the immediate task. ${ }^{25}$

Richter, however, maintained his understanding of propaganda while in exile in New York, holding that information and propaganda were not

21 J. Michael Sproule, Propaganda and Democracy: The American Experience of Media and Mass Persuasion (Cambridge: Cambridge University Press, 1997).

22 Rotha, Documentary Film, 92.

23 Ibid., 57.

24 Ibid., 207.

25 Ibid., 206. 
only two different techniques for the interpretation of facts - the one more objective, the other more dramatic - but they also represented two different social concepts. ${ }^{26}$ What is notable about this debate is the fact that Richter was deeply involved in this discussion revolving around the right type of persuasion in advertising film culture and that he worked on the very same artistic problems as the documentary movement - problems that challenged democracy. These problems originated in modern mass society and gained urgency with the rise of authoritarian and totalitarian political systems. Richter's increasing engagement in the fight for democracy throughout the highly critical political circumstances of the 1930 s while in exile in Switzerland came out of Richter's basic idea of the social function of cinema and of art in general. In this sense, the subtitle of his book, 'Towards a Socially Responsible Cinema', can be read as a programme. To a large extent, Richter's pamphlet echoes Rotha's concern about cinema's failure, largely due to the logic of the film industry's economic organization, to deal with the important social issues of modern existence. In this respect, Richter speaks of the social mandate of the official cinema as being a mandate to 'anaesthetize' the audience. The remedy should be what Richter calls 'the progressive cinema', an educational cinema whose task it is to develop the audience's capacities for thought and judgement so that 'they can link the action on the screen with their own lives.. ${ }^{27}$

Fundamentally, such educational cinema is conceptualized both by Rotha and Richter (as well as Grierson) as an alternative to the film industry and theatrical circuits. The avant-garde's involvement in this alternative, largely non-theatrical, government and corporate-sponsored useful cinema and advertising screen culture allowed the avant-garde to remain true to its self-proclaimed principle of 'independence'. This might seem to contradict the avant-garde's self-conception. Yet, the antiinstitutional attitude, which theorists of the avant-garde such as Peter Bürger consider a key feature of the avant-garde, was directed against the film industry and the commodities it produced, and not necessarily against other institutions that operated - such as the avant-garde - beyond commercial cinema circuits in the non-theatrical field and that produced films that were not conceived as commodities, but as tools for persuasion. Among these institutions were corporations, educational organizations,

26 Hans Richter, 'Post-War Planning on Documentary Film', unpublished typescript, [1942], 3 (MoMA Archives, Hans Richter C.XIV.5).

27 Richter, The Struggle for the Film, 133. 
and the state. Independence from the film industry was to be found in the 1930s, after the coming of sound, only in the non-commercial sector and in cooperation with commissioning bodies. Therefore, Rotha could very well maintain that 'propaganda appears to present an alternative to the harsh cash basis for film production'. ${ }^{28}$ This may explain why making commercials and sponsored documentaries did not, in the self-conception of the avant-garde, corrupt the self-proclaimed principle of independence. It only did so in later avant-garde discourses that emerged in the context of the post-war experimental film movement in the United States that was opposed to any utilitarian use of the medium, be it commercial, educational, or ideological, and celebrating artistic self-expression instead. These later discourses have retrospectively overshadowed and obscured the nature of the avant-garde in the 1930s and its involvement in advertising screen culture.

The social concern shared by Rotha, Richter, and many other filmmakers such as Joris Ivens or Alexander Hackenschmied (also known as Hammid) seems to confirm the traditional claim of studies on the cinematic avant-garde in Europe that, in the early 1930s, a shift in focus occurred from a primarily aesthetic to a more social perspective, and that this shift from formal experiment to social engagement went hand in hand with an abandonment of abstract cinema and film poetry for the sake of documentary. The reasons for this shift from poetics to politics are considered to be manifold, owed to changes in technology (introduction of sound), economy (documentary providing a solid foundation for production), and politics (political radicalization, rise of totalitarian systems), which together led to a 'functional differentiation' of the avant-garde in the 1930 s and the dispersal of the movement. ${ }^{29}$ This tendency to move from formal experimentation towards a greater engagement with the social or political context was also contemporarily proclaimed by Richter himself. ${ }^{30}$

Yet I think we should not succumb too easily to the danger of constructing a simple dichotomy between formal experimentation and social perspective.

28 Rotha, Documentary Film, 65 .

29 See Malte Hagener, Moving Forward, Looking Back: The European Avant-Garde and the Invention of Film Culture, 1919-1939 (Amsterdam: Amsterdam University Press, 2007).

30 See, for example, Richter's film lecture with the speaking title 'Vom Avantgardefilm zum Dokumentarfilm' ['From Avant-Garde Film to Documentary'] in which he demonstrated, with the help of movie excerpts, the avant-garde's shifting focus from form to content, described in Harry Goldschmid, 'Die internationale Filmwoche in Basel', Das Werk: Schweizer Monatsschrift für Architektur, Freie Kunst, Angewandte Kunst 26, no. 7 (1939): 12-18. 
To acknowledge the avant-garde's rejection of artistic autonomy and to take its attempt to integrate art and life seriously, to use Bürger's terms again, ${ }^{31}$ can prevent us from creating a false divide between aesthetics and politics. Richter was explicit on this point in an interview with Léo Sauvage in 1937 about his sponsored films: 'I explore aesthetic problems not in isolation, but in relation to the realities posed by life. $3^{22}$ If we are to take the refusal of artistic autonomy seriously, we may on the one hand acknowledge (if not rediscover) the social and profoundly educational dimensions of the aesthetic explorations of the medium in the 1920s. On the other hand, we may reconsider the aesthetically less advanced sponsored documentaries as genuine formal experimentations into film's capacity to cope with the challenges that society poses - challenges that, in the case discussed here, call for the development of filmic methods for training about democracy. I will come back to this point later on. Suffice it to say, for the moment, that the avant-garde and the documentary film movement were allies in rejecting artistic autonomy and in attempting to reconnect art with life. If Richter discards Rotha's notion of propaganda, we can nevertheless ascertain a shared recognition that art is a social function and that it cannot be considered apart from materialist orderings of the society. ${ }^{33}$ Hence arises the social responsibility of the artist.

\section{John Grierson, Hans Richter, and the Theory of Education}

If Paul Rotha refuses a clear distinction between propaganda, information, instruction, and education, arguing that they are relational and gradually overlapping categories, John Grierson goes one step further and declares propaganda and education as one. Defining propaganda as 'the art of public persuasion', ${ }^{34}$ or, as he puts it elsewhere, 'the constructive management of public affairs', ${ }^{35}$ Grierson holds that propaganda is the new democratic education:

31 Peter Bürger, Theory of the Avant-Garde, trans. Michael Shaw (Minneapolis: University of Minnesota Press, 1984), 50.

32 Léo Sauvage, 'Hans Richter: Un des maîtres de l'avant-garde allemande voudrait collaborer avec Méliès', Cinémonde (Paris), no. $45^{8}$ (27 July 1937). My translation.

33 See Rotha, Documentary Film, 66ff.

34 Grierson, 'Propaganda', 119.

35 Quoted in Peter Morris, 'Re-thinking Grierson: The Ideology of John Grierson', in Dialogue: Canadian and Québec Cinema, ed. Pierre Véronneau, Michael Dorland, and Seth Feldman (Montreal: Médiatexte, 1987), 21-56, here 45 . 
In other words, the key to education in the modern complex world no longer lies in what we have known as education but in what we have known as propaganda. By the same token, propaganda, as far from being the denial of the democratic principle of education, becomes the necessary instrument for its practical fulfillment. ${ }^{36}$

Education for citizenship was at the centre of concerns in democratic states and in authoritarian and totalitarian regimes alike. The same anxieties occupied the minds of modernist artists and film-makers, if we think of the importance of visual education and the schooling of the senses in Russian constructivism, the work of Sergei Eisenstein and Dziga Vertov in the service of the creation of the 'New Man' or the Bauhaus, and László Moholy-Nagy's theoretical and practical work on 'New Vision'. ${ }^{37}$ Grierson and Richter can be viewed as representatives of two different theories of citizenship education in democracy based on different political ideologies. They allow us to exemplify and specify the involvement not only of the documentary movement but also of members of the avant-garde in a larger project of modern education of the masses. A comparative perspective on Grierson's and Richter's theoretical and practical work at the crossroads of propaganda and education brings to light theoretical differences as well as shared ideas regarding the conception of citizenship and the formation of a cinema that influences political views and habits and educates for democracy.

In 'Education and Total Effort' (1941), Grierson highlights the need to revolutionize educational outlooks and methods while criticizing democratic educational theory as wrong in itself and proceeding on an altogether false assumption - namely,

the mystical democratic assumption that the citizen can be so taught to understand what is going on about him that he and his fellows in the mass can, through the electoral and parliamentary process, give an educated and rational guidance to the conduct of the state..$^{8}$

36 John Grierson, 'Education and Total Effort' [1941], in Grierson on Documentary, 139.

37 On László Moholy-Nagy's work, see, for example, Elizabeth Otto, 'A “Schooling of the Senses": Post-Dada Visual Experiments in the Bauhaus Photomontages of László Moholy-Nagy and Marianne Brandt', New German Critique 107, vol. 36, no. 2 (Summer 2009): 89-131; on his filmic work, see in particular Jan Sahli, Filmische Sinneserweiterung: László Moholy-Nagys Filmwerk und Theorie (Marburg: Schüren, 2006).

38 Grierson, 'Education and Total Effort', 134. 
Grierson's critique of a key postulate of democratic theory, that of the 'rational citizen', was deeply influenced by the theories of Walter Lippmann and Harold D. Lasswell. Peter Morris, Ian Aitken, Jack C. Ellis, and most recently Stephen Charbonneau have contributed in-depth studies of Grierson's political ideology and his intellectual and aesthetic formation during his postgraduate years in Chicago, Hollywood, and New York in the 1920 s. $^{39}$ While Morris underlines that Walter Lippmann's book Public Opinion (1922) crystallized for Grierson key neoconservative ideas that were already familiar to him and that would become dominant to his ideology, Aitken argues that Grierson's views are closer to the liberal objectivist theories articulated by John Dewey and C.A. Ellwood than to Lippmann's anti-democratic and elitist theory expressed in Public Opinion. Aitken nonetheless acknowledges that Grierson absorbed two views from Lippmann and Lasswell: the diagnosis of a lack of knowledge in citizens owed to the complexity of the modern world and, as a consequence, the necessity of an elite of experts to govern and guide society. From Lasswell, Grierson may have also adopted an understanding of propaganda as a necessary tool of managed society that, as a mere tool, as Lasswell underlines it, 'is no more moral or immoral than a pump handle', and that 'the only effective weapon against propaganda on behalf of one policy seems to be propaganda on behalf of an alternative'. ${ }^{0}$

These ideas had a formative influence on Grierson's views on democracy, propaganda, education, and documentary film. They laid the foundation for Grierson's belief that the chief problem of propaganda in a democracy does not lie in proving its necessity, but rather in 'developing its wise and democratic use along the path of education' ${ }^{41}$ Education, for Grierson, is 'the key to the mobilization of men's minds to right ends or wrong ends, to order or chaos'. ${ }^{42}$ And the democratic interpretation of education, spelled

39 Morris, 'Re-thinking Grierson'; Ian Aitken, Film and Reform:John Grierson and the Documentary Film Movement (London and New York: Routledge, 1990); Jack C. Ellis, John Grierson: Life, Contributions, Influence (Carbondale and Edwardsville: Southern Illinois University Press, 200o); Stephen Charbonneau, 'John Grierson and the United States', in Zoe Druick and Deane Williams, eds., The Grierson Effect: Tracing Documentary's International Movement (London and New York: British Film Institute, 2014), 13-28. See also Martin Stollery, Alternative Empires: European Modernist Cinemas and Cultures of Imperialism (Exeter: University of Exeter Press, 2000).

40 Harold D. Lasswell in his 1933 article for Encyclopaedia of the Social Sciences, quoted in Sproule, Propaganda and Democracy, 69 .

41 John Grierson, 'Propaganda and Education' [19 October 1943], in Grierson on Documentary, 146.

42 John Grierson, 'Education and the New Order' [1941], in Grierson on Documentary, 123. 
out as 'the process by which the minds of men are keyed to the task of good citizenship', ${ }^{43}$ makes propaganda and education one. ${ }^{44}$ In other words, for Grierson, democratic education meant promoting good citizenship and selling democracy.

Grierson's educational theory is informed by anti-rationalistic views of the public mind, which began to emerge in the late nineteenth century and were particularly strong in Europe in the fields of sociology and philosophy. A major influence was Gustave Le Bon's work on the psychology of the crowd (La Psychologie des Foules [1895] / The Crowd:A Study of the Popular Mind [1896]). Regarded as the founder of mass psychology, Le Bon published studies on the irrationality of the crowd and the role of the unconscious in mass society, which influenced not only Sigmund Freud and Max Weber but also informed the avant-garde and gained wider public acceptance due to the experience of World War I. Also in the United States, the idea of society's irrationality began to challenge the traditional liberal faith in reasoned public opinion. As Sproule shows, these European influences helped to lay an intellectual foundation in the United States upon which a post-World War I propaganda consciousness could be built. ${ }^{45}$

If Hans Richter, profoundly affected by the irrationality and futility of World War I, shares the anti-rationalistic view of modern mass society, which finds salient expression in Richter's participation in Dada, Richter advocates for a different theory of education than Grierson to cope with the allegedly irrational character of mass society. However, two aspects complicate the study of Richter's ideas of education. As Stephen C. Foster has underlined, few artists spanned the movements of early 2oth-century art as completely as did Hans Richter. He was a major force in the developments of expressionism, Dada, constructivism, surrealism, and of abstract cinema. After his immigration to New York, Richter contributed to modernism in the United States, thus serving as an important conduit between the American and European art communities. ${ }^{46}$ Richter's position towards modernity is complex and ambivalent; it shifted with changing political and social circumstances. Second, Richter's long and eventful career, marked by several exiles, was historicized and interpreted in retrospect in many books, essays, and interviews by the artist himself, thus providing scholars

43 Ibid., 122.

44 See Grierson, 'Propaganda and Education', 155.

45 Sproule, Propaganda and Democracy, 33.

46 Stephen C. Foster, ed., Hans Richter:Activism, Modernism, and the Avant-Garde (Cambridge, MA and London: MIT Press, 1998). 
with ready explanations that, as is typical for memory stories, give structure, sense, and closure to life and work while glossing over discrepancies and inconsistencies. Accordingly, Richter's retrospective interpretation of his own career has to be read with some precaution and, if available, verified by contemporary sources, as is my attempt here.

Malcolm Turvey, in his essay 'Dada between Heaven and Hell: Abstraction and Universal Language in the Rhythm Films of Hans Richter', argues that in responding to problems of modernity, Richter's abstract films intend to reconcile conflicting tendencies of liberty and order, chaos and structure. They try to restore the putatively lost balance between reason and unreason. ${ }^{47}$ Turvey aligns Richter's search for a universal language with the critique of rationality expressed by Friedrich Schiller in his essay 'On the Aesthetic Education of Man' (1795). In this treatise, Schiller sees fine art as an instrument to restore the balance between the different faculties or drives lost in modernity. Turvey's argument is based on Richter's retrospective interpretation of Dada put forward in his book Dada Art and Anti-Art (1964) and not contextualized in contemporary writings and discourses; the question of whether Richter was more influenced by Schiller or by Friedrich Nietzsche lends itself to debate. Significant for this study, however, is the recognition of Richter's complex position between rationalist and anti-rationalist traditions and the acknowledgement of a counterbalancing impulse that characterizes Richter's views to better understand Richter's pedagogical ideas and educational efforts that he developed in the 1930s and early 1940 s upon working within a non-theatrical, non-fictional useful cinema culture characterized by sponsorship and persuasive rhetoric.

In his aforementioned book The Struggle for the Film, Richter distinguishes between propaganda and education by stating that propaganda is too onesided, since its only aim is to further a particular cause whereas the aim of education, by contrast, is 'a harmonious and meaningful formation of the whole man'. ${ }^{48}$ If it is sufficient for propaganda to hammer in ideas, education, according to Richter, aims to awaken people and stimulate them to use their own abilities. ${ }^{49} \mathrm{In}$ a liberal democratic tradition following the legacy of the Enlightenment, Richter shows much more faith in the mental capacities of humans to think than does Grierson, who, in the line of Lippmann and other neoconservative thinkers, criticizes the belief in the capacity of the masses

47 Malcolm Turvey, 'Dada Between Heaven and Hell: Abstraction and Universal Language in the Rhythm Films of Hans Richter', October 105 (Summer 2003): 13-36.

48 Richter, The Struggle for the Film, 143.

49 Ibid. 
to make reasonable decisions as 'mythical democracy'. As a consequence, Grierson does not want people 'to know everything about everything all the time', holding that this is impossible, but to see society 'emancipated from its confusion and bewilderment, and given some imaginative leadership in the articulation of a faith'. $5^{0}$

It is important to acknowledge that both Grierson and Richter were equally puzzled by problems of political education, and in that, they can be considered characteristic European intellectuals of the 1930s, but it is also evident that they followed different theories. Grierson's model of democratic education is clearly based on the idea of public management. Richter also wanted 'cinema to intervene actively in the consciousness and emotional life of its spectators', but with the aim 'to bring the spectators into conscious contact with reality and to put into their hands or heads the means whereby they can recognize their real interests and act accordingly'..$^{1}$ According to Richter, the aim of cinema must be to induce the audience to think..$^{2}$ Trusting the mental capacities of the audience and believing in the power of education to produce rational citizens, Richter wanted to train audiences to think rather than to persuade them to conform to authorities, even if they are democratic. Whereas Grierson's educational model rests upon the power of persuasion, the goal of Richter's concept of education, in the tradition of Enlightenment, is emancipation.

Despite apparently different political and educational concepts to sell democracy, both Richter and Grierson share with their contemporaries a belief in film as an efficient tool for manipulation emerging from an underlying conception of citizenship - and spectatorship - that is based on the notion of citizens/audiences as deficient and therefore in need of guidance and instruction. This basic idea of the ignorant and passive citizen/spectator that must be activated, made aware of the social situation, and trained by an elite of experts has been at the foundation of modern art and society. ${ }^{53}$ The same concept of modern spectatorship as mass audience with a passive attitude that is prone to manipulation and that needs activation - through persuasion, education, or alienation - underlies modern art and philosophy from Bertolt Brecht's theatre pedagogy to critical theory and the Frankfurt School.

\footnotetext{
50 Grierson, 'Education and Total Effort', 136.

51 Richter, The Struggle for the Film, 131.

52 See ibid., 164.

53 For a cultural and political history of audiences in the United States, see Richard Butsch, The Citizen Audience: Crowds, Publics, and Individuals (New York: Routledge, 2008). Butsch's study reveals that the judgement of audiences against the standards of good citizenship has been a constant in the changing history of attitudes towards audiences.
} 


\section{Searching for New Methods to Advertise Democracy: Documentary and the 'Film Essay'}

Sharing the idea that the purpose of cinema is civic training for democracy, both Grierson and Richter considered the reformation of educational film and the finding of new cinematic methods for teaching citizenship to be salient. Grierson presents the documentary as the formal solution to what he terms 'the central problem of the age: that of the creating of a "mature citizenry", 54 arguing that

the only methods which will convey the nature of the society are dramatic methods. That is why the documentary film has achieved unique importance in the new world of education. It does not teach the new world by analyzing it. Uniquely and for the first time it communicates the new world by showing it in its corporate and living nature. 55

Much has been written on the documentary tradition, its educational impulse, and its formal innovation. And recent studies have highlighted that this tradition was part of a larger useful cinema - and, as I suggest advertising film culture. ${ }^{56}$ Lesser known, however, is Hans Richter's similar effort to search for a new cinematic form for democratic education. In this quest for a new dramaturgy to produce a democratic citizenry, Richter draws a distinction between the official, obscurantist cinema and a progressive, enlightening cinema. If it is the aim of the progressive cinema 'to intervene actively in the consciousness and emotional life of its spectators', as Richter claims, 'special methods have to be developed by which to carry out that aim'. ${ }^{7}$ Finding a new dramaturgy that reaches the masses and develops the audience's capacities for thought and judgement and that, following Brecht's dictum of 'the pleasure of learning', at the same time satisfies 'the masses' need for spectacle and entertainment' becomes the aesthetic problem and artistic challenge for Richter during his exile in Switzerland. ${ }^{8}$ Richter's sponsored films from the late 1930 s can be interpreted as experiments to turn cinema into an art of mass enlightenment and non-fictional film

54 Quoted in Aitken, Film and Reform, 57.

55 Grierson, 'Education and the New Order', 129.

56 See, for example, Lee Grieveson and Colin MacCabe, eds., Empire and Film (London and New York: Palgrave, 2011); Lee Grieveson and Colin MacCabe, eds., Film and the End of Empire and Film (London and New York: Palgrave, 2011).

57 Richter, The Struggle for the Film, 131.

$5^{8}$ Ibid., 133 . 
into a weapon for democracy. His involvement in screen advertising during exile was thus more than just a job to make ends meet, but prompted by a serious political concern.

In 1940 Richter came up with the 'film essay' as a novel cinematic form and solution to this very problem. In an article in the Swiss daily newspaper National-Zeitung, Richter presented the film essay as 'a new type of documentary film' that was capable of visualizing what cannot be seen: 'the invisible world of imagination, thoughts, and ideas'.59 Unlike manufacturing processes or the workings of a machine, abstract thoughts and ideas cannot just be recorded and thus reproduced by the camera, but need to be produced; that is, they must rendered visible and thus understandable, with the specific techniques of film. Like Dziga Vertov and Jean Epstein, Richter saw in cinema an epistemological instrument to reveal reality, thus sharing the belief in the capacity of cinema to open the eyes of the masses. ${ }^{60}$ Also in Grierson's theory, revealing reality was also a precondition to create a persuasive film. ${ }^{61}$ Similar to Grierson's approach with the documentary film, Richter developed and implemented his concept of the film essay within the institutional framework of corporate and government sponsorship. This is noteworthy also in regard to the essay film tradition in which Richter, together with Alexandre Astruc, figures as a precursor - despite the fact that the essay film as it emerged in the post-war period was first developed by auteurs belonging to the French nouvelle vague as a means to break with 'propagandistic' non-fictional film and advertising screen culture after World War II. ${ }^{62}$ It is equally important to notice that Richter's concept of the film essay corresponds only in part with the personal, subjective, and highly self-reflexive essay film from later

59 Hans Richter, 'Der Filmessay: Eine neue Form des Dokumentarfilms', National-Zeitung, no. 192 (25 April 1940). Reprinted in Christa Blümlinger and Constantin Wulff, eds., Schreiben Bilder Sprechen: Texte zum essayistischen Film (Vienna: Sonderzahl, 1992), 195-198. English translation: 'The Film Essay: A New Type of Documentary Film', in Essays on the Essay Film, ed. Nora M. Alter and Timothy Corrigan, trans. Maria P. Alter (New York: Columbia University Press, 2017), 89-92.

6o In his insightful book on revelationist cinema, Malcolm Turvey includes Vertov, Epstein, Béla Balázs, and Siegfried Kracauer in the revelationist tradition. Neither Richter nor Grierson are considered. See Malcolm Turvey, Doubting Vision: Film and the Revelationist Tradition (Oxford and New York: Oxford University Press, 2008).

61 See Grierson, 'Propaganda and Education', in particular 155.

62 See Thomas Elsaesser, 'The Essay Film: From Festival Favorite to Flexible Commodity Form?' [2015], in Essays on the Essay Film, 243. See also Timothy Corrigan, The Essay Film: From Montaigne, After Marker (New York: Oxford University Press, 2011). 
periods discussed in recent scholarship. Richter's idea of the film essay is a documentary form in which

the filmmaker is not bound by the depiction of external phenomena and the constraints of chronological sequences, but, on the contrary, has to enlist material from everywhere, the filmmaker can bounce around freely in space and time. For example, he can switch from objective representation to fantastic allegory and from there to a staged scene; the filmmaker can portray dead as well as living things, and artificial as well as natural objects - as long as they serve the purpose of making visible the fundamental idea. ${ }^{63}$

Richter mentions a number of films that, in his eyes, have the potential for further development of this allegedly new type of documentary film, among them films by the French group around Jacques Brunius (Violons d'Ingres [1939]), films by the Belgian Henri Storck (Regards sur la Belgique ancienne [1936]), and the works of the British documentary movement by Alberto Cavalcanti, Basil Wright, and Grierson, all produced for and sponsored by the Empire Marketing Board and the General Post Office. ${ }^{64}$ Richter also labels two of his own works film essays: Inflation (1928) and Die Börse als Barometer der Wirtschaftslage (The Stock Exchange, 1939), a film on the evolution, the functioning, and the importance of the stock exchange. The film was sponsored by the Swiss Stock Exchange in Zurich, with the goal to restore the confidence of private investors in the institution of the stock exchange, which had suffered drastically from the Great Depression. In other words, it advertised the Swiss stock market.

To render visible and intelligible the history, workings, and importance of the stock exchange, Richter uses a large variety of visual material, both still and moving, from all kinds of sources: images of historical paintings, drawings, and engravings; re-enactments and emblematic images to reanimate the past; documentary footage shot for the purpose; and stock footage both from third-party documentaries and newsreels as well as from Richter's own earlier films, among them shots from Alles dreht sich, alles bewegt sich / Everything Turns, Everything Revolves (1929). This compilation of heterogeneous visual material serves to illustrate the voice-over commentary that copiously narrates the genealogy of trade from barter to immaterialized

63 Richter, 'The Film Essay', 91-92.

64 Richter, 'Der Filmessay', reprinted in Schreiben Bilder Sprechen, 197. The title of Storck's film that Richter gives L'histoire de l'ancienne Belgique. 
finance. In his famous study on the compilation film Films Beget Films (1964), Jay Leyda discusses Richter's concept of the film essay, underlining that Richter compiles pre-existing film not merely to record and document, but to express ideas through the juxtaposition of images..$^{6}$ The technique of compilation and collage also characterizes Richter's filmic work in the United States, most obviously Dadascope I (1956-1961) and Dadascope II (1968), in which shots from Richter's past films accompany a soundtrack composed of poems by Dada poets recorded between 1916 and 1922.

Die Börse was awarded 'best film' at the Swiss national exhibition held in Zurich in 1939. This showcase of national achievements in art and industry, in history and politics, was an instance of non-theatrical film culture in full bloom with multiple institutional strands of film culture converging, among them the avant-garde, pedagogues, and private enterprises. Five of the seven sponsored films Richter made during exile in Switzerland were produced for this very occasion, among them Die Börse. ${ }^{66}$ The exhibition registered 10.5 million admissions (the country had a total population of four million then) and was the most popular public event on national ground to date. ${ }^{67}$

Die Börse has raised scholarly controversy: some critics have dismissed the film as a naïve advertisement for modern capitalist economy that corrupts Richter's own political ideas. Thomas Tode, for example, holds that the film 'does no credit to a filmmaker who once was a secretary of education of a republic of councils' ${ }^{68}$ Others have celebrated Die Börse as an implicit critique of capitalism and as an instance of formal resistance. ${ }^{69}$ Both interpretations are based on the same understanding of sponsored film-making and working within advertising screen culture as inevitably creating a moral, political, and/or artistic conflict that forces the author to either compromise or resist. To accuse Richter of betraying his revolutionary ideals from the late $1910 \mathrm{~s}$

65 See Jay Leyda, Films Beget Films: A Study of the Compilation Film (New York: Hill and Wang, 1964), 3of.

66 On the Swiss national exhibition, see Yvonne Zimmermann, "The Avant-Garde, Education and Marketing: The Making of Nontheatrical Film Culture in Interwar Switzerland', in The Emergence of Film Culture: Knowledge Production, Institution Building, and the Fate of the Avant-Garde in Europe, 1919-1945, ed. Malte Hagener (Oxford and New York: Berghahn, 2014), 199-224.

67 If we want to believe the statistics, each visitor spent an average of 100 minutes watching films. See Schweizerische Landesausstellung 1939 Zürich, ed., Administrativer Bericht, vorgelegt vom Liquidationskomitee der Schweizerischen Landesausstellung 1939 (Zurich: Schweizerische Landesausstellung, 1942), 115 .

68 Thomas Tode, 'Ein Bild ist ein Argument: Hans Richter und die Anfänge des Filmessays', Navigationen 2, no. 2 (February 2002): 103.

69 Urs Stäheli and Dirk Verdicchio, 'Das Unsichtbare sichtbar machen: Hans Richters Die Börse als Barometer der Wirtschaftslage', Montage AV 15, no. 1 (2006): 108-122. 
and early 1920 s is to forget that the avant-garde's 'revolutionary frame of mind' changed 'according to changing historical conditions', as William C. Wees has put it ${ }^{70}$ and to neglect the avant-garde's imbrication in educational film, useful cinema, and advertising screen culture. The film stands as an example for the potential confluence of objectives connected with film sponsorship. For the sponsor, Die Börse served - and still serves - as an advertising film: on its first release, it promoted the stock exchange to regain the confidence of private investors. Ever since 1939, Swiss Stock Exchange in Zurich has been screening the film on anniversaries and other special occasions, bestowing a memorial function on the moving images for the corporation. ${ }^{71}$ At the same time, for Richter, the brief of the commissioner (to persuade investors to invest in the stock market again) was an aesthetic challenge, and Die Börse was a genuine search for a new documentary method to make visible - and understandable - ideas and arguments on the screen. Persuasion or influence (the sponsor's perspective) and education (the film-maker's perspective) do not necessarily contradict each other, but may go hand in hand or side by side quite smoothly within the framework of a non-theatrical film culture that depended on sponsorship and believed in the persuasive power of moving images..$^{2}$

In this context, it might be the moment to briefly bring up the question of the film-makers' earnestness about their involvement in questions of propaganda and education in the service of democracy. In his book Claiming the Real, Brian Winston doubts whether Grierson cared about reform or only about film: 'Yet he did not really mean this. It was nothing more than rhetoric for the sponsors' ears; for Grierson, too, was only concerned with film'.73 Winston interprets Grierson's oratory for reform as pure rhetoric or business talk to please sponsors. Since it was vital for non-fiction film producers to sell the advertising potential of film to sponsors and persuade them of the usefulness of investing in moving images, Grierson's as well as Rotha's and Richter's social engagement can be seen as a means to an

70 Open letter attacking the International Experimental Film Congress held in Toronto in the spring of 1989 , in which members of the 1980 s experimental film generation rebelled against former avant-garde discourses and practices; quoted in William C. Wees, 'The Changing of the Garde(s)', Public, no. 25 (2002): 18.

71 Die Börse was preserved and restored by the Swiss Film Archive in 2006.

72 For a more detailed analysis of Die Börse and Richter's concept and practice of the film essay see Yvonne Zimmermann, 'Hans Richter and the Filmessay: A Media Archaeological Case Study of Documentary Film History and Historiography', in A Companion to Documentary Film History, ed. Joshua Malitzky (Bloomington: Indiana University Press, forthcoming).

73 Brian Winston, Claiming the Real: The Grierson Documentary and Its Legitimations (London: British Film Institute, 1995). 
end - to acquire sponsorship. But even if this was the case, it does not necessarily preclude a personal commitment to the cause. In Richter's case, there is a strong pedagogical impulse that runs through his entire work. Seen from a larger political and sociocultural perspective, non-fiction film emerged and developed within projects of social reform and had been aligned with education, alongside persuasion, from the beginning. As the books by Sproule and Gary illustrate, anxieties about propaganda and education for democracy occupied the minds of intellectuals, politicians, and artists alike, and it is rather implausible that either Grierson or Rotha and Richter devoted so much theoretical and practical work on the matter for pure business interest without any personal conviction.

\section{Selling Democracy across the Atlantic: Transatlantic Exchange of Educational Film Culture}

In Switzerland and later in New York, Richter incessantly advocated theory and practice for the film essay, but he had less success in branding the 'film essay' as a new method for educational cinema than Grierson had in branding the 'documentary' as such. Nevertheless, Richter played an important role in the transatlantic exchange of educational film culture, even though his contribution is by no means as well-known as Rotha's who, upon his visit to New York in 1937-1938, introduced 'the whole documentary idea of public service using social purpose for progress' to the United States. ${ }^{74}$ In its very first issue in 1938, Business Screen provided a platform for Rotha to familiarize an American readership with the British documentary film. Rotha took the opportunity and introduced British documentary film as a player in 'the revitalization of citizenship, without which, its makers believe, democracy cannot continue to exist'.75 Invited by Iris Barry, curator of the Museum of Modern Art's (MOMA) Film Library, Rotha spent five months at the Film Library, where, as Barry and Richard Griffith recounted in 1942, 'as special assistant to the director, he lectured and conferred with educational authorities and film producers in an effort to encourage the consistent and planned production of fact films in the United States'. ${ }^{6}$ Rotha brought

74 Paul Rotha, Documentary Diary: An Informal History of the British Documentary Film, 1928-1939 (London: Secker \& Warburg, 1973), 171.

75 Paul Rotha, 'British Documentary Films Offer American Business Some New Opportunities', Business Screen 1, no. 1 (1938): 25-26, here 26.

76 Iris Barry and Richard Griffith, 'The Film Library and the Film of Fact', in The Museum of Modern Art Film Library Films of Fact 1942 (Museum of Modern Art, Department of Film Archive, 
with him a selection of British documentary films that received their first screenings in the United States and became part of MoMA's Circulating Film Programs.

As Stephen Charbonneau has underlined, Rotha's visit, upon which he advanced a particular view of educational cinema for civic training - namely, Griersonian documentary - was part of a broader effort to mobilize educational and propagandistic cinema in the United States in the $1930{ }^{77}$ Within the larger context of the progressive education movement that recognized the lack of citizenship skills as a major threat to democracy, cinema as a mass media was viewed both as a danger and a promise for democracy. To teach about and with film became a major issue for the academy, philanthropic foundations such as the Rockefeller Foundation, schools, and, during World War II, also the state. The Payne Fund Studies, which researched the effect of movies on children's behaviour; programmes such as the 'Secret of Success' and 'Human Relations Series of Films', which used edited Hollywood film shorts to teach character education and human relations in schools; and film appreciation programmes intending to produce better consumers of film that would put pressure on Hollywood to produce better films ${ }^{78}$ contributed to a broad film culture in an educational setting. ${ }^{99}$ The documentary was part and parcel of this broad educational film culture, and so were members of the European avant-garde and documentary film movement whose paths crossed again in New York in the late 1930s and the early 1940 s.

In this respect, it is noteworthy that even though Hilla von Rebay, curator at the Museum for Non-Objective Painting (later the Guggenheim Museum), helped Richter to obtain a visa for the United States (in exchange for Richter's

Circulating Film Programs), 3.

77 Charbonneau, 'John Grierson and the United States', $13-28$.

78 Film appreciation in the United States in the 1930s parallels to some extent the avant-garde's intention to improve film taste in cine-clubs and film societies to increase the demand for - and supply of - aesthetically and morally 'good' films.

79 On the Payne Fund Studies, see Garth S. Jowett, Ian C. Jarvie, and Kathryn H. Fuller, Children and the Movies: Media Influence and the Payne Fund Controversy (Cambridge: Cambridge University Press, 1996). On character education with Hollywood films, see Craig Kridel, 'Educational Film Projects of the 1930s: Secrets of Success and the Human Relations Film Series', in Learning with the Lights Off, 215-229; and Charles R. Acland, 'Hollywood's Educators: Mark May and Teaching Film Custodian', in Useful Cinema, ed. Charles R. Acland and Haidee Wasson (Durham, NC and New York: Duke University Press, 2011), 59-80. On film appreciation programmes, see Eric Smoodin, “'What a Power for Education!": The Cinema and Sites of Learning in the 1930s', in Useful Cinema, ed. Charles R. Acland and Haidee Wasson (Durham, NC and New York: Duke University Press, 2011), 17-33; and Lea Jacobs, 'Reformers and Spectators: The Film Education Movement in the 1930s', Camera Obscura 22 (January 1990): 29-49. 
personal collection of abstract films, that is), ${ }^{80}$ upon arriving in New York in spring 1941 Richter presented himself primarily as a documentary filmmaker. He lectured, amongst other engagements, at the Association of Documentary Film Producers in June-July 1941 and became a member of the association the same year. ${ }^{81} \mathrm{He}$ also developed three projects for film essays - 'The Monroe Doctrine', 'The Four Freedoms', and 'The Role of Women in America' - all in the service of democracy, freedom, and human rights, but Richter failed to find sponsors and establish himself as a documentary film-maker. During the war, Richter, like Siegfried Kracauer, also invested in the analysis of film propaganda. ${ }^{82}$ Richter focussed not only on the 'totalitarian' propaganda by Nazi Germany and fascist Italy that were at the core of Kracauer's critical attention, but also included examples from the Soviet Union that, according to Richter, would activate the audience in the spirit of the new government. In his two articles published on the topic, as well as in many unpublished typescripts, Richter also discussed recent filmic efforts from Britain and the United States that would turn documentary film into a weapon for democracy to defeat fascism. ${ }^{83}$ In doing so, Richter inserted himself in the us tradition of progressive propaganda critique and analysis. This tradition is most prominently aligned with Harold D. Lasswell and his scientific study of propaganda. The efforts to develop a theory and pedagogy of propaganda analysis led to the inception of the Institute for Propaganda Analysis in 1937, which institutionalized the progressive belief

8o Richter contributed Viking Eggeling's Symphonie diagonale (1924) and his Rhythmus 21 along with works by Ruttmann and Oskar Fischinger to the Museum of Non-Objective Painting's film collection that originated in the early 1940s. On this and Richter's negotiation with MomA, see Malte Hagener and Yvonne Zimmermann, 'Viking Eggeling and European Avant-Garde Cinema', in A Cultural History of the Avant-Garde in the Nordic Countries 1925-1950, vol. 2, ed. Benedikt Hjartarson, Andrea Kollnitz, Per Stounbjerg, Marianne Ølholm, and Tania Ørum (Leiden: Brill, 2019), 82-101.

81 See Documentary Film News 1, no. 6 (September 1941): n.p.

82 On Kracauer's studies on Nazi propaganda films at the мома Film Library, see Dennis Culbert, 'The Rockefeller Foundation, the Museum of Modern Art Film Library, and Siegfried Kracauer, 1941', Historical Journal of Film, Radio, and Television 13, no. 4 (1993): 495-511; Brett Gary, The Nervous Liberals: Propaganda Anxieties from Word War I to the Cold War (New York: Columbia University Press, 1999), 114-118.

83 See Hans Richter, 'Die Entwicklung des politischen Films', Deutsche Blätter (Santiago de Chile) 2, no. 1 (1944): 21-24; and Hans Richter, 'Der politische Film (II)', Deutsche Blätter (Santiago de Chile) 2, no. 2 (1944): 17-20, both articles reprinted in: Karsten Witte, ed., Theorie des Kinos (Frankfurt: Suhrkamp, 1972), 61-63. See also the unpublished nineteen-page manuscript 'Secret Weapons... to Beat Hitler' (1942), in which Richter analyses German propaganda films to learn from them for democracy (Museum of Modern Art Archives: Hans Richter C.XIV.5). 


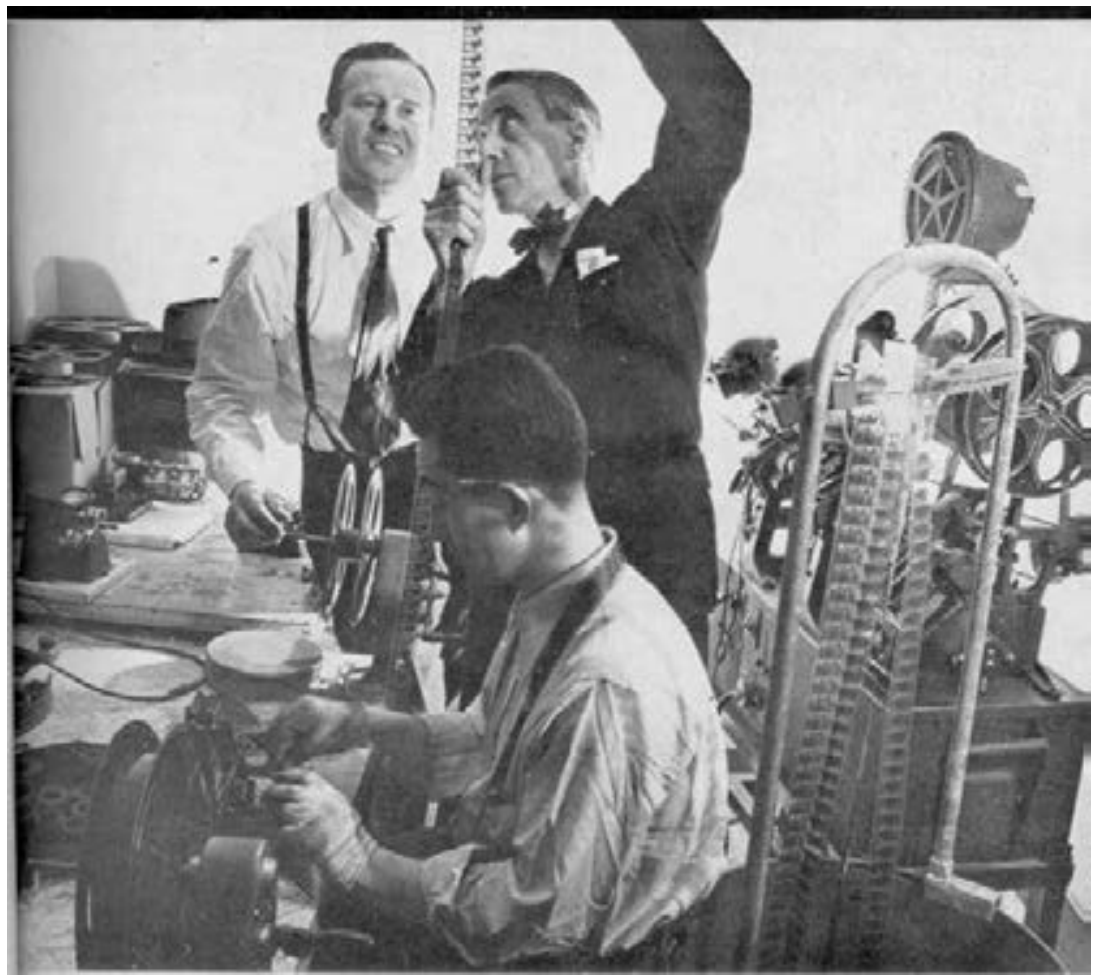

Figure 3.1: Hans Richter teaching at the Institute of Film Techniques at City College New York, 1947 (Hans Richter, 'Films: A Fighting Weapon', The City College Alumnus 43:1 [September 1947]: 11).

that, to sustain democracy, average citizen must learn how to think for themselves. $^{84}$

However, Richter's most important contribution to educational film and advertising screen culture in the service of selling democracy in the United States was his teaching at the Institute of Film Techniques at City College New York. The Institute was founded by documentary producer Irving Jacoby in 1941 with the immediate aim to fill the government's need for trained specialists to produce wartime information films. Its pedagogical goal was 'to provide practical instruction in the production and use of educational and public-service motion picture. ${ }^{85}$ In other words, the Institute's programme was built exclusively around the purpose to train people to make and use

84 On the Institute for Propaganda Analysis, see Sproule, Propaganda and Democracy.

85 Irving Jacoby, 'Statement concerning the Film Institute and Unit at the City College', unpublished two-page manuscript, February 1943 (CCNY Archives, Institute of Film Techniques, Vertical File 353). 
educational films. Among us film schools, the Institute was unique in specializing in documentary and educational cinema. Richter joined the faculty in late 1941 and was appointed director in 1948, yet was more or less in charge from about 1942, when Irving Jacoby left the Institute to serve as film producer for the Office of War Information.

Transferring and adapting his pedagogical concept of the film essay developed in Europe to his teaching at City College New York, Richter produced with his students a series of films in workshops through 1944, among them It's Up to You, a film on the black market sponsored by the Office of Price Administration, and Education for Democracy, a film essay that advertised the importance of liberal arts education. Until 1956, about 20 films were made in workshops at the Institute under Richter, most of them produced by notable documentary figures such as Alexander Hammid and Leo Seltzer. In fact, the Institute was a hub in the network of educational film culture in the United States. In 1946, for example, Richter taught 'Fundamentals of Film Production', a lecture course in which the social importance of the documentary film as well as its technique was explained. Renowned photographer and film-maker Willard Van Dyke, who had served as a cameraman on Pare Lorentz's The River in 1938, taught a course in documentary film directing. Albert Hemsing, head of the overseas non-theatrical operations of the Office of War Information, taught a course in how to use film, that is, how to select, exhibit, evaluate, and distribute films. Among the guest lecturers were Robert J. Flaherty, John Grierson (whom Richter had met in London in 1929 for the first time), Leo Hurwitz, John Ferno, Joris Ivens, Alice M. Keliher, Stuart Legg, and Irving Lerner. ${ }^{86}$

With Richter, Ivens, and Hammid, three representatives of the European interwar film avant-garde found themselves at the Institute of Film Techniques deeply imbricated in the expansive network of educational film culture in the United States. To give just one example of the wide ramification of this network, Alice M. Keliher, an experienced early childhood educator and professor of education at New York University, chaired the Commission on Human Relations formed in 1935 and with her staff produced, distributed, and assessed the use of feature film excerpts in high schools as a pedagogical tool to discuss human behaviour. As Craig Kridel has shown, Joris Ivens served as the first production director and later technical adviser of what was called 'The Human Relations Series of Films' and included his films in the series. Irving Lerner, who, in the early 1930s, was a member of the Workers 


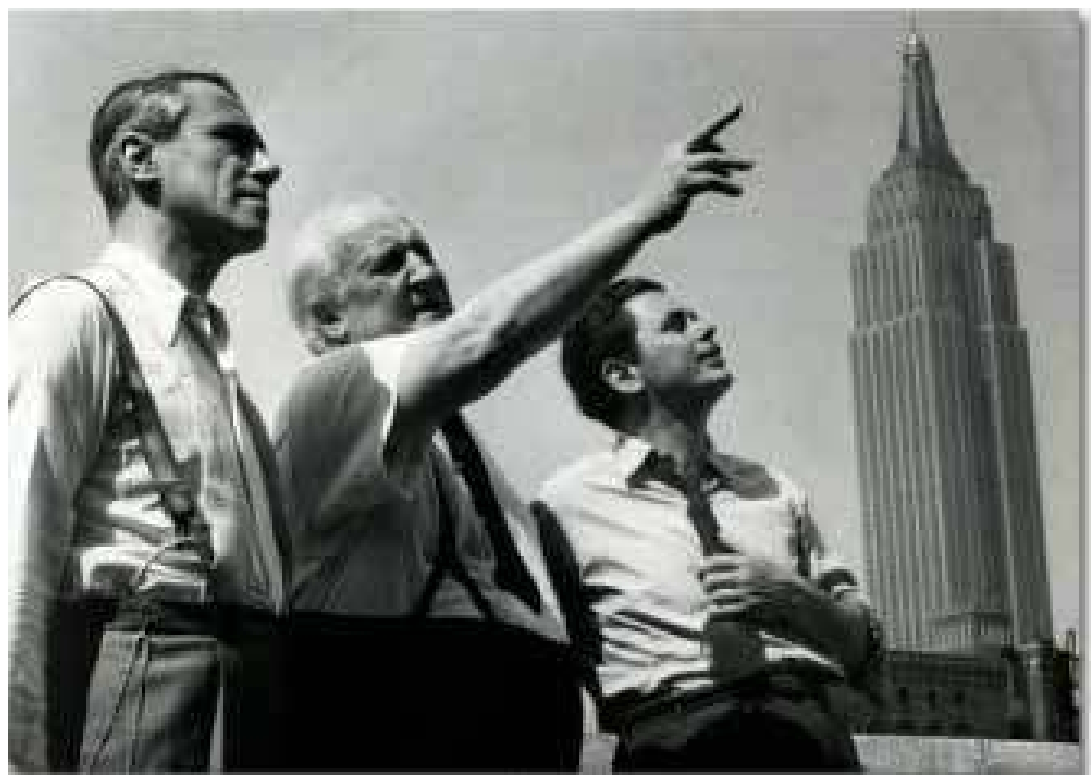

Figure 3.2: Hans Richter with Robert J. Flaherty and Joris Ivens, New York, 1942 (The Hans Richter Estate).

Film and Photo League and became the head of New York University's Educational Film Institute after the war, was another production director in the film series. ${ }^{87}$ Their paths all crossed at the Institute of Film Techniques.

At a particular moment in time, the Institute brought together avantgarde, documentary, and educational cinema under the banner of selling democracy in the context of a useful cinema culture that was based upon sponsorship, located on the us East Coast, and that presented itself as an alternative model to the entertainment film industry housed in Hollywood. In this regard, the Institute stands as the emblem of the entangled transnational histories of avant-garde, documentary, and educational film united by the goal to fight authoritarian propaganda and produce democratic citizens in the 1930 s and early 1940s. That the Institute of Film Techniques is totally absent from the historiography of film studies ${ }^{88}$ is not necessarily a sign of

87 Craig Kridel, 'Educational Film Projects of the 1930s: Secrets of Success and the Human Relations Film Series', in Learning with the Lights Off, 226.

88 The two most notable contributions to the field in the us context are Dana Polan, Scenes of Instructions: The Beginnings of the U.S. Study of Film (Berkeley: University of California Press, 2007); and Lee Grieveson and Haidee Wasson, eds., Inventing Film Studies: A Genealogy of Studying Cinema (Durham: Duke University Press, 2008). For Europe, see Malte Hagener, ed., The Emergence of Film Culture: Knowledge Production, Institution Building, and the Fate of the Avant-Garde in Europe, 1919-1945 (Oxford and New York: Berghahn, 2014). 
its insignificance, but rather can be explained by Eric Smoodin's observation that the discipline is among the least historicized of all the humanities and social science fields. ${ }^{89}$ As a consequence, the various manifestations of film studies and film education before the 196os, as well as beyond universities, are still to be discovered in their full extent and inserted in the ramified networks of educational and advertising screen culture that not only helped produce the democratic citizen, but also the consumer citizen.

\section{Conclusion}

The aim of this chapter is to bring together, within the framework of advertising understood as a broad category for film in the service of persuasion, fields of non-theatrical film culture that in film studies tend to be viewed and analysed separately as distinct categories - such as avant-garde, the documentary, and educational film. My approach set out to blur the boundaries between these categories and to bring to light the larger political and cultural context in which they were inserted. In the 1930s, the documentary movement and most members of the avant-garde were confronted by the same political threat, that of totalitarian regimes; they were faced with the same social question, that of education for democracy; and they were challenged by the same aesthetic problem, the development of new filmic forms that would meet the educational needs of the time. The documentary film can be interpreted as one solution to this problem, Richter's film essay another. Such cinematic experimentation happened in the domain of educational film and in the economic and institutional framework of corporate and government sponsorship. It was thus equally and simultaneously part of educational film culture and useful cinema culture. Whether we address it as educational or useful cinema culture depends on the interpretive framework we adopt. The object of study, however, remains the same.

Formal experimentation in these environments is clearly not primarily artistic self-expression, but a social contribution. In this respect, it is important to recognize that working for corporate and government sponsors was not mere breadwinning, as is often postulated. Instead, it allowed artists such as Richter to 'explore aesthetic problems [...] in relation to the realities posed by life', to quote his own words again..$^{\circ}$ The realities

89 Smoodin, 'What a Power for Education!', 31.

90 Léo Sauvage, 'Hans Richter: Un des maîtres de l'avant-garde allemande voudrait collaborer avec Méliès', Cinémonde (Paris), no. $45^{8}$ (27 July 1937). My translation. 
posed by life at that moment in time were perceived as calling for visual education in the service of citizenship training. Under these particular political circumstances, the documentary movement and representatives of the avant-garde such as Hans Richter, Joris Ivens, Alexander Hammid, László Moholy-Nagy, and the Bauhaus artists all followed this call and became 'propagandists' - or advertisers - for democracy, first in Europe and then continuing their mission in the United States in the early 1940 s. They were part of a larger transnational network of educational film culture. The involvement of artists in citizenship education and the quest for new, 'democratic' forms of media thus have a longer history than Fred Turner in The Democratic Surround posits. If in post-war America, multimedia environments were considered to be the new, democratic media art that would produce the 'democratic personality', it was the documentary and Richter's film essay that held a similar position in the 1930 s and early 1940s. They were presented as the democratic answer to totalitarian propaganda, as the educational tool to sell democracy. The origins of both the documentary and the film essay can thus be reinserted within a larger trend in non-fiction educational film culture that was committed to education for democracy.

However, as I intend to demonstrate, instead of a general consensus, there was vivid debate about the theories of propaganda and education not only among intellectuals and politicians but also among film-makers. The respective writings by Paul Rotha, John Grierson, and Hans Richter are cases in point. These debates were sparked by different political ideologies and respective notions of the (anti-)rational citizen and the capacity of the human mind to think. Ultimately, the discussions about propaganda and education can be interpreted as disputes about whether persuasion or emancipation would be the 'democratic' tool to produce democratic citizens. John Grierson, in line with Lippmann, clearly represented the belief in persuasion and public management as the adequate theory for education in democracy, whereas Hans Richter in the legacy of the Enlightenment advocated for the emancipation of the citizen. Both views, divergent as they may be, are anchored in the belief that an elite of experts (that includes artists, of course) is necessary to govern society. And Grierson and Richter shared the belief with their contemporaries that mass media and moving images in particular are a powerful, manipulative tool for shaping the human mind. Thus, the idea of the persuasive power of media - or what I address as advertising in this chapter - was at the origin of these debates. 


\section{Bibliography}

Acland, Charles R. Swift Viewing: The Popular Life of Subliminal Influence. Durham, NC: Duke University Press, 2011.

Acland, Charles R. 'Hollywood's Educators: Mark May and Teaching Film Custodian.' In Useful Cinema, edited by Charles R. Acland, Haidee Wasson, 59-80. Durham, NC and New York: Duke University Press, 2011.

Acland, Charles R., and Haidee Wasson, eds. Useful Cinema. Durham, NC: Duke University Press, 2011.

Ahnert, Laurel E. 'The Factual Treatment of Actuality: The Emergence of Educational Film in the 1920 s and its Relation to Documentary Film Proper.' InterDisciplines 1 (2013): 77-101.

Aitken, Ian. Film and Reform:John Grierson and the Documentary Film Movement. London and New York: Routledge, 1990.

Barry, Iris, and Richard Griffith. 'The Film Library and the Film of Fact.' In The Museum of Modern Art Film Library Films of Fact 1942. Museum of Modern Art, Department of Film Archive, Circulating Film Programs.

Bernays, Edward L. Crystallizing Public Opinion. New York: Boni and Liveright, 1923. Bürger, Peter. Theory of the Avant-Garde, translated by Michael Shaw. Minneapolis: University of Minnesota Press, 1984.

Butsch, Richard. The Citizen Audience: Crowds, Publics, and Individuals. New York: Routledge, 2008.

Charbonneau, Stephen. 'John Grierson and the United States.' In The Grierson Effect: Tracing Documentary's International Movement, edited by Zoe Druick and Deane Williams, 13-28. London and New York: British Film Institute, 2014. Corrigan, Timothy. The Essay Film: From Montaigne, After Marker. New York: Oxford University Press, 2011.

Cowan, Michael. 'Advertising, Rhythm, and the Filmic Avant-Garde in Weimar: Guido Seeber and Julius Pinschewer's Kipho Film.' October 131 (Winter 2010): 23-50.

Cowan, Michael. Walter Ruttmann and the Cinema of Multiplicity: Avant-Garde, Advertising, Modernity. Amsterdam: Amsterdam University Press, 2014.

Culbert, Dennis. 'The Rockefeller Foundation, the Museum of Modern Art Film Library, and Siegfried Kracauer, 1941.' Historical Journal of Film, Radio, and Television 13, no. 4 (1993): 495-511.

Ellis, Jack C.John Grierson: Life, Contributions, Influence. Carbondale and Edwardsville: Southern Illinois University Press, 2000.

Elsaesser, Thomas. 'The Essay Film: From Festival Favorite to Flexible Commodity Form?' [2015]. In Essays on the Essay Film, edited by Nora M. Alter and Timothy Corrigan, 240-258. New York: Columbia University Press, 2017. 
Foster, Stephen C., ed. Hans Richter: Activism, Modernism, and the Avant-Garde. Cambridge, MA and London: MIT Press, 1998.

Gary, Brett. The Nervous Liberals: Propaganda Anxieties from World War I to the Cold War. New York: Columbia University Press, 1999.

Goldschmid, Harry. 'Die internationale Filmwoche in Basel.' Das Werk: Schweizer Monatsschrift für Architektur, Freie Kunst, Angewandte Kunst 26, no. 7 (1939):12-18.

Grierson, John. 'Education and the New Order' [1941]. In Grierson on Documentary, edited by Forsyth Hardy, 122-132. London and Boston: Faber \& Faber, 1979 [1946]. Grierson, John. 'Education and Total Effort' [1941]. In Grierson on Documentary, edited by Forsyth Hardy, 133-140. London and Boston: Faber \& Faber, 1979 [1946]. Grierson, John. 'Propaganda and Education' [19 October 1943]. In Grierson on Documentary, edited by Forsyth Hardy, 141-155. London and Boston: Faber \& Faber, 1979 [1946].

Grierson, John. 'Propaganda: A Problem for Educational Theory and for Cinema.' Sight and Sound 2, no. 8 (Winter 1933-1934):119-121.

Grierson, John. 'The Documentary Idea: 1942.' In Grierson on Documentary, edited by Forsyth Hardy, 111-121. London and Boston: Faber \& Faber, 1979 [1946].

Grieveson, Lee, and Colin MacCabe, eds. Empire and Film. London and New York: Palgrave, 2011.

Grieveson, Lee, and Colin MacCabe, eds. Film and the End of Empire and Film. London and New York: Palgrave, 2011.

Grieveson, Lee, and Haidee Wasson, eds. Inventing Film Studies: A Genealogy of Studying Cinema. Durham, NC: Duke University Press, 2008.

Hagener, Malte. Moving Forward, Looking Back: The European Avant-Garde and the Invention of Film Culture, 1919-1939. Amsterdam: Amsterdam University Press, 2007.

Hagener, Malte, ed. The Emergence of Film Culture: Knowledge Production, Institution Building, and the Fate of the Avant-Garde in Europe, 1919-1945. Oxford and New York: Berghahn, 2014.

Hagener, Malte, and Yvonne Zimmermann. 'Viking Eggeling and European AvantGarde Cinema.' In A Cultural History of the Avant-Garde in the Nordic Countries 1925-1950, vol. 2, edited by Benedikt Hjartarson, Andrea Kollnitz, Per Stounbjerg, Marianne Ølholm, and Tania Ørum, 82-101. Leiden: Brill, 2019.

Hake, Sabine. 'Das Kino, die Werbung und die Avantgarde.' In Die Spur durch den Spiegel. Der Film in der Kultur der Moderne, edited by Malte Hagener, Johann Schmidt, and Michael Wedel, 193-206. Berlin: Bertz, 2004.

Hediger, Vinzenz, and Patrick Vonderau, eds. Films that Work: Industrial Film and the Productivity of Media. Amsterdam: Amsterdam University Press, 2009.

Jacobs, Lea. 'Reformers and Spectators: The Film Education Movement in the 1930s.' Camera Obscura 22 (January 1990): 29-49. 
Jacoby, Irving. 'Statement concerning the Film Institute and Unit at the City College.' Unpublished manuscript, [February 1943]. CCNY Archives, Institute of Film Techniques, Vertical File 353.

Jowett, Garth S., and Victoria O'Donnell, Propaganda and Persuasion, $2^{\text {nd }}$ ed. Newbury Park, London, and New Dehli: Sage, 1992.

Jowett, Garth S., Ian C. Jarvie, and Kathryn H. Fuller. Children and the Movies: Media Influence and the Payne Fund Controversy. Cambridge: Cambridge University Press, 1996.

Kridel, Craig. 'Educational Film Projects of the 1930s: Secrets of Success and the Human Relations Film Series.' In Learning with the Lights Off, Educational Cinema in the United States, edited by Devin Orgeron, Marsha Orgeron, and Dan Streible, 215-229. New York and Oxford: Oxford University Press, 2012.

Leyda, Jay. Films Beget Films: A Study of the Compilation Film. New York: Hill and Wang, 1964.

Morris, Peter. 'Re-thinking Grierson: The Ideology of John Grierson.' In Dialogue: Canadian and Québec Cinema, edited by Pierre Véronneau, Michael Dorland, and Seth Feldman, 21-56. Montreal: Médiatexte, 1987.

Nichols, Bill. 'Documentary Film and the Modernist Avant-Garde.' Critical Inquiry 27, no. 4 (Summer 2001): 580-610.

Orgeron, Devin, Marsha Orgeron, and Dan Streible, eds. Learning with the Lights Off: Educational Cinema in the United States. New York and Oxford: Oxford University Press, 2012.

Otto, Elizabeth. 'A "Schooling of the Senses": Post-Dada Visual Experiments in the Bauhaus Photomontages of László Moholy-Nagy and Marianne Brandt.' New German Critique 107, vol. 36, no. 2 (Summer 2009): 89-131.

Plenge, Johann. Deutsche Propaganda. Die Lehre von der Propaganda als praktische Gesellschaftslehre. Bremen: Angelsachsen-Verlag, 1922.

Polan, Dana. Scenes of Instructions: The Beginnings of the U.S. Study of Film. Berkeley: University of California Press, 2007.

Richter, Hans. 'Der Filmessay: Eine neue Form des Dokumentarfilms.' NationalZeitung, no. 192 (25 April 1940). Reprinted in Schreiben Bilder Sprechen: Texte zum essayistischen Film, edited by Christa Blümlinger and Constantin Wulff, 195-198. Vienna: Sonderzahl, 1992.

Richter, Hans. 'Der politische Film (II).' Deutsche Blätter (Santiago de Chile) 2, no. 2 (1944): 17-20. Reprinted in Theorie des Kinos, edited by Karsten Witte, 61-63. Frankfurt: Suhrkamp, 1972.

Richter, Hans. 'Die Entwicklung des politischen Films.' Deutsche Blätter (Santiago de Chile) 2, no. 1 (1944): 21-24. Reprinted in Theorie des Kinos, edited by Karsten Witte, 61-63. Frankfurt: Suhrkamp, 1972. 
Richter, Hans. 'The Institute of Film Techniques.' Film News: World Wide News of the Information Film 7, no. 5 (February-March 1946): 10.

Richter, Hans. 'The Film Essay: A New Type of Documentary Film.' In Essays on the Essay Film, edited by Nora M. Alter and Timothy Corrigan, translated by Maria P. Alter, 89-92. New York: Columbia University Press, 2017.

Richter, Hans. The Struggle for the Film: Towards a Socially Responsible Cinema, edited by Jürgen Römhild, translated by Ben Brewster. New York: St. Martin's Press, 1986.

Richter, Hans. 'Post-War Planning on Documentary Film.' Unpublished typescript, [1942], 3. Museum of Modern Art Archives, Hans Richter C.XIV.5.

Richter, Hans. 'Secret Weapons... to Beat Hitler.' Unpublished manuscript, [1942]. Museum of Modern Art Archives: Hans Richter C.XIV.5

Rotha, Paul. 'British Documentary Films Offer American Business Some New Opportunities.' Business Screen 1, no. 1 (1938).

Rotha, Paul. Documentary Diary: An Informal History of the British Documentary Film, 1928-1939. London: Secker \& Warburg, 1973.

Rotha, Paul. Documentary Film: The Use of the Film Medium to Interpret Creatively and in Social Term the Life of People as It Exists in Reality, in collaboration with Sinclair Road and Richard Griffith. London: Faber \& Faber, 1968 [1935].

Sahli, Jan. Filmische Sinneserweiterung: László Moholy-Nagys Filmwerk und Theorie. Marburg: Schüren, 2006.

Sauvage, Léo. 'Hans Richter: Un des maîtres de l'avant-garde allemande voudrait collaborer avec Méliès.' Cinémonde (Paris), no. $45^{8}$ (27 July 1937).

Schweizerische Landesausstellung 1939 Zürich, ed. Administrativer Bericht, vorgelegt vom Liquidationskomitee der Schweizerischen Landesausstellung 1939, Zurich, 1942.

Smoodin, Eric. “'What a Power for Education!": The Cinema and Sites of Learning in the 1930.' In Useful Cinema, edited by Charles R. Acland and Haidee Wasson, 17-33. Durham, NC and New York: Duke University Press, 2011.

Sproule, J. Michael. Propaganda and Democracy: The American Experience of Media and Mass Persuasion. Cambridge: Cambridge University Press, 1997.

Stäheli, Urs, and Dirk Verdicchio. 'Das Unsichtbare sichtbar machen: Hans Richters Die Börse als Barometer der Wirtschaftslage.' Montage AV15, no. 1 (2006): 108-122. Stollery, Martin. Alternative Empires: European Modernist Cinemas and Cultures of Imperialism. Exeter: University of Exeter Press, 2000.

Tode, Thomas. 'Ein Bild ist ein Argument: Hans Richter und die Anfänge des Filmessays.' Navigationen 2, no. 2 (February 2002): 99-108.

Turner, Fred. From Counterculture to Cyberculture: Stewart Brand, the Whole Earth Network, and the Rise of Digital Utopianism. Chicago and London: University of Chicago Press, 2005. 
Turner, Fred. The Democratic Surround: Multimedia \& American Liberalism from World War II to the Psychedelic Sixties. Chicago and London: University of Chicago Press, 2013.

Turvey, Malcolm. 'Dada Between Heaven and Hell: Abstraction and Universal Language in the Rhythm Films of Hans Richter.' October 105 (Summer 2003): 13-36. Turvey, Malcolm. Doubting Vision: Film and the Revelationist Tradition. Oxford and New York: Oxford University Press, 2008.

Wees, William C. 'The Changing of the Gardes.' Public no. 25 (2002): 18.

Werner, Michael, and Bénédicte Zimmermann. 'Beyond Comparison: Histoire Croisée and the Challenge of Reflexivity.' History and Theory 45, 1 (2006):30-50. Werner, Michael, and Bénédicte Zimmermann. De la comparaison à l'histoire croisée. Paris: Seuil, 2004.

Werner, Michael, and Bénédicte Zimmermann. 'Vergleich, Transfer, Verflechtung: Der Ansatz der Histoire croisée und die Herausforderung des Transnationalen.' Geschichte und Gesellschaft 28 (2002): 607-636.

Winston, Brian. Claiming the Real: The Grierson Documentary and Its Legitimations. London: British Film Institute, 1995.

Zimmermann, Yvonne. 'Hans Richter and the Filmessay: A Media Archaeological Case Study of Documentary Film History and Historiography.' In A Companion to Documentary Film History, edited by Joshua Malitzky. Bloomington: Indiana University Press, forthcoming.

Zimmermann, Yvonne. 'Advertising and Film: A Topological Approach.' In Films That Sell: Moving Pictures and Advertising, edited by Bo Florin, Nico de Klerk, and Patrick Vonderau, 21-39. London and New York: Palgrave, 2016.

Zimmermann, Yvonne. 'The Avant-Garde, Education and Marketing: The Making of Nontheatrical Film Culture in Interwar Switzerland.' In The Emergence of Film Culture: Knowledge Production, Institution Building, and the Fate of the Avant-Garde in Europe, 1919-1945, edited by Malte Hagener, 199-224. Oxford and New York: Berghahn, 2014. 



\title{
4. Advertising as Institution: Charles Wilp and German Television, 1950- 1970
}

\author{
Patrick Vonderau
}

\begin{abstract}
This chapter proposes a self-reflexive view vis-à-vis the Charles Wilp Collection at Deutsche Kinemathek, a collection dedicated to the work of one of Germany's best-known (and most notorious) advertisers of the 1960 and 1970s. After critically reviewing the notion of institution as it is used in advertising research, the main part of the text provides a historical account of Wilp's work and proposes a definition of screen advertising and an analytical heuristics for describing moving image advertisements.
\end{abstract}

Keywords: institution, Charles Wilp, archival policies, production studies

Historians tend to see advertising as something more than just a media industry: it is considered an institution of society. Some of them describe advertising as mirroring dominant social values and lifestyles. In their view, an ad is a 'mirror that barely reflects society back on itself'. ${ }^{1}$ For others, this mirror is fundamentally broken. Ads are seen to 'obscure and avoid the real issues of society'2 ${ }^{\prime 2}$ they create systems of social differentiation and rework ideologies in order to establish a 'supremacy of commodity relations'. ${ }^{3}$ In this latter view, advertising does not respond to social trends; it produces them. Yet whether advertising is seen to mirror or mould society, it is usually

1 Stephen Fox, The Mirror Makers: A History of American Advertising and Its Creators (New York: Vintage Books, 1985), 329.

2 Judith Williamson, Decoding Advertisements (London: Marion Boyars, 1981), 47.

3 Robert Goldman, Reading Ads Socially (London: Routledge, 1992), 2.

Florin, B., P. Vonderau, Y. Zimmermann, Advertising and the Transformation of Screen Cultures. Amsterdam: Amsterdam University Press, 2021 DOI 10.5117/9789462989153_CHO4 
endowed with power and omnipresence, and appears collective, univocal, and global in its impact on culture and society.

The institutional view on advertising has a long tradition in political economy, communication, and cultural studies, in which media institutions are attributed a 'pivotal role' in 'organizing the images and discourses through which people make sense of the world'.4 'There is no denying that advertising is pervasive as a social institution,' Geoffrey P. Lantos once summarized this position, 'much like the home, church, school [...], and entertainment [...], advertising unintentionally affects our society in both a negative as well as in a positive way'. ${ }^{5}$ Concerned with the fading relevance of traditional American institutions, critics see advertising as exercising cultural hegemony over society. ${ }^{6}$ 'In the absence of traditional authority, advertising has become a kind of social guide', Richard W. Pollay argues. ${ }^{7}$ Others fear power is being granted to an institution that takes 'no social responsibility for what it does with its influence'. ${ }^{8}$

Media historians active in the nascent field of research on sponsored, non-theatrical, or industrial film often take an institutional viewpoint as well. In Useful Cinema, for instance, Charles Acland and Haidee Wasson approach sponsored film as an 'institutional tool'. They explain the forms of educational, industrial, or advertising films in regard to the 'cultural and institutional functions' these films performed 'in order to instruct, to sell, and to make or remake citizens.' ${ }^{9}$ Other scholars specializing in this field likewise suggest the study of both the 'institutional framework' producing sponsored film and 'the situation or constellation that the film produces', echoing the idea of an institution that both 'mirrors' and 'moulds'.

But the institutional view on advertising is also controversial for a number of reasons. It is often just taken for granted, to the degree that business

4 Graham Murdock and Peter Golding, 'Culture, Communications and Political Economy', Mass Media and Society, $4^{\text {th }}$ ed., ed. James Curran and Michael Gurevitch (London: Arnold, 2005), 6o; Raymond Williams, Keywords (London: Fontana, 1983), 165ff.

5 Geoffrey P. Lantos, 'Advertising: Looking Glass or Mirror of the Masses?', Journal of Public Policy and Marketing 6 (1987): 104.

6 Goldman, Reading Ads Socially, 2.

7 Richard W. Pollay, 'The Distorted Mirror: Reflections on the Unintended Consequences of Advertising', Journal of Marketing 50, no. 2 (1986): 22.

8 David M. Potter, People of Plenty (Chicago: University of Chicago Press, 1954), 177.

9 Charles R. Acland and Haidee Wasson, 'Introduction', in Useful Cinema (Durham, NC and London: Duke University Press, 2011), 3.

10 Vinzenz Hediger and Patrick Vonderau, 'Record, Rhetoric, Rationalization: Industrial Organization and Film', in Films that Work: Industrial Film and the Productivity of Media, ed. Vinzenz Hediger and Patrick Vonderau (Amsterdam: Amsterdam University Press, 2009), 11. 
scholar Morris B. Holbrook coined an acronym, 'CWOPO, conventional wisdom or prevailing opinion', to mock its undiscussed core beliefs. Holbrook questioned the idea of a 'monolithic institution' that would make ad agencies, marketers, and media 'join in concert to foster certain common ends and objectives': ${ }^{11}$

Most of the institutions involved in advertising appear on closer examination to be bastions of pluralism, characterized by infighting, checks and balances, and various other contrapuntal tendencies. In particular, one notes the unwritten laws that guide the behavior of most ad agencies and marketing departments: (1) be different, (2) seek a unique niche, (3) avoid head-to-head competition, and (4) protect proprietary secrets. In this climate of jealous competitive secrecy and internecine business strategizing, one sees little of advertising as a monolithic institution in which everybody preaches the party line in perfectly synchronized unison or harmony. Rather, one sees advertisers - that is, media, agencies, and their organizational clients - as a vast particularistic assortment of atomistic elements, each engaged in a sort of communicational random walk that contributes to the informational chaos of the overall cluttered spectacle. ${ }^{12}$

Holbrook correctly observes that we often use the term institution as a placeholder to avoid a more detailed historical account of the way advertising practices are organized. Is it possible, for instance, to speak of Europe's advertising practices as an institution on par with the one described for the United States? The institutional view also obscures, rather than explains, the relation of the institution to its 'cultural tools' - that is, of advertising to advertisements - implying that ads are identical to their institutional function(s), or made to maintain and reproduce the institution. Furthermore, it downplays differences between various media or between producers and consumers. Here, the social institution of advertising appears as a mighty apparatus, or dispositif, that determines how ads are made and understood.

The institutional view even relates to a common way of viewing screen ads; both advertising and advertisements are perceived 'in the aggregate.. ${ }^{13}$ We rarely study individual ads, and almost never study them in their own sake. It is more common to study their reflection of 'widely held ideas,

11 Morris B. Holbrook, 'Mirror, Mirror, On the Wall: What's Unfair in the Reflections on Advertising?', Journal of Marketing 51, no. 3 (July 1987): 95.

12 Ibid., 98.

13 Pollay, 'The Distorted Mirror.' 
beliefs, notions, myths, values, archetypes', an approach that tends to follow the same checklist:

What role does the product have in society? Who uses it? Why do they use it? What does it tell us about social, economic, and political matters? For example, does it reflect anomie, alienation, anxiety, stereotyping, generational conflict, or boredom? ${ }^{14}$

As a consequence, we lack analytical approaches and filmographic data. This in turn causes problems for moving image archivists who need analytical criteria to differentiate, select, and categorize advertising materials, and to devise comprehensive collection policies. ${ }^{15}$

In her book $A$ Word from Our Sponsor: Admen, Advertising, and the Golden Age of Radio, Cynthia B. Meyers suggests studying advertising not as a mirror of American culture or as a functionalist method of persuasion, but 'as a media industry deeply integrated into other media industries, especially broadcasting'. ${ }^{16}$ She abandons the institutional angle in favour of an approach that studies advertising as a form of cultural production, and production as a site of struggle and contestation between various industry stakeholders. Meyers claims that media industries lack any 'shared consciousness'; they are merely made up of 'individual agents negotiating various social, economic, and cultural structures and constraints'. ${ }^{17}$ The notion of institution indeed often implies a conception of order that sees it as a conscious, purposive, intentional activity.

We do not need to think of institutions as achieving order through conscious control and planning; in many cases, the concept of institution could simply be replaced with another concept, such as organization. At the same time, the notion of institution obviously has been helpful in the past to describe a social dynamic that goes beyond what an industry, a firm, or any individual agent aims to achieve. Institutions, as defined within social theory, are systems of rules and practices that structure social interactions; they enable, rather than constrain, by creating a special kind of power marked by rights,

14 Arthur Asa Berger, Ads, Fads, and Consumer Culture: Advertising's Impact on American Character and Society (Lanham: Rowman \& Littlefield, 2000), 184.

15 Catherine Cormon, 'The Challenge of Advertising Commercials', in Films that Sell: Moving Pictures and Advertising, ed. Bo Florin, Nico De Klerk, and Patrick Vonderau (London: British Film Institute, 2016), 275-282.

16 Cynthia B. Meyers, A Word from Our Sponsor: Admen, Advertising, and the Golden Age of Radio (New York: Fordham University Press, 2014), 19.

17 Ibid. 
duties, obligations, expectations, norms, empowerments, or certifications. ${ }^{18}$ Many entities now regularly described as institutions, such as advertising or television, often lack a rigorous, directed 'systemness' of power on which the institutional view seems premised. But there certainly is historical evidence that individuals active in advertising related to some notion of collective intentionality and to formal or informal social rules specific to the idea of a professional field, such as law, regulatory standards, production guidelines, notions of 'best practice', expectations, and tacit knowledge.

In other words, while it is unnecessary to adopt a substantialist notion of this or that institution, it is productive to trace how media industries have institutionalized, following the process by which they came to devise, negotiate, or adopt strategies and rules and practices meant to be formative for their social fields. This chapter revives an institutional perspective in light of recent work in economic sociology. ${ }^{19}$ In doing so, it illustrates what sources are to be used to examine this process, and which actors to consider. The chapter begins by describing the archival and epistemic framework of advertising research, and by introducing the Charles Wilp Collection at the Deutsche Kinemathek as a case study. After briefly reviewing uses of the notion of institution in the context of cinema and television, the main part of the text provides a historical account of Charles Wilp's work in German advertising during the 1960s and 1970s. It then proposes a definition of screen advertising and an analytical heuristics for describing moving image advertisements. Finally, it demonstrates the productivity of an institutional perspective for coming to terms with the aesthetics and production practices of screen advertising.

\section{Archival Frameworks}

In 1985, photographer and film-maker Charles Wilp (1932-2005) sold a large portion of his film and photo archive to Bildarchiv Preussischer Kulturbesitz (BPK) in Berlin. Since BPK does not have a separate film department, the filmrelated material of this collection was deposited at Deutsche Kinemathek, where, after having been provisionally inventoried, it remained untouched until 2004. Starting that year, research archivist Annette Groschke began officially accessioning the material and preparing detailed inspection

18 John Searle, 'What Is an Institution?', Journal of Institutional Economics 1, no. 1 (2005): 10. Institutions are more properly defined below. I use the notion of 'system' in a broad and generic sense, in other words, not in intentional accordance with a systems theory approach.

19 Francesco Duina, Institutions and the Economy (Cambridge: Polity Press, 2011). 
reports. The Charles Wilp Collection consists of several documentaries and short films, and of 489 short commercials made by Wilp during the 1950-1980 period. The ads are stored on aggregate reels, meaning that several spots are spliced together according to brand but otherwise in no apparent order, with several reels in one can to save storage space. In total, the collection database lists 895 entries. This includes all the available negatives, outtakes, and prints, as well as dozens of magnetic tapes. Wilp also sometimes made several versions for the client, and once accepted, a spot was often released in multiple variants over the course of a campaign. In comparison to other archives, the collection is small and homogeneous and therefore somewhat manageable. By contrast, Insel-Film Collection at Deutsches Filminstitut (DFI) Frankfurt holds more than 5000 German screen ads; the collections of Geesink and Toonder studios at Eye Filmmuseum Amsterdam comprise around 4000 titles; Archivio Nazionale Cinema d'Impresa (ANCI) in Turin holds around 65,00o; and the recently acquired Clio award collection at Indiana University more than $100,000 .^{20}$

The Wilp Collection also does not aim to be representative in historical terms when it comes to the product categories and brands advertised. By far the largest part of the screen ad corpus relates to alcohol and soft drinks. While there are 27 brands in the collection, 23 spots were made for the Isenbeck beer brewery, 19 for Puschkin Vodka, 18 for a traditional corn schnapps called Schinkenhäger, 23 for soft drink Afri-Cola, and 17 for Bluna, a German competitor of Fanta. Other larger campaigns include Martini \& Rossi, Polar Rum, a Skol beer, and Bosco Bitter Tonic, but there are also ads for heat pump manufacturer Stiebel Eltron (20 spots), shoemaker Salamander, shoe polish Erdal, and Fit, a hairstyling gel. While the collection spans almost three decades, most of the spots were made between 1965 and 1975. Wilp thrived on six key accounts: Puschkin (1956-1962), Schinkenhäger (1961-1971), Isenbeck (1967-1974), Afri-Cola (1968-1978), Stiebel Eltron (1970-1974), and Bluna (1970-1977). The collection does not contain the manifold print ads, radio spots, and posters that formed an important part of each of these campaigns, and it lacks any written documentation apart from Groschke's inspection notes of the cans. This lack of written records documenting production and strategy, and the separation of film from other media, are common features of screen ad archiving.

20 Cf. Cormon, 'The Challenge of Advertising Commercials'; Ariana Turci, 'The Archivio Nazionale Cinema d'Impresa Collections: An Overview', in Films that Sell, 289-298; Indiana University Bloomington, 'IU Libraries Moving Image Archive is the new home for decades of award-winning commercials', press release, 14 December 2017, https://news.iu.edu/stories/2017/12/ iub/releases/14-clio-collection.html (last accessed 5 April 2021). 

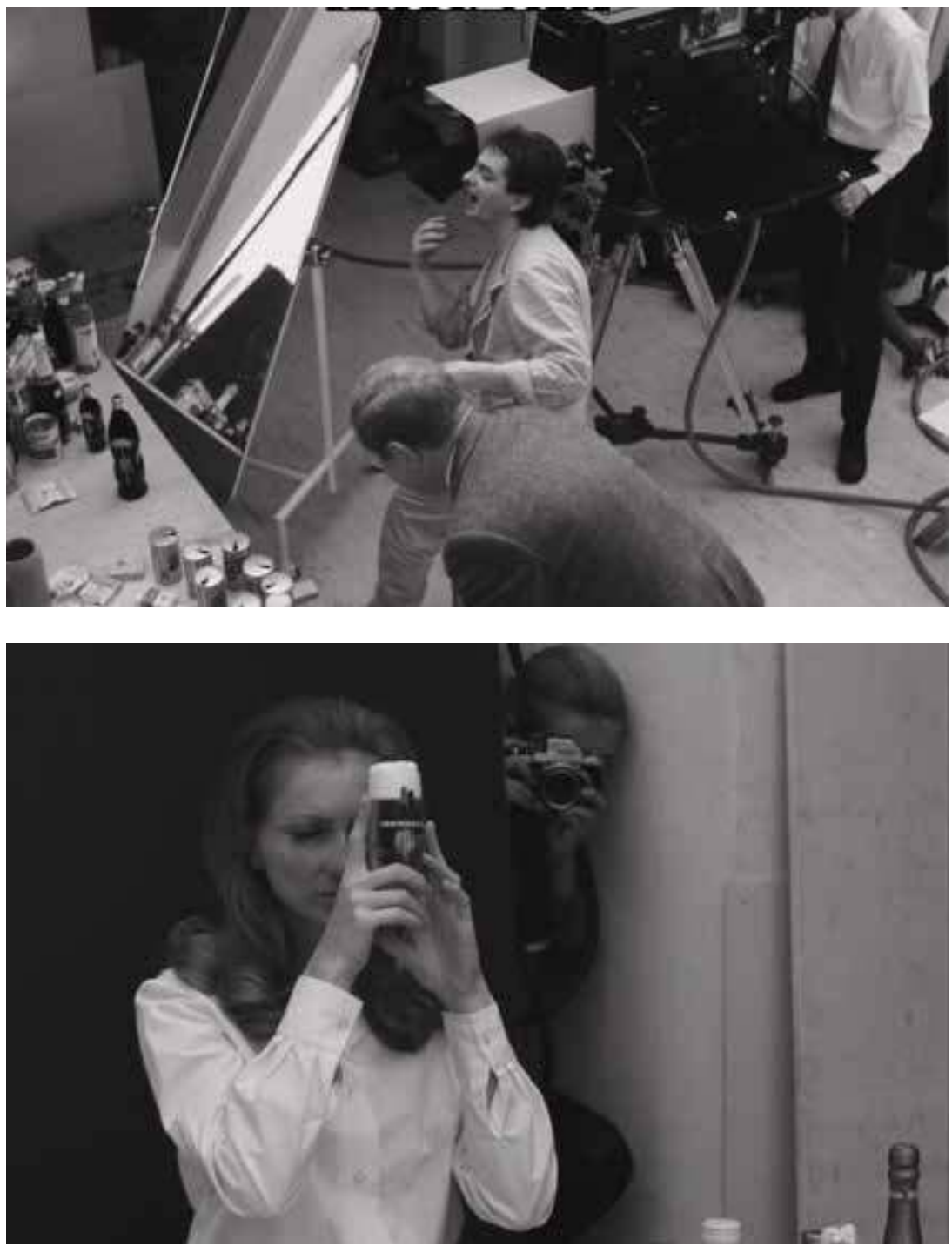

What sets the Wilp Collection apart from other screen ad collections is Wilp himself. Especially in the public eye, Wilp's name recognition has long outlived the attention created by his spots. Charles Wilp was and is widely known in German-speaking countries for his flamboyant self-promotional stunts, pseudo expertise ('Advertising belongs to a product like electricity to a light bulb'), and talk-show appearances. Dressed in yellow overalls, he appeared in numerous behind-the-scenes clips showing him 'at work' with models before the camera. One of 

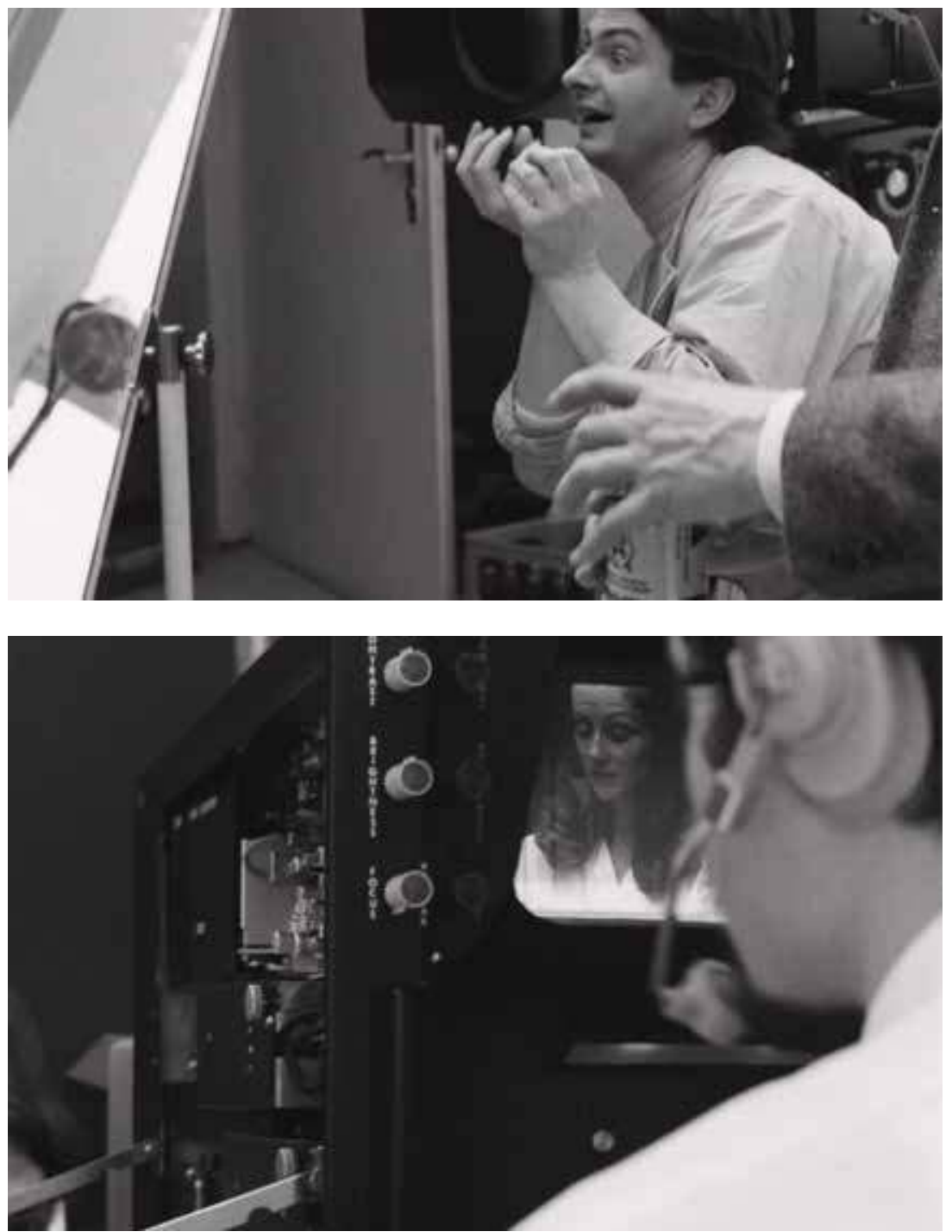

Figures 4.1-4.4: Behind the Scenes: Wilp at Work (Deutsche Kinemathek).

his models, Frank S. Thorn (also known as Hans Meyer), later acted in nouvelle vague films such as Godard's Pierrot Le Fou (1965). Wilp experimented with drugs, composed music (Charles Wilp fotografiert Bunny, 1965), and published books (Dazzledorf/Düsseldorf: Vorort der Welt, 1979) and pin-up calendars (Wilp-Girl 7o), engaged in other spectacular activities such as space travel. He was said to own a photo studio in London, a TV station licence (Radio TV Sonne + Mond), and a farm in 
Kenya. ${ }^{21}$ Importantly, he also maintained long-term connections to the art world. After allegedly studying in New York with Man Ray, ${ }^{22}$ he befriended Joseph Beuys, Christo, and Yves Klein, had an art gallery in London, and exhibited some of his advertising-related materials in 1972 at Documenta V in Kassel.

Wilp's name is not only publicly established but also closely connected to the form of his ads. Many of the screen ads made during the heyday of Wilp's career gave his production company on-screen credit ('Charles Wilp Film', inserted over the opening shot), a rather unusual practice even today. By foregrounding and repeating a number of formal elements, he created a sense of creative authorship in what we may call his signature campaigns for Puschkin, Isenbeck, Afri-Cola, Bluna, Martini \& Rossi, and Bero Center (a shopping mall). Here, an author image is evoked by certain stylistic, aesthetic, and ideological properties repeated among the various spots 'signed' by Wilp, creating the impression of a metadiscursive message traceable across this set of films - a message not fully aligned with the overt commercial function of the spots. On the surface, the excessive style of these productions matched the hyperbole associated with Wilp's public persona, condensing all sorts of visual and acoustic attractions into an ironically self-reflexive commodity spectacle: celebrities, trance-like sensuality, brown bears, nuns, secret agents, helicopters, loud colours, distant atonal orchestra scores, and absurdly 'persuasive' ad copy. Accordingly, film historians have understood Wilp's spots - and especially his most widely known signature campaigns - as documenting the period's mentalité or zeitgeist characterized by mass culture critique, sexual liberation, pop art, and psychedelic fantasies. ${ }^{23}$

The Charles Wilp Collection appears to be a privileged epistemic site for a research project on screen advertising. Yet doing research in that collection also means engaging with an implicit framework or order of knowledge. Screen ad archives often establish a disposition that makes it difficult to relate ads to advertising. While this is certainly not intended by the archivists, the collection itself suggests the reading of ads as a trace - of a

21 Anon., 'Poesie mit Amalie', Der Spiegel, 31 March 1969; Anon., 'Sehr rauschig', Der Spiegel, 1 December 1969 .

22 Wilp obviously did not tell the truth about his own biography, claiming that his father, a roofer, had been Germany's first rapeseed oil importer and that his mother, a farmer's daughter, was a pianist accompanying silent films at Studio Babelsberg. See Harald Keller, 'Der große Afri-Cola Rausch', Frankfurter Allgemeine Zeitung, 28 August 2008. His claims that he studied with Man Ray and industrial designer Raymond Loewy in New York could not be verified.

23 Jörg Becker, 'Die Voltstärke eines Emotionskomplexes. Der Werbekünstler Charles Wilp (1932-2005)', Recherche Film und Fernsehen 2, no. 3 (2008): 14. 
zeitgeist or personality, for example - rather than analysing them as belonging to a larger class of materials designed to promote consumption. Reading traces is different from analysing texts. It means subscribing to what Carlo Ginzburg called the 'evidentiary paradigm' of the modern human sciences, a paradigm built on casuistics, or case-based reasoning, instead of the sciences' abstractions and generalizations. ${ }^{24}$ Collections of screen ads tend to de-emphasize commonalities between ads, the complex relations of film production to agencies and commissioning firms, and the way the practice of making screen ads is codified through law and professional standards. They invite us to read films retroactively as traces of something absent, a method of retroactive deciphering that is both indirect and presumptive.

To illustrate, consider how screen ad material is collected, stored, and made accessible. The Wilp Collection resulted from a process that involved archivists and donors in a longer negotiation of the collection's aims and purposes. The first step was to establish Wilp's name as the legal framework for the collection, to categorize its materials, and to infer meaning onto its texts. 'Wilp' describes the intellectual property (who owns it), the content (what is it about), and the epistemic framework (what can be known) of the collection. Given its archival mission, the Kinemathek aimed to preserve these materials as they seemed 'important for future generations; they tell something about the society back then'. ${ }^{25}$ Wilp's widow Ingrid Schmidt-Winkeler 'wanted the films to be on the art market', thus preventing a wider distribution via YouTube. ${ }^{26}$ The second related and unavoidable step consisted in separating the films from other relevant materials: from Wilp's photographical work - still at BPK - and from any written documentation of production or Wilp's interaction with ad agencies and the commissioning firms (kept private by Schmidt-Winkeler, or discarded earlier). The third step was to store the ads on so-called aggregate reels. The $35 \mathrm{~mm}$ spots are spliced together in 266 cans, meaning that individual versions or variants are time-consuming to find and usually inaccessible for independent or repeat viewing. ${ }^{27}$

24 Carlo Ginzburg, 'Clues: Roots of A Scientific Paradigm', Theory \& Society 7 , no. 3 (May 1979): $273^{-288 .}$

25 Taz Morgan, 5 th Amsterdam Workshop: The Images that Changed your Life: Advertising Films, unpublished manuscript (2009).

26 Ibid. - Schmidt-Winkeler does not hold the rights to the material, but clearly advocated an author-oeuvre-oriented view on the advertising productions in which Wilp was involved. Ingrid Schmidt-Winkeler, personal communication with the author, 20 January 2015.

27 Getting access to this material was time-consuming; it took about six months before screenings with selected materials could be arranged, given that these materials were deposited in a remote storage facility and because of work priorities within the archive due to financial constraints. 
In sum, the collection approaches screen ads in a way that partly resembles the institutional view described above, while differing in other respects. It invites us to study screen advertising as film, or rather, as an aggregate of films, disaggregated from other media, detached from utility, but consistent in their idiosyncratic artistry. Screen ads become orphan films, as it were, as they have to be separated from both their parents (the sponsors) and their siblings (the other media in the Medienverbund). Consequently, they are often read (rather than studied) as clues about something larger than themselves, in this case, as symptoms of a society filtered through Wilp's personality or creative authorship. While authorial and national approaches can be helpful in understanding national ad markets, or the role and function of particular advertising studios within such markets, for instance, ${ }^{28}$ the traces leading out of this 'orphanage' lead down no path in particular. Somewhat ironically, we can easily read the ads as representative of an author or of a nation, but not of advertising in the sense of representative product types or brands, organizations, working modes, or period styles. As material artefacts, screen ads are well-defined within the archival world, but as conceptual artefacts they are not. ${ }^{29}$ The Wilp Collection thus prompts us, first, to connect the material artefacts in the collection to a proper conceptualization of screen ads, and second, to analytically link screen ads to the larger whole of organizations, practices, strategies, or forms usually associated with the institution of advertising.

\section{The Concept of 'Institution'}

How does the institution of cinema relate to the institution of advertising? What do we mean by speaking of institutions to begin with? In what ways does an institution frame or determine the form of, and our experience with, screen ads? And how may the Wilp Collection be unlocked as a resource for studies that seek to analyse screen advertising in more systematic ways?

Within cinema studies, there are at least three different uses of the term, all of which describe a particular historical ensemble of factors that

28 For example, André Amsler, Wer dem Werbefilm verfällt, ist verloren für die Welt: Das Werkvon Julius Pinschewer 1883-1961 (Zurich: Chronos, 1997); Lenke Ripmeester, 'The Geesink Collection: Selection Criteria Reconsidered', in Films that Sell, 283-288.

29 Cf. Giovanni Fossati, From Grain to Pixel: The Archival Life of Film in Transition (Amsterdam: Amsterdam University Press, 2009), 105. 
determines how films are made, distributed, consumed, and understood. ${ }^{30}$ First is an idea of systemness. The notion of institution is not just an umbrella term for various social or extra-textual factors; it also speaks to the ways those factors are integrated or organized. In this sense, the cinematic institution is 'a real system, capable of integrating different aspects, dictating behavioural rules, and providing precise statutes for its components'. ${ }^{11}$ Speaking of cinema as an institution suggests a larger system that developed within particular historical circumstances, such as the studio system or classical Hollywood cinema, a system that is complex, stable, and central for the ordering of the social, a well-planned system that extends its powers over time and space to govern what film was in a particular territory and period.

The second facet emphasizes governance. Christian Metz famously described cinema as a set of several interlocked 'machines', employed to guide and govern film experience..$^{22}$ The cinematic institution, in this view, is both outside and inside of us, indistinctly collective and intimate, sociological and psychoanalytic, a 'mental machinery' that spectators 'accustomed to the cinema' have internalized historically and that has adapted them to the consumption of films. Seeing the cinema industry and spectator psychology as part of the same institution allowed Metz to identify a key 'mechanism' that determined the way films - and more specifically, Hollywood productions - could achieve their singular status in popular culture and even beyond. ${ }^{33}$ Others, such as Janet Staiger, similarly used the term

30 The notion of institution was introduced to disciplines such as psychology and sociology to explain how individual behaviour links to forms of social organization (Michel Foucault, 'La psychologie de $185^{\circ}$ à 1950', in Histoire de la philosophie européenne, vol. 2, ed. D. Huisman and A. Weber [Paris: Klincksiek, 1957], 591-6o6). In this context, it connoted a social structure infused with the capacity to endure. In the 1940s, the concept travelled from social psychology to communication studies, in which it came to frame functional analyses of media organizations, among others (Paul DiMaggio and Paul M. Hirsch 'Production Organization in the Arts', American Behavioral Scientist 19, no. 6 [July-August 1976]: 735-754; Paul DiMaggio and Walter W. Powell, 'The Iron Cage Revisited', American Sociological Review 48, no. 2 [April 1983]: 147-16o). Media institutions such as television were studied as performing functions essential to the maintenance of society, a capacity they were thought to hold by embodying role structures, norms, values, or conventions. In the late 1940s, the term was also taken up by the French filmologists in Durkheim's sense of a fait social, or social fact that conditions human action (Gilbert Cohen-Séat, Essai sur les principes d'une philosophie du cinéma [Paris: Presses Universitaires de France, 1946], 56f).

$3^{1}$ Francesco Casetti, Theories of Cinema, 1945-1995 (Austin: University of Texas Press, 1999), 109 .

32 Christian Metz, 'The Imaginary Signifier', Screen, 16, no. 2 (July 1975): 14-76.

33 A few years later, Stephen Neale adopted the terminology for a more 'systematic analysis' of cinema's 'texts, its sources of finance, its modes and circuits of production, distribution and exhibition, its relationship to the state, the nature of the discourses used to support and 
to invoke the workings of an abstract 'mechanism' governing a dominant mode of film production practice, in this case of classical Hollywood's mode of production. ${ }^{34}$ What made this practice such a uniform and pervasive one, according to Staiger, were specific discourses established through institutions, such as production manuals, promotional materials, or film reviews, discourses that worked 'to formalize and disperse descriptive and prescriptive analyses of the most efficient production practices, the newest technologies, and the best look and sound for the films'.35 In her account, institutions materialize (only) in their discourses, and discourses again inform practices that harden into modes of production.

The third path of inquiry has taken a different theoretical turn. While keeping the focus on film as text, it has emphasized the pragmatics of film viewing and the alleged contractuality of this arrangement. Here, the institution becomes a key frame of reference for the viewer, so that one and the same text seen within different exhibition contexts can take on very different meanings: a fiction film can be used as a work of art given that the institutional framing is that of art, for instance, or as a document, when shown in school. It is thus the major social institutions of art, education, the family, and the like that frame how texts are construed in spaces of production and consumption. ${ }^{6}$ The institution appears to be a structure

promote it, the institutional basis of these discourses, the relations within and across each of these elements and the structure of the international film industry' (Stephen Neale, 'Art Cinema as Institution', Screen 22, no. 1 [1981]: 11-40). The notion of institution here is again invoked as a broad umbrella term, before then being employed to develop a historical method that allows us to distinguish systems from subsystems, or cinema from art cinema. Neale used the term to pinpoint how 'a configuration of forces inside and outside the cinematic institution began to fracture that unity into a set of distinct spheres of practice, circulation, discussion and activity' (30). Describing art cinema as a 'distinct sector' within the cinematic institution, he underlined that various 'spheres of circulation' may develop within one institutional space. Similar conceptions also resonate in John Ellis's Visible Fictions, among others. Ellis described 'classic cinema' as an 'institution that includes both films and the ways in which those films are made available and govern the ways they are watched', and used the term to distinguish the particular 'regime' of classic cinema from television (John Ellis, Visible Fictions: Cinema, Television, Video [London: Routledge, 1982], 90, 184).

34 Janet Staiger, 'The Hollywood Mode of Production to 1930', in The Classical Hollywood Cinema: Film Style \& Mode of Production to 196o, ed. David Bordwell, Janet Staiger, and Kristin Thompson (New York: Routledge, 1985), 89 and passim; cf. Noel Burch, 'Porter, or Ambivalence', Screen 19, no. 4 (1978-1979): 91-105.

35 Staiger, 'Hollywood Mode', ibid.

36 Roger Odin, 'Pour une sémio-pragmatique du cinéma', Iris 1 (1983): 1-12; Roger Odin, 'Le film de famille dans l'institution familiale', in Le film de famille, usage privé, usage public, ed. Roger Odin (Paris: Méridiens-Klincksieck, 1995), 27-42. 
that regulates how viewers relate to this or that contract of communication. ${ }^{37}$ The term also serves as a heuristic tool for the study of how the function of media undergoes historical changes. ${ }^{38}$ Adopting a sociological perspective, other pragmatists even use the notion to relate a given film to its various milieus, again with an eye on informal and formal rules of production..$^{39}$ In this latter view, the film is always 'an image or paraphrase of its institution'. ${ }^{40}$

Systemness, governance, and contractuality certainly have proven productive as facets of the institutional analysis of cinema. They are of limited use when it comes to screen advertising, however. In the view of these concepts, institutions have a certain size and stability, they centralize power and agency, and they store and distribute knowledge in an explicit and somewhat unique way. This is not to be taken for granted here, since the 'screen' is not an institution on par with advertising or media but only one of many arenas where market activities take place. One may even ask whether cinema itself qualifies as a social institution; it is quite possible to imagine a state without cinema, but difficult to imagine a cinema without state. ${ }^{41}$ The term institution also suggests stasis and unity where we may discover internal contradictions, tensions, and constant change.

Finally, how to deal with the undifferentiated flood of 'discourses' that offer themselves to be read as traces (or 'paraphrases') of the 'institution' of (screen) advertising? To use trade papers or films as institutional discourses to reconstruct the Hollywood studio system may be an obvious methodical choice, but using ads to reconstruct advertising is not. As an object, the screen ad is much less specific than a Hollywood feature. Ads have multiple points of origin and address. There is no quasi-oligopolistic 'machine' that churns out one type of content according to preconceived market patterns, but rather - as Holbrook suggests - 'a vast particularistic assortment of atomistic elements, each engaged in a sort of communicational random walk that contributes to the informational chaos of the overall cluttered spectacle'. ${ }^{42}$

No single screen ad studio, or ad agency, or commissioning client ever gained the monolithic market power now associated with Hollywood: it

37 Francesco Casetti and Roger Odin 'De la paléo- à la néo-télévision', Communications 51, no. 1 (1990): 9; Barrette 1997.

38 Frank Kessler, 'Notes on Dispositif', unpublished working paper (2002).

39 Jean-Pierre Esquenazi, 'Éléments de sociologie du film', Cinémas 17, no. 2/3 (2007): 117; cf. Georges Friedmann and Edgar Morin 'Sociologie du cinéma', Revue Internationale de Filmologie 3 (1952):10-24. 40 Ibid., 141.

41 Media, on the other hand, may well be thought of as both indispensable to and going beyond any state.

42 Holbrook, 'Mirror, Mirror', 98. 
is safe to say that all of them have to constantly network competitively. There is also little indication that ads are 'tools' that function according to some preconceived master plan: some ads succeed, others fail, and none of them works without proper embedding in other markets that in turn are regulated through state policies and powers, such as markets for goods and services. Even if advertising indeed is an institution, its permanent struggle to establish 'good object relations' between us and the ads is well-known, for we usually neither pay for screen ads nor find it desirable to watch them, already knowing that most of them displease rather than please. ${ }^{43}$ Ads are a form of content that brands push onto audiences, not content audiences pull themselves into. ${ }^{44}$

The concept of advertising as institution thus needs to be reassessed through a confrontation with the empirical object of screen ads. If advertising consisted of competitive small-scale organizations rather than monopoly actors that are able to establish a global system of control, the concept needs to be historically specified. In what ways can German advertising of the 1960 s and 1970 s be described as an institution? In addition to situating the concept historically, we may also use it to describe a process. Institutions are beyond direct observation, ${ }^{45}$ but the efforts that go into establishing them are well-documented. How did advertisers attempt to institutionalize? Was this process marked by any internal contradictions, crises, or tensions? Furthermore, instead of taking the significance of screens for granted when it comes to advertising, it seems more productive to see film as part of a much larger toolkit, or Medienverbund. ${ }^{46}$ What role did screens play for advertising's institutionalization in the 1960s and 1970s, as compared to other promotional tools?

\section{Institutionalizing Screen Advertising: The Case of Wilp}

These and other questions allow the development of a framework to explain the particular form of film found in the Wilp Collection. To study Wilp's films as a 'paraphrase' or image of their institutional context obviously

44 Thanks to Cynthia Meyers for this observation.

45 Markus Stauff, 'Zur Sichtbarkeit von Gesellschaft. Institution in den Filmen von Frederick Wiseman und in Us-amerikanischen Fernsehserien', in Frederick Wiseman: Kino des Sozialen, ed. Eva Hohenberger (Berlin: Vorwerk 8, 2009), 85-104.

46 Thomas Elsaesser, 'Archives and Archaeologies: The Place of Non-Fiction in Contemporary Media', in Films that Work, 22. 
assumes that an institution existed, and that the films' production and consumption were institutionally framed in explicit and formal ways (and not just informally or tacitly), so that all involved parties could agree on these films indeed being ads. Yet we cannot take it as a given that contemporaries agreed that the films were working as ads, given the fact that Wilp had crossed over to the art world since the 1950s, as well as the widely noted self-reflexive character of these works. It may indeed appear as if his works merely promoted his reputation, allowing brands to trade on it by associating themselves with Wilp. We also cannot assume that German advertising, or that screen advertising in general, had become a formalized system of organizations by the 1970s, given that even in the United States institutionalization remained a conflicted and non-linear process. ${ }^{47}$

I define advertising as a process associated with a set of codified practices and a host of content types or cultural forms designed for promoting consumption. ${ }^{48}$ This process is institutionalized to the degree that a 'system of interrelated informal and formal elements - customs, conventions, norms, beliefs, and rules' can be established. ${ }^{49}$ The function of this system is to govern social relationships within which actors pursue and fix the limits of legitimate interests. The ability to establish such a system is open-ended and historically contingent: sometimes it works, sometimes it does not, and no system persists without ongoing efforts to keep itself alive. An indicator that advertising has matured into a system is the degree to which professional groups and practices integrate to form a division of labour - a division of labour then subsequently understood to be indispensable for the functioning of the system as a whole. In the case of advertising, this included, for instance, the integration of creation, strategy, and market research into the services offered by ad agencies. Clients judged the professionalism of agencies in regard to how they integrated these practices into their service. Agencies that offered creation but no market research, for instance, would fail this test..$^{0}$

Screen ads are one of many content types or cultural forms used in the process of advertising. Their use varies greatly depending on how

47 Jeremy W. Groskopf, Profit Margins: The American Silent Cinema and the Marginalization of Advertising (Georgia State University: unpublished manuscript, 2013).

48 Patrick Vonderau, 'On Advertising's Relation to Moving Pictures', in Films that Sell, 5 .

49 Victor Nee and Sonja Opper, 'Economic Institutions from Networks', in Re-Imagining Sociology, ed. Patrik Aspers and Nigel Dodd (Oxford: Oxford University Press, 2015), 149.

$5^{\circ}$ Cf. Thomas Schierl, Werbung im Fernsehen. Eine medienökonomische Untersuchung zur Effektivität und Effizienz werblicher TV-Kommunikation (Cologne: Halem-Verlag, 2003), 89-98. 
institutionalized this process turned out to be. As Yvonne Zimmermann shows in her first chapter in this section, European avant-garde filmmakers of the 1930s and 1940s did commissioned work whose results have been labelled as advertising, although neither the films' form nor the context of their making qualifies as advertising in a strictly institutional sense. Established institutional rules and codified practices also had to be overthrown periodically, given the constant drive for innovation within capitalist systems. We therefore need to historicize even the definition of screen ads, acknowledging the diversity of ad-making practices. One way to do so is to think of these practices as spread out across a spectrum of more or less direct, theatrical, and institutional modes. ${ }^{5^{1}}$ Screen ads include a commercial's direct product advertisement as much as the indirect promotion of a feature film 'tie-in', or product placement. They include ads shown in cinema and outside of cinema: in schools, waiting rooms, businesses, clubs, and other venues, and ads made by prominent agencies as much as by complete outsiders. ${ }^{5^{2}}$ The notion of the screen ad also includes slides, a dominating promotional format for much of cinema's history. ${ }^{53}$

The Wilp Collection consists of moving picture screen ads that have one obvious feature in common: their length. Of the about 120 ads that were accessible for this research, formats varied between 20, 30, and 60 seconds; only one single ad had a three-minute runtime. Length is a key indicator to understand how the films were meant to be programmed, and by extension, how institutionalized the process of screen advertising was. ${ }^{54}$ In Germany in the 1960 s and 1970s, screen advertisers had no choice but to fit the length of their ads to the programming grids made available by cinema or television. Advertisers did not control the distribution of their ads. They did not have the power and cultural cachet they have today, where screen ads permeate (and define) a multitude of moving image media. Ads had also only recently begun to make an impact on television.

$5^{1}$ Vonderau, 'On Advertising's Relation to Moving Pictures', 7.

52 For some, lumping commissioned films, product placements, merchandising, and spot commercials all together into a broad category of screen advertising may appear unacceptable, given significant differences in the way these practices were organized. In Wilp's case - and in regard to German advertising practices at that time - however, such an inclusive definition acknowledges the fluidity of institutional boundaries and rules described in this chapter.

53 Groskopf, Profit Margins; Ralf Forster, Ufa und Nordmark: Zwei Firmengeschichten und der deutsche Werbefilm 1919-1945 (Trier: Wissenschaftlicher Verlag Trier, 2005).

54 Cf. Corinna Müller, Frühe deutsche Kinematographie. Formale, wirtschaftliche und kulturelle Entwicklungen 1907-1912 (Stuttgart and Weimar: Metzler, 1994). 
Public service broadcasting started in Germany in 1956 with one channel and six minutes of daily advertising; by the end of the 1960s, 73 per cent of all German households received two channels and a daily dose of 20 minutes of advertising. As a consequence of the limited screen time available for advertising, ad slots had to be bought well in advance and were constantly overbooked.55 The average length of TV spots remained constant at 27 seconds during the entire $1960-1970$ period, with a minimum of seven and a maximum of 60 seconds of screen time. ${ }^{6}$ Cinema had no length restrictions for ad-makers, ${ }^{57}$ although 30 seconds was considered a minimum and three minutes was common for 'Werbefilme', as opposed to 'Filmlets', a 20-second 'moving slide' format resembling today's vertical digital screens. ${ }^{5}$ Many cinemas confined spot programming to a maximum of three minutes in total per show, given the prevalence of slides, so that a show's promotional slot often remained reserved for a single three-minute ad. ${ }^{59}$ Overall, cinema remained a marginal ad medium compared to television. In 1968 alone, the production of $25^{0}$ short theatrical spots was weak in comparison to the more than 4000 television spots made that same year, as trade journal Filmtechnikum noted.$^{60}$ While there were around 100 film production companies engaged in screen advertising, over 9o per cent of all ads were made by just 20 of these companies; advertising was a marginal sector even within film. In 1970, television's ad revenue was at 525 million DM, while cinema's ad revenue amounted to eleven per cent of that sum, or 57 million DM, a proportional distribution that remained constant during the 1980 . $^{61}$

55 Günther Sawatzki, Die verwirtschaftete Freiheit: Ein Beitrag zum Verhältnis zwischen Presse und Fernsehen (Frankfurt: Knecht, 1964), 69.

56 Helmut Demme, Die Rechtsnatur des Werbefernsehens und die Rechtmäßigkeit des von den Werbegesellschaften geübten Verteilungsmaßstabes bei der Vergabe von Sendezeiten zum Zwecke der Werbung (Göttingen: Schwartz \& Co., 1968), 10; Jürgen Pfifferling, Wirkungschancen der Werbung in den Massenmedien (Frankfurt: Arbeitsgemeinschaft Rundfunkwerbung, 1975), 14; Christoph Fechler, 'Die Gestaltung und die Produktion der Fernsehwerbung', in Die Werbung. Handbuch der Kommunikations- und Werbewirtschaft, vol. 2: Die Werbebotschaften, die Werbemittel und die Werbeträger, ed. Bruno Tietz (Landsberg: Verlag Moderne Industrie, 1982), 1315.

57 Melinde Dierks, 'Die wirtschaftliche Bedeutung der Werbung in Filmtheatern', in Die Werbung, vol. 2, 1584 .

58 Friedrich-Georg Amberg, Werbung im Filmtheater (Berlin: Kulturbuch-Verlag, 1956), 56.

59 Matthias Steinmann, Das Werbefernsehen im Konkurrenzkampf der Werbemittel und Werbeträger (Zurich: Polygraphischer Verlag, 1967), 46.

60 Anon., '4. Deutsches Werbefilm-Forum', Filmtechnikum 21, no. 5 (May 1970): 171.

61 Wolfgang Seubert, Struktur und Entwicklung des Rundfunk-Werbemarktes. Band ${ }_{11}$ (Düsseldorf: Landesregierung NRW, 1988), 35 . 
The short running time underlines that Wilp's ads were largely made for television; the lack of colour, ${ }^{62}$ the $4: 3$ aspect ratio, and the small promotional stories narrated in some of these 20 - to 30 -second ads all also indicate that these ads were meant for television. For instance, a series of five 26 -second spots made in 1968 for Skol, ${ }^{63}$ an international beer-brewing franchise entering the German market in 1967 , shows couples at a party while a sports broadcast is on in the background, with the models turning to their TV and a female model suggestively stating: 'This is where we belong, what we are part of, sports is our world' ('Wir gehören dazu, wir sind dabei, Sport ist unsere Welt'). Consider, on the other hand, Wilp's three-minute spot for the newly opened Bero shopping mall in Oberhausen, ${ }^{64}$ shot in 1971 in colour Cinemascope - it even featured Tarzan's Johnny Weissmueller, in ironic reference to the cinematic experience the spot was supposed to evoke. This long ad tells a story about what cinema was supposedly like in the late 1960s, by being arty and formally disorganized: there is no proper ad copy and the spot is a disjunctive montage that includes a Wilp cameo, blaring atonal music, and various half-naked female models lingering around on a tiger skin, among other elements. It is thus safe to say that most of the Wilp spots were not only made for television, but were even institutionally formatted according to the rules defined by television: they related to prevalent ideas of television's medium specificity, dayparting, target groups, and aesthetic or ethical codes. ${ }^{65}$

Is Cynthia B. Meyers right then in claiming that advertising is a 'media industry deeply integrated into other media industries, especially broadcasting'? ${ }^{66}$ This of course depends on how 'the media industry' is defined. Economic sociologists understand an industry as 'a set of markets, one of which is the core or leading market, and to which other markets are auxiliary'. ${ }^{6}$ There is little doubt that television was the leading market when it came to German screen advertising in the 1960 s and 1970s. Advertising film had 'growth difficulties', ${ }^{68}$ while television turned into a 527 million

62 Colour television was only introduced in 1967 and was regarded as a specific feature of theatrical screen ads (Demme, Die Rechtsnatur des Werbefernsehens, 46).

63 Sammlung Charles Wilp, Kinemathek Berlin, SDK69o9-K-6913-K, 35mm, 1968, black and white.

64 Sammlung Charles Wilp, Kinemathek Berlin, SDK6838-K, 35mm, 1971.

65 Cf. Yvonne Zimmermann, 'Advertising and Film: A Topological Approach', in Films that Sell, 21-40.

66 Meyers, $A$ Word from Our Sponsor, 4.

67 Patrik Aspers, Markets (Cambridge: Polity Press, 2013), 33.

68 Bernd Glocke, 'Farbiger, doch nicht besser: 3. Werbefilm-Forum', Werben \& Verkaufen 7, no. 3 (April 1969). 
DM industry with a $25^{\circ}$ per cent excess demand for ad slots. ${ }^{69}$ Yet television was not the largest market for advertising. Advertisers ranked broadcasting far behind print - that is, behind newspapers, ad supplements, popular magazines, and trade journals..$^{70}$ In 1964, for instance, newspaper ads generated 1699 million DM in revenue, as compared to 374.7 million DM generated by television. ${ }^{71}$ By 1972, gross advertising expenditure for newspapers was at 27.6 per cent, while only 8 per cent was spent on television. ${ }^{7^{2}}$ Although print representatives often conjured up the threat of television, ${ }^{73}$ ads in newspapers continued to dominate well into the 1980s. Advertising culture was, and remained, largely a graphically oriented culture.

Does this mean that print was the industry advertising was 'integrated into'? Obviously not, because advertising existed beyond the level of day-today market operations as an idea or system that extended beyond any single medium, and was enacted via open-ended negotiations of standards, shared beliefs, divisions of labour, organizational roles, and the like. If advertising was a cultural production, as Meyers states, this production was not entirely governed by market imperatives. In accordance with their cultural beliefs, advertisers engaged in risky rather than purely economic behaviour (by insisting on the primacy of creation over strategy, for instance) and partly did not live up to the standards introduced and touted by their institution (by adhering to something other than a period's Leitmedium). Even if we were to define advertising simply as an industry, or set of markets, we would do better to see these markets as processes and not as static entities. ${ }^{74}$ During the 1960 s and 1970s, advertising, television, and cinema all transformed at different speeds and in different directions - and none of them constituted an entirely stable market. As historians, we therefore cannot approach this 'industry' as a matryoshka doll in which markets are neatly stacked into each other by size, assuming they are identical in shape and function. Rather, we have to acknowledge the tensions between these various markets, their frictions and uncertainties, and to understand these frictions as key drivers of advertising's institutionalization, as will become apparent below.

69 Anon., 'Mehr Werbefernsehen?', Filmtechnikum 23, no. 5 (May 1972): 159.

70 Frank-Jürgen Stockmann, 'Die klassischen Medien im Überblick', in Die Werbung, vol. 2, 1786.

71 Hans Schneider, Werbung im Rundfunk (Frankfurt: Metzner Verlag, 1965), 10.

72 Siegfried S. Schmidt and Brigitte Spieß, Die Kommerzialisierung der Kommunikation.

Fernsehwerbung und sozialer Wandel 1956-1989 (Frankfurt: Suhrkamp, 1996), 201.

73 Sawatzki, Die verwirtschaftete Freiheit.

74 Hans Kjellberg and C.F. Helgesson 'On the Nature of Markets and Their Practices', Marketing Theory 7 , no. 2 (2007): 137-162. 


\section{Was Charles Wilp an Advertiser?}

How did Charles Wilp position himself vis-à-vis this emerging institution? Shall we consider him an advertiser, a film-maker, an artist? To answer this question, we need to get a better understanding of the culture he formed a part of. Institutional representatives often distanced themselves from Wilp, whom they described as an outsider, despite his continuous work in advertising. The trade journal Werben \& Verkaufen, for instance, ran a series of articles that spread a negative view of Wilp when he was at the height of his success in the late 1960s. The series started in December 1969, after a long TV documentary had been broadcast about him. Two major trade organizations, Zentralausschuss der Werberwirtschaft and ADW-Verband deutscher Werbeagenturen und Werbemittlungen, published an open letter in which they complained about the documentary. They noted that it 'favored an extreme outsider to German advertising' whose work had 'nothing to do with reality' and would harm advertising's image. Wilp was also called a 'fraud' and was cautioned against becoming a 'megalomaniac'. Other critics noted his blatant self-promotion and the product placements in this documentary. Werben \& Verkaufen's editorial staff did not share the view put forward by those 'overeager clubmen', but agreed that Wilp was a 'loner' and was eager to promote himself.75

The ridicule intensified in 1972, when Wilp 'once again came to represent German advertising,' this time at Documenta V in Kassel. ${ }^{76}$ The journal sarcastically mocked 'Master Wilp's' efforts to cast himself as celebrity advertiser and enfant terrible, and the oversized reproductions of his print ads now prominently featuring as artworks: 'Not only the Master's works have been found to bear such weight; he himself has been turned into an artwork [...]. Charles Wilp has become the definite measure of art in advertising.' The journal reminded its readers that he had never won a Golden Lion in Venice nor had he ever won any other industry award. He went unnoticed in most other trade publications. Wilp's major campaigns, such as Afri-Cola, were seen as word-of-mouth public relations efforts rather than proper brand advertising. ${ }^{77}$ His creative work did not integrate with

75 Anon., 'Verärgerte Verbände: Wilp-Sendung erregt Mißfallen', Werben \& Verkaufen, 19 December 1969; Peter Reichard, 'Offener Brief an Charles Wilp', Werben \& Verkaufen, 12 December 1969; Ralph Schlehofer, 'Ärger mit Charlie', Werben \& Verkaufen, 12 December 1969; Anon., 'Charles Wilp und die Schleichwerbung', Werben \& Verkaufen, 19 December 1969.

76 Anon., 'Werbung als Kunstwerk oder wie Charles Wilp auf der Documenta wieder einmal die deutsche Werbung repräsentiert', Werben \& Verkaufen, 25 August 1972.

77 Karl Grün, 'Werbung sucht neue Aufgaben', Frankfurter Allgemeine Zeitung, 25 June 1968 (my translation). 
strategy or market research. ${ }^{7}$ As Wilp himself stated, 'I am not advertising in the usual way, but rather offer experiences into which the product is embedded' 79

Wilp's signature campaigns indeed appear to be a pop cultural reflection of contemporary advertising rather than actual advertising. A campaign commissioned by Isenbeck brewery between 1967 and 1974 exemplifies this quality. The campaign consisted of several series of television spots, print ads, and posters. One of these series, made in $1968,{ }^{80}$ builds its promotion around an action film mini plot reminiscent of the James Bond franchise. An attractive blonde or brunette is held captive by gangsters in a speedboat, helicopter, or at a party, only to be freed by 'Herr Isenbeck', a classy gentleman in a suit rushing to her rescue ('Please don't shoot, dear Isenbeck Pils!'). The five 30 -second spots feature action such as chases and showdown scenarios easily recognized from genre film in order to establish the gentleman as a brand character and, consequently, Isenbeck beer as 'the new trend', playfully overstating the claims made by more conventional beverage ads: 'You will experience the Eighth Wonder of the World!' Wilp's campaign not only played on popular entertainment, however, it also alluded to an outdoor fashion ad campaign created by famous British photographer Terence Donovan in 1961. Donovan's 'spy shoots' featured a suited man with a machine gun even before the first Bond film was released in 1962 . Wilp's work was linked to Swinging London in multiple ways: he owned a photo studio in Kensington, often contracted British models, and seems to have moulded his own public persona on David Bailey, the legendary photographer immortalized in Blow-Up (1966). ${ }^{81}$

To picture Wilp as a misfit or as an outside commentator of German advertising's production culture, however, does not acknowledge his success and the actual role he played within that culture. For almost three decades from the mid 1950s through the 1970s - Wilp managed to work continuously in the industry. He had a legendary 'flair for converting unknown products into household names' ${ }^{82}$ Isenbeck, for instance, reportedly increased its

78 Hans Kuh, 'Die geeiste Glasplatte: Charles Wilp wirbt für Afri-Cola', Gebrauchsgraphik 40, no. 8 (1969): 14-17.

79 Ibid., 14.

80 According to Annette Groschke's inventory list, the can in the Wilp collection is labelled 'Boot 1968' (Boat 1968). SDKo7003-K, 35mm, black and white.

81 Wilp resembled Bailey (or rather, David Hemmings's Blow-Up impersonation of Bailey) with his air of 'tired paparazzi', as one contemporary put it, with his easy-listening jazz-infused studio footage, and by engaging with female models in eccentric and sexualized ways.

82 Anon., 'Europe's Creative New Breed', Time Magazine 95, no. 11 (1970). 
sales by 29 per cent after Wilp's campaign. For his Afri-Cola spots, Wilp had a 4 million DM budget; Afri-Cola's turnover allegedly grew by 15 per cent in Germany and by 13 per cent in Austria in 1968 as a result of his promotion. ${ }^{83}$ A campaign Wilp launched for the German Red Cross in 1969 earned him 525,000 DM, and he was said to have had an annual budget of 15 million DM that year. ${ }^{84}$

Wilp also was not an agent of mass culture critique - quite the opposite. He co-organized Teenage Fair 1969 in Düsseldorf, a consumer fair targeting young people, which was massively criticized by consumer advocates, the Socialist German Student Union (SDS), and APO (the extraparliamentary opposition) for the way it aimed to transform young people's anti-capitalist protests into a consumer spectacle. ${ }^{85}$ Many of Wilp's ads were more sexist than other ads of the time. ${ }^{86}$ His well-known Afri-Cola campaign also appears to be racist. It promoted a brand that had been invented by the company F. Blumhoffer Nachfolger in 1931 as the 'German alternative' to Coca-Cola - a form of 'post-colonial commodity racism' that has been linked to statements by Wilp on how women of colour were "close to nature" and "animalistic". ${ }^{87}$

To explain Wilp's role in advertising's production culture, we have to acknowledge how both his career and the industry changed during the 1960 . Wilp began as a photographer whose work was commissioned by ad agencies for campaigns in which Wilp had little or no creative control. He is, for instance, often credited with having created a longer series of films and ads for Puschkin Vodka from 1956 to 1962 . This alleged Wilp signature

83 Hans Kuh, 'Die geeiste Glasplatte: Charles Wilp wirbt für Afri-Cola', Gebrauchsgraphik 40, no. 8 (1969): 14-17.

84 Anon., 'Freche Kampagne', Der Spiegel, 27 October 1969; Anon., 'Sehr rauschig', Der Spiegel, 1 December 1969. All these figures are questionable, however, and are now hard to verify. Alexander Flach later revealed that Afri-Cola never increased its sales to the degree claimed earlier (Harald Keller, 'Der große Afri-Cola Rausch', Frankfurter Allgemeine Zeitung, 28 August 2008). 85 Anon., 'Kampf der Bakterie', Der Spiegel, 18 August 1969.

86 The Bero Center ads (1972), for instance, are explicit in their use of soft-core conventions. Contemporaries noted that Wilp's campaign for Pirelli tires (1965) was extraordinary in the way it focussed on naked female legs. Another campaign sexed up the German Red Cross by featuring 'sex sisters', as Der Spiegel commented (Anon., 'Freche Kampagne', Der Spiegel, 27 October 1969). 87 Katharina Eggers and Robert Fechner, "The "German Alternative”: Nationalism and Racism in Afri-Cola', in Colonial Advertising \& Commodity Racism, ed. Wulf D. Hund, Michael Pickering, and Anandi Ramamurthy (Münster: LIT, 2013), 197-213; Jeff Schutts, 'Die erfrischende Pause: Marketing Coca-Cola in Hitler's Germany', in Selling Modernity: Advertising in 2oth Century Germany, ed. Pamela E. Swett, S. Jonathan Wiesen, and Jonathan R. Zaitlin (Durham, NC: Duke University Press, 2007), 165. To describe Wilp's Afri-Cola campaign as deliberately or dominantly racist, however, would overstretch the argument. 
campaign, however, was developed by Düsseldorf-based ad agency Team (which, in 1973, became вBDo Germany). Team was founded in 1956, and Puschkin was one of their first major accounts. Team was also the first German ad agency 'co-le[a]d by creatives from the very first day', ${ }^{88}$ among them famed art directors Vilim Vasata and Jürgen Scholz. ${ }^{89}$ Wilp, while acting as a creative, was merely hired in 1959 to do the photography for the films used during that campaign, based on Scholz's and Vasata's existing print strategy. By the 1960s, companies routinely outsourced advertising to ad agencies, and agencies usually interacted directly with corporate management in devising creation and strategy. ${ }^{90}$ Although he later claimed credit for Team's landmark campaigns for Volkswagen or Tchibo, Wilp 'only followed the instructions of ad agencies' ${ }^{91}$ until he managed to acquire the Isenbeck account in 1967. He was eager to surf the wave of the 196os creative revolution without having initiated it.

This revolution is often associated with Doyle Dane Berbach (DDB) and a legendary 1959 print ad campaign for the Volkswagen Beetle..$^{2}$ The New York agency not only changed the look, language, and tone of American advertising, but also broke with a managerial style epitomized by large bureaucratized agencies such as J. Walter Thompson that monopolized clients and excessively supervised their creatives. Decisions within these agencies were made by account executives and businessmen rather than by designers. Some of the young revolutionizers such as George Lois left DDB in the early 196os to start their own creative workshops, embracing a lack of constraints, bureaucracy, [and] established procedure', and 'an allegiance to art rather than science'.93 This trend was even observed in Germany. Team, considered 'more alike DDB than any other German agency', had been founded in response to overmanaged agencies such as Hubert Strauf's

88 Team BвDo, Die Agentur (Hamburg: Team/BвDo Hamburg, 1979).

89 Anon., 'Markt für Muffel', Der Spiegel, 23 May 1966. Another article names Wolfgang Vorwerk as the creative mind behind this campaign, but there is evidence that creative decisions were made in teams. Anon., 'Weil er hart ist', Der Spiegel, zo October 1963.

9o Hans-Gerd Schmidt, 'Wie Zeitgeist in die Werbung kommt. Aspekte einer produktionsästhetischen Analyse von Sinalco-Werbefilmen', in Werbefilme: Spiegel der Zeiten - Chronik des Alltags, ed. Hans-Gerd Schmidt and Bernd Wiesener (Bielefeld: Verlag für Regionalgeschichte 2002), 67; Schmidt and Spieß, Die Kommerzialisierung der Kommunikation, 207.

91 Anon., 'Weg vom Zinn', Der Spiegel, 20 February 1967; personal communication with Stephanie Pahmeyer, BвDo Group Germany, 28 June 2017.

92 Thomas Frank, The Conquest of Cool: Business Culture, Counter Culture, and the Rise of Hip Consumerism (Chicago: University of Chicago Press, 1997), 55. The legendary 'Think Small' ad features an empty white background with only a small vw beetle in view.

93 Ibid., 82. 
Die Werbe. ${ }^{94}$ By 1969, Team itself started to lose its teams. ${ }^{95}$ More and more young advertisers opened independent 'workshops', opting out of an inefficient agency culture that was based on market research rather than on creativity. Young German promoters such as Uschi Roos, Wolfdietrich Spehr, Michael Grashoff - and Charles Wilp - chose such kinds of increasingly independent, flexible careers in advertising. ${ }^{96}$ In 1969, Werben \& Verkaufen counted 25 to 30 'hot shops' specialized in supplying creation either directly to companies or as a service to agencies.

The journal also warned against 'a few frauds' among the new hip creatives, 'whose performance is nothing but illusion based on fancy masquerade'. 97 This probably alluded to Wilp and his eccentric yellow overalls, because the journal featured an open letter calling him out as a fraud on the very next page. Both institutional representatives and young creatives seemed to dissociate themselves. The signature campaigns Wilp developed as a freelancer after ${ }^{196} 67$ imitated the anti-establishment attitudes of George Lois or Jerry Della Femina, with the difference that Wilp had no proper agency background and did not subject creation to strategy. His Afri-Cola spot commercials (1968-1978) come closest to Lois's conviction that advertising should shock like art: 'It should unhinge your nervous system. It should knock you out! [...] In that swift interval between the initial shock and the realization that what you are seeing is not as outrageous as it seems, you capture the audience..$^{8}$ Afri-Cola's shock aesthetics relied on fast-paced, disjunctive editing, for instance, and on outrageous subjects (lustful nuns, naked soldiers), as well as an atonal, noisy score provided by controversial beat band The Monks.

Wilp's career can thus be situated within a paradigm of creative freelance work that shaped Germany's advertising culture in the 196os. This shift from agency integration to freelance creation was facilitated by two factors. First, clients were not yet used to interacting professionally with ad agencies. Companies lacked proper marketing departments, and decisions were often made by company owners themselves. Isenbeck's president Egon Wüstenhofer engaged Wilp, for instance, as did Afri-Cola's founder Karl Flach, who handed Wilp a blank cheque without asking for market research

94 Anon., 'Markt für Muffel', Der Spiegel, 23 May 1966.

95 Anon., 'Sternchen im Kopf', Der Spiegel, 10 March 1969.

96 Gunter R. Gerlach, 'Sind die Agenturen noch zu retten?', Werben \& Verkaufen, 12 December 1969; Anon., 'Joghurt für Jungfern', Der Spiegel, 4 September 1967.

97 Anon., 'Kreative Zulieferanten der deutschen Werbung', Werben \& Verkaufen, 12 December 1969 .

98 Quoted in Frank, The Conquest of Cool, 85 . 
or concept presentations in return. ${ }^{99}$ The lack of standards and specifications meant low barriers of entry for newcomers. A second facilitating factor was the spectacular revaluation of creative work in the United States and Great Britain. Even more established brands began to cut out the middlemen when learning about the cost efficiency of American or British campaigns. Martini \& Rossi separated from their agency and handed the account to Wilp in 1969, for instance. ${ }^{100}$

While Wilp managed to work in the industry for almost three decades, he did not succeed in acquiring larger accounts after 1970. Before 1967, he mostly worked as a photographer for ad agencies, and as a freelancer he only had long-term relations with Isenbeck, Afri-Cola and Bluna (both owned by Karl Flach), and Stiebel Eltron, none of which were major brands. Martini \& Rossi only commissioned six spot commercials in 1968-1969 and in 1976 chose Team to promote its products. ${ }^{101}$ In other words, Wilp was 'hot' from 1968 to 1970 when his work was commissioned by multiple firms, even smaller ones such as Skol, Schwechater, Signal, Lukiluft, Neff, Jedermann Furniture, or Kwas. Ad agencies then quickly co-opted the attitude and designs of the creative revolution. Wilp, in turn, began to reproduce his Isenbeck and Afri-Cola campaigns rather than develop new approaches.

His renunciation in trade journals around 1969 was due to several factors. Wilp's initial surprise success threatened to further deteriorate agency-client relations. He became an easy scapegoat for advertising representatives who were careful not to speak out against more established freelance creatives. The latter, in turn, might have seen his work as derivative, since it was not properly based on market research. ${ }^{102}$ Finally, Wilp's public statements and ads were deliberately provocative.

\section{Are Wilp's Films Ads?}

Shall we consider the films in the Charles Wilp Collection as 'tools' that were 'useful' for the institution of advertising? Obviously not, at least not

99 '80 Jahre anders. Interview mit Alexander Flach, Sohn des afri Erfinders Karl Flach', undated. Thanks to Helga Peter, Marketing Manager, Mineralbrunnen Überkingen Teinach AG, for providing me with this interview.

100 Anon, 'Joghurt für Jungfern', Der Spiegel, 4 September 1967.

101 Team BвDo, Die Agentur.

102 Speaking for the creatives, Gerlach noted that creation always had to be fully integrated into research in a broad sense (Gunter R. Gerlach, 'Sind die Agenturen noch zu retten?', Werben \& Verkaufen, 12 December 1969; Anon., 'Joghurt für Jungfern', Der Spiegel, 4 September 1967). 
in a direct, positive, and simple sense. Wilp's work after 1967 contradicted ideas of what advertising was. If anything, these works defined a negative standard against which principles of best practices could be articulated. This included the need to integrate creation and market research so that the ads would target particular groups of consumers, to follow the ethical and aesthetic frameworks of television programming, and to communicate unambiguous ad claims.

The lustful nuns in Wilp's signature campaign for Afri-Cola, for instance, were said to have failed to persuade young people between 14 and 24 years of age, a target demographic for cola drinks. ${ }^{103}$ Wilp also seems to have been accused of missing Isenbeck's key target market, an accusation he tried to counter by rehearsing arguments on an audio tape found in the Wilp Collection. ${ }^{104}$ He thus breached a principle of efficiency that agencies such as Team BBDO would later codify into what they called the 'Four-Point Process', a process that subjugated any media strategy to the aim of knowing your prime prospect, knowing your prime prospect's problem, knowing your product, and breaking the boredom barrier. ${ }^{105}$ While Wilp certainly succeeded with the last of these goals, he also clearly violated the explicit and tacit rules of German television advertising with his signature campaigns for Afri-Cola, Bluna, and Isenbeck. Public-service television's 'Programmrichtlinien' (programming guidelines) of the $1960 \mathrm{~s}$ defined marriage and family as institutions that were not to be questioned or ridiculed. International guidelines furthermore demanded that advertising should 'not include anything which either directly or by way of implication, omission, or ambiguity may mislead the consumer'. ${ }^{106}$ Wilp's signature ads suspended literally every rule of traditional television advertising. ${ }^{107}$ At the same time, the ads obviously worked for his long-time clients.

Hence, while all parties agreed that Wilp's films were meant to function as ads, they did not all agree on their function. If advertising is a 'system of systems', then this system stabilizes through failures as much as successes. But what about Wilp's work before 1967? These earlier spots are mostly unknown.

103 Anon., 'Mit Differenzierung durch den Geschmack den Anteil auf dem Cola-Markt vergrößern', Werben \& Verkaufen, 25 February 1972.

104 Sammlung Charles Wilp, Kinemathek Berlin, CDo7, Tracks o6 and 07.

105 Team ввDo, Die Agentur.

106 Friedrich Knilli, Der tägliche Sündenfall: Fernsehen und Werbung (Frankfurt: Haus der Evangelischen Publizistik 1972), 19.

107 A 1954 book commissioned by powerful ad agency McCann, for instance, asked to avoid optical tricks, overly exaggerated claims, and implausible product benefits (Harry Wayne McMahan, Fernsehwerbung. Gestaltung und Produktion wirksamer Werbesendungen [Düsseldorf: Econ, 1957], 17). 
Are there formal continuities in the Wilp ads made before and after 1967 , and what are the commonalities between Wilp's ads and ads more generally?

\section{Screen Ads: A Definition}

To answer this question, we need a minimal definition of the screen ad form. Above, I have already introduced a typology that includes both direct and indirect, theatrical and non-theatrical (or non-televisual), and more or less institutional forms. When it comes to the form of screen advertising itself, some more precision is necessary. What are the essential elements that allow us to distinguish a promotional form from one that does not promote? Pragmatists caution against such essentialism, of course, pointing to the fact that any film could theoretically be turned into a commercial if shown in a certain context. Most viewers nevertheless have histories with this form that allow them to make such a distinction, and this includes consumers as much as clients, film-makers, and ad agency personnel. Tentatively, we may define the basic form of all screen advertisements as consisting of four recurring elements. First, a brand. An ad always refers to a name given to some product, service, or idea. Second, there is some relation of indexicality between the object thus named and the viewers' lifeworld. Third, a form of presentation that shows the object as being shown to the viewer. And fourth, a movement of sorts.

Brands and trademarks are key in advertising because they establish a unique relationship between name and product, image and real-life object. Without brands, we lack any criteria for distinguishing between similar goods and services and thus the very basis of consumer capitalism. As I have noted elsewhere, trademarks are signifiers that establish the right of sellers to exclude others from using the sellers' reputation for the quality of their goods. ${ }^{108}$ Trademarks can of course be shown in screen ads in- and outside of cinema or television, in direct or indirect ways (e.g., in a product placement). They can also be presented in inadequate, useless, or unprofessional ways, as judged by the institution.

Brands in film may be fictional but figure as trademarks only when becoming reality at some point, such as Bubba Gump Shrimp, which became a restaurant franchise after being mentioned in Forrest Gump (1994), or the Wonka Bar chocolates introduced in the wake of Roald Dahl's Charlie and the Chocolate Factory. In other words, a film only qualifies as a screen ad 
when its featured brand relates to a good or service that once existed. If the film's branded object were not available in the real world as something to desire, purchase, or remember, the film's form would be a representation of advertising rather than advertising.

Yet brands are not simply presented for viewing. They are also shown in a way that shows the showing. To some degree, all screen ads gesture demonstratively to their viewers. Even the allure of showing a brand in passing remains a purposeful showing recognizable as such. Ads are paid for by clients rather than viewers, and the clients want to recognize their brand as being shown; a Rolex featured in a Bond movie needs to be featured with its name or recognizable design, so that the name can be seen and remembered. Traditional spot commercials introduced the pack shot as a separate segment, often near the end, that would lend time and space to recognizably feature a product's name and qualities. Even negative campaigning has to be done in a 'demonstrative language' or an attractional display that follows an instrumental logic of actions towards a final goal. ${ }^{109}$

All screen ads also include some form of movement. Screen ads are not permanently on-screen like a bumper sticker on the back of a computer. Some move passively, like slides that are moved on and off the screen, presenting an object as motionless. Others may display varying degrees of movement in the image, from an image's gradual build-up in today's vertical digital display ads to the rapid montage of a 20 -second TV commercial. Sometimes the advertised object itself may move; sometimes it may remain static or appear simply as a background image. But screen ad programming requires movement, as it depends on catching viewers' attention. Commercials are always shown in blocks, rather than separately; change has to occur. An entire feature may be devoted to a brand, such as the volleyball Wilson featured in Cast Away (2001), with plenty of movement in the picture. Most screen ads use a sequencing of information, narrative or not, that requires the movement of images. ${ }^{110}$

109 André Gaudreault, From Plato to Lumière: Narration and Monstration in Literature and Cinema (London and Toronto: University of Toronto Press, 1988), 72.

110 I am not making a distinction here between screen ads and more conventional billboard displays, digital or non-digital (backlit paper). Shopping mall displays, for instance, sometimes have rotating copy to provide eye-catching movement, and this practice is related to moving picture screen ads in the narrower sense. My definition of course is debatable because making posters for billboards and making commercials are different fields of practice. But in making this distinction, one would also need to differentiate between slides and films shown in cinema. With the increase of digital outdoor displays, movement may increase in the future, further blurring the boundaries between screen ad practices. 
All of Wilp's films fit into this larger pattern. Even his unorganized, arty, theatrical spot commercial for Bero Center (1971) features a branded shopping mall that actually exists, addressing viewers in a direct promotional way through a juxtaposition of shots and movements in the image. Yet formal specificities extend beyond these general features of Wilp's ads. There is one commonality in almost all of Wilp's screen advertisements, which is striking given his reputation as enfant terrible: they are merely animated billboards. Comparing the print and film campaigns, it becomes obvious that Wilp's films are largely filmed posters or print ads. They augment print and poster photography with limited movement through character action and editing as well as sound. ${ }^{111}$ In terms of production, it seems that Wilp often used the same photo studio set-up to shoot the print ad material as well as the commercial. This even explains why his public image and contemporary making-of documentations centre on the studio photo shoots. Over three decades of work, Wilp thus stayed within the graphically oriented culture of German print advertising.

To elaborate, consider the element of movement in two commercials made for Bosco Tonic in 1969, another soft drink distributed by Karl Flach. ${ }^{112}$ The ads consist of one static full-body shot, showing a half-naked female 'boxer' with curly blonde hair working out her legs without moving around. The model swings her fists before her chest, probably playing with a male viewer's anticipation that she might incidentally reveal her breasts. A sportsman in a white sweatsuit kneels at her side, presenting a can of Bosco Tonic to the viewer (and, by implication, her). Both face the viewer directly and are placed against a black background. The exact same imagery is found in an accompanying print ad campaign, which also includes the identical claim, 'Das Erfrischungsgetränk für Erwachsene' ('The soft drink for adults'). A similar approach even occurs in one series of spots made for Isenbeck beer, for instance, which features camera-facing models set against a black background in a static shot accompanied by party music and off-screen copy claims, and in the Afri-Cola and Bluna signature campaigns. ${ }^{113}$ Importantly, this is the same approach Wilp had already followed before 1967 when

111 This is a feature also found in other screen ads associated with the so-called creative revolution, such as the 'Think Small' campaign. See, for instance, 'Legendary vw beetle Think Small commercial!', www.youtube.com/watch?v=qw2rRSLvIOo (last accessed 5 April 2021). 112 Sammlung Charles Wilp, Kinemathek Berlin, SDK6877-K-6878-K. The two spots use different models but are identical in other respects.

113 For instance, Sammlung Charles Wilp, Kinemathek Berlin, Bluna SDK6934-6944-K; SDK6956K-6966-K. Afri-Cola spots circulate widely on the internet. 


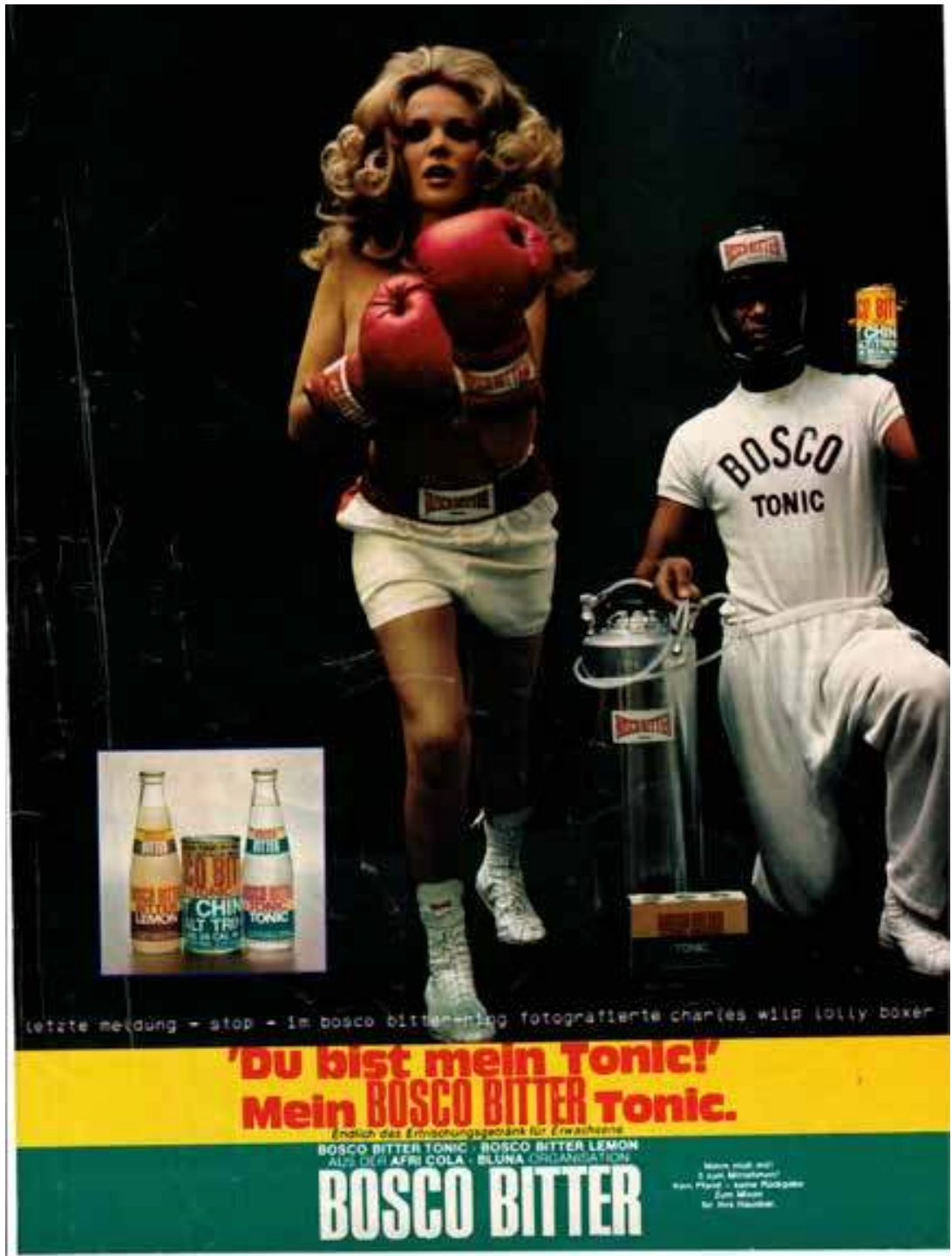

Figure 4.5: Identical Set-Up for Print Ad and TV Spot: Bosco Bitter Tonic (author's collection).

working for Team's Puschkin Vodka and other brand campaigns he photographed.

The eighteen black-and-white television spots made for Puschkin between 1957 and 1962 are all structured in an identical way. ${ }^{114}$ In 20 seconds, they

114 Sammlung Charles Wilp, Kinemathek Berlin, Puschkin, SDKo7010-K. 

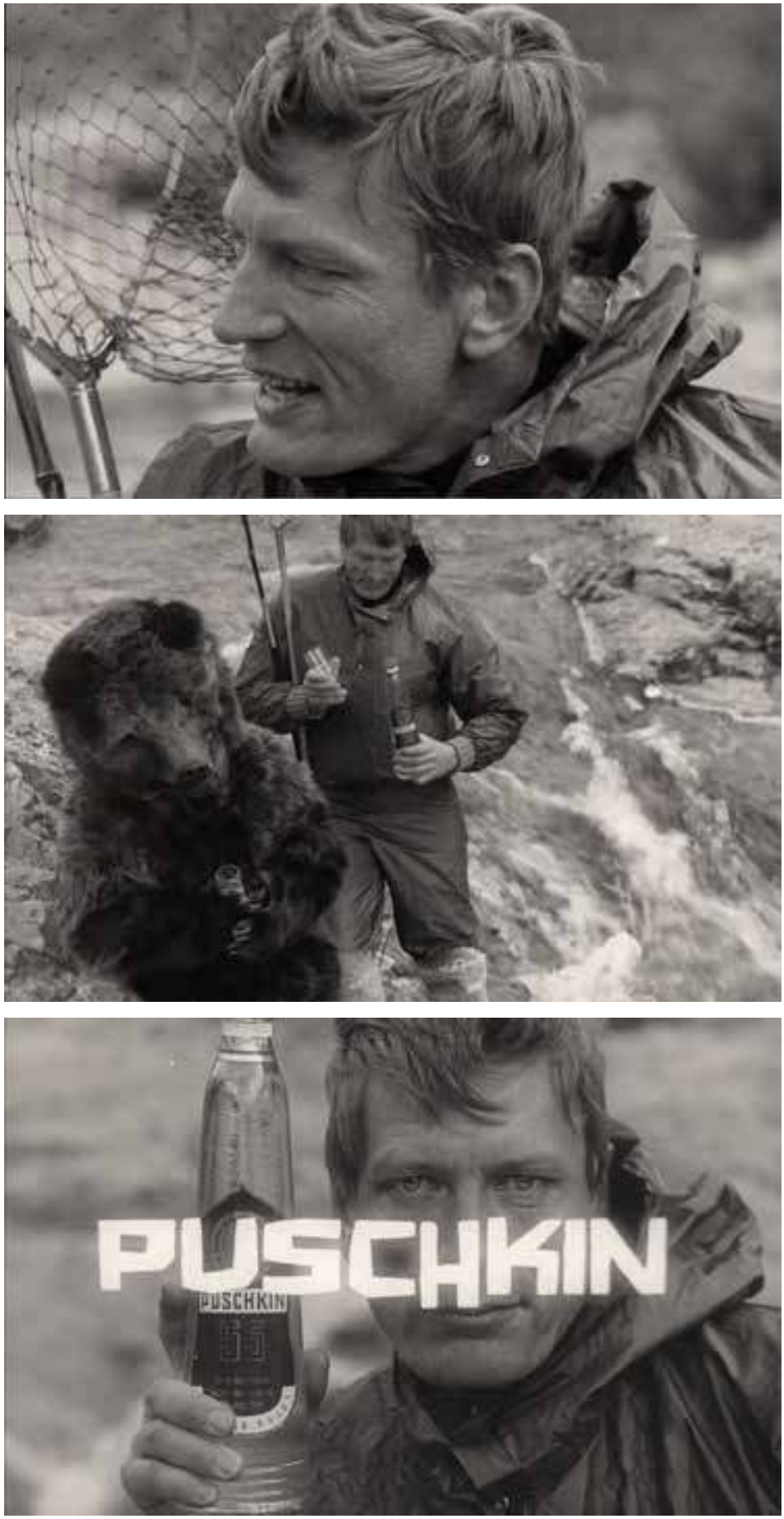

Figure 4.6-4.8: 'For Tough Men': An Ad for Puschkin Vodka (Deutsche Kinemathek). 
stage a brief conversation between a classy gentleman and a brown bear. Many of them follow the same editing pattern, consisting of merely three or four shots. The first shot shows model Hans Meyer in a close-up of his head and shoulders against an outdoors background of streaming water and rocks, his hair blowing in the wind. He speaks to someone off-screen. Secondly, a medium long shot reveals the bear he is talking to and a bit more of the outdoor scenario that was implied in the first shot. The third shot presents the man and the branded Puschkin bottle in close-up, facing the viewer. The copy reads: (1) The man: 'They [i.e. the fish] are not getting hooked.' Voice of bear: 'Must be the bait.' (2) The man: 'Puschkin would be the right one.' The bear: 'For trout?' (3) The man: 'For tough men.. 115 The pattern is varied in different scenarios: on a mountaintop, in an airplane, at a bar, in a hunter's tree stand; it always returns to Puschkin's tough-guy claim at the very end.

The screen ads and their drinking scenarios are identical to the print ad campaign, including the dialogue conveyed in print. What differs is not so much the movement in the image - there is very little movement - but the visual pun made possible by editing from a close-up to a medium long shot, so that the viewer is surprised to see the 'tough guy' talking to a bear. Although this and many other Wilp ads were gendered in a traditional and sometimes chauvinistic way, the ad ironizes 'toughness' by having the tough-guy talk to an unlikely (inner) friend. The overall form of the ads amounts to a repetition of a simple, minimalist design principle. This principle seems to have first been developed by Team's legendary art director Vilim Vasata for print ad design. In Vasata's view, print ads would need to work 'against the medium and for the ad' to get a reader's attention. He called ads a 'technique of gaining attention and remembrance' that used a 'mechanics of repetition'. ${ }^{116}$ Referring to the Puschkin print ad campaign, Vasata spoke of the need to 'always offer some new content while keeping as background a unique and unchanging layout context'. Vasata also underlined the advantage of using eye-catching imagery, surprises, and a form of 'creative selling' or 'artful self-reference', playing on the fact that both readers and advertisers know what they are engaging in.

115 “"Die beißen nicht an." - "Liegt wohl am Köder." - "Puschkin wäre der richtige." - "Für Forellen?" - "Für harte Männer."' Sammlung Charles Wilp, ibid.

116 Vilim Vasata, 'Die Gestaltung von Anzeigen in Publikumszeitschriften', in Die Werbung, vol. $2,1185 \mathrm{ff}$. 


\section{'Outer' and 'Inner' Principles of Form}

We may therefore say that Wilp's ads adopt both an 'inner' and an 'outer' principle of form. I have described the inner form principle above as rooted in a graphically oriented practice that had been institutionally codified in print advertising. The Puschkin Vodka campaign followed an inner form that relates to other works created by Wilp before 1967. In 1964, for instance, he shot ten 20 -second television spots for a hairstyling gel called Fit, commissioned by Schwarzkopf, a well-established German brand. ${ }^{117}$ The campaign has the same marks of irony, reduction, and repetition. The spots consisted only of two static shots. The first always showed a male model in close-up against a white background, while the second was a group shot. The surprise and eye-catching effect here related to the first close-up shot of the man facing an existential hair problem: how to deal with unruly hair? The problem was conveyed visually, while a voice-over offered various solutions: (1) 'You may choose to go out only after dark [...] to hide in your bed [2] or, to use Fit by Schwarzkopf', making the last solution the most obvious. Again, this principle was varied across the entire series, introducing different problems. The ads had the same understated, ironic quality as the Puschkin ads, building on the underdog appearance of a male model clueless about how to handle his hair.

By outer form, I refer to how screen ads integrated with the medium in which they were presented, or more specifically, how they obeyed the formal rules ad-makers associated with television or cinema. Thus, while Wilp's ads partly relied on principles known from print advertising, they also related to media theories circulating within the advertising sector. A campaign's media strategy usually started from some idea about media specificity, spelled out in terms of target audiences, for instance, but also in regard to a mode of aesthetic experience, apart from the obvious factor of screen time.

Television was not seen as a medium that could be used for targeting specific groups. Public service broadcasting's strictly regulated 'Werbeblock', or daily ad slot, aggregated ads for various audiences without differentiating between them. Although Tv households increased nationwide, ads were not widely accepted and were considered an unwelcome break by many, according to surveys. Critics within advertising described TV ads as too short and ephemeral to leave an impression. Sound and image were inconsistent, cramped with information, and derivative of print ads. On the positive side, TV 

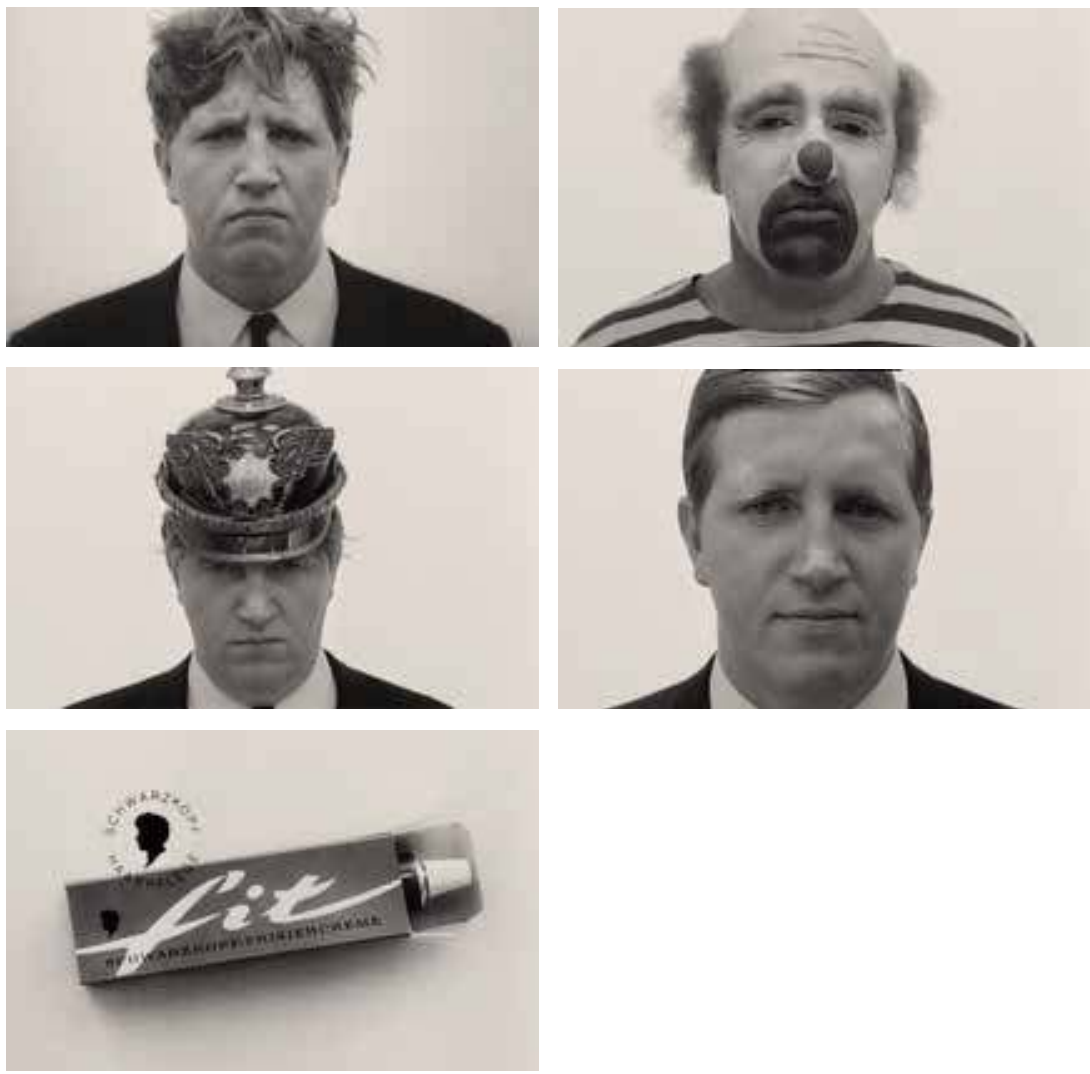

Figure 4.9-4.13: 'Change Your Profession. Or Use Fit - by Schwarzkopf' (Deutsche Kinemathek).

ads could demonstrate a product's benefits in a realistic way; they combined image, movement, sound, and typography; and they were viewed in the home in a relaxed mode and without much competition from other media. ${ }^{118}$

Cinema, on the other hand, turned into a target medium, as its audiences developed into specific demographic segments during the 1960-1980 period, which was especially useful for reaching those aged 14 to 30 years of age. ${ }^{119}$ Its advantages were 'strong impact, a multi-sensorial medium, colour, the big screen'.120 Audiences were placed in the dark and fully focussed on the

118 Steinmann, Das Werbefernsehen im Konkurrenzkampf, 37f.; Stockmann, 'Die klassischen Medien im Überblick', $1806 \mathrm{ff}$.

119 Stockmann, 'Die klassischen Medien im Überblick', 1808f; Dierks, 'Die wirtschaftliche Bedeutung der Werbung in Filmtheatern', 1583.

120 Ibid. 
screen, in Metz's sense of a dispositif: 'The darkened space, the large and fully illuminated screen, the excellent colour rendering, the good sound quality, and the relaxed state of the viewer are ideal communicative conditions' ${ }^{121}$ And yet, cinema never developed into a dominating medium for direct screen advertising, probably because it held greater potential for indirect forms of promotion and merchandising.

To summarize, Charles Wilp produced screen advertisements for television that were aesthetically organized akin to print ads and might have had a larger impact on theatrical screens, if cinema would have been recognized as a key advertising medium. Thus, while Wilp definitely aimed to act as an advertiser - although one without agency experience - his work was caught between more than two stools. What does this imply for advertising as an institution? And in what ways could these historical findings be helpful for archivists?

\section{Conclusion}

As historian Pierre Sorlin once noted, 'what appears as a simple consideration of institutional determinants turns out to be terribly complicated'! ${ }^{122}$ As Sorlin went on to elaborate,

before we even start to theorize practices, we have to study the differences between their determining factors. I am thinking of determinants which are not empty words such as 'institution of propaganda' or 'institution of advertising,' but actual social forms of behaviour that can be studied in regard to their spatial and temporal variants. ${ }^{123}$

As this chapter has shown, the practices of screen advertising were indeed determined by many factors distributed in time and space rather than one all-encompassing and never-changing institution. We have to acknowledge the 'non-synchronisms' (in Ernst Bloch's sense) of these determinants, such as print's prevalence in a world of television. We also need to acknowledge that these practices were never fully determined by anything. On the contrary, any practice, even a failing one, fed back into the overall 'system of systems'. As a social, cultural, and aesthetic practice, direct spot advertising was not owned by a particular industry or medium. At the same time, its form was

121 Stockmann, 'Die klassischen Medien im Überblick', $1808 \mathrm{f}$.

122 Pierre Sorlin, 'Promenade dans Rome', Iris 2, no. 2 (1984): 15. My translation.

123 Ibid. 
surprisingly robust, relying on a standard of length and structure already established in the 1910s, and kept alive through institutional negotiations between various actors.

The notion of the institution is helpful to produce a differentiated historical account of screen advertising. It also has enabled us to observe a strange 'inbetweenness' of advertising practices. Wilp seems to have constantly moved between different worlds: the worlds of art, television, print, and cinema, as did many other of his contemporaries in this business. In-betweenness seems constitutive for advertising more generally. It is key for practitioners in order to carve out a space for themselves; to sell their ads, they have to integrate or adapt to various media and styles. But it is also key for the selling of products within the ads; such selling always needs to work against the learning histories of media users who, quickly accustomed to even a recently introduced technique of persuasion, may fail to like it or be pleased. Advertising thus is not so much a powerful parasite of existing cultural forms but 'para-sited' in between various social or cultural institutions, as I have argued elsewhere. ${ }^{124}$

As this chapter has demonstrated, any methodology for the study of screen advertising obviously depends on access to materials, and the way access is framed by archival epistemologies. While written documentation remains sparse, pilot projects involving both archivists and academic researchers show new efforts to access, digitize, classify, and present relevant collections, and more systematic attempts to relate screen ad material to data provided by ad agencies, key production workers, and other archives. Deutsche Kinemathek's work on the Charles Wilp Collection here may serve as a starting point. ${ }^{125}$ Advertising may not necessarily belong 'to a product like electricity to a light bulb', as Charles Wilp proclaimed, but it forms part of cultural production and ought to be acknowledged as such.

\section{Bibliography}

Acland, Charles R., and Haidee Wasson. Useful Cinema. Durham, NC and London: Duke University Press, 2013. Amberg, Friedrich-Georg. Werbung im Filmtheater. Berlin: Kulturbuch-Verlag, 1956.

124 Vonderau, 'On Advertising's Relation to Moving Pictures'.

125 This project developed during the research for this chapter, initially funded by Riksbankens Jubileumsfond (Stockholm), and involved Annette Groschke, Martin Koerber, Daniel Meiller, and Maxi Zimmermann (all Deutsche Kinemathek, Berlin) as well as the author. Its aim was to digitize the Wilp collection and to develop an online presentation of these materials that allows for their proper historical contextualization. 
Amsler, André. Wer dem Werbefilm verfällt, ist verloren für die Welt: Das Werk von Julius Pinschewer 1883-1961. Zurich: Chronos 1997.

Anonymous. '4. Deutsches Werbefilm-Forum.' Filmtechnikum 21, no. 5 (May 1970): 171. Anonymous. 'Charles Wilp und die Schleichwerbung.' Werben \& Verkaufen (19 December 1969).

Anonymous. 'Europe's Creative New Breed.' Time Magazine 95, no. 11 (1970).

Anonymous. 'Freche Kampagne.' Der Spiegel (27 October 1969): 93.

Anonymous. 'Joghurt für Jungfern.' Der Spiegel (4 September 1967).

Anonymous. 'Kampf der Bakterie.' Der Spiegel (18 August 1969): 66.

Anonymous. 'Kreative Zulieferanten der deutschen Werbung.' Werben \& Verkaufen

(12 December 1969).

Anonymous. 'Markt für Muffel.' Der Spiegel (23 May 1966): 44-45.

Anonymous. 'Mehr Werbefernsehen?' Filmtechnikum 23, no. 5 (May 1972): 159.

Anonymous. 'Mit Differenzierung durch den Geschmack den Anteil auf dem

Cola-Markt vergrößern.' Werben \& Verkaufen (25 February 1972).

Anonymous. 'Poesie mit Amalie.' Der Spiegel (31 March 1969): 44-45.

Anonymous. 'Sehr rauschig.' Der Spiegel (1 December 1969): 224.

Anonymous. 'Sternchen im Kopf.' Der Spiegel (10 March 1969): 92-94.

Anonymous. 'Verärgerte Verbände: Wilp-Sendung erregt Mißfallen.' Werben \& Verkaufen (19 December 1969).

Anonymous. 'Weg vom Zinn.' Der Spiegel (2o February 1967): 59-6o.

Anonymous. 'Weil er hart ist.' Der Spiegel (3o October 1963): 46-47.

Anonymous. 'Werbung als Kunstwerk oder wie Charles Wilp auf der Documenta wieder einmal die deutsche Werbung repräsentiert.' Werben \& Verkaufen (25 August 1972).

Aspers, Patrik. Markets. Cambridge: Polity Press 2013.

Becker, Jörg. 'Die Voltstärke eines Emotionskomplexes. Der Werbekünstler Charles Wilp. 1932-2005.' Recherche Film und Fernsehen 2, no. 3 (2008): 14-19.

Berger, Arthur Asa. Ads, Fads, and Consumer Culture: Advertising's Impact on American Character and Society. Lanham: Rowman \& Littlefield, 2000.

Burch, Noel. 'Porter, or Ambivalence.' Screen 19, no. 4 (1978-1979): 91-105.

Casetti, Francesco, and Roger Odin. 'De la paléo- à la néo-télévision.' Communications 51, no. 1 (1990): 9-26.

Casetti, Francesco. Theories of Cinema, 1945-1995. Austin: University of Texas Press, 1999.

Cohen-Séat, Gilbert. Essai sur les principes d'une philosophie du cinema. Paris: Presses Universitaires de France, 1946.

Cormon, Catherine. 'The Challenge of Advertising Commercials.' In Films that Sell: Moving Pictures and Advertising, edited by Bo Florin, Nico de Klerk, and Patrick Vonderau, 275-282. London: British Film Institute, 2016. 
Demme, Helmut. Die Rechtsnatur des Werbefernsehens und die Rechtmäßigkeit des von den Werbegesellschaften geübten Verteilungsmaßstabes bei der Vergabe von Sendezeiten zum Zwecke der Werbung. Göttingen: Schwartz \& Co. 1968.

Dierks, Melinde. 'Die wirtschaftliche Bedeutung der Werbung in Filmtheatern.' In Die Werbung. Handbuch der Kommunikations- und Werbewirtschaft, vol. 2: Die Werbebotschaften, die Werbemittel und die Werbeträger, edited by Bruno Tietz, 1538-1550. Landsberg: Verlag Moderne Industrie, 1982.

DiMaggio, Paul, and Paul M. Hirsch. 'Production Organization in the Arts.' American Behaviorial Scientist 19, no. 6 (July-August 1976): 735-754.

DiMaggio, Paul, and Walter W. Powell. 'The Iron Cage Revisited.' American Sociological Review 48, no. 2 (April 1983): 147-160.

Duina, Francesco. Institutions and the Economy. Cambridge: Polity Press, 2011.

Eggers, Katharina, and Robert Fechner. 'The "German Alternative": Nationalism and Racism in Afri-Cola.' In Colonial Advertising \& Commodity Racism, edited by Wulf D. Hund, Michael Pickering, and Anandi Ramamurthy, 197-213. Münster: LIT, 2013.

Ellis, John. Visible Fictions: Cinema, Television, Video. London: Routledge, 1992.

Elsaesser, Thomas. 'Archives and Archaeologies: The Place of Non-Fiction in Contemporary Media.' In Films that Work: Industrial Film and the Productivity of Media, edited by Vinzenz Hediger and Patrick Vonderau, 19-34. Amsterdam: Amsterdam University Press, 2009.

Esquenazi, Jean-Pierre. 'Éléments de sociologie du film.' Cinémas 17, no. 2/3 (2007): 117-141.

Fechler, Christoph. 'Die Gestaltung und die Produktion der Fernsehwerbung.' In Die Werbung. Handbuch der Kommunikations- und Werbewirtschaft, vol. 2: Die Werbebotschaften, die Werbemittel und die Werbeträger, edited by Bruno Tietz, 1313-1376. Landsberg: Verlag Moderne Industrie 1982.

Forster, Ralf. Ufa und Nordmark: Zwei Firmengeschichten und der deutsche Werbefilm 1919-1945. Trier: Wissenschaftlicher Verlag Trier 2005.

Fossati, Giovanni. From Grain to Pixel: The Archival Life of Film in Transition. Amsterdam: Amsterdam University Press 2009.

Foucault, Michel. 'La psychologie de $185^{0}$ à 1950.' In Histoire de la philosophie européenne, vol. 2, edited by D. Huisman and A. Weber, 591-606. Paris: Klincksiek, 1957.

Fox, Stephen. The Mirror Makers: A History of American Advertising and Its Creators. New York: Vintage Books, 1985.

Frank, Thomas. The Conquest of Cool: Business Culture, Counter Culture, and the Rise of Hip Consumerism. Chicago: University of Chicago Press, 1997.

Friedmann, Georges, and Edgar Morin. 'Sociologie du cinéma.' Revue Internationale de Filmologie 3 (1952): 10-24. 
Gaudreault, André. From Plato to Lumière: Narration and Monstration in Literature and Cinema. London and Toronto: University of Toronto Press, 1988.

Gerlach, Gunter R. 'Sind die Agenturen noch zu retten?' Werben \& Verkaufen (12 December 1969)

Ginzburg, Carlo. 'Clues: Roots of A Scientific Paradigm.' Theory \& Society 7, no. 3 (May 1979): 273-288.

Glocke, Bernd. 'Farbiger, doch nicht besser: 3. Werbefilm-Forum.' Werben \& Verkaufen 7, no. 3 (April 1969).

Goldman, Robert. Reading Ads Socially. London: Routledge 1992.

Groskopf, Jeremy. Profit Margins: The American Silent Cinema and t8he Marginalization of Advertising. Dissertation, Georgia State University, 2013.

Grün, Karl. 'Werbung sucht neue Aufgaben.' Frankfurter Allgemeine Zeitung (25 June 1968).

Hediger, Vinzenz, and Patrick Vonderau. 'Record, Rhetoric, Rationalization: Industrial Organization and Film.' In Films that Work: Industrial Film and the Productivity of Media, edited by Vinzenz Hediger and Patrick Vonderau, 35-49. Amsterdam: Amsterdam University Press, 2009.

Holbrook, Morris B. 'Mirror, Mirror, On the Wall: What's Unfair in the Reflections on Advertising?' Journal of Marketing 51, no. 3 (July 1987): 95-103.

Indiana University Bloomington. 'IU Libraries Moving Image Archive is the new home for decades of award-winning commercials.' Press release (14 December 2017), https://news.iu.edu/stories/2017/12/iub/releases/14-clio-collection. html. Last accessed 5 April 2021.

Keller, Harald. 'Der große Afri-Cola Rausch.' Frankfurter Allgemeine Zeitung (28 August 2008).

Kessler, Frank. 'Notes on Dispositif.' Unpublished working paper, 2002.

Kjellberg, Hans, and C.F. Helgesson. 'On the Nature of Markets and Their Practices.' Marketing Theory 7, no. 2 (2007): 137-162.

Knilli, Friedrich. Der tägliche Sündenfall: Fernsehen und Werbung. Frankfurt: Haus der Evangelischen Publizistik, 1972.

Kuh, Hans. 'Die geeiste Glasplatte: Charles Wilp wirbt für Afri-Cola.' Gebrauchsgraphik 40, no. 8 (1969): 14-17.

Lantos, Geoffrey P. 'Advertising: Looking Glass or Mirror of the Masses?' Journal of Public Policy and Marketing 6 (1987): 104-128.

McMahan, Harry Wayne. Fernsehwerbung. Gestaltung und Produktion wirksamer Werbesendungen. Düsseldorf: Econ, 1957.

Metz, Christian. 'The Imaginary Signifier.' Screen 16, no. 2 (July 1975): 14-76.

Meyers, Cynthia B. A Word from Our Sponsor: Admen, Advertising, and the Golden Age of Radio. New York: Fordham University Press 2014. 
Morgan, Taz. 5th Amsterdam Workshop: The Images that Changed your Life: Advertising Films. Unpublished manuscript. 2009.

Müller, Corinna. Frühe deutsche Kinematographie. Formale, wirtschaftliche und kulturelle Entwicklungen 1907-1912. Stuttgart and Weimar: Metzler 1994.

Murdock, Graham, and Peter Golding. 'Culture, Communications and Political Economy.' Mass Media and Society, $4^{\text {th }}$ ed., edited by James Curran and Michael Gurevitch, 6o-83. London: Arnold 2005.

Neale, Stephen. 'Art Cinema as Institution.' Screen 22, no. 1 (1981): 11-40.

Nee, Victor, and Sonja Opper. 'Economic Institutions from Networks.' In ReImagining Sociology, edited by Patrik Aspers and Nigel Dodd, 148-172. Oxford: Oxford University Press, 2015.

Odin, Roger. 'Le film de famille dans l'institution familiale.' In Le film de famille, usage privé, usage public, edited by Roger Odin, 27-42. Paris: Méridiens-Klincksieck, 1995 .

Odin, Roger. 'Pour une sémio-pragmatique du cinéma.' Iris 1 (1983): 1-12.

Pfffferling, Jürgen. Wirkungschancen der Werbung in den Massenmedien. Frankfurt: Arbeitsgemeinschaft Rundfunkwerbung 1975.

Pollay, Richard W. 'The Distorted Mirror: Reflections on the Unintended Consequences of Advertising.' Journal of Marketing 50, no. 2 (1986): 18-36.

Potter, David M. People of Plenty. Chicago: University of Chicago Press 1954.

Reichard, Peter. 'Offener Brief an Charles Wilp.' Werben \& Verkaufen (12 December 1969).

Ripmeester, Lenke. 'The Geesink Collection: Selection Criteria Reconsidered.' In Films that Sell: Moving Pictures and Advertising, edited by Bo Florin, Nico de Klerk, and Patrick Vonderau, 283-288. London: British Film Institute, 2016.

Sawatzki, Günther. Die verwirtschaftete Freiheit: Ein Beitrag zum Verhältnis zwischen Presse und Fernsehen. Frankfurt: Knecht 1964.

Schierl, Thomas. Werbung im Fernsehen. Eine medienökonomische Untersuchung zur Effektivität und Effizienz werblicher Tv-Kommunikation. Cologne: Halem-Verlag, 2003. Schlehofer, Ralph. 'Ärger mit Charlie.' Werben \& Verkaufen (12 December 1969). Schmidt, Hans-Gerd. 'Wie Zeitgeist in die Werbung kommt. Aspekte einer produktionsästhetischen Analyse von Sinalco-Werbefilmen.' In Werbefilme: Spiegel der Zeiten - Chronik des Alltags, edited by Hans-Gerd Schmidt and Bernd Wiesener, 67-88. Bielefeld: Verlag für Regionalgeschichte 2002.

Schmidt, Siegfried S., and Brigitte Spieß. Die Kommerzialisierung der Kommunikation. Fernsehwerbung und sozialer Wandel 1956-1989. Frankfurt: Suhrkamp 1996. Schneider, Hans. Werbung im Rundfunk. Frankfurt: Metzner Verlag 1965.

Schutts, Jeff. 'Die erfrischende Pause: Marketing Coca-Cola in Hitler's Germany.' In Selling Modernity: Advertising in 2oth Century Germany, edited by Pamela E. Swett, S. Jonathan Wiesen, and Jonathan R. Zaitlin. Durham, NC: Duke University Press, 2007. 
Searle, John. 'What Is An Institution?' Journal of Institutional Economics 1, no. 1 (2005): 1-22.

Seubert, Wolfgang. Struktur und Entwicklung des Rundfunk-Werbemarktes. Band 11. Düsseldorf: Landesregierung NRW, 1988.

Sorlin, Pierre. 'Promenade dans Rome,' Iris 2, no. 2 (1984): 5-16.

Staiger, Janet. 'The Hollywood Mode of Production to 1930.' In The Classical Hollywood Cinema: Film Style \& Mode of Production to 196o, edited by David Bordwell, Janet Staiger, and Kristin Thompson, 88-244. New York: Routledge 1985.

Stauff, Markus. 'Zur Sichtbarkeit von Gesellschaft. Institution in den Filmen von Frederick Wiseman und in us-amerikanischen Fernsehserien.' In Frederick Wiseman: Kino des Sozialen, edited by Eva Hohenberger, 85-104. Berlin: Vorwerk 8, 2009 .

Steinmann, Matthias. Das Werbefernsehen im Konkurrenzkampf der Werbemittel und Werbeträger. Zurich: Polygraphischer Verlag 1967.

Stockmann, Frank-Jürgen. 'Die klassischen Medien im Überblick.' Die Werbung. Handbuch der Kommunikations- und Werbewirtschaft, vol. 2: Die Werbebotschaften, die Werbemittel und die Werbeträger, edited by Bruno Tietz, 1786-1814. Landsberg: Verlag Moderne Industrie, 1982.

Turci, Ariana. 'The Archivio Nazionale Cinema d'Impresa Collections: An Overview.' In Films that Sell: Moving Pictures and Advertising, edited by Bo Florin, Nico de Klerk, and Patrick Vonderau, 289-298. London: British Film Institute, 2016.

Vasata, Vilim. 'Die Gestaltung von Anzeigen in Publikumszeitschriften.' In Die Werbung. Handbuch der Kommunikations- und Werbewirtschaft, vol. 2: Die Werbebotschaften, die Werbemittel und die Werbeträger, edited by Bruno Tietz, 1184-1201. Landsberg: Verlag Moderne Industrie, 1982.

Vonderau, Patrick. 'On Advertising's Relation to Moving Pictures.' In Films that Sell: Moving Pictures and Advertising, edited by Bo Florin, Nico de Klerk, and Patrick Vonderau, 1-18. London: British Film Institute, 2016.

Williams, Raymond. Keywords. London: Fontana, 1983.

Williamson, Judith. Decoding Advertisements: Ideology and Meaning in Advertising. London: Marion Boyars, 1978.

Zimmermann, Yvonne. 'Advertising and Film: A Topological Approach.' In Films that Sell: Moving Pictures and Advertising, edited by Bo Florin, Nico de Klerk, and Patrick Vonderau, 21-40. London: British Film Institute, 2016. 


\title{
5. Advertising and the Apparatus: Cinema, Television, and Out-of-Home Screens
}

\author{
Yvonne Zimmermann
}

\begin{abstract}
In this chapter, the notion of the dispositif serves as a conceptual framework to both theorize and analyse the programming of moving image advertising on three types of screens: cinema, network-era television, and digital out-of-home displays. The chapter shows how screen ads stitch together different forms of intermittent movements - of bodies, images, and objects - and thus help create flows. In bringing the programme in conversation with the dispositif, the chapter also draws attention to the programme, which in cinema studies, if not to the same extent also in media studies, is an extremely under-researched category despite its importance for production as well as for reception. Any study interested in the pragmatics of screen advertising as well as screen media cannot do without the programme.
\end{abstract}

Keywords: dispositif, programme, out-of-home advertising, cinema, television, movement and mobilities

Recent research into non-theatrical film and screen advertising has put an emphasis on the topologies of moving pictures and has started to explore the many sites and networks of moving images beyond commercial cinema circuits. Behind this approach is the idea that sites are key to understanding how moving images were and are put to use. Sites matter for the many particular ways moving images are exhibited and experienced. Moving images, in other words, have been comprehended

Florin, B., P. Vonderau, Y. Zimmermann, Advertising and the Transformation of Screen Cultures. Amsterdam: Amsterdam University Press, 2021 DOI 10.5117/9789462989153_CHO5 
and studied as being site-specific, as sited in concrete places, practices, and materials. ${ }^{1}$

In what follows, I do not wish to further explore screen advertising as a site-specific phenomenon. Instead, I propose an approach that focusses on different media dispositifs in which screen advertising has been involved. Following Jean-Louis Baudry, the notion of dispositif describes a particular set of media technologies and specific conditions of reception. The three historically and geographically distinctive dispositifs I will examine are post-war cinema in Western Europe, home television in the network era in the United States with an eye to public service broadcasting in Western Europe, and contemporary train platforms in Germany equipped with digital out-of-home screens. The reason for selecting these dispositifs resides in their respective prevalence at a certain time and place: cinema and broadcast television were the dominant forms of mass media in the 2oth century, while, with the advent of digital signage and out-of-home screens, out-of-home media dispositifs have acquired more importance and visibility. The three dispositifs, at specific moments in time, constitute and have constituted the predominant viewing modes of moving images - and hence also the principal viewing modes of screen advertising, for, as mentioned above, advertising has been an integral part of these dispositifs.

Dispositifs are first of all specific spatial arrangements that produce a viewing position in particular ways. Baudry's notion of dispositif and his description of 'the positioned viewer' may create an impression of fixation and transhistorical stability both of the dispositif as a whole and of the viewer position. However, the elements of dispositifs are subject to historical change; dispositifs are historically relative and hence historically specific. Consequently, to echo Jacques Aumont, 'the study of the dispositif is inevitably a historical study: there is no dispositif outside history'. ${ }^{2}$

The viewer position within a particular dispositif is also not stable. Instead, in all dispositifs under discussion here, there is a constant, ongoing effort to sustain and direct audience engagement, and thus a continuing process of positioning viewers. The procedural element of the positioning process

1 See, for example, Gregory A. Waller, 'International Harvester, Business Screen and the History of Advertising Film', in Films That Sell: Moving Pictures and Advertising, ed. Bo Florin, Nico de Klerk, and Patrick Vonderau (London and New York: Palgrave, 2016), 40; and Patrick Vonderau, 'Introduction: On Advertising's Relation to Moving Images', in Films That Sell, ed. Florin, de Klerk, and Vonderau, 13.

2 Jacques Aumont, L'Image (Paris: Nathan, 1990), 147. 
points to the temporal dimension of time-based media dispositifs. Or, as Bernard Vouilloux has highlighted, the dispositif is not an arrangement for simply imposing behaviours; rather, it regulates the movement of forces that traverse it.

The dispositive captures and channels energy in order to redistribute it. The dispositive does not have the purity of structures; its form is never anything but the temporally and spatially determined disposition within which are stabilized the flows with which it deals. ${ }^{3}$

Nevertheless, many studies have stressed the spatial element of dispositifs, since dispositifs are usually conceived as spatial arrangements of spectator, representation, and machinery. My attempt here is to examine screen advertising's place in the temporal structure of the three dispositifs to learn more about screen advertising's part in the process of positioning viewers. To this end, I explore screen advertising as an element in the time structure and chronological sequencing of movement within the above-mentioned dispositifs. Thereby, three types of movement are considered: moving images on the screen, bodily movements of the viewers, and movements of objects. While the first type of movement draws attention to the relations between moving images and directs the focus on the programme structure of moving images and screen advertising's place in it, the second two types highlight the relations of moving images to other forms of movement occurring in the respective dispositifs.

From this description, it should be clear that the notion of dispositif that underlines this essay does not borrow Baudry's narrow focus on the cinematic dispositif (even though this will be important when looking at the cinema dispositif), but constitutes a broadened understanding of the dispositif as the configuration or arrangement of heterogeneous elements, or, as Michel Foucault has put it, the 'connection that exists between these heterogeneous elements.' ${ }^{4}$ The notion of dispositif has been re-conceptualized in media studies, as well as in other scientific fields, if we think of the work

3 Bernard Vouilloux, 'Du dispositif', in Discours, image, dispositif, ed. Philippe Ortel (Paris: L'Harmattan, 2008), 20, quoted in Will Straw, 'Pulling Apart the Apparatus', Recherches sémiotiques 31, no. 1-2-3 (2011): 66. https://www.erudit.org/fr/revues/rssi/2011-v31-n1-2-3-rssio1601/1027441ar/ (last accessed 6 April 2021).

4 Michel Foucault, Power/Knowledge: Selected Interviews and Other Writings 1972-1977, ed. Colin Gordon (New York: Pantheon Books, 1980), 194-195. Note that, in English, the term dispositif in Foucault's work has been translated as apparatus. To avoid any confusion, I use the French term dispositif throughout the essay. 
by Foucault, Gilles Deleuze and Félix Guattari, and Michel de Certeau, among many others. For the present purpose, the concept of dispositif is understood, as outlined by Frank Kessler, as a heuristic tool 'offering ways to account for the complexities of media(texts) in situational contexts offering, or aiming at producing specific spectatorial positions.' ${ }^{5}$ This approach is in line with Maria Tortajada and François Albera's take on the dispositif as an epistemic schema and in support of their idea that the dispositif needs to be constructed as a notion. ${ }^{6}$ Following Foucault, I am also interested in how the interplay of various elements - screen advertising being one of them - produces power structures. Because of the relative openness of the concept, it can be applied to various levels of analysis, which will be the case in the following.

Therefore, instead of studying screen advertising in isolation, I wish to study it in relation to other moving images as well as in relation to moving bodies and moving objects in order to better understand how screen advertising structures time and contributes to producing specific viewing positions. I argue that - despite major differences between the three examined dispositifs in terms of historical context, institutional anchoring, geographical location, and media - screen advertising occupies a somewhat identical place in between time sequences and that it plays an equal role in structuring movements in time: it manages transitions and structures flows. As such, screen advertising is a key actor in the positioning processes within different media dispositifs.

While this essay is informed by concepts developed in cinema and television studies (most notably Raymond Williams's notion of flow) as well as in media studies, it also draws on paradigms from the social sciences. It is particularly inspired by movement and mobilities studies and by Mimi Sheller and John Urry's endeavour to 'offer new perspectives on making of place through the temporal coordination of mobilities'. For the present purpose, Sheller and Urry's attempt may translate into an effort to study the making of dispositifs through screen advertising's temporal coordination of movements and mobilities.

5 Frank Kessler, 'Notes on dispositif', work in progress paper, version from November 2007, pp. 1-19, here p. 17, http://www.frankkessler.nl/wp-content/uploads/2010/05/Dispositif-Notes. pdf (last accessed 6 April 2021).

6 François Albera and Maria Tortajada, 'The Dispositive Does Not Exist!', in Cine-Dispositives: Essays in Epistemology Across Media, ed. François Albera and Maria Tortajada (Amsterdam: Amsterdam University Press, 2015), 32.

7 Mimi Sheller and John Urry, eds., Mobile Technologies of the City (London and New York: Routledge, 2006), 4. 


\section{Screen Advertising and the Dispositif of Cinema}

Unlike in the United States, where the history of screen advertising has been one of negotiating for a permanent place in commercial cinemas and has been marked by moving in and out of cinemas, ${ }^{8}$ in most Western European countries, screen advertising has been part of regular cinema programmes since the introduction of the long feature film during World War I, if not earlier. In their sales ads, French production companies such as Pathé Frères, Gaumont, Eclipse, and Raleigh \& Robert offered 'views' of work and industrial processes under the label of scènes d'art et d'industrie for the international market in the early 19oos. These process films circulated in the short film programmes of commercial cinemas worldwide. Even though written sources on the production of these films are mostly missing, it can be assumed that these films were sponsored by companies with the aim to explain, brand, and promote their products - among them, mainly food and consumer goods such as cigars, tea, cookies, and milk powder. Tourist associations also sponsored travelogues from early on to promote sights and instigate travel. In Germany, advertising film pioneer Julius Pinschewer had built a theatrical distribution network for short advertising films by 1912 . On the basis of this network, commercials became a regular part of the programme of shorts in cinemas in Germany. ${ }^{9}$ This model was copied after the war in many other European countries, among them Switzerland, where Praesens Film and its spin-off Central Film had a quasi-monopolistic position in theatrical distribution of advertising films starting in the mid $1920{ }^{10}{ }^{10}$ With the shift during World War I from the short film programme towards a (usually fictional) feature film as the standard programme format of commercial cinema entertainment, the rest of the short film programme shrank into

8 See Deron Overpeck, 'Subversion, Desperation, and Captivity: Pre-film Advertising in American Film Exhibition Since 1977', Film History 22, no. 2 (2010): 219-234; Yvonne Zimmermann, 'Advertising and Film: A Topological Approach', in Films That Sell, ed. Florin, de Klerk, and Vonderau, 21-39, esp. 26-30.

9 On Pinschewer, see Martin Loiperdinger, 'Julius Pinschewer - Pionier, Klassiker und Avantgardist des Werbefilms', in Julius Pinschewer. Klassiker des Werbefilms, DVD Booklet (Berlin: absolut Medien, 2010), 3-12; André Amsler, 'Wer dem Werbefilm verfällt, ist verloren für die Welt': Das Werk von Julius Pinschewer 1883-1961 (Zurich: Chronos, 1997). For a broader history of advertising film in Germany, see Ralf Forster, Ufa und Nordmark: Zwei Firmengeschichten und der deutsche Werbefilm 1919-1945 (Trier: Wissenschaftlicher Verlag Trier, 2005).

10 See Regula Bochsler and Pascal Derungs, eds., Und führe uns in Versuchung: 1oo Jahre Schweizer Werbefilm (Zurich: Museum für Gestaltung, 1998). 
what would be called the programme of shorts. ${ }^{11}$ This programme of shorts usually started with a section of commercials (one to six per programme, depending on the country), ${ }^{12}$ followed by a series of trailers, newsreels, and a so-called Kulturfilm (a cultural film, described in greater detail below). In some countries, commercials were not part of the programme of shorts, but were screened in the intermission. In the late 1940s, such was the case in Belgium, France, some Scandinavian countries, and some theatres in Italy, whereas in England, the Netherlands, Switzerland, and in other theatres in Italy, commercials were part of the programme of shorts. ${ }^{13}$ Contrary to what one of the few historical sources for this very vague survey states, commercials were shown at the beginning of screenings in Sweden in the 1940s. ${ }^{14}$ Kulturfilm were generally non-fictional films of 10 to 20 minutes that, in a more or less entertaining way, imparted knowledge on educational topics such as geography, biology, history, and customs. ${ }^{15}$ While commercials and trailers were blunt advertisements, the Kulturfilm, albeit normally sponsored by public and private organizations, was not permitted to openly promote goods and services, but had to display their qualities in a discreet way. Otherwise, they would not have been awarded the Kulturfilm label. This label was vital for the films to make it into the regular programmes of cinemas. Starting in 1926, cinema owners in Germany received tax breaks as an incentive to include Kulturfilm in their programmes. This helped establish this category of indirect screen advertising in Germany, as well as in Austria and Switzerland (and other countries at certain points in time). The ideology behind this policy was to domesticate potentially 'detrimental' cinema entertainment by counterbalancing it with bourgeois education. ${ }^{16}$

11 The interwar period saw a variety of programme formats in European cinemas that this short overview cannot consider. Double features and continuous programming were common in Great Britain, for example. Some cinemas specialized in actualities, in other words, newsreels. 12 See, for example, Schweizerischer Reklame Verband, ed., Die Grundlagen der Filmwerbung: Eine Wegleitung für Auftraggeber (Zurich, [1949]).

13 See ibid., for example.

14 Carina Sjöholm, Gå på bio. Rum för drömmar ifolkhemmets Sverige (Stockholm and Stehag: Brutus Östlings Bokförlag Symposion, 2003), 181. A transnational comparison of programme formats and the placement of commercials in cinemas is a research desideratum.

15 See Yvonne Zimmermann, 'Advertising and Film: A Topological Approach', in Films That Sell, ed. Florin, de Klerk, and Vonderau.

16 See Klaus Kreimeier, Antje Ehmann, and Jeanpaul Goergen, eds., Geschichte des dokumentarischen Films in Deutschland, vol. 2: Weimarer Republik 1918-1933 (Stuttgart: Reclam, 2005); Peter Zimmermann and Kay Hofmann, eds., Geschichte des dokumentarischen Films in Deutschland, vol. 3: 'Drittes Reich'1933-1945 (Stuttgart: Reclam, 2005); Ramón Reichert, ed., Kulturfilm im 'Dritten Reich' (Vienna: Synema, 2006); Yvonne Zimmermann, ed., Schaufenster Schweiz: Dokumentarische Gebrauchsfilme 1896-1964 (Zurich: Limmat, 2011). 
Since screen advertising's place in the programme is central to examining its relation to other types of moving images as well as to other types of movement, it may be useful to think about the programme in more detail. The term 'programme' is ambiguous; it can mean the announcement of the course of action of a presentation (e.g., the bill of fare or a TV guide), or it can designate the predefined succession and the procedure of a presentation, an operating process, or a technical installation. Finally, programme can also describe the determination of intentions and goals and a wilful intent (e.g., party platform). ${ }^{17}$ In regard to mass media, the term has a double structure, with programme meaning both the announcement of a (film, radio, or TV) programme and the actual screening or broadcasting of what is (or is not) announced. ${ }^{18}$ In the following, I am interested in the second meaning of the word. Programme in this sense can be defined as the relation between many, usually diverse, products, which are presented in a sequence over time and in a single place or channel. ${ }^{19}$ Programmes organize media objects in time, they are principles of temporal arrangements, they set the pace and rhythms, and they structure sequences and flows. In doing so, programmes not only organize the presentation of moving images, they also organize the reception of moving images and as such are central for media experience. ${ }^{20}$ Thus, programmes always have two sides; they are at the same time a category of production and presentation (for those who organize and screen or broadcast programmes) and a category of reception (for those who experience them).

In his studies on the ideological effects of film and the dispositif, Baudry does not pay any attention to the discursive organization of moving images and the programme. ${ }^{21}$ Instead, Baudry is interested in how filmic instruments produce specific ideological effects (through 'the impression of reality') beyond the 'messages' of single films or the arrangement of films, in other words, programmes. And he underlines how the spatial and technical arrangement of cinema, its dispositif, produces ideological effects,

17 Ludwig Fischer, 'Vorwort', in Programm und Programmatik: Kultur- und medienwissenschaftliche Analysen, ed. Ludwig Fischer (Konstanz: UVK, 2005), 11.

18 See Knut Hickethier, 'Aspekte der Programmemtheorie des Fernsehens', Communications, no. 3 (1991): 329-330.

19 Knut Hickethier, Film- und Fernsehanalyse, $3^{\text {rd }}$ revised ed. (Stuttgart and Weimar: Metzler, 2001), 216.

20 Ludwig Fischer, 'Vorwort', in Programm und Programmatik: Kultur- und medienwissenschaftliche Analysen, ed. Ludwig Fischer (Konstanz: UVK, 2005), 13.

21 Jean-Louis Baudry, 'Effets idéologiques produits par l'appareil de base', Cinéthique no. 6/7 (1970); Jean-Louis Baudry, 'Le dispositive. Approches métapsychologiques de l'impression de réalité', Communications 23 (1975): 56-72. 
most notably through the subject positioning of spectators. While Baudry stresses the role of the spatial arrangement of technology, moving images, and bodies in organizing perception and creating ideological effects, he fails to perceive that cinema is more than the screening of a single film to positioned spectators. Baudry's notion of the dispositif of cinema implies arrest and does not account for the complex dynamics of movements of images and bodies that produce the space of cinema. It reduces cinema to the moment when audiences are sitting immobilized in the dark, positioned by the projector behind them and the screen in front of them. However, the moments when audiences are fixed and captivated by the screen are transitory. Audiences enter the cinema, settle into their seats, may get up at the intermission, and may leave the auditorium to purchase food and drinks in the foyer or visit the bathroom; they take a seat again, get up (again), and leave the cinema after the screening. The degree of attention paid to the screen also varies and can shift between inattention and captivation. The cinema also is not a darkened room, but it is characterized by changing intensities of light and the alternation between light and darkness.

Thus, the dispositif of cinema consists of a complex dynamic of light and darkness and of overlapping and interacting movements of bodies in the auditorium and of images on the screen. Within this dynamic, commercials can be found in the transitional phase when attention shifts away from the social interaction in the auditorium towards the screen and the audience turns into individual spectators. When screened at the beginning of the programme of shorts, commercials orchestrate this transition on several levels. They are at the threshold between still and moving images on the screen: they moderate the transition from advertising slides to advertising films, thus setting the images on the screen in motion. While initiating movement on the screen, commercials at the same time help bring bodily movements to a temporary halt. Commercials also mark the moment when the lights in the cinema dim and attention is geared towards the screen. Thus, they moderate the transition from light to darkness, from social interaction to individual concentration, from bodily movement to bodily arrest, from still images to moving images, and from potential inattention to the screen to potentially growing captivation. If screened in the intermission, commercials again interplay with changing lighting conditions (from darkness to lights turned on, and from light to darkness again) and orchestrate the potential movement of bodies during the intermission. In this way, commercials temporally organize the movements of bodies in the cinema. Importantly, commercials also moderate the interruption of the feature movie during the intermission by keeping the movement of images on the screen going until 
the feature film sets in again. While commercials placed at the beginning of the programme of shorts substitute the movement of arrested bodies, commercials screened in the intermission maintain the movement of images on the screen.

It is not only commercials, but the programme of shorts as a whole with its different types of advertising that is involved in this management of transition: beginning with blunt advertising for goods and services, the visibility of advertising continuously decreases in the course of the programme of shorts, ending with the Kulturfilm, indirect advertising, and product placement. The programme of shorts thus manages a seamless transition towards the main attraction, the feature fiction film and its predominant form of advertising, product placement. ${ }^{22}$ In this sense, screen advertising orchestrates the subject positioning of the spectator that is central to theoreticians of the cinematic apparatus and the dispositif. Screen advertising is at the threshold between the real world and the imaginary. In Baudry's psychoanalytical wording, one could claim that screen advertising puts audiences to sleep and helps spectators fall into a dreamlike state. In this way, screen advertising plays an important role as an accomplice of the dispositif of cinema in positioning - and disciplining - audiences.

\section{Screen Advertising as Discrete Programme Unit and Mini Programme}

Screen advertising points to the necessity to include the programme in the analysis of time-based media dispositifs. Early cinema borrowed the notion of the programme from theatre and vaudeville. From the latter, it also borrowed its programme format (a sequence of short films). Like theatre and vaudeville performances, cinema screenings are discrete events. Each screening is singular and, to a certain extent, a performance event with a participatory character. And, unlike television with its temporal infinity, cinema screenings are limited in time - they have a beginning and an end - and the temporal unfolding of the programme is sequential. Within this framework, programme units are distinct and the transition from one unit to the next is often marked by additional signs such as fully opening the curtains or darkening the auditorium when the feature film

22 On product placement, see Patrick Vonderau, 'Kim Novak and Morgan Stairways: Thinking about the Theory and History of the Tie-in', in Films That Sell, ed. Florin, de Klerk, and Vonderau, 209-220. 
starts. In the case of the programme of shorts, the programme sections of commercials and trailers can be considered mini programmes within the programme of shorts.

This is important for any study of advertising that is interested in exhibition and reception, but also in the production of moving image advertising. In exhibition practice, in the majority of cases, commercials do not come alone and do not stand alone. Instead, they are part of a commercial programme unit. Sequentially organized in small programmes, commercials are perceived by audiences not in isolation as individual advertisements, but in relation to and in interaction with other commercials. This is also evident in the fact that we speak of watching screen advertising (Werbung) rather than of watching advertisements (Werbefilme). Commercials then raise a somewhat similar question as the shorts in early cinema's short film programmes - namely, what is the unit - and, as a consequence, the object of study? Is it the individual film or the programme? The answer of early cinema scholars is unequivocal: it is the programme. As Andrea Haller and Martin Loiperdinger argue, in early cinema, the individual films were not considered important in the overall programme composition. Rather, the impression as a whole was significant: 'The form of the programme was the determining factor, not the content'. ${ }^{23}$ This finding is not immediately transferable to the mini programmes of commercials, since they are part of larger programmes and since their aesthetic and economic programme rationale differs from that of early cinema's short film programmes. Still, I argue, it is productive to conceive of commercials as programme elements instead of individual short films, because this allows for the study of screen advertising as a relational phenomenon: it permits an examination of the relations between individual commercials as well as the relations between the mini programme of commercials and other programme units, and the overall programme structure. Such an approach can take account of the temporal dimension of moving image advertising and its ontological difference from print advertising.

However, to study screen advertising as a programme - as both a serial and sequential phenomenon rather than as individual advertisements - poses serious historiographical difficulties regarding sources that document

23 See, for example, Andrea Haller and Martin Loiperdinger, 'Stimulating the Audience: Early Cinema's Short Film Programme Format 1906 to 1912', in Early Cinema Today: The Art of Programming and Live Performance, ed. Martin Loiperdinger (New Barnet and Herts: John Libbey, 2011), 9 . 
historical programmes or allow for their reconstruction, for these sources are virtually non-existent. Even if, in archival practice, commercials are often treated as part of a series rather than as individual films, they are regarded as belonging to a series of commercials of a particular company, brand, or advertising campaign, but not as part of an advertising programme. Nico de Klerk is certainly correct when claiming that the programme is 'one of the most, if not the most, underrated and under-researched aspects of the history of screen practice'. ${ }^{24}$ This research deficit is the result of not only a lack of scholarly interest but also the poor documentation of programmes. Programmes may indeed be the worst documented objects in screen history - despite the fact that programmes, rather than individual films, have been formative for the experience of time-based media.

\section{The Place and Role of Commercials in Network-Era Television Programming}

The challenge for television historians is the same as for cinema historians: while individual TV shows, news segments, and commercials may have survived, it is hardly possible to reconstruct the embedding of individual broadcasts within larger historical programme structures due to a lack of sources. Unlike cinema studies, however, television studies have long considered the programme a central object of analysis - although, as William Boddy and others have observed, commercials and network and station promos have received little critical attention as a result of that. ${ }^{25}$ All the more remarkable is British scholar Raymond Williams's concept of flow, in which a pivotal role is attributed to advertising. Williams argues that flow is the characteristic organization, and hence the characteristic experience of broadcasting systems. For Williams, flow is the defining feature of television both as a technology and as a cultural form, and it is above all advertising that creates the flow. ${ }^{26}$

Writing in 1974, Williams noticed a significant shift from the concept of sequence as programming (with discrete units following one another) to the concept of sequence as flow, that is

24 Nico de Klerk, 'The Moment of Screening: What Non-Fiction Films Can Do', in Triumph der Bilder: Kultur- und Dokumentarfilme vor 1945 im internationalen Vergleich, ed. Peter Zimmermann and Kay Hoffmann (Konstanz: UVK, 2003), 291.

25 William Boddy, 'Advertising Form, Technological Change and Screen Practices in the USA', in Films That Sell, ed. Florin, de Klerk, and Vonderau, 164.

26 Raymond Williams, Television: Technology and Cultural Form (London and New York: Routledge, 2003 [1974]). 
the replacement of a programme series of timed sequential units by a flow of series of differently related units in which the timing, though real, is undeclared, and in which the real internal organisation is something other than the declared organisation. ${ }^{27}$

Focussing on television in the United States and in the United Kingdom, Williams refers to national differences in the organization of broadcasting systems (both radio and television) and the dissimilar role of advertising in it. While advertising has been the main source by which radio and television in the United States are financed, in the United Kingdom, advertising became a feature of television only in the 1950 s and of radio in the early 1970s. ${ }^{28}$ I will come back to different business models, because they are crucial for an understanding of the particular places and roles of advertising in television programmes. The period in television broadcasting Williams refers to is known as the network era in us television history. During this period, from $195^{2}$ to the mid 1980s, three large television networks, $\mathrm{ABC}, \mathrm{CBS}$, and NBC, controlled the us television market. These networks were first established by radio, and they continued radio's advertising business model of single sponsorship, in which advertisers financed and controlled programming, in television broadcasting. In the 1960s, however, us commercial television shifted from the radio-era business model towards the network-era model, in which networks took over programme control and sold interstitial minutes for commercials to advertisers. ${ }^{29}$ This shift from single sponsorship towards the new advertising model, called the 'participation format', introduced the 30-second commercial as the standard television advertising format. ${ }^{30}$ According to Cynthia B. Meyers, participating sponsors originally had 6o-second slots, but they began to insert two 30-second commercials for two different products to economize and efficiently use airtime..$^{31}$ This shift away from single sponsorship towards participating sponsorship formats went hand in hand with a 'creative revolution' in the advertising industry, which was supported by advertisers' investment in high-production-value commercials

27 Ibid., 89 .

28 See ibid., 66.

29 See Cynthia B. Meyers, 'The Best Thing on TV: 196os Us Television Commercials', in Films That Sell, ed. Florin, de Klerk, and Vonderau, 173.

$3^{0}$ See Amanda D. Lotz, The Television Will Be Revolutionized (New York: New York University Press, 2007).

31 See Cynthia B. Meyers, 'The Best Thing on Tv: 196os us Television Commercials', in Films That Sell, ed. Florin, de Klerk, and Vonderau, 175 . 
instead of programme development. This 'revolution' included a shift from hard-sell strategies towards soft-sell strategies, the adoption of a more cinematic visual style, the use of countercultural imagery and language, and self-irony. ${ }^{32}$

Returning to the notion of the dispositif, the above-mentioned shift in programming exemplifies how changes in the configuration of one element within the overall programme structure, commercials in this case, reconfigure other elements (economic, structural, aesthetic) and their interplay with each other in the dispositif. Due to the pertinent role of screen advertising in this reconfiguration, the analytical focus examining the television dispositif is on the level of the programme structure.

Williams claims that the insertion of commercials in unsponsored programmes - resulting from the shift from single sponsorship towards participation sponsorship - has had 'extraordinary effects on television as a sequential experience' and has created 'quite new visual rhythms'. Williams sees us television based on the network-era business model as 'a sequence in which the advertisements are integral rather than as a programme interrupted by advertisements'.33 Williams promises to discuss this question in more detail, but does not take up the issue later in his book. Yet he emphasizes the 'organic relationship between commercials and other kinds of material', arguing that, due to the sequential and integrating features of television, this 'organic relationship' is much more evident in television advertising than in any earlier systems of advertising. ${ }^{44}$ For Williams, it is this organic relationship between advertising and other broadcast content that makes television advertising qualitatively different from press and poster or display advertising.

Williams's claim that commercials are not an interruption of the flow, but an organic part of it, and his conclusion that commercials, together with trailers and promos, create the flow, are quite notable. Television scholars, and probably most television watchers, usually perceive commercial 'breaks' - the name says it all - as an interruption in the programme. ${ }^{35}$ On the other hand, there is consensus in television studies that interruptions are not a perversion of the viewing experience, but that they define television experience. ${ }^{36}$ For Mary Ann Doane, interruption is crucial to

32 See Ibid., 173-193.

33 Williams, Television, 66-67.

34 Ibid., 68.

35 See, for example, John Fiske, Television Culture (London and New York: Routledge, 1987), 99.

36 See, for example, Jeremy G. Butler, 'An Introduction to Television Structures and Systems: Ebb and Flow in the Postnetwork Era', in Television: Critical Methods and Applications, $4^{\text {th }}$ ed. 
television, because it 'corroborates television's access to the momentary, the discontinuous, the real'.37 John Fiske, who speaks of 'the movement of the television text' instead of flow, characterizes this movement as 'discontinuous, interrupted, and segmented': $3^{8}$

The television text, then, is composed of a rapid succession of compressed, vivid segments where the principle of logic and cause and effect is subordinated to that of association and consequence to sequence. [...] Its attempts at closure, at a unitary meaning, or a unified viewing subject, are constantly subjected to fracturing forces. 39

For Jeremy G. Butler, television's segmental nature is evident in all types of programmes, but 'peaks in the 30 -second (and shorter) advertisement'..$^{40}$ In that sense, commercials can be comprehended as the smallest unit both in the organization of network-era television and in the experience of it. How these segments interact with each other and with other television materials in the process of producing meaning has been a major theme in television studies. For John Ellis, the experience of watching advertisements is 'that of seeing segments cluster together, inciting each other. ${ }^{11}$ While their specific meanings have relatively little to do with each other, it is, Ellis argues, 'their generalised generic meanings (a domestic consumerist relation to objects)' that gives them a certain common thematic: "These segments are not made to combine as a montage fragment into a larger organisation of meaning. Thirty seconds by thirty seconds, the "spot" advertisement expands but does not combine. ${ }^{42}$

However, even seemingly disconnected segments of television's flow may interact with each other semantically, as studies on the relationship between narratives and advertisements have shown. In their analysis of the commercials inserted into an episode of Fantasy Island, Mike Budd, Steve Craig, and Clay Steinman detect clear links between the first commercial of each commercial break and the preceding narrative sequence. This brings them to the conclusion that commercials 'respond fairly directly to the problems, desires and fantasies articulated in the programme's narrative by promising

(New York and London: Routledge, 2012), 12.

37 Mary Ann Doane, 'Information, Crisis, Catastrophe', in Logics of Television, ed. Patricia Mellencamp (Bloomington: Indiana University Press, 1990), 238.

38 Fiske, Television Culture, 105.

39 Ibid.

40 Butler, 'An Introduction to Television Structures and Systems', 13.

41 John Ellis, Visible Fictions: Cinema, Television, Video (London: Routledge, 1992), 118.

42 Ibid., 118-119. 
gratification through products'. ${ }^{43}$ Sandy Flitterman's study on the interaction between commercials and the female narrative of the soap opera, and John Fiske's comparable examination of the relations between commercials and masculine narratives such as The A-Team, produce somewhat similar results. ${ }^{44}$ In both cases, the commercials complement the diegetic world of the narratives. Flitterman argues that commercials are mini narratives that - unlike the narrative of the soap - reach successful closure (at least temporarily); by contrast, masculine narratives, according to Fiske, close with successful achievement, while the commercials inserted frequently highlight the means to that achievement rather than the achievement itself. Thus, for Fiske, the commercials

mediate between the diegetic world of the programme and the world of the viewer - they show that the diegetic world is not complete within itself, but that its boundaries can be broken where it intersects with the 'real' world of the viewer. ${ }^{45}$

Commercials mediate between the world of the diegesis and the 'real' world of the viewers on a semantic level and manage the transition between the two worlds. Jane Feuer has argued that television has three diegetic worlds - that of the programme, that of the commercials and promos, and that of the viewing family - and that these three worlds persistently intersect and interrupt each other.$^{46}$ While I do not deny the experience of commercials interrupting programmes, I suggest that this interruption is rather interpreted as a threshold between two worlds, a transition that is coordinated and orchestrated by commercials. In this sense, commercials act as intermediaries between the world of the programme and the world of the viewers.

In a similar vein, commercials can also be considered intermediaries between different channels, when viewers are triggered to use the remote

43 Mike Budd, Steve Craig, and Clay Steinman, 'Fantasy Island: Marketplace of Desire', in Mass Communication Review Yearbook, vol. 5, ed. Michael Gurevitch and Mark Levy (Beverly Hills: Sage, 1985), 297.

44 Sandy Flitterman, 'The Real Soap Operas: Tv Commercials', in Regarding Television: Critical Approaches - An Anthology, ed. E. Ann Kaplan (Los Angeles: American Film Institute and University Publications of America, 1983), 84-96; John Fiske, 'Gendered Television: Masculinity', in Fiske, Television Culture, 198-223.

45 Fiske, Television Culture, 146-147.

46 Jane Feuer, 'Narrative Form in American Network Television', in High Theory / Low Culture, ed. Colin MacCabe (Manchester: Manchester University Press, 1986), 101-104. 
control to switch channels during commercial breaks. The remote control is yet another factor interrupting the typical television experience, while also serving as a tool for viewers to interrupt the planned flow and switch from the horizontal axis of a single linear programme to other channels and the vertical axis of programming, thus producing their own flow. But interruptions in the programme, I argue, following Williams, are not necessarily interruptions of the flow. Rather, they are essential parts of it in that they help create the flow.

Viewers can interrupt television's flow not only with the help of the remote control or later viewing technologies such as the video recorder. They can interrupt television consumption by leaving the room, by turning away from the screen, or by simple inattention. The dispositif of television does not position the viewer as tightly as the dispositif of cinema, for the spatial relations in television viewing differ significantly from the viewing position in cinema. The TV set in the network era, as many scholars have pointed out, is an ambient component of the domestic space, and television programming is structured according to the daily routine with specific time frames for children, women, and the family to watch TV. At the same time, television's schedule structures daily routines both temporally and spatially in a normative way. Television viewers are frequently engaged in other activities such as household work, and have therefore been considered 'intermittent viewers'. ${ }^{47}$ Intermittent viewing is in stark contrast - at least in theory, but not necessarily in practice, as we have seen - to the captive spectator in cinema. As a consequence, television constantly struggles for viewers' attention. The segmented structure that television adopted is a means to pare television down into small portions to encourage viewer engagement. From this perspective, as the smallest unit of television, commercials can somewhat paradoxically be regarded as the smallest element in television's strategy to direct audience engagement and maintain viewer attention. ${ }^{48}$

47 Tania Modleski, 'The Rhythms of Reception: Daytime Television and Women's Work', in Regarding Television, ed. Kaplan, 67-75.

48 Given the focus of this chapter on movement, I exclude the crucial role of television audio as an ambient aural component of the domestic space. For how television audio manipulates and commodifies inattentive audiences by sustaining, focussing, and directing audience engagement in network television, see Rick Altman, 'Television/Sound', in Studies in Entertainment: Critical Approaches to Mass Culture, ed. Tania Modleski (Bloomington: Indiana University Press, 1986), 39-54; John Ellis, 'Broadcast TV as Sound and Image', in Film Theory and Criticism: Introductory Readings, ed. Gerald Mast, Marshall Cohen, and Leo Braudy (New York: Oxford University Press, 1999), 385-394. Altman argues that television sound mediates the relationship between 'household flow' and 'programming flow'. For an overview of television sound studies and developments 


\section{The Place and Role of Commercials in Public Service Broadcasting}

Television's flow is a matter of degree, however. The previous description of the place and role of commercials in television programming applies to a business model that is based on advertising. In this model, according to Butler, 'programmes are just filler, a necessary inconvenience interrupting the true function of television: broadcasting commercials' ${ }^{49}$ As Rick Altman has pointed out, the extent of flow is related to television's economic context; flow both endorses and is exploited by commercial interests of television. ${ }^{0}$ While network-era television in the United States strongly relied on flow, public service broadcasting in Western Europe even today shows a much lesser degree of flow. The extent of flow depends on the financing model of broadcasting: while commercial TV channels in Europe also heavily promote flow (within the regulatory framework in which they operate), ${ }^{51}$ public-service television stations still strongly rely on discrete programming. This is particularly evident in the case of advertising. Ever since the inclusion of commercials in public service broadcasting, and even before, the place of advertising in public-service programmes has been highly contested and subjected to strict regulations. In Germany, for example, where advertising became part of public-service television in 1956, the broadcasting of commercials on channels such as ARD and ZDF is at present restricted to a yearly average of 20 minutes of advertising on workdays before 8:00 p.m. On Sundays and on national holidays, advertising is not allowed. The broadcasting of commercials is also restricted to block advertising. ${ }^{52}$ This means that commercials of 10 , 15, 20, or more seconds in length are broadcast only in commercial blocks and as a general rule are inserted in 'natural' programme breaks, that

in the field that take into account recent technological developments, see Carolyn Birdsall and Anthony Enns, 'Editorial: Rethinking Theories of Television Sound', Journal of Sonic Studies 3, no. 1 (October 2012), https://hdl.handle.net/11245/1.377378 (last accessed 6 April 2021).

49 Butler, 'An Introduction to Television Structures and Systems', 13.

50 Altman, 'Television/Sound'.

51 See 'Fact Sheets on the European Union: Audiovisual and Media Policy', http://www.europarl. europa.eu/atyourservice/en/displayFtu.html?ftuId=FTU_3.6.2.html (last accessed 6 April 2021). An update of the regulatory framework of the 'Audiovisual Media Services Directive' (AVMSD) was launched in 2015 that proposes to change the limit for commercial communications from 12 minutes per hour to 20 per cent of the time between 7:00 a.m. and 11:00 p.m. EU Parliament and the Council are currently reviewing the proposal (ibid.).

$5^{2}$ http://www.ard.de/home/intern/fakten/abc-der-ard/Rundfunkwerbung/553184/index. html (last accessed 6 April 2021). 
is, between when one programme unit finishes and another one begins. Importantly, commercials must also be clearly marked as advertising and be separated from other elements of the programme with the help of visual or acoustic signals..$^{53}$ And not only is the commercial block separated from the rest of the programme, the commercials within the block are themselves separated from one another through cartoons or stills. ${ }^{4}$ Hence, the shift from the concept of sequence as programming to the concept of sequence as flow that Williams observed in 1974 has not been nearly as complete and comprehensive as postulated. Programming has been much more complex and diverse. Deregulated or subject to national and/ or supranational regulations (as in the case of the European Union), TV programmes reflect historically specific economic and political interests that have also affected the place and role of advertising.

To better understand the specific place of screen advertising in public service broadcasting in Western Europe from its beginnings, we can take as an example the first commercial 'break' ever aired on Swiss German television, on 1 February $1965 .{ }^{55}$ Fortunately, the entire commercial block has been archived by Swiss television, although the programme elements that preceded and followed it were not. ${ }^{6}$ The mini programme of commercials begins with a cartoon bumper that separates the commercials from the rest of the programme; its credit title 'Telespot' makes explicit that what follows is advertising. Thus, advertising is unmistakably marked as advertising. The cartoon features two figures: a child, presumably a boy, and a bearded man. The latter intends to take a photograph of the boy sitting in front of him on a swivel chair, and presses the flash button, but nothing happens. When the man inspects

53 'ARD-Richtlinien für Werbung, Sponsoring, Gewinnspiele und Produktionshilfe in der Fassung vom 12.03.2010', 2, http://www.ard.de/download/553234/ARD_Richtlinien_fuer_Werbung__Sponsoring__Gewinnspiele_und_Produktionshilfe_in_der_Fassung_vom_12_3_2010. pdf (last accessed 6 April 2021).

54 http://www.ard.de/home/intern/fakten/abc-der-ard/Rundfunkwerbung/553184/index. html (last accessed 6 April 2021). In 2012, broadcasting (both radio and television) advertising and sponsorship contributed six per cent to the total revenue of state broadcasting in Germany (ibid.).

55 In Switzerland, it took nine more years of negotiations than in Germany before commercials were granted a permanent place in public broadcasting. At that moment, no commercial channels existed in either Germany or in Switzerland; commercial television stations in Europe increased in the 1980 s due to new developments in broadcasting technologies and the introduction of the dual broadcasting system.

56 See André Hofer, 'Schon 20 Jahre Tv -Werbung!', in TV Transit Express: AG für das Werbefernsehen (Bern, January 1985), n.p. 
the flash, it flashes the photographer, making his eyes spin in circles (see Figures 5.1 and 5.2 ). This intro is followed by eight commercials in total for the following brands:

- Ovomaltine (Ovaltine) by Wander, a milk flavouring product usually made with malt extract, sugar (if not in Switzerland), whey, and, originally, eggs;

- Via and Radion detergents, a cartoon advertising two products on promotion;

- Chocoletti by Lindt, a stop-motion animated picture;

- Opel Kadett, a car model that, as the slogan has it, first of all would have to please Yvonne;

- Maggi pea soup with speck, making suggestions for 'light meals' such as Maggi pea soup with speck and sausages;

- Union Bank of Switzerland, featuring a testimonial from an elder man in a suit, tie, and hat sitting with friends on a terrace in Ascona at the shore of Lago Maggiore getting ready for a boat trip with a young woman;

- Pepsi-Cola, somewhat the continuation of the preceding commercial in that a group of young people have fun in a car that drives on water;

- Jubilor coffee by Coop, another animated picture.

The total length of the commercial break is five minutes and it is in standard black and white. ${ }^{57}$ The commercials are clearly separated from one another through the insertion of silent kaleidoscopic images between the commercials that display white lines against a black background merging into ever changing formations (see Figures 5.3 to 5.17 ). The commercial block closes with a continuation of the cartoon bumper that opened it. The photographer is still about to take a picture of the child, but this time, the child turns over the flash and directs it towards the camera lens so that the photographer gets flashed again when he pushes the button. The commercial break closes with the same 'Telespot' logo with which the programme opened (see Figures 5.18 to 5.20).

Obviously, the structure of the mini programme of commercials is that of a series of sequentially timed units in which the boundaries between even the smallest programme units, the commercials, are visually and acoustically (through silence) marked, thus creating discrete and distinctive intervals instead of a flow. The 'organic relationship' between commercials and other parts of the programme that Williams emphasizes is disrupted

57 Even though the technology was available starting in the 1950s, colour television became standard only in the 1970s. 

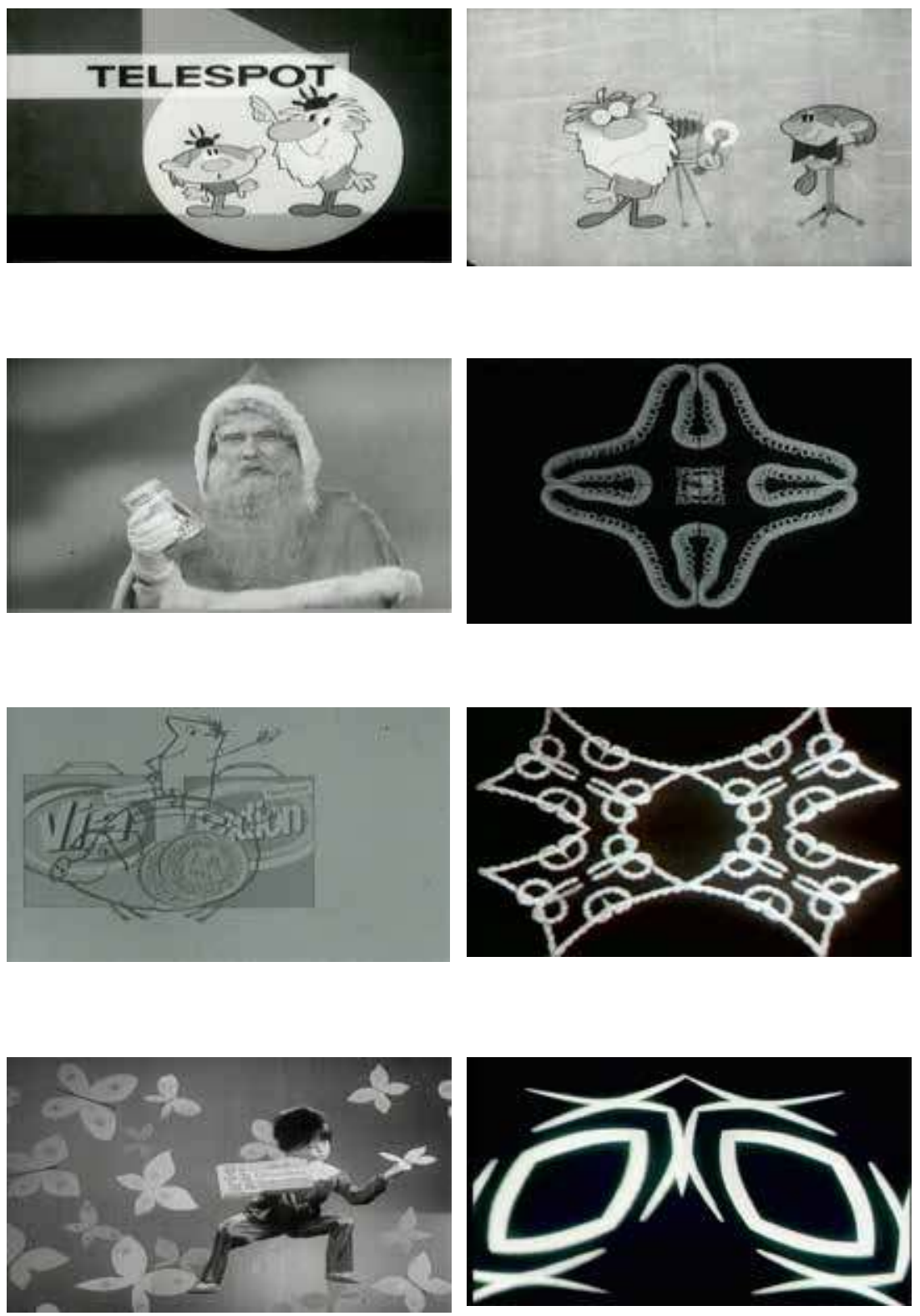

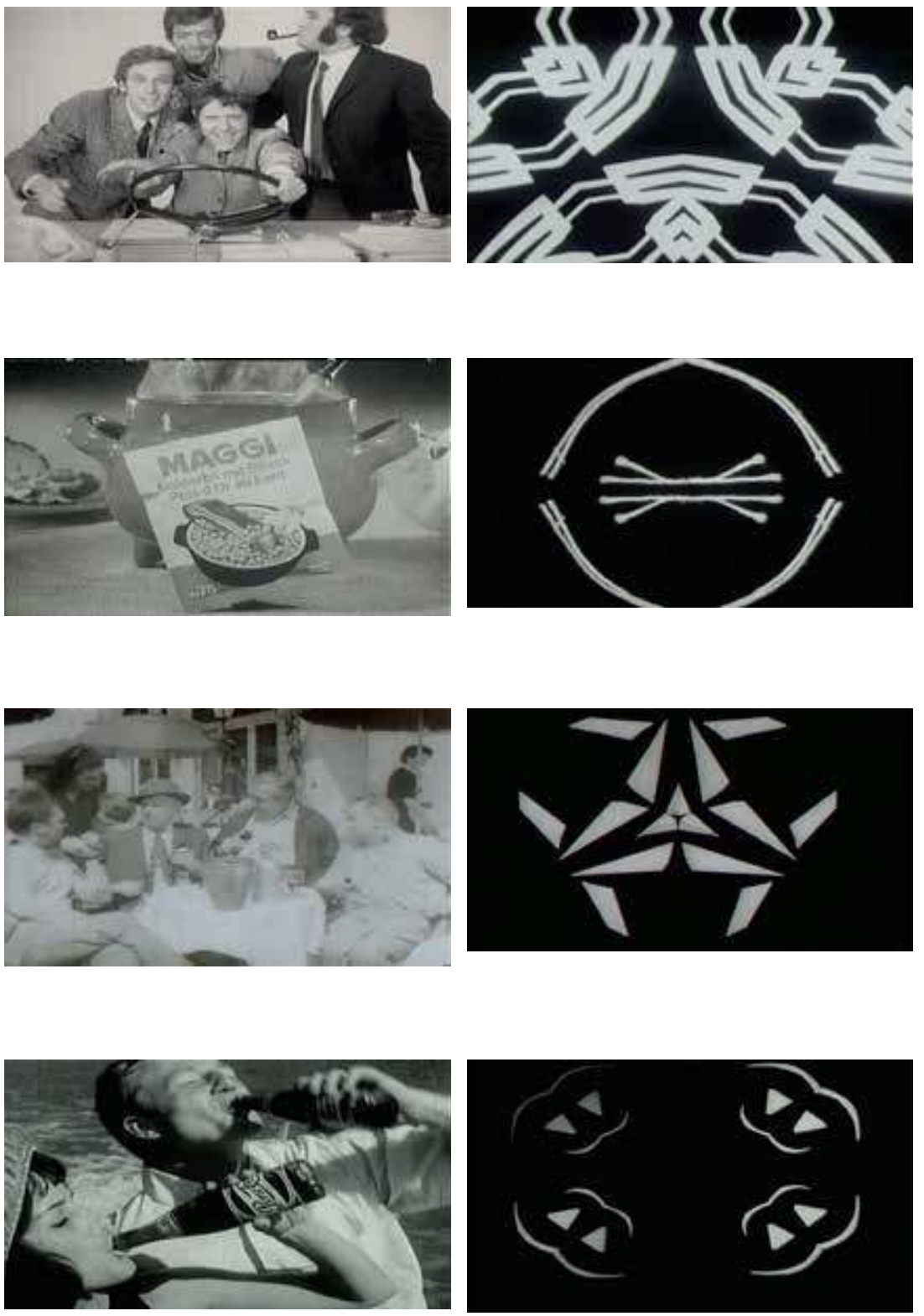

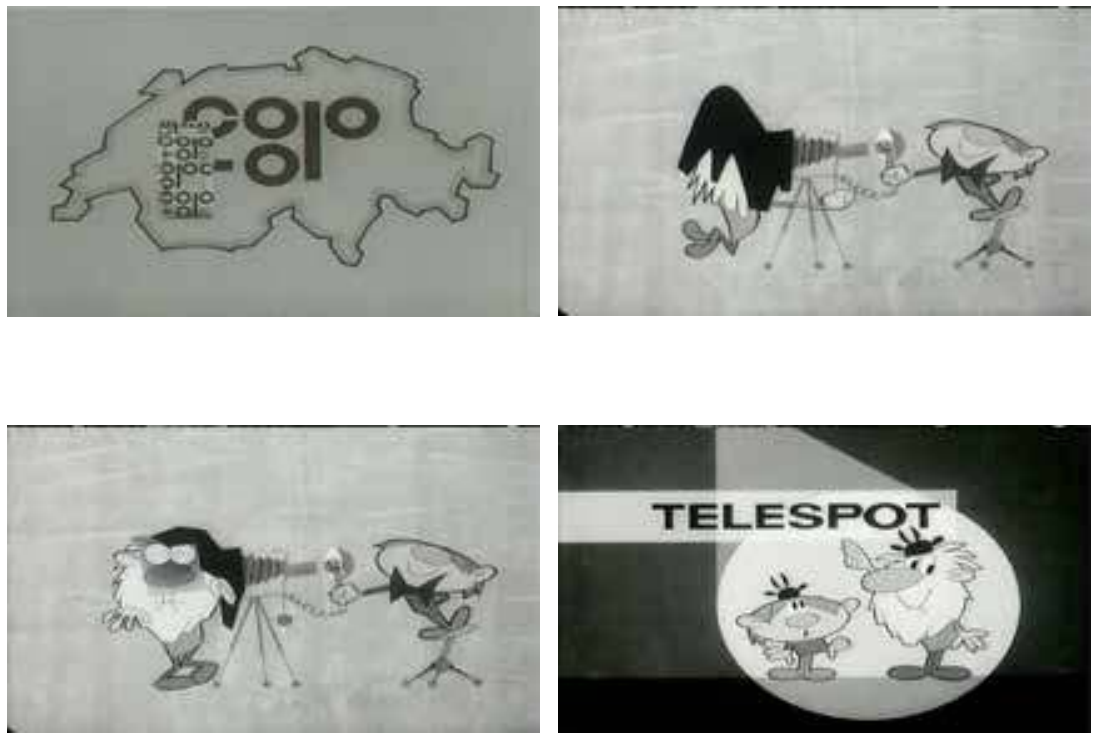

Figure 5.1-5.20: Screenshots from the first commercial 'break' aired on Swiss German television, on 1 February 1965.

in this example by clear-cut markers of boundaries both between programme units and between individual elements within the programme unit. However, this does not preclude that connections can be drawn between commercials, here most obviously between the Union Bank and the Pepsi-Cola commercial, with the latter somewhat continuing the story of the former.

Some peculiarities in the commercial break deserve mentioning. The opening Ovomaltine commercial features Santa Claus, who specifically addresses children and announces in Swiss German that Ovomaltine boxes are now - in early February (!) - coming with arts-and-crafts sheets for Christmas decoration. While the vast majority of the commercials are plain, simple, of low production value, and hard sell, the Pepsi Cola commercial stands out from the rest of the advertising programme for its cinematic visual style, its framing and fast and rhythmic editing pace - a prime example of the 'creative revolution' in the us advertising industry. As such, the commercial break internalizes tensions between the national specificity of television, the vernacular, and the international in the form of us popular culture: the national specificity resides in television's organization and regulation, but also in its addressing German-speaking 
Switzerland (one of four official national language communities) in High German as a national audience. By contrast, Santa Claus's Swiss German dialect in a deep voice creates the intimate homelike atmosphere of the vernacular. Finally, the Pepsi-Cola commercial breathes the spirit of us youth and pop culture. In that respect, the chronological order of the commercials is notable: it begins with the vernacular, which is closest to the world of the viewers and which serves to introduce them to the new world of screen advertising on Swiss television, and it ends with a commercial that promotes Coop's coffee (of all products!) as a national product, the pack shot showing the coffee package and trademark embedded within a drawing that represents the shape of Switzerland (see Figure 5.17). In this way, the international feel of the penultimate commercial, the Pepsi-Cola commercial, is repatriated, so to speak, and the nation-building public-service mission accomplished - with the help of advertising.

The regulatory framework that insists on marking commercial breaks as separate from other parts of the public service broadcast programme has had some unexpected side effects. Some cartoon bumpers - if not the one in the Swiss example mentioned above - have become cult. In Germany, the cartoon series 'Äffle und Pferdle' (Ape and Horse), which aired on the South German broadcasting service starting in 1960, and 'Mainzelmännchen' (Manikins from Mainz), which aired on zDF from the beginning of the station in 1963 , are still very popular on television and have been enjoying a vibrant second and third life on DVD and on YouTube (see Figures 5.21 and 5.22)..$^{8}$ The bumpers, a regulatory tool to separate commercials both from other parts of the programme and from other commercials, in today's television practice very often connect the commercial block with preceding programme material as well as commercials with each other rather than separating elements from one another. Bumpers such as 'Mainzelmännchen' often interact with the programme content and the content of commercials by way of picking up on themes and motifs of preceding programmes or commercials, thus mimicking, commenting on, and sometimes even parodying television material, thereby adding a self-reflexive level to advertising and television

$5^{8}$ I particularly recommend for viewing the 'Hafer und Bananenblues' (Oat and Banana Blues) from the 'Äffle und Pferdle' series: https://www.youtube.com/watch?v=7FyaEEMRY_A (last accessed 6 April 2021). For 'Mainzelmännchen', see: https:/www.youtube.com/results?search_ query=mainzelm\%C3\%A4nnchen (last accessed 6 April 2021). For international bumpers on YouTube, see: https://www.youtube.com/results?search_query=bumpers (last accessed 6 April 2021). 


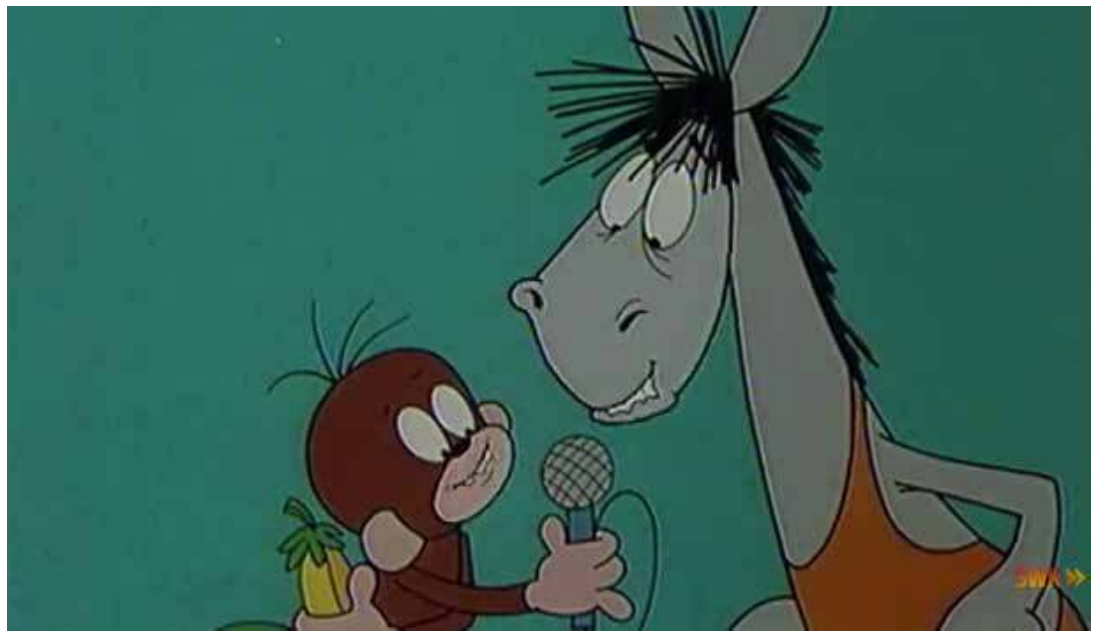

Figure 5.21: Screenshot from the cartoon series 'Äffle und Pferdle' (Ape and Horse).

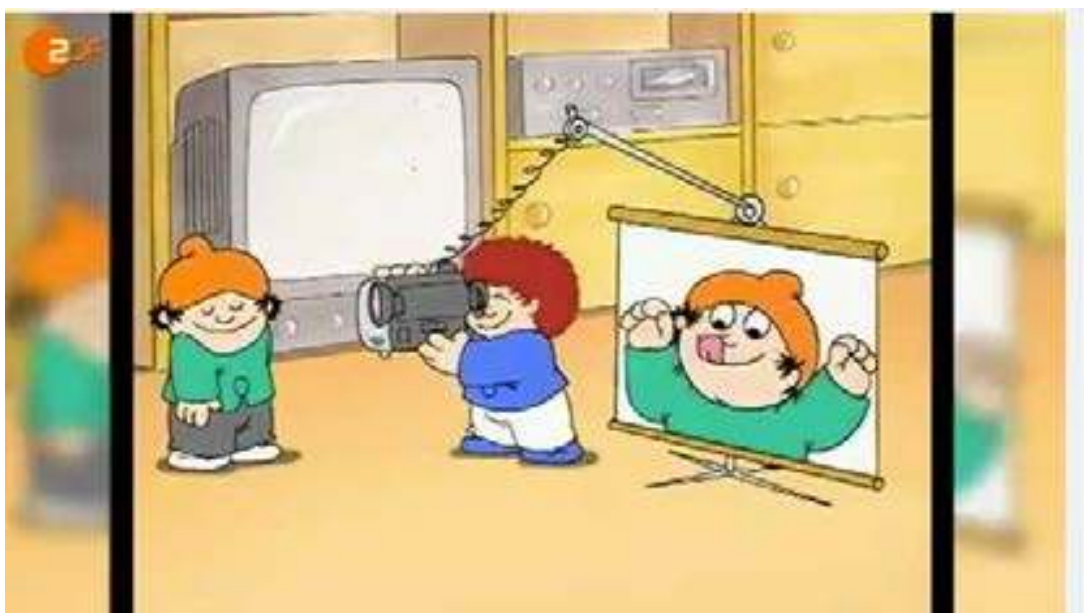

Figure 5.22: Screenshot from 'Mainzelmännchen' (Manikins from Mainz).

programming in general. Despite strict regulations to separate commercial blocks from the rest of the programme and to clearly mark advertising as advertising, it is of all things the markers themselves - that is, the cartoon bumpers - that establish connections between distinctive programme units, thus stitching the programme together. It can be concluded then 
that, in contemporary public service broadcasting, commercials, with the help of bumpers, work as intermediaries between programme units, thus managing transitions rather than signalling an interruption in the programme 'flow'.

\section{Moving Images - Visual Mobility}

The development of interactive viewing technologies such as digital video recorders and online video has complicated the idea that Williams's concept of flow developed for network-era television can explain television in the post-network era. But what television studies can still take from Williams is his insistence that media texts are not to be considered in isolation as textual entities, but rather that we focus on how these texts connect and interact with other texts, institutions, technologies, and practices. ${ }^{59}$ While this chapter is in line with Williams's focus on the relational dimensions of screen advertising, I wish to pick up on yet another point that Williams makes in 1974 and that has been rather neglected, if not repudiated altogether by television studies. Thinking about the innovative forms of television, Williams considers television itself as an innovative form, because it provides new experiences of seeing. To get this kind of attention, Williams suggests that we turn off the sound, which often directs attention to content: 'What then can happen, in some surprising ways, is an experience of visual mobility, of contrast of angle, of variation of focus, which is often very beautiful, ${ }^{60}$ Williams insists that this aesthetic experience of visual mobility is not a by-product of some other experience, but 'one of the primary processes of the technology itself, and one that may come to have increasing importance. ${ }^{61}$

Pioneering television sound studies by Rick Altman and John Ellis in the 1980s, however, glossed over Williams's idea of television's genuine visuality, arguing that television is closer to radio than to film and that sound is more important than images in television. ${ }^{62}$ Building on Altman and Ellis's work, Michel Chion in the 199os claimed that 'television is fundamentally a kind of radio, "illustrated" by images', which brought him to the conclusion

59 Michael Kackman et al., eds., Flow Tv: Television in the Age of Media Convergence (New York and London: Routledge, 2011), 2.

6o Williams, Television, 75 .

61 Ibid., 76 .

62 Altman, 'Television/Sound'; Ellis, 'Broadcast TV as Sound and Image'. 
that 'silent television is inconceivable ${ }^{\prime 63}$ - a view that has been seriously challenged by the increasing practices of silent $\mathrm{TV}$ watching in public places. While the idea of television as 'illustrated radio' has become the basis of television sound studies for several decades, it was John Caldwell who questioned in the mid 1990s the persistent notion that television privileges the ear, whereas film privileges the eye, pointing to television's 'obsession with making images that spectacularize, dazzle, and elicit gazelike viewing, ${ }^{64}$ The production, distribution, and reception of television has significantly changed in recent years (with the rise of home entertainment systems, widescreen televisions, $3 \mathrm{D}$ technology, out-of-home television, digital television networks, mobile media, etc.) and has triggered television sound studies to rethink earlier approaches to television sound. ${ }^{65}$ In light of this current development, Williams's insistence in 1974 that television's innovative form resides in providing 'an experience of visual mobility' is even more remarkable.

\section{Out-of-Home Advertising with Infoscreens}

Moving from network-era home television to today's out-of-home advertising screens, I bring along Williams's notion that moving images provide an experience of visual mobility when examining a media dispositif in a public space that is both structuring and structured by the relational contingencies between mobility and immobility, between movement and arrest. In the following discussion, train platforms in Germany serve as an exemplary case to study the place and role of screen advertising in out-of-home media dispositifs. I draw predominantly on literature from mobilities studies, which developed within the social sciences in the course of a mobility 'turn' in the 1990s. The contemporary mobilities paradigm as it originated in the work of sociologist John Urry in 2000 is devoted to the examination of diverse mobilities of peoples, objects, images, information, and wastes, and the interdependencies between

63 Michel Chion, Audio-Vision: Sound on Screen, ed. and trans. Claudia Gorbman (New York: Columbia University Press, 1994), 165.

64 John T. Caldwell, Televisuality: Style, Crisis, and Authority in American Television (New Brunswick: Rutgers University Press, 1995), 158.

65 See Journal of Sonic Studies 3, no. 1 (October 2012), a special issue dedicated to rethinking theories of television sound. 
these different kinds of mobilities. ${ }^{66}$ I wish to bring this sociological approach into dialogue with attempts in media and communication studies to re-examine the notion of flow in an increasingly mobile media environment in which digital screens can no longer be understood in terms of medium specificity. According to Kathleen Oswald and Jeremy Packer, such a reconsideration of flow 2.0 includes a shift in attention from the programming of content in a sequence for a single device towards 'the programming of a fluidly scheduled mobile life via networked terminals and mobile devices'. ${ }^{67}$ The question of flow thus becomes one of how the use of multiple screens, fixed and mobile, 'orchestrate the individual's material flow through space according to a fluid set of temporal programmes' ${ }^{68}$

My point of departure to examine screen advertising's place in flow 2.0 are so-called Infoscreens: large digital screens on busy subway and suburban train station platforms as well as at long-distance train stations. These screens belong to a long and contested history of out-of-home media displays that can be traced back to ancient Rome's painted or carved wall inscriptions that were meant to attract attention. ${ }^{69}$ Reproduction technologies such as Johannes Gutenberg's invention of movable type printing in $145^{\circ}$ and the invention of lithography in the late 1790 s gave rise to handbills and illustrated posters, respectively. Out-of-home advertising proliferated and was institutionalized in the nineteenth century. As Erkki Huhtamo, in his media archaeology of public media displays unearths, placard advertising was realized early at railway stations - for the same reason train stations, airports, and other transit zones are privileged advertising locations today: "The constant flow of passers-by made them attractive'. ${ }^{70}$ Since the instalment of the first digital billboards in $2005^{71}$ and the replacement of traditional billboards with dynamic LED

66 See John Urry, Sociology Beyond Societies: Mobilities for the Twenty-First Century (London: Routledge, 2000).

67 Kathleen Oswald and Jeremy Packer, 'Flow and Mobile Media: Broadcast Fixity to Digital Fluidity', in Communication Matters: Materialist Approaches to Media, Mobility and Networks, ed. Jeremy Packer and Stephen B. Crofts Wiley (London and New York: Routledge, 2012), 279.

68 Ibid. 277.

69 Erkki Huhtamo, 'Messages on the Wall: An Archaeology of Public Media Displays', in Urban Screen Reader, ed. Scott McQuire, Meredith Martin, and Sabine Niederer (Amsterdam: Institute of Network Cultures, 2009), 15-28, here 16.

70 Erkki Huhtamo, 'Messages on the Wall: An Archaeology of Public Media Displays', in Urban Screen Reader, ed. Scott McQuire, Meredith Martin, and Sabine Niederer (Amsterdam: Institute of Network Cultures, 2009), 18.

71 See Outdoor Advertising Association of America (OAAA), 'History of ooH', https://oaaa.org/ AboutOOH/OOHBasics/HistoryofOOH.aspx (last accessed 6 April 2021). 
billboards, digital out-of-home advertising has massively proliferated. In the United Kingdom, for example, the number of digital screens has increased from 2056 in 2009 to over 17,000 in $2017.7^{2}$ According to the value proposition of Outdoor Advertising Association of America (OAAA), the leading trade association representing the out-of-home advertising industry in the United States founded in 1891, out-of-home advertising has gained in importance and effectiveness once again in the age of digital and social media:

In a world of clicks, likes, and page views, out of home (OOH) advertising is more of a core media buy than ever before. be blocked, skipped, or viewed by bots. оOH is always on, surrounding and immersing audiences with the real, powerful, advertising, wherever consumers live, work, travel, shop, and play. ${ }^{73}$

Back in Germany, Infoscreen GmbH was founded in 1991 in Nuremberg and installed its first Infoscreen system at Odeonsplatz station in Munich in 1994. Infoscreen $\mathrm{GmbH}$ is a Ströer subsidiary; Ströer is a stock market-listed German company operating on an international level to market out-of-home advertising. The company is one of the largest providers of out-of-home media in German-speaking countries (with the umbrella company's sales reaching $€_{1.33}$ billion by the end of 2017) ${ }^{74}$ specializing in digital out-of-home advertising at high-frequency touchpoints. Infoscreen $\mathrm{GmbH}$ operates five different place-based advertising media: Infoscreen (which I will examine in more detail in the following), mall video, station video, super motion (i.e., large screens in highly exposed locations in public spaces), and Dus ad walk (i.e., five displays coordinated in walking areas such as airports that make one series of images). In 2017, the company operated approximately 300,000 out-of-home advertising media in total..$^{75}$ According to the company's website, Infoscreen is currently present in eighteen cities in Germany, with a total of 506 screens. ${ }^{7}$ Since 1997 , Infoscreen also operates in Austria; since

72 Nick Hammond, 'Why Digital Out-of-Home Advertising Is not Really Digital (Yet)', 9 October 2017, https://www.econsultancy.com/blog/69491-why-digital-out-of-home-advertising-isnot-really-digital-yet (last accessed 6 April 2021).

73 See Outdoor Advertising Association of America (OAAA), 'оoн Value Proposition', https:// oaaa.org/AboutOOH/OOHBasics/OOHValueProposition.aspx (last accessed 6 April 2021).

74 https://www.stroeer.com/unternehmen/profil/auf-einen-blick.html (last accessed 6 April 2021).

75 https://www.stroeer.com/unternehmen/profil/auf-einen-blick.html (last accessed 6 April 2021).

76 https://www.infoscreen.de/en/plan-calculate/media-locations/ (last accessed 21 March 2018). 


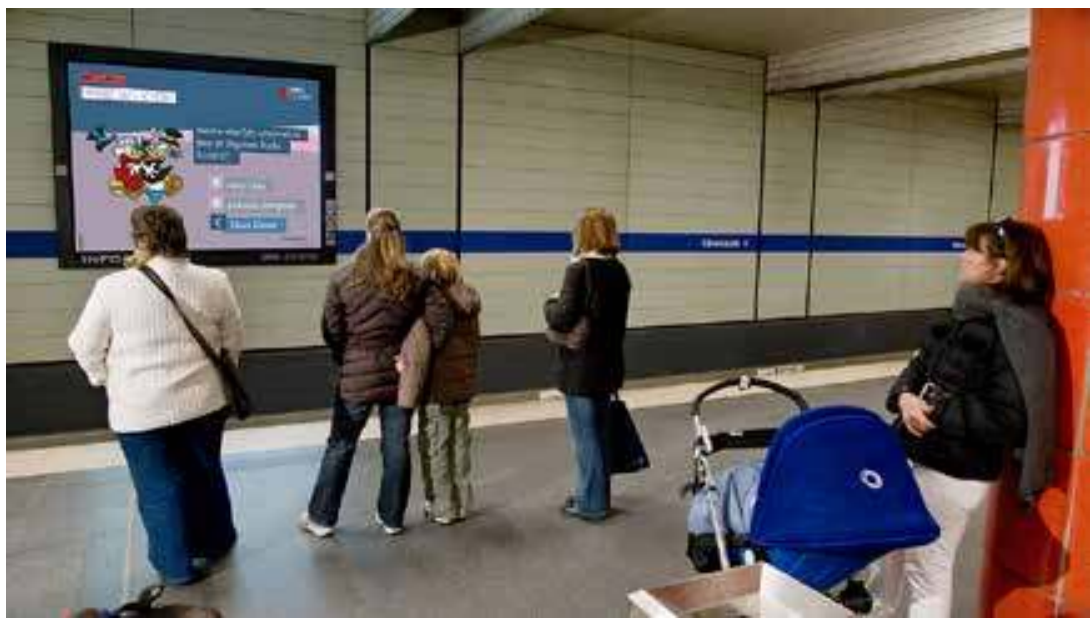

Figure 5.23: Infoscreen at Munich Odeonsplatz (Infoscreen).

2003, Infoscreen has been owned by Gewista Werbegesellschaft $\mathrm{GmbH}$, which is a group company of JCDecaux, the world's largest out-of-home advertising company. ${ }^{77}$ Infoscreen Austria currently operates 48 screens in stations in Vienna and over 2500 screens in trams and buses in Vienna, Graz, Linz, Innsbruck, Klagenfurt, and Eisenstadt. ${ }^{8}$

In Germany, Infoscreens (aspect ratio: 4:3, resolution: 1024 x 768 pixel) operate daily from 6:00 a.m. to midnight. They are placed on (partition) walls that passengers face while waiting on train platforms, the tracks spatially separating commuters from Infoscreens. The programme is structured in a loop that repeats itself every ten minutes and consists of a mix of editorial and advertising content, with commercial length varying from 5 to 30 seconds. The screens are silent; therefore, there is only visual, no aural, interaction between screens and (potential) onlookers possible. Aural interactions come from loudspeakers announcing arriving and departing trains. For this reason, the commercials are often adapted from posters and other still artwork (which communicate without sound), lending them the character of animated signage. ${ }^{79}$ The editorial content, which is said to be at least 60 per cent,${ }^{80}$ includes news, weather reports,

77 http://www.infoscreen.at/infoscreen/impressum/ (last accessed 21 March 2018).

78 http://www.infoscreen.at/werben/mediaplaner/ (last accessed 21 March 2018).

79 In a short video on its website, Infoscreen gives an example of how a poster can be adapted to an animated Infoscreen spot. See https://www.infoscreen.de/en/our-media/infoscreen/ production/ (last accessed 21 March 2018).

80 https://www.infoscreen.de/en/our-media/infoscreen/ (last accessed 21 March 2018). 
and trivia organized in recurring categories such as 'Geschmackssache' (Question of Taste) for recipes, 'Zitiert' (Quoted) for quotes by famous people, 'Warten \& Raten' (Waiting and Guessing) for quiz questions, 'Zahlen, bitte' (Numbers, Please) for amazing numbers, and 'Fun Factor' mostly for sports activities (Figure 5.23). The transitions from editorial to advertising content are unmarked and the programme is sequentially structured to create a flow of images typical for screens whose raison d'être is advertising.

\section{Screen Advertising While You Wait}

Infoscreen advertises itself to potential customers as an advertising tool that gets 'a lot of attention in the low-stimulus public space: your target group is grateful for the change of pace that your advertising provides in the waiting situation. During the average five-minute wait even longer messages can be taken in. ${ }^{81}$ In a similar vein, the Ströer media data info sheet claims that

Infoscreens catch the audience's eye with an attractive range of the latest information, entertainment, and advertising, ensuring widespread reach in the process. The unique opportunities for advertising while commuters wait for their trains are guaranteed to grab the target audience's attention and provide high-impact advertising. Infoscreens are not perceived as a form of advertising, rather as a familiar companion for the target audience as they travel through the city. ${ }^{82}$

Infoscreen can be regarded as somewhat similar to what Anna McCarthy termed 'television while you wait': like out-of-home television, Infoscreens accompany - and commodify - the act of waiting, which, to use McCarthy's words, foregrounds 'the centrality of time, and environmental rhythms, in the processes through which television and TV images interweave with the habitual atmospheres of social space'. ${ }^{83}$ While McCarthy examines how TV sets regulate the flow and experience of time, I wish to take into

81 https://www.infoscreen.de/en/our-media/infoscreen/ (last accessed 21 March 2018).

82 Ströer Media Data, 'Campaign Media Digital: Infoscreen' (January 2017), 2. Last accessed 21 March 2018; no longer available online. For Ströer Media Data 2021 on Infoscreen and DOOH, see https://www.stroeer.de/fileadmin/regional/wt_downloads/9395.pdf?Mediadaten\%2o Infoscreen\%202021.pdf (last accessed 23 March 2021).

83 Anna McCarthy, Ambient Television: Visual Culture and Public Space (Durham, NC and London: Duke University Press, 2001), 195. 
consideration the relational dynamics between the movements of images, people, and objects with which Infoscreens are interlocked. The media dispositif of train platforms is, as mentioned earlier, characterized by a constant flow of passers-by who may - or may not - glance at the public screens or may prefer to interact with their own private mobile screens. At the same time, frictions in flows, immobilities, standstills, and dwellings constitute the dispositif. Train platforms are transit zones, but they are also waiting zones, non-lieux (non-places) in French anthropologist Marc Augé's description. ${ }^{84}$ The aspect of waiting is emphasized both by McCarthy and by Infoscreen's self-promotion. Obviously, waiting is an interruption: on platforms, the flow of bodies is temporarily halted, and bodily movement is reduced to small-scale on-site movements. As in the dispositifs of cinema and network-era television, interruption (here, the temporary suspension of corporeal movement) is the very moment screen advertising comes into play. On platforms, as in cinemas, while the movement of bodies is suspended, the movement of images on the screen continues the flow of movement, with advertising coordinating and orchestrating the transition between the different types of movements, thus stitching together the flow of bodies with the flow of images and the flow of objects.

The latter becomes evident when looking at how the rhythms of Infoscreens are synchronized with the rhythms of trains arriving and departing. The programme of Infoscreen may be organized in a loop repeating itself every ten minutes. The experienced temporalities of Infoscreens on the platform, however, are different, as a result of a harmonization of the movements of bodies and images and the mobilities of public transport: shortly before a train arrives at the platform, which is announced over the loudspeakers, Infoscreen's programme disrupts and the screen goes still and nearly blank, announcing in white letters that 'Zug fährt ein!' In the next line, in slightly smaller characters, is the same message in English - namely, 'Train arriving!' At the top of the screen, the city train logo can be seen (Figure 5.24). ${ }^{85}$ The flow of images stops when a train arrives that picks up on the movement of the images and continues the flow.

The dispositif of train platforms equipped with Infoscreens is temporally structured by intermittent movements - of bodies, images, and objects. If television viewers have been conceived as intermittent viewers, here, all

84 Marc Augé, Non-Places: An Introduction to Supermodernity, trans. John Howe (London: Verso: 2009 [1992]).

85 This description refers to the scenario at a suburban train platform at Frankfurt central station on 11 March 2017. 


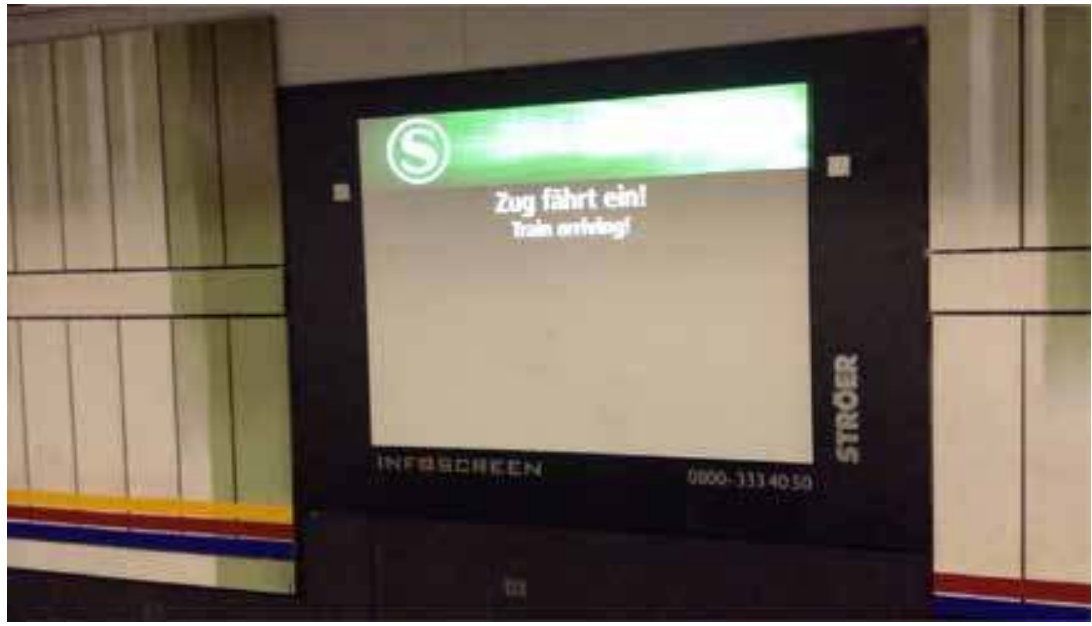

Figure 5.24: Infoscreen at Frankfurt central station, 2017 (photo by author).

movements and mobilities can be considered temporarily intermittent. In that sense, Infoscreens are part of a dispositif that Sheller and Urry describe as 'immobile infrastructures that organize the intermittent flow of people, information, and image'. ${ }^{86}$ Thus, a complex interlocking of mobility and mooring systems characterizes the media dispositif of train stations equipped with Infoscreens and testifies to an intricate coordination between transport and communication. This coordination 'mobilizes' the requirements and characteristics of co-presence 'into a new kind of mobility nexus', according to Kevin Hannam, Sheller, and Urry. ${ }^{87}$

While mobility studies have focussed on the relational contingencies between mobility and immobility and have considered the mobility of one as being at the expense of the immobility of another, ${ }^{88}$ David Bissell, in 'Animating Suspension: Waiting for Mobilities', suggests a new focus on the corporeal experience of the event of waiting during travel that considers waiting not through the relationality between mobility and immobility, but through the relationality between activity and inactivity: ${ }^{89}$

86 Mimi Sheller and John Urry, 'The New Mobilities Paradigm', in Environment and Planning A 38 (2006): 212.

87 Kevin Hannam, Mimi Sheller, and John Urry, 'Editorial: Mobilities, Immobilities and Moorings', Mobilities 1, no. 1 (March 2006): 4.

88 See Peter Adey, 'If Mobility Is Everything then It Is Nothing: Towards a Relational Politics of (Im)mobilities', Mobilities 1, no. 1 (2006): 75-94.

89 David Bissell, 'Animating Suspension: Waiting for Mobilities', Mobilities 2, no. 2 (July 2007): 277-298. 
Contrary to thinking through the event of waiting as a slowed rhythm, perhaps it does take effort and therefore some form of intentional action to wait. In other words, for the body to be immobile, it is still primarily pursuing an active purposive role of making-of-the-world and maintenance of meaning. In many ways, an active doing of waiting and how a subject comes to wait could be seen as an achievement of a specific set of ongoing embodied tasks. These might include the agentive capacity of making decisions of where to wait and what to do while waiting..$^{\circ}$

Waiting, from this perspective, is a chasm, a temporal void of 'dead time', in Joe Moran's words, ${ }^{91}$ or 'empty intervals between instants', in Harold Schweizer's, ${ }^{92}$ to be filled somehow with activity. Bodily stasis during periods of waiting, Bissnell and other have argued, heralds a heightened corporeal attentiveness and sensual responsiveness to the immediate environment, and produces a different kind of 'relationality from relation-in-the-world towards a relation-to-the-word'. 93

The idea that waiting involves heightened responsiveness is also the sales pitch for Infoscreen, which, as mentioned before, claims that, while travellers wait, advertising is guaranteed to grab their attention, for commuters are 'grateful for the change of pace' that advertising provides in the waiting situation. The company's English slogan 'We Get People Watching' - 'Wir machen Hingucker zu Zuschauern' in German ${ }^{94}$ - refers to the particular relation-to-the-world in waiting, in which heightened attentiveness and responsiveness stimulate a shift from coincidental glancing towards attentive gazing. In this particular dispositif, Infoscreens may temporarily position the immobilized bodies of commuters in front of the screen and turn passers-by into spectators.

Clearly, screen advertising exploits this perceptive environment while people wait. At the same time, as Bissell has suggested, we can also think of some of the numerous activities that are enacted while waiting as 'a method of harmonising' the different temporalities of stasis and mobility during periods of waiting. ${ }^{95}$ From this perspective, screen advertising can

90 Ibid., 285 .

91 Joe Moran, 'November in Berlin: The End of the Everyday', History Workshop Journal 57, no. 1 (Spring 2004): 218.

92 Harold Schweizer, 'On Waiting', University of Toronto Quarterly, no. 3 (2005): 789 . See also Barry Schwartz, Queuing and Waiting: Studies in the Organization of Access and Delay (Chicago: University of Chicago Press, 1975).

93 Bissell, 'Animating Suspension', 287.

94 https://www.infoscreen.de/en/ and https://www.infoscreen.de (last accessed 21 March 2018).

95 Bissell, 'Animating Suspension', 290. 
be comprehended as a mediator between different temporalities, one that acts as a temporal intermediary between mobility and immobility and that organizes the relational contingencies between mobility and immobility. In this way, screen advertising is deeply involved in the complex orchestration of (im)mobility and the synchronization of different kinds of intermittent movements within the dispositif of train platforms.

\section{Conclusion}

This chapter has suggested an approach to screen advertising that takes the movement of moving image advertising and its temporal sequence as a starting point to study screen advertising in relation to other moving images as well as to moving bodies and objects. The spotlight on three prevailing media dispositifs in which screen advertising has been involved - postwar cinema, network-era television, and contemporary suburban train platforms - and on-screen advertising's interaction in the inter-relational dynamics between movements of images, bodies, and objects within these dispositifs has drawn attention to the temporal dimensions of the spatial media arrangements that we call dispositifs. It has also shown how screen advertising is interwoven with the rhythms of these dispositifs, and how it both structures and is structured by these rhythms.

The examination of screen advertising from the point of view of movements and mobilities has highlighted that the movements of images, objects, and bodies are defined by interruptions of movements. While screen advertising is often experienced as interruption, I argue that interruption is not a distinctive feature of advertising. Screen advertising may indeed draw attention to interruptions, but interruptions are the normal condition. This suggests that we think of movements of images, bodies, and objects as being intermittent and interlocked in complex dynamics between movement and stasis. What I hope to have shown is that screen advertising interacts in this dynamic of intermittent movements in a specific way - namely, in that it manages interruption and mediates transition: screen advertising mediates transitions between moving images in cinema and television programmes, between television channels, between the world of the diegesis and the 'real world' of the audience, and between different types and rhythms of movements. Screen advertising structures the interrelations of intermittent movements and works as an intermediary, stitching together different worlds and harmonizing different temporalities. In this sense, screen advertising is characterized by a permanent in-betweenness. It is in between worlds and in between movements 
and mobilities, at the threshold, itself a transient phenomenon that points to the future and bears promise for imminent change. Instead of interrupting the flow of movement, screen advertising, from this perspective, appears to connect intermittent flows with its 'visual mobility', to take up Williams's notion again, which helps create a permanent flow of different types of intermittent movements stitched together by screen advertising.

Thus, the temporalities of screen advertising are somewhat paradoxical: while commercials may interrupt a feature film, discontinue a television programme, or delay access to a YouTube video, for example, they also create continuity in keeping up visual mobility while moving forward in time. These paradoxical temporalities could be one explanation for the fact that, at some moments, we may experience screen advertising as a disturbance, while in other situations, we may be inclined to greet it as a welcome opportunity to while away time, to tune into the mood for a feature film in the cinema, or to get 'a few minutes smarter', as the Infoscreen Austria slogan has it. ${ }^{96}$

In all three dispositifs, screen advertising is significantly involved in an ongoing process of positioning viewers. In cinema, screen advertising helps immobilize bodily movements and turn inattention into captivation, thus co-producing, together with the technological arrangement, the subject position of the spectator. If Infoscreen gets people watching, as it claims to do, it certainly also positions viewers - and in doing so disciplines them in public spaces: travellers engaged in watching an Infoscreen will be less likely to play loud music, conduct themselves immorally, or litter. In that sense, screen advertising plays a key role not only in the sequential organization of moving images but also in the formal organization of spectatorship. As such, screen advertising is involved in the disciplining of audiences and can be considered an accomplice of governance.

\section{Bibliography}

Adey, Peter. 'If Mobility Is Everything then It Is Nothing: Towards a Relational Politics of (Im)mobilities.' Mobilities 1, no. 1 (2006): 75-94.

Albera François and Maria Tortajada. 'The Dispositive Does Not Exist.' In CineDispositives: Essays in Epistemology Across Media, edited by François Albera and Maria Tortajada, 21-44. Amsterdam: Amsterdam University Press, 2015.

96 In German, the slogan reads 'Und wieder ein paar Minuten klüger!' (And a few minutes smarter again), http://www.infoscreen.at/ (last accessed 21 March 2018). 
Altman, Rick. 'Television/Sound.' In Studies in Entertainment: Critical Approaches to Mass Culture, edited by Tania Modleski, 39-54. Bloomington: Indiana University Press, 1986.

Amsler, André. Wer dem Werbefilm verfällt, ist verloren für die Welt: Das Werkvon Julius Pinschewer 1883-1961. Zurich: Chronos 1997.

'ARD-Richtlinien für Werbung, Sponsoring, Gewinnspiele und Produktionshilfe in der Fassung vom 12.03.2010.' 2, http://www.ard.de/download/553234/ ARD_Richtlinien_fuer_Werbung__Sponsoring__Gewinnspiele_und_Produktionshilfe_in_der_Fassung_vom_12_3_2010.pdf. Last accessed 6 April 2021.

'ARD-Rundfunkwerbung.' http://www.ard.de/home/intern/fakten/abc-der-ard/ Rundfunkwerbung/553184/index.html. Last accessed 6 April 2021.

Augé, Marc. Non-Places: An Introduction to Supermodernity, translated by John Howe. London: Verso: 2009 [1992].

Aumont, Jacques. L'Image. Paris: Nathan, 1990.

Baudry, Jean-Louis. 'Effets idéologiques produits par l'appareil de base.' Cinéthique no. 6/7 (1970): 1-8.

Baudry, Jean-Louis. 'Le dispositive. Approches métapsychologiques de l'impression de réalité.' Communications 23 (1975): 56-72.

Birdsall, Carolyn, and Anthony Enns. 'Editorial: Rethinking Theories of Television Sound.' Journal of Sonic Studies 3, no. 1 (October 2012), https://hdl.handle. net/11245/1.377378. Last accessed 6 April 2021.

Bissell, David. 'Animating Suspension: Waiting for Mobilites.' Mobilities 2, no. 2 (July 2007): 277-298.

Bochsler, Regula, and Pascal Derungs, eds. Und führe uns in Versuchung: 10o Jahre Schweizer Werbefilm. Zurich: Museum für Gestaltung, 1998.

Boddy, William. 'Advertising Form, Technological Change and Screen Practices in the USA.' In Films That Sell: Moving Pictures and Advertising, edited by Bo Florin, Nico de Klerk, and Patrick Vonderau, 163-172. London and New York: Palgrave, 2016.

Budd, Mike, Steve Craig, and Clay Steinman. 'Fantasy Island: Marketplace of Desire.' In Mass Communication Review Yearbook, vol. 5, edited by Michael Gurevitch and Mark Levy, 291-301. Beverly Hills: Sage, 1985.

Butler, Jeremy G. Television: Critical Methods and Applications, $4^{\text {th }}$ ed. New York and London: Routledge, 2012.

Caldwell, John T. Televisuality: Style, Crisis, and Authority in American Television. New Brunswick: Rutgers University Press, 1995.

Chion, Michel. Audio-Vision: Sound on Screen, edited and translated by Claudia Gorbman. New York: Columbia University Press, 1994.

de Klerk, Nico. 'The Moment of Screening: What Non-Fiction Films Can Do.' In Triumph der Bilder: Kultur- und Dokumentarfilme vor 1945 im internationalen 
Vergleich, edited by Peter Zimmermann and Kay Hoffmann, 291-301. Konstanz: UVK, 2003.

Doane, Mary Ann. 'Information, Crisis, Catastrophe.' In Logics of Television, edited by Patricia Mellencamp, 222-239. Bloomington: Indiana University Press, 1990. Ellis, John. 'Broadcast TV as Sound and Image.' In Film Theory and Criticism: Introductory Readings, edited by Gerald Mast, Marshall Cohen, and Leo Braudy, 385-394. New York: Oxford University Press, 1999.

Ellis, John. Visible Fictions: Cinema, Television, Video. London: Routledge, 1992.

'Fact Sheets on the European Union: Audiovisual and Media Policy.' http://www. europarl.europa.eu/atyourservice/en/displayFtu.html?ftuId=FTU_3.6.2.html. Last accessed 6 April 2021.

Feuer, Jane. 'Narrative Form in American Network Television.' In High Theory / Low Culture, edited by Colin MacCabe, 101-104. Manchester: Manchester University Press, 1986.

Fischer, Ludwig. 'Vorwort.' In Programm und Programmatik: Kultur- und medienwissenschaftliche Analysen, edited by Ludwig Fischer, 11-15. Konstanz: UVK, 2005.

Fiske, John. Television Culture. London and New York: Routledge, 1987.

Flitterman, Sandy. 'The Real Soap Operas: Tv Commercials.' In Regarding Television: Critical Approaches - An Anthology, edited by E. Ann Kaplan, 84-96. Los Angeles: American Film Institute and University Publications of America, 1983.

Forster, Ralf. Ufa und Nordmark: Zwei Firmengeschichten und der deutsche Werbefilm 1919-1945. Trier: Wissenschaftlicher Verlag Trier, 2005.

Foucault, Michel. Power/Knowledge: Selected Interviews and Other Writings 1972-1977, edited by Colin Gordon. New York: Pantheon Books, 1980.

Haller, Andrea, and Martin Loiperdinger. 'Stimulating the Audience: Early Cinema's Short Film Programme Format 1906 to 1912.' In Early Cinema Today: The Art of Programming and Live Performance, edited by Martin Loiperdinger, 7-21. New Barnet and Herts: John Libbey, 2011.

Hammond, Nick. 'Why Digital Out-of-Home Advertising Is not Really Digital (Yet).' 9 October 2017, https://www.econsultancy.com/blog/69491-why-digital-out-ofhome-advertising-is-not-really-digital-yet. Last accessed 6 April 2021.

Hannam, Kevin, Mimi Sheller, and John Urry. 'Editorial: Mobilities, Immobilities and Moorings.' Mobilities 1, no. 1 (March 2006): 1-22.

Hickethier, Knut. Film- und Fernsehanalyse, $3^{\text {rd }}$ revised ed. Stuttgart and Weimar: Metzler, 2001.

Hofer, André. 'Schon 20 Jahre TV-Werbung!' In TV Transit Express: AG für das Werbefernsehen. Bern, January 1985, n.p.

Huhtamo, Erkki. 'Messages on the Wall: An Archaeology of Public Media Displays.' In Urban Screen Reader, edited by Scott McQuire, Meredith Martin, and Sabine Niederer, 15-28. Amsterdam: Institute of Network Cultures, 2009. 
'Impressum.' http://www.infoscreen.at/infoscreen/impressum/. Last accessed 21 March 2018.

'Infoscreen Austria.' http://www.infoscreen.at/. Last accessed 21 March 2018.

Kackman, Michael et al., eds. Flow Tv: Television in the Age of Media Convergence. New York and London: Routledge, 2011.

Kessler, Frank. 'Notes on Dispositif.' Unpublished working paper, 2002.

Kreimeier, Klaus, Antje Ehmann, and Jeanpaul Goergen, eds. Geschichte des dokumentarischen Films in Deutschland, vol. 2: Weimarer Republik 1918-1933. Stuttgart: Reclam, 2005.

Loiperdinger, Martin. 'Julius Pinschewer - Pionier, Klassiker und Avantgardist des Werbefilms.' In Julius Pinschewer. Klassiker des Werbefilms, DVD Booklet 3-12. Berlin: absolut Medien, 2010.

Lotz, Amanda D. The Television Will Be Revolutionized. New York: New York University Press, 2007.

McCarthy, Anna. Ambient Television: Visual Culture and Public Space. Durham, NC and London: Duke University Press, 2001.

'Mediaplaner.' http://www.infoscreen.at/werben/mediaplaner/. Last accessed 21 March 2018.

Meyers, Cynthia B. 'The Best Thing on TV: 196os us Television Commercials.' In Films That Sell: Moving Pictures and Advertising, edited by Bo Florin, Nico de Klerk, and Patrick Vonderau, 173-193. London and New York: Palgrave, 2016.

Modleski, Tania. 'The Rhythms of Reception: Daytime Television and Women's Work.' In Regarding Television: Critical Approaches - An Anthology, edited by E. Ann Kaplan, 67-75. Los Angeles: American Film Institute and University Publications of America, 1983.

Moran, Joe. 'November in Berlin: The End of the Everyday.' History Workshop Journal 57, no. 1 (Spring 2004): 216-234.

Oswald, Kathleen, and Jeremy Packer. 'Flow and Mobile Media: Broadcast Fixity to Digital Fluidity.' In Communication Matters: Materialist Approaches to Media, Mobility and Networks, edited by Jeremy Packer and Stephen B. Crofts Wiley, 276-287. London and New York: Routledge, 2012.

Outdoor Advertising Association of America (OAAA), 'History of ooH.' https://oaaa. org/AboutOOH/OOHBasics/HistoryofOOH.aspx. Last accessed 6 April 2021.

Outdoor Advertising Association of America (OAAA), 'ОоH Value Proposition.' https://oaaa.org/AboutOOH/OOHBasics/OOHValueProposition.aspx. Last accessed 6 April 2021.

Overpeck, Deron. 'Subversion, Desperation, and Captivity: Pre-film Advertising in American Film Exhibition Since 1977.' Film History 22, no. 2 (2010): 219-234. Reichert, Ramón, ed. Kulturfilm im 'Dritten Reich.' Vienna: Synema, 2006. 
Schwartz, Barry. Queuing and Waiting: Studies in the Organization of Access and Delay. Chicago: University of Chicago Press, 1975.

Schweizer, Harold. 'On Waiting.' University of Toronto Quarterly, no. 3 (2005): 777-792.

Schweizerischer Reklame Verband, ed. Die Grundlagen der Filmwerbung: Eine Wegleitung für Auftraggeber. Zurich, [1949].

Sheller, Mimi, and John Urry, eds. Mobile Technologies of the City. London and New York: Routledge, 2006.

Sheller, Mimi, and John Urry. 'The New Mobilities Paradigm.' Environment and Planning A 38 (2006): 207-226.

Sjöholm, Carina. Gå på bio. Rum för drömmar i folkhemmets Sverige. Stockholm and Stehag: Brutus Östlings Bokförlag Symposion, 2003.

Straw, Will. 'Pulling Apart the Apparatus.' Recherches sémiotiques 31, no. 1-2-3 (2011), https://www.erudit.org/fr/revues/rssi/2011-v31-n1-2-3-rssio1601/1027441ar/. Last accessed 6 April 2021.

Ströer Media Data. 'Campaign Media Digital: Infoscreen.' (January 2017). Last accessed 21 March 2018; no longer available online. For Ströer Media Data 2021 on Infoscreen and DOOH, see https://www.stroeer.de/fileadmin/regional/ wt_downloads/9395.pdf?Mediadaten\%2oInfoscreen\%202021.pdf

Ströer Media Data. 'Profil-Auf einen Blick.' https://www.stroeer.com/unternehmen/ profil/auf-einen-blick.html. Last accessed 6 April 2021.

Urry, John. Sociology Beyond Societies: Mobilities for the Twenty-First Century. London: Routledge, 2000.

Waller, Gregory A. 'International Harvester, Business Screen and the History of Advertising Film.' In Films That Sell: Moving Pictures and Advertising, edited by Bo Florin, Nico de Klerk, and Patrick Vonderau, 40-53. London and New York: Palgrave, 2016.

Williams, Raymond. Television: Technology and Cultural Form. London and New York: Routledge, 2003 [1974].

'Willkommen bei Infoscreen, Ihrem Premium-Partner für Video in der Öffentlichkeit.' https://www.infoscreen.de/en/plan-calculate/media-locations/. Last accessed 21 March 2018.

Vonderau, Patrick. 'Introduction: On Advertising's Relation to Moving Images.' In Films That Sell: Moving Pictures and Advertising, edited by Bo Florin, Nico de Klerk, and Patrick Vonderau, 1-18. London and New York: Palgrave, 2016.

Vonderau, Patrick. 'Kim Novak and Morgan Stairways: Thinking about the Theory and History of the Tie-in.' In Films That Sell: Moving Pictures and Advertising, edited by Bo Florin, Nico de Klerk, and Patrick Vonderau, 209-220. London and New York: Palgrave, 2016. 
Vouilloux, Bernard. 'Du dispositif.' In Discours, image, dispositif, edited by Philippe Ortel. Paris: L'Harmattan, 2008.

Zimmermann, Peter, and Kay Hofmann, eds. Geschichte des dokumentarischen Films in Deutschland, vol. 3: 'Drittes Reich' 1933-1945. Stuttgart: Reclam, 2005. Zimmermann, Yvonne. 'Advertising and Film: A Topological Approach.' In Films That Sell: Moving Pictures and Advertising, edited by Bo Florin, Nico de Klerk, and Patrick Vonderau, 21-39. London and New York: Palgrave, 2016.

Zimmermann, Yvonne, ed. Schaufenster Schweiz: Dokumentarische Gebrauchsfilme 1896-1964. Zurich: Limmat, 2011. 


\title{
6. Advertising as Commercial Speech: Truth and Trademarks in Testimonial Advertising
}

\author{
Patrick Vonderau
}

\begin{abstract}
This chapter explores the long history of moving images' promotional relation to trademarks by focussing on us American case law and a controversy that surrounded a brief moment in the feature film The Hangover II (2011). In the second part, the chapter develops and outlines a typology of moving image testimonials.
\end{abstract}

Keywords: screen advertising, public relations, testimonials, marketing, product placement

A few minutes into the farce of The Hangover II (2011), bachelor Stu and his 'wolf pack' of friends arrive at the airport to catch a plane to Thailand, where Stu plans to celebrate his second marriage. While anxious to avoid the disasters of an earlier bachelor party, relayed in the first movie of the Hangover franchise, Stu cannot keep his friends from instantly misbehaving. Marching into the departures area in a white colonial-style tropics outfit, Alan (Zach Galifianakis) greets Stu's Thai brother-in-law, sixteen-year-old wunderkind Teddy (Mason Lee) by implying the latter to be gay, and refuses to let Teddy sit down next to him in the waiting hall. 'Wolf pack only, find another chair', Alan declares, prompting Stu to put down the travel bag with which Alan had blocked the adjacent seat. 'Careful', Alan exclaims, 'that is a Lewis... a Lewis Vuitton', unknowingly mispronouncing the trademark name of the French luxury fashion house, Louis Vuitton Malletier (LVM).

This essay takes this brief and ultimately trivial moment in The Hangover II as an example of the intricate relationship between moving images and

Florin, B., P. Vonderau, Y. Zimmermann, Advertising and the Transformation of Screen Cultures. Amsterdam: Amsterdam University Press, 2021 DOI 10.5117/9789462989153_CHO6 
trademarks in contexts in which this relationship is, or could be, interpreted as being of a commercial nature. Although the mention of the brand in this film's opening moments has never been discussed as a form of undisclosed promotion or product placement, let alone as brand advertising, it is in many ways intrinsically related to the essential nature of advertising: a form of commercial speech. And while Vuitton here is only referred to for 3.4 seconds in speech, and visible on an over-the-shoulder travel bag from varying distances, discontinuously, inconclusively, for less than 20 seconds over the entire duration of the scene, neither the brevity nor the casual nature of that mention could prevent LVM from suing Warner Bros. Entertainment Inc. over 'misrepresenting' its fashion trademark. ${ }^{1}$ At the core of this lawsuit, which was settled in June 2012 in favour of Warner Bros., was the question of how the appearance of the bag in the film would be interpreted. I will take this question as a starting point to explore moving images' relation to trademarks more generally.

As noted elsewhere, trademarks are closely connected to ideas of control over consumer demand. ${ }^{2}$ How else would demand for particular goods be created if there were no criteria for distinguishing between similar goods in the first place? Trademarks are signifiers that establish the right of sellers to exclude others from using the sellers' reputation for the quality of their goods. Similar to patents or copyrights, trademarks thus facilitate the deployment of informational capital. Although they may have existed since ancient times, their codification into law historically relates to the advent of capitalism. Both in Europe and in the United States, trademarks gradually received protection between approximately 1870 and 1905 . The codification of trademark law thus came to introduce a key distinction between goods on both continents, a distinction that not only contributed to the emergence of capitalist markets and market theories but also incentivized, and established, reputations to begin with. At the same time, significant differences in legal and cultural practice led to largely different histories of screen advertising in the United States and Europe. Focussing on American case law, and the aggressively litigious us situation, this chapter seeks to show how this difference played out in one particular case - the use of

1 Louis Vuitton Mallatier S.A. v. Warner Bros. Entertainment Inc., United States District Court, Southern District of New York, 11 Civ. 9436 (ALC) (HBP), 868 F. Supp. 2d 172 (SDNY 2012).

2 Patrick Vonderau, 'On Advertising's Relation to Moving Pictures', in Films that Sell: Moving Pictures and Advertising, ed. Bo Florin, Nico de Klerk, and Patrick Vonderau (London: British Film Institute, 2016), 1-18. 

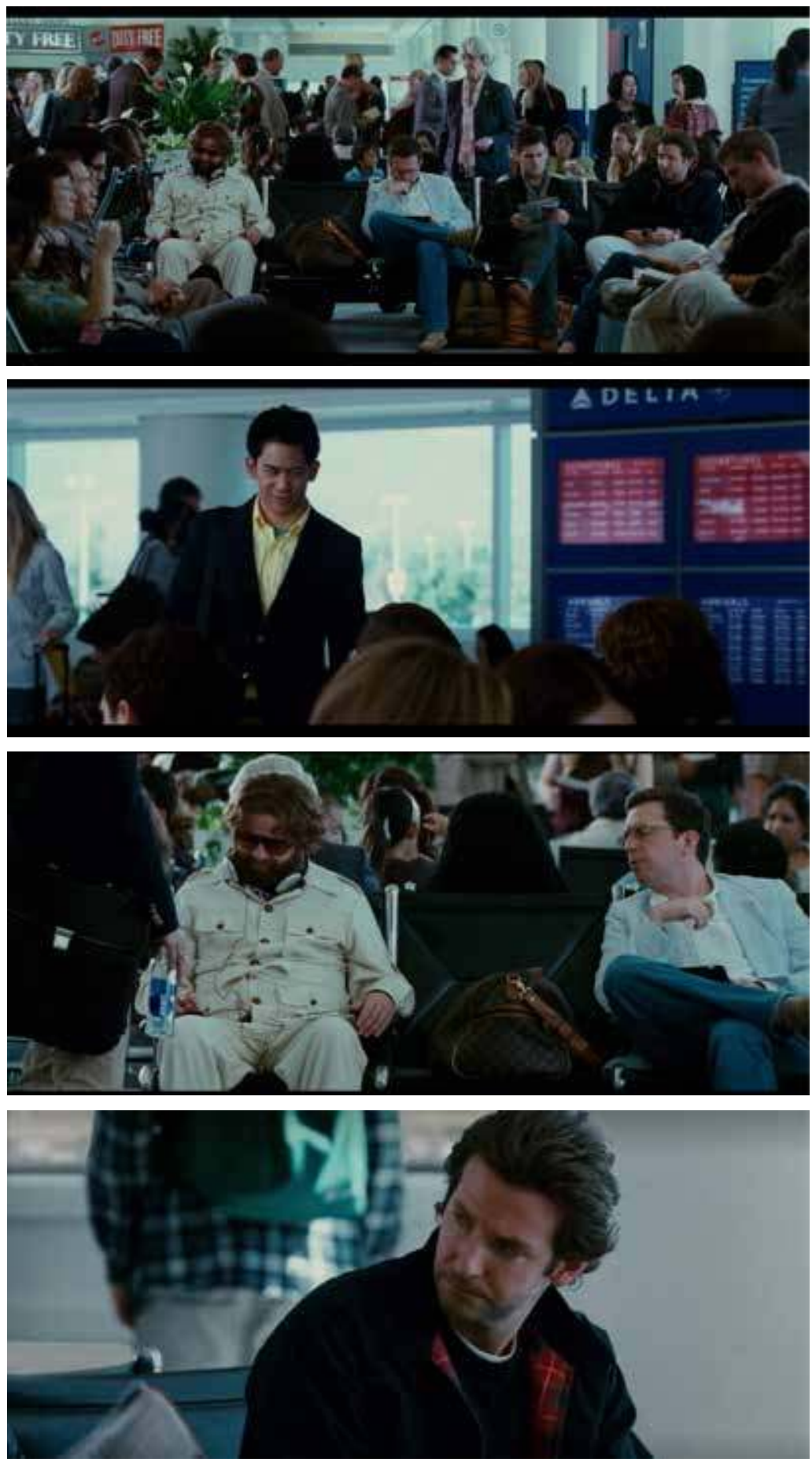

Figures 6.1-6.4: The Hangover II (2011): 'Careful, that is a Lewis Vuitton.' 
trademarks in testimonial advertising. ${ }^{3}$ After briefly sketching the legal situation that led to the litigation against the makers of The Hangover II, the chapter analyses in more detail how 'commercial speech' translates into the aesthetics of feature film-making. It concludes by contextualizing its findings within a brief history of indirect advertising, and with a typology of moving image testimonials. The overall objective of this chapter is to understand how legal frameworks and practices play into advertising as a cultural production, and into the institutional codification of this production. ${ }^{4}$

\section{Moving Images and Commercial 'Speech'}

Given the significance trademarks hold for distinguishing products and for building reputations, and the revenue today generated through trademark licensing, it may not come as a surprise that brand owners have grown increasingly nervous about potential misuse of their brands in entertainment and other media content. Mark Bartholomew and John Tehranian have documented the legal history that led to a number of trademark infringement cases after 2010, including The Hangover II, noting a recent 'softening' of the legal approach to balance trademark rights with freedom of artistic expression. ${ }^{5}$ It would, however, be misleading to understand present court decisions in the United States as indicating a general shift in legislation towards a higher protection of non-commercial speech, not only because trademark and intellectual property disputes have increased over the past decade but also because the legal distinction between commercial and non-commercial speech, and between infringing and non-infringing uses of a trademark, is far from satisfactory.

3 A comparative study of European or Asian legal practices would certainly be rewarding, but is outside of the scope of this chapter. What complicates such a study is the heterogeneity of the respective legal systems. There is also little historical evidence so far that indirect advertising techniques and practices have played a comparable role in Europe or in Asia.

4 Cf. my chapter on Charles Wilp in this volume.

5 Mark Bartholomew and John Tehranian, 'The Changing Landscape of Trademark Law in Tinseltown: From Debbie Does Dallas to The Hangover', in Hollywood and the Law, ed. Paul McDonald et al. (London: British Film Institute, 2016), 47-68. See also, Paul Siegel, ed., Cases in Communication Law, $4^{\text {th }}$ ed. (Lanham, Boulder, and New York: Rowman \& Littlefield, 2014), 191-198. 
Intellectual property lawyer Charles E. Colman has criticized the legal scholarship and often dismissive case law on the subject in the United States as providing an 'insufficiently nuanced analysis of communicative dynamics in the parodic context (if not in trademark disputes, more generally), ${ }^{6}$ In the United States, legal authority is distributed between federal and state laws; while trademark law is traditionally the preserve of federal law, judges involved in civil actions on the state level also make laws by developing case-based frameworks. Federal principles and individual 'tests' thus come together in constituting the legal setting for deciding on trademark issues. ${ }^{7}$ Colman and others describe this combined lawmaking as 'reductionist' and lacking statutory conventions especially when it comes to the legal interpretation of (moving) images. ${ }^{8}$

In Louis Vuitton Malletier S.A. v. Warner Bros. Entertainment Inc. and in many similar cases, judges often rely on two rudimentary standards. First, on the 1946 Lanham Act, which protects trademarks against uses 'in commerce' that are 'likely to cause confusion' among consumers as to the 'origin, sponsorship, or approval' of a trademark representation. ${ }^{9}$ Second, in addition to federal trademark law, judges regularly look to the precedent of other judicial decisions. In this context, the Second Circuit's decision in the 1989 case of Rogers $v$. Grimaldi, a case that came to establish a widely used multifactorial framework to test, and elaborate upon, the Lanham Act. ${ }^{10}$ As Colman explains, under the Rogers test, the Lanham Act is not to be applied to expressive works unless the trademark has absolutely no artistic relevance to the artistic work, or explicitly misleads as to the source or the content of the work. ${ }^{11}$ Over the past 20 years, this translation of federal law into civil action lawmaking practice

6 Charles E. Colman, 'Trademark Law and the Prickly Ambivalence of Post-Parodies', University of Pennsylvania Law Review Online 11 (2014), 163; New York University School of Law, Public Law Research Paper No. 14-45.

7 Eric Hoyt et al, 'Introduction: On the Legal Lives of Hollywood', in Hollywood and the Law, ed. Paul McDonald et al. (London: British Film Institute, 2016), 8-10. This text provides a useful overview of the us legal system.

8 Colman, 'Trademark Law', 50; Elizabeth G. Porter, 'Taking Images Seriously', Columbia Law Review 114.7 (2014): 1687-1782, especially 1777-1778; University of Washington School of Law Research Paper No. 2014-14.

915 U.S.C. $\S 1125(\mathrm{a})(1)(2012)$.

10 Rogers v. Grimaldi, 875 F.2d 994 (2d Cir. 1989). The case is documented in Bartholomew and Tehranian, 'The Changing Landscape of Trademark Law', and refers to the title of Federico Fellini's Ginger e Fred (1986). Ginger Rogers took legal action against an alleged trademark infringement in the film's title.

11 Colman, 'Trademark Law', 40; see also Bartholomew and Tehranian, 'The Changing Landscape of Trademark Law', 54-55. 
has seemingly strengthened constitutional protection for artists, leading to the apparent 'softening' of the legal view on expressive trademark uses observed by Bartholomew and Tehranian above. As Colman makes clear, however, the continuing lack of interpretative standards when dealing with such 'expressive' forms, and (moving) images in particular, allows judges to do without any 'analysis at all beyond the usual multifactor test' and to favour 'value judgments about objects whose very nature is alien to the analytic framework used. ${ }^{12}$

Louis Vuitton's civil action against Warner Bros. makes for a case in point. In briefly describing a single scene of The Hangover II - the aforementioned 'airport scene' - District Judge Andrew L. Carter, Jr., found that Vuitton's complaint of a trademark misrepresentation was implausible. The plaintiff had invoked the Lanham Act, but Carter argued that the film's use of the bag was protected under the Rogers framework. ${ }^{13} \mathrm{He}$ understood that the defendant 'intended an artistic - i.e., non-commercial association with the plaintiff's mark' because of the generic and fictional character of this particular scene:

\begin{abstract}
Alan's terse remark to 'be careful' because his bag 'is a Lewis Vuitton' comes across as snobbish only because the public signifies Louis Vuitton [...] with luxury and a high society lifestyle. His remark also comes across as funny because he mispronounces the French 'Louis' like the English 'Lewis,' and ironic because he cannot correctly pronounce the brand name of one of his expensive possessions, adding to the image of Alan as a socially inept and comically misinformed character. [...] Lastly, Louis Vuitton is objecting to a statement made by a fictional character in a fictional movie, which it characterizes as an affirmative misrepresentation. ${ }^{14}$
\end{abstract}

To complicate the issue, Vuitton actually had not filed a complaint against Warner Bros. because of its use of a Vuitton bag or because they felt the studio had misled the audience into believing that they had sponsored or were affiliated with the film. Rather, the plaintiff complained against the use of a knock-off of its Keepall bag in the film, since the 'Vuitton'

\footnotetext{
12 Colman, 'Trademark Law', 41 and 54; see also Ashley E. Hofmeister, 'Louis Vuitton Malletier v Dooney \& Burke: Resisting Expansion of Trademark Protection in the Fashion Industry',Journal of Business \& Technology Law 3.1 (2008): 187-205.

13 Louis Vuitton Malletier S.A. v. Warner Bros. Entertainment Inc., 2012, 5.

14 Ibid., 15.
} 
shown was actually produced by Diophy, an American company using a monogram design intentionally similar to Vuitton's famous Toile Monogram. In other words, Vuitton argued that consumers might be confused about the bag, not the scene, and that they might take the Diophy knock-off as a real Vuitton bag, implying that the defendant intended to dupe consumers into buying another company's products by showcasing a trademark-infringing prop.

Carter's opinion on the matter certainly merits more nuance and aesthetic insight than other us court orders in trademark disputes related to media entertainment. At the same time, however, even this wellinformed opinion remained within the limits of a legal doctrine focussed on speech. It described one sentence of spoken language and one brief scene without commenting on that scene's visual, narrative, or rhetoric integration into the overall film, or on the relation of this (knock-off) trademark to other trademarks in the same movie, and importantly also failed to note the ambiguity in the ways the 'Vuitton' is 'spoken' about. Is this indeed a purely non-commercial association? If so, what distinguishes commercial from non-commercial speech? Given the long history of verbal, pictorial, or audiovisual endorsements of products for advertising purposes, and the current abundance of commercial speech in forms and formats unregulated by us federal law, such as YouTube 'influencer' videos, promotional Tweets, or paid-for Facebook 'Likes', Louis Vuitton Malletier S.A. v. Warner Bros. Entertainment Inc. is an interesting contemporary starting point to elaborate if, and how, legal discourse shapes advertising practice.

\section{The Hangover II: Art and/or Commerce?}

To begin with, the film's sounds and images never actually represent LVM in the way such representation is usually conceived in the sense of an indexical bond between reality and its photographic rendition, because what the film shows is a Diophy bag, and what it speaks of is a 'Lewis Vuitton', leaving the association between LVM and the prop as one to be made by the audience. Although it is not difficult to make this association, it still has to be established as a factual one by a viewer willing, and able, to read against the film's own explicit construction of a Lewis Vuitton-Diophy bag. In short, while it is historically untrue that Diophy bags are identical to Vuitton bags, it is true that the former may be mistaken for the latter. Such a reading, of course, is entirely in accordance with a generic logic 
where pleasure often emanates, as Rick Altman contends, at 'crossroad events' prompting viewers to choose between a cultural norm and generic pleasure. ${ }^{15}$ While enjoying manslaughter is perverse in reality, reading a horror film along cultural norms would ruin the pleasure of reading it as genre. Similarly, the airport scene in The Hangover II guides viewers down a generic road where they can laugh about luxury bags as empty, unstable signifiers associated with racist, socially awkward, and snobbishly misinformed behaviour.

Yet there is an ambivalence here that relates to the problem of explaining the scene in simple oppositional terms, as either true or false in associating a trademark, or as either successfully or unsuccessfully parodistic in how it is shown. In the context of previous Vuitton trademark disputes, parody had been legally defined

as a simple form of entertainment conveyed by juxtaposing the irreverent representation of the trademark with the idealized image created by the mark's owner. [...] A parody must convey two simultaneous - and contradictory - messages: that it is the original, but also that it is not the original and is instead a parody. ${ }^{16}$

Following this doctrine, The Hangover II was successful in conveying the double message of (not) presenting an original Vuitton bag, and thus not infringing on Vuitton's trademark. Yet what, if anything, is actually parodied here - is it the bag or the attitude of its bearer, or perhaps on a metalevel the widespread practice of inserting endorsements of luxury fashion into 'non-commercial' contexts? And does this narrow legal definition of parody sufficiently acknowledge that The Hangover II hardly articulates a critique of high-end fashion, instead engaging viewers in a 'post-parodic', ${ }^{17}$ if not directly affirmative relationship with brands going beyond a 'simple' attitude of loyalty or opposition? The Diophy prop's association with Vuitton is not just 'funny' or 'ironic', it relates to the film's genericity and also to a widespread ambivalence in featuring famous fashion brands that extends well beyond this film and even cinema.

But let's stay within the film's universe for a moment to take the role of an advocatus diaboli, reversing our analytical position for a thought 
experiment. Judge Carter followed the legal doctrine in defining commercial speech as 'speech that does no more than propose a commercial transaction', emphasizing in his opinion that The Hangover II certainly did a lot more than that: he saw the film primarily as an 'artistic work'. And yet, is there indeed 'no indication' that the use of the Diophy bag was 'commercially motivated'? ${ }^{18}$ What if Vuitton was right? Broadening the analysis beyond the single scene, it is hard to miss the elaborate placement of trademarks throughout the film, often extending well beyond narrative functionality (not to speak of cinematic realism). The Hangover II pokes fun at many brands. Before the airport scene, we see the friends at IHOP, the International House of Pancakes, presented as a most unlikely place to have an amusing bachelor party: cantaloupe pancakes, orange juice with a napkin on top, old people, and no alcohol - 'We are at fucking IHOP!', one of the characters exclaims. Or consider Alan's first encounter with Teddy at the airport, where he refers to Teen People Magazine as having provided him with his knowledge about gay wunderkind boys ('It's true, I have read it in Teen People!'). Similar punchline references to established trademarks include P.F. Chang's, Long John Silver's, MSNBC, Fanta soda, Skype, Hard Rock Café, and Bally Total Fitness, and are complemented by traditional product placements (for Delta Airlines, Singha beer, Adidas, or Smart Water) and more subtle fashion brand appearances, including Ike Behar (T-shirts) and Oliver Peoples (sunglasses).

If the film qualifies as an artistic work, then product placements form part of its alleged artistry. Neither the Vuitton bag nor other trademarks appeared by chance. ${ }^{19}$ Rather, each inclusion was clearly calculated to appeal to an audience knowledgeable of on-screen endorsements, and favouring some brands over others. The ambivalence here obviously consists in establishing a background of some less-fitting brands (such as Vuitton) to offset more 'authentic' labels against this background, yet without alienating any of the two consumer groups. Seen from the male target audience's perspective,

18 Louis Vuitton Malletier S.A. v. Warner Bros. Entertainment Inc., 2012, 7 and passim.

19 Given constant scripts and rights clearances procedures during us mainstream feature film production, and given the fact that property master Russell Bobbitt is an industry veteran, it is extremely unlikely that any branded prop in use in the film was accidental. For a brief history of product placements, see Jay Newell, Charles T. Salmon, and Susan Chang, 'The Hidden History of Product Placement', Journal of Broadcasting and Electronic Media 50.4 (2006): 575-594; and Patrick Vonderau, 'Kim Novak and Morgan Stairways: Thinking about the History and Theory of the Tie-In', in Films that Sell, ed. Florin, de Klerk, and Vonderau, 209-222. 
it may seem absurd to have a bachelor brunch at IHOP, or to meet your adventure-loving buddies with a collection of Vuitton bags at the airport, but the brands themselves are nevertheless featured in their suggested qualities - as fresh and delicious, or luxurious and exclusive, respectively. And again, if this indeed is the case, what then distinguishes commercial from non-commercial speech?

The Louis Vuitton Malletier S.A. v. Warner Bros. Entertainment Inc. case file only provides peripheral commentary on the question of what, in the eyes of the court, would have turned the Lewis Vuitton mention into a proper (Diophy) bag promotion. This includes a use of trademarks that is clearly more than 'legally de minimis', that is 'actionable', and that is related to actual consumer purchasing decisions. ${ }^{20}$ In the judge's opinion, the film failed on all three counts; however, he did not take the film's general brand treatment into account. From a legal perspective, it in fact seems easier to define what commercial speech is not, than to state what it is. ${ }^{21}$ Speech someone pays money to disseminate does not simply count as commercial, for otherwise all paid advertisements would qualify as commercial speech. Even ads, however, may be 'complex mixtures of commercial and non-commercial elements'. ${ }^{22}$ Speech that is sold is not rendered commercial because of its sale; otherwise, all movies, books, and other media, would be commercial speech. Speech on commercial subjects is not necessarily commercial speech, or else news would qualify; speech is not commercial because it solicits money, or religious speech would often qualify. For lawmakers, commercial speech is more objective than non-commercial speech because its truth is more easily verifiable, and its truthfulness is clearly protected against false and misleading claims (such as deceptive advertisements). ${ }^{23}$

According to a broad definition suggested in 2002 by the California Supreme Court, the commercial or non-commercial character of a statement can be identified by considering the speaker, the intended audience, and the content of the message. If the speaker is engaged in commerce or acting on behalf of someone who is, if the intended audience is likely to be actual or potential buyers or customers of the speaker's goods or services, and if the speech consists of 'representations of fact' about these

20 Louis Vuitton Malletier S.A. v. Warner Bros. Entertainment Inc., 2012, 5.

21 Here and in the following, Steven G. Brody and Bruce E.H. Johnson, Advertising and Commercial Speech, 2nd ed. (New York: Practising Law Institute, 2004), especially Chapter 2.

22 Ibid., 2-11 (quoting Justice Steven in a Supreme Court case).

23 Ibid., 2-6. 
products or services, then we would have an instance of commercial speech. ${ }^{24}$ Under this newer regulation of speech, most if not all corporate speech would count as commercial speech, but the us Supreme Court has yet to decide whether the Californian rule will have an impact on federal level. This leaves state bodies to implement the governmental regulation of speech with nothing but guidelines for suggesting standards of communication. Of central importance in this respect are the Federal Trade Commission's (FTC) Endorsement Guides designed to help advertisers meet the legal standard of constitutional protection for truthful commercial speech, in the sense of a minimal regulatory standard. ${ }^{25}$ If nothing can safely be exempt from being a commercial statement, the Guides seem to say, let's at least make sure that advertisements are 'honest' about themselves, and about the good or service at hand. Addressing television, print, and radio, as well as social media, the FTC focusses on endorsements and testimonials in advertising, giving detailed advice on issues of disclosure, solicitation, or compensation, in order to avoid such advertising being found as deceptive. In doing so, the FTC authoritatively identifies endorsements and testimonials with the 2002 definition of commercial speech. ${ }^{26}$

Judge Carter ruled out the possibility that Alan's moronic statement 'Careful, that is a Lewis... a Lewis Vuitton' could be interpreted as commercial speech. But are this statement, its speaker, and the intended audience indeed categorically different from those of an on-screen endorsement, in light of the strategic brand placements throughout the film, and given the legal equation of endorsements with commercial speech? Since no transaction between LVM and Warner Bros. has been documented that would evidence such a promotional arrangement, the question may seem purely academic, but it prompts us at least to relate trademark law to (moving) images, and to the wider history of advertising endorsements and testimonial practices. In the remainder of this chapter, I propose that

\footnotetext{
24 Ibid., 2-24.

25 The FTC's Endorsement Guides: What People Are Asking, https://www.ftc.gov/tips-advice/ business-center/guidance/ftcs-endorsement-guides-what-people-are-asking (last accessed 6 April 2021).

26 'An endorsement means any advertising message (including verbal statements, demonstrations, or depictions of the name, signature, likeness or other identifying personal characteristics of an individual or the name or seal of an organization) that consumers are likely to believe reflects the opinions, beliefs, findings, or experiences of a party other than the sponsoring advertiser, even if the views expressed by that party are identical to those of the sponsoring advertiser.' Federal Trade Commission, 16 CFR Part 255, Guides Concerning the Use of Endorsements and Testimonials in Advertising.
} 
the prevalence of these practices in screen contexts is not coincidental, but is intrinsically related to moral, normative, and legal concerns over commercial speech.

\section{Testimonials and Endorsements: A Short History}

While 'commercial speech' was first legally defined in a 1942 us Supreme Court Case, the practices of advertising endorsements and testimonials reach back to the nineteenth century. And while the FTC treats endorsements and testimonials largely as synonyms, and as related to either product placement, sponsored content, or disguised commercials, both endorsements and testimonials first developed as more distinctive forms of indirect promotion. Testimonials insert into the negotiation between buyer and seller the words of a third party, presented as disinterested in the commercial transaction but in some way knowledgeable about the product and willing to share that knowledge. Historically, testimonials have been given both by experts whose opinions carry weight because of occupational knowledge, established talent, or a life lived in the public eye, and by typical or average consumers whose experience will be recognized and widely shared. One key function of this practice initially was to forge commercialized 'advice networks' connecting specific target groups to the company and to each other. ${ }^{27}$

To illustrate, consider the historical beginnings of testimonial advertising in newspapers and mass distribution journals such as Harper's Weekly, Scribner's, Century, Ladies Home Journal, Saturday Evening Post, or Good Housekeeping in the late nineteenth century. ${ }^{28}$ Testimonials here were introduced for products whose value was not primarily or solely defined via price, but via use value - and where such use value would appear uncertain or contestable to consumers. Think of cosmetics, tobacco, and importantly, patent medicine - three categories of commodities that widely came to be associated with testimonial ads in mass-circulation magazines between 1870 and $1915 .{ }^{29}$ For instance, Paine's Celery Compound, created by phar-

27 Elysa R. Engelman, 'The Face That Haunts Me Ever': Consumers, Retailers, Critics, and the Branded Personality of Lydia E. Pinkham (dissertation, Boston University, 2003).

28 For a historical overview, see Marlis Schweitzer and Marina Moskowitz, eds., Testimonial Advertising in the American Marketplace: Emulation, Identity, Community (London: Palgrave, 2009).

29 Cf. Kerry Segrave, Endorsements in Advertising (Jefferson, NC: McFarland, 2005), especially $5^{-13}$. 
macist Milton K. Paine in 1882 to treat insomnia, dyspepsia, nervousness and excitability, stress, loss of appetite, rheumatism, and colds, and based not least on a strong dose of alcohol, required testimonials that its grand claims as a quasi-universal cure were indeed justified. Using the written attestation of both average consumers and authority figures, Paine's producer Wells \& Richardson in 1892 even distributed a free booklet, entitled Our Album, through pharmacies to underline such claims. Readers of mass-circulation magazines would thus become aware of the product, or be reminded of its existence and reassured of its value at the local point of sale, not only by the pharmacist selling the cure but also, for instance, by James McShane, the Mayor of Montreal ('Overworked! Run-Down! Lost his Appetite!'); by a 'grateful father' recommending the product 'for all children's troubles'; and by a very 'nervous' Canadian named James Venn (213 Wilton Avenue, Toronto - 'His Prayer Was Answered'). In marketing the product by establishing bonds between consumers, Wells \& Richardson responded to the need to defend a trademark both against the competition and against a widely shared distrust in the type of product.

In short, testimonials are representations of consumer experience in the form of first-hand narratives provided to demonstrate that the promise of a given good or service has proven true for someone. ${ }^{30}$ They appear as coincidental or to be given freely, but codify word-of-mouth recommendations in order to make them public. Agencies introduced this practice as a marketing tool to cope with the prolongation of commodity chains caused by the advent of mass retail and mail-to-order services, that is, at the historical moment when relations between producers and consumers became more indirect, even in a literal geographical sense. ${ }^{31}$ In this context, testimonials came to simulate a sphere of informal trading or gift exchange within an otherwise increasingly rigidly formalized marketplace, suggesting to consumers that, through their consumption, they would be able to join a community of people sharing experiences. Images are important here, as they allow 'eclipsing the verbal basis of testimonials by pictorial associations rather than explicit mentions'. ${ }^{22}$ That is, while movement itself as a defining quality of the moving image remained secondary to the quality of images to eclipse words, such images

30 Schweitzer and Moskowitz, 'Introduction: The Spirit of Emulation', in ibid., 1-22.

31 James R. Beniger, The Control Revolution: Technological and Economic Origins of the Information Society (Cambridge, MA: Harvard University Press, 1986), 344-389.

32 Ibid., 2. 
(moving or not) allowed for the integration of testimonials in new social and aesthetic contexts, such as cinema.

Historically, there is a fine distinction between testimonials and endorsements in that endorsements generally lack the promotional personwho-knows or 'advice' element constitutive of early testimonials. First commissioned in high society circles, endorsements have come to be defined as based on celebrity appeal rather than advice - as a well-known person's often undisclosed paid use of a particular product, without any explanatory text or narrative. Given the increasing use of moving images over the past hundred years, as well as the broad spectrum of more suggestive techniques of indirect promotion, however, the boundaries between testimonials and endorsements have become blurred. Still, the FTC today maintains a definition that identifies endorsements primarily with undisclosed promotional statements. According to FTC guidelines, the use of a celebrity in commercial speech normally would not constitute an endorsement because consumers likely recognize the celebrity is speaking on behalf of a brand, while celebrities with no long-term association with a brand and hence, unrecognizable in their promotional role, would count as endorsers 'even if the celebrity never actually makes any overt testimonial statements' ${ }^{33}$

\section{More than Just Handbags: A Typology of Moving Image Testimonials}

While actor Zach Galifianakis might be an ironically inapt endorser of Vuitton handbags, actress Angelina Jolie is not. In what appears to be a surprising coincidence, Jolie starred in an advertising film, in print ads, and on a Vuitton micro site to promote the company's 'core values' to wealthy jet-setters in 2011. While The Hangover II was set in Thailand, Vuitton's simultaneously released campaign was set in neighbouring Cambodia. The Jolie film also engaged in storytelling; in this case, Jolie related seemingly unscripted anecdotes about her soul-searching Asian travels, ending with a 'making-of' montage that showed her dreamily posing with a Vuitton bag for star photographer Annie Leibovitz. ${ }^{34}$ The coincidence might explain

33 Roy L. Moore, Carmen Maye, and Erik L. Collins, Advertising and Public Relations Law, $2^{\text {nd }}$ ed. (New York and London: Routledge, 2011), 255-256.

34 YouTube versions of the film differ in length and editing, varying between seven and ten minutes. See, for example, Angelina Jolie's Journal to Cambodia, www.youtube.com/ watch?v=pTaN3QLsAkA (last accessed 6 April 2021). 
Vuitton's litigious response to Galifianakis's mock endorsement, not least since Vuitton had invested close to \$10 million in the Jolie endorsement deal. ${ }^{35}$ Yet neither Jolie's nor Galifianakis's association with the trademark might qualify as an endorsement in strictly legal or FTC terms, that is, as an undisclosed form of commercial speech.

The inadequacy in terms of formal legal descriptions of endorsements and testimonials urges us to attempt a preliminary typology of their forms in moving images. Despite variations and differences between testimonials and endorsements, the 'human element' transgressing the instrumentality of a purely commercial message is, again, key for establishing or speaking to a community of potentially like-minded people. Direct address, first-person narrative, and product in use are the three more specific elements that have come together in shaping the historical paradigm of what has been recognized as an advertising testimonial, in printed as much as in moving images, while celebrity endorsements are usually identified with more open, implicit, or non-verbal associations. In 1929, the formula was neatly described by Stanley Resor, then president of J. Walter Thompson, as a way to convey promotion through the 'medium of personalities'. ${ }^{6}$ As Resor observed, consumers were looking to see product or use value 'personified', in what he understood to be a quest for social, moral, or taste authority. While testimonials in print ads thrived especially in the 1920s and 1930s, their audiovisual counterparts began to spread more widely during the 1970s and have not stopped ever since. ${ }^{37}$

A preliminarily typology of moving image testimonials may be built on the following broad classification:

(1) traditional screen advertising: commercials or theatrical ads using the testimonial technique to convey a promotional message, either by employing an anonymous model or actor for presenting a product or for showing a product in use, or by employing a celebrity, to the effect of integrating personal appeal into an otherwise short, conventional advertising format; ${ }^{3}$ 
(2) customer and expert testimonials: 'real people', that is publicly often unknown yet apparently historical and not fictitious persons appearing in informal or interview situations disclosed or otherwise easily identifiable as advertising, but varying in length and format, in order to authenticate the value of a trademark through demonstration or personal statement; 39 (3) 'embedded advertising': in the Federal Communications Commission's definition, forms of product placement (using a brand as a prop, with a fee paid by the brand to promote the product), and product integration (including a brand into a plot or dialogue), $4^{40}$ but the category could be broadened to refer to sponsored content, to the promotional inclusion of brands in non-promotional content, in both traditional screen media and social media, and in a form that is more or less undisclosed.

These three broad categories or ideal types indicate a spectrum of 'embeddedness', varying from forms that are clearly demarcated as advertising within a programme structure to forms that run unobtrusively in and out of a programme flow. The strategic communicative intent with either form is obvious: to prompt a mode of viewer interaction that responds to the ad's aim of promoting consumption. 'Personifying' the value of a product or service here means to create 'intimacy at a distance' in the sense of Horten and Wohl's para-social interaction - as an intimacy that is 'extremely influential with, and satisfying for, the great numbers who willingly receive it and share in it'. ${ }^{41}$ As Horten and Wohl underlined, this mode of interaction is not manipulatively working against a viewer's will, but is predicated on the existence of a communicative contract between viewer and medium: both knowingly engage in the illusion of direct address. The regulatory concern here is that undisclosed or fully embedded testimonials would constitute a 'breach of contract' - in the legislatorial view, they fall outside of the institutionally administered exchange between a medium and its publics.

Alan's terse Lewis Vuitton remark in The Hangover II does not qualify as product integration in legal terms, because there is no evidence of an economic transaction between LVM and Warner Bros. and hence no legal reason to disclose anything. ${ }^{42}$ As I have argued above, the remark neverthe-

Think, for instance, of the Jolie Vuitton campaign.

40 Federal Communications Commission, 'Notice of Inquiry and Notice of Proposed Rulemaking in the Matter of Sponsorship Identification Rules and Embedded Advertising', 73 Fed. Reg. 43194. 41 Donald Horton and Richard R. Wohl, 'Mass Communication and Para-Social Interaction', Psychology 19 (1956): 216 (my emphasis).

42 Rita Marie Cain, 'Embedded Advertising on Television: Disclosure, Deception, and Free Speech Rights', Journal of Public Policy \& Marketing 30.2 (Fall 2011): 226-238. 
less is 'funny' partly because it mocks the way brands are regularly placed in mainstream feature films. In other words, this and other trademark appearances in the film deliberately play with the audience's knowledge of advertising practices. What regulators miss is the fact that testimonials have been part and parcel of the institution of cinema for decades. Trademarks are intrinsic to the experience of cinema; we find them regularly in film, as identifiable products fill on-screen worlds. Trademarks thus are not 'outside' of contractual agreements but internalized as constitutive for fictional truths in mainstream entertainment and it is only because of this that they also may be comically alluded to.

\section{Conclusion}

There is indeed plenty of historical evidence that indirect forms of promotion were a long-standing paradigm for theatrical on-screen advertising in the United States, rather than a marginal phenomenon. As Jeremy W. Groskopf and others have documented, cinema was abandoned early as a key medium for direct advertising because of concerns over audience irritation, and still holds a marginal position in this respect vis-à-vis television and social media. ${ }^{43}$ At the same time, 'tie-ins' or what were later referred to as product placements, came to be an integral part of production planning in the 1930s, and have since professionalized into their own industry branch that includes specialized agencies, studio departments, and occupational roles. One may thus argue that in the United States, cinema's social and moral norms have crystallized around the very form of promotion that legal norms have failed to adequately address. Compared to the history of screen advertising in Europe, where promotional film was part of regular theatrical programming early on, ${ }^{44}$ but also considerably more strictly regulated, American advertisers had to work their way not so much around legal notions of commercial speech, but around what social psychologists call 'reactance effects' - that is, motivational states by which individuals react when they feel their freedom of choice being restricted..$^{45}$ Hence, despite the overtly litigious approach of trademark owners in the United

43 Jeremy W. Groskopf, Profit Margins: The American Silent Cinema and the Marginalization of Advertising (dissertation, Georgia State University, 2013); see also Vonderau, 'On Advertising's Relation to Moving Pictures'.

44 Vonderau, 'On Advertising's Relation to Moving Pictures', 12.

45 Jack W. Brehm, Theory of Psychological Reactance (New York: Academic Press, 1966). 
States, and despite the long history of legal philosophy this chapter has documented, what mattered historically and still does is how moving image advertising is experienced, rather than how it is judged. Those laughing about 'Lewis Vuitton', if only because there was so little else to enjoy in The Hangover II, just got the point: the fictional truth of a trademark is not a matter of speech as such, but of how those bags, T-shirts, or soft drinks are spoken about.

\section{Bibliography}

Altman, Rick. Film/Genre. London: British Film Institute, 2000.

Bartholomew, Mark, and John Tehranian. 'The Changing Landscape of Trademark Law in Tinseltown: From Debbie Does Dallas to The Hangover.' In Hollywood and the Law, edited by Paul McDonald et al., 47-68. London: British Film Institute, 2016.

Beniger, James R. The Control Revolution: Technological and Economic Origins of the Information Society. Cambridge, MA: Harvard University Press, 1986.

Brehm, Jack W. A Theory of Psychological Reactance. New York: Academic Press, 1966. Brody, Steven G., and Bruce E.H. Johnson. Advertising and Commercial Speech, 2nd ed. New York: Practising Law Institute, 2004.

Cain, Rita Marie. 'Embedded Advertising on Television: Disclosure, Deception, and Free Speech Rights.' Journal of Public Policy \& Marketing 30, no. 2 (Fall 2011): 226-238

Colman, Charles E. 'Trademark Law and the Prickly Ambivalence of Post-Parodies.' University of Pennsylvania Law Review Online 11 (2014).

Engelman, Elysa R. 'The Face That Haunts Me Ever': Consumers, Retailers, Critics, and the Branded Personality of Lydia E. Pinkham. Dissertation, Boston University, 2003.

Groskopf, Jeremy. 'Profit Margins: Silent Era Precursors of Online Advertising Tactics.' Film History 24, no. 1 (2012): 82-96.

Hofmeister, Ashley E. 'Louis Vuitton Malletier v Dooney \& Burke: Resisting Expansion of Trademark Protection in the Fashion Industry.' Journal of Business \& Technology Law 3, no. 1 (2008): 187-205.

Horton, Donald, and Richard R. Wohl. 'Mass Communication and Para-Social Interaction.' Psychology 19 (1956): 215-230.

Hoyt, Eric et al. 'Introduction: On the Legal Lives of Hollywood.' In Hollywood and the Law, edited by Paul McDonald et al. London: British Film Institute, 2016.

Marchand, Roland. Advertising the American Dream: Making Way for Modernity 1920-1940. Berkeley, Los Angeles, and London: University of California Press, 1986. 
Moore, Roy L., Carmen Maye, and Erik L. Collins. Advertising and Public Relations Law, $2^{\text {nd }}$ ed. New York and London: Routledge, 2011.

Newell, Jay, Charles T. Salmon, and Susan Chang. 'The Hidden History of Product Placement.' Journal of Broadcasting \& Electronic Media (December 2006): 575-594.

O'Leary, Noreen. 'Will Angelina Jolie Front for Vuitton?' Adweek (27 April 2011).

Porter, Elizabeth G. 'Taking Images Seriously.' Columbia Law Review 114.7 (2014): 1687-1782.

Schweitzer, Marlis, and Marina Moskowitz, eds. Testimonial Advertising in the American Marketplace: Emulation, Identity, Community. London: Palgrave, 2009. Segrave, Kerry. Endorsements in Advertising. Jefferson: McFarland, 2005.

Siegel, Paul, ed., Cases in Communication Law, $4^{\text {th }}$ ed. Lanham, Boulder, and New York: Rowman \& Littlefield, 2014.

Vonderau, Patrick. 'Kim Novak and Morgan Stairways: Thinking about the History and Theory of the Tie-In.' In Films that Sell: Moving Pictures and Advertising, edited by Bo Florin, Nico de Klerk, and Patrick Vonderau, 209-222. London: British Film Institute, 2016.

Vonderau, Patrick. 'On Advertising's Relation to Moving Pictures.' In Films that Sell: Moving Pictures and Advertising, edited by Bo Florin, Nico de Klerk, and Patrick Vonderau, 1-18. London: British Film Institute, 2016. 



\title{
7. Advertising's Self-Reference: From Early Cinema to the Super Bowl
}

\author{
Yvonne Zimmermann
}

\begin{abstract}
This chapter takes up the notion of self-reference and self-reflexivity so present in cinema, media and literature studies, if only to redefine it. Self-reference is no longer understood as a textual feature of revelation that produces knowledge about media, but as a particular mode of address: when looking at self-reference from the perspective of screen advertising and screen ads, it becomes evident that rather than displaying the medium itself, self-reference acts against reactance in that it exhibits the assumed media knowledge of the viewers and celebrates media expertise. Thus, the chapter contributes to discussions about the many notions and layers of self-reference and self-reflexivity in cinema and media studies.
\end{abstract}

Keywords: self-reference, self-reflexivity, advertising, media expertise, reactance

Self-reference is a multidisciplinary object of research, as Steven J. Bartlett and Peter Suber's comprehensive survey of themes and studies in more than 20 fields of research illustrates. ${ }^{1}$ While literature on self-reference in art and media is abundant, self-reference in advertising has been the subject of only a rather small number of studies, and these studies are mostly dedicated to print advertising. ${ }^{2}$ In a similar vein, while cinema has lent itself to plentiful explorations of its self-referential dimensions, only a few works, mostly

1 Steven J. Bartlett and Peter Suber, eds., Self-Reference: Reflections on Reflexivity (Dordrecht: Nijhoff, 1987).

2 See, for instance, the three contributions on self-referential advertising in Winfried Nöth and Nina Bishara, eds., Self-Reference in the Media (Berlin and New York: De Gruyter, 2008); Winfried Nöth, Nina Bishara, and Britta Neitzel, 'Selbstreferenz in der Werbung', in Mediale

Florin, B., P. Vonderau, Y. Zimmermann, Advertising and the Transformation of Screen Cultures. Amsterdam: Amsterdam University Press, 2021 DOI 10.5117/9789462989153_CHO7 
from the field of communication studies, deal in a pronounced way with self-reference in moving image advertising. More often than not, such research privileges references of moving image advertising for films over other types of self-reference and shows particular interest in retracing quotations, allusions, and other intertextual relations between commercials and cinema. ${ }^{3}$ This is certainly a rich field to investigate, given the seemingly ever-increasing circulation of personnel, motives, narratives, generic codes, and stylistic features between movies and commercials - all markers of the entangled intertextual relationship between advertising culture and entertainment industry. Other types of self-reference in moving images, however, have been neglected, so that the phenomenon in its entirety still remains to be explored.

Moreover, self-reference in advertising has largely been studied as an isolated topic and has rarely been considered in a larger context of selfreference in media. My attempt in the following is to broaden the perspective and include forms of self-reference in literature and cinema in the discussion of self-reference in moving image advertising. I do this for two reasons. First, this broader approach promises to provide a better understanding of the particularities of self-reference in moving image advertising. Second, it allows for the reconsideration of the concepts of self-reference in literature and cinema studies in light of self-reference in moving image advertising. It should be clear from the start that self-reference in any kind of advertising is a sales strategy. But instead of being satisfied with criticizing advertising for being and doing advertising, as critical studies tend to, I think it is worth taking a closer look at how self-reference is manifested in moving image advertising and how it interacts with viewers. I will argue that rather than being a textual feature, self-reference in moving image advertising is a particular mode of address - one that acknowledges, exhibits, and celebrates media expertise that advertisers assume audiences have. In that sense, selfreference not only adds another mode of address, the celebratory mode, to the list of self-referential modes of address in art and popular visual culture.

Selbstreferenz: Grundlagen und Fallstudien zu Werbung, Computerspiel und den Comics (Cologne: Halem, 2008), 57-118.

3 See, for example, Gloria Withalm, 'Commercial Intertextuality', in Logica, dialogica, ideologica. I segni tra funzionalità ed eccedenza, ed. Patrizia Calefato (Milan: Mimesis, 2003), 425-435; Gloria Withalm, 'Recycling Dorothy, Dinosaurs, and Dead Actors: Digi-Textuality in the TV-Commercials of the 1990s', Semiotische Berichte 27, no 1 (2003): 297-315; Gloria Withalm, 'Commericalization of Filmic Self-referentiality', Semiotica 148, no. 1-4 (2004): 337-360; Ursula von Keitz, 'Adaption und Funktionalisierung von Spielfilmcodes im neueren Werbefilm', Spiel 11, no. 1 (1992): 165-189. 
It also tells us something about what advertisers - and media producers in general - think they know about what viewers know about media.

As far as the term self-reference is concerned, I share Winfried Nöth's semiotic understanding of a self-referential sign as 'any sign that refers to itself or to aspects of itself'. ${ }^{4}$ In literature, cinema, and media studies, as well as in cultural studies, self-reference in this broad sense is sometimes used as synonym for, but sometimes distinguished from, concepts such as reflexivity, self-reflexivity, self-representation, or autoreferentiality. ${ }^{5}$ In his 1985 book Reflexivity in Film and Literature, Robert Stam uses the term reflexivity to describe 'the process by which texts, both literary and filmic, foreground their own production, their authorship, their intertextual influences, their reception, or their enunciation', whereas self-referentiality for Stam designates the ways in which texts can refer or point to themselves. ${ }^{6}$ Robert Goldman and Stephen Papson, in Sign Wars: The Cluttered Landscape of Advertising (1996), which to my knowledge is the only nearly book-length study of self-reference in moving image advertising, define media self-referentiality and intertextuality as the process by which 'ads either refer to other ads or are about the subject of advertising itself as a method of positioning the commodity brand name'. For Michael Dunne, self-referentiality is advertisement 'of a communicator's presence. ${ }^{8}$ His 1992 study Metapop: Self-referentiality in Contemporary American Popular Culture draws on examples of self-referentiality from television, film, rock and country music, music videos, and comic strips. It has no particular focus on advertising, but includes a few examples of self-referential ads.

Within the semiotic framework of self-reference in the media outlined by Nöth, the forms of self-reference this essay focusses on are enunciative (or communicative) self-reference, metatextual self-reference, and intertextual self-reference. Enunciative or communicative self-reference 'involves the communicative situation and describes reference of the speaker, writer, composer, or producer of the sign but also the role of the audience or spectators'. Metatextual self-references, on the other hand, are 'comments on the

4 Winfried Nöth, 'Self-Reference in the Media: The Semiotic Framework', in Self-Reference in the Media, 8.

5 For more details, see ibid.

6 Robert Stam, Reflexivity in Film and Literature. From Don Quixote to Jean-Luc Godard (New York: Columbia University Press, 1992 [1985]), xiii resp. xiv.

7 Robert Goldman and Stephen Papson, Sign Wars: The Cluttered Landscape of Advertising (New York and London: The Guilford Press, 1996), 15.

8 Michael Dunne, Metapop: Self-referentiality in Contemporary American Popular Culture (Jackson and London: University Press of Mississippi, 2010 [1992]), 4. 
text, its narrative form, its content and its structure, its plot, previous or subsequent chapters, its beginning and its end'. ${ }^{9}$ According to this description, metatextual reference is a type of self-reference that is elsewhere often addressed as self-reflection, self-representation, or self-reflexivity. The sources of intertextual self-reference in Nöth's system of definitions are 'quotations, allusions, adaptations, influences, borrowings from texts, films, or any other medium'. ${ }^{10}$ Intertextuality typically manifests itself, to quote Gérard Genette, 'as the actual presence of one text within another text'. ${ }^{11}$ If in the following the term self-reference is used, it is to refer to these particular communicative, metatextual, and intertextual forms of self-reference, which include forms that are often addressed as reflexivity or self-referentiality. ${ }^{12}$

\section{Self-Reference in Art, Literature, and Cinema}

Studies on self-reference in art, literature, and cinema usually focus on a tradition of reflexivity that interrogates conventions 'which break with art as enchantment and point to their own factitiousness as textual constructs' ${ }^{13}$ Reflexivity, according to Robert Stam, 'subverts the assumption that art can be a transparent medium of communication, a window on the world, a mirror promenading down a highway'. ${ }^{14}$ Reflexivity demystifies fictions and our naïve faith in fiction, and, according to Stam, makes this demystification a source for new fiction. ${ }^{15}$

In documentary studies, reflexivity is also regarded as a form that draws attention to the process of selecting and reconstructing events to convey meaning. As Jeanne Allen puts it in her essay 'Self-reflexivity in

9 Nöth, 'Self-Reference in the Media', 15, 18.

10 Ibid., 19.

11 Gérard Genette, Palimpsets. Literature in the Second Degree (Lincoln: University of Nebraska Press 1997 [1982]), 1.

12 I do not distinguish, as some authors do, between self-reference as allegorical or metaphorical use of self and reflexivity as conscious awareness, i.e., being conscious of self-consciousness. Jay Ruby, for example, holds that one can be reflective without being reflexive (Jay Ruby, 'The Image Mirrored: Reflexivity and the Documentary Film', in New Challenges for Documentary, ed. Alan Rosenthal [Berkeley: University of California Press, 1988], 66). This distinction sounds convincing in theory, but when it comes to specific examples, it is often hard to tell whether they are 'truly' reflexive or 'only' reflective.

13 Stam, Reflexivity in Film and Literature, xi.

14 Ibid.

15 Ibid. 
Documentary': 'Self-reflexivity becomes then a reaction against or a way of countering the traditional mode of the documentary which emphasizes verisimilitude.. ${ }^{16}$ Or, as Jay Ruby also in regard to the documentary claims: 'Reflexivity offers us a means whereby we can instruct our audiences to understand the process of producing statements about the world'. ${ }^{17}$

In these studies, self-reference is addressed as a signature of both modern art and postmodern culture and, in line with Bertolt Brecht, is understood - and celebrated - as a critical method. For Brecht, drawing attention to the constructed nature of a text triggers 'alienation effects' that serve as a means to open those texts to audience dialogue and criticism. With Fernando Andacht, the discourses on self-reference in art, media, and cinema studies can be summed up as follows:

Reflexivity has been hailed as a noble component of high culture and equally as a valuable method of high theory. In the realm of culture, reflexivity serves to make explicit and to explore artistically the selfconsciousness that a [sic] creators put into their works of representation. ${ }^{18}$

Self-reference, so we can conclude, has been understood as an analytical tool for critical thinking about media and appraised as a moral, political, and epistemological virtue.

But, as Stam underlines, '[r]eflexivity comes with no pro-attached political valuence. ${ }^{19}$ In other words, self-reference is not perceived as a virtue per se. As a matter of fact, Stam distinguishes between two kinds of reflexivity, between 'authentic' and 'debased' reflexivity. Taking the example of commercial television, Stam holds that this kind of reflexivity is 'ambiguous' and often of a 'debased' kind because commercial television does not trigger any alienation effects. Rather, as Stam criticizes, " $[\mathrm{t}]$ he commercial interruptions that place programs on hold [...] are not pauses for reflection but breaks for manipulation, intended not to make us think but to make us feel and buy'. ${ }^{20}$ Going on from television to moving image advertising, Stam asserts that

[t]he self-referentiality of commercials that parody themselves or other commercials $[. .$.$] are calculated to mystify rather than disenchant. The$

16 Jeanne Allen, 'Self-Reflexivity in Documentary', Ciné-Tracts 1, no. 2 (1977): 37.

17 Ruby, 'The Image Mirrored', 75 .

18 Fernando Andacht, 'On the Use of Self-disclosure as a Mode of Audiovisual Reflexivity', in Self-Reference in the Media, 177 .

19 Stam, Reflexivity in Film and Literature, xvi.

20 Ibid., 16. 
self-referential humour signals to the spectator that the commercial is not to be taken seriously, and this relaxed state of expectation renders the viewer more permeable to its message. The self-referentiality, far from demystifying the product or exposing hidden codes, conceals the deadly seriousness of the commercial - the fact that it is after the spectator's money. $^{21}$

For Stam, self-reference in moving image advertising is not an instrument of demystification and revelation; on the contrary, it is a perfidious strategy of lulling the spectators' critical senses and of concealing the commercial's true agenda. Whereas 'authentic' reflexivity in Stam's view elicits an actively thinking spectator, 'debased' reflexivity as found on television and in moving image advertising elicits a passive consumer of entertainment whose viewing habits as well as buying habits television and moving image advertising aim to transform. ${ }^{22}$

In a similar vein, neo-Marxists Robert Goldman and Stephen Papson assert that reflexivity as a critical method has 'been absorbed by advertising and used against the intention of critics. ${ }^{23}$ In advertising, the authors claim, reflexivity has been perverted into a strategy to 'reroute viewer criticism' and 'to create an emphatic relationship with the audience by foregrounding the constructed nature of the text'. ${ }^{24}$ Advertising practices are seen to turn self-reflexive awareness of advertising codes into an object of consumption. Hence, in Goldman and Papson's eyes, reflexivity in advertising is commoditized reflexivity. Self-referential moving image advertising is dispraised for perverting the 'enlightening' function of self-reference in modernism and for turning it into a cynical selling strategy.

This broadside on self-reference in advertising dates back to at least the 1960s. Renowned film critic Pauline Kael, in her 1965 article 'Spoofing and Schtik', reads the fact that 'advertising kids advertising, TV commercials kid TV commercials, movies kid movies' as a symptom of 'a commercialized society that nobody believes in'. ${ }^{25}$ This disbelief poses a problem to advertising. Therefore, TV commercials are trying to outwit disbelief by including it in the sell. But unlike satire, spoofing - Kael does not use the term self-reference or reflexivity - has no serious goals: 'It's just a technique

Ibid., 16.

Ibid., $16 f$.

Goldman and Papson, Sign Wars, 74.

Ibid.

Pauline Kael, 'Spoofing and Schtik', Atlantic Monthly (December 1965): 85 . 
of ingratiation: the spoof apologizes for its existence, assures us that it is harmless, that it isn't aiming for beauty or expressiveness or meaning or even relevance'. ${ }^{26}$ Self-reference in Kael's view is a new kind of flattery of the customer, a new selling strategy based on ingratiation. ${ }^{27}$

To summarize, research into self-reference asserts that there are different types of self-reference, and that these different types are appraised differently. On the one hand, there is 'authentic', critical, and therefore 'good' self-reference in modernist art, novels, and films such as Dziga Vertov's Man with a Movie Camera (1929); on the other hand, there is 'debased', uncritical, entertaining, perverted, and therefore 'bad' self-reference in popular culture, television, and commercials.

Ultimately, critical studies criticize self-reference for being a selling strategy in advertising. And yes, it is. But then, what else could it be? It is advertising after all. However, we can be more precise about the nature of this strategy. Self-reference in moving image advertising is a strategy to act against reactance. The theory of psychological reactance, which was introduced by Jack W. Brehm in the mid 196os, explains negative motivational reactions to influence attempts that are perceived to threaten behavioural freedoms.$^{28}$ From this perspective, self-reference in advertising can be understood as a strategy to overcome viewers' negative attitude towards commercials. How commercials make use of self-reference in their attempt to eschew audience reactance will be discussed in detail later on. First, let us look at an alternative approach to self-reference in advertising.

\section{Self-Reference in Advertising According to Systems Theory}

While critical studies in concert with media and cinema studies blame self-reference in advertising as a cynical form that does not reveal, but instead conceals and curries favour, systems theory considers self-reference

26 Ibid.

27 A somewhat similar result is found in Jane Feuer's analysis of self-referential Hollywood musicals. Feuer observes that musicals may use the same 'Brechtian' techniques as Jean-Luc Godard did in his films, but the effect is different. In musicals, self-reference in the form of direct address to the spectator, backstage musicals, and behind-the-scenes footage does not trigger alienation, but is a pattern of demystification and remystification: 'Demystification is always followed by a new mystification, the seamless final show or placing back on her pedestal of a disgraced performer.' Jane Feuer, The Hollywood Musical (Bloomington and Indianapolis: Indiana University Press, 1993 [1982]), 44.

28 Jack W. Brehm, A Theory of Psychological Reactance (New York: Academic Press, 1966). 
in advertising to be a privileged site of knowledge about advertising. It is therefore worth taking a closer look at what exactly can be learned from self-reference in advertising about advertising, according to systems theory. Indebted to Niklas Luhmann's theory of social systems, German communication scholar Siegfried J. Schmidt, in his article 'Modes of Self-Reference in Advertising', conceptualizes advertising in terms of a social system that represents a subsystem of the economic system. ${ }^{29}$ As is characteristic of all systems, according to Luhmann's theory, advertising follows its own system-specific logic. The specific logic of the advertising system consists of a particular form of communication, which Schmidt along with Guido Zurstiege ${ }^{30}$ - terms a 'macro-form of communication'. Within this theoretical framework, advertising is described as one of four 'macro-forms of communications', the others being journalism, literature and art, and public relations. Each of these macro forms of communication possesses different modes of reference to 'reality' and of self-reference. Schmidt identifies five modes of self-reference, holding that - and this is Schmidt's general hypothesis - 'only owing to self-referential maneuvers of or in the advertising system we as the addressees of media supply are able to observe the advertising system at all' ${ }^{31}$ In other words, for Schmidt, the only way we can observe - and learn about - the advertising system is through self-reference in advertising.

The first among the five modes of self-reference in advertising that Schmidt identifies is intertextuality, which includes, as mentioned above, citations, repetitions, recursions, or other kinds of reference to signs, texts, or other media. Advertising referring to the advertising system is mentioned as the second type of self-reference in advertising and is described as advertisers advertising for advertising, a practice that, according to Schmidt, makes advertising a topic and demands attention for itself, mostly in ironic and humorous ways. The third mode consists of advertising observing its own practices by means of advertising research carried out by advertising agencies themselves. The last two types of self-reference in advertising that, according to Schmidt, allow observation of the advertising system are self-descriptive statements by advertising agencies (concerning their own visions, missions, and philosophies) and manuals and how-to literature about best practices

29 Siegfried J. Schmidt, 'Modes of Self-Reference in Advertsing', in Self-Reference in the Media, 47-6o.

30 See, for instance, Guido Zurstiege, Zwischen Kritik und Faszination: Was wir beobachten, wenn wir die Werbung beobachten, wie sie die Gesellschaft beobachtet (Cologne: Halem, 2005).

31 Schmidt, 'Modes of Self-Reference in Advertising', $5^{0 .}$ 
in advertising written by advertisers. In systems theory, so we can conclude, self-reference is first of all considered an instrument of observation and a, if not the, epistemic key to an understanding of advertising.

\section{Self-Reference in Moving Image Advertising}

While I do share the assumption of advertising studies indebted to systems theory that self-reference in advertising has epistemological value, it needs to be examined what exactly we can learn from self-referential moving image advertisements about advertising that we don't already know. But before going into this question, we should take a closer look at the prevalent forms of self-reference in moving image advertising and at the methods commercials use to act against audience reactance. This is illustrated by a few pertinent examples. To begin with, it can be acknowledged that moving image advertisements are self-referential on all possible levels: they address the producer, the process, and the product of advertising; they refer to modes of text production and text reception; they foreground the materiality, temporality and mediality of moving image advertising as well as its historicity; and they lay open rhetorical and economic processes of advertising. Thereby, they make use of the entire arsenal of reflexive devices that Christian Metz in Impersonal Enunciation, or the Place of Film (1991) lists as follows: direct visual address to the camera, direct verbal address, reflexive intertitles, the frame-within-the-frame, the film-within-the-film, subjective imagery, and the display of the apparatus. ${ }^{32}$

The gamut of self-reference in moving image advertising could be studied by drawing on particular advertising campaigns such as the Bo Knows series of television commercials, which ran in 1989 and 1990, for Nike cross-training shoes with baseball and American football player Bo Jackson. The series heavily relies on metacommunication, intertextuality, and self-reflexive awareness. In 'Air. By Bo Jackson' (1991),33 for example, Jackson interrupts the production of an over-the-top musical number in which he serves as the lead singer, stating: 'This is ridiculous. I am an athlete, not an actor. Let me out of this thing.' He walks off the set and steps out of a television screen right

32 Christian Metz, L'Enonciation impersonnelle, ou le site du film (Paris: Klinksieck, 1991) / Impersonal Enunciation, or the Place of Film, trans. Cormac Deane (New York: Columbia University Press, 2016 [1991]).

33 'Air By Bo Jackson Nike Television Commercial 1991 - Air Trainer Max 91', https://www. youtube.com/watch?v=dgp4gXEIh $4 \mathrm{Y}$ (last accessed 6 April 2021). 
into the living room of a dazzled family gathered around the TV set, takes his Nike shoes with him, and goes straight to the gym for exercise. When the jingle of the musical is heard in the gym, Jackson yells at a screen-filling wall covered with the Nike Air logo that he does not have time for this. Cut to George Forman in the same musical set seen before, stating with a big smile: 'But I do.' The possibly conflicting tasks of a spokesperson and a sportsman and the possibly conflicting interests between a corporation and its spokesman are openly addressed in this commercial.

The same issue surfaces in another Nike campaign with Michael Jordan and Spike Lee playing Mars Blackmon, the same character (a big fan of the New York Knicks and Air Jordan shoes) Lee played in his 1986 comedy She's Gotta Have It. ${ }^{34}$ Mars wants to know what makes Jordan the best player in the universe and insists that it has to be the shoes. When Jordan repeatedly denies that it is the shoes, an intertitle appears on the screen that reads: 'Mr. Jordan's opinions do not necessarily reflect those of Nike, Inc.'. This corporate comment draws attention to the fact that spokespersons and corporations may have different opinions on products and certainly do have different agendas. In both Nike campaigns, the audience is repeatedly directly addressed both visually and verbally. An early 1990 os Bo Jackson commercial with Denis Leary from the Bo Knows series ${ }^{35}$ refers to Jackson's hip injury and shows him working out, commented on by Leary who, all of a sudden, looks straight into the camera and aggressively shouts: 'And what are you and your good hip doing right now? Watching commercials!!!' The ad reproaches the audience for doing what the corporation wants the audience to do: watch commercials. Leary knocks at the screen and threatens to come in and bring Bo and his big bad hip' with him. The commercial ends with the slogan 'Just do it.' This example refers to the specific media conditions of watching moving images, in other words, the separateness of the spheres of mediated sounds and images and real life by drawing attention to the fourth wall.

Self-reference in moving image advertising is by no means a particularity of American commercials. The advertising campaign for ICA, the leading grocery retailer in Sweden, would lend itself equally well to studying the gamut of self-reference in moving image advertising. The ICA supermarket commercial series was included in the The Guinness Book of Records in 2007 for being the longest-running television advertising drama, having started in 2001. After 512

34 'Retro Michael Jordan and Spike Lee Commercial', https://www.youtube.com/watch?v=Abr_ LU822rQ (last accessed 6 April 2021).

35 'Early 9o's Bo Jackson Nike Commercial with Denis Leary', https://www.youtube.com/ watch?v=ag6kzktWR78 (last accessed 24 August 2016). 
episodes, Carl Johan 'Loa' Falkman replaced Hans Mosesson as 'Stig' in $2015{ }^{36}$ The 45-second episodes about store manager Stig and his ICA store advertise the weekly groceries on sale in different and often self-referential ways. 'ICA - Jamie Oliver ${ }^{37}$ draws attention to the production process of commercials and takes the viewer backstage to witness the rude, arrogant, and ill-tempered appearance of guest Jamie Oliver, who even gives Stig the cold shoulder. The famous British chef only puts on his winning smile when the camera is running, and with an exuberant hug, presents Stig as 'one of my oldest friends, Steve from Ikea'. The commercial stages a clash between the backstage and onstage personas of Oliver and displays self-mockery both on the part of Oliver and of the ICA corporation, which self-ironically plays with the fact that ICA is mistaken for Ikea, a Swedish brand that, unlike ICA, is internationally known.

In 'ICA Sales Problem', ${ }^{8}$ ICA employees deliberate how to tell their clients that ICA products are on sale. Staff members suggest producing commercials to advertise products on sale. Each proposition - all of which are actually successfully practised by ICA - is turned down by the head of the meeting because he does not think that TV spots will work. This commercial bluntly parodies ICA's own advertising practices. But there is more to it: 'ICA Sales Problem' is a Norwegian commercial. From 2005 to 2008 , the ICA campaign model was exported to Norway, but the commercials were still made in Sweden by the same agency, King. The Swedish like to tell jokes about their Norwegian neighbours (and vice versa), and the spot makes fun of Norwegians for being ignorant about how to advertise or being too stupid to recognize that they actually do advertise.

A similar sensibility can be found in 'Reklam i verkligheten' (Commercials in Real Life): ${ }^{39}$ the commercial is set during summer vacation when presumably no one is watching TV, so the ICA employees decide to come to the viewers instead. This means that they approach people in public spaces and obtrusively put products and price tags in front of them. People seem to react 'naturally', as if filmed by a hidden camera. After a while, someone

36 See ICA 'Hans Mosesson slutar som ICA-Stig',

http://www.ica.se/erbjudanden/icas-reklamfilmer/hans-mosesson-slutar-som-ica-stig/ (last accessed 6 April 2021).

37 'Ica Reklam - Jamie Oliver (V. 50)',

https://www.youtube.com/watch?v=ZBf66 $7 \mathrm{sBCmo}$; in lower quality, but with English subtitles: https://www.youtube.com/watch?v=epGFPxJUusM (last accessed 6 April 2021).

38 'Funny ICA Ad "Salesproblem",

https://www.youtube.com/watch?v=cJx_QWaR3sw (last accessed 6 April 2021).

39 'ICA reklamfilm 2015 v.30 - Reklam i verkligheten', https://www.youtube.com/ watch? $\mathrm{v}=\mathrm{sShpgfwH} 4 \mathrm{n} 4$ (last accessed 6 April 2021). 
comments: 'You are a bit disturbing right now...' and gets the answer 'Yes! But that's the point! It's advertising!' Again, advertising practices are staged in a self-parodying way, acknowledging awareness of their often disturbing and obtrusive character. It is a feature of the ad campaign that each advertised product has a prominent price tag in big white numbers attached to it. In each episode, foods with price tags are displayed most ostentatiously and make fun of the allegedly 'inconspicuousness' of product placement. This alone refers to advertising practice in a humorous way.

Commercials that refer to their own historicity often work with split screens to contrast a historical commercial with a new one. 'Tomorrow's Classics' for Volvo S6o (2006) is mentioned in Bo Florin's chapter 'Moving Objects: The Case of Volvo' as a typical example of this strategy. In the series of commercials for the German insurance company Allianz called Allianz Klassiker (Allianz Classics; started in 2015), commercials from 35 years ago are placed on the left side of the screen: for example, the commercial 'Tomatenstapel' (Pile of Tomatoes) ${ }^{40}$ for car insurance or 'Unfall' (Accident) ${ }^{41}$ for casualty insurance. On the right-hand side of the screen, there is a shotfor-shot remake of the old commercial, but the new version is adapted to the present and features new accident risks (skateboard instead of banana peel), up-to-date communication technology (tablet or smartphone instead of written papers), and changed gender roles (the mother of the family goes out for work while the father stays home). In the final image of the commercials, the corporation's slogan 'Eine Allianz fürs Leben' (A Lifelong Alliance) is completed with 'Damals wie heute' (Then as Now). Rather than parody, moving image advertising referring to its own history is a nostalgic reminder of past advertising practices, if not of the past itself. As an advertising strategy, it promises stability and continuity, and thus a sense of security in today's complex and rapidly changing world. In these examples, self-reflective nostalgia serves as a means to build consumer confidence and loyalty. It is therefore no coincidence that an insurance company pursues this strategy.

Quite differently, commercials that draw attention to the mediality of moving image advertising play on the funny clash between the laws of reality and of mediated reality. The diegesis of the Heineken commercial 'Lip Sync Drama' (UK 1988) ${ }^{42}$ is set in a classical drama world. A yearning

40 'Allianz Klassiker: 35 Jahre später - manche Dinge ändern sich nie', https://www.youtube. com/watch?v=NZM5-1c9D5o (last accessed 6 April 2021).

41 'Allianz Klassiker: Der Film „Unfall“ 35 Jahre später', https://www.youtube.com/watch? v=ysGVT6mo1yA (last accessed 6 April 2021).

42 'Heineken - Lip Sync Drama (1988, UK)',

https://www.youtube.com/watch?v=AaBxNOUgEJQ (last accessed 25 August 2016). 
couple in a chi-chi colonial-style hotel experiences a serious problem: they are talking out of sync! But after drinking a glass of Heineken, sound and image are in sync again and the commercial, clearly a parody of Hollywood genre conventions, gets its happy ending. In a similar vein, a commercial for Aristoc tights, ${ }^{43}$ shot in widescreen in the style of a visually sophisticated art-house movie, derives its humour from a character's impossible knowledge on a technical feature of post-production: an attractive woman seeks to discuss a serious problem with her partner. Their Italian dialogue is subtitled in English. What sounded like a relationship problem turns out to be a subtitle problem: the woman complains about the positioning of her subtitles, for they are not at the bottom of the image, but on top so that they cover her face. Her partner explains that this is because she is wearing Aristoc Slimline System tights, and that it would be a crime to cover them up. When the woman takes a seat in a chair with her legs posed for the final product presentation, the Aristoc tights package fades in to cover not only her face, but the entire upper part of her body. During the whole commercial, all attention is on her legs; her face is never shown. Here again, the boundaries between the diegesis of the commercial and the commercial as a media object are transgressed, but this time to make fun of product-staging practices in advertising, which could not care less about gender neutrality or reducing women to their legs.

\section{What Do Self-Referential Advertisements Know about Advertising that We Don't Already Know?}

Many more examples could be added to describe the variegated facets of self-reference in moving image advertising. Writing about self-reference poses a somewhat similar problem as writing about intermediality: the phenomenon can be located in its many places and analysed in its many forms. But what else do we get out of that except acknowledging that the phenomenon exists in various locations and manifestations? With its claim that self-reference in advertising provides knowledge about advertising, systems theory suggests an answer to this problem that critical theory cannot. But what exactly can we learn from self-referential moving image advertisements about advertising that we don't already know? So far, it has become evident that self-referential commercials display an

43 'Aristoc funnyz',

https://www.youtube.com/watch?v=pUxCirLX4bE (last accessed 6 April 2021). 
awareness that they are advertisements. Or, as Michael Dunne puts it, '[s]elf-referential ads openly advertise that they are advertisements and assume that their audiences know this perfectly well'. ${ }^{44}$ Since audiences generally know that advertising is advertising, especially if they are plainly told so by the advertisements themselves, self-disclosing the attempt to influence is a strategy to overcome possible resistance to persuasion and to cause the viewers' attitude towards a brand to be more favourable, but it does not yet provide new knowledge about advertising. What is there, then, to learn from self-reference in moving image advertising, beyond what we already know? Some more examples will help to explore this question.

A series of television advertisements for Isuzu cars and trucks that aired on American television from 1986 to 1990 is based on reflexivity about the nature of advertisements. ${ }^{45}$ The fictional spokesman of the series is Joe Isuzu, a pathological liar who makes outrageous and overinflated claims about Isuzu cars and trucks. The commercial 'Save a Billion ${ }^{46}$ refers to the popular advertising strategy that the more you buy, the more you could save, and extends this argument ad absurdum: Joe Isuzu directly addresses the audience and invites them to buy one thousand Isuzu troopers in order to save two million dollars, or even better, to by one million troopers and save two billion dollars. To illustrate the absurdity, the screen is split into tons of tiny little images of miniature troopers while Isuzu is shown standing amidst heaps and heaps of dollar bills. In 'Joe Isuzu for Isuzu Pup', ${ }^{47}$ Isuzu presents a man in the background as a Supreme Court justice to verify his claims. A subtitle appears to contradict this information, pointing out 'He's lying. That's his cousin.' Later in the commercial, Joe Isuzu announces that if you buy one pickup, you get one free. This message is countered by a subtitle reading 'We are generous, not stupid.' Each commercial in the series closes with the slogan 'You have my word on it.'

The commercials tell us, in a satirical way, that car salesmen and car ads are dishonest. They expose the excess and exaggeration of advertising. If I use the word 'expose', I mean it in the sense of 'exhibiting' rather than in the sense of 'revealing', because audiences have known about the excess and exaggeration of advertising for a long time. The commercials neither

44 Dunne, Metapop, viii.

45 The series was created by the ad agency Della Femina, Travisano, and Partners.

46 'Isuzu “Save a Billion”', https://www.youtube.com/watch? $\mathrm{v}=\mathrm{xFIcjfWvNYw} \mathrm{(last} \mathrm{accessed}$ 6 April 2021).

47 'Joe Isuzu for the Isuzu Pup', https://www.youtube.com/watch?v=SNOvNrZ6S_E (last accessed 6 April 2021). 

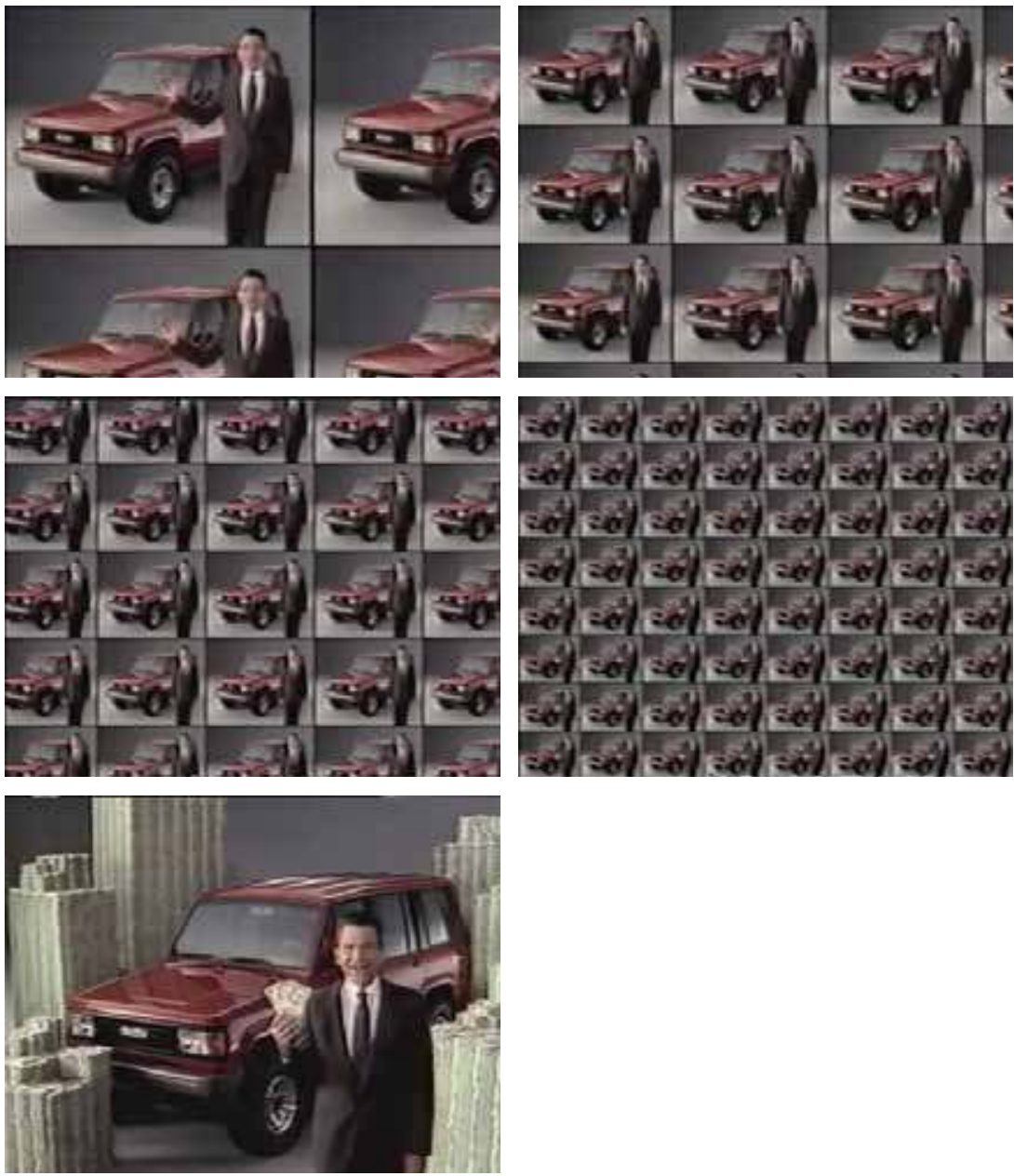

Figures 7.1-7.5: Joe Isuzu in 'Save a Billion'.

uncover a hidden fact nor conceal a hidden agenda. Instead, they ostentatiously exhibit what the audience is already well aware of. In The Reality of the Mass Media, Niklas Luhmann writes about advertising, stating that '[a] dvertising seeks to manipulate, it works insincerely and assumes that that is taken for granted'. ${ }^{48}$ With regard to self-reference, Luhmann's statement can be used to argue that self-reference in advertising makes explicit and exhibits what advertisers assume is taken for granted by the audience.

48 Niklas Luhmann, The Reality of the Mass Media, trans. by Kathleen Cross (Stanford: Stanford University Press, 2000), 44. 
The next example refers to the economy of advertising: the 200o Super Bowl commercial 'Wasted \$2 Million Bucks ${ }^{49}$ for $\mathrm{E}^{*}$ Trade features the company's advertising character, the so-called E*Trade Monkey, together with two goony men sitting in a garage and clapping along to a version of the traditional Spanish folk song 'La Cucaracha'. The line at the end of the commercial says that the company has just wasted two million dollars on this commercial. It is commonly known that Super Bowl ads are extremely expensive, possibly the most expensive ads. According to Time, the 30-second commercials that ran during the 2011 Super Bowl cost an average of $\$ 3.5$ million each..$^{50}$ So the amount mentioned in the commercial is realistic. It is also commonly known that advertisers struggle to predict the response to their advertising; in other words, to follow marketing pioneer John Wanamaker, we as consumers understand that advertisers know that half the money that they spend on advertising is wasted - they just never know which half. So, again, we have not learned anything about the economy of advertising from this example that we didn't already know. On the contrary, the commercial builds its joke on the very assumption that we know this.

Self-reference in the discussed commercials does not produce knowledge on the process of advertising, neither does it reveal nor conceal any hidden agenda of the advertisers. Instead, it acknowledges that consumers have a clear notion of the aims and workings of advertising. Self-reference in moving image advertising operates on the premise of a knowledgeable audience and demonstrates the viewers' competence and advertising literacy as well as, more generally, the viewers' literacy in media and popular culture. This media literacy is acknowledged and celebrated in many of the Energizer battery television commercials starring the marketing mascot, the Energizer Bunny. The commercial series starting in 1989 drew on popular Hollywood movies - such as King Kong, Star Wars, James Bond, and Wile E. Coyote - and restaged scenes and characters to create an environment for the Energizer Bunny to co-inhabit. In each episode, the Energizer Bunny is on the verge of being eliminated, but either the batteries run out in the (fake) competitor's weapon, or there are other obstacles that prevent the villain from capturing the Energizer Bunny; for example, a window shuts on the toes of King Kong

49 'Super Bowl Ad (99?) E*Trade - "Wasted \$2 Million Bucks"', https://www.youtube.com/ watch? $\mathrm{v}=$ BnQMq5wtZcg (last accessed 6 April 2021).

50 Popular television programmes such as American Idol pull in approximately $\$ 475,000$ per 30 -second spot, according to $A d W e e k$. Even less popular nationally televised programmes, says AdWeek, often charged in excess of $\$ 100,000$ for a 30 -second spot in 2011. Nancy Wagner, 'How Much Does Television Advertising Really Cost?', Chron.com [n.d.], http://smallbusiness.chron. com/much-television-advertising-really-cost-58718.html (last accessed 6 April 2021). 

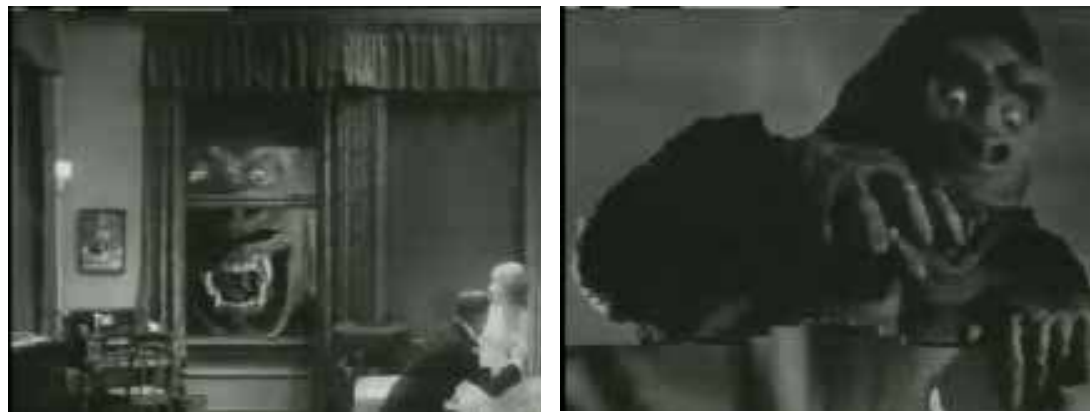

Figures 7.6-7.7: Energizer Bunny and 'King Kong'.

and makes him fall off the Empire State Building before he gets hold of the Energizer Bunny who, incessantly beating his drum, 'keeps going and going and going', as the slogan of the campaign has it..$^{1}$ These commercials are built on viewers' familiarity with popular movie culture. Another strand of Energizer Bunny commercials refers to the advertising system itself when fake commercials for headache tablets, underwear, or breakfast cereals for children serve as an environment for Energizer Bunny to invade. These commercials are based on the assumption that audiences perfectly know what 'ordinary' advertisements look like, or in other words, that viewers are familiar with the conventions of commercials.

Moreover, the Energizer Bunny's invasion of other commercials adds a self-reflective meta- or hyper-level layer that exhibits in a humorous way the fact that commercials communicate with commercials. Self-referential advertising more ostentatiously than any other kind of advertisement exhibits that advertising first and foremost is about advertising - and not about products or services. It makes explicit how commercials observe other commercials, how commercials address and respond to each other, and how they make fun of one another. Self-referential advertisements demonstrate how advertising competes with advertising. More than any other example, the series of mutually targeted television advertisements and marketing campaigns between Coca-Cola and Pepsi-Cola in the 196os known as the 'cola wars' illustrates this fact. A lesser known, but vivid case in point is the DHL commercial 'Trojan Mailing', $5^{2}$ which documents how DHL tricked its competitors into involuntarily and unknowingly advertising for

$5^{1}$ 'Energizer Bunny ${ }^{\circ}$ - King Kong - 1993 Tv Commercial', https://www.youtube.com/ watch?v=RUMvkGaI-3c (last accessed 6 April 2021).

$5^{2}$ 'Trojan Mailing', https://www.youtube.com/watch?v=vHVWegNfQlo (last accessed 6 April 2021). 
DHL. Giant packages were taped all over with thermo-active foil and cooled down below the freezing point. Competitors picked up a black package that transformed at temperatures above freezing, with the result that they delivered DHL packages. The voice-over narrator presents the ruse as 'an innovative way to communicate', much cheaper than a classical advertising campaign. The commercial closes with a sarcastic 'Thank you very much' addressed to the competitors.

Self-reference makes visible - and thus observable, to use systems theory's terms and premises - that within the advertising system, competition first and foremost is between advertisements, and not between brands, products, and services. Self-reference exposes the fact that advertising is competition in communication rather than competition in commodity. Therefore, Goldman and Papson refer to advertising as a 'sign contest' or 'sign war'. As early as 1928, advertising pioneer Edward L. Bernays predicted that commodities would increasingly be sold through advertising differentiation rather than product differentiation when he wrote: 'I believe that competition in the future will not be only an advertising competition between individual products or between big associations, but that it will in addition be a competition of propaganda'. 53

But apart from this (rather obvious) fact, which is at the heart of advertising studies indebted to systems theory, what else can be learned from the above-mentioned examples? The examined commercials illustrate that self-referential advertisements are neither a privileged source of knowledge about the processes of advertising nor a perverted tool for consumer manipulation. Rather, self-referential commercials openly advertise the assumed knowledge that viewers have about advertising and media at large. Therefore, self-reference in moving image advertising can be interpreted as an acknowledgement, exhibition, and celebration of the viewers' media competence.

\section{Self-Reference as a Mode of Address}

Speaking of the audience, it is crucial to note that different forms of selfreference in art, popular media culture, and advertising are based on different concepts of the audience. Whereas modern art, including the cinematic avant-garde, acts on the assumption of an illiterate audience that suffers from media incompetence and is therefore in need of education 
and enlightenment, moving image advertisements address the audience as media literate, competent, and knowledgeable.

The different forms of self-reference can then be seen as resulting from different ideas about the audience - and these concepts of the audience are reflected in different modes of audience address. Robert Stam distinguishes three perennial modes of reflexive art that can be helpful to illuminate this point. These three modes are ludic, aggressive, and didactic. The ludic mode, according to Stam, is illustrated by the playful self-referentiality of a Keaton two-reeler or a TV sitcom, the aggressive mode is represented by the modernist dehumanization typical of Buñuel's L'Age d'or (1930), while the didactic mode is characterized by the Brechtian materialist fictions of Godard and Alain Tanner. ${ }^{54}$ Clearly, the self-reflective works of the cinematic avant-garde in the interwar period also belong in this third category.

From the perspective of advertising, a fourth mode of reflexivity needs to be added to this list, the celebratory mode, which is predominant in self-referential moving image advertising. It is not limited to advertising, however, for it is present in popular media culture at large. This mode takes the viewers' media competence seriously and addresses the viewer as an emancipated spectator in the sense outlined by Jacques Rancière..$^{55}$ The very fact that self-referential commercials' take the audience's media expertise seriously is an important part of the fun of self-referential moving image advertisements, besides self-irony, parody, and satire. Of course, this is not exactly a new observation. Studies on self-reference in popular culture and (moving image) advertising unanimously remark that self-reference recognizes a savvy, media-literate audience. But scholars mention it only in passing and do not reflect on the importance and meaning of this fact. Or, to put it differently, they do not take the viewers' media expertise seriously enough to consider its theoretical and conceptual consequences.

If we do, it becomes evident that self-reference's referring to the text is basically a way of referring to the audience. Self-reference in this light appears less as a textual feature than a semi-pragmatic operation. Self-reference can be conceptualized as a communication strategy, or a particular mode of address that within different espaces de communication, different spaces of communication - to refer to a concept suggested by Roger Odin - elicits particular reading modes and establishes particular forms of connectivity 
between text and audience. ${ }^{5}$ Self-reference can therefore be considered a technique to shape the relationship between text and viewer. As such, it can be a used as a strategy to connect viewers to the text, but also to disconnect them from the text. In regard to moving image advertising, self-reference works as a strategy to connect text and viewer by means of celebrating shared media knowledge.

From a larger perspective of self-reference in art and media, a closer look at self-reference in moving image advertising suggests that it is more productive to understand self-reference as a mode of address that regulates the relation between viewer and text in terms of closeness and distance than to make value distinctions between critical and thus authentic forms of self-reference and assertive, celebratory, and therefore debased forms of self-reference. From this perspective, self-reference is no longer understood as a form of either concealment or revelation, but as a form of exhibition - a form that exhibits the assumed media knowledge of the viewers as much as it displays the medium itself.

\section{Self-Reference in the History of Moving Image Advertising}

Self-reference is widely considered a characteristic of postmodernity, and one could therefore anticipate an increase in self-referential commercials in history. In her study on commercial intertextuality, Gloria Withalm holds that moving image advertising has always referred to popular media culture and used movie and television stars to promote brands. In the 1970s, Withalm observes a decline in intertextuality, but in the 1980 s she sees advertisers taking up the production of self-referential advertising again, and in the 199os, the trend was evident in advertisements for all products. ${ }^{57}$ Withalm's observation is in line with Goldman and Papson's claim that the late 1980 s also saw a massive increase in moving image advertisements that made use of enunciative and metatextual self-reference. ${ }^{8}$ Unlike Withalm, who grants intertextuality in moving image advertising a history that dates back to the emergence of the movies, Goldman and Papson consider self-referential commercials to be a new phenomenon of the late 1980 ,

56 Roger Odin, Les Espaces de communication: Introduction à la sémio-pragmatique (Grenoble: Presses universitaires de Grenoble, 2011).

57 Withalm, 'Commercial Intertextuality,' 425-435.

$5^{8}$ Goldman and Papson, Sign Wars. 
when a new genre of ads emerged that 'played at being self-reflexive about the arbitrary process of meaning construction in ads' 59

If self-reflexivity was not frequent enough through the history of moving image advertising to form a genre by itself for many decades, the argument of the 'novelty' of self-referential advertisements in the 1980 os is easily disproved: 'Laveuses' (Laundresses, also known as 'Washing Day in Switzerland'), which, according to some historians, is 'the first purposive advertising film in film history, ${ }^{60}$ is also a very early example - if not the first? - of self-reference in moving image advertising. Attributed to Alexandre Promio, but shot by Emile Lavanchy in $1896,{ }^{61}$ the 'view' premiered in New York on 27 June 1896 and was subsequently screened in Lyon on 20 September $1896{ }^{62}$ This commercial for Sunlight Soap was initiated by François-Henri Lavanchy-Clarke, the licence holder of the Cinémathographe Lumière in Switzerland, who also happened to be the representative in that country of Lever Brothers, manufacturers of Sunlight soap. The reason why Lavanchy-Clarke acquired the licence of the Cinémathographe Lumière, which allowed the shooting and projection of moving images with the same device, was the possibility to promote his licensed products in an innovative new way. ${ }^{63}$ Interestingly enough, there are two different versions of this putatively first advertising film. While one version is innocent of any self-reference, ${ }^{64}$ the 'official' version, ${ }^{65}$ listed in the Catalogue Lumière as 'Vue no. 6o' ${ }^{66}$ shows Lavanchy-Clarke entering the scene from the right-hand corner of the screen and instructing a little girl to hand over a small bucket of water to an older girl who stands on a wooden box labelled 'Sunlight Savon' (Sunlight Soap) and helps two

59 Ibid., 17.

6 o Jeanpaul Goergen, 'Drei Männer und die Anfänge des deutschen Werbefilms', in Werbefilme: Spiegel der Zeiten - Chronik des Alltags, ed. Hans-Gerd Schmidt and Bernd Wiesener (Bielefeld: Verlag für Regionalgeschichte, 2002), 171.

61 See 'Francois-Henri Lavanchy-Clarke', Who's Who of Victorian Cinema, http://www.victoriancinema.net/lavanchyclarke (last accessed 6 April 2021).

62 'L'œuvre cinématographique des frères Lumière: Laveuses Vue No 6o', https://cataloguelumiere.com/laveuses/ (last accessed 6 April 2021).

63 See Roland Cosandey, 'Le Catalogue Lumière 1896-1907 et la Suisse: Éléments pour une filmographie nationale', 1895, no. 14 (December 1993); Roland Cosandey and Jean-Marie Pastor, 'Lavanchy-Clarke: Sunlight \& Lumière, ou les debuts du cinématographe en Suisse', Equinox, no. 7 (June 1992). For a similar strategy to promote consumer goods with the latest technology of moving images, see Martin Loiperdinger, Film \& Schokolade: Stollwercks Geschäfte mit lebenden Bildern (Basel: Stroemfeld, 1999).

64 https://www.youtube.com/watch?v=ztV6zDmoiCs (last accessed 30 August 2016).

65 'Auguste \& Louis Lumière: Laveuses (1896)', https://www.youtube.com/watch?v=uhoI TDfQpwU (last accessed 6 April 2021).

66 'L'œuvre cinématographique des frères Lumière: Laveuses Vue No 6o'. 


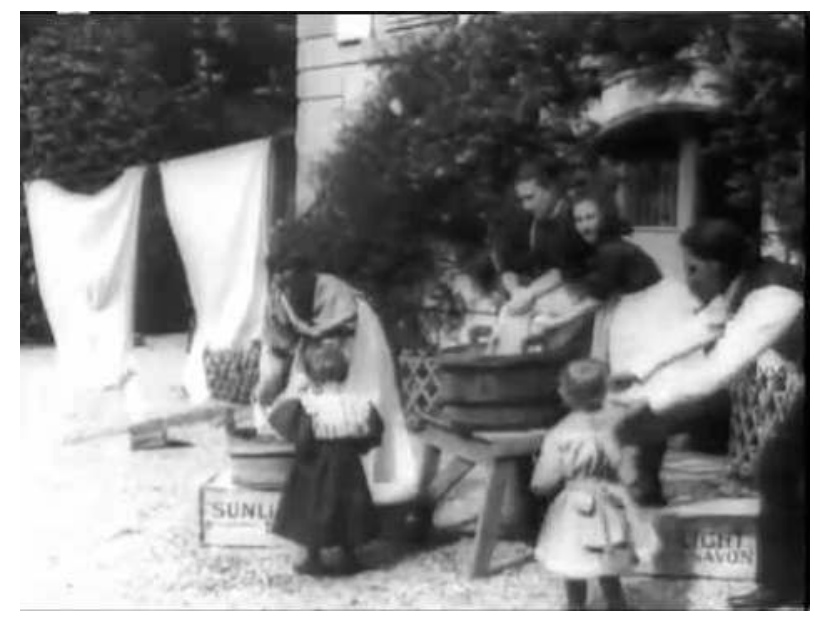

Figure 7.8: François-Henri Lavanchy-Clarke appearing in 'Laveuses'.

women washing clothes in a wooden tub. Another wooden box labelled in German - 'Sunlight Seife'- is placed on the left-hand corner of the screen. With this kind of product placement, two language communities could be reached at a single stroke. Lavanchy-Clarke's appearance in person brands the commercial with his personal figure (in the sense of Hitchcock's later cameos in his movies), a strategy that Lavanchy-Clarke used, like many (local) film pioneers, to 'sign' his moving pictures. At the same time, the appearances allowed the producers of early films, be they actualities, local views, or advertising films, to encourage people in the picture to move so that the new technological possibilities to reproduce movement could be fully exploited. Equally important, Lavanchy-Clarke's entry draws attention to the production process of the 'view' and its constructed nature. In doing so, it refers to the apparatus that makes the construction possible in the first place.

Self-reference in 'Laveuses' can be considered a typical example of what Tom Gunning has termed 'the cinema of attractions', which is characterized by an explicit gesture of presentation and exhibition by means of frontal staging, posing for the camera, directly addressing the audience, and drawing attention to the production process. Moving image advertising has shared these practices with early cinema since its joint and entangled emergence, but while feature fictions developed towards a system of representation and narrative integration, moving image advertising (together with some other cinematic forms) has continued to rely heavily on modes of representation and address that are characteristic of early cinema. 


\section{Reconsidering Media History through the Lens of Advertising}

Early cinema has been acknowledged as a highly self-reflective period. As David Thorburn and Henry Jenkins, in concert with other scholars, have pointed out, 'the introduction of a new technology always seems to provoke thoughtfulness, reflection, and self-examination in the culture seeking to absorb it'. ${ }^{6}$ If periods of media change are characterized by an acute self-consciousness, it comes as no surprise that the history of self-reference in moving image advertising can be traced to the emergence of the form, that is, to the beginning of moving images. Still, Goldman and Papson's diagnosis of a substantial proliferation of commercials that refer to themselves or other commercials in the 1980 s is correct. From a larger perspective, while acknowledging the precedents in high and popular art, Dunne similarly holds that self-reference has become much more common and more elaborate in popular culture since the 1980s. Dunne reads this proliferation of self-reference in media as a symptom of an increasing immersion of the audience in all forms of mediation. ${ }^{68}$ This observation does not necessarily stand in contradiction to the assumption that self-reference is a typical feature for media transitions. But the 'problem' with postmodernity is, as Nana Verhoeff has explained, that with its advent, recognizing selfreflexivity has become 'a bit of a platitude', and that it needs to be specified 'what it is that self-reflection puts on the table. When referencing each other, pointing out their own mediated status, media texts suggest very different agendas, different degrees and directions, even destinations, of self-reflexivity' ${ }^{69}$ While I could not agree more with Verhoeff's call for a differentiated examination of self-reference in various fields of media, I would add that a similar approach to self-reference is necessary also in regard to modernism. Feuer's admonition that Hollywood musical needs to be properly situated in the history of entertainment to understand this particular type of self-reference (and to not mistake it as modernist

67 David Thorburn and Henry Jenkins, 'Toward an Aesthetics of Transition', in Rethinking Media Change: The Aesthetics of Transition, ed. David Thorburn and Henry Jenkins (Cambridge, MA: MIT Press, 2003), 4.

68 Dunne, Metapop, 11. On increasing reflexivity from a larger social perspective, largely interpreted as a result of economic deregulation and the transition from organized to 'disorganized' capitalism (Lash and Urry) in the 1980s. See, for example, Anthony Giddens, Modernity and Self-Identity (Cambridge: Polity, 1991); Ulrich Beck, Risk Society: Towards a New Modernity, trans. Mark Ritter (London: Sage, 1992); Scott Lash and John Urry, Economies of Signs and Space (London: Sage, 1994).

69 Nana Verhoeff, Mobile Screens: The Visual Regime of Navigation (Amsterdam: Amsterdam University Press, 2012), 54. 
self-reference $)^{70}$ is equally relevant for research into self-reference into moving image advertising.

The history of self-reference in moving image advertising before postmodernism is still to be written. To frame such an endeavour methodologically and conceptually, self-reference could be understood as a symptom of media transition, as suggested by Thorburn and Jenkins and others, and at the same time, it could be examined as a sign of increasing mediation, as suggested by Dunne. If self-reference is understood as a mode of address rather than a textual feature, as I suggest in this essay, self-reference could also be studied as an indicator of assumed media expertise of the viewers. In this way, selfreferential media, be it moving image advertising, art, literature, or cinema could be questioned for what media assume their audiences know - or do not know and are therefore in need of education - about respective media. Such an approach offers a methodology that shifts the emphasis from the filmic text to reception and the viewers' media knowledge. Addressing self-reference as a source of knowledge about the assumed media knowledge of the viewers allows for the reconstruction of what kind, range, and depth of media expertise media producers do - or do not - grant their viewers. It is understood that self-reference cannot provide direct access to media expertise of historical viewers, but it can help to further open up the window to media consumption, experience, and expertise in media history, and it lends itself to a media archaeological study of the allegedly ever-increasing immersion of audiences in mediation.

'Im Filmatelier' (In the Film Studio), a puppet animation produced by German advertising film pioneer Julius Pinschewer in 1927, shows how a commercial for the painkiller Aspirin is shot. ${ }^{71}$ While an actress, distorted with pain, is lying on a chaise longue, the director instructs her from behind the scenes on how to present the product so that the camera - and the audience - gets the best view of it. The commercial also gives instructions on the correct use of the product, so that, as the director underlines, the audience can learn from the actress. Clearly, audiences are assumed to be familiar with the practices of product display and directions for product use in commercials. The commercial for Aristoc tights discussed earlier can be interpreted as a somewhat similar, if more sophisticated, version of a moving image advertising addressing the viewers' knowledge about the conventions of product display in moving image advertising.

70 Feuer, The Hollywood Musical, 47.

71 The film is featured on the DVD Julius Pinschewer. Klassiker des Werbefilms, ed. Martin Loiperdinger (Berlin: absolut medien, 2010). 
On a different level, the 1959 animated television commercial for Instant Butter-Nut Coffee, 'Subliminal', parodies the fear of being easy prey to subliminal advertising messages. ${ }^{72}$ Anxieties about subliminal methods of influence were addressed Vance Packard in his book The Hidden Persuaders (1957), a study of psychological techniques including subliminal tactics used by advertisers to manipulate consumer behaviour. Marketing researcher James Vicary fuelled those anxieties even further with experiments in subliminal messaging to 'eat popcorn' and 'drink Coca-Cola' at a cinema in the summer of 1957. Even though Vicary admitted five years later that the results were exaggerated, the case has remained, as Charles R. Acland in his detailed reconstruction of the event retains, 'a touchstone for awareness of subliminal advertising'.73 The cartoon makes fun of the so-called subliminal messaging when a character on a stage addresses the audience directly and announces that this commercial is going to use - it takes three attempts to pronounce the word correctly - 'subliminal' advertising, explaining that this means 'you'll never see or hear the name of the product. It will be on the screen all right but the naked eye cannot detect it'. Of course, both the name of the product and its qualities are exhibited in most obtrusive ways with bold characters and most visible flashes (which stand for the invisible flashes of the subliminal) whenever the character starts to tell a - presumably funny - story. Even the punchline of the story is drowned in images and jingling sounds that are anything but subliminal. This spoof of subliminal advertising comments on the discourses on subliminal advertising and can be interpreted as evidence of trust in consumers' serenity towards overly exaggerated claims of advertising (and media) influence.

Attention to self-reference in moving image advertising may even challenge media theoretical models of critical self-reference. The celebratory mode of audience address that the marketing-driven practice of advertising has used as action against reactance lends itself as a tool to reconsider self-reference in modernist art and media. For the ludic, aggressive, and especially the didactic mode of audience address could be questioned in light of advertising's celebratory mode of audience expertise. The disclosure of media conventions in a Godard film, for example, could just as well be interpreted as a somewhat snobbish acknowledgement of advanced media expertise on the part of a knowing audience. From this perspective, what has

72 The film is featured on the DVD Classic Food Commercials of the 5o's and 6o's, ed. Historical Archive 'Preserving History Digitally' (2009).

73 Charles R. Acland, Swift Viewing: The Popular Life of Subliminal Influence (Durham, NC and London: Duke University Press, 2012), 92. 
largely been acknowledged as film pedagogy can just as well be interpreted as a celebration of elitist media expertise. If one follows this thesis, it would be interesting to search film history for moments of transition from didactic to celebratory modes of address in certain fields, while of course keeping in mind that modes of address are neither exclusive nor successive, but possibly simultaneous and dependent on different ranges of media knowledge and experience of viewers. What one viewer may perceive as a didactic mode of address, another viewer may experience as a celebratory mode of address. After all, moving image advertising, one could conclude on a somewhat cynical note, is perhaps the only place in the history of film and cinema where media expertise of the audience has been acknowledged from the beginning and celebrated as significant knowledge ever since.

\section{Bibliography}

Acland, Charles R. Swift Viewing: The Popular Life of Subliminal Influence. Durham, NC: Duke University Press, 2011.

Allen, Jeanne. 'Self-Reflexivity in Documentary.' Ciné-Tracts 1, no. 2 (1977): 37-43. Andacht, Fernando. 'On the Use of Self-disclosure as a Mode of Audiovisual Reflexivity.' In Self-Reference in the Media, edited by Winfried Nöth and Nina Bishara, 165-182. Berlin and New York: De Gruyter, 2008.

Bartlett, Steven J., and Peter Suber, eds. Self-Reference: Reflections on Reflexivity. Dordrecht: Nijhoff, 1987.

Beck, Ulrich. Risk Society: Towards a New Modernity, translated by Mark Ritter. London: Sage, 1992.

Bernays, Edward L. Propaganda. Brooklyn: Ig publishing, 2005 [1928].

Brehm, Jack W. A Theory of Psychological Reactance. New York: Academic Press, 1966. Cosandey, Roland. 'Le Catalogue Lumière 1896-1907 et la Suisse: Éléments pour une filmographie nationale.' 1895, no. 14 (December 1993): 3-30.

Cosandey, Roland, and Jean-Marie Pastor. 'Lavanchy-Clarke: Sunlight \& Lumière, ou les debuts du cinématographe en Suisse.' Equinox, no. 7 (June 1992): 9-27.

Dunne, Michael. Metapop: Self-referentiality in Contemporary American Popular Culture. Jackson and London: University Press of Mississippi, 2010 [1992].

Feuer, Jane. The Hollywood Musical. Bloomington and Indianapolis: Indiana University Press, 1993 [1982].

'Francois-Henri Lavanchy-Clarke.' Who's Who of Victorian Cinema, http://www. victorian-cinema.net/lavanchyclarke. Last accessed 6 April 2021.

Genette, Gérard. Palimpsets. Literature in the Second Degree. Lincoln: University of Nebraska Press 1997 [1982]. 
Giddens, Anthony. Modernity and Self-Identity. Cambridge: Polity, 1991.

Goergen, Jeanpaul. 'Drei Männer und die Anfänge des deutschen Werbefilms.' In Werbefilme: Spiegel der Zeiten - Chronik des Alltags, edited by Hans-Gerd Schmidt and Bernd Wiesener, 171-195. Bielefeld: Verlag für Regionalgeschichte, 2002.

Goldman, Robert, and Stephen Papson. Sign Wars: The Cluttered Landscape of Advertising. New York and London: The Guilford Press, 1996.

Kael, Pauline. 'Spoofing and Schtik.' Atlantic Monthly (December 1965): 84-85.

Lash, Scott, and John Urry. Economies of Signs and Space. London: Sage, 1994.

'L'œuvre cinématographique des frères Lumière: Laveuses Vue No 6o.' https:// catalogue-lumiere.com/laveuses/. Last accessed 6 April 2021.

Loiperdinger, Martin. Film \& Schokolade: Stollwercks Geschäfte mit lebenden Bildern. Basel: Stroemfeld, 1999 .

Luhmann, Niklas. The Reality of the Mass Media, translated by Kathleen Cross. Stanford: Stanford University Press, 2000.

Metz, Christian. Impersonal Enunciation, or the Place of Film, translated by Cormac Deane. New York: Columbia University Press, 2016 [1991].

Metz, Christian. L'Enonciation impersonnelle, ou le site du film. Paris: Klinksieck, 1991.

Nöth, Winfried, Nina Bishara, and Britta Neitzel. 'Selbstreferenz in der Werbung.' In Mediale Selbstreferenz: Grundlagen und Fallstudien zu Werbung, Computerspiel und den Comics, 57-118. Cologne: Halem, 2008.

Nöth, Winfried, and Nina Bishara, eds. Self-Reference in the Media. Berlin and New York: De Gruyter, 2008.

Odin, Roger. Les Espaces de communication: Introduction à la sémio-pragmatique. Grenoble: Presses universitaires de Grenoble, 2011.

Rancière, Jacques. The Emancipated Spectator, translated by Gregory Elliott. New York: Verso, 2009.

Ruby, Jay. 'The Image Mirrored: Reflexivity and the Documentary Film.' In New Challenges for Documentary, edited by Alan Rosenthal, 64-77. Berkeley: University of California Press, 1988.

Schmidt, Siegfried J. 'Modes of Self-Reference in Advertsing.' In Self-Reference in the Media, edited by Winfried Nöth and Nina Bishara, 47-6o. Berlin and New York: De Gruyter, 2008.

Stam, Robert. Reflexivity in Film and Literature. From Don Quixote to Jean-Luc Godard. New York: Columbia University Press, 1992 [1985].

Thorburn, David, and Henry Jenkins, eds. Rethinking Media Change: The Aesthetics of Transition. Cambridge, MA: MIT Press, 2003.

Verhoeff, Nana. Mobile Screens: The Visual Regime of Navigation. Amsterdam: Amsterdam University Press, 2012.

von Keitz, Ursula. 'Adaption und Funktionalisierung von Spielfilmcodes im neueren Werbefilm.' Spiel 11, no. 1 (1992): 165-189. 
Wagner, Nancy. 'How Much Does Television Advertising Really Cost?' chron.com [n.d.], http://smallbusiness.chron.com/much-television-advertising-reallycost-58718.html. Last accessed 6 April 2021.

Withalm, Gloria. 'Commercial Intertextuality.' In Logica, dialogica, ideologica. I segni tra funzionalità ed eccedenza, edited by Patrizia Calefato, 425-435. Milan: Mimesis, 2003.

Withalm, Gloria. 'Commercialzation of Filmic Self-referentiality.' Semiotica 148, no. 1-4 (2004): 337-36o.

Withalm, Gloria. 'Recycling Dorothy, Dinosaurs, and Dead Actors: Digi-Textuality in the TV-Commercials of the 1990s.' Semiotische Berichte 27, no. 1 (2003): 297-315. Zurstiege, Guido. Zwischen Kritik und Faszination: Was wir beobachten, wenn wir die Werbung beobachten, wie sie die Gesellschaft beobachtet. Cologne: Halem, 2005. 


\section{Part II}

Cases and Materials 



\title{
8. Moving Objects: The Case of Volvo
}

\author{
Bo Florin
}

\begin{abstract}
In 'Moving Objects: The Case of Volvo', the concept of mobility is investigated on several levels - the movement of the cars, the movement of people, and the movement of the camera - and how this concept is launched within the ads along with 'Scandinavian' values. The commercials also point back to the basic definition of cinema qua moving images, aiming in turn at moving the audience.
\end{abstract}

Keywords: cars, mobility, movement, Volvo

In the history of advertising film, cars have played a pivotal role as advertised objects for many decades. However, in comparing print and moving picture ads for cars, it is striking that, whereas print ads in general seem to suggest mobility, advertisers in moving images have, on the contrary, frequently chosen to depict the cars as immobile objects. ${ }^{1}$

The very definition of cinema as moving images, perhaps the most banal but also the most general, adopted from early on, points to the fact that the ability to create movement in film has fascinated viewers from the early years of cinema and onwards. In his Images mobiles, Jean-Louis Schefer initially claims that amazement is the basic capacity of cinema. ${ }^{2}$ At the same time, he also notes that motors, giant machines, and other bizarre

\footnotetext{
1 See, for instance, the Un-Pimp Your Ride series for Volkswagen (2006); 'The Slowest Car We've Ever Built' for Audi R8 (2007); 'Human Car' for Ford (2008); ‘Change Perspective' for Saab (2009); 'Everything is Sport' for Renault Megane (2010); 'German Car' for Opel Astra (2012); 'Le meilleur, sinon rien' for Mercedes-Benz (2013); 'The Car That Answers Today's Questions' for Citroën C4 Cactus (2014); 'X' for Fiat 50oX (2014); 'Piggy Bank' for Toyota (2015). As for paper ads, see Bo Florin, 'Morfaus - ihmisestä moottoriksi' (Morphing - from man to motor), Lähikuva 4 (2001): 23-27.

2 Jean-Louis Schefer, Images mobiles (Paris: P.O.L, 1999), 17.
}

Florin, B., P. Vonderau, Y. Zimmermann, Advertising and the Transformation of Screen Cultures. Amsterdam: Amsterdam University Press, 2021 DOI 10.5117/9789462989153_CHo8 
mobile objects that frequently occur in early cinema - an art that, in many ways, constitutes modernity - are often used to equal humans; if cinema is a modern art, he argues, it is indeed in this capacity, that it registers and includes a number of objects, images, or sequences in its constant movement - and that cinema expresses the passing of time in reproducing human mobility, and 'inspiring feelings, suspense, fright, boredom, pleasure'. ${ }^{3}$ This ability to make objects move was also adopted early on in advertising films, which Michael Cowan observed in his analysis of Julius Pinschewer's animated films from the 1910s, in which he discusses how they, in showing products in movement, thus anthropomorphize commodities. Equalling human culture and its products in this way also sheds light on modernity, in which consumer culture and its products have gradually acquired 'an autonomous status'. ${ }^{4}$ Cars combine - with other technological means of transportation - the unique capacity of being mechanical objects with the ability to move. Automobiles, trains, or airplanes were thus cherished objects in early cinema, both in commercials and in other films. Later, however, as cameras became increasingly mobile, the concept of movement in film was extended to also creating movement by film - which creates a new tension between the movement within the frame and the movements of the frame itself, which opens for the new modes of mobility that the history of cinema has indeed explored in depth.

In the following, I will analyse the paradoxical relation between movement and arrest in car advertising through a number of Volvo film ads, in which the very name of the car - 'I am rolling' in Latin - suggests movement and mobility. 5 To what extent is this expressed, and how do the ads address the concept of mobility? I will discuss the degree of mobility in connection with the degree of visibility of the car as object, and how the ads actually

3 Ibid, 235 .

4 Michael Cowan, 'Advertising and Animation: From the Invisible Hand to Attention Management', in Films That Sell:Moving Pictures and Advertising, ed. Bo Florin, Nico de Klerk, and Patrick Vonderau (London and New York: Palgrave, 2016), 99.

5 The archive of Volvo films and stills is kept by the Gothenburg company Frontema AB, on behalf of the Volvo museum archive. This archive contains around 5000 films, both industrial films and advertising films. Around 3000 of these films were made between 2000 and 2015; the remaining 2000 films were made between 1927 and 1999. Almost all of the films from the 1930 s are missing. The few remaining films from 1927 to the end of World War II are on nitrate. According to Peter Ohlson at Frontema AB, most of the films from the period would have been destroyed due to the risks of preserving nitrate films (personal email 20 November 2014). For a definition of industrial film, see, for instance, Vinzenz Hediger and Patrick Vonderau, eds., Films that Work: Industrial Film and the Productivity of Media (Amsterdam: Amsterdam University Press, 2009). 
communicate their message. Secondly, I will investigate the impact of the company's ownership ${ }^{6}$ and of ad agencies over time. In what ways - if any - do changes in ownership or of agency change the style and mode of address of the ads, and the ways of depicting mobility?

I have limited this study to cinema and television commercials, and my main source will be the commercials themselves. In addressing the theme of mobility, I have focussed on a few particularly significant films from each decade, thus also choosing a qualitative approach to the films rather than attempting to write a complete history of Volvo ads. Though my aim is not primarily historical, this analysis nevertheless inevitably contains a historical dimension, since the films discussed are made during several decades, from the 1940 s to the 2010s. The reason for this is that, when going through the archival material, I found that it contains a number of central themes that are repeated and varied throughout the decades, and which I attempt to deal with in the following: from general, denotative aspects relating to the car as such - car model, fuel consumption, safety - to more connotative "added values", such as national iconography and cars as lifestyle. In dealing with Volvo's history of different owners and different advertising agencies, the issue of national versus international in the modes of advertising is also inevitably brought to the fore. I am interested in how the films are made: in which kind of surroundings the cars are shown, and above all, which cinematic devices are used? My main focus thus remains with representational issues and cinematic techniques.

Since the early 19oos, two co-existing theories of advertising have competed on the market: the hard sell and the soft sell. Hard-sell advertising, according to early theorists such as John E. Kennedy, Claude Hopkins, or Albert Lasker, was what they called 'salesmanship in print'. In Juliann Sivulka's words, this means that one should 'state in print what a salesman would have said in words to a customer. That is, it should offer a sensible argument with specific reasons why the product was worth buying.7 Applied to TV or cinema commercials, that could mean using both a spoken comment and a written text.

On the other hand, 'proponents of the soft sell', Cynthia B. Meyers writes, 'following such rival theorists as Theodore MacManus, appeal to

6 The Volvo Cars Company was owned by Aв Volvo (Sweden) until 1999. Then Ford Motor Company acquired the company; in 2010 the Zhejiang Geely Holding Group of China took over. 7 Juliann Sivulka, 'History: 1900-1920', in The Advertising Age Encyclopedia of Advertising, vol. 2, ed. John McDonough and Karen Egolf (London: Fitzroy Dearborn Publishers, 2003), 761 
the consumers' emotional needs. [...] They attract the consumer with clever concepts, puns, humor, and visually arresting imagery'.

These two kinds of advertising, which will also reappear in the following, may be clearly illustrated by a couple of Volvo commercials, each dealing with safety, a core value for Volvo according to The Advertising Age Encyclopedia of Advertising, which contains an entry on 'Automobiles', in which Volvo appears under the heading 'Selling Safety', and it is emphasized that '[s]afety has been a cornerstone of Volvo's advertising [...].' 9

This statement may be confirmed for example by a commercial from 1957 called 'A Golden V for Volvo' for Volvo P444 (agency unknown), in which eight seconds of the 6o-second commercial are exclusively devoted to advertising safety. A car is driving on a suburban road, and a lady with a dog is walking on the pavement. Suddenly, she moves to cross the street, but the car is quickly approaching. Then there is a close-up shot of the pedals, with the driver slamming the brakes, followed by another close-up of a wheel braking quickly. Finally, we see the car safely stopped and the lady with the dog crossing the street just in front of it - a mutual glance of understanding between the driver and the lady ends the scene. During the scene the voice-over states, "The brakes of the new Volvo, with peak power, give you peak security'.

A second example appears in 'Lucky Guy' for Volvo V4o (42 seconds), made by Forsman \& Bodenfors in 1999. A man is walking on the pavement on a city street. He is wearing earphones (we can hear a reggae tune on the soundtrack) and he does not seem to take any notice of what is happening around him. Then there is a cut to a builder on scaffolding, laying bricks. Back to the man on the pavement, who - without noticing - hits an old lady with his backpack and makes a man on a Vespa roll over when he crosses the street. Then again there is a cut to the worker on the scaffolding high above the street. Just as the pedestrian approaches, a brick falls, but the man stops short; something has caught his attention, and the brick hits the ground just in front of him (he still doesn't notice). The subject of his attention is a car parked on the opposite side of the street. He walks away,

8 Cynthia B. Meyers, 'The Best Thing on TV: 1960 os Us Television Commercials', in Films That Sell: Moving Pictures and Advertising, ed. Bo Florin, Nico de Klerk, and Patrick Vonderau (London and New York: Palgrave, 2016), 176. It is not that the soft sell can't use words; MacManus's famous 'The Penalty of Leadership' ad for Cadillac only consisted of words (and no illustrations). It is rather a question of tone.

9 Jean Halliday, 'Automobiles', in The Advertising Age Encyclopedia of Advertising, vol. 1, ed. John McDonough and Karen Egolf (London: Fitzroy Dearborn Publishers, 2003), 113. 
out of the frame, and leaves the car in focus. The closing text appears: 'Volvo V40. Designed to save lives.'

Not only do the two films deal with advertising in different ways, using hard sell and soft sell respectively, but there are obviously many other differences between the two commercials. They are made at different times, when the dominating cinematic devices also differed; they are made under different ownerships; they are made for a national and an international audience, respectively; in the first, the word safety is used literally, referring to the brakes of the car, whereas the second uses the term metaphorically; and last but not least, while the first film shows a car in quite dramatic motion, the car in the latter is parked alongside the pavement. Still, movement is equally important in this second film, which points back to the hypothesis mentioned initially, and which will be further explored in the following, that the focus of mobility in these ads is gradually shifting from the movement of the car as such to other kinds of movement within the image as well as to the movement of the image as such.

\section{Cars, Nation, and Lifestyle - An Iconography in Movement}

Among the most high-profile recent Volvo films was the 2014 Volvo advertising campaign 'Made by Sweden', featuring famous football player Zlatan Ibrahimović, later followed by 'Made by Sweden - prologue' and 'Made by Sweden - epilogue', both from 2016. Made in the north of Sweden, the 2014 ad centres on adventures in the wilderness: we see Ibrahimović diving into a hole in the ice, running, hunting deer, and sitting by the fire. And we see the car - Volvo $\mathrm{XC}_{70}$ - in this wild landscape, often from a distance. The film lasts for two minutes and contains no fewer than 75 shots. Of these, cars only appear in 20 shots (the logo included). Thus, the film suggests movement and speed, but less through the car than through the editing. In several shots, the car is actually stationary. Interspersed with pictures of the cold and of wild nature, there are on the one hand images from Ibrahimovićs home - his wife looking through a window as if longing for her husband outside, but also of them together in bed, or of Ibrahimović playing with his children - and on the other hand footage of Ibrahimović playing football for Sweden. All of this is accompanied by Ibrahimovic 's voice, reading a slightly changed version of the Swedish national anthem to music produced by Max Martin. In its evocation of mobile life, this film places itself at the heart of the matter. 
In the earlier history of Volvo ads, there is both movement and arrest. Cars are shown driving to demonstrate good traction or efficient brakes. Alternatively, the cars remain still, and the film focusses on comfort, the capacity of the boot, or the spacious interior, instead using the movements of the camera to create a sense of mobility.

Two films from the early 1970s, both directed by Bo Widerberg, may serve as examples here. In the first, 'Sauna' (1972), a parked Volvo 140 appears for a short moment in a story about an older man enjoying a sauna. The car then reappears in the last shot of the film. The voice-over - by actor Max von Sydow - is talking about life expectancy, of Swedes and of Volvo cars, and that the Swedish passion for fitness may be the reason for the Swedes' longevity. Volvo cars, like all Swedes, also have long lives, because, as the slogan explains, 'We build them the way we build them because we have to'. From the immobile car to human movement in a demonstration of a 'passion for fitness', the connection made in the voice-over commentary between passion for fitness and longevity is transferred from human to vehicle. In other words, the car will similarly live a long life, as it is built according to 'fitness' principles. In 'Cost of Living' (1972), cars are shown by means of paper ads. A little girl is sitting at a table, drawing. Beside her sits her father, taking care of family finances and looking into paper ads for cars, whereas the mother is busy putting groceries into the refrigerator. Max von Sydow, in voice-over, talks about the high cost of living and the need for financial planning, especially when it comes to buying a car. Thus, the durability of the car is particularly important. At the same time, a paper ad for Volvo comes into focus. The film again ends with the comment: 'We build them the way we build them because we have to.' According to the voice-over, it is worth it for the family, who are about to buy a new car, to choose a Swedish car, a Volvo, as this means that it will last for many years in the Swedish climate. ${ }^{10}$ The family is impressed by the pictures of the new seats, which have little to do with movement. In this ad, thus, there is no actual car, but only an image within the film image of a car. This ad within the ad, this mise en abyme, introduces a meta perspective to the film - a virtual movement from the ad depicted in the film to the actual film ad.

10 Without any explicit reference, this lines up with the classic slogan launched in 1944 by CEO Assar Gabrielsson: Volvos värde varar ('the value of Volvo lasts'). This slogan was actually still in use into the 1970s. 
In his two-volume book on the image of Sweden and Swedishness in the United States, Jeff Werner devotes a chapter to the Swedishness of Volvo. ${ }^{11}$ Here, he discusses Hanne Niss's general research on the importance of nationality in marketing. ${ }^{12}$ According to Niss, national signifiers are often used by new companies seeking to benefit from concepts associated with the nation. Werner notes that this also summarizes well the way in which Volvo was using concepts such as 'Swedish quality', 'Swedish craftsmanship', or 'design' during the first ten years of advertising. ${ }^{13}$ Werner's chapter focuses only on print ads, but I would claim that his study is equally valid for commercial films.

Hanne Niss's argument is also relevant for early Volvo commercials. However, it is not possible to extend her point, on new companies specifically using the nation as trademark, to a later period in time. On the contrary, Sweden has recently returned as a featured component in Swedish-produced Volvo advertising, not least through the Zlatan Ibrahimović films. Forsman \& Bodenfors, the agency behind the campaign 'Made by Sweden', started their Volvo campaign with the slogan 'Made by Scandinavia' (2012), in a similar manner referring to Scandinavian nature, but without any focus on celebrity. ${ }^{14}$ After this rather broad Scandinavian view, the agency has gradually sharpened its focus. In later print ads, the focus is further narrowed to Swedish landscapes: 'Made by Gästrikland' and 'Made by Södermanland', for example. In the film 'Made by Sweden', Swedish wilderness, Ibrahimović, and cars have been the producer's keywords. Forsman \& Bodenfors writes:

Together with Zlatan Ibrahimović we have done a celebration to Sweden. It's our country's unique nature that inspires and challenges the people at Volvo when they develop their cars. It's also here, at home, in the magnificent wilderness that they find their strength. Just as Zlatan does. ${ }^{15}$

11 Jeff Werner, Medelvägens estetik, Sverigebilder i USA, Del 2. (Hedemora: Gidlunds förlag 2008), 173-209.

12 Hanne Niss, Made in Denmark. Nationalitetens betydning i international marknadsføring (Aalborg: Aalborg Universitetsforlag 1994).

13 Werner, Medelvägens estetik, 189.

14 Forsman \& Bodenfors work with paraphrases, not only of the national anthem. Here, on the soundtrack, a child reads a paraphrased version of 'He's got the whole world in his hands': 'You've got the whole world in your hands'. With 'You've got you and me in your hands', the traditional Volvo focus on safety becomes quite apparent.

15 'Made by Sweden feat. Zlatan', http://www.fb.se/work/volvo/made-by-sweden (last accessed 6 April 2021). 
And along with the ad on Volvo's YouTube site the text reads:

Sweden is our home. Mountains, vast forests, long distances, sun, rain, darkness, snow and ice. This inspires and challenges us when we develop our cars. The Swedish wilderness is our heritage and it is here we find our strength. Just like Zlatan Ibrahimović. This is our celebration of Sweden. ${ }^{16}$

The fact that Ibrahimović reads the national anthem in the film quickly attracted commentary, as he has never taken part in the singing of the anthem with the Swedish national team. The words of the national anthem, however, are also changed in the Volvo ad: whereas the original refers to living and dying in 'the North' (Norden), this changed to 'Sweden' in the Ibrahimović film. This change also became a subject for heated debate in Sweden, as it was interpreted as an expression of a new nationalism. ${ }^{17}$

Interestingly enough, the image of a wooden cabin or a sauna in the film clearly parallels the already mentioned in 'Sauna' by Widerberg. Both of them evoke a Swedish or Nordic iconography, with the sauna in a winter landscape. I will return to this type of intertextual connection between different advertising films later in this essay.

The film 'Made by Sweden feat. Zlatan' was significant in its turn to celebrity as a way to market Volvo cars. As has already been noted, only 20 of the 75 shots in the film actually show the car. Another important aspect is the audible quality of cars. Hearing the car when it is out of sight could be an alternative way of featuring the car. In this ad, there are no car sounds when the car is not visible, and we can barely hear the sound of the car even when it is visible (because of the voice-over and the music). ${ }^{18}$ The majority of the images exemplify instead what may be called lifestyle images: the wild life with hunting, the home life with the family, and so on.

This is parallel to a development Jeff Werner traced in print ads; he notes that an increasing proportion of ads from the turn of the millennium onwards tend to be general 'lifestyle pictures', rather than specifically product related, to the extent that

16 'Volvo XC70 feat. Zlatan - Made by Sweden', https://www.youtube.com/watch?v=cbvdzQ7 uVPc\&list=PLnQowESnmpOfNzpaEc-r2LBeKsVtJkJxx\&index=3 (last accessed 6 April 2021).

17 DN 2014-01-28; $S v D$ 2014-01-28.

18 This is an important aspect, which could also be elaborated on a more general level. Due to the limited format of this study, however, I have chosen to omit it here. 
there are no pictures of cars whatsoever. The models are instead presented separately, in compositions with emphasis on luxury and speed. People reappear in the images, but they are no longer staged as car drivers or car owners. Instead, it is adults and now again often children who appear in attractive environments, engaged in tempting activities. Strikingly often, they are at the seaside. ${ }^{19}$

Here, though, almost all films differ from the print ad: the cars are still present, though framed through celebrities and their lifestyles.

In 2013, Forsman \& Bodenfors produced 'Leave the World Behind', which connects the so-called supergroup Swedish House Mafia, and their decision to stop touring, to Volvo XC6o: 'a cross-country car that can take you far away from the stressful city life'. ${ }^{20}$ The company also developed 'Made by Sweden' into a series, featuring different Swedish celebrities. Another 2014 film features the famous Swedish artist Robyn driving around after a day at work in Los Angeles, but also shows glimpses of her summer home in Sweden. This was followed by 'A Winter's Tale' (2015), a four-minute ad from different parts of Sweden featuring the song 'En vintersaga' by Ted Ström (1984) - a song that actually includes the line 'A lonely Volvo struggles in the headwind on the Tjörn Bridge' - and capturing the melancholy season. Featured celebrities include former hockey player Börje Salming; singers Timbuktu, Oskar Linnros, and Amanda Bergman; high jumper Emma Green; and fashion designer Carin Rodebjer. ${ }^{21}$

This celebrity trend - sometimes more local, sometimes more international - can also be traced in the earlier historical material. An ad for Volvo PV444, 'A New Star' (1947), opens with images of Greta Garbo and Ingrid Bergman, who are introduced as 'Swedish stars'. This is followed by an image of 'a new Swedish star': Volvo, which in turn is linked to 'Swedish beauty and style', accompanied by images of the Carl Milles fountain at the KTH Royal Institute of Technology campus and glass art from Orrefors. The film concludes that this beauty and style are 'qualities that have often won the day in global competition'. Though these earlier ads, both Swedish and international, emphasize the properties of the car - for example, the ad 'A Swedish Beauty' (1947) points out that the Volvo PV444 is spacious and

19 Werner, Medelvägens estetik, 185 .

20 'Leave the World Behind', http://www.fb.se/work/volvo/leave-the-world-behind (last accessed 6 April 2021).

21 Because of the length of the film, it is often shown in shorter pieces with only one celebrity at a time. 
fast, with low fuel consumption - they also link it to lifestyle and celebrity: excursions, sleepovers, and the like come into the picture, with the car as the vehicle for these seemingly endless possibilities.

Interestingly enough, the references to celebrities closely follow the pattern outlined above in connection to the question of the national. The national stars also return in a big way a decade into the new millennium, whereas they seemed to have disappeared by the mid 196os in national ads, as the general references to Sweden declined. Internationally, however, there is no such trend; here, Swedishness has remained an important topos throughout the decades.

\section{A Changing History: From Proprietors to Agencies}

In 1999, Volvo was bought by the American-owned Ford Motor Company. It would be easy to assume that this would mean a radical change of strategies in advertising the car. However, head designer Peter Horbury, who had been hired by Volvo already in 1991, stated around the millennium that ' $[\mathrm{i}] \mathrm{t}$ is important that the roots are Swedish. We will continue to emphasize the feeling for light, functionality, and timelessness that is found here. We make a Swedish car'. ${ }^{22}$ Furthermore, Werner quotes a Q\&A for sellers from the period:

Q: I know Volvo is owned by Ford. How much of this car is Ford-driven? A: The $\mathrm{S}_{40}$ (and all Volvo models) features true Scandinavian design. The new $\mathrm{S}_{40} \mathrm{w}$ will be built in Ghent, Belgium. Ford is our parent company; yet we remain true to Volvo values of safety, quality, and environmental care. ${ }^{23}$

The question here is whether this is reflected in the film ads. When Volvo was first bought by Ford, the Volvo car was integrated into a general Ford advertising campaign (1999). Swedish journalist Lennart Pehrson writes:

The campaign underlines how Ford now increasingly integrates Volvo as one of several trademarks under a Ford umbrella. Beside Volvo, there are Ford, Lincoln, Mercury, Jaguar, Mazda and Aston Martin. At 9 pm, local time, Ford will show a two-minute long advertising film for TV audiences all over the world. The consumers in New Zealand will be the first to see the film, which then will follow the time differences towards the west, 
in a way that is supposed to remind of how the new millennium will be rung in. Ford counts on reaching 300000 households or approximately a billion consumers all over the world in one strike. ${ }^{24}$

On the soundtrack, there is no talk about cars, but only a song accompanying the visuals, 'Just Wave Hello', by then thirteen-year-old Welsh soprano Charlotte Church. It was written especially for the advertising campaign, and as Pehrson noted, Ford hoped that it would become 'the global national anthem' of the company. ${ }^{25}$ The Ford film, a piece in slow motion but constant movement, shows people together, across all continents around the globe. They meet in various connections and situations, and between generations: a wedding, a deathbed, a newborn baby with her mother. They are people that meet or just pass by, people embracing, laughing and dancing, people performing rituals or stretching out their arms, celebrating freedom and liberty (one of them standing on a car, another sitting in one). During the whole film, there is sun and music, 40 shots of cars are quickly inserted - only nine of them in motion, while the rest stand still - all of the different types of cars owned by Ford. Each logo is visible once, and only the Ford logo reappears on several occasions. Thus, thanks to Ford, not only cars but also people from many nations are happily united - and thanks to the different cars, mobility and meetings are facilitated across the globe. The constant movement of the camera takes up the movement of the car in the first shot, caught through the image of a hand on a rear-view mirror in an otherwise blurred picture, which introduces human movement as the third part in this circulation between different kinds of movements and mobilities.

In the United States, the film was shown simultaneously on 38 different TV channels, including the largest broadcasters ABC, NBC, and CBS, and in Sweden, it was shown on cable channels such as CNN International, Discovery, MTV, and Eurosport. But it turned out that this campaign would remain exceptional, and the increasing integration predicted by Pehrson never really took place. Rather, it is striking that, apart from this singular attempt, advertisements for the Ford Company continued to be separate for each particular type of car. With Volvo ads, it was thus back to business as usual - but with a renewed focus on Sweden and Scandinavia.

In 2019, Zhejiang Geely Holding took over Volvo from Ford. At that point, there were no attempts similar to that of the early Ford ad to integrate

25 Lennart Pehrson, 'Bilindustrin: Volvo med i Fords 2000-kampanj. Tv-reklam ska stärka det amerikanska företagets varumärken', DNEkonomi, 31 October 1999. 
Volvo into the company's overall profile. The changes in ownership thus turn out to have had only a minor influence on the way that the car has been advertised. ${ }^{26}$ Rather, the new owners have tended to emphasize the continuity and stability of the brand.

What, then, about changes in the advertising agencies used, nationally and internationally? In an essay on the history of Swedish trade and industry, business historian Oskar Broberg notes, '[a]lready in the 1920s, a couple of American advertising agencies had opened offices in Sweden, but they didn't last that long. Instead, it was during the 199os that the trade started to become truly international. ${ }^{27} \mathrm{He}$ describes the different strategies used by Swedish companies as they established themselves on an international market. Among the most successful were Forsman \& Bodenfors, who, according to Broberg 'established connections with globally active companies like Ikea and Volvo. These collaborations, in an otherwise very changeable trade, would turn out to be long term and important for the future development of the companies'.28

Internationally, the changeability of the trade is quite visible in the case of Volvo advertising, especially in the start as Volvo entered the us market in $1955 .{ }^{29}$ Little is known, however, about moving image ads from these early years in the United States. These years also marked the beginning of the so-called Creative Revolution, about which Cynthia B. Meyers writes:

In the late 1950s, the agency Doyle Dane Bernbach (DDB) designed an ad campaign since mythologised as the launch pad for the Creative Revolution. In one print ad, a black-and-white photograph of a Volkswagen Beetle the size of a coin appeared on a page of mostly white space, with the headline "Think Small'. The ad copy noted the advantages of 'small' insurance and 'small' repair bills and of being able to squeeze into 'small' parking spaces, implicitly mocking the excessive blustering of hard-sell claims of 'bigger, better. $3^{0}$

The revolutionary aspect of DDB's working method was to let copywriters and art directors work together, encouraging a more artistic way of advertising,

26 There are some exceptions to this general rule. In 2012, after the takeover of Volvo of a Chinese company from Ford, the American basketball star Jeremy Lin, of East Asian origin, signed an advertising contract with Volvo for ads in China and in the United States.

27 Oskar Broberg, 'Globalisering, entreprenörskap och humankapital', Det svenska näringslivets historia 1864-2014, ed. Mats Larsson (Stockholm: Dialogos Förlag AB: 2014), 628.

28 Ibid.

29 In 1955, Volvo entered the Us market, using Ed Belford Agency for advertisement purposes. In 1959, Anderson \& Cairns (later, Chirurg \& Cairns) took over for two years, but were replaced by Sind \& Sullivan in 1961, though only for six months.

30 Meyers, 'The Best Thing on TV', 177. 
often using irony to convey their message. The Volkswagen campaign also came up with a television commercial in a similar vein to the print ad described above. ${ }^{31}$

In 1962, Volvo signed with Carl Ally Inc., and remained with that agency until 1967. An article in AdAge notes that 'Ally moved Volvo onto TV and sharpened its durability theme with the promise that "Nine out of every 10 [Volvos] registered here [i.e., in Sweden] in the last 11 years are still on the road"'.32 It is obvious that Carl Ally was inspired by DDB - as were many other agencies during this time, and for many years to come. Carl Ally's first campaign for Volvo featured a car pushed to its limits by a rally driver. The ad starts with a close-up of the car's bonnet, and as a voice-over tells us that 'this is a Volvo, the Swedish-built compact', the engine starts to rumble and then the car goes with a flying start. The voice-over continues to describe the car as it drives on, very quickly, on a dirt road, raising a great deal of dust. The ad ends when the car suddenly brakes, and the camera zooms in on the logo at the back of the car. The campaign achieved much acclaim within the industry, and its slogans 'You can drive a Volvo like you hate it' (in the print ad combined with the price \$2565) and 'It's cheaper than psychiatry' became famous and placed Volvo on the us map. The ad has also been given new attention as it was part of a project, 'Re: Brief by Google', in which Amil Gargano, the art director of the ad, discusses it with younger colleagues. ${ }^{33}$

Volvo's first long-lasting relationship with an ad agency was with Scali, McCabe, Sloves, from 1967 to 1990, though it was abruptly ended after a controversy concerning a commercial. ${ }^{34}$ One of their late commercials, 'Replacement Parts' (1990), stands out: the camera zooms out from a close-up on a rotating cranium and the text 'Cranium' appears. After that, the camera moves on, focussing on 'Lumbar Vertebrae', 'Scapula', 'Radius', 'Metacarpus', 'Thorax', 'Pelvis', and 'Metatarsus', each shot featuring - either in movement or with moving camera - the different parts of

31 'TV commercial film for Volkswagen “Think Small” HD', https://www.youtube.com/ watch?v=UUlZmZ_sd_E (last accessed 6 April 2021).

32 'Volvo', Ad Age, http://adage.com/article/adage-encyclopedia/volvo/98923 (last accessed 6 April 2021).

33 Project Re: Brief - Amil Gargano - Re-imagining Volvo, "Drive it Like You Hate it", https:// www.youtube.com/watch?v=RUHEyPtScıE (last accessed 6 April 2021).

34 'Scali's undoing was the "Bear Foot" commercial, filmed in Austin, Tex., in which a giant pickup truck with tires nearly as tall as a man crunched its way across a line of cars, flattening all but a Volvo station wagon. The advertisement was presented as a real demonstration of Volvo's superior construction, but the results had been rigged by reinforcing the Volvo.' Kim Foltz, 'The Media Business: Advertising; Scali Quits Volvo Account, Citing Faked Commercial', The New York Times, 14 November 1990. 


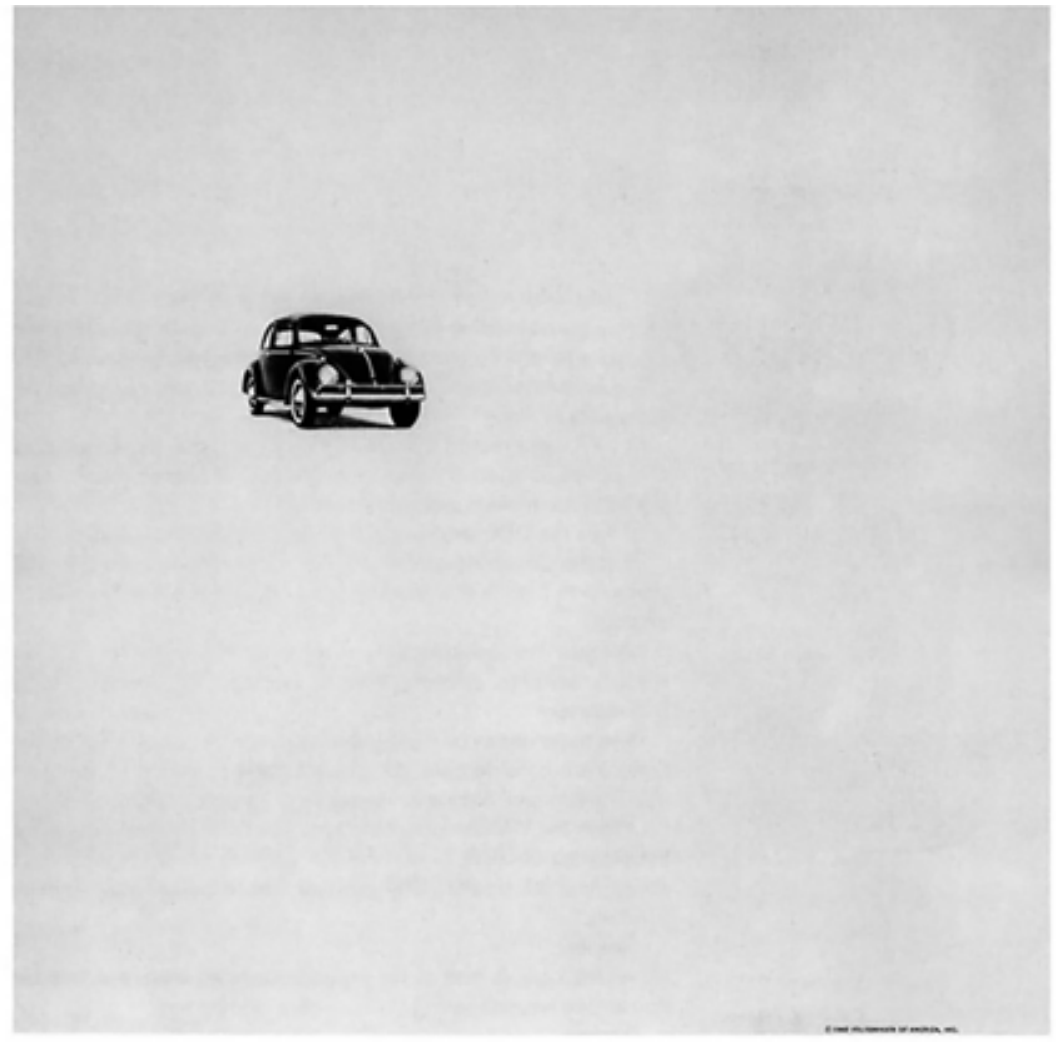

Think small.

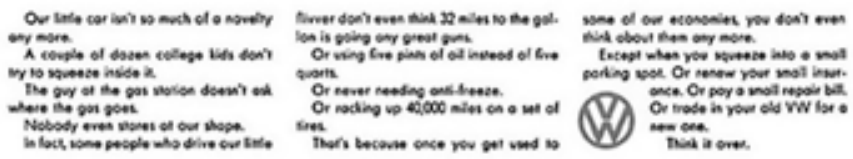

Figure 8.1: Ad for Volkswagen by DDB, 1959.

the human skeleton. The ad ends with a voice-over saying, 'Drive a Volvo, because replacement parts are hard to find', and a text, 'Volvo - A car you can believe in', together with an image of a stationary Volvo car. Though the car itself is stationary, the ad as a whole is constantly in motion, both through the camera and through the rotating parts of the skeleton, thus playing with the ideas of mobility and stability through the double entendre of 'replacement parts'. This car commercial also constitutes an early example of an ad in which the car itself is absent until the very last image. 


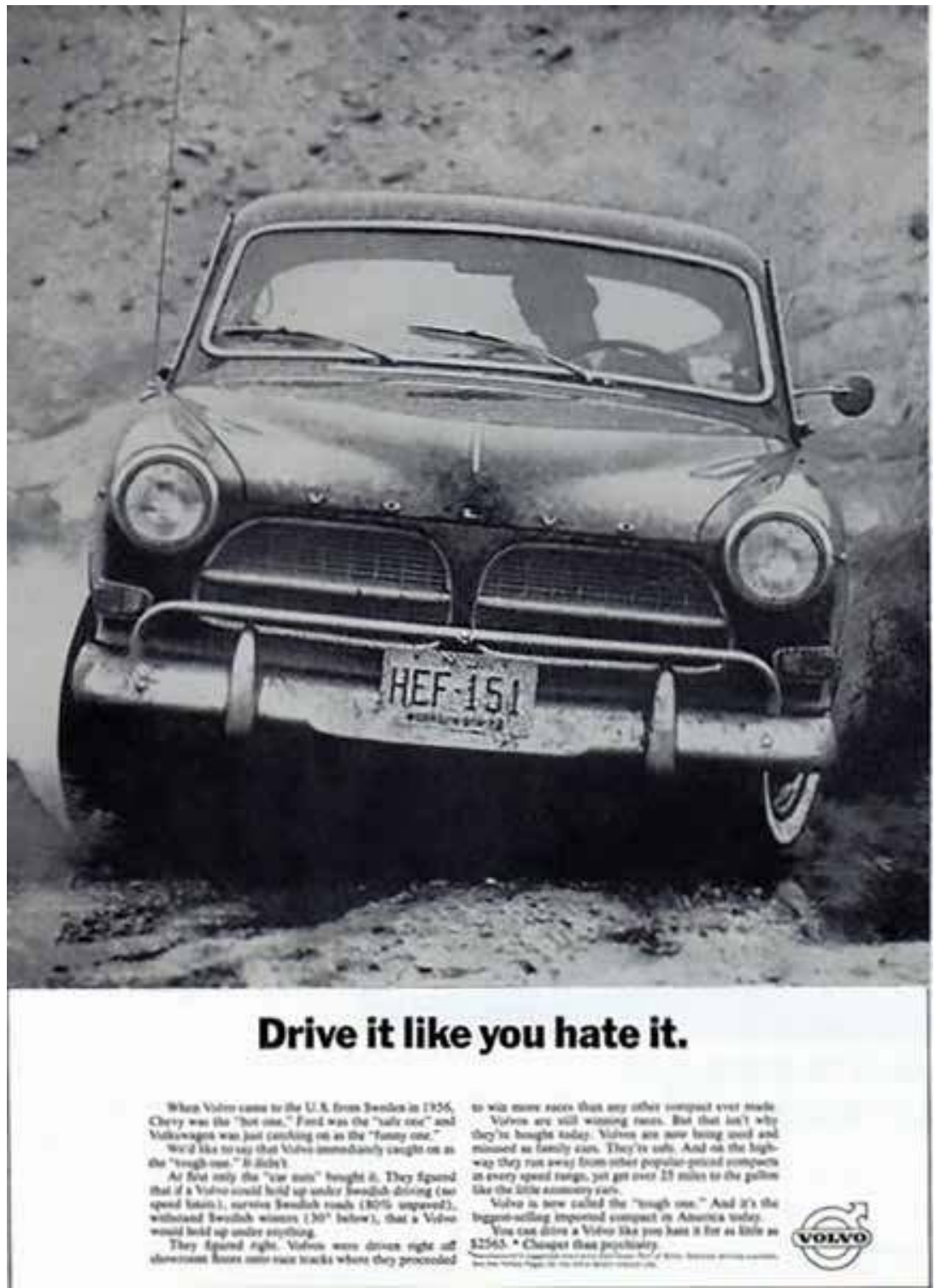

Figure 8.2: Ad for Volvo by Carl Ally Inc., 1962.

In 1991, Messner Vetere Berger McNamee Schmetterer, later MVBMs/Euro RSCG, took over, and was responsible for an important part of the company's international ads until 2014 in different collaborations. From 2007, for example, they collaborated with Arnold Worldwide, part of Havas, an advertisting agency, in which Euro RSCG is also included. During this period, according to the same article in AdAge, Volvo also completely shifted its media focus to TV. From a 
Swedish or Scandinavian perspective, however, there was a radical change as, according to Swedish journalist Bengt Carlsson, 'in 1994, Volvo gathered many of its ads, which at that time were spread across several agencies, within Forsman \& Bodenfors' 35 Though mainly responsible for the Swedish, Nordic, or European market, they have also been working on a global basis, parallel to MVBMS/Euro RSCG. In 2014, Grey London took over the international market.

\section{Different Agencies - Different Strategies?}

Examples from the different advertising agencies point to clear changes in strategies. Through the following selected examples, I will analyse some of the changes that occurred across the three different ownerships of the company and consequently also the varying ad agencies. The two different advertising theories, hard sell and soft sell, should also be kept in mind here: to what extent can they be traced throughout these strategic changes?

In 'Survivors' (1994), produced by MVBMs/EuroRSCG, eight scenes from different everyday environments are shown, all with distinctly named persons in different configurations: family, woman, couple, man, couple, three men, couple, two women. These 'survivors' are in movement: jogging, playing sports, dancing, fishing... The shots are accompanied on the soundtrack by tones of a moving carol, 'What Sweeter Music', arranged by John Rutter and performed by the Cambridge Singers. Thereafter, a voice-over solemnly announces that ' $[t]$ he people you've been looking at, all share a common belief, that a car saved their lives'. At the end, there is a slogan: 'Volvo. Drive Safely', but no car is visible whatsoever.

In 1997, Forsman \& Bodenfors produced 'The Golfer', an ad for the new Volvo V7o Bi-fuel. The soundtrack includes a song by the Ink Spots from the 1940s, 'Whispering Grass (Don't tell the Trees)'. On the image track in 'The Golfer', movement is once again in focus. Two golfers are shown. The first makes a perfect strike, and the ball lands only a short distance from the hole. His satisfied 'Hmm', following this achievement, is quite clear. The second man makes his strike, and the ball bounces, like in a pinball machine, between the trees, only to end up with a hole-in-one. He hums back. Then we see him putting the equipment into the boot. Here, the camera focusses on the 'Bi-fuel' on the car, which suggests that the car is environmentally friendly, and which immediately links to the slogan: 'One

35 Bengt Carlsson, 'Kreativiteten flyttad till Göteborg. Svensk reklambyråundersökning. Varumärkesbyggarna Forsman och Bodenfors högst rankad I landet', DNEkonomi, 8 (December 1996). 
day nature will thank you.' The car - visible for the first time, in the last ten seconds of the ad - starts moving just at the end. The very structure of the ad thus suggests a respect for nature, where the car has only a limited, albeit important, role. In this highly visual ad, as well as in other ads from Forsman \& Bodenfors, there are no real arguments, but rather slogans that connect to the highly visual advertising strategies.

Three years later, in 2000, Euro RSCG produced 'Saturday' for the Volvo V7o Turbo. This ad tells a story that takes place in two locations simultaneously, as a father dashes back and forth, constantly moving between his two children's sports events: his son's swimming competition as well as his daughter's football match. The background music is 'Get a move on' by Mr. Scruff. 'Thank heaven for Turbos. It's all about family', the speaker tells us.

The similarity with Forsman \& Bodenfors's 'Toast' for Volvo V70 (2000) is striking: the husband is preparing breakfast, and after having found out that there is no more butter, he quickly leaves and returns just in time to watch the bread pop out of the toaster. One great difference is the car movement. In 'Saturday', the car is present in the ad about half of the time, and is almost always in movement. In 'Toast', on the other hand, the car is only present for a few seconds, mostly in arrest, and when it is moving, it is barely visible because it drives too fast. Another great difference is that, whereas Euro RSCG uses a lot of spoken argument, the 'Toast' ad is just accompanied by music and the simple slogan ' 250 HP. o to 100 in 7.1 seconds'. That is also a general conclusion concerning Euro RSCG - they use more arguments, both spoken and written.

Through the Arnold agency, in 'Wheels' (2007), four of the Volvo $\mathrm{XC}_{70}$ crossover's qualities are addressed, using the melody of the popular children's song 'The Wheels on the Bus'. The first verse goes: 'The wheels on the car go round and round', referring to the fact that the car is equipped with all-wheel drive (AWD), but also that the car is generally durable, and the ad shows a couple driving in mountain scenery. The second verse goes: 'The power tailgate goes up and down, up and down', and we see the car stop to pick up a mountaineer, and his backpack goes into the boot, pointing out the automatic tailgate.

After that, the car goes downhill and the song goes: 'The hill descent control goes nice and slow, nice and slow', which means that the car has an automatic descent control that makes the car go nice and slow, without using the brakes. The final verse - 'There is room in the car for everyone, everyone' - and the car stops again, this time picking up two more mountaineers. Here, just like in the previous ads, it is clear that the car enables other kinds of movement, such as climbing or hiking. The ad then ends with the slogan 'Life is better lived together'. Arnold's ads generally use the 
soundtrack to make arguments - in this one, by the song, although in other examples by spoken words.

The first ad by Grey London was 'The Swell' (2014) for the Volvo XC6o, and it used a kind of 'horror film' aesthetic to deliver the message. An empty car is parked on the beach, the doors are open, the lights are still on, and so is the radio, broadcasting - in Swedish - a forecast that predicts bad weather. From inside, the camera slowly moves in one long take: out and around the car, down along the sand, and out into the sea. At the same time, a dark voice says: 'To feel, to really feel, is a rare thing these days.' The ad continues under the sea and rises up, revealing a woman sitting on a surfboard - the camera comes closer, gets swallowed by a wave, and comes up again, showing the woman lying on the board surfing on a wave. Once again, in addition to the aesthetics, the car is associated with the possibility to gain access to other kinds of movement - and in this case, also to get away if needed. Then the ad abruptly goes black and the text 'SEEK FEELING' is thrown right into our eyes, and after that 'The Responsive XC6o'.

From this survey, it is possible to trace two main types of contemporary advertising films for Volvo. There may of course be variations in local or national agencies, but two tendencies nevertheless stand out. On one hand, the American or global form of ad, represented by MvBMs/Euro RSCG or Arnold, features arguments made both on the soundtrack and through texts on the image track, and cars are often shown in movement. On the other hand, the Swedish formula, as represented by Forsman \& Bodenfors, displays no argument save for a discreet and subtle slogan..$^{6}$ Their ads mostly feature a stationary car, and their emphasis is thus not on movements of the car, but rather on movement itself, to allude to something that the car is able to do. Grey London seems to take a position somewhat in between these two different strands. From what they have produced so far, there is a strong connection to the cinematic and to film history. ${ }^{37}$

36 The aforementioned ad campaign by British AмV ввDо ('Fog' and 'Kids', 1999) and a campaign for Volvo S6o by McCann Tel Aviv (2008) with the slogan 'It will take you time to realize it's really yours' are also examples of this kind of more discreet methods. All these ads were made for potential use both in cinema and on television, though I have not gone into detail in exploring the actual uses.

37 It is interesting to compare with the development in print ads, as described by Werner: 'That the image dominates over the text has to do with the view of branding as a largely visual strategy. It is supposed to be easier for the consumers to take in visual material and incorporate it into their own dreams and visions. At the same time, this makes many demands on the visual material: it has to open up towards the longings and fantasies of many different people. The environments in which the cars and the people are situated are therefore general in their character. There are coastal villages, downtowns, deserts, mountains and winter landscapes.' 
It is also obvious that, in spite of varying ownerships or ad agencies, all of these commercials seem to work within the soft-sell tradition, using 'clever concepts, puns, humor, and visually arresting imagery'. Perhaps, though, the Arnold commercial 'Wheels' could be seen as an exception, a hybrid between hard and soft sell, which - even if it is done in a humorous way - argues for both by explicitly showing the different advantages of the car and by using the text in the song as a parallel argument.

Thus, the history of Volvo commercials also clearly shows that there is no such thing as a 'Volvo shot' reappearing throughout the decades and across agencies. Rather, it would be possible to single out, for example, a typical 'Forsman \& Bodenfors shot'; that is, the agencies have their own distinct profiles and also to a large extent form the images of the products they advertise.

At the same time, as we have seen, many aspects unite all of these films. There are common themes, such as the concept of Volvo as a lifestyle or the central role of nature, but there are also more specific images that reoccur. We have already seen how 'Made by Sweden' with Zlatan Ibrahimović echoes 'Sauna'. This could, of course, be pure coincidence, but as it turns out, there are a number of similar examples. Lighthouses - if not specifically Swedish, at least reoccur in Swedish imagery - appear in 'Cabriolet' (1998) by мvвмS/ Euro RSCG, as well as in Forsman \& Bodenfors's 'Leave the World Behind' (2013) and in 'The Connected Car' (2014) by MPG (Havens).

This shows how agencies, in their Volvo ads, work in a 'classicist' way; 'classicist' in the sense of their searching for imagery and displaying their creativity within an already established aesthetic framework, rather than trying to create something really new. That this makes agencies look back at earlier ads is demonstrated with extreme clarity in an ad by Forsman \& Bodenfors, the film 'Tomorrow's Classics' for Volvo S6o (2006). The film is built up as a classic split-screen film. To the left, there is an old ad for Volvo Amazon (1960), which drives around in a shifting landscape. To the right, in parallel, an updated version with a Volvo S6o shown in a similar landscape. Towards the end of the film, as both cars are driving towards the camera, the new car to the right steps on the gas and leaves the Amazon behind. Now, the right part of the image takes over completely, and the text 'Introducing tomorrow's classics' appears on the screen. The new car has overtaken the old, but they share the quality of classics, of yesterday and tomorrow. ${ }^{38}$

38 The Volvo home page, under the label 'Heritage', states: 'LOOKING BACK HELPS US LOOK FORWARD - We're still building on our legendary heritage', http://www.volvocars.com/intl/ about/our-company/heritage (last accessed 6 April 2021). 


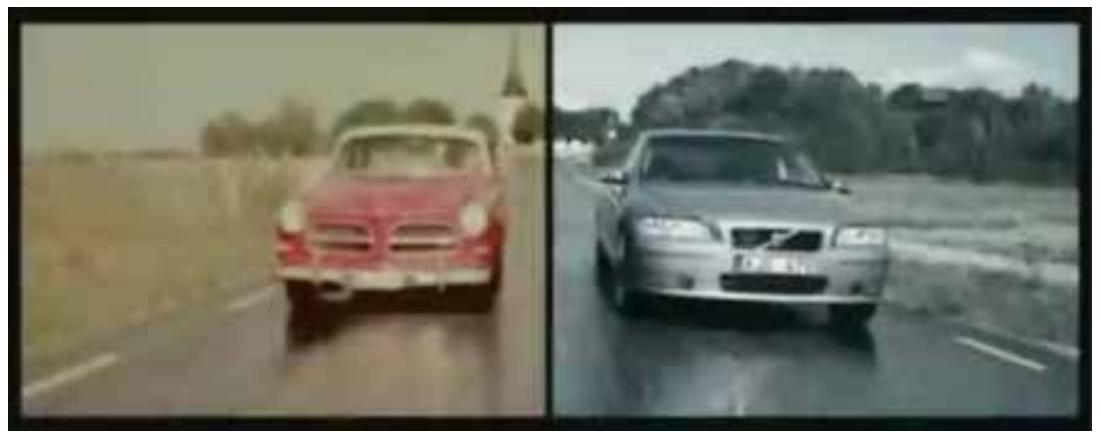

Figure 8.3: 'Tomorrow's Classics', screen ad for Volvo by Forsman \& Bodenfors, 2006.

Volvo's agencies do not only look at their own heritage; other car brands and other media are also used. An example is the British AMV BBDo commercial 'Fog' (1999), with a foggy landscape and only the car headlights visible - and the text 'The Volvo V4o/voted the world's most beautiful estate car/but sometimes looks aren't everything'. This ad obviously refers to DDB's famous Beetle campaign from the early 196os, with print ads like 'We finally came up with a beautiful picture of a Volkswagen', in which the only sign of the car is the tracks that it has made in the winter landscape that is shown, or the 'No point showing the '62 Volkswagen. It still looks the same', with a totally white paper replacing a picture. The history of advertising, across brands as well as across media, thus forms a common framework in which references and self-references frequently appear. The question of reference and self-reference is further elaborated in Yvonne Zimmermann's chapter 'Advertising's Self-Reference: From Early Cinema to the Super Bowl' in this book.

\section{Widening the Concept of Mobility}

If the car as moving object was highlighted in earlier film ads, this has changed quite radically throughout the decades. An important change in emphasis, as we have seen, is that from hard sell to soft sell, from the car and its specific qualities to more general questions of lifestyle and values. From the movement of the car as such, there is also an increasing switch towards the mobile life that the car enables: it takes you places you would never have dreamed of. The car now rather appears as a metonymy for mobility in life.

At the same time, cinematic movement as such is also used as a way to highlight mobility, and as a displacement in which the movement of the car is rather expressed through other images in movement. This reduces the 
redundancy of showing the car as moving, and instead introduces a rich variety of references to the history of moving images, including the theoretical assumptions from the beginning of the film medium qua movement. Interestingly enough, some of the ads from the turn of the millennium onwards - following the centenary of cinema - also seem to nourish a certain cinematic nostalgia in their references to film history, as in 'The Swell'. It is worth noticing that this nostalgic movement backwards is paradoxically combined with the fact that the ads today are mainly spread through the internet, using 'friendvertising' as a means to communicate their message. Thus, advertising itself has taken on a new kind of mobility as well. ${ }^{39}$

The ads for Volvo $\mathrm{C}_{70}$ Cabriolet produced by MvBMs/Euro RSCG from 1998 provide an earlier example of the same trend. A car drives through a mobile, urban landscape, with huge billboard ads for Volvo, shown in split-screen image together with the car. The people in the ads are moving, as are many objects in shop windows: a frock, a violin, a pair of shoes. In spite of the more advanced technology, the aesthetics here are quite similar to silent cinema's celebrations of mobility, as already mentioned initially in connection with early cinema and animation. ${ }^{40}$ The song on the soundtrack states that 'it's magic time', also alluding to early cinema's alignment with magic, from Méliès onwards.

The common final slogan of these films states: 'It will move you in ways Volvo never has.' These ads thus also introduce the idea of movement that is not only physical but also imaginary, of which 'Survivors' is another example. Through Volvo, the film ads throughout the decades seem to conclude that there are always possibilities for moving and for being moved in new and unexpected directions.

Would it then be possible to draw some kind of general conclusion from all these observations on movement in Volvo ads? Jean-Louis Schefer asks the rhetorical question, also suggesting a meta dimension to machines in cinema:

What, then, is a machine in cinema? Simply cinema itself which reveals its body, that is the system which drives movement? But cinema has no proper body, special or specific [...] The body of cinema is the succession and the montage of whatever, real or invented, is constituted as an image $[. ..] .^{41}$ 


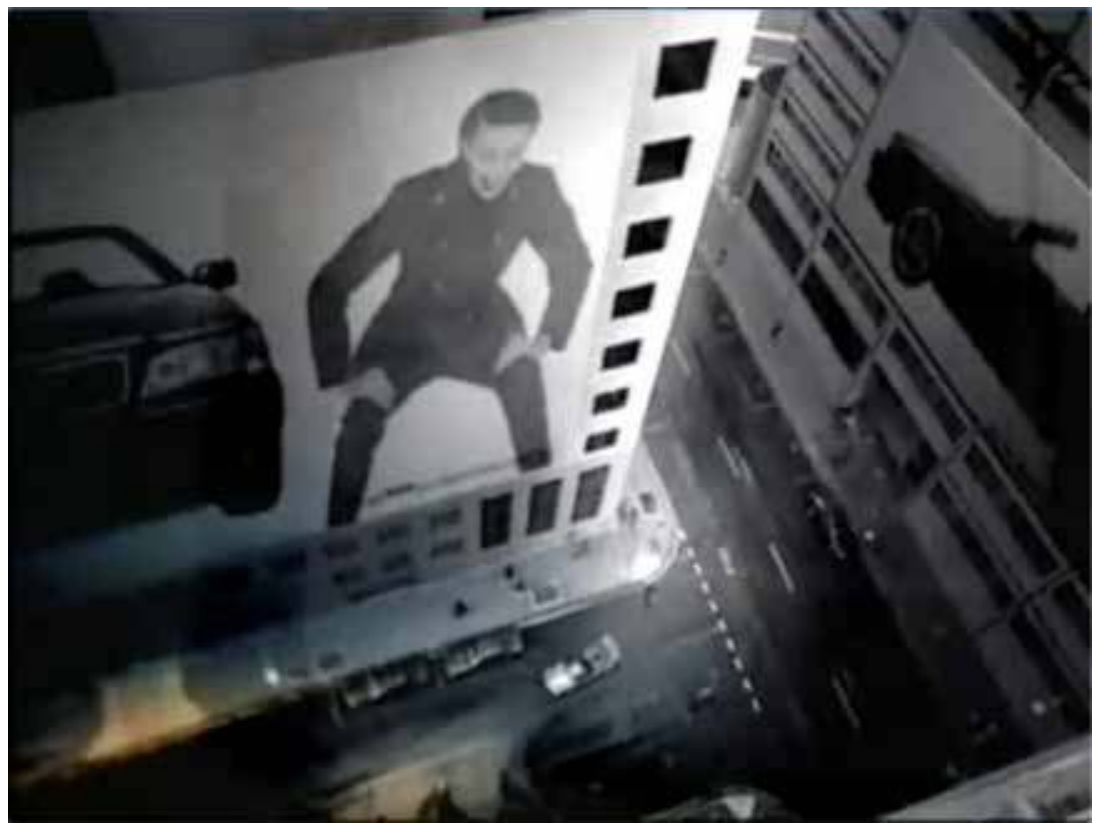

Figure 8.4: The moving person on the wall; the windows resemble the perforations on film stock. Screen ad for Volvo by MVBMS/EURO RSCG, 1998.

His conclusion, then, would be that both humans and machines in cinema are equally constituted as subjects, both belonging to the very movement of the image, as they take part in the same structure in which movement actually constitutes the image. Whether humans or machines, all are images; their lives and their movements together form the film. ${ }^{42}$

From moving cars to moving people and moving camera, the development of the dynamics of the Volvo ads thus actually reveals a meta dimension, albeit different from the one originally suggested by Schefer. By capturing all these movements in moving images and by gradually combining and multiplying their effects in increasingly complex patterns, these commercials actually all add to the basic capacity of cinema, to amaze and move its audiences, thus also introducing a new way of thinking within the movement, which can lead to changes in behaviour - indeed the very raison d'être for advertising films. 


\section{Bibliography}

Broberg, Oskar. 'Globalisering, entreprenörskap och humankapital.' Det svenska näringslivets historia 1864-2014, edited by Mats Larsson. Stockholm: Dialogos Förlag AB: 2014.

Florin, Bo, Nico de Klerk, and Patrick Vonderau, eds. Films That Sell: Moving Pictures and Advertising. London and New York: Palgrave, 2016.

Hediger, Vinzenz, and Patrick Vonderau, eds. Films that Work: Industrial Film and the Productivity of Media. Amsterdam: Amsterdam University Press, 2009.

Niss, Hanne. Made in Denmark. Nationalitetens betydning i international marknadsføring. Aalborg: Aalborg Universitetsforlag 1994.

Schefer, Jean-Louis. Images mobiles. Paris: P.O.L. 1999.

Sivulka, Juliann. 'History: 1900-1920.' In The Advertising Age Encyclopedia of Advertising, vol. 2, edited by John McDonough and Karen Egolf. London: Fitzroy Dearborn Publishers, 2003.

Werner, Jeff. Medelvägens estetik, Sverigebilder i USA, Del 2. Hedemora: Gidlunds förlag 2008. 



\title{
9. Cinematic Intertexts: $H \& M$ Goes YouTube
}

\author{
Bo Florin
}

\begin{abstract}
'Cinematic Intertexts: H\&M Goes YouTube' studies the designer collaborations of H\&M, with a focus on the campaigns launched at the beginning of social media's ubiquity. The campaigns as such combine high culture and popular culture, and span from exclusive consumerism to equal opportunities for all, with the Lanvin collaboration as an early example of 'friendvertising'. I will also discuss how H\&M uses YouTube as an archive.
\end{abstract}

Keywords: H\&M, YouTube, friendvertising, archive

When the Swedish fashion retailer H\&M (Hennes \& Mauritz) first launched their collaboration with Karl Lagerfeld in 2004, it was before the rise of social media. However, the Lagerfeld collaboration turned out to be only the first in an ongoing campaign of collaborations with different designers. During these years, within a rapidly changing media landscape, H\&M have also gradually changed their advertising platforms. In the following, I intend to discuss how H\&M have, to an increasing degree throughout the years, used social media to launch their designer collaborations - with Lanvin 2010, the first campaign that was launched through social media, as a specific case study. Still, H\&M relies heavily, as I will argue, on established devices from the culture of advertising film. Finally, I will also shed some specific light on the use of YouTube, both as an advertising channel and as an 'archive' of advertising films.

A key moment in this transitional process could be identified with the launch of the Balmain campaign. On 18 May 2015, H\&M globally advertised their new collaboration with the French design house Balmain through a

Florin, B., P. Vonderau, Y. Zimmermann, Advertising and the Transformation of Screen Cultures. Amsterdam: Amsterdam University Press, 2021 DOI 10.5117/9789462989153_CHO9 
press release on their home page. ${ }^{1}$ The collection was announced to be on the market as of 5 November. Simultaneously, through their other social media channels - Facebook, YouTube, Twitter, Instagram, and Google+ - H\&M also invited everybody to experience and join "\#HMBalmaination - a movement of togetherness'. As Balmain's creative director Olivier Rousteing stated in the press release,

I want to talk to my generation: this is my main purpose as a designer. H\&M offers me the unique possibility to bring everyone into the world of Balmain, getting a piece of the dream and creating a global \#HMBalmaination: a movement of togetherness, fueled on a hashtag. The collaboration felt extremely natural to me because everybody can connect with the H\&M brand. It calls for unity, and I am all for it. ${ }^{2}$

The quote from Rousteing introduces a new, specific focus on social media as such, as a key to a new, global nation, including everybody regardless of nation, class, or any other potentially excluding category.

This initial launch was followed by a number of ads in social media, in the form of interviews and teasers as well as opportunities to ask questions, until the advertising film 'Balmain $\mathrm{x}$ H\&M ' was published on YouTube (with links from other social media pages) on 29 October. $^{3}$ The film - directed by Johan Sandberg and Henrik Timonen (Sandberg\&Timonen) and produced by Strange Cargo Film - had reached more than five million views within a week. The campaign was a mix of television, fashion magazines, social media, online banners, and out-of-home, digital exterior ads. The aim was 'to invite our customers to our shops and show them the latest in our fashion. We want our advertising to be inviting and surprising. ${ }^{4}$

I use the term 'advertising film', in relation both to the Balmain commercial mentioned above and later also to discuss the ads for Lanvin. This

1 'H\&M is proud to announce its autumn guest collaboration with the Parisian house of Balmain. A veritable bastion of French luxury, under the creative directorship of young Olivier Rousteing, Balmain has grown into a global pop-culture phenomenon',

Balmain and $H \& M$ call for \#HMBalmaination, $H \& M$ home page, https://about.hm.com/news/hmbalmaination.html (last accessed 6 April 2021).

2 Ibid.

3 'Balmain x H\&M', https://www.youtube.com/watch?v=L9o96NoAowM\&list=PL8SMpuBlg s3nFtfuRıi8SSTEMQlkovQ_7\&index=1 (last accessed 6 April 2021).

4 According to Johanna Dahl, PR manager at H\&M Sweden, Julia Lundin, 'Svenska kreatörer bakom H\&м:s Balain-kampanj', Resumé, 3 November 2015. http://www.resume.se/nyheter/ artiklar/2015/11/o3/kendall-jenners-danstavling-i-hms-balmain-kampanj/ (last accessed 6 April 2021). 
may seem odd at first, given the new media channels used for the actual releases. However, both these advertising campaigns, just like the Marni campaign (2012) directed by Sofia Coppola, use established styles and devices borrowed from cinema, as well as established film directors such as Sofia Coppola or Mike Figgis, while they also explore the different topologies and new networks of moving images. ${ }^{5}$ Yvonne Zimmerman also deals with these topological issues within a broader theoretical perspective, following Jean-Louis Baudry, in her chapter 'Advertising and the Apparatus'. Here, I will focus primarily on the intersection between the cinematic medium and the emerging 'new media' platforms, the latter including everything from private use of the internet to digital out-of-home screens. A quote from Mike Figgis, the director of the advertising film for Lanvin, emphasizes that the releases of the new H\&M ads in different social media still heavily rely on 'old' media, in this case primarily on the film medium:

Normally when you do something like this, they say 'Okay, 60 seconds and 30 seconds.' This is 5 minutes, 6 minutes... as long as it needs to be. You know, it's a film. [...] And it's designed as something that is entertaining and at the same time you learn something about this particular design. And it's gonna be in the store and it's gonna be on the internet, and it's gonna be in the cinema, and so on. It has many functions. ${ }^{6}$

The use of specific cinematic devices associated with certain directors, as well as the use of general cinematic intertexts - such as visual references to The Shining (Stanley Kubrick, 1980) in the advertising film for Lanvin - contribute to the general idea of 'advertising films' rooted in cinematic tradition, regardless of the medium by which they are released. H\&M - like many other advertisers - also tend to use a longer format for ads shown on their own channels. These longer ads are thus associated more closely with cinema, while shorter versions, using different parts of the longer films, are released as commercials on other media channels.

However, to start from the beginning, with H\&M this close relationship between advertising and selling has only become more integrated over

5 When presenting the latest collaboration with fashion designer 'ERDEM', which would be available in stores in November 2017, they wrote in a press release:

'H\&M is also pleased to reveal that the visionary filmmaker Baz Luhrmann will bring the collection to life through his unique storytelling.' https://erdem.com/en-eu/posts/h-and-m (last accessed 6 April 2021).

6 Mike Figgis in the 'Behind-the Scenes of The Lanvin Ad for H and M', https://www.youtube. com/watch? v=53Ilv2fGBsQ (last accessed 6 April 2021). 
the years. The company that was to develop into fashion retailer Hennes \& Mauritz АВ was founded in 1947 in Västerås, and was at first named simply 'Hennes' ('Hers'), offering only women's clothing. In 1952, the first store opened in Stockholm. In 1968, the company bought the fishing and hunting equipment store Mauritz Widforss, and then also changed their name to Hennes \& Mauritz, while also beginning to sell men's and children's clothing. In 1976, the first store outside of Scandinavia was opened, in London. In 1990, the first advertising campaign using well-known actors or models was launched. Online shopping was launched in 1998, and in 2000, the first us store opened in New York. H\&M had become a truly global brand. ${ }^{7}$

Historically, the stores have remained the most important channel of marketing for H\&M. 'When used correctly, the storefronts on the hottest commercial streets - as well as the internal streets, floors and walls - are formidable advertisement, formally for free. ${ }^{8}$ In the early 1990s, the most visible change in $H \& M$ 's advertising strategy was the change from the press ads to out-of-home ads. The most important ads were found on poster advertisements in streets and public places, at bus stops, and in the subway. From Swedish press ads in the daily newspaper Dagens Nyheter in the 1970s, H\&M had changed to a global perspective with bus-stop advertising and billboards by JCDecaux in the 199 os. $^{9}$

It was only in 1988 that television ads were allowed in Sweden, and then only on the TV3 channel, which in the beginning, was broadcast from London. In 1992, TV4 also initiated television ads. The early, quite limited, attempts of $H \& M$ to get into television were quite like the poster advertisements, with models posing in front of a white or neutral background. In 1999, H\&M launched, under the label 'Strictly Personal', a series of six advertising films featuring actor Gary Oldman, produced by McCann Stockholm (Gary Oldman was also the poster model that year). In the films, Oldman describes his own personal view of different aspects of clothing, always with a humorous twist. ${ }^{10}$ The same year, a series of juvenile film ads for 'bad idea jeans', that is Rocky Jeans, was made for H\&M by Hollingworth/Mehrotra. ${ }^{11}$

7 Bo Petterson, HandelsMännen, Så skapade Erling och Stefan Persson sitt modeimperium (Stockholm: Ekerlids Förlag 2001), 49, 54, 70-71, 114, 147, 172.

8 Ibid., 223.

9 Ibid., 224.

10 See, for example, 'H\&m Ad with Gary Oldman', https://www.youtube.com/watch?v= ScICjRvTy3E (last accessed 6 April 2021).

11 See 'Rocky Jeans H\&M Small Dicks', https://www.youtube.com/watch?v=xiA7ihgqRLI (last accessed 6 April 2021). 
In 2001, H\&M radically changed its advertising policy by creating its own ad department instead of using an external ad agency. They began to choose only to engage directors, set designers, and the like for special assignments. As marketing strategist Jörgen Andersson stated in an article in Resumé:

What we need is to buy creativity and communication solutions from outside, and this is what we will do. This gives us flexibility and freedom to work with whoever we wish to work with, and to find the best solution for any area. ${ }^{12}$

The new in-house ad department was called 'Red Room', as an equivalent to the design department called 'White Room'. Its first series of five films was made in 2002, 'People's Front for Nudist Liberation'. In these films, a radical political group aiming to liberate the nudists stages a series of demonstrations, including sending a fully clothed (supposedly in $\mathrm{H} \& \mathrm{M}$ products) 'reverse-streaker' through a nudist camp, much to the outrage of its inhabitants. ${ }^{13}$

In 2004, as already mentioned, H\&M started its collaboration with designers, with Karl Lagerfeld. This international campaign used all of the then available channels: out-of-home ads, the press, the stores, as well as a commercials for television and cinemas. The collaboration was initiated by Jörgen Andersson and creative director Jan Nord, who were leading the H\&M ad department. The idea was to turn away from 'bad advertising' - at the time, there was general criticism of $\mathrm{H} \& \mathrm{M}$ for their underwear advertising in particular ${ }^{14}$ - as well as to attract new customers to the ordinary range by playing the luxury card. ${ }^{15}$ A professional director, Johan Renck, was hired to make the official advertising film for the Lagerfeld cooperation. The film hints at 'rumours and gossip' preceding and surrounding it: 'I have heard...

12 Pia Grahn, 'Oväntat byråval av H\&M', Resumé, 10 December 2001. http://www.resume.se/ nyheter/artiklar/2001/12/10/ovantat-byraval-av-hm/ (last accessed 6 April 2021).

13 The videos are available to subscribers at Advertolog: http:/www.advertolog.com/brands/hm-6120955\%2Cyear-2002/ (last accessed 15 July 2017).

14 Jessica Enbom and Stina Gustafsson, Sexually Provocative Advertising: How Young Men Respond to It (thesis, Department of Business Administration and Social Sciences, Luleå University of Technology 2005), 28: 'When Anna-Nicole Smith was on the H\&m's ads it raised a major outcry. People tore down posters and now they don't care anymore. It doesn't matter who is sitting there.' A glance on the internet indicates a shift in the critique, from women's lingerie to male underwear, and from posters to commercials: the series of ads with David Beckham (2011-2016) has more recently come under fire.

15 Oskar Serrander and Ted Wärnåker, 'Karl Lagerfeld for H\&M'- En studie av Hennes \& Mauritz varumärkesstrategi (thesis, Department of Business Studies, Uppsala University, 2004), 26-29. 
is it really true? Looks like it... it is on everybody's lips... whispers... keep all this under covers... Has he really?' Then the rumours appear to have been confirmed, which in turn gives rise to new questions: 'Some pleased, some plain disoriented; what will people say and do? Why have a garden when you can have a forest?"16 Although this advertising film was made several years before the breakthrough of social media, it builds to a large extent on a similar communication model that was to be fully developed only later as they became commonplace, by spreading by word of mouth, playing on different rumours and hints.

As the Lagerfeld project became a success, $H \& M$ followed up by launching a new series, 'H\&M Guest Designer Collaborations', with a campaign every year, sometimes twice a year: Stella McCartney in 2005, Viktor \& Rolf in 2006, Roberto Cavalli in 2007, Comme des Garçons in 2008, Mathew Williamson in 2009, Jimmy Choo in 2009, Sonia Rykiel in 2010, Lanvin in 2010, Versace in 2011, Marni in 2012, Maison Martin Margiela in 2012, Isabel Marant in 2013, Alexander Wang in 2014, Balmain in 2015, Kenzo in 2016, Erdem in 2017, Moschino in 2018, and Giambattista Valli in 2019.

Independently of each different release, they all seem to share the same aim: to reach a broad audience across different media channels. Initially, I described this as a 'mix'. This also seems to remain true to a large extent throughout different ambitions and media varieties expressed by the company. But whereas the concept of a 'mix' still seems valid, there is also a clear turn towards social media as the main mode of media presence, even though this 'new' communication channel still heavily relies on 'old' media channels. The advertising films produced mainly for other media formats are continually also used on big screens in storefronts and inside of the stores. Though the techniques are new, they are still based on the same concept as quoted above - with internal streets in addition to other arenas as an important topos for advertising.

When H\&M launched its collaboration with Lanvin in 2010, it was the last one for which Jörgen Andersson and Jan Nord were responsible for the advertising; they both left H\&M in 2011. It was also the first time that social media played a central role in the advertising campaign. Already in 2007, H\&M had started a YouTube channel, and in 2010, they had just launched a page on Facebook. Interestingly, the Lanvin launch shares a general theme

16 The video is not to be found on H\&M's YouTube channel, but it is available elsewhere on YouTube: https://www.youtube.com/watch?v=9NYGtjVXcmw (last accessed 6 April 2021), or on Johan Renck's home page, http://www.johanrenck.com/\#/projects/karl-lagerfeld/ (last accessed 6 April 2021). 
of rumours and gossip with the earlier Lagerfeld ad, though the advertising strategies were refined and elaborated. I have chosen to focus here on the H\&M Lanvin collaboration as a case study. The Lanvin case stands out among other $\mathrm{H} \& \mathrm{M}$ advertising campaigns as quite a unique exploration of new ways of advertising for the first time. My specific aim here is to investigate how H\&M uses social media, and YouTube in particular, as a means of reaching new markets, more or less for free. But before going into this specific case, a few words must be said about advertising and social media.

\section{Friendvertising and YouTube}

Today, the home pages of all major companies typically contain references to their Facebook pages; Instagram, Twitter, and Pinterest accounts; and to their channel on YouTube. Social media became increasingly important advertising channels, and 'friendvertising' became a catchword. ${ }^{17}$ According to forecasting company Zenithoptimedia, the internet turn was supposed to take place in 2016, when internet advertising grew three times quicker than television advertising. By 2017, they argued that the change would be accomplished, and internet advertising took the lead over television advertising. ${ }^{18}$

In her book Advertising 2.o: Social Media in a Web 2.o World, Tracy L. Tuten devotes a chapter to 'friendvertising', which she describes in her glossary as '[a] branding and communication approach, which relies upon social networks to enable consumers to befriend brands and share brand information with other friends in their networks'. ${ }^{19}$ According to Tuten, social-networking sites could be divided into different categories, in which 'general social-networking sites', such as Facebook, 'have social networking among friends as the primary focus'. ${ }^{20}$ YouTube, according to Tuten, is often mentioned in other contexts, but '[it] does, however, meet the basic criteria

17 Kicki Ahlm, "Friendvertising” är reklammakarnas nya metod', SVT Nyheter, 16 January 2014, http://www.svt.se/nyheter/utrikes/friendvertising-reklammakarnas-nya-metod (last accessed 6 April 2021). Another, earlier expression, with almost the same connotations, is 'word-of-mouth marketing' (or sometimes just 'buzz'). The term 'Friendvertising' is more connected to social media, however.

18 'Internetreklam hetare än tv-reklam', TT-Reuters, $S v D$, 22 March 2016.

19 Tracy L. Tuten, Advertising 2.o: Social Media Marketing in a Web 2.o World (Westport: Praeger 2008), 180 .

20 Ibid., 35. 
of social networking in that it enables the development and maintenance of networks on the site..21

In his article 'The Appearance of Archives', Rick Prelinger cites YouTube's offer of 'basic [...] social-networking features' as one of five aspects that made YouTube attractive to the public, which is here in line with Tuten's argument. ${ }^{22} \mathrm{He}$ refers to the fact that 'it's possible to link individuals to their uploads and favourite videos, to send favourite videos to other people', but there is also the possibility to use the comment field to communicate with other viewers. ${ }^{23}$ Eggo Müller writes, that 'a dialogic structure is characteristic of online video-sharing sites, which links YouTube to traditions of oral cultures'. ${ }^{24}$ This brings us back to word of mouth and 'friendvertising'. It is clear that all those social network possibilities have contributed immensely to the general outcome of the new paradigm at H\&M. Two of Prelinger's other aspects may have also played a part in making the $\mathrm{H} \& \mathrm{M}$ advertising campaign successful - namely, that YouTube was 'open to user contribution'25 and that 'though it takes some skill to download a video from YouTube, the videos were very easily embeddable. ${ }^{26}$ The two last aspects that Prelinger mentions are related to more traditional archival questions: accessibility and completeness - issues I will come back to later.

\section{The Lanvin Launch on YouTube}

It all started with a 20-second video teaser on 29 August 2010, directed by Sandberg\&Timonen and produced by Strange Cargo Film. ${ }^{27}$ Over the course of four days, until 1 September, no less than seven video teasers were posted on the Web in which different people appear, supposedly designers,

\footnotetext{
21 Ibid., 39.

22 Rick Prelinger, 'The Appearance of Archives', in The YouTube Reader, ed. Pelle Snickars and Patrick Vonderau (Stockholm: National Library of Sweden 2009), 271.

23 Ibid. That is, at least at this early stage of YouTube. For the Balmain campaign in 2015, the 'comments are disabled'.

24 Eggo Müller, 'Formated spaces of participation: Interactive television and the changing relationship between production and consumption', in Digital Material: Tracing New Media in Everyday Life and Technology, ed. Marianne van den Boomen et al. (Amsterdam: Amsterdam University Press, 2009), 58.

25 Prelinger, 'The Appearance of Archives', 270.

26 Ibid., 272.

27 Strange Cargo Film has actually been involved in almost every ‘H\&M Designer Collaboration' from Stella McCartney (2005) to Balmain (2015), as well as a lot of other ads made for H\&M during these years.
} 


\section{$\equiv$ voulube}
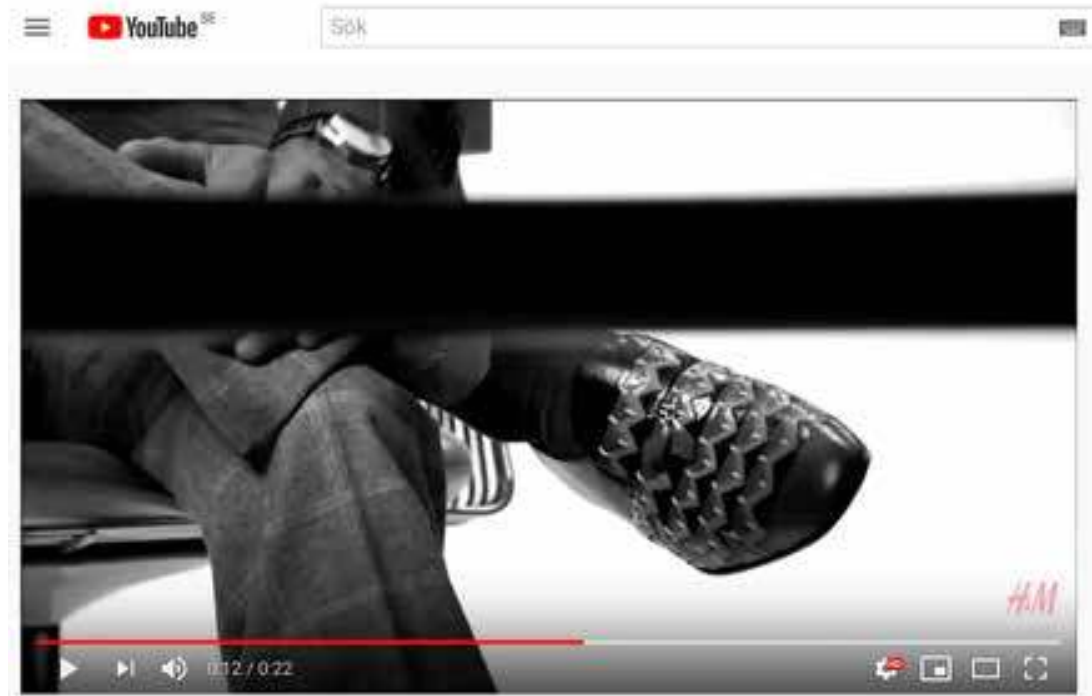

H\&M Designer Collaboration 2010 - Smart Women

77.656 visningar + Publicerades den 29 avg. 2010

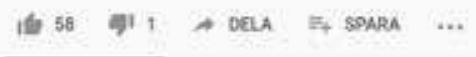

$H: H$

HSM O

377 in prenumeranter

Hyve you heard the rumours? or did you start them?

Visit hm.com on September 9 th 2010.

Figure 9.1: 'Have you heard the rumours?...' - an aura of mysticism by H\&M.

but without their faces being revealed.$^{28}$ Four of them apparently depict women, and three men. On the soundtrack, Lanvin designer Alber Elbaz actually appears in all seven of the ads, but with a manipulated voice, both with male and female connotations. All of this of course aims to create an aura of suspense concerning the upcoming project: with whom will $H \& M$ collaborate next?

Each ad has a title, and most of them seem to hint at specific designers, according to the online comments. Each film actually creates intense discussions on who it might be, but the communication is not only between spectators - H\&M also comments on the ongoing speculations concerning each of the teasers. 'Smart women' was supposed to refer to Tomas Maier

28 'H\&M Designer Collaboration 2010 - Smart Women', https://www.youtube.com/watch?

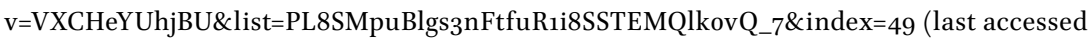
6 April 2021). 
(Bottega Veneta), or maybe Christian Audigier or Christian Lacroix. Here, a comment from H\&M asks, 'Have you heard the rumours? Or did you start them?' - another reference to the 'rumours and gossip' theme from the very first Lagerfeld collaboration. ${ }^{29}$ Concerning 'Future of Fashion', which seems to allude to Vivienne Westwood, H\&M asks, 'Can you go high and low at the same time? The speculations range from high to low. Where will they go now?'30 In 'Very Melodramatic', the H\&M comment states: 'Interesting. Aha. Yes, that makes perfect sense.' According to one comment, the ad refers to Anna Sui, whereas another commentator claims that 'she is too thin to be Anna Sui', and a third comment suggests 'IS LANVIN'. ${ }^{11}$ Concerning 'Speed of Fashion', there was another debate; someone suggests that it might be John Galliano (Dior), but another spectator replies that he doesn't have any tattoos, and Stefano Pilato (YSL) does. The question of speed made H\&M comment: 'How fast can you work out what's going on? Have some water. Helps you think'.32 As the person in the ad is drinking water, this is only to explain that the designer in the new collaboration shares with H\&M the obsession of speed in fashion. 'Smart Design', in which H\&M states that 'Smart is beautiful. Are you beautiful enough to understand?', 33 seems to allude to Frida Gianini from Gucci, whereas 'Design is Relevant' states that 'Cool becomes cold. Relevant is always the right temperature. Have you figured it out yet', and was associated with Hedi Slimane at YSL. ${ }^{34}$ In the last teaser, 'Real and Surreal', H\&M asks the rhetorical question: 'How rational are your emotions? Are your dreams more real than your life?' The ad clearly hints at Lanvin. ${ }^{35}$ The H\&M comments both refer back to earlier

29 Ibid.

30 'H\&M Designer Collaboration 2010 - The Future Fashion', https://www.youtube.com/wa tch?v=EZF5a5hiJPc\&list=PL8SMpuBlgs3nFtfuRii8SSTEMQlkovQ_7\&index=48 (last accessed 6 April 2021).

31 'H\&M Designer Collaboration 2010 - Very Melodramatic', https://www.youtube.com/wat ch?v=zF8o7naOqb4\&list=PL8SMpuBlgs3nFtfuR1i8SSTEMQlkovQ_7\&index=51 (last accessed 6 April 2021).

32 'H\&M Designer Collaboration 2010 - Speed of Fashion', https://www.youtube.com/watch ?v=VNuXnsAIoOw\&list=PL8SMpuBlgs3nFtfuRıi8SSTEMQlkovQ_7\&index=53 (last accessed 6 April 2021).

33 'H\&M Designer Collaboration 2010 - Smart Design', https://www.youtube.com/watch?v=SK7 tiXfHEcw\&list=PL8SMpuBlgs3nFtfuRıi8SSTEMQlkovQ_7\&index=52 (last accessed 6 April 2021). 34 'H\&M Designer Collaboration 2010 - Design is Relevant', https://www.youtube.com/ watch?v=C_nyE79vjIE\&list=PL8SMpuBlgs3nFtfuRıi8SSTEMQlkovQ_7\&index=54 (last accessed 6 April 2021).

35 'H\&M Designer Collaboration 2010 - Real and Surreal',

https://www.youtube.com/watch?v=7xo3wz8bOLo\&index=43\&list=PL8SMpuBlgs3nFtfuRıi8 SSTEMQlkovQ_7 (last accessed 6 April 2021). 
discussions and point forward to the actual ad. Clearly, these 'rumours' may also be interpreted as a self-reflexive way of dealing with social media and their specific function to build 'word of mouth'.

The first of September was also the day of the actual revelation, when Alber Elbaz appeared as himself in the film ' $\mathrm{H} \& \mathrm{M}$ Designer Collaboration 2010 - The Dream, ${ }^{\prime}{ }^{36}$ created in much the same way as the teasers but now showing his face and with his own voice. A text comment states: 'Guess what? Some of you got it right. Here is a special thanks to all of you who took the time to comment.' There was also yet another teaser: 'On September 9, visit www.hm.com for more videos!' On 8 September, a film in the series 'Fashion Video' was posted, a 'Behind-the-Scene Project' in which a number of actors and actresses are presented who had worked for the upcoming launch, talking about their excitement and the great fun they had - but we only see their faces. ${ }^{37}$ The Lanvin clothes they are wearing are blurred to pixels, just to maintain the suspense - to the great disappointment of a number of spectators in the comments. Within the behind-the-scenes footage, one can also find comments on the multiple functions of the ad: that it will be shown in cinemas and on the Web as well as in the actual stores. Following this, yet another series of clips were posted, with Alber Elbaz developing his views on the collaboration with H\&M. On the home page, the H\&M Fashion Show, to be shown on hm.com at 8:00 a.m. on 2 November, was also advertised.

On 2 November, then - more than two months later - the real secret was finally revealed. Pictures of the collection were published on the home page, and the official advertising film, 'The Show', was launched - four and a half minutes long. ${ }^{38}$ On 18 November, another programme was made for the 'Fashion Video' series, in which Joe Zee, creative director for American Elle, but also famous for playing himself in the TV series Stylista (2008-2009) and The City (2009-2010) looks at and comments on the collection..$^{39}$ On 20 November, another programme was made for 'Fashion Video' about a

36 'H\&M Designer Collaboration 2010 - The Dream', https://www.youtube.com/watch?v=HGd 4d2fCljI\&list=PL8SMpuBlgs3nFtfuRıi8SSTEMQlkovQ_7\&index=42 (last accessed 6 April 2021). 37 'H\&M Fashion Video - Lanvin for H\&M',

https://www.youtube.com/watch?v=nScoporcrıQ\&list=PL8SMpuBlgs3nFtfuRii8SSTEMQlkov Q_7\&index=41 (last accessed 15 July 2017).

38 'Lanvin for H\&M - The Show', https://www.youtube.com/watch?v=X8s3VSGqiJs\&index=5 7\&list=PL8SMpuBlgs3nFtfuRii8SSTEMQlkovQ_7 (last accessed 6 April 2021).

39 'Lanvin for H\&M Collection - H\&M Fashion Video', https://www.youtube.com/ watch?v=QtDbNUHow-o\&list=PL8SMpuBlgs3nFtfuRıi8SSTEMQlkovQ_7\&index=55 (last accessed 15 July 2017). 
fashion show in New York, following blogger Susie Bubble (Susanne Lau) rather than representing the show or the clothes. ${ }^{40}$ These two programmes are clearly directed towards two different target groups: the Elle version towards a more mature audience, and the blogger version to attract younger spectators. Then, on 23 November, nearly three months after the first teasers on the Web, the collection finally came to selected stores, as well as to the online shop. There was an instant rush.

\section{Other Social Media}

As the Facebook page of H\&M was created in January or February 2010, the H\&M Designer collaboration 2010 with Lanvin was also launched on Facebook. ${ }^{41}$ On 30 August, four different posts were published to launch the collaboration, such as ' $\mathrm{H} \& \mathrm{M}$ Designer Collaboration 2010 - Click the YouTube tab on our Facebook page and start guessing!' (which generated 40 comments), and 'Have you heard the rumours? Or did you start them?' (which echoes the YouTube ad and includes a link to the ad 'Smart Women'; the post generated 109 comments). But an active dialogue was also initiated with the commenters, inviting them to react: 'Good eye there, @Michael McQueen! So what do you make of the hands in this video?' (linked to 'The Future of Fashion', with 74 comments), or 'Interesting connection, @Natalya Posukhova. Will this video confirm or confuse? Let us know!' (linking to 'Very Melodramatic', with $5^{6}$ comments). On $3_{1}^{1}$ August, five posts were published according to the same pattern, followed by four more teasers on 1 September, the last two of which mirroring the YouTube formula, 'Guess what? Some of you got it right...' (the second generated 121 comments, the best result so far). On 8 September came 'Lanvin $<3$ H\&M. Hope you like it!' (96 comments), and on 9 September another three posts, which, in addition to repeating 'Lanvin $<3 \mathrm{H} \& \mathrm{M}$ ' also added an ad for the backstage material. Two more posts on 13 September were followed by a period of suspense until the real launch of the Alber Elbaz video on 2 November: 'Watch the Lanvin $<3$ H\&M Fashion show [...] and let us know what you think of the collection', which generated 109 comments, followed by 'Lanvin $<3$ H\&M Fashion Show! What do you think of the video?' (with a link to 'The Show

40 'At the Lanvin for H\&M Fashion Show - H\&M Fashion Video', https://www.youtube.com/ watch?v=XuzZJ-wSaZo\&index=56\&list=PL8SMpuBlgs3nFtfuRii8SSTEMQlkovQ_7 (last accessed 15 July 2017).

41 H\&M Facebook page, https://www.facebook.com/hm (last accessed 6 April 2021). 
Video', generating no less than 290 comments). To conclude the Facebook campaign, the two 'Fashion Video' programmes were also launched on 18 and 23 November, respectively.

The use of Twitter was also explored for the first time by H\&M in the Lanvin launch (Twitter had started in 2006). ${ }^{42}$ The use of Twitter, however, was much more limited at the time than that of YouTube or Facebook. On 30 August, a first tweet announces: 'H\&M Designer Collaboration 2010. Speculations are in full swing. Have you seen the latest video?' with a link to the YouTube page. The following day brought another tweet: 'We are very impressed with your guesses concerning H\&M's next guest designer. Here is some more information', with a link to the 'Design is Relevant' video on YouTube. On 1 September, the tweet of the day was: '\#Fashion lovers! Finally it is official and you can see the first video on the H\&M \#Designer Collaboration 2010 at [...]'. On 9 September, another tweet encouraged followers to 'Check out \#Lanvin for H\&M at www.hm.com - hope you like what you see!' On 2 November, finally, a tweet announced: 'Now you can see Lanvin for H\&M Fashion Show at www.hm.com/lanvin.'

The conclusion that may be drawn from these examples is that it is obvious that, with the Lanvin launch, H\&M had started to actively use YouTube as well as other social media as a means of 'friendvertising', a practice that was prefigured already in the Lagerfeld collaboration. Their campaign is largely built on word of mouth and on 'buzz marketing', which implies a reliance that the message will be spread and conveyed to those interested. Here again, Prelinger's point on the social networking aspects of YouTube is of huge relevance for H\&M's friendvertising agenda. Today, however, friendvertising has spread over the whole field of social media. In the Balmain campaign on YouTube, it is stated that 'Comments are disabled for this video', but the communication takes place on other channels, such as Twitter, Instagram, or Google+.

The Balmain launch, which after a week had generated five million views on YouTube, had on 3 April 2016 - five months later - generated 6,66o,342 views. A comparison with the Lanvin ad, 'The Show', which has hitherto only generated 246,515 views on H\&M's YouTube site, shows the explosive development of social media. ${ }^{43}$ Prelinger's comments (about user contributions and

42 The examples given are from H\&M's Swedish Twitter account, but the tweets from H\&M's accounts in other countries are very similar.

43 Another interesting comparison: 'Smart Women', the first teaser for Lanvin, has to this day 77,501 views, while the teaser for the upcoming collaboration with ERDEM had 313,146 views in one month - more than four times the earlier total. 'ERDEMхн\&м teaser film by Baz Luhrmann', https://www.youtube.com/watch?v=hgdgox_AM5A (last accessed 6 April 2021). 
downloading or embedding) are supported by a general search in the YouTube archive, because, as Eggo Müller writes, '[e]ven those who do not upload their own clips can still create a channel by choosing clips already available on YouTube.' ${ }^{44}$ There are actually (at least) four more versions of 'The Show' on YouTube; the only difference is that they lack the initial red H\&M logo in the lower right corner, and the final image that announces the time of the release. The handle 'watchFashionNews' has 658,367 views; 'Wendy Lam' has 475,445; 'stripbg' has 76,803 ; and 'cerestv' has 79 views. ${ }^{45}$ This makes 1,457,209 views in all. ${ }^{46}$ In addition to the official YouTube launch, the new releases made of the clips by the different users grant an 'afterlife' to the ad campaigns.

Thus, the first question launched in social media - who is it? - as well as the second - what will it look like? - all add to the suspense preceding and gradually introducing the advertising film, which is supposed to be the culminating point of the campaign. This clearly illustrates the point raised above, how the turn to social media in moving image advertising at least during the early years still to a large degree tended to rely upon, and point to, the launch of the 'actual ad' - the film.

\section{The 'Actual Ad' - 'The Show'}

The advertising film 'The Show' was produced by Strange Cargo Film for the H\&M in-house agency 'Red Room', with Mike Figgis hired as director and Shona Heath as set designer. The ad is indeed complex, as it includes an intricate relationship between at least three elements: brand, creator, and agency. The picture is further complicated by the fact that there are two brands at stake here, as well as two creators. Is it an ad for H\&M or for Lanvin? Of course, it is for both, but how does the ad balance these very different brands? And what about Figgis or Heath - to what extent does the ad exploit their respective brands? They both add to the campaign because of their artistic track records,

44 Müller, 'Formated spaces of participation', 57.

45 watchFashionNews, 'Lanvin for H\&M - The Show (Promo 2011)', https://www.youtube.com/ watch?v=-NqxL4uwqHE; Wendy Lam, 'Lanvin for H\&M - Fashion Show', https://www.youtube. com/watch?v=sdV4xpTiSıs; stripbg, 'Advertising campaign Lanvin for H\&M - Fall Winter Full Fashion Show', https://www.youtube.com/watch?v=LZovaZkyQZQ; cerestv, 'Lanvin y H\&M juntos', https://www.youtube.com/watch?v=vtNkRngxCJM (last accessed, in all cases, 15 July 2017). 46 In addition, there are two more examples of The Show, with different music added: from user 'sharung11' with 906 views ('Lanvin for H\&M - The Show [Promo 2011], https://www.youtube.com/ watch? $v=K_{2}$ F8EszA4k) and from user 'kcolls88' with 406 views, ('TV ON THE RADIO - young liars meets Lanvin X H\&M' https://www.youtube.com/watch?v=nRQiwı6SWIY) (last accessed in both cases 6 April 2021). 


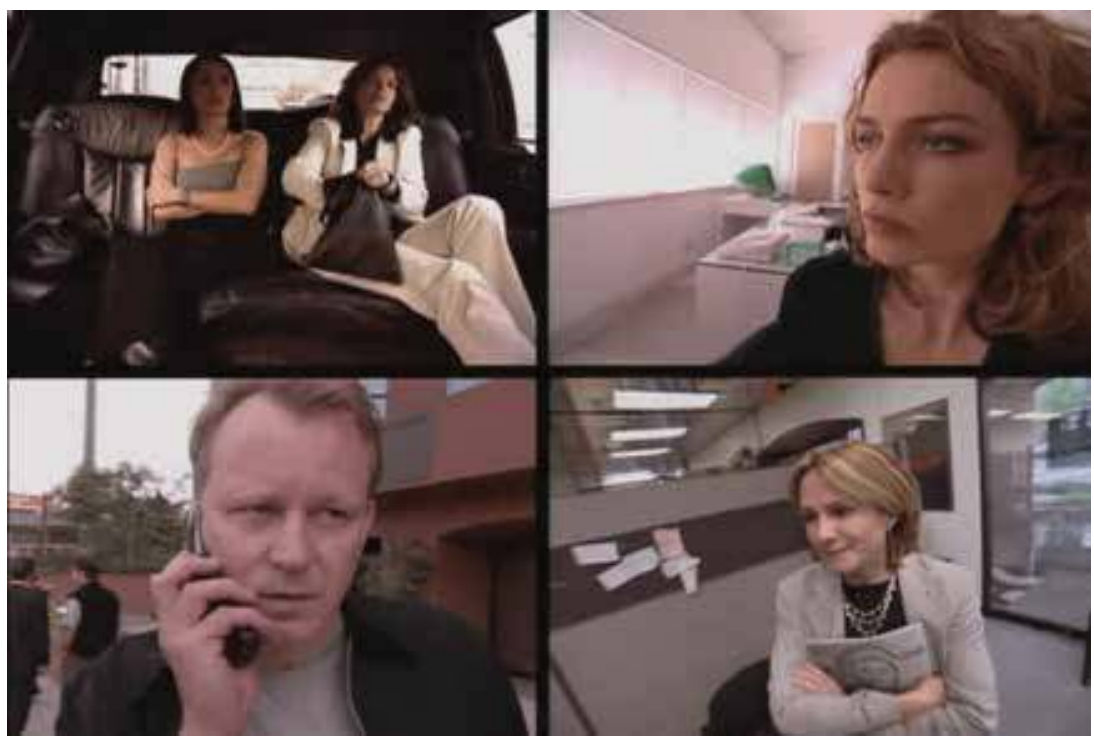

Figure 9.2: Split screen in Time Code by Mike Figgis, 2000.

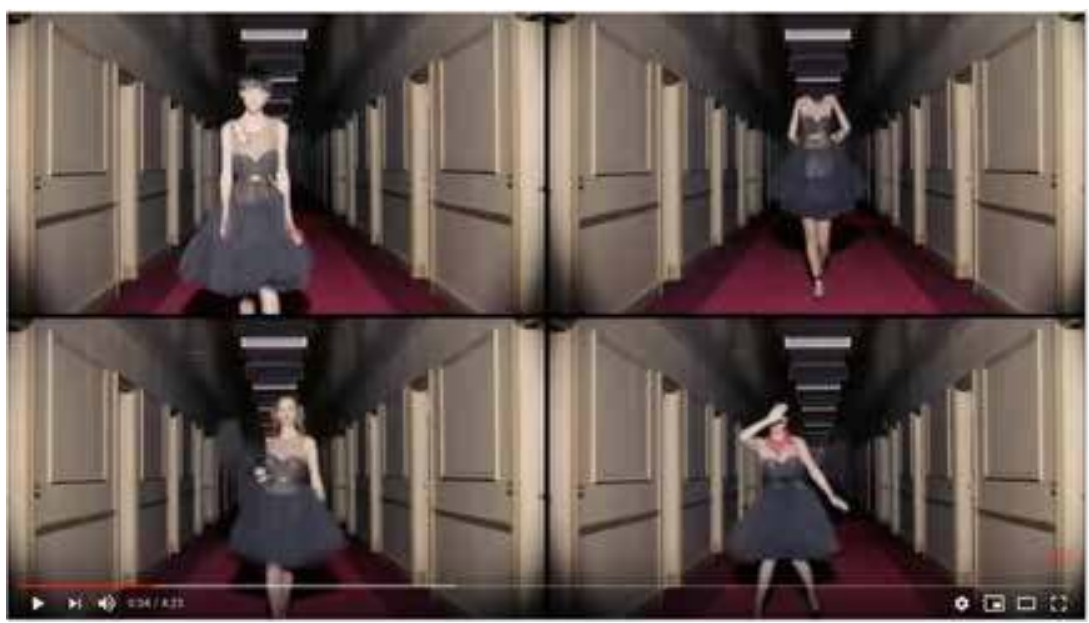

Figure 9.3: Split screen in 'The Show'.

but by lending their names to the campaign, they also add to their own artistic personas. The Red Room agency, finally, which had started so successfully with the designer collaborations in the Lagerfeld campaign, here reached a peak by uniting the three elements - brand, creator, agency - which also allowed for multiple expressions and brands to coexist and cross-fertilize each other.

Figgis and Heath have indeed both left their traces in different ways in the film. In the opening sequence, a screen divided into four - Mike Figgis's 


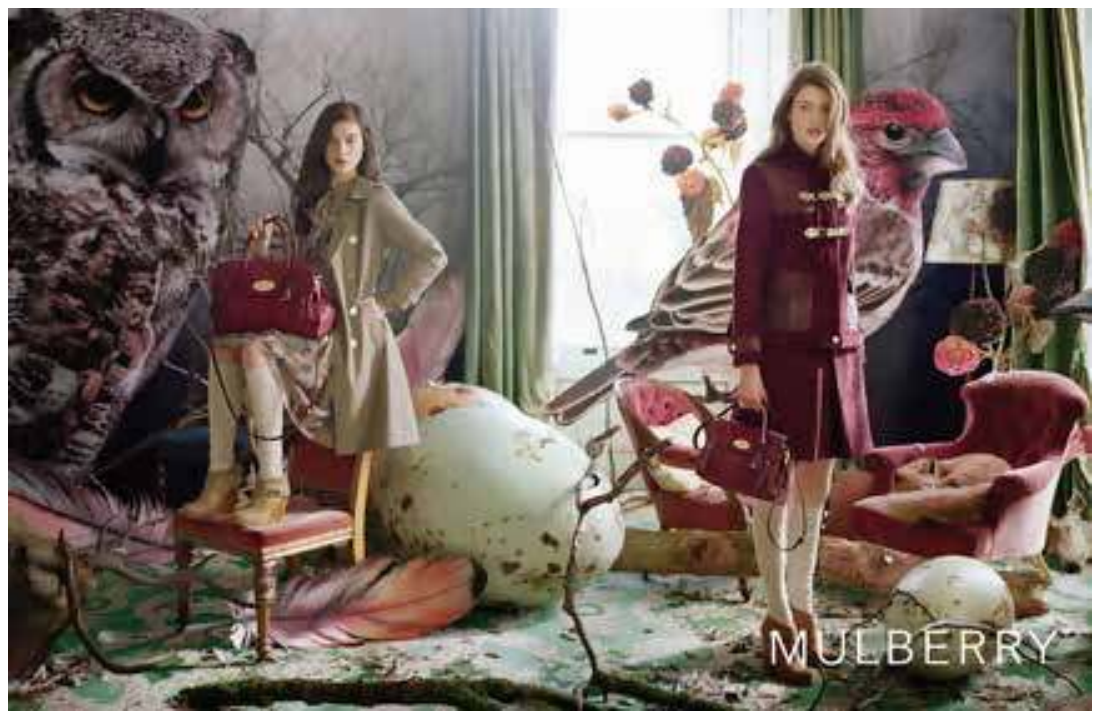

Figure 9.4: Set design for Mulberry by Shona Heath.

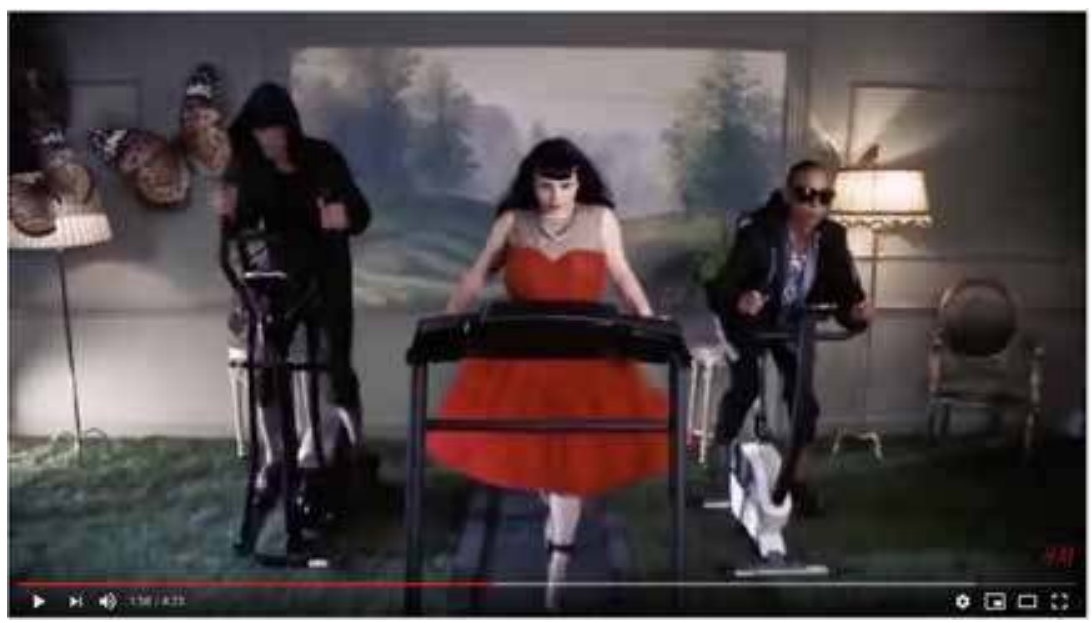

Figure 9.5: Set design by Shona Heath in 'The Show'.

signature from his own feature film Time Code (2000) - shows four different models each wearing the same dress in similar hotel corridors. Shona Heath's set designs featuring animals, and uncertain borders between indoor and outdoor space, are also clearly recognizable. ${ }^{47}$

47 There is also a director's cut version of the ad (nine minutes long), which contains scenes cut from the released version. One of them concerns a girl wearing a red dress who gets in the shower. 
There is a dreamlike quality about 'The Show' as a film, which to a large extent has to do with repetition and sameness; Heath's set designs also share this surreal dimension. But, as already mentioned, the first ad with Alber Elbaz was also called 'The Dream'. In this ad, he talks about dreams in another sense of the word - namely, the H\&M request to 'translate the dream that we created at Lanvin to a bigger audience'. Figgis's director's cut version was also called 'Is It a Dream?', which not only connects to the first ad but also clearly reflects his own track record: an ad from 2007 for Agent Provocateur made with Kate Moss was called 'The Four Dreams of Miss $X^{\prime}$, and in 2009, he participated in a collective work with 42 directors each making a 42-second contribution on the theme of dreams: 42 One Dream Rush. In the case of the Lanvin ad, it is indeed a dream, but a dream that has come true. In Alber Elbaz's words:

In design we are dealing actually with real and surreal, with surreal and real, with fantasy and a dream, dream and fantasy. The mix of the two, I think, is the essence of design. It's this emotional and rational, both at the same time. ('Real and Surreal')

A central episode in 'The Show' consists of women from three generations wearing the same dress, which draws upon and develops the original Lanvin logo from 1927, by Paul Iribe, showing a mother and a daughter in the same outfit. This is also something that Elbaz talks about in the behind-the-scenes material and further elaborates on in one of the clips on the collaboration, called 'Daughter, Mother and Grandmother'. ${ }^{4}$

One of the 'stories' runs as a common thread all the way throughout the ad; here, a girl rejects both flowers and diamonds from her lover-to-be: 'I want Lanvin. [...] I love Lanvin.' In the behind-the-scenes footage, the actress

This remains quite enigmatic in the ad; in the director's cut version, however, we also see her leave the shower and go to her wardrobe, where she has six more dresses identical to the one she was wearing. This version is not accessible on H\&M's YouTube page, however. See 'H\&M Lanvin by Mike Figgis, DIRECTORS'S CUT.mov', https://www.youtube.com/watch?v=VpRXuFpn7fc (last accessed 6 April 2021). Another interesting aspect of the scene mentioned above is that there is a queer side to it: a person coded as a man is putting on nail polish, and is later seen in a purple frock. In 2010, this scene was cut from the official advertising film, but seven years later H\&M has 'come out' showing a dress worn 'by her... or him.... 'Bring it on', http://www.fb.se/work/ hm/bring-it-on (last accessed 6 April 2021).

48 'H\&M Designer Collaboration 2010 - Daughter, Mother and Grandmother', https://www. youtube.com/watch?v=y3xVmgGPLsQ\&index=47\&list=PL8SMpuBlgs3nFtfuRıi8SSTEMQlko vQ_7 (last accessed 6 April 2021). 
comments: 'He doesn't know how to please me, basically'. ${ }^{49}$ The ads for the designer collaborations were supposed to contradict the sexism of which H\&M had been accused, not least in relation to their underwear campaigns, which were criticized for being all about how to please men, while what is at stake here is instead how to please women.

When the girl desiring Lanvin finally gets what she truly wants, it is one of the dresses that the spectator has already seen the girls in the waiting room wearing. Whereas Lanvin as haute couture stands for the expensive, the exclusive, and the singular, H\&M stands for the cheap, the mass-produced, and the widely available. But this in no way contradicts the idea that Lanvin for $H \& M$ can be the true fulfilment of her desire. As Alber Elbaz comments in 'The Dream', in which he first 'comes out' as the H\&M designer in public: 'I loved the idea that $H \& M$ was going luxury rather than Lanvin is going public.' Thus, instead of complaining about everyone wearing the same thing, the ad seems to turn things upside down. The 'Oh My God' exclamation when two girls meet in a hotel corridor and discover that they are wearing the same dress, or the 'I love your dress' compliment when two others, also wearing the same outfit, meet in an awkward situation and find relief in this, also contribute to telling a story in which sameness rules. From Lagerfeld to Lanvin, then, the H\&M ads seem to firmly establish their own position concerning the critique generally directed towards their label, in both cases with humour and irony as weapons. In the former, they argue that H\&M isn't cheap - that the concept of 'cheapness' has two possible meanings is of course a major question; even if the inexpensive part in itself is uncontroversial, the question remains whether inexpensive fashion can ever be anything but cheap. In the latter, they argue that everyone wearing the same thing is a strength rather than a drawback. Fashion, after all, is about people wanting to dress alike. Of course, as Lagerfeld stated, 'If you are cheap, nothing helps' - but as he also argued, 'It is all about taste'. The advertising part for H\&M still remains very discreet; only the 'Lanvin loves $H \& M$ ' bag, and the final image with the release date of the collection, reveals the actual object of the ad.

This advertising film thus, as mentioned, includes both a film director and a set designer: the former associated with feature films made for the cinema; the latter previously involved mostly in printed ads. As it contains not only two different artists, but also two different brands, and through its launch in social media, which has been highlighted in my discussion, it may

49 'H\&M Fashion Video - Lanvin for H\&M', https://www.youtube.com/watch? $v=n S c o p o r c r 1 Q$ \&list=PL8SMpuBlgs3nFtfuRıi8SSTEMQlkovQ_7\&index=41 (last accessed 15 July 2017). 


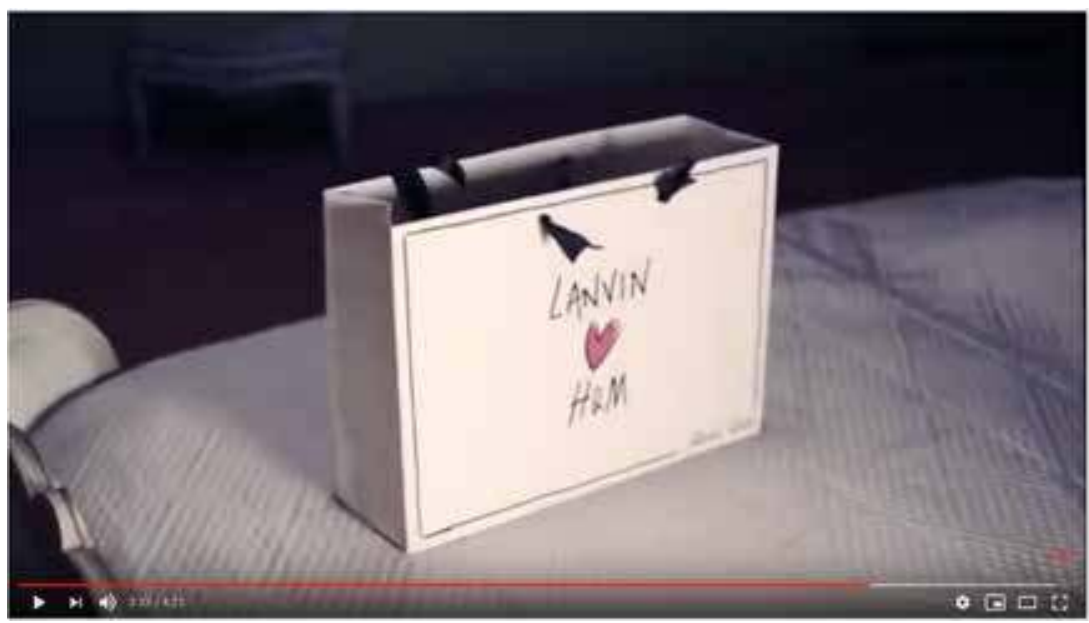

Figure 9.6: Discreet advertising for H\&M in 'The Show'.

also contribute to the understanding of the complex topologies that are at stake here, which include several different media technologies and hence also equally diverging frameworks for reception, through many different platforms. The reliance upon the cinematic auteur tradition, with a number of renowned directors involved, combined with the - at least initial - novelty of the social media platforms, as well as the general principle of collaboration across media, nations, and cultural boundaries, indeed forms the specific framework of all these designer collaboration advertisements for H\&M.

\section{H\&M's YouTube Page as Archive}

As I have attempted to exemplify above, in addition to their advertising campaigns using YouTube among other channels, H\&M have also actually expanded them to include a meta dimension to the ads, in creating a Web archive on YouTube, documenting the very process of advertising their collections and their campaigns. Whether there has been an actual ambition to use YouTube as a public archive, or if this is just a way for H\&M to use a low-cost or free interface to share parts of their collections and their advertising history, is not the point here. Regardless of the aims, the H\&M YouTube page, ${ }^{50}$ divided into a number of themes, does function as an informal archive. H\&M Fashion Inspiration contains 231 videos, whereas H\&M Campaigns contains 92. Then follows H\&M Fashion Events, with 106 
videos, ranging from store openings to the H\&M Design Award. The category H\&M Conscious, which contains a number of ads for the corporate social responsibility of the company, contains only 23 videos, but spans a large number of fields, from ' $\mathrm{H} \& \mathrm{M}$ in Bangladesh', to 'H\&M Conscious Action Highlights 2014', to the presentation of the 'H\&M Conscious Foundation Ambassador' Alek Wek, or 'H\&M on Water Stewardship'. Behind the Scenes at H\&M contains 113 videos, both from the designer collaborations and several new collections or campaigns, such as H\&M Fashion Against Aids 2011. The Popular Uploads category contains no fewer than 988 uploads, several of them, however, figuring repeatedly. Beside these central headlines, there are also a number of 'Created playlists', with examples such as H\&M Loves Music (23 films), H\&M Design Award 2014 (12 films), H\&M Conscious (23 films), Lookbook ( 5 films), and Liked Videos ( 38 films). Here, H\&M Guest Designer Collaborations also figures, with 69 films.

To return to Prelinger's idea of YouTube as archive, it is interesting to study the H\&M process of archiving on YouTube. More specifically, how are the guest designer collaborations staged on YouTube? The advantages for the company are obvious. As the investment in the film ads had already been made, uploading them on YouTube is a way to reach new audiences essentially for free. Rick Prelinger's point about YouTube's openness for user contributions, here applies well to $\mathrm{H} \& \mathrm{M}$, for users may take advantage of YouTube as a communication channel. However, users are not only users, but also producers, which allows for new users to additionally contribute to the campaign, through the possibility of social networking by commenting.

As H\&M obviously have used their YouTube page in quite a systematic manner, one could have expected that all the collaborations would have been there, forming a complete archive of the campaigns. However, a quick glance at the list of collaborations reveals the opposite. The campaigns from 2004 and a couple of years afterwards - Lagerfeld, Stella McCartney, Viktor \& Rolf, Roberto Cavalli, Comme des Garçons - are all absent. The 2009 Mathew Williamson collaboration, however, appears on the YouTube page, but not Jimmy Choo from the year after, whereas Sonia Rykiel and Lanvin, both from 2010, appear. After that, both Versace and Marni are absent, whereas Maison Martin Margiela as well as Alexander Wang are there, but not Isabel Marant from the year in between. The Balmain 2015 campaign is there, as well as Erdem 2017, but Kenzo 2016 is not, nor is Moschino 2018 or Giambattista Valli in 2019. Still, it is unclear how these decisions are made. There may well be copyright issues or other problems that remain unarticulated. There is also the question of how long this archive will remain. Several of the films, such as the Marni film, were removed from the $H \& M$ 
YouTube page after some time. Who makes these decisions, and for what reasons? This thinning-out process is also typical for corporate archives, which usually sort out what no longer generates any value - to which of course a specific and more complex dimension is added in the advertising context as several layers of 'value' are at stake: the immediate commercial value, which could be downplayed as soon as the specific campaign is over and the products are sold, but also the added value of collaboration across 'high' and 'low' fashion, with its global and democratic ambitions, which is a more stable, ideological value, but possibly also generating commercial effects in a long-term perspective. Whether a 'complete' corporate archive, where the original material is stored, actually exists in this case also remains unclear. ${ }^{51}$ It is equally clear that understanding YouTube as an archive introduces a new conception of the archive, where stability and complete coverage are no longer evident, but where the basic idea of the archive, to preserve and to transmit the essential, is perfectly in place. Companies may be less motivated to preserve advertising campaigns, ephemeral by definition, in an archive than other materials with more long-standing aims. At the same time, the same ephemerality is true of YouTube as a channel. And even though far from all the campaigns are available, the $H \& M$ YouTube page still allows for fundamental insights into the H\&M way of advertising. It is useful from a conceptual viewpoint, though less so from a strictly historical perspective.

To conclude, it remains perfectly clear that the H\&M YouTube page as an archive, at least in the sense that we are used to, suffers from serious gaps in information. At the same time, much of the information lacking from the official H\&M YouTube page is to be found on other YouTube pages. For example, the advertising film Marni at H\&M, directed by Sofia Coppola, with music by Bryan Ferry (Avalon, by Roxy Music), which can no longer be found on the H\&M page, may instead be found on Ferry's YouTube page, which strengthens the hypothesis of copyright issues being at stake..$^{52}$ Still, this practice, in which spectators and other people involved in the videos

51 I tried to get in touch with H\&M several times to get answers to those questions, but I have not even received a reply. The strange thing is that $\mathrm{H} \& \mathrm{M}$ - through the 'The Erling-Persson Family Foundation' - made possible the foundation of the Center for Fashion Studies at Stockholm University, and in that sense supports scientific research. But, it seems, not research on H\&M. $5^{2}$ 'н\&м Marni - Directed by Sophia [sic] Coppola',

https://www.youtube.com/watch?v=iPoqyCzSc-w (last accessed 6 April 2021). There is a 'Behind the scenes of the Marni at H\&M commercial' on the H\&M YouTube site, though, showing that not all material concerning the Marni collaboration is gone, just the advertising film with the tune by Bryan Ferry. https://www.youtube.com/watch?v=A7x4pCMRVQw (last accessed 6 April 2021). 
have uploaded them on YouTube, also refers to the last point made by Rick Prelinger - that the videos were very easily embeddable. The reason for their presence on YouTube - or on someone's website or blog - is precisely this practice of spreading by uploading - yet another way of 'friendvertising'.

\section{Bibliography}

Müller, Eggo. 'Formated spaces of participation: Interactive television and the changing relationship between production and consumption.' In Digital Material: Tracing New Media in Everyday Life and Technology, edited by Marianne van den Boomen et al. Amsterdam: Amsterdam University Press, 2009.

Petterson, Bo. HandelsMännen, Så skapade Erling och Stefan Persson sitt modeimperium. Stockholm: Ekerlids Förlag 2001.

Prelinger, Rick. 'The Appearance of Archives.' In The YouTube Reader, edited by Pelle Snickars and Patrick Vonderau. Stockholm: National Library of Sweden 2009.

Tuten, Tracy L. Advertising 2.o: Social Media Marketing in a Web 2.o World. Westport: Praeger 2008. 


\title{
10. Beyond Promotion: The UN Global Goal Campaign
}

\author{
Bo Florin
}

\begin{abstract}
'Beyond Promotion: The UN Global Goals Campaign', deals with the latter as a particularly interesting example, given the way this campaign did not advertise a product, but rather a policy. Does this change the way of relating to history? Advertising sustainability requires both economic development, environmental protection, and social responsibility. The chapter shows that the launch of this campaign, not least by using Aardman Animations, relies heavily on both film history and the history of commercials.
\end{abstract}

Keywords: United Nations, Global Goals Campaign, policy, film history

As the United Nations in 2000 adopted the eight Millennium Development Goals for Sustainable Development, which in 2015 were replaced with the seventeen Sustainable Development Goals, the focus of world politics and policies gradually shifted towards creating a sustainable future for the planet and for human societies. Looking back at the two previously discussed brands, Volvo and H\&M, it becomes clear that this major shift also marks a change in advertising strategies, as values concerning sustainability are gradually entering into, challenging, and changing the companies' advertising agendas.

When you talk about Volvo, you probably think of a car. But you are wrong. What Volvo is about today is rather an assemblage, an exhaust emission control device put together with a number of other devices, all designed for sustainability.

Florin, B., P. Vonderau, Y. Zimmermann, Advertising and the Transformation of Screen Cultures. Amsterdam: Amsterdam University Press, 2021 DOI 10.5117/9789462989153_CH1O 
The quote, attributed to a Volvo salesperson, points to the fact that sustainability has really become a core value in advertising today, marketing the quality of sustainable solutions rather than the product itself. ${ }^{1}$

On the Volvo home page in 2016, the year after the adoption of the Global Goals, there is a double focus on sustainability - 'we've reduced their impact on the environment' - and on the future, on 'entering a new era'. ${ }^{2}$ Already with the new millennium - coinciding with the UN adoption of the Millennium Development Goals - Volvo had delivered its first sustainability report. The yearly reports from 2004 onwards are available on the home page, after the practice first became formalized in 2003. The same year, a new commercial for Volvo S 60 was also launched: 'Jogger', produced by Forsman \& Bodenfors. ${ }^{3} \mathrm{~A}$ woman is sitting behind the wheel in an urban environment. She is distracted by the sight of a jogger in her rear-view mirror; he is running just behind her car. More joggers join. Although she switches lanes, the joggers - now a small crowd - continue to run behind her car, ignoring the rest of the traffic. A slogan explains: 'A car that turns harmful ozone into oxygen.' The ad was reported to the Swedish Marknadsetiska rådet (The Council on Market Ethics), which found that it broke the rules of the International Chamber of Commerce (ICC). The slogan was later prohibited by a decision in the Swedish Market Court. ${ }^{4}$ This, however, hasn't changed Volvo's basic strategy, to claim a unique consciousness of environmental and sustainability issues, based on the argument that '[w]e come from a different place. So we think about cars in a different way. It's in our nature'. 5

1 Quoted from Jack Spaapen at a seminar on quality assessment with the Swedish Research Council at Stockholm Waterfront, 15 June 2016.

2 Volvo website (Sweden), https://www.volvocars.com/sg/cars/new-models/vgo-old/madeby-sweden (last accessed 6 April 2021); Volvo website (UK), http://www.volvocars.com/uk/cars/ new-models/ninety (last accessed 6 April 2021). It is interesting to note that versions vary. The Swedish as well as the global version are more elaborated than certain national versions, such as that of the United Kingdom. The former states that: 'because this is what the world needs', or 'because this is what the future requires'.

3 'Volvo - “Jogger"', Adforum.com, http://www.adforum.com/creative-work/ad/player/23867/ jogger/volvo (last accessed 6 April 2021).

4 Sveriges Domstol, Marknadsdomstolen, Domstolsnummer 2004-4, Avgörandedatum 200402-10, Referat MD 2004:4, http://www.rattsinfosok.dom.se/lagrummet/index.jsp (last accessed 15 July 2017).

5 Volvo website, https://www.volvocars.com/sg/cars/new-models/v9o-old/made-by-sweden (last accessed 6 April 2021). Recently, Volvo also announced their support of the UN Global Compact: 'As a founding member of the Un Global Compact, Volvo Cars is delighted to have hosted the Nordic Network of the world's largest corporate sustainability initiative on 8-9 May 2017. The Compact is the world's largest and most influential corporate sustainability initiative with 
Like Volvo, H\&M has also been subject to criticism for breaking international conventions, though in their case, this criticism had no relationship to advertising, which was rather used as a remedy, a means of re-establishing the company's reputation. After a number of reports on suspected child labour, ${ }^{6}$ in $2013 \mathrm{H} \& \mathrm{M}$ established a playlist on their YouTube channel called ' $\mathrm{H} \& \mathrm{M}$ Conscious', which today contains 25 films. ${ }^{7}$ The content ranges from short ads - 'H\&M All for Children 2013' (in support of UNICEF) or 'H\&M in Bangladesh' - to seminars for H\&M staff filmed in their entirety. That social responsibility and sustainability has become a key question for the company is obvious to anyone consulting the playlist. In a seminar from 2016, it is stated that 'Turning from linear "take, make, waste" to circular productions where products and resources are used again and again is a key challenge for the fashion industry'. This is also the subject of two recent commercials on recycling, which have both generated a huge public response. In 2015, a film with the 'Godfather of Punk', Iggy Pop, called 'Close the Loop', was produced by Forsman \& Bodenfors under the label 'Sustainable fashion through recycled clothes', with almost ten million views. ${ }^{8}$ Through a series of dichotomies 'Stand out - blend in', 'Be trashy - be neat', or 'rule-breaking' advice - such as to 'wear red as a redhead' or 'wear yellow as a blonde' - the final slogan sets the basic rule: 'There are no rules in fashion but one: recycle your clothes!' Under the same label, a music video was produced in 2016, also by Forsman \& Bodenfors, 'World Recycle Week featuring M.I.A.', with three million views, with the final slogan, 'Join in a global fashion movement for the planet'. ${ }^{9}$ Through the slogan 'Reworn - reused - recycled', H\&m has strived to establish its image as a fashion brand that has made circularity, and thus sustainability, its guiding star. How, then, do these two particular cases relate to a broader context of advertising in the age of sustainable development?

over 9,0oo companies in 170 countries.' http://www.volvocars.com/intl/about/our-company/ sustainability (last accessed 6 April 2021).

6 See Jamie Doward, 'H\&m Comes under Pressure to Act on Child-Labour Cotton', The Guardian, 15 December 2012, https://www.theguardian.com/business/2012/dec/15/cotton-child-labouruzbekistan-fashion (last accessed 6 April 2021).

7 H\&M's official YouTube channel, https://www.youtube.com/hm (last accessed 6 April 2021).

8 'Close the loop', https://www.youtube.com/watch? $=\mathrm{v}=\mathrm{s} 4 \mathrm{xnyr} 2 \mathrm{mCuI}$ (last accessed 6 April 2021).

9 'World Recycle Week featuring M.I.A.', https://www.youtube.com/watch?v=f7MskKkn2Jg (last accessed 6 April 2021). The ad 'Bring it on' (2017), also by Forsman \& Bodenfors for H\&M, goes even further, and shows more explicitly the idea of recycling: http://www.fb.se/work/hm/ bring-it-on (last accessed 6 April 2021). 


\section{From Basic Marketing to the Sustainability Goals}

In their book Sustainability Marketing: A Global Perspective, Frank-Martin Belz and Ken Peattie describe a development based in the oth century, 'the century that transformed the world'. The threshold of the new millennium was an occasion to reflect on 'the state of the world and the future prospects for humankind', and thus also - within marketing business - on the marketing of the future. ${ }^{10}$ In their study, they show how the four P's put forward by E.J. McCarthy in Basic Marketing 1960 - product, price, promotion, place - were replaced by four C's, as suggested by Robert F. Lauterborn in a 1990 article in Advertising Age: consumer wants and needs, cost, communication, and convenience. ${ }^{11}$ This also marks a shift of focus from producer to consumer, paving the way for 'a new sustainability-oriented marketing mainstream, ${ }^{12}$ which is the vision of the authors, oriented towards the future and built on sustainable consumer solutions and relationships. In 2012, in a late edition of his book Marketing Management, Philip Kotler takes this one step further, by arguing for four new P's: people, processes, programmes, and performance..$^{13}$ In the 21 st century, the focus has passed well beyond the producer-consumer dichotomy.

It could be argued that Kotler's non-dualistic approach focusses on more all-embracing, 'softer' values, or even that it is more value-oriented in general. However, while any ad for a commodity necessarily also contains values, which may change over time with the change of values in society - as the examples of Volvo or H\&M clearly show - another type of change occurs when what is being advertised is no longer a commodity at all, but instead a set of values. The very idea of marketing still remains closely related to the launch of products and services for a market, with the aim to create a behavioural change in the consumer and thus to generate profit. These products and services are mostly launched through images, or rather, they have become images themselves. Does the marketing of 'pure values', then, differ from that of commodities, in principle or in practice? These questions have become all the more relevant as sustainability itself has become the object of marketing. The United Nations has communicated the seventeen

10 Frank-Martin Belz and Ken Peattie, Sustainability Marketing: A Global Perspective, 2nd ed. (West Sussex: Wiley 2012), $6 \mathrm{ff}$.

11 See E.J. McCarthy, Basic Marketing: A Managerial Approach (Homewood: Irwin, 196o); and R.F. Lauterborn, 'New Marketing Litany: 4 Ps passé; C-Words Take Over', Advertising Age (1 October 1990), 26.

12 Belz and Peattie, Sustainability Marketing, xiv

13 Philip Kotler, Marketing Management, 14th ed. (Harlow: Pearson, 2012 [1967]), 25. 
Sustainable Development Goals, agreed upon by the General Assembly in 2015 , to the world, not only through traditional political or news channels but also through advertising films, circulated both through traditional and social media, in 'any and many ways'. ${ }^{14}$ In the following, I will explore a part of these 'ways', with a specific focus on the Global Goals Campaign, launched in 2015 within the United Nations Development Program (UNDP).

The aim of this campaign - which corresponds well with Kotler's four P's - people, processes, programmes, and performance - is broad. What is at stake is the survival of the planet and, in the end, even of the human species. Not only the United Nations itself, but all their member states, are committed to realizing the goals, which are implemented in different ways in each country. The Global Goals Campaign has been described as 'the biggest ever collaboration of NGOs, global brands, public figures, educators, sports clubs, faith leaders, TV and Radio broadcasters, Cinema Advertising companies, telecoms operators, digital and social media platforms, creative and media agencies, publishers, artists and grassroots organisations.' ${ }^{15}$

What is particularly interesting with this campaign is that it was created by the United Nations with a global and non-profit aim. A possible parallel that comes to mind would be the PSA - public service announcements - a format for sponsored productions delivering messages in the public interest, with the aim to change attitudes and behaviours towards social issues, and which thus also clearly articulate certain values and priorities. The comparison is perfectly valid, especially when it comes to the individual parts of the campaign, but still, it can be argued that the Un campaign aims at an even larger format than creating a number of PSAs only. The ambition is to advertise the goals through a very broad range of forms and formats - including a specific campaign within the campaign, inviting companies to join a 'Make a PSA'. ${ }^{16}$

A key moment of the initial launch of the Global Goals Campaign was the initiation of 'Project Everyone' by screenwriter and film director Richard Curtis, with the aim to advertise the Sustainable Development Goals: 'The

14 Richard Curtis in 'Making the SDG's famous,' https://www.youtube.com/watch?v=rKir2GhwXCw (last accessed 6 April 2021).

15 SAwA/The Global Goals press release, 11 September 2015, 2,

https://press.ncm.com/press-releases/press-release-details/2015/The-Cinema-Medium-Preparesfor-the-Release-of-the-First-Ever-Global-Cinema-Ad-Campaign-to-Promote-the-Launch-of-theUnited-Nations-Global-Goals/default.aspx (last accessed 6 April 2021).

16 United Nations, Creative Community Outreach Initiative (CCOI) https://www.un.org/en/ ccoi/page/make-psa (last accessed 6 April 2021). 
simple but mighty ambition of Project Everyone - is to share the global goals with all 7 billion people on this planet'. ${ }^{17}$ Though independently organized, Project Everyone has indeed been part and parcel of the launch of the Global Goals by the UNDP. A YouTube clip featuring Helen Clark, Head of the UNDP, particularly emphasizes the partnership between UNDP and Project Everyone. ${ }^{18}$ The Project Everyone home page equally emphasizes the close connection to the United States by quoting UN Secretary Special Adviser Amina J. Mohammed, who states that ' $[\mathrm{w}] \mathrm{e}$ welcome the extraordinary contribution and commitment from Richard Curtis and the Project Everyone team to make these global goals famous.' ${ }^{19}$ The idea was born out of a conviction that the failure of the Millennium Development Goals was partly due to the fact that they hadn't been spread widely enough and had simply remained unknown to the general public. Project Everyone is being realized in many different ways and through all channels available including, in Curtis's own words, 'online, digital, schools, faith, TV, radio'. The examples of dissemination strategies are quite varied: the 'World's Largest Lesson' reached 500 million children in 103 countries through commitments from Ministries of Education; mobile operators texted 5.2 billion customers; the Global Citizen Festival attracted 6o,ooo live spectators and was broadcast on $\mathrm{TV}$ in 26 countries, with the ambition of becoming a yearly event until 2030; 1.3 million people shared \#globalgoals on social media; 250 million people engaged via Radio Everyone in 75 countries through 600 radio partners. ${ }^{20}$

A number of films have also been created and uploaded to the Global Goals home page, such as the film 'No Point Going Halfway' from 3 September 2015. ${ }^{21}$ This film links back to the Millennium Development Goals, with the general aim to highlight that many results have actually been achieved over the preceding fifteen years: 43 million more kids go to school, new HIV infections have been reduced by 40 per cent, two billion people have access to cleaner drinking water, and extreme poverty has been halved. These are facts that, according to the Global Goals Campaign, need to be told and retold, and they offer a factual framework that allows the audience to better prepare for the new ads to come and for a more positive reading of the new

17 Project Everyone, home page, https://www.project-everyone.org (last accessed 6 April 2021).

18 'Helen Clark on the launch of the Sustainable Development Goals', https://www.youtube. com/watch?v=vSFIxHQmk_4\&index=28\&list=PLhanS7jySFTJDozpollZiRREPilDkJvE4 (last accessed 6 April 2021).

19 Project Everyone, home page, https://www.project-everyone.org (last accessed 6 April 2021).

20 Ibid.

21 'No Point Going Halfway', https://www.youtube.com/watch?v=DdLqiTvFwJk (last accessed 6 April 2021). 
goals; they are not picked out of the blue, but are only a consequent way to follow up on what has already been achieved. It is also a way to, afterwards, advertise the Millennium Development Goals. Here, however, I will focus on the two major film projects launched by Project Everyone in connection to the decision about the goals on 25 September 2015.

\section{We the People}

On 3 September 2015, there was a first launch of the four-minute-long 'We the People', featuring a performance group of teenagers, Get Lit, from high schools in Los Angeles County. ${ }^{22}$ Here, spectators were encouraged to 'join the world's biggest cast and film yourself saying your favourite goal', all to 'ignite the world's leaders'. The spectators addressed in this launch were further encouraged by the more concrete fact that, in the final film, they might star alongside actors such as Meryl Streep, Cate Blanchett, or Daniel Craig; scientists such as Stephen Hawking; musicians such as Chris Martin or Stevie Wonder (also un Messenger of Peace); royalty such as Queen Rania of Jordan; artists such as Ai Weiwei; or other prominent people such as Bill and Melinda Gates or Nobel Peace Prize winner Malala Yousafzai - all this taking place 'on Tv, online and live'. For each goal, the phrase 'We live in a world where...' is repeated (e.g., 'where nobody, anywhere, will live in extreme poverty'), each sentence anticipating the fulfilment of one of the goals.

On 24 September, the final three-minute film was launched, which, apart from repeating the phrases from the first ad, also adds both the 'stars' and a large number of 'ordinary' people alongside the Get Lit group, to express the fact that these goals concern us all as global citizens. ${ }^{23}$

Following the same dramaturgical pattern as the 'call for contributions', the result nevertheless becomes much more complex both visually and aurally. That the film is crowd-sourced is one of its most striking features, as is the fact that that the general public and high-profile public figures appear together, and together turn to the spectator in direct address - a strongly rhetorical address. The direct address on-screen for rhetorical purposes is also strongly linked to the media history of the United Nations, which, as Pelle Snickars among others has noted, was to an important extent

22 'We the People needs you feat. Get Lit', http://www.un.org/sustainabledevelopment/ blog/2015/og/we-the-people-needs-you-global-goals (last accessed 6 April 2021).

23 “We The People" for The Global Goals': https://www.youtube.com/watch?v=RpqVmvMCmpo (last accessed 6 April 2021). 


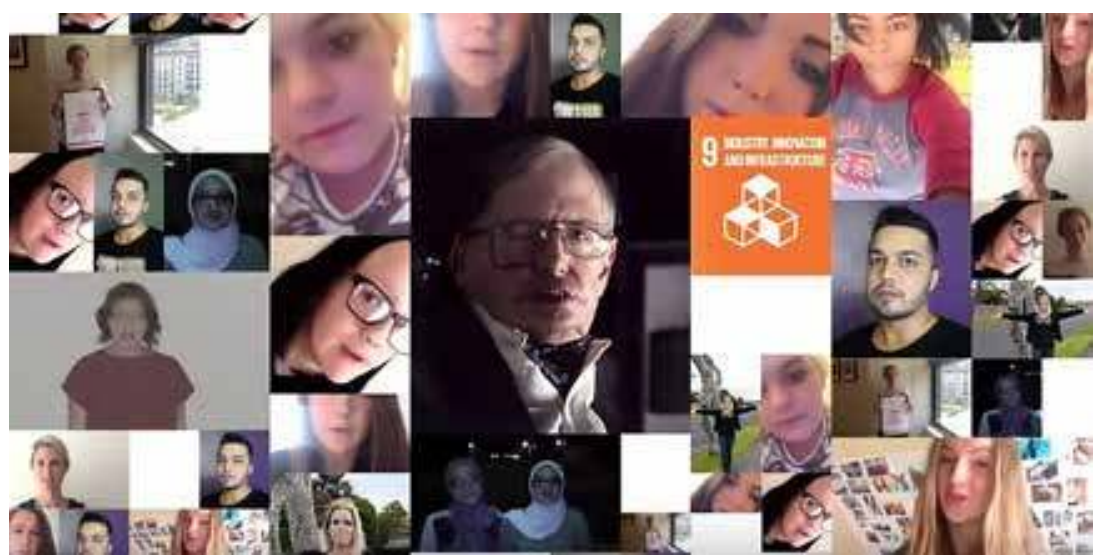

Figure 10.1: Fame and ordinariness - Stephen Hawking in 'We the People'.

developed by Secretary General Dag Hammarskjöld, who early on adopted a strategy for the 'mediatisation of politics', using the power of media to influence opinion as part of his diplomatic mission. A central part of this was his speeches on UN Day and on other important occasions in direct address to the spectator and often also in different languages (English, German, French, Swedish), which were filmed to reach out to and address spectators around the globe. ${ }^{24}$

'We The People' delivers testimonials from both celebrities and ordinary people. While clearly endorsing celebrity, the celebrities are mixed with other contributors to the film in a way that does not allow for any real distinction between fame and ordinariness. ${ }^{25}$ This, indeed, is a key message: these addresses concern us all. People also appear as representatives of whole sectors of society. Some are filmed in their home environment, thus representing anybody or everybody. Some, such as Chris Martin, who is filmed in his music studio, or football player Kolo Touré, who is filmed with the Liverpool emblem behind him, become representatives for sectors of society; Liverpool is also one of the football teams supporting the so-called Dizzy Goal Challenge, 'A Dizzy Penalty for the Global Goals'. ${ }^{26}$ The

24 Pelle Snickars, 'Hammarskjöld tog kommandot över medierna', $S v D$ (28 July 2005). See also Bo Florin and Astrid Söderbergh Widding, 'Dag Hammarskjöld i FN:s filmarkiv', Signum 1 (2006): 12-17. For Hammarskjöld's speech, see: https://www.youtube.com/watch?v=HuppZpNG3kQ (last accessed 6 April 2021).

25 For a short history on, and definitions of, testimonials and endorsements, see Patrick Vonderau's chapter 'Advertising as Commercial Speech' in this book.

26 The idea is to film as you take a spin and then try to shoot a goal, and if you miss, to add: 'I missed my goal so that world leaders don't miss theirs'; or if you score: 'If I can score a dizzy 
participants in 'We the People' obviously share the same goals - but they also share sentences: one person starts, another continues the same sentence, and a third person may finish it. During several key moments throughout the film, the many different voices also join into a chorus, whether it is in the introduction or in reading out parts of the goals together. They also share screen space: whereas some people - mostly high-profile figures - appear alone on-screen, these single shots are interwoven with split-screen shots, in which many people are represented, and global diversity is emphasized. Two pictures stand out: the portrait of Stephen Hawking, the only one with a cut from full shot to close-up, as if to particularly emphasize his authority, and the image of a person demonstrating sun panels on an outdoor roof corresponding to the seventh goal of affordable and clean energy - one of the few times that the film abandons its individual focus and indoor space format, and also the only time that it comes close to suggesting a way to actually realize the goal.

The seventeenth and last goal, 'Partnerships of all kinds', is followed by a unanimous declaration: 'Let's go to work! Let's make it happen!' The whole dramaturgy of the film is based on a productive and creative tension between unity and diversity - we, the people, are one, but we are also many. In the end, after the seventeenth goal, the voices are once again dissolved into disparity. But at the same time, as the image zooms out, many frames appear on-screen, rapidly proliferating, and we see people's faces, all in agreement, which finally transform into a globe, where miniature pictures of people come to form images of the different continents - a picture that then in turn is transformed into the logotype for the Sustainable Development Goals. This final sequence reinvents the end of Richard Curtis's earlier film Love Actually (2003), in which, towards the end, an increasing number of small frames form a heart. This ending corresponds well with the fact that the film has a highly emotional tone in addressing the spectator, with the ambition of creating 'a shareable manifesto for change by the people, of the people, for the people', ${ }^{27}$ which also adds to the strong rhetorical message that these questions are fateful indeed, of utmost importance for the survival of our planet and of the human species. The fact that 'We the People' are also the first three words in the preamble to the American Constitution lends a dignity to the campaign as such while also emphasizing its importance 
as a message deriving its power from popular sovereignty. ${ }^{28}$ In a way, it could be said to widen the American address to its citizens to embrace all people around the globe.

\section{We Have a Plan}

Another part of the 'Project Everyone' on-screen was realized simultaneously, 'The First Ever Global Cinema Ad’, titled ‘\#WEHAVEAPLAN’. It was directed by advertising executive Sir John Hegarty, from Bartle Bogle Hegarty (BBH), in collaboration with Darren Dubicki at Aardman Animations and Global Cinema Advertising Association (sAwA), with Liam Neeson and Michelle Rodriguez lending their voices to the film and with music by Peter Gabriel. In this film, the idea was to reach cinema audiences all over the globe during the week immediately following the release of the goals. A leaflet from sAwA states in the headline: 'The cinema medium prepares for the release of the first ever global cinema ad campaign to promote the launch of the United Nations Global Goals'. ${ }^{29}$ After mentioning the partners in the United States - Cinema Advertising Council (CAC), a national non-profit trade association, Members National CineMedia (NCM), Screenvision, and Spotlight Cinema Networks - the aim of the campaign is expressed:

The Global Goals campaign has just been announced with a bid to reach 7 billion people in 7 days with news of the Global Goals for Sustainable Development. This unprecedented effort will culminate on 25 September at the UN when 193 world leaders adopt the Global Goals, a series of 17 ambitious targets to end poverty, fight inequality \& injustice and tackle climate change for everyone by 2030. If the goals are famous - if people care about what has been promised by the politicians, it greatly increases their chance of being implemented. So today the campaign is calling on everyone to help make the goals famous. ${ }^{30}$

The ad was first launched through a teaser campaign with a 20 -second film, ${ }^{31}$ screened in 30 different countries in fourteen languages, with a

\footnotetext{
28 'Constitution USA with Peter Sagal', http://www.pbs.org/tpt/constitution-usa-peter-sagal/ we-the-people/\#.V4tBrHhYFUN (last accessed 6 April 2021).

29 SAwA/The Global Goals press release, 1.

30 Ibid.

31 SAwA Global Cinema Teaser for the United Nations Global Goals, https://www.youtube. com/watch?v=wF-9Pqnw9PQ (last accessed 6 April 2021).
} 
voice-over from the late Nelson Mandela, from his famous speech 'Make Poverty History', which he delivered at Trafalgar Square in $2005 \cdot{ }^{32}$ The first shot, seemingly a satellite hovering above the globe, also contains the Un logotype, and the slogan: '193 leaders meeting to agree on a plan.' The UN logo is then changed for Global Goals logotype, and the slogan: 'Reaching 7 billion people in 7 days.' Nelson Mandela's message picked for the ad is short but deep: 'Poverty is not natural. It is man-made. And it can be overcome.' As he starts speaking, to the slogan 'No Poverty', there is a cut to an image of black hands under fresh running water. The next cut, to a class where small children, both girls and boys, all raise their hands, is followed by the slogan 'Reduce Inequalities'. A third image, with the slogan 'Protect the Planet', shows an iceberg floating in the sea. As Mandela stops talking, there is a cut back to the initial picture of the globe, with the slogan '\#WEHAVEAPLAN, The First Ever Global Cinema Ad Campaign', 'Coming September 2015'. The teaser thereby succeeds both in delivering a key message, which might be extended from poverty to all of the other Sustainable Development Goals, of specifically pointing to the three main groups of goals - poverty, inequality, climate - and to promote not only the unique decision of the United Nations but also the uniqueness of the campaign as such. The choice of Nelson Mandela's voice from this key moment also links the Sustainable Development Goals to similar efforts in the recent past, in line with the earlier Millennium Development Goals, and so makes them a link in a larger chain of events aimed at making the world a better place. Mandela's voice also joins together the dead and the living, thus embracing past, present, and future.

The full ad lasts for 60 seconds. ${ }^{33}$ It premiered at the AMC Empire 25 in New York City on the eve of the Global Goals launch, 24 September, and on 25 September it was screened on thousands of cinema screens all around the world, distributed globally by UNIQUE DIGITAL. From 25 September to 2 October, it was screened at over 4000 cinemas in countries from Japan to South Africa, from Finland to Oman. The idea was to continue the screenings until the end of the year, wherever possible. The ad also launched the Global Goals Interactive App, produced by CINIME International, in order to ‘\#telleveryone'. In a behind-the-scenes video, the director Sir John Hegarty

32 'Nelson Mandela Speech in Trafalgar Square', https://www.youtube.com/watch?v=1NennMCLG7A (last accessed 6 April 2021).

33 'First Ever Global Cinema Ad \#WEHAVEAPLAN \#GlobalGoals - FULL ADVERT', https:// www.youtube.com/watch?v=7V3eSHgMEFM (last accessed 6 April 2021). 
states that 'the cinema now speaks directly to the audience'; unlike any other screening, the audience is here asked to leave their mobiles on, 'and the actual ad on screen will communicate with your phone'. The idea was to 'connect the power of the big Screen to the magic of the small screen and share the Global Goals' ${ }^{34}$

The ad first shows the globe at a distance, as in the teaser, but with an explanatory message, repeating the title of the ad: 'We have a plan to end poverty, reduce inequalities and fight climate change.' The next image shows an 'animated' un building from above, from a 'God's-eye view' perspective. This is followed by an image from below, of a number of flags outside the building, accompanied by the text Un Headquarters, to the sound of sirens and with rapidly passing vehicles. Then, after a cut to a garage, vehicles are seen arriving, escorted by police motorbikes. The surveillance camera (highlighted by a close-up shot) adds to the seriousness of the issue, and a number of screens imply that this is something being telecast in real time through several channels across the globe. A cut and a zoom in towards the rostrum in the UN General Assembly Hall surprisingly reveals a llama entering the stage, obviously personifying the Head of UNDP Helen Clark from New Zealand. While the physical environment is familiar, all of the other delegates also turn out to be animals, each personifying its particular country. The llama now announces that 'We have a plan', and that 'the plan is agreed by everyone!' It is interesting to note that the teaser doesn't reveal anything about the film being an animation, in order to increase the surprise effect.

But why animals? According to Andreas Fuchs, the director Sir John Hegarty, who wanted to celebrate the historical moment of the adoption of the Global Goals with his film, still asked himself how to put some drama into this. He then came up with the idea 'to use every country's national animal instead of the delegates, and show that they could come together? And if they can come together, then this shows that we can all do it.....35

Despite apparent minor disagreements between delegates, all of the animals basically seem to share the vision of the llama. The prophetic resonances of a messianic moment when hostile animals are reconciled

34 'World's first cinema ad from SAWA', The Global Goals website, http://www.globalgoals. org/cinema/ (last accessed 6 April 2021).

35 Andreas Fuchs, 'Noble Goals: Marketing the First-Ever Global Cinema Ad Campaign', Film Journal International, 28 September 2015, http://fijj.webedia.us/features/noble-goalsmarketing-fijirst-ever-global-cinema-ad-campaign (last accessed 6 April 2021). 


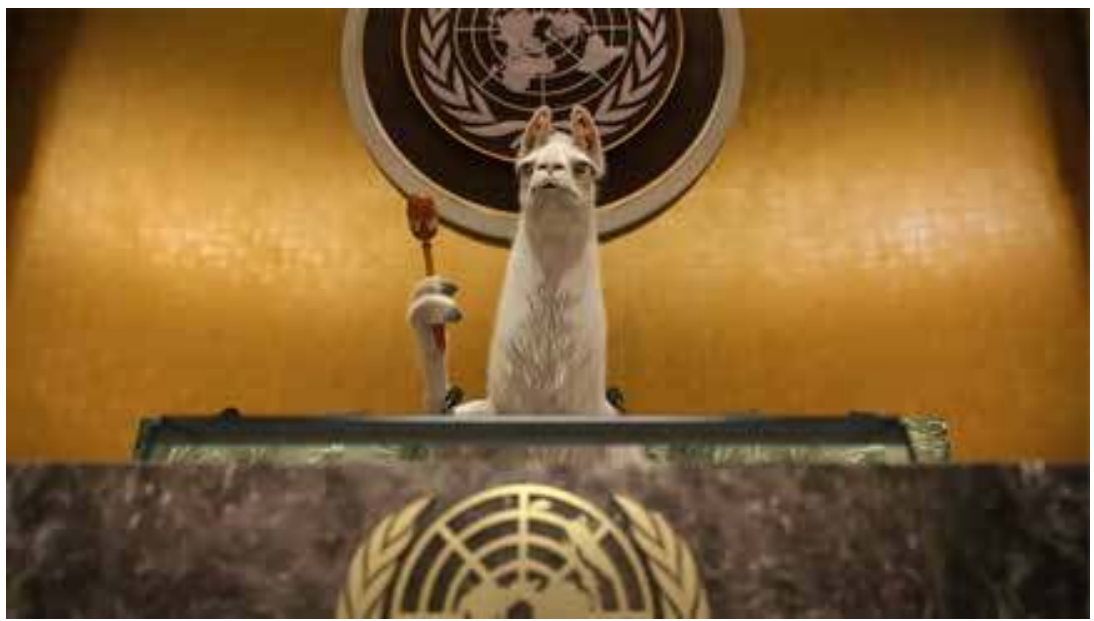

Figure 10.2: UN General Assembly Hall (and Head of undp Helen Clark?) in 'We Have a Plan'.

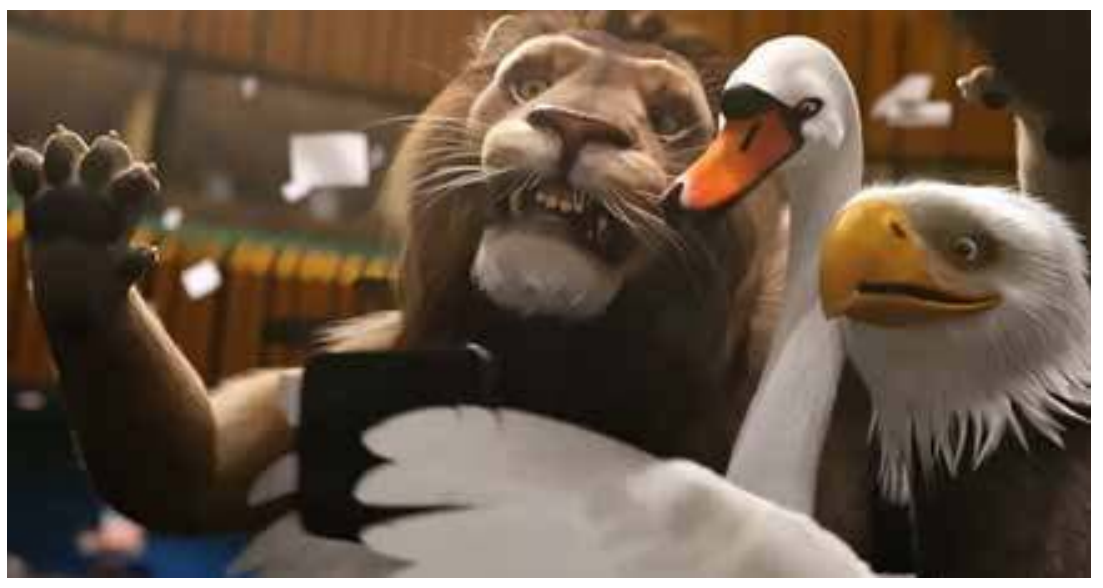

Figure 10.3: Biblical references in 'We Have a Plan'.

should be obvious for viewers with a biblical cultural heritage; the moment of adopting the Global Goals by the UN is indeed kairos, the right moment for the planet. ${ }^{36}$

The use of animals, however, must also be considered in relation to the historical role of Aardman animations within British advertising film. Here, the Creature Comforts advertisements, produced from 1990 to 1992, marked an important shift in British television advertising, analysed among others 
by Renée Dickason. She saw Creature Comforts as a clear case in point, introducing 'the caring nineties', as she calls them:

There was certainly plenty of evidence in the advertisements of the time, to suggest that the egoism of the 1980 s had disappeared, even if the term 'caring' is open to a variety of interpretations. One meaning of the expression was the desire to make life comfortable and easy for oneself. ${ }^{37}$

But if Creature Comforts did leave a mark in British advertising history, it was less as an ad for electricity - indeed, as Malcolm Cook has shown, the trade press at the time wrongly attributed the ads to a gas company - than as a trademark in itself..$^{8}$ Cook writes:

Regardless of the effectiveness of these commercials for the client brand, Heat Electric, in shifting to the use of characters created for other purposes, the 'Creature Comfort' commercials start to assert the Aardman studio's distinctive authorial voice and style as the dominant feature of its work at the expense of the brand being promoted. It may even be argued the brand the 'Creature Comforts' commercials most effectively promoted was Aardman itself. 39

The use of animals thus not only makes reference to a strong brand, where the use of animals already in the early 1990s had marked the shift from consumerism to sharing and caring, but in fact continues in the same vein, now using the Aardman brand and its popularity among the general public to promote the global goals.

Apart from their common overall message, the two films also share an interesting media-specific dimension. In an interview, sAwA General Manager Cheryl Wannell commented on the project: 'The aim is to make these goals FAMOUS, and what better place to do that than on the big screen? Cinema educates, inspires and influences people by changing hearts and minds ${ }^{40}$ In a similar vein, President of Sales and Marketing with National CineMedia Cliff Marks stated, in a hyperbolic claim:

37 Renée Dickason, British Television Advertising:Cultural Identity and Communication (Luton: University of Luton Press 2000), 92.

38 Malcolm Cook, “All You Do Is Call Me, I'll Be Anything You Need”: Aardman Animations, Music Videos and Commercials', in Beyond Stop-Motion Film: Production, Style and Representation in Aardman Animations, ed. Annabelle Honess Roe (London: Bloomsbury, 2020).

39 Ibid.

40 SAWA/The Global Goals press release, 1. 


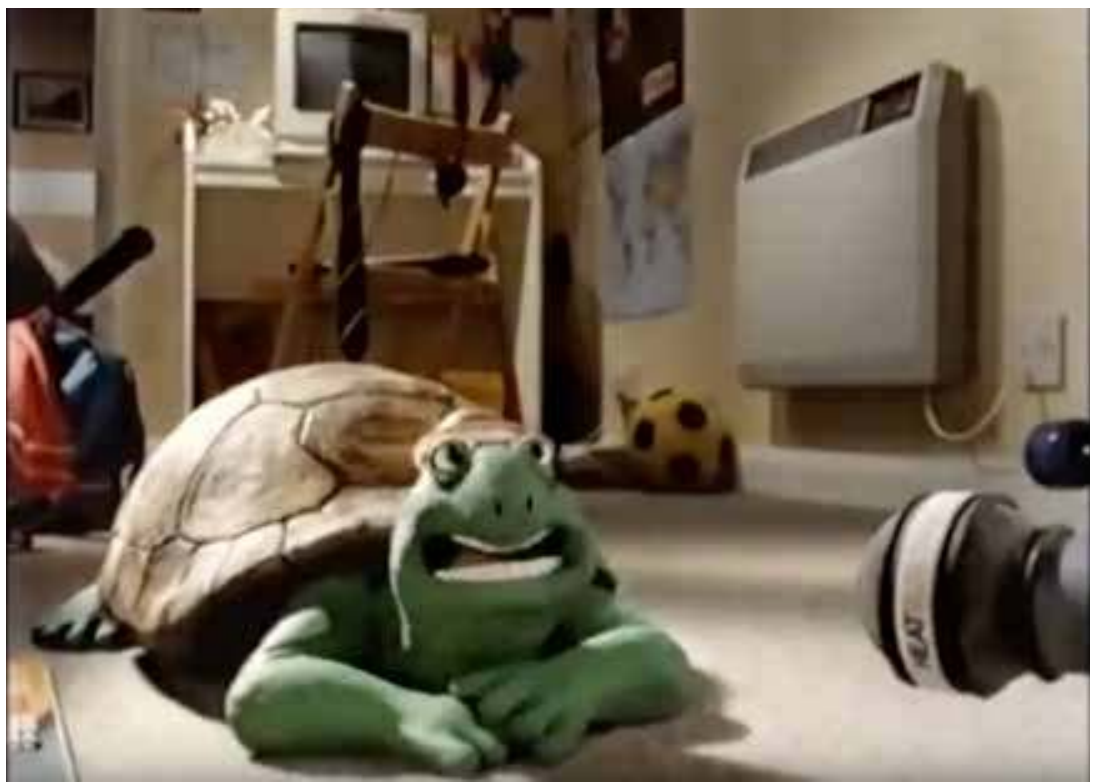

Figure 10.4: Screen ad for Heat Electric by Aardman animations Ltd., 1990.

Cinema has so many powerful storytelling capabilities, and to think that the UN chose our medium to most profoundly share their Global Goals [...] in movie theatres around the world speaks volumes about the engagement and emotional connection of our 50 -foot screens. Today's millennial audiences truly want to help change the world, and the best place to reach them with this important message is at the movies. ${ }^{41}$

As already noted, the connection between the cinema ad and the mobile app was here used to create a unique combination. From a media historical perspective, however, it is particularly interesting to note the emphasis on the big screen from both of these media representatives. The hyperbolic claims from Wannell and Marks about the great potential of cinema even today, based on the historical weight that it carries, is unanimous: the large screens, the storytelling capacity of the movies, as well as their potential to engage and to change minds. For an audience used to manifold media, many screens, and small screens, the impact of the big, $5^{0}$-foot screen here takes on an almost solemn quality: only the cinema medium seems to be really apt or suitable to convey the importance of this message. Though launched as 'big screen' ads, it is however clear 
that in practice, they have also allowed for widespread resonances across other media channels.

Another take on the relation between cinema and the project of advertising the goals was offered by a second 'We Have a Plan' ad, this time released on YouTube on 16 September 2016 by the UNDP. On the one hand, cinema was not introduced here through the format of the big screen. On the other hand, it was just as present, since the film is almost entirely (1:23 minutes) made up of a series of quotations from famous films, organized in three steps. After the initial 'We have a problem', from Ron Howard's Apollo 13 (1995), a number of quotes, starting with Gone Girl (David Fincher, 2014), ask the rhetorical question: 'What's the plan?' In the next step, a number of new quotes, introduced by the lemur from Madagascar (Eric Darnell \& Tom McGrath, 2005), proclaims that 'I have a plan', and finally, a number of statements praise the plan. ${ }^{42}$

The choice of the film format by the United Nations, albeit in different ways, plays an important role here: among all media, cinema was selected to transmit this unique event in history. The advertisers thus show confidence in the cinema as a privileged arena for transmitting a key message. The idea of cinema as the moving image medium par excellence may appeal to older audiences with a film-historical background, as well as to cinephiles of all ages. But the fact that audiences are told to leave their mobiles on suggests that the ad is addressed mostly towards younger audiences, who also are the ones who in the end have to realize the goals. The choice of using commercial cinema combined with the use of new media through cell phones thus appears as solving the Gordian knot - a universal solution which is able to reach out to everybody. But from an advertising point of view, how unique is the message of Project Everyone?

\section{Project Everyone: A New Take on Advertising?}

Whereas Belz and Peattie in their book Sustainability Marketing focus on commercial marketing, they also deal with social marketing as another 
branch with 'a longstanding tradition of influencing behaviour in the pursuit of societal and environmental goals'. ${ }^{43}$ They note that social marketing shares 'considerable synergy' with sustainability marketing, rather offering a 'social proposition' than a physical product. As examples, they have chosen campaigns in Australia, Denmark, and Canada for cycling or walking, campaigns that try to effect a change in behaviour away from an unsustainable, energy-intensive mode of transportation to a healthier mode, both for the individual and for the planet. ${ }^{44}$

To a certain extent, Project Everyone may seem to share its basic concerns with social marketing, and it is clear that it relies on a number of existing practices in basing its attempt at education, social communication, and raising awareness on solid market research. ${ }^{45}$ As already noted, the new focus proposed by Philip Kotler on people, processes, programmes, and performance also seems to correspond well with this wider vision of marketing, as well as with the general design of the Global Goals Campaign, not least the fact that people stand united, the processes reflect a lot of creativity brought to marketing, there are a number of 'consumer-directed' activities related to the campaign, and as such, it is mostly based on performance. ${ }^{46}$

However, there is one important difference in comparison to social marketing. Whereas cycling campaigns, among other possible examples of social marketing, typically serve the purpose of influencing a target audience to either accept or reject a certain behaviour for social benefit, the Global Goals Campaign and Project Everyone have no such concrete behavioural changes in view. Neither do they aim to promote the United Nations and their decision to adopt the goals as such. Rather, they aim to challenge the worldview of the spectator, to include the audience in a common vision for the future, shared not only by the officials or politicians in the United Nations, but extending to every citizen in every country across the globe. In this, they also aim to challenge the borders of advertising, whereas the four new P's suggested by Kotler basically remain within the world of advertising, focussing on its specific content and form.

If sustainability marketing has followed general marketing strategies in turning from the four P's to the four C's and then to the four new P's, Project Everyone attempts to add a new aspect, a fifth $\mathrm{P}$ for power. As formulated by Richard Curtis,

Kotler, Marketing Management, 25. 
I'm hoping that people will see the ad, remember it, talk about it, share it, and then look into it and actually find that if you are a person who cares passionately about the world in any way, these goals are going to be one of the big machines by which changes happen. So I hope people will watch, laugh, share, act. ${ }^{47}$

The basic aim of Project Everyone is, as we have seen, to '\#telleveryone' about the Global Goals. But telling everyone is not an aim in itself. It is because 'knowledge is power', and the project is based on a conviction that it is necessary to spread the word about the decisions of the politicians in many ways, that neither the politics nor the ordinary news channels will be enough, and so a systematic way of communicating, country by country, is needed. Telling everyone, however, is not innocent - it also contains an agenda of putting pressure on politicians. 'We all need to know what our rights are in order to claim them. This [...] means that we can now begin to hold our politicians to account in addressing the 17 core issues', and according to Richard Curtis, there is also a message from Project Everyone to the world leaders - namely, that they now share a unique opportunity to create enormous results, not only nationally but also globally. ${ }^{48}$

The Global Goals Campaign and Project Everyone strive to bridge the gap between advertising and politics, between cinema and new media, between individual and global goals. There is no target audience - the global audience is the target. There are no specific social benefits to be gained - the survival of the globe is the general gain. There is a call for a global change in behaviour - but these ads contain no specific formulas to obtain the goals. Thus, they may seem quite unique as advertisements, not so much through their strategy as through their general purpose. They rely on their capacity to convince and to reach out to the spectators, encouraging them to explore their own possibilities to share in realizing the Global Goals, and trusting that they will all want to share in realizing a sustainable future for the planet. In emphasizing the uniqueness, both of the global campaign as such and of the Sustainable Development Goals as a very particular moment in world history, they blend global advertising with global politics, letting the films serve as a powerful tool, together with a number of other forms of expressions, all with the aim of actually changing the world. 
However, historicizing the ads offers - just like in the case of Aardman Animations - another possible framework. Yvonne Zimmermann has made an important distinction between on one hand 'advertising film in a narrow sense', 'often called "commercials", "spots" or simply "ads", and on the other 'advertising films in a broad sense, understood as a rhetorical type of moving image that intends to influence opinions, attitudes and behaviour'. ${ }^{49}$ This distinction proves to be quite relevant in this connection, as 'We Have a Plan' is precisely such a rhetorical piece of work. A useful historical point of reference are the documentaries produced at UNESCO, which - with John Grierson as the first director of the Mass Communication division 1947-1948, and with Arthur Elton, Paul Rotha, and Basil Wright continuously engaged with UNESCO until the late 196os - have heavily relied on the British documentary tradition, as Zoë Druick has analysed in her essay 'Visualising the World'. $5^{\circ}$ The framework for this analysis, the history of the General Post Office Film Unit, connects a couple of 'world-themed' films produced for the British Ministry of Information during the war - World of Plenty (1943) and The World Is Rich (1947), both directed by Paul Rotha - as well as a later BBC television series - The World Is Ours (1954) - to World Without End (1953), directed by Rotha together with Basil Wright, indeed an advertising film in the broader sense defined by Zimmermann. The latter, a UNESCO film, which Jack Ellis has called 'the last big brave representation of internationalism from the old Griersonians', ${ }^{1}$ bears many resemblances to the 'We Have a Plan' project. In both films, the opening shows a spinning globe from an outside perspective. World Without End is shot in Mexico and Thailand, linking together people in developing nations across the globe. Both films present the viewer with a number of problems - in World Without End related to health, agriculture, and education - which are 'then solved by UN agencies. [...] The film ends in a crescendo of positive images'. $5^{2}$ Whereas

49 Yvonne Zimmermann, 'Advertising and Film: A Topological Approach', in Films That Sell: Moving Pictures and Advertising, ed. Bo Florin, Nico de Klerk, and Patrick Vonderau (London and New York: Palgrave, 2016), 22.

50 Zoë Druick, 'Visualising the World: The British Documentary at UnEsco', in The Projection of Britain: A History of the GPO Film Unit, ed. Scott Anthony and James G. Mansell (London: British Film Institute, 2011), 272-280. See also Richard MacDonald, 'Evasive Enlightenment: World Without End and the Internationalism of Postwar Documentary', Journal of British Cinema and Television 10, no. 3 (2013): 452-474; and Rob Aitken, 'A "World Without End": Post-War Reconstruction and Everyday Internationalism in Documentary Film', The International History Review 35, no. 4 (2013): 657-680.

$5^{1}$ Jack C. Ellis, John Grierson: Life, Contributions, Influence (Carbondale: Southern Illinois University Press, 200o), cited in Druick, 'Visualising the World', 273.

52 Druick, 'Visualising the World', 277. 
'We Have a Plan' starts with images of the UN headquarters, immediately following the initial image of the globe, the emblematic building also appears in World Without End, although later in the film, as the narrator states that '[n]ow, as the world shrinks, the neighbours are closer together. We all live in the same world'. 'We Have a Plan', just like 'We the People', also includes montage sequences representing people from all across the globe, just like World Without End, which features a montage of children from every part of the world. Even though the Sustainable Development Goals in themselves represent a unique moment in history, the advertising strategy adopted rather tends to rely on already established historical patterns, established by UNESCO among others, and blending documentary and advertisement - and both in that sense belonging to the broader category of advertising films as defined by Zimmermann. ${ }^{53}$ Through varying historical circumstances and changing technologies, the UN discourses and communication strategies surrounding common values across the globe thus seem to have remained quite stable.

\section{Marketing Through Sustainability}

The initial comparison in this essay between the ads for Volvo and H\&M mostly focussed on issues of sustainability, thus creating an unexpected link to the Global Goals Campaign. This also widens the perspective from these commercials in the narrow sense towards advertising film in the broader sense. However, it would be too simplistic to consider the Global Goals Campaign as a more value-centred enterprise, in contrast to overtly commercial ads.

As we have seen, Volvo had to restore its reputation after being forced to withdraw its controversial slogan, and make less speculative commercials while still drawing on sustainability as a core value. H\&M on the other hand, as we have also seen, had to defend itself against repeated accusations on the use of child labour, and turned to social responsibility and sustainability through recycling as means of restoring its tarnished brand. Similarly, the Global Goals Campaign may be seen not only as a way to market the goals as such, but just as much as a means to rebrand and revive the image of the often-contested United Nations through the goals: in other words, a way to show its efficiency, its universal relevance, and its engagement and care

53 See also Yvonne Zimmermanns's chapter 'Advertising and Avant-Gardes' and her discussion on Grierson. 
for global development to the world. ${ }^{4}$ However, one might question the real impact of the campaign.

Even though the Global Goals Campaign by Project Everyone as a whole must be considered successful - 'we reached 3 billion people in 7 days'55 - we do not really know about the impact of 'We Have a Plan'. It was 'premiered across 34 countries', ${ }^{6}$ but how many people actually saw it? If we look at the number of views on YouTube, it cannot be considered very successful as a commercial campaign, with 6000 views on SAWA and 21,000 views on the Aardman Animation home page for 'We Have a Plan' (and slightly more than 6000 views for the follow-up ad with the same title on YouTube, launched by the UNDP).

The contrast to an earlier UN ad, ' 805 Million Names', made for the World Food Programme and addressing the second Sustainable Development Goal, 'No Hunger', is striking. This ad, featuring Zlatan Ibrahimović, was made by Forsman \& Bodenfors, thus linking it both to the Volvo and to the H\&M ads discussed above. As Paris Saint-Germain played against Caen on 14 February 2015, Ibrahimović, after scoring a goal, pulled off his sweater to reveal 50 new names added to his existing tattoos. These 50 names had been chosen to represent the 805 million people suffering from hunger across the globe. The gesture, which earned the player a yellow card, was shown in an ad with Ibrahimović himself talking about his motives, as well as in a longer version documenting the process of making the ad. According to Forsman \& Bodenfors, the ad has reached over 1.2 billion people, with 16.8 million combined views, and has resulted in 4.4 million social interactions as well as approximately 4600 news articles. ${ }^{57}$ The huge success, however, was due less to the United Nations, or even to Forsman \& Bodenfors, than to Zlatan Ibrahimović himself, who contacted the company and wanted them to make this ad. Researcher in business administration Eva Ossiansson has commented on his systematic way of working on his brand, in which both the Volvo ad portraying him as a global Swede (discussed in the chapter on Volvo), and the UN campaign, broadening his brand as a global role model,

54 On Wikipedia, a post entitled 'Criticism of the United Nations' runs to nearly 4000 words, and spans from philosophical, moral, or administrative criticisms to criticisms of scandals. Thus, interpreting the Global Goals Campaign partly as a means to respond to the critics turns out not to be too far-fetched.

55 Project Everyone, home page, https://www.project-everyone.org (last accessed 6 April 2021).

56 Ibid.

57 Forsman \& Bodenfors, '805 Million names', http://www.fb.se/work/world-foodprogramme/805-million-names (last accessed 6 April 2021). 
contribute to creating and developing his own myth..$^{8}$ When commenting on the Volvo ad, he emphasized that he makes his own choices about whom to work with:

Volvo was small before meeting me! First it was 'Made by Sweden', now it is: 'Made by Zlatan'. My God, during the first week after the ad Volvo sold more than they normally do in six months. This is really nothing to brag about, the result speaks for itself. But that is the kind of thing I'm looking for, exciting projects. To work with small companies and make them [...] gigantic. 59

The '805 Million Names', just like the Global Goals Campaign and Project Everyone, aim to spread the word rather than just launch a commercial. Still, they also promote certain brands - that of the United Nations, of Aardman Animations, or of Zlatan Ibrahimović. The varying degree of success reveals a fundamental aspect of the logic of advertising, apart from the benefit of using a skilful advertising company. That is, that however much 'high' values -such as sustainability - are used for promotion, whether it is for commercial or rhetorical purposes primarily, they mean little or nothing in comparison to a 'real' brand, acquired outside of the world of advertising, such as that of Zlatan Ibrahimović. Here, the aims of promoting the brand of Ibrahimović himself and the brand of Volvo, or the brand of the United Nations in eliminating hunger globally, actually converge. A brand, then, is not only an outcome of advertising but also a tool or a means to promote the very product of advertising; thus, the ad in the more narrow sense merges with the broader vision of advertising, aiming to change values: 'opinions, attitudes, and behaviour'. ${ }^{60}$

As the Global Goals Campaign was launched, this was probably the most ambitious effort in the history of advertising film ever to reach out globally in advertising pure values. The idea, to succeed where the first attempts to advertise the millennial goals had failed, was met with high ambitions, not only using all available new media platforms, but also, last but not least, connecting to historical traditions, such as the UNESCO films or the use of

$5^{8}$ Eva Ossiansson quoted in Andreas Rågsjö Thorell, 'Han vet att han formar sin myt efter sitt agerande', Resumé, 17 February 2015, https://www.resume.se/nyheter/artiklar/2015/02/17/ han-vet-att-han-formar-sin-myt-efter-sitt-agerande/ (last accessed 6 April 2021).

59 'Zlatan - legenden', Camilla Tollstoy, Scandinavian Traveler, 31 May 2016, https://scandinaviantraveler.com/se/manniskor/zlatan-legenden (last accessed 6 April 2021).

6o Thanks to Yvonne Zimmermann for useful thoughts in this connection. Zimmermann, 'Advertising and Film', 22. 
Aardman animations, and using cinema as a major platform. Today, the knowledge about the Sustainable Development Goals is widespread across the globe. The question remains, however, to what extent this result can be ascribed to the Global Goals Campaign and Project Everyone.

\section{Bibliography}

Aitken, Rob. 'A "World Without End": Post-War Reconstruction and Everyday Internationalism in Documentary Film.' The International History Review 35, no. 4 (2013): 657-680.

Belz, Frank-Martin, and Ken Peattie. Sustainability Marketing: A Global Perspective, 2nd ed. West Sussex: Wiley, 2012.

Cook, Malcolm. "All You Do Is Call Me, I'll Be Anything You Need": Aardman Animations, Music Videos and Commercials.' In Beyond Stop-Motion Film:Production, Style and Representation in Aardman Animations, edited by Annabelle Honess Roe. London: Bloomsbury, 2020.

Dickason, Renée. British Television Advertising:Cultural Identity and Communication. Luton: University of Luton Press, 2000.

Druick, Zoë. 'Visualising the World: The British Documentary at UnEsco.' In The Projection of Britain: A History of the GPO Film Unit, edited by Scott Anthony and James G. Mansell, 272-28o. London: British Film Institute, 2011.

Ellis, Jack C. John Grierson: Life, Contributions, Influence. Carbondale and Edwardsville: Southern Illinois University Press, 2000.

Florin, Bo, and Astrid Söderbergh Widding. 'Dag Hammarskjöld i FN:s filmarkiv.' Signum 1 (2006): 12-17.

Florin, Bo, Nico de Klerk, and Patrick Vonderau, eds. Films That Sell:Moving Pictures and Advertising. London and New York: Palgrave, 2016.

Kotler, Philip. Marketing Management, 14th ed. Harlow: Pearson, 2012 [1967].

MacDonald, Richard. 'Evasive Enlightenment: World Without End and the Internationalism of Postwar Documentary.'Journal of British Cinema and Television 10, no. 3 (2013): $45^{2-474 .}$

McCarthy, E.J. Basic Marketing:A Managerial Approach. Homewood: Irwin, 1960. 



\section{Select Bibliography}

Abel, Richard. 'From Pathé to Paramount: Visual Design in Movie Advertising to 1915.' In The Image in Early Cinema: Form and Material, edited by Scott Curtis, Philippe Gauthier, Tom Gunning, and Joshua Yumibe, 78-93. Bloomington: Indiana University Press, 2018.

Abel, Richard. The Red Rooster Scare: Making Cinema American, 190o-1910. Berkeley, Los Angeles, and London: University of California Press, 1999.

Acland, Charles R. Swift Viewing: The Popular Life of Subliminal Influence. Durham, NC: Duke University Press, 2011.

Acland, Charles R., and Haidee Wasson, eds. Useful Cinema. Durham, NC and London: Duke University Press, 2013.

Adey, Peter. 'If Mobility Is Everything then It Is Nothing: Towards a Relational Politics of (Im)mobilities.' Mobilities 1, no. 1 (2006): 75-94.

Adorno, Theodor W. The Culture Industry: Selected Essays on Mass Culture. London and New York: Routledge, 1991.

Ahnert, Laurel E. 'The Factual Treatment of Actuality: The Emergence of Educational Film in the 1920 s and its Relation to Documentary Film Proper.' InterDisciplines 1 (2013): 77-101.

Aitken, Ian. Film and Reform:John Grierson and the Documentary Film Movement. London, New York: Routledge, 1990.

Aitken, Rob. 'A “World Without End”: Post-War Reconstruction and Everyday Internationalism in Documentary Film.' The International History Review 35, no. 4 (2013): 657-680.

Allen, Jeanne. 'Self-Reflexivity in Documentary.' Ciné-Tracts 1, no. 2 (1977): 37-43.

Alter, Nora M., and Timothy Corrigan, eds. Essays on the Essay Film. New York: Columbia University Press, 2017.

Altman, Rick. Film/Genre. London: British Film Institute, 2000.

Amberg, Friedrich-Georg. Werbung im Filmtheater. Berlin: Kulturbuch-Verlag, 1956. Amsler, André. Wer dem Werbefilm verfällt, ist verloren für die Welt: Das Werk von Julius Pinschewer 1883-1961. Zurich: Chronos 1997.

Aspers, Patrik. Markets. Cambridge: Polity Press 2013.

Augé, Marc. Non-Places: An Introduction to Supermodernity, translated by John Howe. London: Verso: 2009 [1992].

Aumont, Jacques. L'Image. Paris: Nathan, 1990.

Baran, Paul, and Paul Sweezy. Monopoly Capital. New York: Monthly Review Press, 1966. 
Barry, Iris, and Richard Griffith. 'The Film Library and the Film of Fact.' In The Museum of Modern Art Film Library Films of Fact 1942. Museum of Modern Art, Department of Film Archive, Circulating Film Programs.

Bartholomew, Mark, and John Tehranian. 'The Changing Landscape of Trademark Law in Tinseltown: From Debbie Does Dallas to The Hangover.' In Hollywood and the Law, edited by Paul McDonald et al., 47-68. London: British Film Institute, 2016.

Bartlett, Steven J., and Peter Suber, eds. Self-Reference: Reflections on Reflexivity. Dordrecht: Nijhoff, 1987.

Baudry, Jean-Louis. 'Cinéma: Effets idéologiques de l'appareil de base.' Cinéthique 9/10 (1970): 1-8.

Baudry, Jean-Louis. 'Effects idéologiques produits par l'appareil de base.' In Cinéthique no. 6/7 (1970).

Baudry, Jean-Louis. 'Le dispositive. Approches métapsychologiques de l'impression de réalité.' Communications 23 (1975): 56-72.

Beck, Ulrich. Risk Society: Towards a New Modernity, translated by Mark Ritter. London: Sage, 1992.

Becker, Jörg. 'Die Voltstärke eines Emotionskomplexes. Der Werbekünstler Charles Wilp. 1932-2005.' Recherche Film und Fernsehen 2, no. 3 (2008): 14-19.

Belz, Frank-Martin, and Ken Peattie. Sustainability Marketing: A Global Perspective, 2nd ed. West Sussex: Wiley, 2012.

Beniger, James R. The Control Revolution: Technological and Economic Origins of the Information Society. Cambridge, MA: Harvard University Press, 1986.

Berger, Arthur Asa. Ads, Fads, and Consumer Culture: Advertising's Impact on American Character and Society. Lanham: Rowman \& Littlefield, 2000.

Berger, Arthur Asa. Television as an Instrument of Terror: Essays on Media, Popular Culture, and Everyday Life. New Brunswick and London: Transaction Publishers, 1980.

Bernays, Edward L. Crystallizing Public Opinion. New York: Boni and Liveright, 1923.

Bernays, Edward L. Propaganda. New York: Ig publishing, 2005 [1928].

Birdsall, Carolyn, and Anthony Enns. 'Editorial: Rethinking Theories of Television Sound.' Journal of Sonic Studies 3, no. 1 (October 2012).

Bissell, David. 'Animating Suspension: Waiting for Mobilites.' Mobilities 2, no. 2 (July 2007): 277-298.

Blümlinger, Christa, and Constantin Wulff, eds. Schreiben Bilder Sprechen: Texte zum essayistischen Film. Vienna: Sonderzahl, 1992.

Bochsler, Regula, and Pascal Derungs, eds. Und führe uns in Versuchung: 10oJahre Schweizer Werbefilm. Zurich: Museum für Gestaltung, 1998.

Boorstin, Daniel. The Image: A Guide to Pseudo Events in America. New York: Harper \& Row, 1961.

Brehm, Jack W. A Theory of Psychological Reactance. New York: Academic Press, 1966. 
Broberg, Oskar. 'Globalisering, entreprenörskap och humankapital.' Det svenska näringslivets historia 1864-2014, edited by Mats Larsson. Stockholm: Dialogos Förlag AB: 2014 .

Brody, Steven G., and Bruce E.H. Johnson. Advertising and Commercial Speech, 2nd ed. New York: Practising Law Institute, 2004.

Bronner, Simon J., ed. Accumulation and Display of Goods in America 1880-1920. New York and London: W.W. Norton \& Company, 1989.

Brown, Bill. 'Thing Theory.' In The Object Reader, edited by Fiona Candlin and Raiford Guins, 86-92. London and New York: Routledge, 2009.

Budd, Mike, Steve Craig, and Clay Steinman. 'Fantasy Island: Marketplace of Desire.' In Mass Communication Review Yearbook, vol. 5, edited by Michael Gurevitch and Mark Levy, 291-301. Beverly Hills: Sage, 1985.

Burch, Noel. 'Porter, or Ambivalence.' Screen 19, no. 4 (1978-1979): 91-105.

Bürger, Peter. Theory of the Avant-Garde, translated by Michael Shaw. Minneapolis: University of Minnesota Press, 1984.

Butler, Jeremy G. 'An Introduction to Television Structures and Systems: Ebb and Flow in the Postnetwork Era.' In Television: Critical Methods and Applications, $4^{\text {th }}$ ed. New York and London: Routledge, 2012.

Butsch, Richard. The Citizen Audience: Crowds, Publics, and Individuals. New York: Routledge, 2008.

Cain, Rita Marie. 'Embedded Advertising on Television: Disclosure, Deception, and Free Speech Rights.' Journal of Public Policy \& Marketing 30, no. 2 (Fall 2011): 226-238.

Caldwell, John T. Televisuality: Style, Crisis, and Authority in American Television. New Brunswick: Rutgers University Press, 1995.

Carroll, Michael Thomas. Popular Modernity in America: Experience, Technology, Mythohistory. New York: SUNY Press, 2000.

Casetti, Francesco, and Roger Odin. 'De la paléo- à la néo-télévision.' Communications 51, no. 1 (1990): 9-26.

Casetti, Francesco. Theories of Cinema, 1945-1995. Austin: University of Texas Press 1999 .

Charbonneau, Stephen. 'John Grierson and the United States.' In The Grierson Effect: Tracing Documentary's International Movement, edited by Zoe Druick and Deane Williams, 13-28. London and New York: British Film Institute, 2014.

Charney, Leo, and Vanessa R. Schwartz, eds. Cinema and the Invention of Modern Life. Berkeley: University of California Press, 1995.

Chion, Michel. Audio-Vision: Sound on Screen, edited and translated by Claudia Gorbman. New York: Columbia University Press, 1994.

Cohen-Séat, Gilbert. Essai sur les principes d'une philosophie du cinéma. Paris: Presses Universitaires de France, 1946. 
Colman, Charles E. 'Trademark Law and the Prickly Ambivalence of Post-Parodies.' University of Pennsylvania Law Review Online 11 (2014).

Cook, Guy. The Discourse of Advertising. London and New York: Routledge, 2001.

Cook, James W. The Arts of Deception: Playing with Fraud in the Age of Barnum. Cambridge, MA: Harvard University Press, 2001.

Cook, Malcolm, and Kristin Moana Thompson, eds. Animation and Advertising. New York: Palgrave, 2020.

Cook, Malcolm. “All You Do Is Call Me, I'll Be Anything You Need”: Aardman Animations, Music Videos and Commercials.' In Beyond Stop-Motion Film:Production, Style and Representation in Aardman Animations, edited by Annabelle Honess Roe. London: Bloomsbury, 2020.

Corrigan, Timothy. The Essay Film: From Montaigne, After Marker. New York: Oxford University Press, 2011.

Cosandey, Roland. 'Le Catalogue Lumière 1896-1907 et la Suisse: Elements pour une filmographie nationale.' 1895 , no. 14 (December 1993).

Cosandey, Roland, and Jean-Marie Pastor. 'Lavanchy-Clarke: Sunlight \& Lumière, ou les debuts du cinématographe en Suisse.' Equinox, no. 7 (June 1992): 9-27.

Couldry, Nick, and Joseph Turow. 'Advertising, Big Data, and the Clearance of the Public Realm: Marketers' New Approaches to the Content Subsidy.' International Journal of Communication 8 (2014): 1710-1726.

Cowan, Michael. 'Advertising, Rhythm, and the Filmic Avant-Garde in Weimar: Guido Seeber and Julius Pinschewer's Kipho Film.' October 131 (Winter 2010): 23-50.

Cowan, Michael. Walter Ruttmann and the Cinema of Multiplicity: Avant-Garde, Advertising, Modernity. Amsterdam: Amsterdam University Press, 2014.

Cubitt, Sean. The Cinema Effect. Cambridge, MA and London: MIT Press, 2004.

Culbert, Dennis. 'The Rockefeller Foundation, the Museum of Modern Art Film Library, and Siegfried Kracauer, 1941.' Historical Journal of Film, Radio, and Television 13, no. 4 (1993): 495-511.

Culver, Stuart. 'What Manikins Want: The Wonderful Wizard of Oz and The Art of Decorating Dry Goods Windows.' Representations 21 (Winter 1988): 97-116.

Curti, Merle. "The Changing Concept of "Human Nature" in the Literature of American Advertising.' The Business History Review 41, no. 4 (Winter 1967): 335-357.

de Klerk, Nico. 'The Moment of Screening: What Non-Fiction Films Can Do.' In Triumph der Bilder: Kultur- und Dokumentarfilme vor 1945 im internationalen Vergleich, edited by Peter Zimmermann and Kay Hoffmann, 291-301. Konstanz: UVK, 2003.

Deleuze, Gilles, and Felix Guattari, Anti-Oedipus. London: Continuum, 2004.

Demme, Helmut. Die Rechtsnatur des Werbefernsehens und die Rechtmäßigkeit des von den Werbegesellschaften geübten Verteilungsmaßstabes bei der Vergabe von Sendezeiten zum Zwecke der Werbung. Göttingen: Schwartz \& Co. 1968. 
Dench, Ernest A. Advertising by Motion Pictures. Cincinnati: Standard Publishing Company, 1916.

Dickason, Renée. British Television Advertising: Cultural Identity and Communication. Luton: University of Luton Press, 2000.

Dierks, Melinde. 'Die wirtschaftliche Bedeutung der Werbung in Filmtheatern.' In Die Werbung. Handbuch der Kommunikations- und Werbewirtschaft, vol. 2: Die Werbebotschaften, die Werbemittel und die Werbeträger, edited by Bruno Tietz, 1538-1550. Landsberg: Verlag Moderne Industrie, 1982.

DiMaggio, Paul, and Paul M. Hirsch. 'Production Organization in the Arts.' American Behaviorial Scientist 19, no. 6 (July-August 1976): 735-754.

DiMaggio, Paul, and Walter W. Powell. 'The Iron Cage Revisited.' American Sociological Review 48, no. 2 (April 1983): 147-160.

Doane, Mary Ann. 'Information, Crisis, Catastrophe.' In Logics of Television, edited by Patricia Mellencamp, 222-239. Bloomington: Indiana University Press, 1990.

Doane, Mary Ann. The Emergence of Cinematic Time: Modernity, Contingency, the Archive. Cambridge, MA and London: Harvard University Press, 2002.

Druick, Zoë. 'Visualising the World: The British Documentary at UnEsco.' In The Projection of Britain: A History of the GPO Film Unit, edited by Scott Anthony and James G. Mansell, 272-28o. London: British Film Institute, 2011.

Dunne, Michael. Metapop: Self-referentiality in Contemporary American Popular Culture. Jackson and London: University Press of Mississippi, 2010 [1992].

Dyer, Gillian. Advertising as Communication. London: Methuen, 1982.

Eggers, Katharina, and Robert Fechner, 'The "German Alternative": Nationalism and Racism in Afri-Cola.' In Colonial Advertising \& Commodity Racism, edited by Wulf D. Hund, Michael Pickering, and Anandi Ramamurthy, 197-213. Münster: LIT, 2013.

Ellis, Jack C.John Grierson: Life, Contributions, Influence. Carbondale and Edwardsville: Southern Illinois University Press, 2000.

Ellis, John. 'Broadcast TV as Sound and Image.' In Film Theory and Criticism: Introductory Readings, edited by Gerald Mast, Marshall Cohen, and Leo Braudy, 385-394. New York: Oxford University Press, 1999.

Ellis, John. 'Interstitials: How the "Bits in Between" Define the Programmes.' In Ephemeral Media: Transitory Screen Culture from Television to YouTube, edited by Paul Graine, 59-69. London: Palgrave Macmillan, 2011.

Ellis, John. Visible Fictions: Cinema, Television, Video. London: Routledge, 1992.

Elsaesser, Thomas. Weimar Cinema and After: Germany's Historical Imaginary. New York: Routledge, 2000.

Engelman, Elysa R. 'The Face That Haunts Me Ever': Consumers, Retailers, Critics, and the Branded Personality of Lydia E. Pinkham. Dissertation, Boston University, 2003. 
Esquenazi, Jean-Pierre. 'Éléments de sociologie du film.' Cinémas 17, no. 2/3 (2007): 117-141.

Ewen, Stuart. Captains of Consciousness: Advertising and the Social Roots of Consumer Culture. New York: McGraw-Hill, 1976.

Ewen, Stuart, and Elizabeth Ewen. Channels of Desire: Mass Images and the Shaping of American Consciousness. New York and St. Louis: McGraw-Hill, 1982.

Featherstone, Mike. Consumer Culture and Postmodernism. London: Sage, 1991.

Fechler, Christoph. 'Die Gestaltung und die Produktion der Fernsehwerbung.'

In Die Werbung. Handbuch der Kommunikations- und Werbewirtschaft, vol. 2: Die Werbebotschaften, die Werbemittel und die Werbeträger, ed. Bruno Tietz, 1313-1376. Landsberg: Verlag Moderne Industrie 1982.

Feuer, Jane. 'Narrative Form in American Network Television.' In High Theory / Low Culture, edited by Colin MacCabe, 101-104. Manchester: Manchester University Press, 1986.

Feuer, Jane. The Hollywood Musical. Bloomington and Indianapolis: Indiana University Press, 1993 [1982].

Fischer, Ludwig. 'Vorwort.' In Programm und Programmatik: Kultur-und medienwissenschaftliche Analysen, edited by Ludwig Fischer, 11-15. Konstanz: UVK, 2005.

Fiske, John. Television Culture. London and New York: Routledge, 1987.

Florin, Bo, and Astrid Söderbergh Widding. 'Dag Hammarskjöld i FN:s filmarkiv,' Signum 1 (2006): 12-17.

Florin, Bo, Nico de Klerk, and Patrick Vonderau, eds. Films That Sell: Moving Pictures and Advertising. London and New York: Palgrave, 2016.

Forceville, Charles. Pictorial Metaphor in Advertising. London: Routledge, 1996.

Forster, Ralf. Ufa und Nordmark: Zwei Firmengeschichten und der deutsche Werbefilm 1919-1945. Trier: Wissenschaftlicher Verlag Trier, 2005.

Fossati, Giovanni. From Grain to Pixel: The Archival Life of Film in Transition. Amsterdam: Amsterdam University Press, 2009.

Foster, Stephen C., ed., Hans Richter: Activism, Modernism, and the Avant-Garde. Cambridge, MA and London: MIT Press, 1998.

Foucault, Michel. 'La psychologie de $185^{0}$ à 1950.' In Histoire de la philosophie européenne, vol. 2, edited by D. Huisman and A. Weber, 591-6o6. Paris: Klincksiek, 1957 .

Foucault, Michel. Power/Knowledge: Selected Interviews and Other Writings 1972-1977, edited by Colin Gordon. New York: Pantheon Books, 1980.

Fox, Stephen. The Mirror Makers: A History of American Advertising and Its Creators. New York: Vintage Books, 1985.

Frank, Thomas. The Conquest of Cool: Business Culture, Counter Culture, and the Rise of Hip Consumerism. Chicago: University of Chicago Press, 1997. 
Friedberg, Anne. Window Shopping: Cinema and the Postmodern. Berkeley: University of California Press, 1993.

Friedmann, Georges, and Edgar Morin. 'Sociologie du cinéma.' Revue Internationale de Filmologie 3 (1952): 10-24.

Gaines, Jane. 'From Elephants to Lux Soap: The Programming and "Flow" of Early Motion Picture Exploitation.' The Velvet Light Trap 25 (Spring 1990): 29-43.

Gary, Brett. The Nervous Liberals: Propaganda Anxieties from World War I to the Cold War. New York: Columbia University Press, 1999.

Gaudreault, André. From Plato to Lumière: Narration and Monstration in Literature and Cinema. London and Toronto: University of Toronto Press, 1988.

Giddens, Anthony. Modernity and Self-Identity. Cambridge: Polity, 1991.

Ginzburg, Carlo. 'Clues: Roots of A Scientific Paradigm.' Theory \& Society 7, no. 3 (May 1979): 273-288.

Glocke, Bernd. 'Farbiger, doch nicht besser: 3. Werbefilm-Forum.' Werben \& Verkaufen 7, no. 3 (April 1969).

Goergen, Jeanpaul. 'Drei Männer und die Anfänge des deutschen Werbefilms.' In Werbefilme: Spiegel der Zeiten - Chronik des Alltags, edited by Hans-Gerd Schmidt and Bernd Wiesener, 171-195. Bielefeld: Verlag für Regionalgeschichte, 2002.

Goffman, Erving. Gender Advertisements. London: Macmillan, 1979.

Goldman, Robert, and Stephen Papson. Sign Wars: The Cluttered Landscape of Advertising. New York and London: The Guilford Press, 1996.

Goldman, Robert. Reading Ads Socially. London: Routledge 1992.

Goldschmid, Harry. 'Die internationale Filmwoche in Basel.' Das Werk: Schweizer Monatsschrift für Architektur, Freie Kunst, Angewandte Kunst 26, no. 7 (1939): 12-18.

Grierson, John. Grierson on Documentary, edited by Forsyth Hardy. London and Boston: Faber \& Faber, 1979.

Grierson, John. 'Propaganda: A Problem for Educational Theory and for Cinema.' Sight and Sound 2, no. 8 (Winter 1933-1934): 119-121.

Grierson, John. 'The Documentary Idea: 1942.' In Grierson on Documentary, edited by Forsyth Hardy. London and Boston: Faber \& Faber, 1979 [1946].

Groskopf, Jeremy. Profit Margins: The American Silent Cinema and the Marginalization of Advertising. Dissertation, Georgia State University, 2013.

Groskopf, Jeremy. 'Profit Margins: Silent Era Precursors of Online Advertising Tactics.' Film History 24, no. 1 (2012): 82-96.

Gunning, Tom. 'Before Documentary: Early Nonfiction Films and the "View" Aesthetic.' In Uncharted Territory: Essays on Early Nonfiction Film, edited by Daan Hertogs and Nico de Klerk, 9-24. Amsterdam: Stichting Nederlands Filmmuseum, 1997. 
Gunning, Tom. 'The Cinema of Attractions: Early Film, Its Spectator and the Avant Garde.' In Early Cinema: Space Frame Narrative, edited by Thomas Elsaesser. London: British Film Institute, 1990 [1986].

Gunning, Tom. 'The World as Object Lesson: Cinema Audiences, Visual Culture and the St. Louis World Fair, 1904.' Film History 6 (1994): 422-444.

Hagener, Malte, ed. The Emergence of Film Culture: Knowledge Production, Institution Building, and the Fate of the Avant-Garde in Europe, 1919-1945. Oxford and New York: Berghahn, 2014.

Hagener, Malte. Moving Forward, Looking Back: The European Avant-Garde and the Invention of Film Culture, 1919-1939. Amsterdam: Amsterdam University Press, 2007.

Hagener, Malte, and Yvonne Zimmermann. 'Viking Eggeling and the European Film Avant-Garde.' In The Cultural History of the Avant-Garde in the Nordic Countries 1925-1950, vol. 2, edited by Benedikt Hjartarson, Andrea Kollnitz, Per Stounbjerg, Marianne Ølholm, and Tania Ørum. Amsterdam: Rodopi, 2015. Hake, Sabine. 'Das Kino, die Werbung und die Avantgarde.' In Die Spur durch den Spiegel. Der Film in der Kultur der Moderne, edited by Malte Hagener, Johann Schmidt, and Michael Wedel, 193-206. Berlin: Bertz, 2004.

Haller, Andrea, and Martin Loiperdinger. 'Stimulating the Audience: Early Cinema's Short Film Programme Format 1906 to 1912.' In Early Cinema Today: The Art of Programming and Live Performance, edited by Martin Loiperdinger, 7-21. New Barnet and Herts: John Libbey, 2011.

Hannam, Kevin, Mimi Sheller, and John Urry. 'Editorial: Mobilities, Immobilities and Moorings.' Mobilities 1, no. 1 (March 2006): 1-22.

Hediger, Vinzenz, and Patrick Vonderau, eds. Films that Work: Industrial Film and the Productivity of Media. Amsterdam: Amsterdam University Press, 2009.

Hermerén, Lars. English for Sale: A Study of the Language of Advertising. Lund: Lund University Press, 1999.

Hertogs, Daan, and Nico de Klerk, eds. Disorderly Order: Colours in Silent Film. Amsterdam: Stichting Nederlands Filmmuseum, 1996.

Hertogs, Daan, and Nico de Klerk, eds. Nonfiction from the Teens. Amsterdam: Stichting Nederlands Filmmuseum, 1994.

Hetherington, Kevin. Capitalism's Eye. New York and London: Routledge, 2007.

Hickethier, Knut. 'Aspekte der Programmemtheorie des Fernsehens.' Communications, no. 3 (1991): 329-346.

Hickethier, Knut. Film- und Fernsehanalyse, $3{ }^{\text {rd }}$ revised ed. Stuttgart and Weimar: Metzler, 2001.

Higashi, Sumiko. 'In Focus: Film History, or a Baedeker Guide to the Historical Turn.' Cinema Journal 44, no. 1 (2004): 94-100. 
Hofmeister, Ashley E. 'Louis Vuitton Malletier v Dooney \& Burke: Resisting Expansion of Trademark Protection in the Fashion Industry.' Journal of Business \& Technology Law 3, no. 1 (2008): 187-205.

Holbrook, Morris B. 'Mirror, Mirror, On the Wall: What's Unfair in the Reflections on Advertising?' Journal of Marketing 51, no. 3 (July 1987): 95-103.

Horkheimer, Max, and Theodor W. Adorno. Dialectics of Enlightenment: Philosophical Fragments, edited by Gunzelin Schmid Noerr, translated by Edmund Jephcott. Stanford: Stanford University Press, 2002.

Howe, Stephen. Empire: A Very Short Introduction. New York: Oxford University Press, 2002.

Hoyt, Eric et al. 'Introduction: On the Legal Lives of Hollywood.' In Hollywood and the Law, edited by Paul McDonald et al. London: British Film Institute, 2016.

Huhtamo, Erkki. 'Messages on the Wall: An Archaeology of Public Media Displays.' In Urban Screen Reader, edited by Scott McQuire, Meredith Martin, and Sabine Niederer, 15-28. Amsterdam: Institute of Network Cultures, 2009.

Jacobs, Lea. 'Reformers and Spectators: The Film Education Movement in the 1930s.' Camera Obscura 22 (January 1990): 29-49.

James, David E. The Most Typical Avant-Garde: History and Geography of Minor Cinemas in Los Angeles. Berkeley: University of California Press, 2005.

Jameson, Fredric. 'Future City.' New Left Review 21 (June 2003).

Jowett, Garth S., and Victoria O'Donnell, Propaganda and Persuasion, $2^{\text {nd }}$ ed. Newbury Park, London, and New Dehli: Sage, 1992.

Jowett, Garth S., Ian C. Jarvie, and Kathryn H. Fuller. Children and the Movies: Media Influence and the Payne Fund Controversy. Cambridge: Cambridge University Press, 1996.

Kackman, Michael et al., eds. Flow Tv: Television in the Age of Media Convergence. New York and London: Routledge, 2011.

Kael, Pauline. 'Spoofing and Schtik.' Atlantic Monthly (December 1965): 84-85. Kaplan, E. Ann, ed. Regarding Television: Critical Approaches - An Anthology. Los Angeles: American Film Institute and University Publications of America, 1983 .

Kessler, Frank. 'Notes on Dispositif.' Unpublished working paper, 2002.

Kevles, Barbara L. 'Slavko Vorkapich on Film as a Visual Language and as a Form of Art.' Film Culture (Fall 1965).

Kjellberg, Hans, and C.F. Helgesson. 'On the Nature of Markets and Their Practices.' Marketing Theory 7, no. 2 (2007): 137-162.

Knilli, Friedrich. Der tägliche Sündenfall: Fernsehen und Werbung. Frankfurt: Haus der Evangelischen Publizistik, 1972.

Kotler, Philip. Marketing Management, 14th ed. Harlow: Pearson, 2012 [1967]. 
Kreimeier, Klaus, Antje Ehmann, and Jeanpaul Goergen, eds. Geschichte des dokumentarischen Films in Deutschland, vol. 2: Weimarer Republik 1918-1933. Stuttgart: Reclam, 2005.

Lantos, Geoffrey P. 'Advertising: Looking Glass or Mirror of the Masses?' Journal of Public Policy and Marketing 6 (1987): 104-128.

Lash, Scott, and John Urry. Economies of Signs and Space. London: Sage, 1994.

Latour, Bruno. Reassembling the Social: An Introduction to Actor-Network-Theory. New York: Oxford University Press, 2005.

Latour, Bruno. We Have Never Been Modern, translated by Catherine Porter. Cambridge, MA: Harvard University Press, 1993.

Leach, William. 'Strategists of Display and the Production of Desire.' In Consuming Visions: Accumulation and Display of Goods in America, 1880-1920, edited by Simon J. Bronner. New York: W. W. Norton, 1989.

Lears, Jackson. 'Some Versions of Fantasy: Toward A Cultural History of Advertising 1880-1930.' Prospects 9 (1984): 567-593.

Lears, T.J. Jackson. Fables of Abundance: A Cultural History of Advertising in America. New York: Basic Books, 1994.

Leyda, Jay. Films Beget Films: A Study of the Compilation Film. New York: Hill and Wang, 1964 .

Loiperdinger, Martin. Film \& Schokolade: Stollwercks Geschäfte mit lebenden Bildern. Basel: Stroemfeld, 1999.

Lotz, Amanda D. The Television Will Be Revolutionized. New York: New York University Press, 2007.

Luhmann, Niklas. The Reality of the Mass Media, translated by Kathleen Cross. Stanford: Stanford University Press, 2000.

MacDonald, Richard. 'Evasive Enlightenment: World Without End and the Internationalism of Postwar Documentary.' Journal of British Cinema and Television 10, no. 3 (2013): 452-474.

Marchand, Roland. Advertising the American Dream: Making Way for Modernity 1920-1940. Berkeley, Los Angeles, and London: University of California Press, 1986.

Markus, Laura. Dreams of Modernity: Psychoanalysis, Literature, Cinema. New York: Cambridge University Press, 2014.

Mayer, Vicki. 'Bringing the Social Back In: Studies of Production Cultures and Social Theory.' In Production Studies: Cultural Studies of Media Industries, edited by Vicki Mayer, Miranda J. Banks, and John T. Caldwell, 15-24. New York: Routledge, 2009 .

McCarthy, Anna. Ambient Television: Visual Culture and Public Space. Durham, NC and London: Duke University Press, 2001.

McCarthy, E.J. Basic Marketing: A Managerial Approach. Homewood: Irwin 1960. 
McDonough, John, and Karen Egolf, eds. The Advertising Age Encyclopedia of Advertising, vol. 1. London: Fitzroy Dearborn Publishers, 2003.

McFall, Liz. Advertising: A Cultural Economy. London: Sage, 2004.

McGovern, Charles. Sold American: Consumption and Citizenship, 189o-1945. Chapel Hill: The University of North Carolina, 2006.

McMahan, Harry Wayne. Fernsehwerbung. Gestaltung und Produktion wirksamer Werbesendungen. Düsseldorf: Econ, 1957.

Metz, Christian. L'Enonciation impersonnelle, ou le site du film. Paris: Klinksieck, 1991.

Metz, Christian. 'The Imaginary Signifier.' Screen 16, no. 2 (July 1975): 14-76.

Meyers, Cynthia B. A Word from Our Sponsor: Admen, Advertising, and the Golden Age of Radio. New York: Fordham University Press 2014.

Michel, Alain P. 'On the Cover: An Image mise en abyme.' Technology \& Culture (October 2008): 967-973.

Michel, Alain P. Travail à la chaîne: Renault 1898-1947. Boulogne-Billancourt: Editions ETAI, 2008.

Modleski, Tania, ed. Studies in Entertainment: Critical Approaches to Mass Culture. Bloomington: Indiana University Press, 1986.

Moore, Roy L., Carmen Maye, and Erik L. Collins. Advertising and Public Relations Law, $2^{\text {nd }}$ ed. New York and London: Routledge, 2011.

Moran, Joe. 'November in Berlin: The End of the Everyday.' History Workshop Journal 57, no. 1 (Spring 2004): 216-234.

Morgan, Taz. 5th Amsterdam Workshop: The Images that Changed your Life:Advertising Films. Unpublished manuscript. 2009.

Moskowitz, Marina, and Marlis Schweitzer, eds. Testimonial Advertising in the American Marketplace. New York: Palgrave, 2009.

Müller, Corinna. Frühe deutsche Kinematographie. Formale, wirtschaftliche und kulturelle Entwicklungen 1907-1912. Stuttgart and Weimar: Metzler 1994.

Müller, Eggo. 'Formated spaces of participation: Interactive television and the changing relationship between production and consumption.' In Digital Material: Tracing New Media in Everyday Life and Technology, edited by Marianne van den Boomen et al. Amsterdam: Amsterdam University Press, 2009.

Murdock, Graham, and Peter Golding. 'Culture, Communications and Political Economy.' in Mass Media and Society, $4^{\text {th }}$ ed., edited by James Curran and Michael Gurevitch, 6o-83. London: Arnold 2005.

Myers, Greg. Words in Ads. London: Edward Arnold, 1994.

Neale, Stephen. 'Art Cinema as Institution.' Screen 22, no. 1 (1981): 11-40.

Nee, Victor, and Sonja Opper. 'Economic Institutions from Networks.' In ReImagining Sociology, edited by Patrik Aspers and Nigel Dodd, 148-172. Oxford: Oxford University Press, 2015. 
Newell, Jay, Charles T. Salmon, and Susan Chang. 'The Hidden History of Product Placement.' Journal of Broadcasting \& Electronic Media (December 2006): 575-594.

Nichols, Bill. 'Documentary Film and the Modernist Avant-Garde.' Critical Inquiry 27, no. 4 (Summer 2001): 580-610.

Niss, Hanne. Made in Denmark. Nationalitetens betydning i international marknadsføring. Aalborg: Aalborg Universitetsforlag 1994.

Noble, Safiya Umoja. Alogrithms of Oppression: How Search Engines Reinforce Racism. New York: New York University Press, 2018.

Nöth, Winfried, and Nina Bishara, eds. Self-Reference in the Media. Berlin and New York: De Gruyter, 2008.

Nöth, Winfried, Nina Bishara, and Britta Neitzel. 'Selbstreferenz in der Werbung.' In Mediale Selbstreferenz: Grundlagen und Fallstudien zu Werbung, Computerspiel und den Comics, 57-118. Cologne: Halem, 2008.

O'Brien, Charles. Cinema's Conversion to Sound: Technology and Film Style in France and the U.S. Bloomington: Indiana University Press, 2005.

Odin, Roger. 'Le film de famille dans l'institution familiale.' In Le film de famille, usage privé, usage public, edited by Roger Odin, 27-42. Paris: Méridiens-Klincksieck, 1995.

Odin, Roger. Les Espaces de communication: Introduction à la sémio-pragmatique. Grenoble: Presses universitaires de Grenoble, 2011.

Odin, Roger. 'Pour une sémio-pragmatique du cinéma.' Iris 1 (1983): 1-12.

Orgeron, Devin, Marsha Orgeron, and Dan Streible, eds. Learning with the Lights Off: Educational Cinema in the United States. New York and Oxford: Oxford University Press, 2012.

Osborne, Peter. Anywhere or Not at All: Philosophy of Contemporary Art. London: Verso, 2013.

Oswald, Kathleen, and Jeremy Packer. 'Flow and Mobile Media: Broadcast Fixity to Digital Fluidity.' In Communication Matters: Materialist Approaches to Media, Mobility and Networks, edited by Jeremy Packer and Stephen B. Crofts Wiley, 276-287. London and New York: Routledge, 2012.

Otto, Elizabeth, 'A “Schooling of the Senses": Post-Dada Visual Experiments in the Bauhaus Photomontages of László Moholy-Nagy and Marianne Brandt.' New German Critique 107, vol. 36, no. 2 (Summer 2009): 89-131.

Overpeck, Deron. 'Subversion, Desperation, and Captivity: Pre-film Advertising in American Film Exhibition Since 1977.' Film History 22, no. 2 (2010): 219-234. Packard, Vance. The Hidden Persuaders. London: Longmans and Green, 1957. Pendergrast, Mark. For God, Country, and Coca-Cola. New York: Penguin, 2000. Peterson, Jennifer Lynn. Education in the School of Dreams: Travelogues and Early Nonfiction Film. Durham, NC and London: Duke University Press, 2013. 
Petterson, Bo. HandelsMännen, Så skapade Erling och Stefan Persson sitt modeimperium. Stockholm: Ekerlids Förlag, 2001.

Pfifferling, Jürgen. Wirkungschancen der Werbung in den Massenmedien. Frankfurt: Arbeitsgemeinschaft Rundfunkwerbung, 1975.

Plenge, Johann. Deutsche Propaganda. Die Lehre von der Propaganda als praktische Gesellschaftslehre. Bremen: Angelsachsen-Verlag, 1922.

Polan, Dana. Scenes of Instructions: The Beginnings of the U.S. Study of Film. Berkeley: University of California Press, 2007.

Pollay, Richard W. 'The Distorted Mirror: Reflections on the Unintended Consequences of Advertising.' Journal of Marketing 50, no. 2 (1986): 18-36.

Porter, Elizabeth G. 'Taking Images Seriously.' Columbia Law Review 114.7 (2014): 1687-1782.

Potter, David M. People of Plenty. Chicago: University of Chicago Press 1954.

Prelinger, Rick. 'The Appearance of Archives.' In The YouTube Reader, edited by Pelle Snickars and Patrick Vonderau. Stockholm: National Library of Sweden 2009.

Rancière, Jacques. The Emancipated Spectator, translated by Gregory Elliott. New York: Verso, 2009.

Rancière, Jacques. The Politics of Aesthetics. Translated with an Introduction by Gabriel Rockhill. London: Continuum, 2004.

Reichert, Ramón, ed. Kulturfilm im 'Dritten Reich.' Vienna: Synema, 2006.

Richter, Hans. The Struggle for the Film: Towards a Socially Responsible Cinema, edited by Jürgen Römhild, translated by Ben Brewster. New York: St. Martin's Press, 1986.

Rotha, Paul. 'British Documentary Films Offer American Business Some New Opportunities.' Business Screen 1, no. 1 (1938).

Rotha, Paul. Documentary Diary: An Informal History of the British Documentary Film, 1928-1939. London: Secker \& Warburg, 1973.

Rotha, Paul. Documentary Film: The Use of the Film Medium to Interpret Creatively and in Social Term the Life of People as It Exists in Reality, in collaboration with Sinclair Road and Richard Griffith. London: Faber \& Faber, 1968 [1935].

Ruby, Jay. 'The Image Mirrored: Reflexivity and the Documentary Film.' In New Challenges for Documentary, edited by Alan Rosenthal, 64-77. Berkeley: University of California Press, 1988.

Sahli, Jan. Filmische Sinneserweiterung: László Moholy-Nagys Filmwerk und Theorie. Marburg: Schüren, 2006.

Salmon, Stéphanie. Pathé: A la conquête du cinéma 1896-1929. Paris: Edition Tallandier, 2014.

Sawatzki, Günther. Die verwirtschaftete Freiheit: Ein Beitrag zum Verhältnis zwischen Presse und Fernsehen. Frankfurt: Knecht, 1964.

Schefer, Jean-Louis. Images mobiles. Paris: P.O.L., 1999. 
Schierl, Thomas. Werbung im Fernsehen. Eine medienökonomische Untersuchung zur Effektivität und Effizienz werblicher TV-Kommunikation. Cologne: Halem-Verlag, 2003.

Schmidt, Hans-Gerd. 'Wie Zeitgeist in die Werbung kommt. Aspekte einer produktionsästhetischen Analyse von Sinalco-Werbefilmen.' In Werbefilme: Spiegel der Zeiten - Chronik des Alltags, edited by Hans-Gerd Schmidt and Bernd Wiesener, 67-88. Bielefeld: Verlag für Regionalgeschichte, 2002.

Schmidt, Siegfried S., and Brigitte Spieß. Die Kommerzialisierung der Kommunikation. Fernsehwerbung und sozialer Wandel 1956-1989. Frankfurt: Suhrkamp, 1996.

Schneider, Hans. Werbung im Rundfunk. Frankfurt: Metzner Verlag, 1965.

Schudson, Michael. Advertising, the Uneasy Persuasion: Its Dubious Impact on American Society. New York: Basic Books, 1984.

Schwartz, Barry. Queuing and Waiting: Studies in the Organization of Access and Delay. Chicago: University of Chicago Press, 1975.

Schwarzkopf, Stefan. 'Discovering the Consumer: Market Research, Product Innovation, and the Creation of Brand Loyalty in Britain and the United States in the Interwar Years.' Journal of Macromarketing 29, no. 1 (2009): 8-20.

Schweitzer, Marlis, and Marina Moskowitz, eds. Testimonial Advertising in the American Marketplace: Emulation, Identity, Community. London: Palgrave, 2009. Schweizer, Harold. 'On Waiting.' In University of Toronto Quarterly, no. 3 (2005): 777-792. Sconce, Jeffrey. 'On the Origins of the Origins of the Influencing Machine.' In Media Archaeology: Approaches, Applications, and Implications, edited by Erkki Huhtamo and Jussi Parikka, 70-94. Berkeley and Los Angeles: University of California Press, 2011.

Searle, John. 'What Is An Institution?' Journal of Institutional Economics 1, no. 1 (2005): 1-22.

Segrave, Kerry. Endorsements in Advertising. Jefferson: McFarland, 2005.

Seubert, Wolfgang. Struktur und Entwicklung des Rundfunk-Werbemarktes. Band 11. Düsseldorf: Landesregierung NRW, 1988.

Sheller, Mimi, and John Urry, eds. Mobile Technologies of the City. London and New York: Routledge, 2006.

Sheller, Mimi, and John Urry. 'The New Mobilities Paradigm.' Environment and Planning A 38 (2006): 207-226.

Siegel, Paul, ed., Cases in Communication Law, $4^{\text {th }}$ ed. Lanham, Boulder, and New York: Rowman \& Littlefield, 2014.

Sivulka, Juliann. 'History: 1900-1920.' In The Advertising Age Encyclopedia of Advertising, vol. 2, edited by John McDonough and Karen Egolf. London: Fitzroy Dearborn Publishers, 2003.

Sjöholm, Carina. Gå på bio. Rum för drömmar i folkhemmets Sverige. Stockholm and Stehag: Brutus Östlings Bokförlag Symposion, 2003. 
Slater, Don. 'Marketing as Monstrosity: The Impossible Place between Culture and Economy.' In Inside Marketing: Practices, Ideologies, Devices, edited by Detlev Zwick and Julien Cayla, 23-41. Oxford: Oxford University Press, 2010.

Sorlin, Pierre. 'Promenade dans Rome.' Iris 2, no. 2 (1984): 5-16.

Sorlin, Pierre. Sociologie du cinéma. Paris: Aubier Montaigne, 1977.

Spigel, Lynn. TV By Design: Modern Art and the Rise of Network Television. Chicago: Chicago University Press, 2008.

Sproule, J. Michael. Propaganda and Democracy: The American Experience of Media and Mass Persuasion. Cambridge: Cambridge University Press, 1997.

Stäheli, Urs, and Dirk Verdicchio. 'Das Unsichtbare sichtbar machen: Hans Richters Die Börse als Barometer der Wirtschaftslage.' Montage AV15, no. 1 (2006): 108-122.

Staiger, Janet. 'The Hollywood Mode of Production to 1930.' In The Classical Hollywood Cinema: Film Style \& Mode of Production to 196o, edited by David Bordwell, Janet Staiger, and Kristin Thompson, 88-244. New York: Routledge 1985.

Stam, Robert. Reflexivity in Film and Literature. From Don Quixote to Jean-Luc Godard. New York: Columbia University Press, 1992 [1985].

Stauff, Markus. 'Zur Sichtbarkeit von Gesellschaft. Institution in den Filmen von Frederick Wiseman und in Us-amerikanischen Fernsehserien.' In Frederick Wiseman: Kino des Sozialen, edited by Eva Hohenberger, 85-104. Berlin: Vorwerk 8,2009 .

Steinmann, Matthias. Das Werbefernsehen im Konkurrenzkampf der Werbemittel und Werbeträger. Zurich: Polygraphischer Verlag 1967.

Stockmann, Frank-Jürgen. 'Die klassischen Medien im Überblick.' in Die Werbung. Handbuch der Kommunikations- und Werbewirtschaft, vol. 2: Die Werbebotschaften, die Werbemittel und die Werbeträger, edited by Bruno Tietz, 1786-1814. Landsberg: Verlag Moderne Industrie, 1982.

Stollery, Martin. Alternative Empires: European Modernist Cinemas and Cultures of Imperialism. Exeter: University of Exeter Press, 2000.

Strasser, Susan. Satisfaction Guaranteed: The Making of the American Mass Market. New York: Pantheon, 1989.

Swerdloff, Arthur LeRoy. A Comparative Analysis of the Filmic Theories of Slavko Vorkapich. Dissertation, June 1950, University of Southern California. Unpublished manuscript.

Swett, Pamela E., Jonathan Wiesen, and Jonathan R. Zaitlin. Selling Modernity: Advertising in Twentieth-Century Germany. Durham, NC: Duke University Press, 2007.

Taylor, Timothy D. The Sounds of Capitalism: Advertising, Music, and the Conquest of Culture. Chicago: Chicago University Press, 2012.

Thorburn, David, and Henry Jenkins, eds. Rethinking Media Change: The Aesthetics of Transition. Cambridge, MA: MIT Press, 2003. 
Tode, Thomas. 'Ein Bild ist ein Argument: Hans Richter und die Anfänge des Filmessays.' Navigationen 2, no. 2 (February 2002): 99-108.

Turner, Fred. From Counterculture to Cyberculture: Stewart Brand, the Whole Earth Network, and the Rise of Digital Utopianism. Chicago and London: University of Chicago Press, 2005.

Turner, Fred. The Democratic Surround: Multimedia \& American Liberalism from World War II to the Psychedelic Sixties. Chicago and London: University of Chicago Press, 2013.

Turnock, Julie A. Plastic Reality: Special Effects, Technology, and the Emergence of $1970 s$ Blockbuster Aesthetics. New York: Columbia University Press, 2015.

Turow, See Joseph. The Daily You: How the Advertising Industry Is Defining Your Identity and Your Worth. New Haven: Yale University Press, 2012.

Turvey, Malcolm. 'Dada Between Heaven and Hell: Abstraction and Universal Language in the Rhythm Films of Hans Richter.' October 105 (Summer 2003): $13-36$.

Turvey, Malcolm. Doubting Vision: Film and the Revelationist Tradition. Oxford and New York: Oxford University Press, 2008.

Tuten, Tracy L. Advertising 2.o: Social Media Marketing in a Web 2.o World. Westport: Praeger, 2008.

Urry, John. Sociology Beyond Societies: Mobilities for the Twenty-First Century. London: Routledge, 2000.

Vasata, Vilim. 'Die Gestaltung von Anzeigen in Publikumszeitschriften.' In Die Werbung. Handbuch der Kommunikations- und Werbewirtschaft, vol. 2: Die Werbebotschaften, die Werbemittel und die Werbeträger, edited by Bruno Tietz, 1184-1201. Landsberg: Verlag Moderne Industrie, 1982.

Verband, Schweizerischer Reklame, ed. Die Grundlagen der Filmwerbung: Eine Wegleitung für Auftraggeber. Zurich, [1949].

Verhoeff, Nana. Mobile Screens: The Visual Regime of Navigation. Amsterdam: Amsterdam University Press, 2012.

von Keitz, Ursula. 'Adaption und Funktionalisierung von Spielfilmcodes im neueren Werbefilm.' Spiel 11, no. 1 (1992): 165-189.

Vonderau, Patrick. 'On Advertising's Relation to Moving Pictures.' In Films that Sell: Moving Pictures and Advertising, edited by Bo Florin, Nico de Klerk, and Patrick Vonderau, 1-18. London: British Film Institute, 2016.

Vonderau, Patrick. 'Kim Novak and Morgan Stairways: Thinking about the Theory and History of the Tie-in.' In Films That Sell: Moving Pictures and Advertising, edited by Bo Florin, Nico de Klerk, and Patrick Vonderau, 209-220. London and New York: Palgrave, 2016.

Vonderau, Patrick. 'Hollywood Montage: Theorie, Geschichte und Ästhetik des "Vorkapich-Effekts".' Montage AV 25, no. 2 (2016): 201-224. 
Vorkapich, Slavko. 'Towards True Cinema.' American Cinematographer 54, no. 7 (July 1973): 884-886, 930-933.

Ward, Janet. Weimar Surfaces: Urban Visual Culture in 1920s Germany. Berkeley: University of California Press, 2001.

Wasson, Haidee, and Lee Grieveson, eds. Inventing Film Studies: A Genealogy of Studying Cinema. Durham, NC: Duke University Press, 2008.

Wees, William C. 'The Changing of the Gardes.' Public no. 25 (2002): 18.

Werner, Jeff. Medelvägens estetik, Sverigebilder i USA, Del 2. Hedemora: Gidlunds förlag 2008.

Werner, Michael, and Bénédicte Zimmermann. 'Beyond Comparison: Histoire Croisée and the Challenge of Reflexivity.' History and Theory 45, 1 (2006): 30-50.

Werner, Michael, and Bénédicte Zimmermann. De la comparaison à l'histoire croisée. Paris: Seuil, 2004.

Werner, Michael, and Bénédicte Zimmermann. 'Vergleich, Transfer, Verflechtung: Der Ansatz der Histoire croisée und die Herausforderung des Transnationalen.' Geschichte und Gesellschaft 28 (2002): 607-636.

Williams, Raymond. 'Advertising: The Magic System.' In Problems in Materialism and Culture. London: Verso, 1980.

Williams, Raymond. Keywords. London: Fontana, 1983.

Williams, Raymond. Television: Technology and Cultural Form. London and New York: Routledge, 2003 [1974].

Williamson, Judith. Decoding Advertisements: Ideology and Meaning in Advertising. London: Marion Boyars, 1978.

Winston, Brian. Claiming the Real: The Grierson Documentary and Its Legitimations. London: British Film Institute, 1995.

Withalm, Gloria. 'Commercial Intertextuality.' In Logica, dialogica, ideologica. I segni tra funzionalità ed eccedenza, edited by Patrizia Calefato, 425-435. Milan: Mimesis, 2003.

Withalm, Gloria. 'Commercial-ization of Filmic Self-referentiality.' Semiotica 148, no. $1 / 4$ (2004): $337-360$.

Withalm, Gloria. 'Recycling Dorothy, Dinosaurs, and Dead Actors: Digi-Textuality in the TV-Commercials of the 1990s.' Semiotische Berichte 27, no 1 (2003): 297-315.

Witte, Karsten, ed. Theorie des Kinos. Frankfurt: Suhrkamp, 1972.

Zimmermann, Peter, and Kay Hofmann, eds. Geschichte des dokumentarischen Films in Deutschland, vol. 3: 'Drittes Reich' 1933-1945. Stuttgart: Reclam, 2005.

Zimmermann, Yvonne, ed. Schaufenster Schweiz: Dokumentarische Gebrauchsfilme 1896-1964. Zurich: Limmat, 2011.

Zimmermann, Yvonne. 'Advertising and Film: A Topological Approach.' In Films That Sell: Moving Pictures and Advertising, edited by Bo Florin, Nico de Klerk, and Patrick Vonderau, 21-39. London and New York: Palgrave, 2016. 
Zimmermann, Yvonne. 'Hans Richter and the Filmessay: A Media Archaeological Case Study of Documentary Film History and Historiography.' In A Companion to Documentary Film History, edited by Joshua Malitzky. Bloomington: Indiana University Press, forthcoming.

Zurstiege, Guido. Zwischen Kritik und Faszination: Was wir beobachten, wenn wir die Werbung beobachten, wie sie die Gesellschaft beobachtet. Cologne: Halem, 2005. 


\section{Index}

Aardman Animations $16,300,303-305,309$, $312-313$

Abel, Richard $30 n 23,34-35,45,315$

Acland, Charles R. $12 \mathrm{n} 12,17-18,52 \mathrm{n} 6,73$, 81n10, 84n19, 10on 79, 107, 110, 114, 149, 239-240, 315

address, mode / style of $10,16,24,28,39$, $41-42,44,79,126,142,176,209-210,215^{-216}$, 221n27, 223-224, 228, 231-234, 236, 238-240, 297-300, 306

Adidas 203

Admiral Cigarette 30

Äffle und Pferdle 177,178

Afri-Cola 118, 121, 133-135, 137-139, 142, $15^{1-15^{2}}, 301,319$

agencies $59,61-62,64,72,126,136-140,148$, $225,228,247-248,251,256-257,259,261$, $273,282-283$

aggregate reels $65,115,118,122-123$

Ahnert, Laurel E. 81

Air Jordan 224

Aitken, Ian 90

Albera, François $\quad 158$

Alles dreht sich, alles bewegt sich / Everything Turns, Everything Revolves $\quad 83,96$

Allianz $\quad 226$

Altman, Rick $170 n 48,171,179,190,202,212,315$

Andersson, Jörgen 273-274

archival policies $13,15,51,55,113,117,122-123$, $149,165,247,276$

Aristoc 227, 238

Arnold Agency $\quad 259,261$

Aspirin 238

Astruc, Alexandre 95

Association of Documentary Film Producers 101

A-Team, The 169

audience address see address, mode / style of

Augé, Marc 185

Aumont, Jacques 156

Austria 135, 160, 182-183, 189, 192

Automobile de France, $L^{\prime} \quad 36$

avant-garde / avantgarde $15,39,56-58,71$, $77-83,86-89,91,97-98,100,104-106,129$, $232-233$

Batten, Barton, Durstine \& Osborn (BBDO) 17 $59,60-65,70,73,136,138-139,262,264$

Bailey, David 134

Börse als Barometer der Wirtschaftslage, Die $\quad 96-98$

Bartholomew, Mark 198, 199n10, 200, 212, 316

Bartlett, Steven J. $\quad 215$

Baudry, Jean-Louis $\quad 156-157,161-163,271$

Bauhaus $78,89,106$
Bayer, Herbert $\quad 78$

Barry, Iris 99

Belgium 160, 254

Belz, Frank-Martin 294

Berlin 15, 117

Berlin-Die Sinfonie der Großstadt 57

Bernese Alps Milk Company / Berner

Alpenmilchgesellschaft BAMG 22,33 , 36,39

Bernese Oberland 21, 43-44

Bernays, Edward L. $\quad 79,84-85,232$

Bero Center 121, 131, 135n86, 142

Beuys, Joseph 121

Bildarchiv Preussischer Kulturbesitz

(BPK) 117, 122

billboards $10,53,141-142,181-182,265,272$

Biograph 34

Bissell, David $\quad$ 186-187

Bloch, Ernst $\quad 148$

Bluna $118,121,138-139,142$

Boddy, William 165

Bosco Bitter Tonic 118, 142-143

boundary work 10

brands, branding $\quad 22,29,33-37,55$, $60-61,71,99,118,123,127-128,133-135,138$,

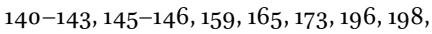
200, 202-206, 208, 210-212, 217, 225, 228, $232-234,236,256,262,264,270,272,275$, 282-283, 286, 291, 293, 295, 304, 310-212, $319,326,328,330$

branded education $\quad 22$

branded entertainment $\quad 22,28$

brand placement see product placement

Brecht, Bertolt $\quad$ 93-94, 219, 221n27, 233

Brehm, Jack W. 221

Britain $85,101,138$

Broberg, Oskar $\quad 256$

Brunius, Jacques 96

Budd, Mike 168

bumper, cartoon $\quad$ 172-173, 177-179

Bürger, Peter 86,88

Business Screen 99

Butler, Jeremy G. 168, 171

Butter-Nut Coffee, Instant 239

Caldwell, John $\quad 180$

Carl Ally Inc. 257, 259

Cast Away 141

Cavalcanti, Basil 96

Chang, Susan 22, 32-33

Charbonneau, Stephen 90,100

Charlie and the Chocolate Factory 140

Chion, Michel 179

Chocoletti 173

Christo 121 
Chronochrome 34

Central Film 159

cinema of attractions $\quad 28,38-39,236$

cinéma vérité 61

cinematic devices $247,249,269,271$

Clark, Helen $\quad 296,302-303$

classified ads 11

Coca-Cola $\quad 53,55,59-61,63,135,231,239$

'cola wars' $51,55 \mathrm{n} 15,59,230$

colonialism 14, 26, 37, 42-43

colour 14, 21-22, 24, 34-35, 38-43, 64-65, 121, $131,135,147-148$

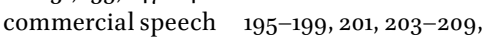
211-213

Commission on Human Relations 104

constructivism $80,89,91$

Cook, Malcolm $8 \mathrm{n}_{5}, 17-18,304,313,318$

Coop 173

Cosandey, Roland 31

Cowan, Michael 56, 8on6, 246

Craig, Steve 168

creative revolution $51,64,136,138,142 \mathrm{n} 111$, $166,176,256$

Creature Comforts $\quad 303-304$

critical theory 93,227

Curtis, Richard $\quad 295^{-296}, 299,307-308$

Dada $83,91-92,97$

Défilé du 8e Bataillon $\quad 31-3^{2}$

de Certeau, Michel $\quad 15^{8}$

de Klerk, Nico $\quad 165$

Deleuze, Gilles $\quad 158$

Della Femina, Jerry $\quad$ 137, 228n 45

Demenÿ, Georges 30

democracy $16,77-80,82-83,85-86,88-90$, 93-95, 98-106

Dench, Ernest E. $\quad 25$

Dewar's Scotch Whisky 30

Dewey, John 90

DHL 231-232

Dickason, Renée 304

Die Werbe (agency) 137

Diophy 201-204

display ads 11

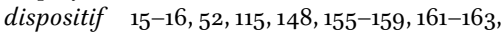
$167,170,180,185^{-189}$

division of labour $10,12,64,128,132$

Doane, Mary Ann $\quad 57,167$

documentary $15,39,64,77-106,133,219$, 309-310

Donovan, Terence 134

Doyle Dane Bernbach (ddb) 136, 256-258, 264

Druick, Zoë 9on39, 309

Dunne, Michael $217,228,237-238$

Düsseldorf $120,135^{-136}$

early cinema $14,16,21-45,163-164,215$, $236-237,246,264-265$

Eclipse $\quad 159$
Edison Manufacturing Company $\quad 30-32$ education $14,16,21-22,24,27,37-38,77-106$, $124,160,232,238,307,309$

educational cinema $13,37,77,79,81-82,86$, 99-100, 103-104, 114

educational film see educational cinema

Education for Democracy 103

Eggeling, Viking 83

Eisenstein, Sergej $\quad 72,89$

Elbaz, Alber $\quad 277,279^{-280}, 285^{-286}$

Ellis, John $\quad 39-40,168,179$

Ellis, Jack C. 90, 309

Ellwood, C.A. $\quad 90$

Empire Marketing Board 96

Energizer Bunny 230-231

endorsements $30,201-203,205^{-206,208-209,}$ $298 \mathrm{n} 25$

England 30,160

Enlightenment $\quad 92-94,106,233$

Epstein, Jean 95

essay film see film essay

E*Trade Monkey 230

Europe / European $13,30,56,78-79,82,87$, $91,93,100,103,106,115,129,156,159,160 n 11$, $171-172,196,211,260$

Euro RSCG $\quad 259-263,265^{-266}$

EYE Film Instituut Nederland see Netherlands Film Museum

Facebook 201, 270, 274-275, 280-281

Falkman, Carl Johan 'Loa' 225

Fanta 203

Federal Trade Commission (FTC) 205-206, 208-210

Ferno, John 103

Feuer, Jane $\quad 169,221,237$

Figgis, Mike $\quad 271,282-283,285$

Film d'Arte Italiana $\quad 41$

film essay / essay film 94-99, 103, 105-106

Filmmuseum Berlin-Deutsche Kinemathek $15,113,117,122,149 n 125$

Fiske, John 168-169

Flaherty, Robert J. $\quad$ 103, 104

Flitterman, Sandy 169

Florin, Bo 14, 16, 226

flow $16,27,71,73,155,157^{-15} 8,161,165^{-168}$, $170-173,179,181,184-186,189,210$

Ford Motor Company $\quad$ 254-255

Forman, George 224

Forrest Gump 140

Forsman \& Bodenfors $248,251,253,256$, 260-264, 292-293, 311

Foucault, Michel $\quad 157-158$

France $31,36,160$

Frank, Thomas $\quad 59,136-137$

Frankfurt School 93

Freud, Sigmund 91

'friendvertising' $16,265,269,275^{-27} 6,281$, 290 
Gaines, Jane 27

Galifianakis, Zach $\quad$ 195, 208

Garry, Brett $\quad 84,99$

Gaumont 159

Gaumontcolor see Chronochrome

General Post Office 96, 309

genre $9,14,21,24-25,37 \mathrm{n}_{42}, 38,41,79,8 \mathrm{on}_{7}$, $134,227,235$

Germany $15,30-31,101,113,121 n 22,129-130$, $135^{-137,156,159-160,171-172,177,180,182-183}$

Godard, Jean-Luc $\quad 53,120,233,239$

Goldman, Robert $\quad 217,232,234,237$

GoodHousekeeping 206

Grashoff, Michael 137

Grey London 260, 262

Grierson, John $\quad 15,77,81-83,86,88-96$, 98-100, 103, 106, 309

Gropius, Walter 78

Groschke, Annette $\quad 17,117-118$

Groskopf, Jeremy W. 17, 211

Guggenheim Museum 100

Guattari, Félix $\quad 15^{8}$

Guinness Book of Records, The 224

Gunning, Tom $\quad 25^{-26,28,39,236}$

Haller, Andrea $\quad 164$

Hammid aka Hackenschmied, Alexander 87 , 103,106

Hangover II, The $15,195,197,198,200-203,208$, 210, 212

Hannam, Kevin 186

hard sell $63,167,176,247,249,256,260$, 263-264

Hard Rock Café 203

Harper's Weekly, 206

Heath, Shona $\quad 282,284$

Hegarty, Sir John $\quad 300-302$

Heineken 226-227

Hemsing, Albert 103

Hennes \& Mauritz see H\&M

H\&M $\quad 16,269-283,285^{-289}, 291,293-294$, $310-311$

Herstellung von holländischem Käse / Comment se fait le fromage de Hollande 34-35

Hertogs, Daan 39-40, 42

Holbrook, Morris B. $\quad 115,126$

Hollywood $61,64-65,70-71,73,90,100,104$, 124-126, 221n27, 227, 230, 237

Hopkins, Claude 247

Huhtamo, Erkki 181

Hurwitz, Leo 103

Ibrahimović, Zlatan $\quad$ 249, 251-252, 263, $311-312$

ICA 224-225

IHOP 203-204

Ikea 225,256

Ike Behar 203

industrial film $\quad 25,57,81,114$ infomercials 22

Infoscreen $180-187,189$

Institute for Propaganda Analysis, The 101 Institute of Film Techniques at City College New York, The 102-104

institution $7,9-12,14-15,24,27-28,37,58$, 79-82, 85-86, 95-97, 101, 104-105, 108, $113-117,123-129,131-133,138-140,146$, $148-149,158,179,181,198,210-211$

interruption $162,167,169-170,179,185,188,219$

interstitial $27,39-40,166$

irony $146,167,233,257,286$

Isenbeck $118,121,134,136-139,142$

Isuzu, Joe 228, 229

Italy 101,160

It's Up to You 103

Ivens, Joris $87,103,104,106$

Jacoby, Irving 102-103

Jackson, Bo 223-224

James Bond $61,134,141,230$

JCDecaux 183, 272

Jenkins, Henry 237-238

jingle $61,64,224$

Jolie, Angelina 208-209

Jordan, Michael 224

Jowett, Garth S. 80

Jubilor 173

J. Walter Thompson $\quad 53,136,209$

Kael, Pauline $\quad 220-221$

Karl Lagerfeld $\quad$ 269, 273-274

Keliher, Alice M. 103

Kennedy, John E. 247

Kenyon \& Eckhardt $\quad 59,61$

Kessler, Frank $\quad 25,34,158$

Kinemacolor 34

kinetoscope $\quad 30-31$

King $\quad 225$

King Kong $\quad 230,231$

Klein, Yves 121

Kleine Optical 34

Kotler, Philip $\quad$ 294-295, 307

Kracauer, Siegfried 100

Kridel, Craig 103

Kulturfilm 160, 163

Ladies Home Journal, 206

Lanham Act 199-200

lantern slides 11,25

Lanvin $\quad$ 16, 269-271, 274-282, 285-286, 288

Lasker, Albert $\quad 247$

Lasswell, Harold D. $\quad$ 90,101

Latour, Bruno 53

Lauterborn, Robert F. 294

Lavanchy, Emile 235

Lavanchy, Jack W. 31

Lavanchy-Clarke, François-Henri $30-33$, $235^{-236}$ 
Laveuses / Washing Day in Switzerland 31, $235^{-236}$

Lears, T. Jackson $\quad 55^{-56}$

Leary, Denis 224

Le Bon, Gustave 91

Lee, Spike 224

Legg, Stuart 103

Lerner, Irving 103

Lever Brothers 30, 235

Leyda, Jay 97

Lindt 173

Lippmann, Walter $79,90,92,106$

Loiperdinger, Martin 26, 31, 164

Lois, George $\quad 136-137$

London 104, 120-121, 134, 260, 262, 272

Lorentz, Pare 103

Louis Vuitton Malletier (LVM) 195-196, 199-205, 210, 212

Luhmann, Niklas $\quad 222,229$

Lumière brothers 30

Lumière, Catalogue 31, 235

Lumière, Cinématographe $\quad 30-31,33,235$

Lumière, vue 31-32, 235

MacManus, Theodore $\quad 247,248 \mathrm{n} 8$

Maggi 173

Mandela, Nelson 301

Man with a Movie Camera 221

Mainzelmännchen 177,178

Martini \& Rossi $\quad 118,121,138$

Masson, Eef 25

McCarthy, Anna $\quad$ 184-185

McCarthy, E.J. 294

mediatisation 298

Méliès, Georges $\quad 34,265$

meta dimension $\quad 265^{-266,287}$

Metz, Christian 124, 148, 223

Meyers, Cynthia B. $\quad 8 n_{5}, 116,131 n 66,166,247$, $248 \mathrm{n} 8,256 \mathrm{n} 30$

Milcherzeugung in der Schweiz / Préparation et exportation du lait par la Sté Laitière des Alpes Bernoises (Milk Production in Switzerland) $22,23,24,26-29,33-34$, $36-44$

mobility $16,179-180,186-189,245^{-247}$, $249-250,255,258,264-265$

mobilities $155,158,180-181,185^{-186,188-189}$, 255

modernism 15, 51, 55-56, 91, 220, 237

modernity $7,9,15,51-58,65,72,91-92,246$

Moholy-Nagy, László $\quad 78,89,106$

montage $15,51,55,57-58,64-65,70-73,81$, $131,141,168,208,265,310$

Morris, Peter 90

Mosesson, Hans 225

MSNBC 203

Müller, Eggo $\quad 276,282$

Munich 182,183

Museum for Non-Objective Painting see Guggenheim Museum
Museum of Modern Art's Film Library 99

Museum of Modern Art's Circulating Film Programs 100

Musser, Charles $\quad 26,29-30,32$

Netherlands $\quad 160$

Netherlands Film Museum 40

Newell, Jay $\quad 22,32-33$

New York $64,85,90-91,99,100-104,121,136$, $235,272,280,301$

New York Knicks 224

Nichols, Bill $\quad 81-82$

Nietzsche, Friedrich $\quad 92$

Nike 223-224

Niss, Hanne $\quad 251$

Nöth, Winfried $\quad 217-218$

non-theatrical $12,58,86,92,97-98,103,105$, $114,140,155$

Nord, Jan $\quad 273^{-274}$

Norway 225

object lesson $\quad 12,25,28$

Odin, Roger 233

O'Donnell, Victoria 80

Office of War Information $\quad 103$

Oliver, Jamie 225

Oliver Peoples 203

Opel Kadett 173

Osborne, Peter 53

Oswald, Kathleen 181

outdoor advertising see out-of-home advertising

Outdoor Advertising Association of America 182

out-of-home advertising $\quad 11,16,27,134,141$ n110, $155^{-156,180-189}$

Ovomaltine / Ovaltine 173,176

Packard, Vance 239

Packer, Jeremy 181

Papson, Stephen: 217, 232, 234, 237

parasite, advertising as $9,13-14,149$

'para-sited cinema', advertising as $\quad 27,149$

parody 177, 202, 219, 226-227, 233

Parvis de Notre-Dame 32

Pastor, Jean-Marie 31

Pathécolor 34,42

Pathé Frères $\quad 22,23,25,33-36,38-39,41-42$, 43,159

Pathé-Natan 36

Payne Fund Studies, The 100

Peattie, Ken 294

Pepsi $15,51,55^{-56}, 5^{8-65}, 71,73,173,176-177$, 231

persuasion $7,14-15,54,77,79-80,85-86,88$, $9^{2}-93,95,98-99,105^{-106}, 116,121,149,228$

persuasive communication / rhetoric see persuasion

Peterson, Jennifer Lynn $\quad$ 26-27

P.F. Chang's 203 
phonograph $\quad 31,36$

Phonoscope, Société générale du 30

Pinschewer, Julius $\quad 8$ on6, 123n28, 159, 238, 246

Plenge, Johann 81

postmodern / postmodernity 219,234 , 237-238

Praesens Film 159

pragmatics $34,125,155$

Prelinger, Rick $\quad 276,281,288,290$

process film 14, 21-44, 159

product placement $12,22,24,27-30,32-33$, $36-37,47,129,133,140,160,163,166,181$,

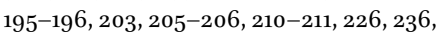
$257-25^{8}, 264$

Production Studies 113, 116

programme $10,24,26-27,37,39-40,57,71,73$, $86,100,102,129,155,157,159-173,176-179$, $181,183-185,188-189,210,2305^{\circ}, 279-281$, 294-295, 307

'Project Everyone' 295-297, 300, 306-308, 311-313

Promio, Alexandre 235

propaganda $16,56,70,77-106,148$

public relations $9-10,84-85,133,195,222$

public service announcement $\quad 295$

public service broadcasting / public-service television $130,139,146,171-179$

Puschkin Vodka $118,121,135^{-136,143, ~ 144, ~}$ $145^{-146}$

\section{Querschnittsmontage 57}

Radion 173

Raleigh \& Robert 159

Rancière, Jacques $\quad 52,233$

Ray, Man 121

reactance $211,215,221,223,239$

reception $84,155,161,164,180,217,223,238,287$

Renault 36

Renck, Johan $\quad$ 273, 274n16

Resor, Stanley 209

Richter, Hans $\quad 15,77-78,82-89,91-106$

Riefenstahl, Leni $\quad 56,72$

River, The 103

Rockefeller Foundation 100

Roos, Uschi 137

Rope Swing $54-56,58,62-65,70-72$

Rotha, Paul 15, 77, 82-88, 98-100, 106, 309

Ruttmann, Walter $\quad 5^{6-57,83}$

Salmon, Charles T. $\quad 22,32-33$

Salmon, Stéphanie 36

Saturday Evening Post, 206

Sauvage, Léo 88

Scandinavia $16,160,245,251,254-255,260$, 272

scènes d'art et d'industrie $\quad 25,159$

screen advertisements / screen ads 11-13, 16,

$55,59,113,115,118,121-123,126-131,140-142$

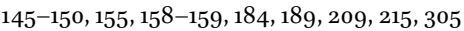

Scribner's 206

Schefer, Jean-Louis $\quad 245,265^{-266}$

Schiller, Friedrich $\quad 92$

Schmidt, Siegfried J. 222

Scholz, Jürgen $\quad 136$

Schwarzkopf 146,147

self-irony see irony

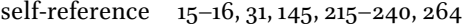

self-reflexivity see self-reference

Seltzer, Leo 103

Sheller, Mimi $\quad$ 158, 186

Sivulka, Juliann 247

Smoodin, Eric 105

Société générale du Phonoscope see Phonoscope, Société générale du

soft sell $167,247,248 \mathrm{n} 8,249,260,263^{-264}$

Sorlin, Pierre 148

sound $36,61,64,78,87,125,142,146-148$, $170{ }^{2} 8,179-180,183,201,224,227,239,25^{2}$, 302 ,

soundtrack $97,248,251 \mathrm{n} 14,255,260,262$, 265,277

Soviet Union 101

spectatorship $\quad 52,93,189$

Spehr, Wolfdietrich 137

Spigel, Lynn 55,70

sponsored film $57-58,79,82-83,86-88,94$, $96-97,114,159-160,200,206,210,295$

spot $11,13,51,55,58,63-65,72,118-119$, 121-122, 129n $52,130-131,134-135,137-139$, 141-143, 146, 148, 168, 225, 230n5o, 309

spot commercial see spot

Sproule, J. Michael $\quad 85,91,99$

Sri Lanka, former Ceylon 42, 44

Staiger, Janet $\quad 124-125$

Stam, Robert $\quad 217-220,233$

Star Wars 230

Steinman, Clay 168

Stig 225

St. Louis World Fair, $1904 \quad 28$

Stockholm 17, 272

Stollwerck $30-31$

Storck, Henri 96

Ströer 182,184

Suber, Peter 215

Sunlight $\quad 30-33,235-36$

Super Bowl 16, 215, 230, 264

sustainability $16,291-94,306-07,310,312$

SWE Advertising Agency 17

Sweden $160,224-225,249,251-257,263,272,312$

Swiss national exhibition, Geneva $1896 \quad 31$

Swiss national exhibition, Zurich $1939 \quad 97$

Swiss Stock Exchange $\quad$ 96, 98

Swiss (German) television $\quad 172-177$

Switzerland $14,22,30-31,34,83,86,94-97$ $98-99,159-60,172-73,176-77,235$

Systems Theory $221-223,227,232$

Team (ad agency) 136-39, 143, 145

Teen People Magazine 203 
Telespot $\quad 172-173$

television spot see spot

television, network(-era) $16,27-28,55,61,64$,

$7^{2}, 155^{-15} 6,165^{-171}, 179^{-180}, 185,188$

testimonial $15,173,195,198,205^{-211}, 298$

Thé, Le: culture, récolte et préparation industrielle 42-43

Thorburn, David $\quad 237-238$

Thorn, Frank S. aka Hans Meyer 120

tie-in see product placement

Tode, Thomas 97

Tortajada, Maria $15^{8}$

trademarks $10,12-13,15,34-36,54,140,177$,

195-196, 198-205, 207, 209-212, 251, 254, 304

trademark law 10, 196, 199-202, 205

trailer $13,160,164,167$

transition $27,44,65,158,162-63,169,179$, $184-85,188,237-38,240-41,269,320$

travelogue $\quad 25^{-28}, 34,38,42$

Trewey, Félicien 30

Turner, Fred $\quad 78,106$

Turvey, Malcolm 92

Tuten, Tracy L. $\quad 275^{-276}$

UN 291, 294-295, 297, 301, 306-307, 310-312

Union Bank of Switzerland 173

United Kingdom $\quad 25,166,182$

United Nations see UN

Unesco 309-310, 312

United States $\quad 25,28,33,37,55,79,83-84$,

$87,91,97,99-103,106,115,128,138,156,159$,

$166,171,182,196,198-199,211,251,255^{-25} 6$, 296, 300

Urry, John $\quad 158,180,186$

useful cinema $12,37,77,81,83,86,92,94,98$, 104-105, 114

Van Dyke, Willard 103

Vasata, Vilim $136,145,154,330$

vaudeville 163

Verhoeff, Nana $\quad 237$

Vertov, Dziga $\quad 89,95$
Via 173

Vicary, James 239

Vitagraph 34

Volvo 16, 226, 245-266, 291-294, 310-312

Vonderau, Patrick $14-15,27$

von Rebay, Hilla 100

von Sydow, Max $25^{\circ}$

'Vorkapich effect' $64 \mathrm{n} 44,65$

Vorkapich, Ed $51,56,64,70-71$

Vorkapich, Slavko $\quad 64,70-72$

Vouilloux, Bernard 157

waiting $129,183-187,195,268$

Waller, Gregory A. $\quad 17,29$

Wanamaker, John 230

Wander 173

Warner Bros. 196, 199-201, 204-205, 210

Wasson, Haidee $\quad 17,114$

Wees, William C. 98

Weber, Max 91

Werben \& Verkaufen $\quad 133,137$

Werner, Jeff $\quad 25 \mathbf{1}^{-25} \mathbf{2}$

Widerberg, Bo $\quad 250,252$

Wile E. Coyote 230

Williams, Raymond $7,14,71-72,158,165^{-167}$, $170,172-173,179-180$

Wilp, Charles $\quad 15,113,117-123,127-129,131$,

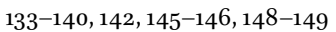

Winston, Brian $\quad 98$

Withalm, Gloria $\quad 234$

word of mouth $133,207,274,275 \mathrm{n} 17,276,279$, 281

World Food Programme 311

World Without End 309-310

Wright, Basil 96, 309

YouTube $11,30,55,65,122,177,189,201,252$, $269-283,287-290,296,306,311$

Zimmermann, Yvonne $\quad$ 14-16, 129, 264, 309

Zurich 96-97

Zurstiege, Guido $\quad$ 222, 242, 332 
Advertising has played a central role in shaping the history of modern media. While often identified with American consumerism and the rise of the 'Information Society', motion picture advertising has been part of European visual culture since the late nineteenth century. With the global spread of ad agencies, moving image advertisements became a privileged cultural form to make people experience the qualities and uses of branded commodities, to articulate visions of a 'good life', and to incite social relationships. Abandoning a conventional delineation of fields by medium, country, or period, this book suggests a lateral view. It charts the audiovisual history of advertising by focussing on objects (products and services), screens (exhibition, programming, physical media), practices (production, marketing), and intermediaries (ad agencies). In this way, the book develops new historical, methodological, and theoretical perspectives.

Bo Florin is Professor of Cinema Studies at the Department for Media Studies, Stockholm University, Sweden. Patrick Vonderau is Professor of Media and Communication Studies at the University of Halle, Germany. Yvonne Zimmermann is Professor of Media Studies at Philipps-University Marburg, Germany.

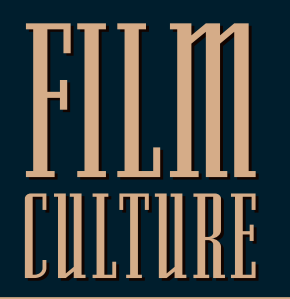

IN TRANSITIDN

"With Advertising and the Transformation of Screen Cultures, Florin, Vonderau, and Zimmermann have crafted an expansive, groundbreaking study of advertising's industrial practices and cultural forms. Covering a range of national contexts, media objects, and historical moments, the book's authors provide an exciting window into the dynamic relationship between advertising and moving images."

ALISA PERREN, UNIVERSITY OF TEXAS

"Remarkably ambitious in its scope, theoretically sophisticated, and always grounded in richly detailed original research that ranges from early cinema to YouTube, Advertising and the Transformation of Screen Cultures is an invaluable contribution to the history of screen advertising and media studies more generally."

GREGORY A. WALLER, INDIANA UNIVERSITY 